\title{
eco tSTP
}

ESCOLA DE COMUNICCAÇÕES E ARTES

UNIVERSIDADE DE SÃO PAULO

\section{MARTA TEREZINHA MOTTA CAMPOS MARTINS}

Diálogo e interações face a face na comunicação interna: um estudo da oralidade nas organizações 


\section{MARTA TEREZINHA MOTTA CAMPOS MARTINS}

Diálogo e interações face a face na comunicação interna: um estudo da oralidade nas organizações

Tese apresentada à Escola de Comunicações e Artes da Universidade de São Paulo para obtenção do título de Doutor em Ciências da Comunicação.

Área de Concentração: Interfaces sociais da comunicação

Orientadora: Prof $^{a}$ Dr $^{a}$ Margarida Maria Krohling Kunsch 
Autorizo a divulgação parcial ou total deste trabalho, por qualquer meio convencional ou eletrônico, para fins de estudo e de pesquisa, desde que citada a fonte.

Ficha Catalográfica elaborada pela bibliotecária Licéia Cianca Fortes, CRB-9 nº 752

M344d Martins, Marta Terezinha Motta Campos

Diálogo e interações face a face na comunicação interna: um estudo da oralidade nas organizações / Marta Terezinha Motta Campos Martins São Paulo, 2012

$291 \mathrm{f}$ : : il ; $30 \mathrm{~cm}$.

Tese (Doutorado em Ciências da Comunicação), Escola de Comunicações e Artes da Universidade de São Paulo.

Orientadora: Margarida Maria Krohling Kunsch

1. Comunicação interna. 2. Oralidade. 3.Diálogo. 4. Discurso. 5. Linguagem. 6. Interações face a face. I. Kunsch, Margarida Maria Krohling. II. Universidade de São Paulo. III. Título. 
MARTINS, Marta Terezinha Motta Campos. Diálogo e interações face a face na comunicação interna: um estudo da oralidade nas organizações. Tese apresentada à Escola de Comunicações e Artes da Universidade de São Paulo para obtenção do título de Doutor em Ciências da Comunicação.

Aprovada em:

\section{BANCA EXAMINADORA}

Prof. Dr. Instituição:

Julgamento: Assinatura:

Prof. Dr. Instituição:

Julgamento: Assinatura:

Prof. Dr. Instituição:

Julgamento: Assinatura:

Prof. Dr. Instituição:

Julgamento: Assinatura:

Prof. Dr. Instituição:

Julgamento: Assinatura: 
Dedico esta tese ao Prof. Dr. Waldyr Gutierrez Fortes (in memoriam) porque sua inspiração sempre moverá o meu fazer no campo acadêmico das relações públicas. Sei que de sua nova morada você está comemorando essa conquista comigo, querido e saudoso mestre-amigo. 


\section{AGRADECIMENTOS}

O aperfeiçoamento profissional é um processo que exige persistência e maturidade. Alcanço um estágio avançado em minha formação e estou certa de que o tempo era este, pois a vida é a grande academia que ensina a enfrentar desafios e com isso nos tornar mais fortes. Eu não estive pronta antes de agora. Creio que este seja o sentido da sabedoria e confio na aprendizagem que vivenciei com quem participou deste percurso a meu lado. Obrigada,

Profa. Dra. Margarida Maria Krohling Kunsch orientadora que me acolheu no seu saber para me dar oportunidade e me guiar na aprendizagem para produzir conhecimento científico. Transporto em minha história a deferência e a honra de ter sua orientação no mestrado e no doutorado.

Prof. Dr. Miguel Luiz Contani, nosso incentivador incansável e condutor para que sejamos produtivos no Departamento de Comunicação da Universidade Estadual de Londrina - UEL. A segurança do olhar científico que com competência e generosidade avista nossas pesquisas leva-nos a produzir à luz de um exemplo real de dedicação e amizade.

Profa. Ms. Licéia Cianca Fortes, bibliotecária rigorosa que ofereceu sua competência, porém com a doçura e serenidade que somente uma boa amiga seria capaz de conciliar em momentos quando a amizade era a motivação maior.

Profa. Dra. Sidinéia Gomes Freitas que me manteve motivada a persistir no tema dessa tese, participou de minha qualificação e contribuiu cientificamente com o estudo.

Prof. Dr. Paulo Roberto Nassar de Oliveira pelo entusiasmo e pelas conversas que expressavam sua confiança no êxito da minha pesquisa e traziam contribuições de muita relevância.

Carina Gomes Rufino, gerente de Comunicação Organizacional da Embrapa Soja de Londrina - PR por ter me acompanhado na imersão que fiz em um centro avançado de produção científica e pela participação generosa em todos os momentos em que solicitei sua interferência. O nível de sua atuação, bem como o dos demais profissionais de sua equipe merecem ser tomados como referência da prática em comunicação organizacional.

Paula Geron Saiz de Melo, Relações-Públicas responsável pela comunicação interna da Embrapa Soja, parceira fiel e dedicada que me mostrou a influência que uma prática competente alcança nos relacionamentos com empregados e me beneficiou com seu reconhecimento junto aos entrevistados da pesquisa.

Aos dirigentes, supervisores e demais empregados da Embrapa Soja, colaboradores indispensáveis para a produção desta tese, agradeço a acolhida e o interesse e boa vontade com que responderam as entrevistas. 
Profa. Dra. Mariângela Benine Ramos Silva, Profa. Dra. Maria Amélia Miranda Pirolo e Profa. Neusa Maria Amaral, parceiras da Universidade Estadual de Londrina que, nesse capítulo de minha vida acadêmica, compartilharam comigo suas experiências científicas.

Aos Relações-Públicas Daniel de Oliveira Figueiredo e Paulo Vitor Targa pelo respeito que como meus ex-alunos dedicam-me e pelo coleguismo profissional manifestado no desenvolvimento da pesquisa. Agradeço à acadêmica de relações públicas da Universidade Estadual de Londrina - UEL, Fernanda Targa pela colaboração no processo de coleta de dados da pesquisa.

A André Contani, conhecedor de preceitos estatísticos que é, provou que solidariedade é um conjunto infinito, conforme o que diz a matemática e o que deixou graficamente visualizado.

À Universidade Estadual de Londrina - UEL que permitiu que eu me dedicasse integralmente aos estudos de doutorado durante os últimos anos.

Agradeço ao Pai Sagrado pela proteção e por manter acesa em mim a chama da fé de que eu seria capaz, apesar das contrariedades.

Aos meus amores maiores, eles que são minha força, coragem, persistência e determinação. Meu marido Daniel, minha filha Marcela e meu filho Fernando, compartilhemos esta conquista e o orgulho de sermos uma família que batalha unida pelos sonhos que cada um de nós carrega e que todos podemos alcançar com nosso apoio mútuo e permanente.

Caso alguém tenha pensado em me atingir com forças contrárias a essa conquista, fique com meu agradecimento, pois as adversidades temperam e dão sabor a uma vitória desta envergadura! 
Toda comunicação inicia no corpo e termina no corpo. Por mais que o espírito humano equivocado queira endeusar as máquinas.

Harry Pross 


\section{RESUMO}

MARTINS, Marta Terezinha Motta Campos. Diálogo e interações face a face na comunicação interna: um estudo da oralidade nas organizações. 2012. 291 f. Tese (Doutorado em Ciências da Comunicação) - Escola de Comunicações e Artes, Universidade de São Paulo, São Paulo, 2012.

As novas demandas de públicos solicitam relacionamentos contíguos com gestores, dirigentes e representantes formais das organizações nas relações entre elas e as comunidades participantes de sua rede de relacionamentos. A pesquisa conduzida neste estudo projeta indicativos sobre modos e usos da oralidade na comunicação com empregados e delineia um elenco de posturas verificadas entre gestores que adotam a oralidade como estratégia relacional com suas equipes. Busca identificar e dimensionar o emprego de postulados da oralidade para compreender em que grau Ihes pode ser conferido um caráter estratégico quando se trata de atingir resultados e agilizar processos de comunicação com público interno. O corpus empírico foi constituído no ambiente da comunicação interna de uma empresa pública, Embrapa Soja, na unidade localizada em Londrina-PR, uma das 47 unidades de pesquisa da estatal Empresa Brasileira de Pesquisa Agropecuária - Embrapa. Uma pluralidade de métodos foi adotada como estratégia de pesquisa e orientou os procedimentos de coleta e análise de dados que também foram extraídos e tratados de modo fenomenológico, qualitativo e quantitativo. Quatro eixos temáticos foram estabelecidos com base na fundamentação desse método: comunicação interna, comunicação oral, uso do diálogo e comunicação face a face. A oralidade revelou-se marcante na prática de trabalho dos sujeitos entrevistados, está absorvida em todas as formas de comunicação interna e promove integração entre funcionários e administração. Pelos fortes indicativos de sua influência nos resultados do grupo e seu impacto positivo no relacionamento com o público externo, pode-se afirmar a presença desse componente na cultura organizacional e seu alto teor de contribuição como elemento de gestão estratégica.

Palavras-chave: Comunicação Interna. Oralidade. Diálogo. Discurso. Linguagem. Interações face a face. 


\begin{abstract}
MARTINS, Marta Terezinha Motta Campos. Dialogue and face-to-face interactions on internal communication: a study of oral speech in organizations. 2012. $291 \mathrm{f}$. Thesis (Doctorate in Communication Sciences). School of Communications and Arts, University of São Paulo, São Paulo, 2012.

New demands on publics require closer relationships with managers, directors and formal representatives of organizations to their connection between themselves and the communities participating in their networking. The research conducted in this study raised indications as to how oral speech is used in the communication with employees and reveals the conducts verified among administrators who adopt oral speech as relational strategy when dealing with their teams. It aims to identify and evaluate the utilization of oral speech postulates in order to understand the degree to which they can be strategically considered when it comes to achieving results and speeding communication processes with the internal public. Data were gathered in the internal communication environment of a public enterprise, the Embrapa Soja, in its unit located in Londrina-PR, one of the 47 research units of the state owned Empresa Brasileira de Pesquisa Agropecuária - Embrapa. Miscellaneous procedures were used in the research orientation, with data collection and analysis being treated through phenomenological principles, both qualitatively and quantitatively. Four thematic axes were established within the selected method: internal communication, oral communication, use of dialogue, and face-to-face communication. Oral speech showed prominent in the work practices of the interviewees, it is absorbed in all internal communication actions and fosters integration among employees and administration. Through the strong evidence of its participation in group results and its positive impact on the relationship with external publics, the firm presence of this component in the organizational culture can be stated as well as the high contribution it can provide as element of strategic management.
\end{abstract}

Key words: Internal Communication. Oral Speech. Dialogue. Discourse. Language. Face-to-face interactions 


\section{LISTA DE QUADROS}

QUADRO 1 - Informações corporativas acerca da Embrapa. 128

QUADRO 2 - Áreas de atuação e funções da equipe. 183

QUADRO 3 - Missão da equipe em relação à Embrapa Soja. 186

QUADRO 4 - Resumo dos modos de divulgação. 195

QUADRO 5 - Uso da oralidade na decisão compartilhada com chefe. 198

QUADRO 6 - Resumo dos achados dos gráficos segmentados por perfil. 202

QUADRO 7 - Relação de questões referentes ao bloco comunicação interna....207

QUADRO 8 - Relação de questões referentes ao bloco comunicação oral entre os empregados. 209

QUADRO 9 - Relação de questões referentes ao bloco uso do diálogo. 211

QUADRO 10 - Relação de questões referentes ao bloco comunicação face a face. 


\section{LISTA DE GRÁFICOS}

GRÁFICO 1 - Nível de instrução dos cientistas da Embrapa. 125

GRÁFICO 2 - Distribuição dos funcionários em setores da Embrapa Soja. 130

GRÁFICO 3 - Informação sobre o setor para os empregados. 196

GRÁFICO 4 - Informação sobre tipo de comunicação para melhorar o trabalho. 200

GRÁFICO 5 - Informação sobre meio de comunicação para melhorar o trabalho201

GRÁFICO 6 - Relação entre a moda e a média encontradas para cada bloco de questões. 203

GRÁFICO 7 - Composição com o agrupamento das respostas para comunicação interna. .205

GRÁFICO 8 - Acoplamento das distribuições de respostas em comunicação Interna.

GRÁFICO 9 - Composição com o agrupamento das respostas para comunicação oral entre os empregados.

GRÁFICO 10 - Acoplamento das distribuições de respostas em comunicação oral entre os empregados

GRÁFICO 11 - Composição com o agrupamento das respostas para uso do diálogo.

GRÁFICO 12 - Acoplamento das distribuições de respostas em uso do diálogo...212

GRÁFICO 13 - Composição com o agrupamento das respostas para comunicação face a face.

GRÁFICO 14 - Acoplamento das distribuições de respostas em comunicação face a face. 


\section{LISTA DE FIGURAS}

FIGURA 1 - Oralidade na comunicação interna - proposta da pesquisa.

FIGURA 2 - Organograma da Embrapa. 124

FIGURA 3 - Organograma da Embrapa Soja. 129

FIGURA 4 - Oralidade na comunicação interna - resultados da pesquisa........235 


\section{SUMÁRIO}

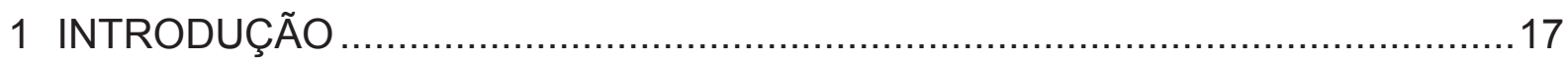

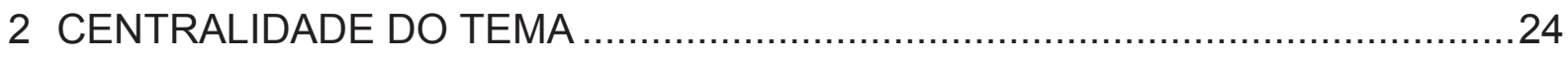

2.1 Descrição de Procedimentos Metodológicos .............................................28

3 INTERFACES DA LINGUAGEM NOS DISCURSOS ORGANIZACIONAIS.........35

3.1 Linguagem como Campo da Comunicação ............................................... 38

3.2 Linguagem e Discurso nas Organizações.............................................42

4 A ORGANIZAÇÃO COMO TERRITÓRIO PARA O DIÁLOGO $\ldots \ldots \ldots \ldots \ldots \ldots \ldots \ldots \ldots . . . . . . . . . . . . .46$

4.1 Tradição e Pós-Moderno: Conjunção Dialógica .......................................... 46

4.2 Estudos Organizacionais: Consequência da Tecnologia, Globalização e

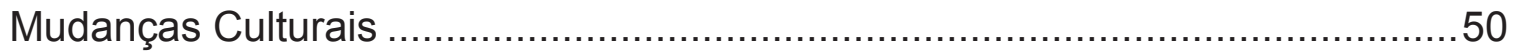

4.3 A Comunicação Mediando Relações com os Públicos ................................. 54

5 COMUNICAÇÃO INTERNA E SUA APTIDÃO PARA O DIÁLOGO .....................60

5.1 Tecnologia e Linguagem na Comunicação Interna ......................................62

5.2 Influência da Comunicação na Performance Interna .................................... 65

5.3 Comunicação Oral Agregando Valor à Liderança ...................................... 68

5.4 Contribuição do Estudo para a Comunicação Organizacional e para as Relações Públicas .73

5.5 Organizações Inseridas no Paradigma Global ........................................ 78

6 ORALIDADE: PRINCÍPIOS E CONCEITOS ............................................... 85

6.1 Interfaces da Comunicação, da Cultura do Diálogo e da Oralidade ...................87

6.2 Oralidade no Processo de Gestão Criativa ...................................................91

6.3 A Obscuridade dos Discursos nos Negócios ..................................................94

7 COMUNICAÇÃO FACE A FACE: PRINCÍPIOS E CONCEITOS .......................98

7.1 Por Que Comunicação Face a Face ...................................................... 103

7.2 Comunicação Face a Face para Empresas Brasileiras .................................106

7.3 Deslocamento para a Comunicação Face a Face ......................................109 
8 ESTUDO DA ORALIDADE EM ORGANIZAÇÃO ESTATAL ..............................121

8.1 Empresa Brasileira de Pesquisa Agropecuária - Embrapa ...........................121

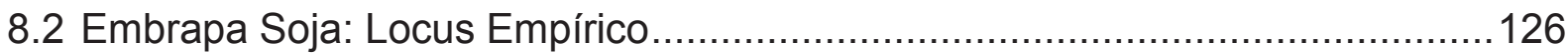

8.3 Gestão e Comunicação Interna na Embrapa Soja: Métodos Utilizados............132

8.4 Etapa Fenomenológica com Dirigentes da Embrapa Soja.............................134

8.5 Etapa Qualitativa com os Supervisores da Embrapa Soja..............................138

8.6 Etapa Quantitativa com os Empregados da Embrapa Soja ............................140

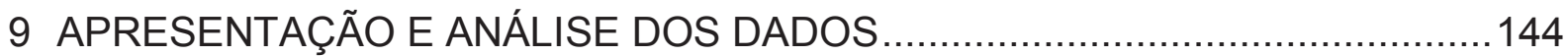

9.1 Análise da Fenomenologia com Dirigentes da Embrapa Soja .......................145

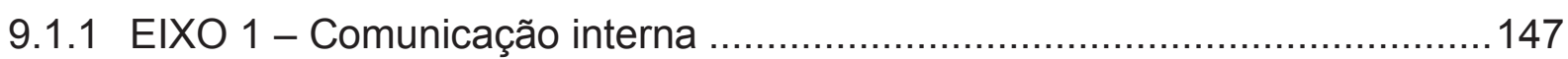

9.1.1.1 Como a missão da área se relacionava à empresa ................................148

9.1.1.2 Sobre a "Política de Comunicação"da Embrapa......................................150

9.1.1.3 Adotava a política na comunicação com os liderados ..............................152

9.1.1.4 Encontrava recomendações sobre a comunicação oral entre chefes e empregados na comunicação interna da unidade

9.1.1.5 Falava ou escrevia a relação entre os objetivos da empresa e o trabalho dos

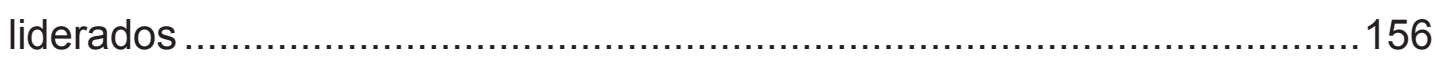

9.1.1.6 Clareza sobre o que é esperado de cada empregado da equipe ..............158

9.1.1.7 Modo como estimula a equipe a contribuir com o melhor.........................160

9.1.2 EIXO 2 - Comunicação oral ...........................................................162

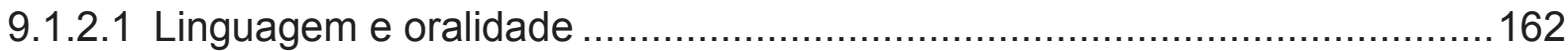

9.1.2.2 A linguagem era compreendida por todos os empregados ......................164

9.1.2.3 Usava a comunicação oral com seus liderados, de outras equipes e

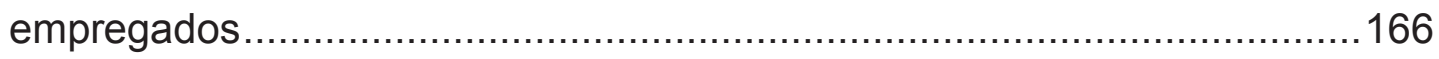

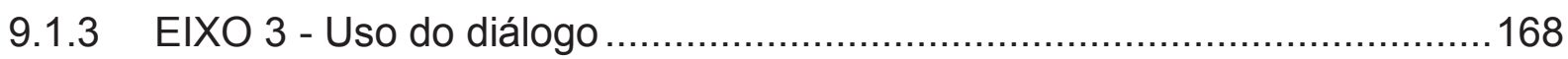

9.1.3.1 Importância atribuída pelo líder ao uso da fala, diálogo e da comunicação face a face entre chefes e equipes na empresa .....................................168

9.1.3.2 Situações que o líder dialogava com subordinados .................................169

9.1.3.3 Abertura para equipe dialogar com líder.............................................170

9.1.3.4 Ouve e acata relatos e sugestões dos subordinados ..............................172

9.1.3.5 Encorajamento para a cooperação com outros grupos, unidades ou

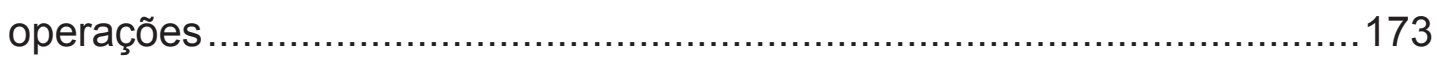

9.1.4 EIXO 4 - Comunicação face a face .......................................................173 
9.1.4.1 Encorajamento de opiniões face a face sobre o estilo de liderar..... 175

9.1.4.2 Encoraja opiniões sobre o trabalho de sua equipe .176

9.1.4.3 Discute face a face melhorias para o desempenho dos subordinados 177

9.1.4.4 Facilidade para dialogar e para comunicar face a face: habilidade inata do indivíduo ou competência gerencial que podia ser desenvolvida 179

9.2 Análise da Etapa Qualitativa com Supervisores Embrapa Soja. 181

9.3 Análise da Etapa Quantitativa com Empregados Embrapa Soja 194

9.3.1 Comunicação interna 195

9.3.2 Comunicação oral entre os empregados 197

9.3.3 Uso do diálogo. 198

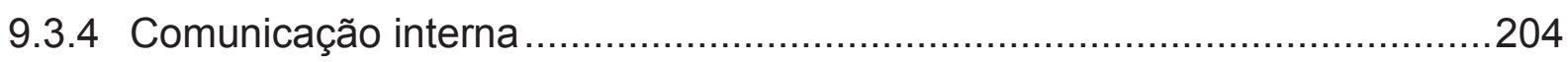

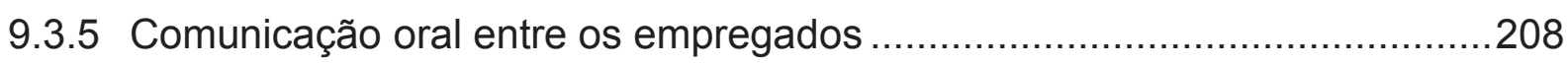

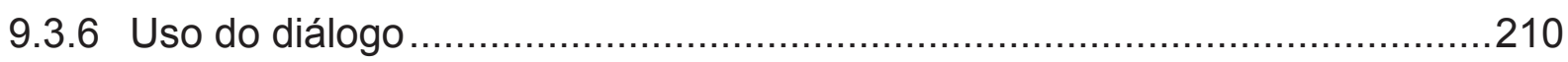

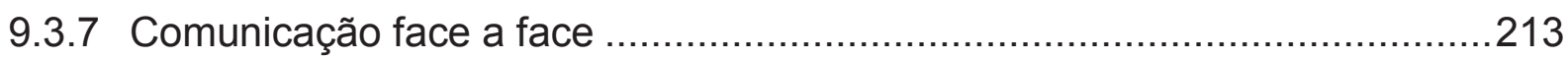

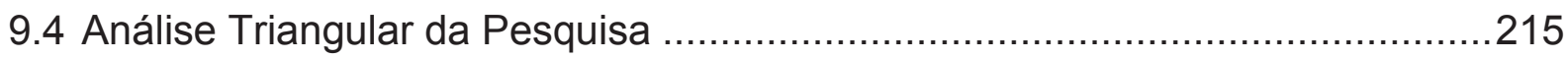

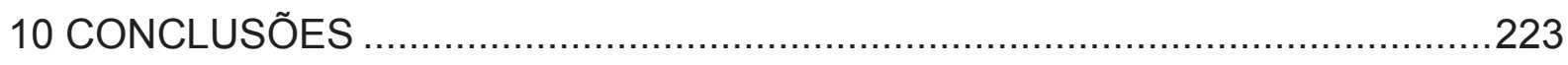

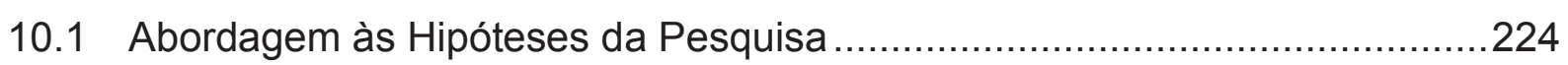

10.2 Direcionamentos Alcançados à Luz dos Objetivos Propostos .....................227

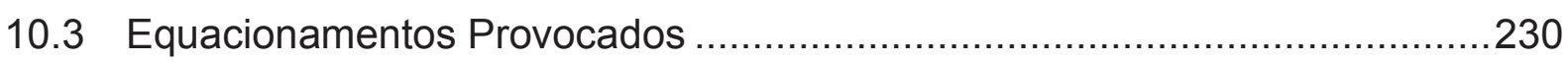

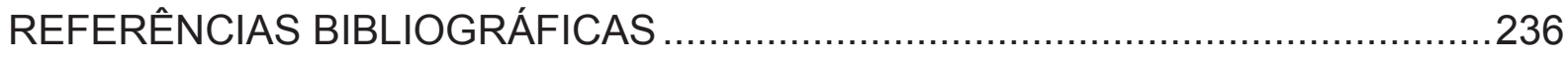

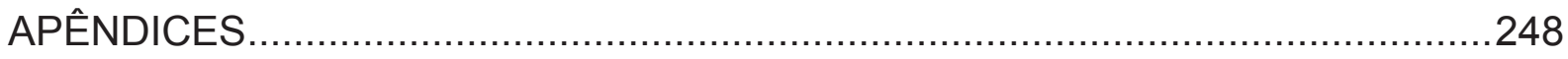

APÊNDICE A - PAUTA DE ENTREVISTA COM DIRIGENTES DA EMBRAPA SOJA 249

APÊNDICE B - INSTRUMENTO PARA ENTREVISTA COM SUPERVISORES ....250

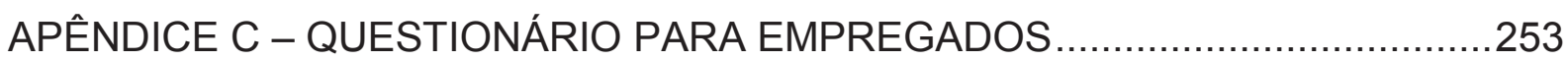
APÊNDICE D - TABULAÇÃO DAS RESPOSTAS OBTIDAS .............................260 


\section{INTRODUÇÃO}

Um modelo de comunicação que funciona para empresas do momento presente é aquele que avançou para além do tradicional processo linear de unicamente transmitir e fazer circular informações. A nova ordem pressupõe comunicar para estabelecer relações com públicos estratégicos tendo em vista que não se pode ignorar que, em essência, a comunicação configura um processo multidirecional, dialógico e interativo do qual as pessoas são participantes ativas. Passa a ser indispensável que elas assim o percebam e compreendam o modo como devem dentro dele operar. Ou seja, os interlocutores recebem, processam, produzem e reproduzem comunicação que repercute nos relacionamentos e gera transformação. A comunicação organizacional é hoje compartilhada entre os atores que assumem responsabilidades pelo seu processamento e distribuição, posto que uma estrutura comunicacional focada em canais e conteúdos não garante posição de destaque nem assegura sobrevivência para empresas no mercado globalizado. A participação do público interno para disseminar e incorporar informação e conhecimento completa a visão sistêmica própria de uma comunicação interna de resultados positivos. Forma-se essa expectativa tanto do ponto de vista dos relacionamentos com públicos, quanto das relações de negócios, e cria-se o campo propício para unificar os interesses que flutuam sobre esse universo.

Democratizar o ambiente empresarial interno é elevar níveis de acesso e tratamento da informação por parte de funcionários, criar condições para o autodesenvolvimento do público interno e associar envolvimento e receptividade dos líderes e de suas equipes de empregados com os objetivos institucionais e mercadológicos da organização. O empregado percebe-se reconhecido e valorizado como pessoa quando sua prática cotidiana expressa os valores da empresa que são materializados através do consentimento para opinar, expor sentimentos, para ser ouvido. Ocorre o mesmo quando, em síntese, se vê de posse da permissão para dialogar com a organização por meio dos demais atores que dela fazem parte.

O indivíduo, antes de ser empregado, é um ser humano, um cidadão que merece ser respeitado e considerado. A comunicação interna deve contribuir para o exercício da cidadania e para a valorização do homem. Quantos valores poderão ser acentuados e descobertos mediante um programa comunicacional participativo! A oportunidade de se manifestar e 
comunicar livremente canalizará energias para fins construtivos, tanto do ponto de vista pessoal quanto profissional" (KUNSCH, 2003, p. 159).

O diálogo potencializa a comunicação interpessoal, é estabelecido nas interações face a face entre atores sociais, e nelas o esclarecimento de dúvidas, o feedback e outras pistas sobre a efetividade da comunicação são provenientes da oralidade como sua fonte mais direta e imediata. A palavra falada, os gestos, as expressões faciais e o tom de voz, tudo se articula com a finalidade suprema de unir tais atores sociais em torno do que está sendo comunicado por um sistema organizacional e sobretudo do relacionamento que ele constrói e aprofunda e no qual passa a ser refletido. Um panorama de tamanha influência ganha uma complexidade que se amplia quando a ele se agrega a oralidade e a essência informal que, em significativa medida, nela está presente. Constitui-se, portanto, um tema que mobiliza ou deveria permanentemente mobilizar interesses em questões norteadoras de um estudo científico. A oralidade, por seu alcance e abrangência, é aqui defendida como uma forma de comunicação humana que ganha status de instrumento estratégico e necessário para lidar com as interações modificadas nas organizações pós-modernas.

Esta tese de doutorado buscou organizar um corpus que se ia adensando na medida em que evoluía a pesquisa e, especialmente quando conceitos e argumentos trazidos pelas referências adotadas inspiravam novos olhares e motivavam contínua revisão. Manter o caráter atual e consistente de cada revisão foi uma escolha no sentido de abranger os problemas levantados e cuidar para que não se afastassem, no momento do recorte, da visão de conjunto demandada por um tema complexo, com implicações amplas, inclusive com elevado grau de subjetividade.

O estudo empírico teve como universo uma empresa estatal e foi realizado na Empresa Brasileira de Pesquisa Agropecuária (Embrapa), organização pública vinculada ao Ministério da Agricultura, Pecuária e Abastecimento. A investigação concentrou-se na proposta de comunicação organizacional interna da Embrapa Soja, localizada na cidade de Londrina - PR. A concepção dos instrumentos de coleta de dados e de guias para descrever e analisar o que era recolhido foi um desafio a ser enfrentado e vencido. Esta convicção marcou, desde o início, o empenho de gerenciar cientificamente o agir com a flexibilidade necessária a um plano de pesquisa dessa natureza, sempre com a disposição para testar 
enfoques, efetuar ajustes e assim não perder a riqueza que este exercício originalmente carrega. A pesquisa ocorreu em três etapas, delimitadas a partir dos requisitos contidos na caracterização de cada método, científico utilizado.

O conjunto de questões abaixo expressa as inquietações que motivaram a escolha pelo tema e direcionaram o desenvolvimento da pesquisa:

- Em que extensão se pode afirmar, no ambiente pesquisado, que a oralidade entendida como construtora de comunicação face a face, é uma habilidade que projeta a competência do líder para conduzir equipes e alcançar objetivos de comunicação interna?

- Que características da oralidade identificadas e descritas nesse ambiente podem ser absorvidas pela comunicação interna?

- Em que medida essa mesma oralidade é capaz de restabelecer diálogo entre líder e sua equipe?

- A comunicação face a face acelera a transferência de mensagens internas nessa organização?

- A oralidade encontrada está sendo capaz de produzir reflexos na adequação de linguagem que, por sua vez, se projetam sobre a relação do líder com as equipes internas?

As hipóteses a seguir descritas foram as diretrizes do processo de investigação:

H1 A organização pesquisada não considera a oralidade como um componente a ser destacado na sua comunicação interna.

H2 O diálogo dos líderes com seus liderados não é reconhecido como um resultado de processo comunicacional.

H3 A maioria dos líderes entrevistados é reconhecida pela sua oralidade.

H4 A oralidade é um método relevante desenvolvido pela comunicação interna da organização.

H5 As lideranças entrevistadas consideram necessário resgatar a oralidade como suporte para os relacionamentos da organização com os públicos.

H6 Gestores reconhecem o caráter estratégico da oralidade para a comunicação interna. 
O objetivo geral colocado para a pesquisa foi o de investigar de que modo a oralidade produz impactos para resgatar e fortalecer o diálogo entre líderes e empregados e para projetá-la ao campo das estratégias de comunicação interna. O caráter intricado da investigação converge para se estabelecerem divisas em um assunto naturalmente amplo. Por ser assim, definiram-se os seguintes objetivos específicos para a pesquisa:

- Levantar como a oralidade é considerada na gestão da comunicação interna da organização estudada;

- Analisar os impactos produzidos pela comunicação estabelecida através do diálogo entre líderes e liderados;

- Investigar que características da oralidade contribuem para esclarecer os objetivos da comunicação interna;

- Avaliar a relação entre popularidade de um líder e uso da oralidade pela liderança;

- Verificar o uso da comunicação face a face como estratégia de gestão no contexto da comunicação interna;

- Comparar o uso da oralidade do líder com sua visibilidade junto aos liderados.

- Analisar de que modo a linguagem interfere na compreensão dos liderados em relação à competência de seu líder;

- Levantar quais características da oralidade são aplicadas na comunicação interna da empresa estudada.

O referencial teórico seguiu um percurso traçado em eixos temáticos que abordam a comunicação interna, a linguagem, a oralidade e a comunicação face a face inseridos no contexto global característico da sociedade contemporânea. Levantaram-se, descreveram-se e se analisaram práticas e competências associadas ao uso da oralidade nos diálogos existentes em um sistema de comunicação interna que foi representativo do resultado que este valor organizacional pode fazer atingir nos relacionamentos internos e na agilidade da comunicação. Teve-se em conta todo o tempo o fato de que, concebida como processo, a comunicação interna realiza-se em múltiplos sentidos para cumprir sua função no ambiente organizacional, comporta variados fluxos interacionais e, se considerada dentro de um composto integrado, aproxima os níveis tático e 
operacional com o nível estratégico. A contribuição buscada por esta pesquisa é no sentido de enunciar propriedades desse fenômeno organizacional em seu papel de dar vigor às relações interpessoais de gestores e funcionários, bem como as relações mais abrangentes da organização com o público interno e permitir que os resultados sejam incorporados ao processo de mútua cooperação entre academia e mercado.

As relações conceituais de linguagem, diálogo, comunicação interna, oralidade e comunicação face a face estão dispostas, embora nem sempre nessa ordem, ao longo das abordagens teórico-metodológicas deste estudo. Elas compõem, no entanto, um encaixe em que se tem a comunicação organizacional como área maior na qual se situa o interesse pela investigação de como acontece a comunicação entre organização, gestores e empregados e, dentro dela, num primeiro recorte, também de natureza ampla, situando-se a comunicação interna. Com maior especificidade, busca-se atingir explicações de como o fenômeno se configura em comunicação face a face no locus definido, de modo a conhecer suas características e reais proporções. Para esse fim, torna-se agora necessário compor um recorte espacial sem esquecer que a precisão da leitura somente poderá advir de um outro recorte, este de natureza conceitual tomando cuidado com sua adequação (numa visão qualitativa integrada).

Por esse motivo buscou-se, num primeiro momento, subordinar o conjunto de conceitos com os quais se pretende dispor os recursos para empreender o estudo e a investigação que Ihe dá consistência: tem-se, portanto, os estudos organizacionais, dentro deles a comunicação organizacional e a comunicação interna como aquela que irá receber contribuições teóricas e fornecer novas perspectivas de conhecimento para as primeiras como uma de suas componentes essenciais. Para empreender essa tarefa, parte-se das conceituações de linguagem com seu amplo espectro, vendo em seguida a oralidade como um de seus elementos constitutivos. Chega o momento de efetivar particularizações e aí comparecem as noções de diálogo e comunicação face a face. A estruturação do trabalho buscou refletir esse encaixe, como se verá da descrição dos capítulos a seguir. O trabalho está organizado em 10 capítulos além desta introdução, identificada como item um. 
O segundo capítulo descreverá a centralidade do tema e deixará claros os contornos da pesquisa. A oralidade, embora vista em seu encaixe específico como componente da linguagem, perpassa todos os momentos e se estabelece como centralidade temática, razão pela qual esse aspecto mereceu discussão em paralelo com a metodologia do estudo, também mostrada neste capítulo. A finalidade é discutir, simultaneamente, a relevância científica do tema e as etapas nas quais foram coletados os dados e o modo como foram tratados a organização informante e os sujeitos respondentes.

No terceiro capítulo, será discutido o conceito de linguagem e seus desdobramentos. Serão vistas as várias acepções do termo, o sentido que adquire na presença dos atores organizacionais e as múltiplas formas que assume quando considerado no âmbito das relações interpessoais e do campo da tarefa e das metas de resultado. Essa conceituação aproveita a abordagem de centralidade do tema, efetivada no capítulo anterior, e que recebe maior nitidez quando enxergada como linguagem.

O quarto capítulo introduz a abordagem da prática do diálogo e o conceito de dialogismo que lhe é derivado. São examinadas as condições de sua implementação e os efeitos de seu emprego como suporte da comunicação face a face e também para integrar o exercício da oralidade. O destaque fica situado na visão da organização como grande arena em que toma corpo e com isso se discute como aquela se transforma para comportar a dinâmica da evolução tecnológica e as relações com os diferentes públicos.

O quinto capítulo amplia o enfoque dialógico, associando-o à comunicação interna para culminar no exame das relações entre líderes e liderados. São integradas, nesse ponto do trabalho, as discussões realizadas nos capítulos precedentes como tecnologia e linguagem, a fim de produzir uma associação de maior profundidade com a comunicação interna, a comunicação organizacional e as relações públicas. O destaque nesse capítulo estará no papel reservado à oralidade em todas essas conexões.

No sexto capítulo, encontra-se o detalhamento acerca da oralidade, figurando, nesta altura do trabalho, numa posição em que se beneficia da compreensão tentada com a integração de todos os termos para examinar as interfaces entre comunicação (organizacional e interna) e cultura do diálogo. 
O sétimo capítulo é instrumentalizado pelas discussões do capítulo anterior para focalizar os princípios e conceitos da comunicação face a face, as razões de ser uma prática desejada, o modo como se configura nas organizações brasileiras e o deslocamento para as efetivas situações de seu emprego.

O oitavo capítulo apresenta a estatal onde foi realizado o estudo e descreve suas características como locus da pesquisa.

O nono capítulo apresenta os dados colhidos e sistematiza as pesquisas qualitativas e quantitativa, respectivamente. Um conjunto de ilustrações é fornecido para permitir o acompanhamento das análises que se seguem a cada demonstração dos dados.

As conclusões, item 10, resgatam as perguntas fundamentais do estudo e as hipóteses que delas foram decorrentes para mostrar como estas últimas foram confirmadas ou refutadas, e como, em decorrência, permitem enunciar certas características e propriedades do fenômeno examinado. Essa parte dá destaque ao grau em que foram atingidos os objetivos do trabalho e, ao mesmo tempo, indica os limites e perspectivas de seguir adotando esse tema como decisão de pesquisa e geração de conhecimento científico.

Pensando na efetiva organização do fio condutor da pesquisa, optou-se por contextualizar o desenvolvimento da tese a partir de uma reflexão a respeito da centralidade do tema selecionado. 


\section{CENTRALIDADE DO TEMA}

Quando sustentada pelo diálogo direto, ainda que com mediação efetuada por recurso tecnológico, a comunicação interna - objeto deste estudo assume sua característica de uso da oralidade. Os grupos sociais estabelecem critérios que consideram compatíveis com a necessidade de tornar ágil a comunicação por meio desse recurso. Comunicação e relacionamento humano fazem-se presentes como temática central diante de padrões organizacionais heterogêneos e da busca de coexistência entre diferentes modos de ver o mesmo objetivo e a mesma meta de trabalho.

A linguagem é, por seu turno, também uma vasta área de estudo, e sua complexidade possibilita variados recortes, todos sempre de grande relevância, sobretudo quando focalizada em seu papel de componente cultural e fator de comunicação. O marco teórico neste campo de estudos registra clássicos como Oralidade e Cultura Escrita de Walter Ong (1998) que aborda a oralidade da linguagem, a moderna descoberta das culturas orais e um importante tópico como a "memória oral". Lembra esse autor que "[...] estamos, quase todos nós [...], tão impregnados da cultura escrita que raramente nos sentimos à vontade numa situação em que a verbalização é tão pouco semelhante a alguma coisa, como ocorre na tradição oral" (ONG, 1998, p. 20). Outra obra importante é Oralidade e Escrita de Fávero, Andrade e Aquino (2005) em que são apresentados os contrastes de organização na fala e na escrita, os fatores constitutivos da atividade conversacional e os níveis de estruturação do texto falado.

O assunto conta com expressivas contribuições no cenário acadêmico nacional como as noticiadas pelo Projeto Norma Linguística Urbana Culta de São Paulo (NURC/SP), na Universidade de São Paulo, sob coordenação do Prof. Dino Preti. Nesse grupo, estuda-se a língua oral e suas relações com a escrita, por meio de pesquisa permanente abrangendo tópicos como análise de textos orais, discurso oral culto, variações e confrontos nos estudos de língua falada, interação na fala e na escrita, diálogos na fala e na escrita, dentre outros. Um ponto ressaltado é que se trata de buscar "[...] atualização num campo em que até pouco tempo atrás, nada se estudava” (PRETI, 2005, p. 7). Há também outras obras voltadas à análise de textos orais e escritos como a de Burgo, Ferreira e Storto (2011) em que se 
abordam expressões da língua falada à luz da análise do discurso e aspectos como gerenciamento de vozes enunciativas e recursos de expressividade.

Nesta tese de doutorado, o interesse situou-se no campo das manifestações e dos usos da fala, entendida em sua inserção na linguagem oral, esta última compondo com a escrita, a mais notável e singular capacidade humana: a de interagir. Trata-se aqui de pensar, neste caso, mais diretamente, a comunicação nas organizações.

A fala, por ser um ato de comunicação, é também uma forma de linguagem. Etimologicamente, oralidade remete àquilo que não é efetuado por escrito. Como procedimento comunicacional, a oralidade consente que interlocutores se utilizem exclusivamente da fala para interagir e para se expressar. A oralidade possui características próprias e obedece a um conjunto de formas e rituais (uma gramática própria) que não são previsíveis ou prontamente enunciáveis e também, por esse motivo, com efeitos nem sempre fáceis de compreender, sem um estudo sistemático. Nas organizações, ambiente do recorte espacial desta investigação, um pressuposto adotado, logo de início, foi o de que a fala é o componente que promove interação e possibilita exprimir o pensamento de modo diverso em relação ao da linguagem escrita. Há, no entanto, entre ambas, afinidades e distanciamentos suaves ou acentuados, de menor ou de maior proporção. Compreendida desta maneira, a oralidade se faz presente nas demandas dos grupos que integram a organização, na prática do diálogo, na comunicação face a face, na comunicação interpessoal, em todos eles como um meio de conduzir um processo sempre mediado pela palavra falada.

Superou-se o tempo em que o poder gerencial no ambiente corporativo era inquestionável. O gestor da nova era exerce função de líder corporativo e tem, dentre as atribuições de seu cargo, a missão, ou até mesmo se poderia dizer "a tarefa" de ouvir seus subordinados, transmitir informações e decisões da empresa de forma clara, como condição para desfrutar do respeito e da adesão de sua equipe de funcionários. Os novos tempos tornam evidente que vultosos investimentos em projetos ambiciosos de comunicação interna não terão resultado se esse aspecto não for levado em conta, pois as organizações necessitam estimular o diálogo, as interlocuções diretas e a comunicação face a face entre gerentes e funcionários para alcançar bons resultados de produção, de identidade e de negócios. 
Basicamente, hoje, a oralidade circula pelos aparatos das novas tecnologias por meio das quais as pessoas se comunicam no seu dia a dia. Este fato produziu a inquietação típica do pesquisador e gerou um segundo pressuposto: se no passado, a oralidade fora responsável pela transmissão de conhecimento humano, hoje uma eventual redução de seu emprego não significará que sua natureza tenha sido alterada. Numa cultura de acentuada informalidade como a brasileira, o uso da comunicação oral está ainda diretamente associado à natureza das interlocuções e das interações entre atores sociais. Cabe, portanto, problematizar e observar a oralidade e os atos comunicacionais originados por meio da fala para que sua função como componente natural de comunicação não seja relegada a um plano secundário. Esse é um tipo de conhecimento que fará falta no moderno ambiente organizacional.

A comunicação organizacional fixa-se nas relações públicas para materializar um relacionamento pautado em princípios como o respeito e a cooperação com o outro, e estes são valores igualmente praticados para promover as organizações perante os públicos estratégicos. Percebe-se, ao mesmo tempo, a necessidade de abdicar de formas individualistas e de se pensar o mundo, a sociedade e a missão organizacional como instâncias contíguas, pois as interações estão assentadas na tecnologia como mediadora de relações que são humanas. Diante disso, a cultura vigente valoriza organizações que constroem um ambiente comunicacional "desobstruído" e que estabeleçam uma política de comunicação radicada por relações dialógicas, as quais ganham visibilidade mediante uma oralidade aceita e adequada à sua cultura. A gestão organizacional aspira a que a comunicação com públicos cumpra a meta de apreciar o elemento humano e de participar da textura de relacionamentos persistentes e satisfatórios. Não se fala aqui de um modismo, mas sim de uma ênfase global determinada para qualquer organização que orbite nesse universo. Comunicação, nos dias de hoje, tem a incumbência de estimular a participação ativa de pessoas e organizações na dinâmica da transformação social, o que é possível mediante uma edificação conjunta entre empresas e atores sociais.

A contribuição dos interessados na comunicação organizacional e nas relações públicas terá relevância desde que os temas sejam transpostos para o campo acadêmico, inspirem estudos que os tomem como objeto e, sobretudo, que estes estudos consolidem as Ciências da Comunicação e legitimem a comunicação 
organizacional e as relações públicas como áreas híbridas e ali inseridas. Informou Prado (2011, p. 80) que a pesquisa realizada pela International Association of Business Comunicators (IABC), abordando 15 mil funcionários de mais de 70 empresas norte-americanas e britânicas, revelou as seguintes informações:

Os colaboradores valorizam a comunicação face a face acima de qualquer
outro canal, principalmente quando ela parte de seu próprio superior. Esta
pesquisa aponta que nos Estados Unidos, por exemplo, $92 \%$ das pessoas
considera seu chefe imediato como principal fonte de informações sobre a
empresa. Em segundo lugar, vêm os membros da direção da empresa, com
$51 \%$ das menções. No Canadá, $88 \%$ dos trabalhadores indica seu chefe
imediato e $55 \%$ citam também a cúpula da empresa; já na Inglaterra, as
porcentagens são de $90 \%$ e $46 \%$, respectivamente.

Concebe-se a reinserção da oralidade no campo de estudos da Ciência da Comunicação como uma forma de mediação necessária para que os sujeitos organizacionais desenvolvam interações que os tornem protagonistas no alcance dos objetivos traçados no plano global e estratégico das empresas. No contexto das organizações, esse é um fator essencial para que o papel do líder seja exercido e vença o desafio de atingir os objetivos e realizar a missão. O exercício da liderança será desempenhado com habilidade e competência se for compreendido como funciona a oralidade junto às equipes de funcionários. Competência aqui significa o conjunto de conhecimentos que sustenta a atuação do líder, cuja visibilidade decorre de sua atitude e também (e principalmente) de sua capacidade de perceber processos que subjazem a um conjunto de fatos grupais. Habilidade é entendida como a capacidade do líder para encaminhar o desempenho de sua equipe em conformidade com o que desejam os dirigentes organizacionais.

Ainda do ponto de vista da comunicação, entende-se que um líder deva desenvolver relações interpessoais e grupais e que estas serão possíveis a partir de sua habilidade para se comunicar e para resolver conflitos. A pesquisa da IABC, segundo Prado (2011, p. 80), indagou os cerca de 15 mil funcionários sobre os canais por eles preferidos para receber informações da empresa. Os dados apurados revelaram que

[...] $74 \%$ dos norte-americanos citam em primeiro lugar a comunicação interpessoal, enquanto apenas $40 \%$ citam os meios impressos. Entre os canadenses, $65 \%$ indicam a comunicação face a face. Os meios impressos ficam em segundo lugar, com $36 \%$ de citações. Na Inglaterra, $72 \%$ preferem a comunicação direta e pessoal; os meios impressos ficaram em segundo lugar, com $36 \%$ das citações. 
A habilidade para se comunicar é, portanto, um elemento da competência de um líder comprometido com a organização e com sua comunicação interna.

\subsection{Descrição de Procedimentos Metodológicos}

A complexidade trazida pelas perguntas e pelos objetivos descritos anteriormente demandou um processo sistemático e lógico inserido nas dimensões teórica e prática, de materialidade e formatação de pesquisa científica. A metodologia adotada concedeu orientações que funcionaram como "lentes corretoras" para a visão acerca do modo de enfrentar o desafio de produzir conhecimento, a partir de um novo olhar para um fenômeno do cotidiano de uma organização complexa. Do ponto de vista de análise teórica, a pesquisa deve ser uma construção de conhecimento que procede de uma etapa prática que sustenta, estrutura e esquematiza toda a investigação científica. Decidir sobre métodos de pesquisa quando o foco é o elemento humano, implica variados níveis de enfoque, como sugere Santaella (2001, p.131):

[...] na base, tem-se o nível mais abstrato do método científico em geral, no meio, os métodos particulares dos tipos de ciências e dos estratos das ciências. Este nível apresenta uma certa generalidade, pois métodos classificatórios, descritivos, exploratórios, empíricos, experimentais e outros mais repetem-se de modo relativamente similar em quaisquer ciências. Enfim, no terceiro nível, tem-se a interferência do pesquisador e de suas escolhas frente às metodologias que sua área científica lhe apresenta e as exigências que the faz o tipo específico de pesquisa que realiza.

Ampliar a visão sobre o uso da oralidade como forma de consolidar o relacionamento interno em organizações foi o recorte definido dentro do campo específico de conhecimento humano, que aqui são as Ciências da Comunicação. A pesquisa adotou um desenho de estudo exploratório por sua aptidão em descobrir como a oralidade pode dar suporte para a construção de uma relação mais produtiva de gestores com seus parceiros internos. Acreditou-se que esta relação poderia ocorrer por meio do sistema de comunicação interna vigente e há, no estudo exploratório, a aptidão para considerar aspectos variados do tema enfocado. Uma fase descritiva foi adotada pois, além do propósito imediato de obter informações sobre o tema, foram consideradas as relações entre os fenômenos nele presentes e as suas características. Observou-se, ainda, a necessidade de uma abordagem de 
pesquisa explicativa pela observação, registro e análise dos fatores presentes nos dados.

Levantou-se o estado da arte sobre a comunicação interna, a oralidade, o uso do diálogo, as interações face a face, para compreender quais aspectos e dimensões dos temas os autores mencionavam, sem prejuízo de um enfoque sobre os limites de contiguidade temporal ou geográfica. Afirma Stumpf (2006) que a revisão de literatura é uma pesquisa acionada pelo sujeito que anseia esclarecer um assunto não suficientemente investigado:

O foco de interesse será buscado na sua vida real, especialmente na vida profissional para os graduados, mas precisa ser estimulado através de um programa de leituras que indique haver um ponto obscuro que precisa ser investigado. [...] De tudo aquilo que leu, muitas ideias serão mantidas, enquanto outras poderão ser abandonadas (STUMPF, 2006, p. 53).

O desafio desta etapa foi o de conhecer estudos já produzidos e destacar o que interessasse ao assunto específico no momento de localizar o que não era considerado (re)inserir a oralidade no interior de organizações pósmodernas. A pesquisa bibliográfica percorreu uma ampla variedade de textos, muitos deles selecionados por sua capacidade de oferecer atualização e direcionamento acerca de como pensar os impactos da comunicação oral. Cuidado foi tomado no sentido de avaliar conceituações provenientes de textos não veiculados por periódicos científicos. Observou-se, nesse caso, o prestígio e a influência dos órgãos que hospedavam as publicações tidas como fonte: associações profissionais, órgãos da imprensa em suas análises de conjuntura e matérias disseminadas por outras mídias. Já os discursos interrogativos e analíticos sobre o conjunto de fenômenos que emergiu da pesquisa empírica receberam respaldo do contato crítico com autores como Bohm (2005), Larkin (2005), Staford, Vanc e White (2010), Goffman (2011), entre outros, com os quais se elaboraram os instrumentos de coleta de dados para dar voz aos informantes da pesquisa e para amplificar o poder explicativo das análises. Cumpre esclarecer que a ênfase recaiu sobre procedimentos metodológicos com maior força do que na intenção de adotar um método com exclusividade. Ou seja, o método fenomenológico recebeu destaque, como se poderá notar, porém não ultrapassou o papel a ele destinado na coleta de dados, como se descreve mais adiante. Para que as análises não se tornassem parciais e acabassem por apenas tangenciar importantes aspectos das 
questões levantadas, fez-se uma combinação, subsequentemente, com procedimentos qualitativos e quantitativos.

Os fundamentos da abordagem fenomenológica foram construtos de Edmund Husserl (1859-1938), filósofo que inspirou pensadores contemporâneos como Heidegger, Jaspers, Sartre, Merleau-Ponty. A corrente filosófica que se relaciona com a fenomenologia defende que esse método é concebido para retornar às coisas como elas são. Segundo Moreira (2002) os fenômenos permitem a observação pelos sentidos, precisam ser mensuráveis em termos da quantidade de variáveis que os definem, bem como devem ser percebidos pelo pesquisador e por outras pessoas. Coltro (2000, p. 37) conceitua a fenomenologia como "[...] um enfoque metodológico para além da modernidade" e argumenta que as ciências sociais possibilitam ao homem compreender suas próprias intenções. Ainda para o autor, o homem pode "[...] interpretar os motivos da conduta de outros homens" e para tanto, as ciências sociais fazem uma imersão no significado de fenômenos que emergem dos atos sociais, podendo valer-se do método fenomenológico para alcançar os achados de uma pesquisa científica. A pesquisa fenomenológica tem como ponto de partida a compreensão do viver e não as definições ou conceitos. Constitui-se, também, uma compreensão voltada para os significados do perceber. Trata-se do universo das ciências sociais que delimitam as pessoas e suas atividades como objeto essencial para seus estudos. Um indivíduo quando inserido em seu ambiente compartilha, interage, relaciona-se, tudo isso como experiência vivenciada porque está contida no cotidiano de cada um.

A palavra falada constituiu-se no grande diferencial na entrevista que foi adotada como o instrumento da coleta fenomenológica pela qual se optou. Atenção foi prestada à indicação de realizar-se com um número discreto de participantes e aconselhando-se uma variação entre um e 10 sujeitos informantes. $A$ pesquisa fenomenológica realizada na empresa estatal Embrapa Soja teve, como sujeitos, os seus dirigentes, somando quatro pessoas entrevistadas em profundidade. As entrevistas em profundidade realizadas oralmente, portanto de forma direta, tiveram como norte uma pauta de assuntos (Apêndice A), elaborada de modo a permitir o aprofundamento dos temas elencados para a aplicação da técnica de entrevista não estruturada. A opção por essa técnica ocorreu devido a sua compatibilidade com a postura pretendida pela pesquisadora como sugere Moreira 
(2002, p. 55) de ouvir e entender os fenômenos que surgiriam por meio da conversa travada com seus entrevistados.

Houve a preservação da flexibilidade indispensável à condução de uma pesquisa que "[...] trabalha com situações complexas, que não permitem a definição exata a priori dos caminhos que a pesquisa irá seguir" (MOREIRA, 2002, p. 57, grifo do autor). As entrevistas foram previamente agendadas com os dirigentes e realizou-se a coleta pessoalmente com os entrevistados, os quais se mantiveram à disposição durante o desenvolvimento integral do encontro e concentrados exclusivamente na entrevista concedida. Os respondentes autorizaram a gravação em áudio das entrevistas, pois compreenderam as características do método fenomenológico que tem foco na reprodução literal das palavras ditas pelo sujeito da pesquisa. Entenderam também que, após as respectivas transcrições, elas constituem os conteúdos ou o objeto da análise fenomenológica que será apresentada em capítulo específico.

Uma segunda etapa da pesquisa empírica foi desenvolvida, agora, com a ajuda dos preceitos do interacionismo simbólico, conforme definiram George Herbert Mead (1934) e Herbert George Blumer (1969). O interacionismo simbólico é apresentado por Moreira (2002, p. 47) como uma configuração que pode estudar os modos como as pessoas "[...] enxergam o sentido nas situações que vivem e dos modos segundo os quais elas conduzem suas atividades, em contatos com outras pessoas, numa base cotidiana". Buscou-se "auscultar" os discursos presentes no dia a dia dos sujeitos da pesquisa dentro do seu local de trabalho, pois é internamente à empresa que os gestores vivem a prática profissional, experimentam e convivem com fenômenos comunicacionais impactantes nas rotinas internas, nos relacionamentos e em seu próprio processo de gestão junto a suas equipes de empregados. Repousa no interacionismo simbólico a noção de que as pessoas se reúnem em grupos, comunicam-se, atuam, interagem para construir sentidos mutuamente. "O interacionismo simbólico, pois, vê o sentido como produto social, como criação que é formada através de atividades definidoras das pessoas à medida que interagem" (MOREIRA, 2002, p. 49).

Elencada por interacionistas simbólicos como das principais técnicas de pesquisa qualitativa, adotou-se a entrevista em profundidade com questões semiestruturadas em um roteiro (Apêndice B) construído e enriquecido a partir dos 
achados da pesquisa fenomenológica. A entrevista semiestruturada, como informa Triviños:

"[...] parte de certos questionamentos básicos, apoiados em teorias e hipóteses que interessam à pesquisa, e que, em seguida, oferecem amplo campo de interrogativas, fruto de novas hipóteses que vão surgindo à medida que se recebem as respostas do informante" (TRIVIÑOS, 1990, p. 146).

Elaboraram-se questões sequencialmente organizadas, mas com possibilidades de o entrevistado suplantá-las, complementá-las ou inserir novas abordagens, com base na sua própria experiência a respeito do tema uso da comunicação oral e da comunicação interna na gestão de pessoas. Foram convidados a participar os gestores de nível tático na empresa que são os supervisores de equipes formalmente designados na estrutura administrativa da empresa. A decisão pela pesquisa qualitativa, nesta fase, ocorreu porque era objetivo investigar a aplicabilidade da comunicação oral e do diálogo entre líderes e empregados e aferir o grau em que a oralidade poderia se fortalecer a ponto de ser projetada para o campo das estratégias de comunicação interna em organizações.

Alguns sujeitos da amostra não teriam disponibilidade para conceder a entrevista direta em profundidade, condição que descaracterizava a abordagem fenomenológica. Era, no entanto, indispensável coletar dados de modo a resguardar a complexidade dos fenômenos que emergiriam das respostas dos 13 supervisores abordados como sujeitos da entrevista realizada. As questões focalizaram a percepção dos gestores a respeito da atuação dos dirigentes da empresa e de como a comunicação oral, o diálogo e a comunicação face a face eram manifestadas no contexto interno de comunicação da unidade da empresa estatal localizada em Londrina, incluindo os modelos de gestão seguidos pelos próprios sujeitos.

Para a terceira etapa, definiu-se que o método quantitativo seria necessário para alcançar os objetivos que remetiam às características da oralidade. O instrumento (Apêndice $\mathrm{C}$ ) foi construído com base no pensamento de Richardson (1989, p. 30) de que pesquisas descritivas buscam descobrir características de um fenômeno. Tanto do ponto de vista do esclarecimento que podem trazer sobre os objetivos da comunicação interna, quanto pela identificação de quais características da oralidade estariam manifestadas na comunicação interna da empresa estatal que serviu como universo para a investigação, a aplicação do método quantitativo teve clara relevância em seu papel de direcionar os achados da pesquisa. A pesquisa 
quantitativa foi aplicada junto a todos os empregados da empresa, e a definição da amostra foi do tipo não probabilístico por acessibilidade ou por conveniência. Adotou-se a recomendação de Gil (2007a, p. 104) para que a pesquisadora selecionasse elementos representativos da população a que teve acesso pois, segundo o autor, estudos exploratórios ou qualitativos são vocacionados para este tipo de amostragem justamente porque não se prendem à exatidão das análises realizadas. Da população de 235 empregados foram pesquisados 171 sujeitos que responderam a um questionário estruturado (Apêndice $\mathrm{C}$ ), construído com perguntas fechadas e, em alguns casos, abertas, para que o respondente pudesse manifestarse mais livremente.

A Figura 1 esquematiza a maneira como está concebida a pesquisa.

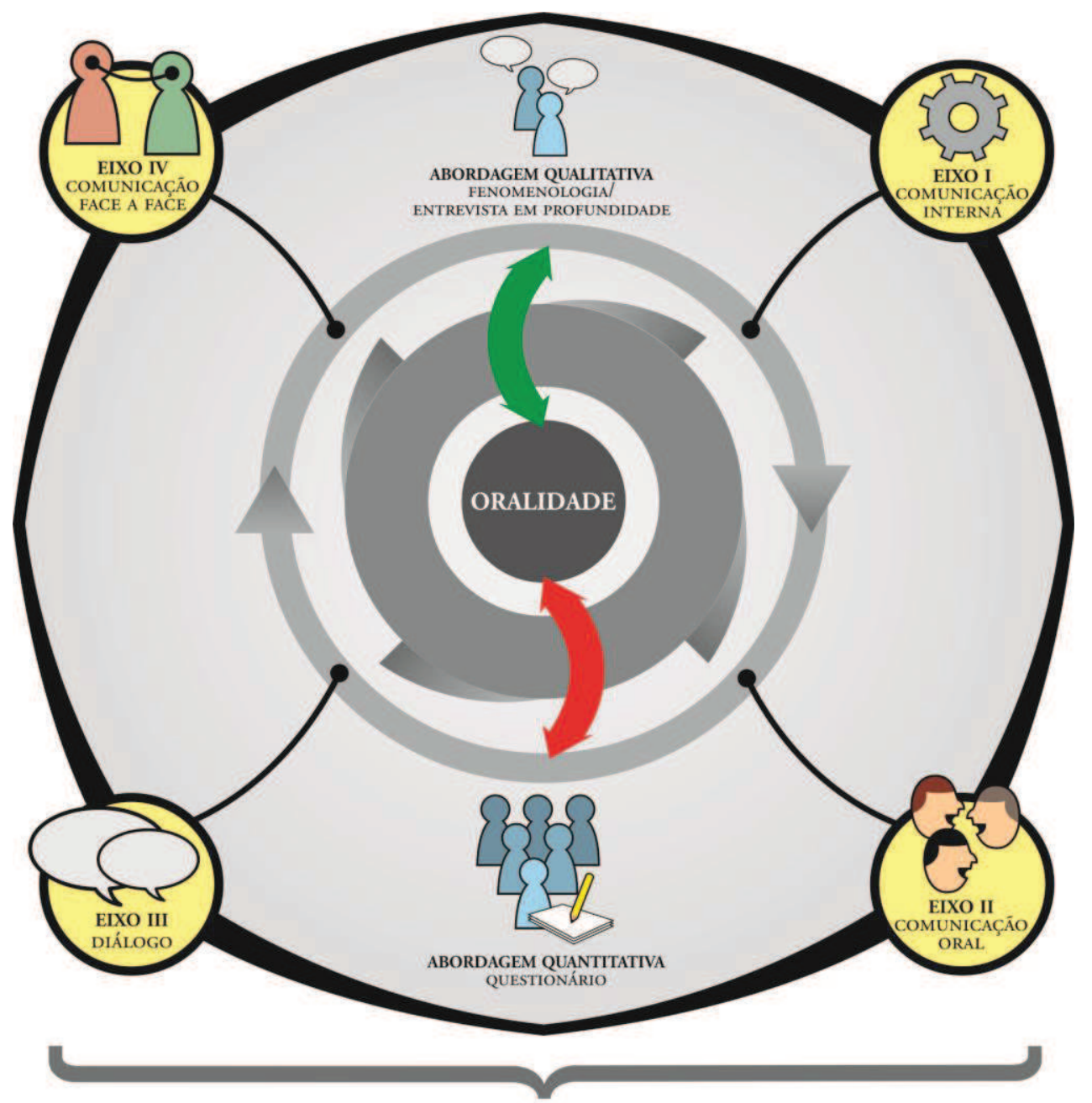

ABORDAGENS METODOLÓGICAS

FIGURA 1 - Oralidade na comunicação interna - proposta da pesquisa.

Fonte: Elaborado pela autora. 
As condutas operacionais da pesquisa foram sustentadas por um percurso no qual o contato crítico com os autores da revisão de literatura fornecesse meios para explicar o comportamento observado na empresa quanto a associar sua política de comunicação à oralidade em um plano de comunicação interna. 0 capítulo a seguir particulariza para as interfaces promovidas pela linguagem no ambiente organizacional, seus desdobramentos na comunicação interna e o modo como estabelece as condições para a realização da prática do diálogo, tópico abordado e expandido no capítulo subsequente. 


\section{INTERFACES DA LINGUAGEM NOS DISCURSOS ORGANIZACIONAIS}

Vale ressaltar que dentro do interesse deste estudo, a linguagem comparece como uma habilidade ou uma experiência de comunicação entre pessoas capaz de traduzir os conteúdos verbais e não verbais de uma língua ${ }^{1}$. Pela linguagem, as pessoas estabelecem diálogo dentro de uma perspectiva de consciência, na qual elas se convertem em participantes ativos do processo de interlocução. A interlocução pode ocorrer por meio de palavras, de gestos e da expressão facial dos interlocutores. Os discursos organizacionais difundem o que os atores expressam nas suas discussões sobre variados assuntos e quando se manifestam e opinam sobre temas de interesse às linguagens correntes em um ambiente interno, que é o das organizações onde pessoas realizam suas práticas funcionais. O emprego da oralidade como um componente e uma manifestação de linguagem no sistema interno de comunicação organizacional pode indicar aptidão para projetar a identidade da organização de modo favorável, concentrando-se no relacionamento com públicos externos e, deste modo, construir resultados interessantes para a empresa.

Atento à complexidade que marca a nova comunicação Citelli (2008, p. 14) reflete sobre a probabilidade de que "[...] uma construção técnica cada vez mais interconectada, convergente, aberta a experiências participativas, tenha de encontrar outras maneiras de trabalhar os desafios da linguagem". A articulação da existência humana ao momento em que o homem começa a falar é uma questão que precisa ser refletida. Acredita Arruda (2010) que o homem é revelado como sujeito a partir e por intermédio da linguagem que viabiliza as relações das pessoas e possibilita a "comunicação inter-humana". Ao analisar as contribuições trazidas pela teoria da linguagem e refletir sobre os vínculos existentes entre estas correntes teóricas e a comunicação, Citelli (2008), focou particularmente a linguagem verbal. Sua análise partiu da interpretação do pensamento dos conceitos de jogo da linguagem, uso e contexto, formulados por Wittgestein (1889-1951).

\footnotetext{
${ }^{1}$ Optou-se por um recorte perante a abundante literatura sobre linguagem em que se estabeleceu como foco as organizações, motivo este que respaldou a seleção das referências utilizadas nesta tese de doutorado.
} 
O pensamento filosófico de Wittgestein considera o uso da linguagem dentro dos contextos de seu usuário, portanto perpassa pelo reconhecimento de que os contextos cultural e histórico interferem na construção da linguagem do usuário. De acordo com John Langshaw Austin (1911-1960) a linguagem é capaz de promover ações, pois a teoria trata dos atos da fala e de enunciados que podem ser constatativos e performativos, conforme levantou Citelli (2008). O interesse particular desta abordagem teórica para a presente tese recai sobre os enunciados performativos devido ao seu uso no ambiente das organizações. Com base em Austin, sob o ponto de vista das ordens e determinações ocorridas pelos atos da fala, pode-se concluir sobre a possibilidade de se revelar o nível do poder de decisão entre os participantes de uma interlocução, dentro de um contexto de relações no trabalho. "Em síntese, a visão performativa da linguagem alimenta a perspectiva de que os atos da fala buscam produzir, junto aos co-enunciadores, efeitos e resultados" (CITELLI, 2008, p. 19).

Parece oportuno traçar uma analogia com a constituição elementar de uma organização, porque os atos da fala poderiam ser meios para que objetivos comuns fossem alcançados pelos constituintes organizacionais. A visão performativa é um padrão de linguagem que sustenta interações entre organização e empregado, considerando-se que esses diálogos promovem engajamento das partes com um sistema organizacional interno de comunicação.

A reflexão sobre a linguagem e seu papel tanto nas relações sociais, quanto nos processos comunicacionais, remete ao pensamento de Habermas (1987 a, b) de que conflitos são dissipados através do diálogo, pois este estabelece discussões autônomas entre as partes envolvidas ou representadas de forma autêntica. Citelli (2008, p. 19) sintetiza o pensamento de Habermas (1987) afirmando que o pensador alemão tratou de "[...] administrar e encontrar planos de convivência em condições de gerar acertos estabilizadores das relações entre os sujeitos, mesmo que cruzados por interesses díspares". Na visão de Habermas (1987 a, b), é possível prescindir da linguagem como um instrumento de negociação, pois a interlocução é a política possível para se alcançar interesses particulares ou coletivos. O uso da razão prática somente será possível a partir do desenvolvimento de um agir comunicativo que se baseia no diálogo exercido pela ação organizacional de modo racionalmente orientado. 
O discurso é, pois, instância administrativa dos conflitos. [...] A linguagem é concebida, por esta via, como prática socialmente construída, alimentada pela capacidade de promover consensos a partir de movimentos dialógicos ativadores de relações intersubjetivas" (CITELLI, 2008, p. 20).

O diálogo dentro das organizações precisa ser reconhecido como uma prática social, pois a linguagem usada nestes ambientes interativos e de comunicação solicitam inteligibilidade, clareza, compreensão e co-operação para que resultados sejam alcançados satisfatoriamente. É como expressa Bakhtin (1981, p. 73) ao considerar que "[...] somente quando contrai relações dialógicas essenciais com as ideias dos outros é que a ideia começa a ter vida, isto é, a formar-se, desenvolver-se, a encontrar e renovar sua expressão verbal, a gerar novas ideias”. A variável conceitual da linguagem, pensada como prática social, terá progresso mediante os procedimentos dialógicos que sejam adotados. Está presente nas falas um conjunto de experiências de linguagem com as quais se convive, independentemente do espaço de convivência. Destacam Guimarães e Ribeiro (2010) que a relação das organizações com seus públicos propicia fenômenos da comunicação organizacional "[...] construídos mediante ações discursivas caracterizadas pelo contexto linguístico e extralinguístico, porém mais centradas na comunicação verbal oral e/ou escrita".

A interlocução presente nos atos da comunicação oral expressa também a linguagem corporal. $O$ uso da linguagem verbal oral precisa ser completado pela observação do outro e da expressão de sua linguagem corporal para que os sentimentos sejam corretamente compreendidos e compatíveis com o que se pretende comunicar, pois até mesmo quando um interlocutor decide manterse em silêncio, ocorre uma interação comunicacional, posto que esta é uma linguagem cuja dimensão é a de uma mensagem comunicada. Segundo analisam Guimarães e Ribeiro (2010) "[...] as conversações são altamente estruturadas com pessoas que têm seus turnos de fala em sequência bem organizada". Esta organização ocorre por meio de recursos verbais que intercalam momentos de fala com momentos de escuta. Os autores ainda afirmam que "[...] o ouvinte indica quando deseja falar e quando prefere continuar ouvindo". A fala efetiva a comunicação e processa a socialização, pois a cultura oral continua presente na maneira de comunicar que se utiliza nos dias de hoje. Este fenômeno se dá graças à evolução dos meios comunicativos e tecnologias da oralidade que se aprimoraram para superar limitações. O avanço tecnológico trouxe importantes transformações 
nos modos de comunicação humana, portanto se ressalta a necessidade de sistematizar um estudo acerca da oralidade que precisa estar inserida internamente à comunicação organizacional.

\subsection{Linguagem como Campo da Comunicação}

O conjunto de meios verbais e não verbais que dá suporte para as interações humanas e para a comunicação deriva do que se chama de linguagem. A linguagem legitima a comunicação dialógica e discursiva. A linguagem verbal compreende a palavra falada e a escrita, incluindo-se as características que as distinguem. O emprego da fala ocorre na comunicação oral, na comunicação face a face, como também mediante tecnologias avançadas de comunicação à distância. Há marcadores conversacionais que não se restringem aos elementos verbais e podem assumir formas não linguísticas como o riso, o olhar, a gesticulação, que "[...] exercem uma função fundamental na interação face a face, na medida em que estabelecem, mantêm e regulam o contato entre os participantes" (FÁVERO; ANDRADE; AQUINO, 2005, p. 44). Um olhar incisivo, em alguns casos, pode indicar

o encerramento de um tópico ou produzir um novo encaminhamento de conversação. O mesmo se pode afirmar com relação a pausas, alongamento e tom de voz. Pausas podem ser longas ou curtas, silenciosas ou preenchidas. Há também o ritmo, a velocidade e os prolongamentos de vogais no fim de frases. Lembram as autoras que pelo fato de investirem em uma conversação, os interlocutores agem de acordo com suas intenções, implicando disponibilidade para negociar, abrandamento de posição, proposta de oferta para uma consideração, dentre outros fatores. Com isso buscam construir um evento comunicativo no qual a mútua cooperação interativa é necessária e esses marcadores ajudam a estruturar.

Comunicação, termo plural e multifacetado, possui correntes que vinculam seu significado à circulação e transmissão de informação; ao discurso e ao conjunto de informações construídas por um agrupamento humano, ou ainda, comunicação como um meio para realizar ações (CASALI; TAYLOR, 2010, p. 73). Este último significado parece bem adequado ao estudo da comunicação organizacional, exatamente porque insinua a transposição de limites para o fenômeno comunicacional. Comunicação despertando ação é a forma pela qual os atores sociais textualizam seu cotidiano. 
Considerar a comunicação como um conjunto de jogos de ações dialógicas central aos seres humanos, deve-se levar em conta que os significados linguísticos são também combinados aos significados cognitivos e perceptuais, nos conduzindo à visão de que mundos diferentes fazem parte dos jogos de ações (BERWIG; GODOI; RIBEIRO, 2010, p. 4).

A abordagem sobre linguagem e comunicação apresentada por Motter (2002, p. 30), com foco na linguagem verbal, estabelece que a gestão da comunicação deve ser compreendida como análise, diagnóstico, intervenção e avaliação. A gestão também presume a capacidade de ver, sentir, compreender, além do uso de métodos e técnicas que permitam avaliar, cientificamente, situações concretas. Gestar para a autora significa propor soluções adequadas para eventuais problemas ou para aperfeiçoar as relações comunicacionais que permeiam o cotidiano do trabalho, as quais são mediadas por linguagens de caráter técnico e pelas tecnologias. Motter (2002) introduziu um olhar no qual propõe esclarecer o gestor da comunicação sobre a relevância da linguagem verbal na sua rotina, seja no âmbito profissional ou no pessoal.

Nenhum impedimento emerge da natureza da linguagem que limite o uso da palavra, conforme sentimentos e desejos do emissor da comunicação. Contudo, as diferenças entre as palavras e a realidade causam reflexos no modo como os interlocutores fazem estas distinções e interpretam as palavras faladas e escritas. As palavras dão forma às ideias e aos objetos, porém as imagens mentais formuladas pelo receptor podem diferir em muito do que pretendia quem estimulou o processo comunicacional. Estudos da linguagem se relacionam com o campo da comunicação organizacional e se integram dentro de um ponto de vista interdisciplinar.

A interação entre os seres humanos dentro de uma cultura e de seus objetos faz com que se desenvolvam motivos e percepções entre os interlocutores, que compartilham e criam entendimentos comuns, promovendo o diálogo entre as consciências por meio da linguagem (GODÓI; RIBEIRO, 2009, p.161).

Godói e Ribeiro (2009) analisaram estudos linguísticos e elaboraram conclusões que permitiram afirmar que comunicação tem interface com avaliação contínua e negociação de significado entre os interlocutores. As autoras mencionam a descrição básica da linguagem como uma escolha sustentada pelo tripé variabilidade, negociabilidade e adaptabilidade. Ao revisarem os conceitos da comunicação organizacional, Godói e Ribeiro (2009, p. 189) identificaram a existência de termos recidivos entre os mencionados pelos estudiosos do tema e 
isolaram as constantes contexto, significado e ambiguidade para nortear sequencialmente a pesquisa. Desta reflexão concluíram que um enunciado pode tomar sentidos associados ao contexto onde é empregado, porém nenhum comprometimento grave ocorrerá porque uma mesma palavra poderá ter um sentido distinto, contudo será traduzida em acordo com o contexto no qual estiver inserida.

A contribuição trazida para a comunicação organizacional por Halliday (2009) relata o percurso de seus estudos sobre a retórica de legitimação, a partir da análise do discurso, hoje disseminada sob o termo análise retórica. Percorreu temas como os objetivos organizacionais, discurso e imagem empresarial e retórica da transcendência que significa o discurso das empresas acerca de questões ambientais, associadas à responsabilidade social e à cidadania. A autora define o termo análise retórica como "[...] um instrumento de pesquisa crítica da comunicação que envolve a descrição, análise, interpretação e avaliação de atos retóricos. É definido como ato retórico todo evento comunicativo gravado em forma escrita, oral ou audiovisual" (HALLIDAY, 2009, p. 43).

$\mathrm{O}$ roteiro de pesquisa da autora compreende quatro fases a saber: análise extrínseca, que se refere ao levantamento e descrição dos antecedentes do ato retórico; análise intrínseca, que se refere aos usos de linguagem; interpretação do ato retórico, que se refere à explicação do discurso; e avaliação, a qual se realiza mediante um parecer crítico sobre o ato retórico. Note-se que os fenômenos estudados pela metodologia sugerida por Halliday (2009) são similares àqueles que Motter (2002) recomenda que sejam observados pelo gestor comunicacional, portanto as estudiosas confirmam o foco de interesse do presente estudo como um conhecimento original que pode ser somado aos estudos da comunicação organizacional no Brasil, visto que a oralidade prevê a análise da linguagem e dos discursos, neste caso, que permeiam as relações internas de uma organização.

A linguagem compreendida como mediadora entre o ser e o mundo participa da produção e da compreensão dos discursos sociais, "[...] diz mais do que aparenta o simples falar presente nas relações de sujeitos que dela fazem uso para suas trocas cotidianas. Ela é um índice de classificação social, define instâncias de poder, revela conflitos e ideologias" (MOTTER, 2002, p. 32). Segundo a autora, a linguagem verbal não se ocupa de desvendar mentiras ou de reproduzir verdades, nem daquilo que os discursos querem fazer crer que dizem. 
A palavra constitui-se de um signo carregado de uma pluralidade de significado que se reproduz no interior das relações grupais e é absorvido isoladamente pelos sujeitos que as compõem. As palavras falam sobre quem as pronuncia, denunciam a visão de mundo de uma pessoa, seus princípios e ideologias. Um indivíduo desempenha papéis distintos nos grupos sociais dos quais participa, além do que cada grupo contém um conjunto de significados diferentes, muitas vezes para os mesmos signos. Deste modo, o indivíduo pode se mostrar autômato e não mais autônomo ao se distanciar da autonomia que caracteriza o ser humano. O homem pode tornar-se um ser alienado aos papéis que se vê obrigado a assumir, até mesmo em função de uma hierarquia de poder, portanto não se trata exatamente da alienação presente na estrutura da vida cotidiana, mas sim, das condições nas quais se realiza. Pensando paralelamente a estas variáveis, Freitas e Garcia (2008) estudam as paixões para analisar os relacionamentos entre uma organização e seus públicos de interesse, como pode ser observado na seguinte afirmação:

Há uma vasta área a ser explorada pelos trabalhos de comunicação que leve em conta a dimensão passional dos discursos, seja na comunicação dos discursos institucionais dentro dos limites das organizações e seus públicos, seja em sentido mais amplo, abarcando os meios de comunicação de massa ou recaindo sobre a chamada Comunicação Integrada nas organizações (FREITAS; GARCIA, 2008, p. 121).

Reflexões sobre o cotidiano sugerem que o conhecimento sobre a linguagem, sobre as interações contidas em seu uso e sobre os discursos por ela construídos desenham a visão de mundo e o modo de agir de um indivíduo. A linguagem é uma mediação que projeta a própria realidade, ou seja, ela é a mediação entre o homem e o mundo, como analisa Motter (2002) a partir de Bakhtin, defensor do caráter dialético da linguagem.

Remete-se a lasbeck (2009) ao afirmar que etimologicamente discursar e discorrer são praticamente sinônimos. O autor analisa a presença de textos verbais, escritos e falados no discurso empresarial, o qual, segundo afirma, pretende conquistar simpatia e confiança dos públicos sobre uma dada organização. Fica evidente a construção de uma tríade interdependente composta pelo discurso, identidade e imagem que emerge da linguagem praticada pela organização e por seu público interno, cujo apelo da oralidade é naturalmente difundido. Filósofos criadores de persistentes correntes teóricas sobre linguagem como Austin, Bakhtin e Habermas, por certo inspiraram a defesa sobre a importância "do outro" nas relações 
organizacionais. O pesquisador compreende "o outro" não somente como os públicos externos, pois se refere a "[...] quem recebe o discurso empresarial, lê e interpreta os textos que a organização produz" (IASBECK, 2009, p. 28).

\subsection{Linguagem e Discurso nas Organizações}

A linguagem absorve influências socioculturais que muitas vezes norteiam a criação do vocabulário de grupos sociais que desenvolvem suas formas de comunicação. A oralidade configura a comunicação que ganha eficiência somando fala e linguagem adotada para bem estabelecer relações interpessoais. A predominância dos discursos da comunicação administrativa ressoa sobre a comunicação interna que deveria estar focada mais em pessoas do que em processos nos dias de hoje. Considerada como espaço de diálogo, a comunicação organizacional necessita de uma política, cuja tradução de discursos seja capaz de criar relacionamentos e projetar uma reputação corporativa esteada pela confiança dos públicos estratégicos. ${ }^{2}$ A natureza política dos processos dialógicos e relacionais de organizações com seus agentes foi analisada por Oliveira (2009) ao considerar que estas são relações que caracterizam a organização, intervêm em sua existência e constituição. Os espaços de diálogo são defendidos como meios para alcançar entendimento e para dar ênfase aos valores praticados pela organização. Pensados deste modo, os processos dialógicos e relacionais provocam impactos na reputação da empresa dando-Ihe a possibilidade de ser fortemente positiva, pois a negociação adota o sentido de convencimento discursivo. "No modelo em questão, a interlocução da organização com os demais atores sociais pressupõe argumentação, troca e diálogo" (OLIVEIRA, 2009, p. 327).

De acordo com o que apresenta Kunsch (2003), políticas, estratégias e programas de ação são construídos dentro de um plano de comunicação interna que vise à interação efetiva entre a organização e seus empregados. Um plano estratégico de comunicação interna contempla uma abordagem sobre a importância do líder como interlocutor de informações e sobre a

\footnotetext{
${ }^{2}$ Esta área vem merecendo destaque nos estudos da comunicação organizacional, conforme consta na revista "Discurso institucional, linguagem e retórica", tema da Organicom: revista brasileira de comunicação organizacional e relações públicas, São Paulo, Ano 5, n. 9, 2.sem. 2008. Outro fator de relevância científica foi o VI Congresso da Abrapcorp, São Luís - MA, 26 a 28 abr. 2012, com o tema "Comunicação, Discurso, Organizações".
} 
questão da retórica utilizada pelas lideranças organizacionais. A argumentação eliciada por um líder centra-se na oralidade e por ela pode-se explicar a comunicação. O contexto apresentado corrobora a consideração de elementos de ordem afetiva e de ordem racional que sustentam o campo do pensamento científico denominado retórica.

Como ordem afetiva tem-se o Ethos, cujo caráter remete particularmente ao orador e a sua credibilidade. Outro elemento de ordem afetiva é o Pathos, que se refere ao conjunto de emoções que o orador desperta na audiência. Avançando na mesma linha de raciocínio chega-se ao Logos, que diz respeito à argumentação do discurso, no que se refere à palavra falada. O caráter estratégico de um discurso organizacional está condicionado ao equilíbrio entre o discurso e as ações praticadas, embora estudiosos como Halliday (2009) defendam que esta dicotomia não se aplica, posto que discurso é ação. O aspecto que se vem formulando até este ponto fundamenta-se neste mesmo princípio, visto que a proposta é estudar as dimensões da oralidade que lhe permitam alcançar a aspiração da comunicação interna estrategicamente nela focada.

Nesta perspectiva humanizada da comunicação interna, Roman (2009) analisou os discursos organizacionais e destacou aqueles que se estabelecem paralelamente à comunicação institucional da organização, expressos por falas e escritos dos funcionários e de seus gerentes. Fazem parte da análise do autor os rumores e variados tipos de mensagens comunicacionais, cujo apelo fuja deliberadamente do controle da administração. Considerados pelos dirigentes ameaças ao clima organizacional, esses discursos contribuem com a pluralidade de enunciados que podem ser aplicados como estratégias de comunicação interna em organizações pós-modernas. Segundo Roman (2009, p. 127), “[...] se os novos modelos organizacionais fundamentados em redes ampliaram as possibilidades de interação além dos limites físicos e geográficos, a robotização, por sua vez, melhorou as condições das interações presenciais". A mesma robotização estimulou maior qualidade para a permanência do trabalhador em seu ambiente de trabalho, pois hoje o contato com maquinário e ferramentas mecânicas está reduzido dentro das organizações. Roman (2009, p. 128) declara sua inspiração em Bakhtin porque concebe a comunicação como um "[...] processo dialógico de estabelecimento de relações, e não apenas de transmissão de informações". Esclarece ainda o autor que a comunicação é um fenômeno intenso que desperta sentimentos transpostos 
para relações internas, as quais podem configurar-se em relações de afeto, de ódio ou de hostilidade, exatamente porque este é um fenômeno processado por pessoas.

A análise metateórica relata que o discurso é um meio para a interação social, portanto o estudo da linguagem nos processos interativos é inerente. Outra linha de pensamento analisada compreende os discursos como formas de fala e textos sociais, porém Fairhurst e Putnam (2010, p. 109) declaram sua concordância com as análises da comunicação como um construto relacionado ao discurso, "[...] que inclui pesquisa fora dos estudos do discurso, como por exemplo análise de redes de relacionamento, processamento de informação e de fluxo de mensagens". Roman (2009) explica sua compreensão sobre enunciado e discurso, pois trata os conceitos indistintamente. Para ele, o enunciado refere-se ao texto verbal produzido dentro da organização, oral ou escrito, com uma intencionalidade particular e o conjunto de enunciados constitui o que é nomeado de discurso organizacional. Por serem providos de uma polifonia discursiva, os discursos foram classificados em "bem-ditos, mal-ditos e não-ditos". Explica Roman (2009) que os discursos bem-ditos, independentemente de serem orais ou escritos, são a "voz" da organização oficialmente divulgada pela sua rede de comunicação. Os bem-ditos "definem, orientam e determinam", embora eles possam circular pela rede informal. Conforme esclarece Roman (2009, p. 131) os bem-ditos ainda abrigam enunciados que permeiam as relações interpessoais "[...] entre os funcionários, sobretudo entre os gerentes e seus funcionários, com temas de interesse do serviço". Entenda-se que nestas relações, o destinatário da comunicação é o funcionário dentro de uma perspectiva de relacionamento de trabalho com a organização emissora.

Os discursos mal-ditos circulam à margem da comunicação institucional. Seu estilo de composição, afirma Roman (2009, p. 131) "[...] reproduz a estrutura frasal da oralidade, com formatação descuidada e até mesmo relaxada". O impacto inicial na leitura do verbo dizer antecedido do adjetivo mal, que compõem a expressão "mal-dito", levam a pensar em outro objeto de estudos, sobre o qual Berwig, Godoi e Ribeiro (2008) se debruçaram e cujo tema foi o mal-entendido nas interações comunicativas. As pesquisadoras concordam que a comunicação seja um processo complexo e partem do pressuposto de que a compreensão de um discurso tenha implicações variadas que podem levar os interlocutores ao malentendido. Como nos apresentam Berwig, Godoi e Ribeiro (2008), mal-entendido 
recebe denominações como "má-comunicação" ou "falha pragmática". A compreensão que interessa a este estudo é que o mal-entendido resulta de formas específicas de interação as quais, por sua vez, podem causar um mal-entendido. Analisa-se, aqui, que a oralidade adotada nas interlocuções necessita da atenção redobrada dos interlocutores para não se embrenharem pelos caminhos dos malentendidos que, seguramente, trarão ecos no complexo da comunicação sob a forma de ruídos ou boatos sabidamente prejudiciais ao fenômeno da comunicação humana.

Os discursos mal-ditos são os enunciados contidos na comunicação informal, cujas interlocuções ocorrem entre sujeitos participantes de um mesmo grupo de relacionamento, porém nem sempre geram mal entendimento dos interlocutores. Seus enunciados não se utilizam dos canais de comunicação oficiais, portanto qualquer pessoa dentro da organização pode ser produtor e participante destas interações espontâneas e informais. Eis o motivo pelo qual desperta tanto temor nos dirigentes a ponto de ser encarado como uma ameaça ao clima organizacional. A característica marcante dos mal-ditos é a capacidade de estreitar as relações entre as pessoas, pois o surgimento destas interações parte do sentimento de confiança no outro. "O bem-dito traz uma versão da realidade. O maldito, por sua vez, traz uma sub-versão da realidade" (ROMAN, 2009, p. 134, grifo do autor). Quando os mal-ditos sofrem algum impedimento para sua expressão espontânea, tem-se os discursos não-ditos.

As interações são atos de sociabilidade e representam processos de enviar mensagens e conversar. É o "fazer" do discurso organizacional, em que o texto é "[...] 'o feito' ou a representação material do discurso em formas faladas ou registradas" (apud FAIRHURST; PUTNAM, 2010, p. 110). A oralidade capacita as pessoas a empregar processos sofisticados de comunicação oral que pode ser espontânea ou planejada, desde que siga uma concepção etimológica que a leve a ser compreendida como um termo vinculado à comunicação "[...] à noção de discurso e à construção de um conjunto de conhecimentos comuns a uma comunidade" (CASALI; TAYLOR, 2010, p. 73). Dentro deste contexto é possível estabelecer a organização como um organismo discursivo, uma macro questão possível somente pelas interações e pelas interlocuções que esta organização estabelecer com o ambiente e que permearão seu espaço interno. O capítulo a seguir pensará esse espaço como território propício ao diálogo. 


\section{A ORGANIZAÇÃO COMO TERRITÓRIO PARA O DIÁLOGO}

O empenho para acompanhar as tendências que promovam a aprovação de organizações pela sociedade, impulsiona estudos organizacionais que se desenvolvem em diferentes níveis de motivação. Um atributo relevante nos estudos organizacionais é seu caráter atemporal, contudo sua inspiração provém das demandas administrativas. O diálogo entre opostos na atualidade, longe de ser uma tendência é um desafio, pois os paradigmas são constructos reais e históricos da sociedade, berço das contraposição entre temas que convivem com as rotinas dos atores sociais. Confrontam-se inquietações coletivas e individuais, engenhosidade e produtividade, demanda e competitividades, todos campos usuais para a comunicação interpessoal e dialógica. Nos espaços organizacionais desenhase a complexidade que impacta diretamente na gestão e no gerenciamento.

Novas capacidades administrativas ganham relevância, algumas delas flutuantes nas organizações e escoltadas pela informalidade das interações entre seus atores. É função da teoria empreender soluções nem sempre novas, mas inovadoras, para problemas que também podem estar marcados por um caráter atemporal e persistente. A reflexão de filósofos, sociólogos e tantos outros pensadores da evolução da sociedade escoram a estrutura atual das organizações que exige precisão para definir paradigmas corporativos, fenômeno que cristaliza a relevância dos estudos organizacionais. Incursionar sobre o que pensam Pross (1971), Bakhtin $(1981,1986)$ e Chanlat e Bédard (1996) abre horizontes para análises aprofundadas à respeito do processo de construção e representação do mundo moderno.

\subsection{Tradição e Pós-Moderno: Conjunção Dialógica}

O jornalista alemão Harry Pross (1971) propôs uma teoria que rompeu os limites da teoria da comunicação e trouxe um enfoque sobre os estudos necessários a respeito de procedimentos que comportavam interação humana em sua essência. A teoria da mídia apresentou uma nova classificação que propunha o sistema de mediação como meio para instalar processos comunicacionais. 0 sistema de mediação foi classificado em mídia primária, secundária e terciária. 
Nesta teoria, Pross (1971) distinguiu procedimentos comunicacionais de suportes técnicos de comunicação, portanto sua abordagem considera a interferência que a cultura provoca nos processos. Trata-se de uma abordagem humanística que considera o corpo (mídia primária) como o meio mais primitivo e essencialmente necessário para as interações humanas e é, portanto, uma teoria que dá suporte para o estudo da oralidade na comunicação interna. A compreensão do corpo como forma primária de interação coexiste com a evolução da humanidade. Para Baitello Junior (2011 a, b) o corpo é uma mídia que antecede a máquina, um texto que transcende a escrita verbal e é um código de comunicação humana.

A supervalorização da tecnologia para mediar e dar visibilidade ao que habita o universo é uma controvérsia debatida desde o século passado. Pela voz de Pross (1971), tinha-se o chamado para o corpo como suporte natural de comunicação e como mídia primária, na qual o indivíduo é a própria mídia. O corpo com "suas muitas e múltiplas linguagens", com frases e vocábulos corporais, é a mediação indispensável para haver interação de um ator social com outro interlocutor. "Toda comunicação humana começa na mídia primária, nas qual os participantes individuais se encontram cara a cara e imediatamente presentes com seu corpo; toda comunicação humana retornará a este ponto" (PROSS, 1971, p. 128). Aponta Baitello Junior (2011b, p. 5) que a mídia primária é presencial e posiciona emissor e receptor a uma interação face a face, dentro dos limites de um mesmo espaço físico e em tempo concomitante, portanto, é a mídia do tempo presente.

Na conjunção dialógica, o pensamento de Bakhtin (1986) confirma que descobertas, pensamentos e anseios nascem da inspiração de um ator social que aspira a sair da subjetividade intrapessoal e reproduzir, em palavras, a experiência por ele vivida. A palavra é a forma primária da linguagem empregada em uma dinâmica natural de compartilhamento entre atores sociais quando mobilizados para se comunicar. Afirma Bakhtin (1986, p. 112) que a palavra é uma função do interlocutor. O meio social, do qual o interlocutor faz parte, influencia suas interpretações, sua expressão e sua visão de mundo. A análise de Bakhtin considera que qualquer palavra "[...] comporta duas faces. Ela é determinada tanto pelo fato de que procede de alguém, como pelo fato de que se dirige para alguém. Ela constitui justamente o produto da interação do locutor e do ouvinte" (BAKHTIN, 1986, p.113, grifo do autor). 
Juntamente com Bauman (2012), Feyereisen e Lannoy (1994) Bakhtin (1986) dimensiona o tempo e o espaço como determinantes da cultura e dos grupos sociais e como fatores intervenientes nas interlocuções entre os sujeitos de um grupo social. A palavra é o conector da interação entre locutor e interlocutor. É função do locutor materializar a palavra por meio de suas relações sociais. A vivência do locutor e do ouvinte, bem como a situação na qual o ato da fala acontece, desenharão a forma e o estilo para esta comunicação. Como diz Bakhtin (1986, p. 115) "[...] quanto mais forte, mais bem organizada e diferenciada for a coletividade no interior da qual o indivíduo se orienta, mais distinto e complexo será o seu interior". O diálogo é uma forma de interação verbal que pode ser compreendida "[...] não apenas como comunicação em voz alta de pessoas colocadas face a face, mas toda comunicação verbal, de qualquer tipo que seja" (BAKHTIN, 1986, p. 125).

Afirma Baitello Junior (2011a) que a capacidade criativa do homem, somada à sua natureza inquieta e insaciável, projeta a necessidade por novas formas de comunicação potencialmente concebidas para expandir o alcance da comunicação possível através da mídia primária. O quadro de mediação avança para o uso de aparatos extracorpóreos do emissor a exemplo da fotografia e de outras imagens, da escrita e dos impressos que constituem, dentro da classificação proposta por Pross (1971), a mídia secundária. Essa mídia agrupa veículos de transmissão de mensagem pelos quais o emissor envia mensagem por tempo mais dilatado e com espaço ampliado. A interpretação do receptor não depende diretamente do impacto da mídia secundária para ser processada.

O avanço da comunicação trouxe a mídia terciária capacitada para atender as precisões tanto do emissor, quanto do receptor elencando variadas mídias derivadas de tecnologias de comunicação cada vez mais avançadas. A evolução de qualquer área não significa afirmar que“[...] o mais moderno suprime o mais antigo", conforme alerta Baitello Junior (2011a, p. 4), pois "[...] qualquer sistema de comunicação conterá necessariamente em seu âmago a interação entre dois corpos".

Afirmam Feyereisen e Lannoy (1994) que as interações humanas expressas pela aparência física e pelos movimentos corporais são linguagens que transcrevem o modo como seus atores agem na sua vida social. No decorrer da evolução da humanidade, a expressão corporal tornou-se objeto de estudos para 
teóricos da comunicação e recebe ainda hoje uma crescente atenção dos profissionais da área. Segundo apontam, um ator social ultrapassa o uso da palavra pela gesticulação que pratica durante o ato comunicacional. Os gestos variam de acordo com a localização geográfica, com o caráter social do momento comunicacional, bem como de acordo com o espaço temporal no qual ocorrem, portanto, traduzem características até mesmo da língua falada por um dado grupo cultural.

A partir da analogia entre gesto e língua, torna-se possível analisar a gesticulação dentro da perspectiva da linguagem oral, pois a língua falada pelo indivíduo pode ser considerada como uma manifestação de sua cultura e como um indicador da sociedade a qual pertence. "A cultura pode influenciar os comportamentos regrando as condições de sua utilização, prescrevendo ou reprimindo, por exemplo, sua manifestação pública" (FEYEREISEN; LANNOY, 1994, p. 21). Há culturas que usam mais os gestos do que outras, contudo não se pode negar que os gestos sejam um artifício que podem tanto reforçar o que é dito pelas palavras como as contradizer, posto que sinalizam as emoções e as contradições de quem se expressa pela palavra falada. Ponderam os autores que a expressão corporal sugere um modelo social ou um conjunto de regras sobre o qual isoladamente um sujeito pode não ter consciência e que compõe o que os autores nomeiam como "inconsciente coletivo". Neste particular, Feyereisen e Lannoy (1994, p. 22) recorrem à visão de Goffman sobre toda interação social como "[...] um jogo, um teatro em que o indivíduo busca, através do comportamento, controlar as representações, as imagens que dele os outros fazem".

O diálogo é uma alternância entre os papéis de locutor e de ouvinte. Durante as interlocuções, a linguagem gestual marca o compasso para o uso da linguagem oral e assim alterna a fala dos atores participantes daquele ato comunicacional. 


\subsection{Estudos Organizacionais: Consequência da Tecnologia, Globalização e Mudanças Culturais}

Estudos organizacionais, segundo Casali (2005) representam “[...] uma das áreas mais produtivas em pesquisa (nos Estados Unidos e no Canadá) nos últimos anos" e a Escola de Montreal é referência desses estudos. Casali (2005), Taylor (2005), Fairhurst e Putnam (2010), Mumby (2010), Taylor e Casali (2010), entre outros, situam este movimento como consequente da tecnologia, da globalização e das mudanças culturais. Afirmam, portanto, os reflexos que fatores analisados no presente estudo provocam inclusive na produção de conhecimento com o surgimento de novas correntes teóricas que dialogam entre si, ao mesmo tempo em que reformulam ou constroem novos paradigmas. Em qualquer tempo, a comunicação face a face permitiu a comunicação não verbal e seu retorno foi imediato, daí vem a riqueza deste modelo como um veículo de comunicação interna.

O processo pelo qual se deu a evolução social implicou na aceleração de procedimentos que atendessem às demandas do desenvolvimento humano e, nesse impulso desenfreado, houve uma depreciação do valor característico da vivência social que são as relações humanas. A história das negociações de troca surgiu em pequenas comunidades, com base essencialmente relacional, posto que os produtos eram deliberadamente similares. A aquisição ou processo de compra era fundamentada na escolha de uma pessoa que inspirasse a outra a de si comprar. A inspiração ocorria porque a pessoa compradora identificava valores na pessoa vendedora que eram definitivos para a decisão de compra. Afinidade e relacionamento pessoal historicamente compõem decisões que permeiam o universo organizacional, inclusive com impactos diretos sobre o consumo.

Anteriormente à organização sistemática dos processos produtivos e à legitimação de diferentes formatos de organizações, as decisões por comprar de um vendedor específico ocorriam porque a pessoa era mais aceita que outra, ou seja, porque tinha melhor reputação, então, fazia melhores negócios. Hoje as organizações são representações de pessoas e esse contexto expõe a necessidade de se enxergarem valores pessoais nos produtos e serviços disponíveis para uma comunidade que é global. O ator social que se reporta ao atendimento de uma organização espera ouvir a voz da empresa pela fala do gerente, pois ele é a pessoa 
que representa a estrutura organizacional. Afirmam Stafford, Vanc e White (2010) que cultura organizacional refere-se à forma como os funcionários se sentem sobre uma organização, de modo que, se houver a percepção de um sentido positivo no interior da organização, este sentido contribuirá para uma cultura organizacional igualmente positiva.

O pensamento comunicacional da Escola de Montreal compõe-se de questões que encaminham para a valorização de fatores subjetivos, pois suas pesquisas delimitam organizações cujo valor atribuído equilibra questões linguísticas e materiais. Taylor (2005) afirma ser impossível imaginar uma organização sem comunicação e seu pensamento elucida o próprio pensamento da Escola de Montreal. Apresenta uma abordagem interpretativa da comunicação organizacional, e seus principais estudiosos defendem que os indivíduos são tanto sujeitos quanto objetos das organizações, pois são eles que as criam, bem como o ambiente onde elas atuam. A organização recebe uma abordagem centralizada nas ações e palavras das pessoas, mas em conjunto com a tecnologia, com a arquitetura e com a junção de objetos. Na perspectiva da Escola de Montreal, o grupo de componentes de uma organização somente a constitui se estiver organizado conjuntamente e entrelaçado pelas vias da comunicação.

As organizações se expressam através das ações e palavras das pessoas que as constituem, pois

[...] se as pessoas quiserem cooperar (isto é literalmente "trabalhar juntas"),
precisam ser capazes de criar algo em comum: alguma coisa que surja de
suas discussões e ações mútuas, em vez de algo que seja transmitido por
uma autoridade a outros que se limitam à condição de instrumentos
passivos (BOHM, 2005, p. 30).

Os seguidores da Escola de Montreal, a exemplo de Casali e Taylor (2010, p. 69) defendem que "[...] o processo da organização emerge da comunicação". A essência dos estudos organizacionais da Escola de Montreal parte de uma perspectiva comunicacional, cuja dinâmica é traduzida como textoconversação. Taylor e Casali (2010, p. 75) relatam focar seus argumentos "[...] em como a realidade é construída nas conversas cotidianas dos indivíduos à medida que estes realizam suas tarefas diárias". O texto foi analisado como o agente conector das pessoas, de suas conversas e de suas tarefas. É da natureza dessas conexões a ação de textualizar: "[...] o texto é a ponte que passa por cima do abismo entre as conversações, isto é, entre situações localizadas de interação. Um texto é 
gerado na comunicação e então, subsequentemente, instrui as conversações das diversas comunidades da organização (CASALI; TAYLOR, 2010, p. 77).

O modelo texto-conversações refere-se ao modo e ao meio como se constituem as organizações. Corresponde às conversações cristalizadas, nas quais o orador do texto é transformado em ator. Segundo o modelo texto-conversações "[...] conversações se transformam em textos e textos são traduzidos em conversações" (CASALI, 2005, p. 35).

O estudo desenvolvido por Stafford, Vanc e White (2010) buscou levantar o senso de comunidade dentro de uma organização e a relação entre essas percepções e a vontade do empregado de defender a reputação do organismo no qual trabalha. Quando questionados sobre comunicação e relacionamentos, os administradores manifestaram a necessidade de perceber uma ampla oportunidade para a comunicação face a face, para a interação interpessoal, especialmente com Chief Executive Office (CEO) e com seus pares, quando lidam com questões estratégicas. Os administradores reconheceram a comunicação interpessoal e a interação face a face como oportunidades únicas para construir o seu senso de comunidade. A investigação de Stafford, Vanc e White (2010) se estendeu por todos os níveis da organização e constatou a importância dada às interações pessoais através da comunicação direta e face a face entre funcionários e CEO, bem como contribuiu tanto para o "espírito de comunidade", quanto para que funcionários se sintam importantes para a organização. Pode ser entendido, ainda pelo estudo de Stafford, Vanc e White (2010), que o CEO é uma fonte de informações confiável, portanto uma fonte fértil para a ocorrência de textos-conversações.

A teoria da co-orientação, construção teórica fruto dos estudos desenvolvidos em Montreal, assume que 0 uso da linguagem constitui a organização. Compreende que a organização esteja na interpretação de suas atividades, dentro de uma perspectiva que pode ser dita dialógica. A contribuição dessa Escola está na inserção de métodos relativistas para interpretar os significados das ações sociais sob a ótica de seus próprios atores. A necessidade crescente de conhecer mais do que assuntos estruturais ou burocráticos sobre as organizações é sentida igualmente por estudiosos brasileiros que reconhecem o valor científico dado à comunicação pela Escola de Montreal, pois como lembra Vilaça (2010, p.1): 
Embora tenhamos consciência de que as mudanças no mundo impactaram nossa forma de ver as organizações e os atores nela insertos, e que as diferenças culturais levariam-nos a buscar soluções diferenciadas para nossos problemas e conflitos, os grupos de pesquisa nacionais ainda se constituem tendo como balizadores os estudos teóricos de autores estrangeiros.

A discussão metateórica de Fairhurst e Putnam (2010) ratifica o argumento de Vilaça (2008) e se apresenta bastante apropriada para a presente tese, no que tange à análise das organizações como construções discursivas. A metateoria analisa três eixos sobre a relação entre discurso e organização, na qual discurso e comunicação são tratados como conceitos complementares, porém não como sinônimos. O binômio discurso e organização é analisado dentro de três orientações pelos autores. A primeira orientação é da organização enquanto objeto, a segunda enxerga a organização como em permanente estado de constituição e a terceira refere-se à organização alicerçada na ação. Sobre os eixos teóricos analisados, lembram as autoras que o que vale extrair da metateoria é aquilo que "[...] somos capazes de enxergar, pensar e falar sobre o que imaginamos dessa relação sob o aspecto de uma orientação versus outra" (FAIRHURST; PUTNAM, 2010, p. 111).

Os estudos críticos organizacionais inserem a experiência humana discutida em plenitude, pois seus seguidores compreendem que organizações formam-se com a participação de pessoas humanas, então precisam ser conduzidas dentro de uma perspectiva humanizada de gestão. Afirmou Mumby (2010, p. 20) que a comunicação organizacional nos Estados Unidos, ao longo de muitos anos, moveu-se pelos interesses corporativos e gerencialistas. Estudiosos da comunicação organizacional no Brasil contextualizaram teorias e práticas focadas no interesse público, acima do interesse corporativo. Estudos críticos da organização recentemente impactaram os estudos organizacionais a partir de uma nova abordagem, cuja ênfase está no estudo das conexões entre organização e humanização. Sobre a teoria crítica, Mumby $(2012$, p. 20) pontualmente define como "[...] um empreendimento humanístico interessado tanto em criticar formas existentes de poder quanto em explorar possibilidades para emancipação e transformação social". Pode-se apreender da teoria crítica organizacional que se trata da contraposição aos métodos para controlar atividades coletivas de atores sociais.

O diálogo entre teorias facilita a criação de direcionamentos e dá sentido ao avanço científico no campo da comunicação. A relevância de divulgar 
informações é refletida nos recursos e no funcionamento atual das organizações. A complexidade dos estudos sobre a comunicação organizacional estimula uma renovação processual, além de agregar valor ao modo operacional convencionado pela sociedade e pelas organizações. Como afirma Taylor (2005) a organização é um contexto de comunicação, por isso o autor justifica que o pensamento norteador de seus estudos "[...] parte de noções interpretativas para definir comunicação e organização, além de procurar compreender a equivalência destes dois processos".

O cuidado em identificar pontos críticos na produção de conhecimento estende o alcance e a importância do retorno esperado em longo prazo quando se empreendem estudos nessa área. Todas estas questões, devidamente ponderadas, levantam novos aspectos que vão desde o surgimento dos estudos da comunicação organizacional e passam por suas modificações, independentemente dos procedimentos normalmente presentes em abordagens positivistas. No mundo atual, a revolução dos costumes maximiza as possibilidades de novos estudos de comunicação organizacional por conta de condições inegavelmente inovadoras, cada vez mais frequentes. É importante questionar o quanto a certificação de metodologias que auxiliam a lidar com a percepção da complexidade da comunicação, possibilita uma melhor visão global dos métodos utilizados na avaliação de resultados da comunicação num contexto organizacional. Evidentemente, o julgamento imparcial das teorias existentes aponta para um refinamento conceitual nas diversas correntes de pensamento. Neste sentido, o desenvolvimento contínuo das ciências sociais obriga à análise do processo de comunicação como um todo, considerando o elevado grau de complexidade aí envolvido.

\subsection{A Comunicação Mediando Relações com Públicos}

O descuido em relação a assuntos vinculados às tradições das quais as pessoas humanas são tributárias, é uma retentiva em direção inversa ao relacionamento, em particular na organização pós-moderna, que se vale de robô como interlocutor de seu discurso. Estudiosos da comunicação organizacional brasileira, como Scroferneker (2008) e Baldissera (2008), defendem a necessidade de se analisar e compreender as tensões, as interações e as relações organizacionais na modernidade, pois o interlocutor tateia o caminho por onde possa 
encontrar relações humanas, as quais hoje se mostram inexistentes. Interroga-se quem é a empresa, e esta é uma questão para a qual a resposta não varia, ou seja, a identidade de uma empresa traduz-se pelas pessoas que produzem produtos e serviços. Se barreiras existirem nas interações entre atores, este será um fenômeno relacional com foco em pessoas e não em tecnologia.

A tecnologia merece, sim, um juízo sobre sua capacidade para simular aspectos humanos e provocar, no usuário, a ilusão de estar interagindo com uma empresa. Ocorre aí um embate entre forças que não podem ser vistas de forma separada, pois o papel da tecnologia é o de reduzir a distância entre as pessoas, mas é esperado que a espinha dorsal dos relacionamentos empresariais seja o repertório socialmente colaborativo da empresa. As relações pretendidas pelos atores sociais, historicamente tomam por base a confiança no fazer de pessoas que provém da identificação de valores coincidentes entre as partes. Defendem Fortes e Silva (2011) que a seleção de linguagem é uma estratégica de relacionamento e seu emprego nas relações dialógicas permite à organização expor valores internos que podem ser praticados nas interações diretas de seus representantes formais com grupos de interessados e de interesse da empresa. Se organizações fazem-se representar por pessoas, então as interações humanas debitam ao gestor empresarial a missão de organizar um conjunto de operações que remeta à gestão de relacionamentos para o nível das decisões estratégicas.

A metateoria, segundo informa Marchiori (2008, p. 181), "[...] é um processo que ocorre após uma teoria ter sido criada e considera a teoria recémcriada como objeto de estudo". Scroferneker (2010) descreveu as trajetórias teóricoconceituais da comunicação organizacional, recuperando seus contextos como informação, divulgação, gerador de relações e como participação. A análise metateórica da comunicação organizacional apresentada por Marchiori (2008) ressalva que a comunicação entre as pessoas influencia suas formas de vida e que isso significa visualizar a comunicação como mediadora na construção de comunidades. O interesse dos sujeitos pela construção de comunidades muda a forma de comunicar e inclui o diálogo como mediação para compreender e compartilhar significados entre os mesmos, conforme avalia Marchiori (2008) nas abordagens funcionalista, interpretativa, crítica e pós-moderna da perspectiva metateórica da comunicação organizacional. 
A sociedade de hoje coabita com a incerteza que provoca impactos diretos na complexidade e na análise de fenômenos. Afirma Mumby (2010) que os produtos de marcas pós-modernas abstraem alguma emoção humana. Este é um discurso que situa a teoria crítica como uma "teoria da sociedade e uma teoria do conhecimento", na qual o fundamento da comunicação está no respeito às diferenças e no cuidado com o "outro", conforme sugere Mumby (2010, p. 26, grifo do autor). Baldissera (2008) propõe um processo de construção bilateral entre sujeitos e sociedade, no qual o sujeito é a força ou parte do todo que, por sua vez, é a sociedade/cultura. A essência da argumentação recai sobre a visão de sujeito como propositor e criador do mundo e permite subjetivamente interpretar que as pessoas dependem de suas práticas e de suas produções. Sob esta perspectiva, é o sujeito quem estabelece os processos socioculturais. A comunicação, segundo Baldissera (2010), distribui os resultados das relações entre sujeitos nas organizações, os quais constituem os significados para a cultura organizacional. $O$ autor traduz a organização para além dos recursos materiais, financeiros ou tecnológicos e fundamenta sua existência a partir dos sujeitos em relação. Dentro desta analogia, Marchiori (2008) afirma que a comunicação e a cultura organizacional se entrelaçam com a rotina, a existência e com a participação das organizações na sociedade. A cultura é um efeito da interação social originada da comunicação. A comunicação organizacional pode ser contextualizada como provedora e disseminadora de conteúdos, pois a organização é uma produtora dos sentidos em seus ambientes organizacionais e "[...] a interpretação desses ambientes é expressa na realidade cultural de uma determinada organização, por meio de seus discursos e relacionamentos" (MARCHIORI, 2008, p. 182).

Ao focar seus argumentos na comunicação organizacional, Baldissera (2008, p. 167) chama a atenção para dois aspectos relevantes para compreender a questão, bem como para visualizar os fios que constituem este "tecido" social: "[...] o fato da comunicação organizacional ser, antes de tudo, comunicação; e o fato de tanto a noção de comunicação quanto a de organização terem a ideia de 'relação' como basilar”. Estas são informações que trazem embutida o entendimento de que comunicação organizacional não significa um subsistema da comunicação, pois a questão relacional medeia tanto a comunicação quanto a organização. O significado da comunicação organizacional tem, nas relações da organização, a porta de acesso para aceitar o conflito como uma oportunidade que 
faz arvorar a criatividade inovadora, afasta pessoas de suas zonas de conforto e as conduzem a admitirem suas limitações. Trata-se de encarar a incerteza com sentido de "[...] (re)tecer a cultura organizacional; potencializar as falas; e aprender a escutar" (BALDISSERA, 2008, p. 174).

Esse pensamento se contrapõe à perspectiva funcionalista da comunicação organizacional e encontra correspondência nas perspectivas interpretativa, crítica e pós-moderna, componentes da análise metateórica apresentada por Marchiori (2008). A recuperação histórica e conceitual da comunicação organizacional apresentada por Scroferneker (2010) remete igualmente a uma visão mais atualizada da comunicação organizacional, a partir de sua descrição dos estudos da Escola de Montreal, bem como das sete linhas de metáforas propostas por Chapman, Phillips e Putnam (2004). O uso de metáforas decorre do esforço dos estudiosos para esclarecer a força presente na relação entre comunicação e organização. Em seu início, o uso das metáforas conservava um apelo focado nas questões linguísticas. A evolução dos estudos ampliou seu enfoque para um universo passível de análise mais profunda, na qual as imbricações devem ser investigadas exaustivamente.

O emprego de metáforas no universo dos estudos comunicacionais liga conceitos abstratos a coisas concretas e sua presença, na construção de teorias, dá-se por variados meios. Como informa Putnam (2009, p. 45) "[...] os estudiosos de comunicação organizacional usam metáforas para gerar novas teorias, desfocar as antigas e elucidar as nuances de diferentes perspectivas". Os grupos metafóricos foram categorizados em sete linhas, criadas para que os estudos da comunicação organizacional encetados fossem analisados com um olhar voltado para a multiplicidade de papéis que a comunicação cumpre no contexto de organizações que são atualmente arquitetadas como espaços de interações.

As metáforas dos estudos organizacionais propostas por Putnam, Phillips e Chapman (2004) classificaram-se em linha do conduíte (comunicação como transmissão), linha da lente (organização como "olhos" que filtram ou distorcem a comunicação), de linkage (organização como rede e comunicação como conexão), da performance (comunicação como interação social), do símbolo (comunicação como interpretação de formas literárias), da voz (a comunicação é expressão e a organização é um coro de vozes) e do discurso (comunicação como conversação). Recentemente, os pesquisadores abriram novas perspectivas sobre 
as metáforas de comunicação organizacional que foram apresentadas por Putnam (2009), emoldurados pelos estudos de comunicação organizacional e de relações públicas.

Segundo Chapman, Phillips e Putnam (2004), a metáfora do discurso diz respeito "[...] à linguagem, às gramáticas e aos atos discursivos que fundamentam tanto a performance quanto a voz". Dentro deste pensamento é inerente compreender organização como interação sequencial entre pessoas, pois a comunicação é traduzida em conversação. Vale ainda destacar que o discurso permite visualizar os entrelaçamentos possíveis e existentes entre texto e contexto. A metáfora do discurso em organizações é perceptível quando o envio de informação seja um processo retórico, cuja análise de imbricações do problema original, tais como questões éticas, políticas e análise de audiência sejam consideradas dentro de seu potencial para injetar maior eficácia à tarefa de comunicar com públicos organizacionais.

A implicação da análise de Putnam (2009, p. 45) sobre sete metáforas de comunicação nomeadas como conduíte, processamento de informação, vínculo, discurso, símbolo, performance e voz preservou a nomenclatura e o sentido da metáfora de conduíte. Referiu-se à comunicação como transmissão, na qual a organização é o canal e acrescentou espécies de comunicação como ferramenta e como transmissão. Importa a essa narrativa a consideração a respeito da habilidade ou competência particular de um gestor. Desta maneira, apreende-se que a metáfora de comunicação, como ferramenta, permite avistar imprecisões nas rotinas de gestão. Por meio de sua habilidade para manusear ferramentas diretas de comunicação, incluindo-se as interações pessoais, o gestor ganha agilidade para transmitir e para rapidamente obter feedback de sua comunicação.

Por sua vez, a metáfora do vínculo arremessa a comunicação para as redes de relacionamento que as pessoas constituem no interior das organizações, e as projetam para além de limites fixos. A performance é a metáfora relativa à interação social, ou seja, aos diálogos que os atores estabelecem para materializar as organizações. A metáfora da voz concentra sua análise em habilidade individual para gerar conhecimento e para exercer poder, tanto no polo dos sujeitos, quanto do sistema organizacional. Encontra-se, nas metáforas destacadas, a valoração da prática do diálogo para conceber espaços que na 
organização consintam germinar a participação coletiva nos seus processos e na sua expressão perante a sociedade.

A revolução dos costumes maximiza possibilidades para se estudar a comunicação organizacional à luz das condições inovadoras e da percepção sobre a sua complexidade. A visão global dos métodos utilizados na comunicação organizacional aponta para o desenvolvimento contínuo e vincula uma releitura de seus processos. Conforme já se destacou, é particularmente necessário que a análise do processo de comunicação atinja abrangência e totalidade, conforme exige a complexidade do ambiente ao qual está inserida modernamente. O esforço da comunicação deve convergir com o propósito organizacional de gerar bons negócios e de obter boa imagem. A comunicação interna abarca um conjunto de ações que visa estabelecer um ambiente favorável para as relações humanas e para a produtividade no espaço de trabalho.

Este capítulo teve a finalidade de discutir o ambiente organizacional focalizado como território do diálogo. Este termo foi empregado com variadas acepções, mas sempre com o cuidado de não afastá-lo desse contexto. Para essa tarefa, a tentativa foi fazer desfilar elementos do marco teórico que aborda as características da comunicação organizacional como campo que se beneficia das preocupações do estudo aqui realizado. A lógica presente nos capítulos, até este ponto, foi a de partir de uma caracterização do que se devia entender por oralidade, preparar nova discussão para examinar o modo como ela se insere no campo dos estudos da linguagem e situar este último no contexto de uma organização atual, culminando na abordagem de como esta última se coloca frente à prática do diálogo. Com os elementos dispostos dessa maneira, o capítulo a seguir terá a finalidade de efetuar correlações mais direcionadas entre comunicação interna e diálogo. 


\section{COMUNICAÇÃO INTERNA E SUA APTIDÃO PARA O DIÁLOGO}

Há na comunicação interna um "sítio" onde a mediação se dá pelas trocas, pela produção e pelo compartilhamento de saberes entre os empregados de uma organização e entre esta e seus ambientes. Gerenciar e fortalecer uma organização implica em ampliar oportunidades de negócios por meio de estratégias de comunicação interna e externa. Caso o plano estratégico estimule o diálogo no ambiente interno, esta será uma iniciativa que aproximará dirigentes e funcionários. Paralelamente às interações entre os atores organizacionais, ocorrerá o conhecimento da alta administração sobre as atitudes e os anseios dos funcionários. A comunicação interna comporta uma notável base para alinhar a imagem ao discurso e, deste modo, arquitetar a credibilidade da organização. A imagem corporativa se relaciona com a necessidade de a organização legitimar sua relação com o ambiente técnico-institucional. Esta legitimidade é conferida à organização quando os públicos dão suporte aos seus objetivos e às suas atividades. A sofisticação da concorrência, na modernidade, demanda uma comunicação engajada para atingir a performance excelente da organização.

Pautada num modelo funcionalista, a comunicação administrativa esclarece sobre a tarefa desenvolvida pelo funcionário, sobre seu cargo, sobre o relacionamento que o empregado exerce com o grupo, além de incitar a percepção sobre a importância que cada função assume diante da organização. O controle irrestrito da administração sobre si já expõe a comunicação administrativa à criação de barreiras de difícil transposição que prejudicam o relacionamento interno. A comunicação interna concilia os interesses da organização com os interesses dos públicos, portanto cumpre a função de integrá-los. Para chegar aos dirigentes organizacionais, as informações podem seguir um percurso lento, insuficiente ou até mesmo provir de fontes externas, como a imprensa e as redes externas de relacionamentos. Insegurança ou medo podem desencadear essas distorções que restringem e censuram a comunicação interna das organizações. A participação democrática será efetiva quando o público interno for privilegiado, reconhecido e respeitado pela organização. Por outro lado, é pretendido que o empregado enxergue a organização como uma aliada na tentativa de alcançar os seus objetivos, como afirma Marchiori (2006, p. 24): 
As organizações devem preocupar-se cada vez mais com o monitoramento das informações e a abertura do diálogo com seus diferentes grupos de interesse, entendendo que seu comportamento deve ir além do repasse de informações. Na realidade, é preciso atuar no sentido de selecionar as informações para que façam parte do contexto vivenciado pela empresa e que tenham sentido para os públicos, produzindo assim uma comunicação que gere atitude.

Idealmente, a comunicação interna estabelece um equilíbrio entre os extremos. Comunicar pouco cria um vácuo que causa desconfiança e especulação; no entanto, muita informação pode resultar em sobrecarga de informação. Stafford, Vanc e White (2010) mencionam, como paradoxo da abundância, aquele no qual a informação estiver em excesso e será ignorada. Ainda no paradoxo da abundância, os funcionários ignorarão informação recebida na justa medida, mas que não seja correta para eles. Selecionar a melhor abordagem da comunicação interna reside nas expectativas e crenças dos empregados, os quais tendem a avaliar os canais de comunicação com base nessas mesmas expectativas. A comunicação interna, como canal dialógico, compreende outros canais de relacionamento e potencializa a aprendizagem dos empregados sobre princípios organizacionais como missão, visão e valores. Os funcionários devem ser orientados a agir e pensar no ambiente de trabalho em sintonia com a organização na qual estão trabalhando. O líder na organização tem a incumbência de formar a consciência de sua equipe acerca de sua participação e comprometimento com os resultados pretendidos pela organização.

É inerente ao ser social defender aquilo que é seu ou defender algo onde tenha participação explícita. Quando o público interno sentir-se bem dentro da organização e tiver seus interesses preservados, estará então motivado a defendêla. Um indivíduo assim contextualizado transforma-se em porta-voz e difunde os valores da organização nas ocasiões em que estiver convivendo com outros grupos como a família e os amigos. Esta atitude cogitará uma imagem organizacional; porém, para que a imagem seja positiva, um trabalho estratégico de relacionamento interno precisa ser desenvolvido.

A importância da comunicação interna reside sobretudo nas possibilidades
que oferece de estimular o diálogo e a troca de informações entre a gestão
executiva e a base operacional, na busca da qualidade total dos produtos
ou serviços e do cumprimento da missão de qualquer organização
(KUNSCH, 2003, p. 159).

Um programa de comunicação interna parte do estabelecimento de metas que são vislumbradas através da análise estratégica da organização, 
conforme defende Argenti (2006, p. 169) e "[...] envolve mais do que memorandos, publicações e as respectivas transmissões. Envolve desenvolver uma cultura corporativa e ter o potencial de motivar a mudança organizacional". Evidentemente, hoje a tecnologia dá suporte para que as organizações alcancem a expansão necessária para se inserir em mercados globais e, para que isso possa ser conseguido, almeja-se que o processo de comunicação seja analisado em sua totalidade. O papel da comunicação interna é contribuir com a construção do conhecimento entre as equipes de funcionários a fim de que a organização projete, para a sociedade, um comportamento uniforme e no mesmo compasso com o que desejam seus públicos estratégicos. Trata-se de um processo de modernização que preveja tecnologia avançada como suporte para o capital humano sintonizar a linguagem da máquina com a linguagem corrente entre os atores da modernidade. $O$ caráter estratégico da comunicação interna associa a missão organizacional às operações convencionais de uma sociedade cujos limites geográficos são inimagináveis. Esta particularidade terá alcance a partir do equilíbrio entre a comunicação humana e a comunicação tecnológica, inseridas internamente na rotina cotidiana de organizações atualizadas.

\subsection{Tecnologia e Linguagem na Comunicação Interna}

O consenso sobre a necessidade de qualificação nos procedimentos e no desenvolvimento de habilidades profissionais para atender ao mercado global está estabelecido. O incentivo ao avanço tecnológico está posto, assim como sua expansão sobre modos de operação convencionais. Empresas adotam tecnologias para a comunicação interna, contrariando o que afirma Larkin (2005) sobre as tecnologias serem meios de distração e não para comunicar. Surgem novas linguagens, novos meios para as interlocuções e se expandem as redes de relacionamentos. A comunicação reforça e preserva a identidade de uma organização, bem como impulsiona mudanças internas nem sempre desejadas pelo público alvo. Essas transformações sociais e tecnológicas resultam na desmassificação, na pluralização das visões de mundo e novos posicionamentos e anseios da sociedade em relação ao todo.

A comunicação organizacional compreende todo fluxo de mensagens o qual constitui a rede de relações de uma organização, portanto solicita 
monitoramento permanente sobre suas ações e resultados, bem como requer manter flexibilidade suficiente para absorver adequações, sempre que se fizer necessário. O fator humano deve nortear o ambiente comunicacional interno de uma organização, pois as empresas não se prestam tão somente à venda de produtos. As engrenagens para o funcionamento excelente de uma organização não são mecânicas, mas movidas pelas pessoas que dão curso à empresa. O público da comunicação interna são os funcionários que a organização mantém em seu quadro, de modo que não há como desconsiderar o que recomenda Larkin ${ }^{3}$ :

As tecnologias não têm um uso efetivo, um peso que faça diferença na comunicação. A melhor comunicação é aquela informal, face a face. Por exemplo, os blogs corporativos. Blog para mim não comunica, é apenas uma propaganda. Os empregados gostam que a pessoa sente e converse. A tecnologia vai servir como uma forma de afastá-los de uma melhor performance de comunicação interna. Vira realmente uma distração (LARKIN, 2005, p. 6).

Um traço particular a levar em conta é que, por ser bastante representativo do relacionamento que as organizações estabelecem na atualidade com as pessoas que participam ativamente de sua existência, acaba por desviar a comunicação interna do que deveria ser uma orientação estratégica de relacionamentos. Parte-se do pressuposto de que, por sua presença marcante na sociedade latino-americana, a comunicação oral tenderia a diminuir esse desvio. Em outras palavras, dar maior atenção à oralidade pode significar estar mais próximo dessa orientação estratégica de relacionamentos. As soluções tecnológicas avigoram organizações desde que se afinem com a pretendida expansão e crescimento organizacional num ambiente tão competitivo. Deve predominar a distinção conferida aos stakeholders, com esforço para construir um centro de relacionamentos e de negócios duradouros, além de produzir uma melhor aceitação e adesão dos públicos pela organização.

Se as organizações do novo século prescindem de redução de custos operacionais para se atualizarem, e a melhor solução desponta no uso de tecnologias, então seria de despertar para a constatação de que as tecnologias de comunicação interna tão somente executam tarefas no cotidiano das organizações.

\footnotetext{
${ }^{3}$ Larkin ministrou curso profissionalizante e concedeu entrevista para a Associação Brasileira de Comunicação Empresarial (Aberje). Esse é um órgão profissional e científico que oferece apoio a pesquisadores através de um centro de memória e referência, além de disponibilizar seu acervo literário em base permanente. Promove atualização de práticas e desenvolve programas e cursos de aperfeiçoamento e capacitação. As produções originadas desse centro são de considerável repercussão e alcance, introduzindo abordagens críticas e inovadoras. Seria uma lacuna injustificável desconsiderar essa fonte em um estudo como o produzido nesta tese.
} 
Essas tecnologias não são passíveis de se ajustar à política de comunicação organizacional, e seu uso como instrumento de comunicação interna terá implicação imediata na imagem da organização percebida pelas suas comunidades de públicos. Conciliar a necessidade organizacional e o potencial tecnológico disponível significa entender que, em se tratando de relacionamento com públicos, um plano de comunicação deve absorver estratégias de comunicação oral e a oralidade como ferramentas afinadas com seu âmbito interno. Elas terão que ser perceptíveis nas decisões de comunicação corporativa, nos departamentos da organização e aos públicos com os quais interagem.

$\mathrm{Na}$ pesquisa norte-americana desenvolvida por Stafford, Vanc e White (2010) as pesquisadoras depararam-se com o que pode ser traduzido como o paradoxo do e-mail. Quando questionados sobre como preferiam receber informações, quase todos os funcionários responderam que era via e-mail. 0 paradoxo revelou-se no momento em que muitos entrevistados indicaram as interações face a face como as preferidas para o recebimento de informações. A contradição ficou registrada em questões abertas, nas quais houve um respondente que admitiu haver uma variedade de veículos de comunicação interna na sua empresa, mas considerou as reuniões como o principal meio para a discussão de assuntos estratégicos e de tomada de decisão. Os dados dessa pesquisa validam o argumento sustentado nesta tese de que a comunicação interna moderna requer práticas conservadoras, sendo a oralidade uma estratégia indissociável do sucesso na gestão de pessoas. A base da comunicação está no relacionamento entre as pessoas, a organização se comunica pelas pessoas, portanto meios eletrônicos, redes sociais, e outras formas de comunicação presentes nas rotinas administrativas, servem somente como ferramentas, embora com reduzido grau estratégico para a comunicação.

O alcance do estudo de Stafford, Vanc e White (2010) atingiu os níveis táticos e entrevistou gerentes que acreditavam muito no acesso às informações publicadas nos sites e portais corporativos, contudo concluíram que o site é uma tecnologia para extrair informações, e não um impulso que se dá através da tecnologia. Decidir por se informar é, antes de tudo, um impulso pessoal que deverá partir de um sujeito ou ator social. A tecnologia dá a interface para se buscar a informação, mas esta tecnologia não dará o start para a informação necessária ou pretendida pela comunicação organizacional interna. Advertem as autoras que não 
se pode presumir que se a informação é colocada no site, os funcionários veem ou sabem que ali ela está localizada.

Nos dias de hoje, o ambiente de negócios demanda soluções que integrem as competências de gestão de pessoas e de uso de tecnologias que permitam obter, não só vantagem competitiva, mas também desenvolvam processos de relacionamentos impecáveis com os públicos estratégicos. Informalidade e oralidade, como se reiterou acima, são características marcantes da comunicação nos ambientes operacionais sul-americanos. Como fenômeno, a oralidade pode estar no cerne da má execução de políticas estratégicas de comunicação. Processos tais como o chamado "gerundismo" ("estar-te-mandando; para-estar-fazendo", etc.) ou o uso permanente de expressões regionais, para alguns públicos passa despercebido enquanto para outros, pode ser objeto de crítica. O que não se pode negar é que são cotidianos e de alta intensidade.

Comunicação é relacionamento humano e implica considerá-la fator presente entre os indicadores para que a sociedade de hoje consiga coexistir com as organizações. Diante disto, a cultura vigente valoriza organizações que constroem um ambiente comunicacional desobstruído e que estabelecem uma política de comunicação consolidada por relações dialógicas, as quais ganham visibilidade mediante uma oralidade adequada à sua cultura.

\subsection{Influência da Comunicação na Performance Interna}

Com a base de conceitos teóricos, discute-se a correlação entre a comunicação, as novas relações de poder no século XXI e a cultura organizacional. Um líder se relaciona e se comunica com pessoas, então a capacidade para liderar, influenciar, conseguir bons resultados em uma negociação ou no atendimento a um cliente faz do líder um ser especial "[...] rico em valores e aprendizados, que se conecta com outros seres humanos, dotados também eles de capacidade, dons e talento" (PASSADORI, 2003, p. 62). Compete apresentar as características desta correlação com a perspectiva de as organizações atenderem melhor as necessidades dos seus públicos, principalmente no que se refere a sua comunicação interna. No contexto apresentado, a comunicação interna é um aspecto fundamental da vida organizacional e é tratada como aquela que prepara os relacionamentos com os públicos de uma organização. Podem-se comparar os 
relacionamentos com um autêntico portfólio de públicos, que tenha como base uma avaliação reflexiva, cujo apelo à lógica formativa e compreensiva dará sentido à sua apreciação final e à sua elaboração, pois:

A qualidade dos meios de comunicação interna nas organizações alcançou um alto patamar de excelência nos últimos anos. Aqueles boletins internos do passado, com péssima resolução gráfica e mal escritos, deram lugar a jornais, revistas, intranets, TVs corporativas, murais e outros canais de primeira linha. Mas nem todos os profissionais da área se deram conta de que existe uma nuance: entre fazer um produto de qualidade e garantir a retenção das mensagens, há um longo caminho (LIPPI, 2009, p. 55).

A abordagem sobre as relações de poder evoca o conhecimento de seus instrumentos em relação aos processos de comunicação, apresentando um caminho para a análise da importância da cultura organizacional nos processos internos e externos de uma organização. O assunto possibilita também visualizar a cultura organizacional sob outros ângulos e de forma significativa para o melhor entendimento dos temas propostos na substância da tese em andamento.

Na pesquisa das norte-americanas Stafford, Vanc e White (2010), a estrutura burocrática das organizações foi reconhecida pelos respondentes como um inevitável fato da vida. Eles reconheceram que a informação flui em uma estrutura hierárquica no modelo descendente, no entanto, em todos os níveis da organização houve evidências de que os funcionários querem receber informações o mais diretamente possível, a partir do superior. A informação direta do CEO foi percebida como meio para reduzir a distribuição desigual da informação e aumentar a credibilidade da informação. Os funcionários reconheceram que o fluxo de informação, de cima para baixo, cria gargalos nos diferentes níveis de supervisão e dificulta a obtenção de informações mais consistentes para todos os níveis da organização. Além do problema da distribuição desigual, o estudo constatou a preocupação de que as informações dos gestores sejam muitas vezes filtradas, e por vezes distorcidas, como as informações transmitidas através das camadas da burocracia. A partir das respostas dos gestores, ficou indicado que o desejo e a decisão de um gestor por compartilhar informações, ou não, muitas vezes é baseada no seu julgamento pessoal.

Motter (2002) estimula um olhar crítico sobre a gestão comunicacional e sobre seu gestor, bem como acerca da linguagem, segundo um ponto de vista comunicacional de interação e de diálogo entre organizações e seu entorno. "Vemos o mundo que nos ensinaram a ver, segundo recortes do senso 
comum mantidos por sucessivas gerações, herdados como verdades calcificadas, e não o mundo complexo, contraditório, movente, mutável e multifacetado que temos diante de nós" (MOTTER, 2002, p. 40). Publicações e pesquisas científicas dão evidência às tecnologias de comunicação como práticas profissionais de vanguarda. Vê-se, no entanto, que a pós-modernidade solicita que os indivíduos retomem sua natureza e se valham do diálogo para fortalecer laços pessoais e de negócios no ambiente organizacional. Com base nesta assertiva, apresenta-se uma defesa da comunicação oral e da oralidade como habilidades indispensáveis para o fazer de organizações contemporâneas, por intermédio de seus gestores.

O trabalho em equipe demanda uma comunicação em que cada ator ou usuário do processo comunicacional participe racionalmente no interior de seu grupo. "A teoria da administração baseada em equipes se caracteriza essencialmente, pela comunicação multidirecional nas organizações. Assume destaque o papel dos líderes, identificados como responsáveis por gerar grupos de trabalhos fortes e coesos" (SCROFERNEKER, 2008, p. 20). Um contexto assim colaborativo dinamiza a interação, bem como a troca de informações, portanto o processo de comunicação é orientado por uma finalidade comum, contudo não mais linear. Este novo modelo de gestão, cujo formato é o do conhecimento coletivo, é um diferencial presente nas organizações bem-sucedidas. O conhecimento elaborado no cerne de uma equipe, somente será possível pela via da comunicação. A comunicação é uma habilidade altamente necessária para um executivo, pois, como afirma Araújo (2009), a "[...] capacidade de tomar decisões e habilidade para se comunicar de forma eficiente e carismática são os dois traços essenciais para um executivo que aspira chegar aos postos mais importantes da empresa". O modo como uma pessoa ou empresa se comunica com seus interlocutores interfere diretamente no seu desempenho.

Araújo (2009) sugere traços comuns aos executivos de alto escalão e avisa sobre a observação dos comportamentos que podem caracterizar seu sucesso. Segundo informa, as características observadas encontram-se dentro de duas grandes dimensões: o processo de tomada de decisão e a capacidade para liderar e influenciar pessoas. A primeira dimensão, relativa ao processo de tomada de decisão, envolve o modo como o executivo pensa, como reage, qual seu foco e o nível de informação sobre o que está focando. Envolve ainda uma capacidade exploratória para analisar o contexto em diferentes ângulos, perspectivas e trabalhar 
com visão estruturada de longo prazo. A segunda dimensão, capacidade para liderar e influenciar pessoas, alista a busca de informações, bem como sua qualidade. As informações serão captadas na rede de relacionamento do executivo, pois ali estão as pessoas com quem conversa e por intermédio das quais busca perspectivas. A procura por diferentes informações, e em diferentes fontes, nutre a capacidade para decidir, estruturar a forma como irá liderar e como irá interagir com os públicos. Quando as lideranças organizacionais comunicam-se mal, é bastante provável que a organização também não faça boa comunicação. Significa recomendar que o executivo seja hábil para impactar a equipe e demonstrar sua abertura para receber inputs.

Outra habilidade pretendida de um líder é a de estimular sua equipe a trocar informações que sejam convertidas em conhecimento, a fim gerar comprometimento e boa performance. Caso uma equipe de empregados não satisfaça a expectativa dos dirigentes organizacionais, pode ocorrer de o líder atribuir esse fato à ausência de engajamento dos empregados com a organização e assim, em sentido inverso, chamar a atenção para sua própria falta de comprometimento. Não é compatível com o papel do líder moderno expressar pessimismo ou se eximir de responsabilidades. A causa de grande parte dos problemas das equipes de funcionários está na falta de comunicação com seus líderes. A atividade de liderança deve partir da resposta do próprio líder a respeito do que ele é ou faz e o que motiva alguém a segui-lo. A comunicação apoia um líder, porém o líder é protagonista da comunicação interna. A comunicação interna não toma para si o papel de afinar os interesses da equipe de empregados aos interesses da organização. Esta é uma competência que está no campo dos conceitos de liderança e que fala sobre um líder com habilidade para se relacionar favoravelmente com seus liderados.

\subsection{Comunicação Oral Agregando Valor à Liderança}

Uma habilidade com potencial para instrumentalizar as condições de obter eficácia na comunicação é a de ouvir o que o outro fala. A empatia é um requisito fundamental para que a comunicação ocorra entre pessoas, mas não se pode esperar que simplesmente saber falar seja sinônimo de comunicar. Reside neste processo racional humano uma série de interferências que poderá alavancar 
ou assolar o desenvolvimento de um diálogo, cuja origem está na interação entre sujeitos. Sem dúvida, o diálogo é um ato de comunicação, mas o contexto em que ocorre o diálogo necessita ser analisado, conforme se analisam elementos componentes de um sistema.

No enfoque aqui apresentado, o contexto deve ser compreendido como um elemento constitutivo da comunicação que se estabelece por meio da fala e do diálogo entre atores sociais. A finalidade que a fala pode cumprir dentro de um processo comunicacional é a de suscitar respostas, a partir do contato face a face travado entre dois ou mais sujeitos envolvidos na conversação. A fala tem o suporte da linguagem verbal que, por sua vez, constitui a comunicação oral. O uso humanizado da comunicação oral promove o contato direto entre interlocutores que se colocam frente a frente para estabelecer comunicação. O diálogo é um meio para que os interlocutores integrem-se em um mesmo contexto e esta integração ocorrerá somente mediante as alusões traduzidas pelos objetos desse contexto. Sinais visuais podem ser vocacionados para comunicar através de linguagem não verbal; entretanto, é pela palavra falada que ocorre uma significativa parcela da transferência imediata de uma informação ou fato, em consonância com a velocidade acelerada que caracteriza o novo século.

Mais um diferencial que a comunicação oral comporta é a capacidade para transmitir estímulos subjetivos, tais como os sentimentos de quem está falando e que são percebidos pela entonação da voz, pelos gestos, bem como pelo contexto situacional em que a comunicação oral acontece. O diálogo é uma plataforma para interações onde o sujeito falante e o sujeito ouvinte têm a possibilidade de realizar uma troca contínua de papéis, dentro de uma concepção genuinamente humanizada de comunicação. É esta dinâmica que põe em evidência a comunicação face a face como estratégia de gestão e, consequentemente, como uma orientação para uma política de relacionamentos internos adequada ao novo mundo. Deixar de considerar essa dinâmica consistirá em omissão e produzirá repercussões, embora nem sempre sejam fáceis de mensurar. Por esse motivo, é relevante manter em evidência o objetivo de conhecer sempre em maior profundidade as condições em que é realizada a comunicação face a face e os componentes que lhe dão comando - a oralidade sendo um dos mais centrais.

Recentemente, a prática empresarial que comportava padronização, cedeu espaço para uma postura em que o que se busca é dar fluidez para a 
comunicação. A administração tem como maior desafio cumprir uma de suas funções básicas, como o controle (orçamento, fluxos, infraestrutura), mas não implica controlar as pessoas - isso somente se daria à custa de um elevado nível de alienação: hoje, se considera amplamente inadmissível "submeter" o empregado. Musa (NORI; VALENTE, 1990) traduziu precocemente um pensamento norteador da prática empresarial na atualidade quando afirmou que "[...] executivo que se comunica mal é mau executivo". O empreendedorismo de Musa (NORI; VALENTE, 1990) ficou registrado nas páginas da obra que relata a ação estratégica de comunicação da Rhodia, empresa multinacional que se abriu para a opinião pública e para estreitar relações com seus stakeholders, há três décadas.

O presidente da empresa entendia a tênue aproximação que a opinião pública estabelece entre uma empresa e seu representante. Por esse motivo, reconheceu sua responsabilidade e assumiu o compromisso de concentrar seus esforços para que o processo de comunicação se completasse na Rhodia. Musa se notabilizou, dentre outras posturas que assumiu, por um posicionamento a esse respeito ao afirmar que um executivo precisa saber comunicar, especialmente pela oralidade, e esta conclusão sustenta-se na sua afirmação sobre a necessidade de o gestor ocupar espaços com bom senso, sem distorções, fosse em entrevistas à imprensa, em discursos, debates, reuniões, eventos internos e externos, ou em qualquer tipo de contato (NORI; VALENTE, 1990, p. 24). Motiva-nos o reforço fornecido por essa clara menção de Musa à comunicação oral, não somente como meio de comunicar, mas nitidamente como um comportamento estratégico que deve ser adotado por dirigentes empresariais. A relevância do objeto de estudo torna-se evidenciada por essa prestigiosa fonte.

A comunicação nas organizações pode estabelecer um clima favorável, no qual não transpareçam nem insatisfação, nem incertezas nas relações. O grande paradoxo do mercado de trabalho é conseguir ser competitivo e também ser mais humano, o que explica as relações sociais no âmbito interno de uma organização estarem elencadas entre as competências de gestão. As organizações em nossos dias são percebidas como "[...] microssociedades, fazem parte de um sistema social abrangente, no qual há uma interdependência de funções e um contínuo processo de troca" (KUNSCH, 2009, p. 196). Para os membros de uma organização, ter ideias sobre as suas demandas e sobre as rotinas presentes no exercício de sua função é uma reação rotineira. O que promoverá 
diferença nas relações e nos resultados organizacionais será a forma como essas ideias serão expressas. A transmissão de ideias pode não funcionar plenamente em virtude de uma falha na comunicação oral e quando a comunicação oral não acontecer, será sinal de que a organização não possui uma política que privilegie relacionamento. O uso da oralidade é muito presente nas organizações, porém, como já se mencionou, nem sempre é absorvido como uma forma de comunicação, com elevado grau de dificuldade para ser controlado.

As pesquisadoras Stafford, Vanc e White (2010) confirmam o importante papel da comunicação interna como estratégia para gerar compromissos com os objetivos e com outras estratégias de uma organização. Segundo afirmam essas autoras, não importa o brilho de uma estratégia de negócio para alcançar a máxima eficácia, se os empregados não estiverem coesos com a organização. As pesquisadoras investigaram a influência pessoal dentro das organizações, pois partiram da afirmação de que o presidente dava o tom para a comunicação interna. A preocupação não deve estar apenas na mensagem a ser transmitida, e sim na forma pela qual será transmitida. Na comunicação oral, o emissor é o elemento designado para elaborar, processar a informação e atingir o feedback pois, como lembra Bazerman (2006, p. 26), "[...] é claro que para nossas palavras realizarem seus atos, elas devem ser ditas pela pessoa certa, na situação certa, com o conjunto certo de compreensões". O líder organizacional é um gestor de comunicação, porém o sucesso da comunicação interna é impossível sem o apoio do mais alto dirigente empresarial. A pesquisa norte-americana encontrou o maior desejo dos empregados que era por mais informações vindas dos executivos. A comunicação face a face com os supervisores foi o canal mais desejável pela maioria dos funcionários, e a pesquisa revelou que os funcionários queriam ver e falar com seus líderes.

Em muitas organizações, a comunicação não flui porque exige simplicidade e coerência. O líder, como agente da comunicação que é, deve compreender que nada substitui o contato, nem a comunicação interpessoal com sua equipe de liderados. Como pode ser observado em Oliveira e Paula (2008, p. 94) para atingir o "[...] modo de as pessoas se posicionarem em relações de diálogo, à negociação, enfim, na interação social, as noções de enunciados e vozes, bem como de repertórios interpretativos são importantes". O líder é quem pode patrocinar a comunicação interna, portanto carece de disposição para doar tempo, presença, exemplo e experiência à sua equipe. 
De acordo com Baldissera (2008, p. 155), "[...] a apreensão que se faz dos fenômenos é mediada pela linguagem e, portanto, não mais se trata do fenômeno em si, mas do fenômeno mediado/falado". A comunicação interna apoiará dirigentes, lideranças e equipe de funcionários de uma organização, mas o líder é quem deve falar com seus liderados. Nenhuma tecnologia, por mais avançada que seja, poderá ocupar o lugar da comunicação face a face que é, por excelência, a forma de comunicação humana. O diálogo entre liderança e liderados implica no discurso da organização com seus públicos. Através do diálogo é possível ampliar a interação entre o líder e sua equipe, reduzir as incertezas, otimizar os esforços e estender seu efeito sobre os resultados de negócios e de relacionamentos organizacionais.

Coloco como premissa para a defesa do diálogo como prática de comunicação a análise sinérgica de três subsistemas - verbal, vocal e gestual -, que só terão significado em determinado contexto. É óbvio que a comunicação verbal não é a única forma de comunicação, mas, quando se pensa em interação, se pressupõe um conjunto de disposições verbais e não-verbais que se exprimem por palavras e que buscam o diálogo e a sinergia das relações entre pessoas ( FREITAS, 2009, p. 141).

É recomendável que um líder, a partir da predisposição para falar com sua equipe, atente para questões simplistas, porém que trarão reflexos imediatos ao sucesso ou ao insucesso de sua comunicação. O líder deve decidir com antecedência o que será dito, falar com bom vocabulário, ser objetivo e claro, elaborar sua mensagem com criatividade e adequação, despertar credibilidade, atentar para sua expressão corporal, para a entonação de sua voz e para sua comunicação não verbal. O líder que expõe oralmente suas ideias e projetos para sua equipe de liderados, estabelece uma conversação alargada e pode observar as respostas de seus interlocutores. Os sinais não verbais emitidos pela equipe de liderados são o retorno esperado pelo líder e indicarão se sua comunicação deve ser ajustada, mantida ou ampliada. Um gestor transmite suas convicções através da sua oralidade, e por esse motivo, a comunicação face a face reflete a crença do líder sobre a importância de comunicar aquilo que ele está comunicando. Esta convicção é subjetivamente projetada por meio da voz, da movimentação, dos gestos e das próprias atitudes que legitimam a liderança perante seus liderados.

A responsabilidade para com as equipes advém da função de liderança que o gestor desempenha. Um líder precisa se mostrar conhecedor da atividade organizacional, bem como deve saber escolher e utilizar métodos e 
técnicas de comunicação adequados ao tipo de desempenho necessário a si mesmo, como também a sua equipe. Somente assim líder e sua equipe manter-seão integrados ao sistema empresarial.

\subsection{Contribuição do Estudo para a Comunicação Organizacional e para as Relações Públicas}

Para desempenhar funções profissionais há uma necessidade crescente de usar a comunicação verbal, a fala, voz e linguagem adequadamente. Como lembram Freitas e Guerra (2011, p. 2) a fala é "[...] um instrumento fundamental na ação do executivo que busca, no contato com o outro, obter resultados e, no entanto, o que sabe ele acerca da palavra?" A voz é um atributo pessoal, e na abordagem sobre atributos da voz Kyrillos (2003, p. 20) afirmam que "[...] as palavras são aprendidas, dependem da nossa vontade e do nosso controle; a voz nos escancara para o mundo". As autoras também analisam a implicação desses atributos no processo comunicacional humano e acrescentam que "[...] quando há concordância entre o que se sente e as palavras que se escolhem, a comunicação é $100 \%$ eficaz".

O equilíbrio entre esses atributos é proposto pelo pensamento das relações públicas ao atuarem na gestão da comunicação interna que poderá ser percebida como positiva na apreciação dos públicos existentes na sociedade moderna. Quem comunica pela fala espera que sua mensagem traduza uma ideia em palavras e que o ouvinte desta fala assimile o que foi dito do modo mais essencial possível. Freitas e Guerra (2011, p. 6) trazem uma análise sobre os discursos organizacionais e remetem sua conclusão a considerar que "[...] há no discurso das organizações uma pluralidade de vozes que constituem a voz corporativa". Contudo, a palavra falada é uma linguagem que se estiver contida no discurso corporativo será uma voz fisicamente caracterizada e poderá ser conectada ao que pensam os públicos acerca da empresa, ideia essa transmitida por meio da voz de seu representante corporativo.

No estudo da comunicação organizacional contemporânea, a análise dos processos comunicacionais deve abranger os meios orais encontrados, pois pela oralidade de uma pessoa, fala a voz de uma organização, apresentam-se características da "personalidade organizacional" e subsidia-se a edificação da 
imagem corporativa elaborada pelos públicos. Reside aí mais uma função estratégica das relações públicas na modernidade, ou seja, adotar uma orientação que valorize as potencialidades das pessoas (entendidas como componente dessa personalidade organizacional), pois esta é uma área cuja essência está nos reflexos que produz na sociedade.

Para uma organização identificar oportunidades no ambiente externo, demanda-se criatividade para antever necessidades emergentes do mercado. Prover seu pessoal de competências administrativas, facilitadoras de sua sobrevivência e competitividade implica uma generalização de habilidades, dentre elas, a de estimular a participação das equipes nas decisões da empresa, de modo a aproveitar o máximo de seu conhecimento em favor do êxito do negócio. Deste modo, e inserido no campo maior da comunicação interna, o estímulo ao desenvolvimento da habilidade para a comunicação oral deve ser uma prática de gestão de pessoas presente em organizações contemporâneas, tendo em conta o que defende Kunsch (2003, p. 154) sobre a comunicação interna vista como "[...] um setor planejado, com objetivos bem definidos, para viabilizar toda a interação possível entre a organização e seus empregados".

É percebido que as organizações têm transferido para as tecnologias a abertura de canais de contato para públicos estratégicos. A tecnologia de comunicação alivia administrativa e financeiramente as tarefas organizacionais, porém pode ser um caminho sem volta quando se analisam as relações humanas. Na comunicação interna, o diálogo e o uso da oralidade associam aos seus sujeitos a capacidade de processamento e uso aplicado de informações colhidas no ambiente de negócios. A comunicação organizacional busca integrar cada vez mais os públicos fazendo com que a imagem corporativa seja forte e lembrada mediante uma filosofia pautada em princípios de ética e de inclusão social de diferentes agrupamentos de públicos. Na parceria entre uma empresa pública, seu servidor e demais grupos ligados a ela, deve imperar confiança e disposição para assumir uma mesma política de comunicação corporativa exercitada pela organização.

Chamamos a atenção para a necessidade de maior valorização, também da comunicação interpessoal por parte das organizações. Acreditamos que ainda é um segmento pouco considerado no âmbito organizacional e não tem sido objeto de muitos estudos no meio acadêmico da área de comunicação social (KUNSCH, 2007, p. 372). 
A macroquestão apresentada refere-se às dimensões da oralidade absorvidas pela comunicação interna e estendidas para as relações com grupos e para a tecitura da rede de relacionamento entre equipes de empregados e gestores empresariais. Examina-se a relação existente entre esse conjunto de procedimentos para que a comunicação oral reconquiste o valor estratégico do diálogo, consolide relações e agilize a transferência de mensagens nas empresas. Do ponto de vista social, a necessidade de dialogar emerge em respeito a um paradigma cultural latino-americano ${ }^{4}$. A compreensão sobre sua eficácia no estabelecimento de relações estratégicas com o público interno deve ser abrangida por meio de estudos voltados para a comunicação interna presente no composto da comunicação organizacional. As transformações sociais evidentemente produzem reflexos na área de relações públicas e dão maior dimensão ao compromisso e à sua contribuição com o contexto social. Como relata Oliveira (2007, p. 182) hoje identificam-se conceitos de relações públicas nos quais há a "[...] preocupação com os aspectos que se tornam essenciais para o exercício pleno da cidadania, ou seja, transparência, responsabilidade social, diálogo, confiança, entre outros”.

A comunicação organizacional, mediante a gestão de pessoas, desencadeia uma rede de interações que se estende para além de seu limite interno. Isso se dá por conta de uma ação comunicacional qualitativa e capacitada para estimular o uso da comunicação interpessoal como suporte de relacionamentos proveitosos com seus públicos estratégicos. Como afirma Kyrillos (2005b, p. 16) “[...] a comunicação interpessoal é a melhor maneira de transmitirmos e recebermos as mensagens, refletindo nossos desejos, anseios e intenções". A habilidade para a comunicação oral é tão necessária na atividade cotidiana que se torna difícil a concepção da própria vida sem o uso da linguagem, aqui compreendida como "[...] o todo necessário para a comunicação de nossos pensamentos e ideias" (PICCOLOTTO; SOARES, 1977, p. 7).

\footnotetext{
${ }^{4}$ Dentre as atividades como docente do Curso de Relações Públicas da Universidade Estadual de Londrina, a autora desta tese vinha estudando em que medida a oralidade podia ser usada nas organizações para atender e satisfazer as necessidades de relacionamentos das novas demandas de públicos. Nesses estudos examinou os fatores e as características da oralidade e da criação de identidade, exatamente com a previsão de que novas buscas poderiam ser desenvolvidas a partir disso (MARTINS; FORTES, 2007a, 2007b, 2007c, 2007d, 2008a, 2008b, 2008c); (MARTINS; GRECA, 2009); (MARTINS, 2011); (MARTINS; GRECA, 2011).
} 
A linguagem absorve influências socioculturais que muitas vezes norteiam a criação do vocabulário de grupos sociais que desenvolvem suas formas de comunicação. A oralidade configura a comunicação que ganha eficiência somando fala e linguagem adotada para bem estabelecer relações sociais. A habilidade de falar expressa, pela voz, o que se é e como se está naquele momento. Por seu lado, a habilidade de ouvir desenvolve formas para diagnosticar como é e como está naquela ocasião, o interlocutor. Por meio da oralidade, até mesmo a capacidade funcional é passível de ser observada visto que, "[...] utilizada para fins profissionais, a voz passa a ser mais exigida tanto em termos de quantidade como de qualidade, segundo critérios variáveis, de acordo com sua profissão" (KYRILLOS, 2003, p. 20). Uma abordagem nessa direção é a que predispõe a uma ideia caricatural, uma vez que há um estilhaçamento que pode vir a significar a abertura para outras vozes, aquelas que estão fazendo falta e às quais a empresa sempre esteve surda (ROMAN, 2009).

A comunicação organizacional busca estabelecer, manter e aprimorar as relações entre a organização e as pessoas que a ela se reportam, de sorte que todos tenham suas expectativas atendidas e as atividades da organização perdurem no mercado tão competitivo. Nas palavras de Kunsch (2003, p. 167):

As organizações modernas não podem se limitar apenas à divulgação dos
seus produtos ou serviços. Necessitam se identificar perante um público
consumidor cada vez mais exigente. A comunicação institucional deve
agregar valor ao negócio das organizações e contribuir para criar um
diferencial no imaginário dos públicos.

A comunicação oral facilita os meios para desenvolver pensamentos e reações dos interlocutores, que podem ser ou não, favoráveis à boa imagem do emissor. Para o desempenho de atividades profissionais, a habilidade da comunicação interpessoal tem o status de ferramenta de trabalho responsável "[...] pela imagem que passamos ao outro, ao mundo; aquilo que nos representa [...] e, consequentemente, representa a empresa em que trabalhamos" (KYRILLOS, 2005b, p. 16). Somam-se às diferenças culturais, as manifestações de pessoas insatisfeitas ou pouco informadas sobre algum assunto da atuação corporativa. As pessoas representam um ativo valioso numa organização e como tal, são as responsáveis legítimas pelo modo como as organizações são compreendidas por seus públicos. Entende-se que o treinamento para a comunicação deva estar previsto entre as atividades planejadas pela organização, uma vez que "[...] diante de uma atitude 
estratégica inovadora, é pertinente observar as ameaças e as oportunidades, com a finalidade de implementar ações de relacionamento apropriadas, a cada configuração que o ambiente externo apresente" (FORTES, 2003, p. 18).

Da comunicação, espera-se clareza, objetividade e eficiência, para que as relações com públicos estratégicos sejam cultivadas e se revelem úteis para as partes. A comunicação organizacional expressa traços socioculturais através daquilo que ela comunica e eles interferem na organização e na sua projeção para o seu meio através da voz e da fala de seus representantes, quando se relacionam por diferentes modos e com variados públicos.

Chanlat e Bédard (1996) alertam para a necessidade de a fala ser compreendida como objeto de ação do executivo para obter resultados mais eficazes na organização. Os autores traçam um comparativo para a fala e afirmam que ela "[...] está para a constituição do indivíduo como a linguagem está para a definição da espécie humana, pois é através dela e de suas vicissitudes que se constrói a existência pessoal" (CHANLAT; BÉDARD, 1996, p. 128). Dentre as barreiras que obstruem o diálogo nas relações de trabalho, os autores distinguem a ideologia e os valores que ela veicula; a "[...] 'língua' administrativa em si mesma; os jargões especializados e a estrutura burocrática, pois se a estrutura formal da organização coagir os empregados a se calarem, mais eles procurarão ter e ouvir a voz nos grupos informais".

Levantar como estão as práticas de comunicação interna é uma das finalidades de avaliar o uso da oralidade como meio para reconquistar o valor estratégico do diálogo e elevar a comunicação oral ao nível de habilidade essencial para gestores estabelecerem boas relações com seus subordinados e com outros atores sociais. Nos processos de recrutamento de funcionários, é crescente a importância conferida à habilidade de comunicação pelas organizações em todo mundo. O motivo para tal procedimento está no campo profissional, pois, ao ingressar numa organização o contratado "[...] passará a representar a imagem da empresa, e é importante que essa imagem seja positiva" (KYRILLOS, 2005b, p. 16). O envolvimento de pessoas é uma particularidade das relações organizacionais, pois as pessoas podem comunicar muito a outras pessoas e também os papéis pessoais desempenhados nas atividades profissionais podem ser identificados. Deste modo, a comunicação tem igualmente uma simbologia intrínseca na "leitura" que os públicos 
fazem da organização, tais como a hierarquia presente, a sua linguagem, a sua identidade visual.

Nassar ([2005], p. 58) argumenta que os gestores da comunicação e de recursos humanos enfrentam um desafio que, embora cotidiano, é bastante complexo. O desafio está em que "[...] cada vez mais, e rapidamente, é preciso comprometer todas as pessoas da organização com seus valores e crenças, nos mínimos detalhes e independentemente de hierarquia". Na perspectiva do autor tanto a gestão de comunicação, quanto a de recursos humanos têm "[...] a tarefa conjunta de habilitar todas as pessoas da organização para as questões ligadas ao simbólico organizacional, o que significa principalmente melhorar a qualidade dos relacionamentos e da comunicação da empresa". A fundamentação abrange aspectos considerados prioritários para investigar o modo como a comunicação interna se vale da oralidade no sentido de recuperar o valor do diálogo como estratégia de comunicação interna. Destaca-se que a comunicação interna é aqui analisada como prática qualitativa para fortalecer as relações interpessoais ao assumir a habilidade de comunicação oral como essencial para gestores interagirem com seus subordinados, dando-lhes o tratamento mais adequado para que as relações internas sejam estrategicamente dialógicas e para se ajustarem ao momento atual das empresas.

\subsection{Organizações Inseridas no Paradigma Global}

A evolução da comunicação organizacional a posiciona perante a nova era e aborda linguagens presentes em uma sociedade global que transporta desafios para um pesquisador da comunicação enfrentar e transformar esse universo, a partir de um conhecimento produzido.

Ao discorrer sobre a pós-modernidade Bauman $^{5}$ analisa os principais impactos surgidos nessa era do desenvolvimento humano e afirma que a identidade não é uma herança, pois em cada época a sociedade cria sua própria identidade à luz de seus valores e anseios. A humanidade redefine seus propósitos, seu modo de vida e, segundo relata Bauman (2012) "[...] a pós-modernidade pode

\footnotetext{
${ }^{5}$ Fronteiras do Pensamento - edição 2011. Entrevista com o filósofo polonês Zygmunt Bauman para o Fronteiras do Pensamento, apresentada na ocasião do encontro com o pensador francês Edgar Morin, em 8 ago. 2011, Porto Alegre e em 9 ago. 2011, São Paulo. Disponível em: <http://www.youtube.com/watch?v=POZcBNo-D4A\&feature=share>. Acesso em: 8 maio 2012.
} 
ser um período de transição de uma ordem social para outra ordem social" e afirma que nenhuma mudança será duradoura. A desmistificação da pós-modernidade é o foco da abordagem, mas está em conexão atemporal com o compasso assumido pela marcha da humanidade. O filósofo destaca duas questões pós-modernas que considera irreversíveis. A primeira diz respeito à interdependência global, resultado do complexo de conexões, do aumento de nós, de relações e de comunicações. A segunda questão destacada é o "dilema ambiental" causado pela aceleração da capacidade produtiva mundial que alterou o meio ambiente. A ação desordenada da humanidade no afã de produzir mais e mais, suplantou a suportabilidade do planeta e desgastou componentes naturais, muitos deles não renováveis, nem recicláveis. Esses são conflitos naturais que serão transferidos para outras gerações.

O posicionamento do Estado na pós-modernidade é também foco da análise de Bauman (2012) somado à crítica sobre sua debilitada atuação frente às necessidades sociais. Embora o Estado ofereça cada vez menos aos cidadãos, o autor atesta a necessidade da cooperação mútua que considera indispensável para equilibrar as diferenças socioculturais de hoje. No mundo pós-moderno, os laços humanos encontram-se frouxos, perdeu-se a compreensão de que a comunidade precede ao indivíduo e se absorveu o conceito de rede como a nova ordem de relacionamentos humanos. Sugere que, ao contrário da comunidade, a rede é mantida viva pela atividade de conectar e de desconectar e que as relações seguem esta mesma lógica. $\mathrm{O}$ ator social conecta pares fortemente motivado pelo poder de se desconectar a partir de um simples comando em seu personal computer. $\mathrm{O}$ acesso e o domínio de avançadas tecnologias "[...] não são conexões verdadeiras, frente a frente, corpo a corpo, olho no olho, face a face" (BAUMAN, 2012). Na vida real, as relações sociais tecem uma rede consistente, seus entrelaçamentos criam comunidades que compartilham rotineiramente experiências e atam laços humanos com firmeza. O rompimento de relações do ponto de vista de relacionamento social é sempre um processo traumático. No mundo virtual, porém, quando o indivíduo desconecta um "amigo" de sua rede tem-se "[...] um solitário que se afasta de uma multidão de solitários". O filósofo afirma que dois valores interferem na satisfação do indivíduo humano: segurança e liberdade. Destaca contudo que, na ambivalência da vida, esses valores não se equilibram, pois a civilização é sempre uma troca, independentemente de interferências cronológicas. 
O discurso crítico de Bauman (2012) constitui-se de declarações tão lúcidas que evocam as emoções dos interlocutores e remete à mesma lucidez como valor indispensável para o indivíduo pós-moderno. Adverte que o destino sempre oferece gamas de opções, "[...] porém o que guia a escolha é o caráter. As pessoas que imitam as formas de vida de outra pessoa não são felizes. Para cada ser humano há um mundo perfeito feito especialmente para ele ou para ela" (BAUMAN, 2012). A pós-modernidade articula sistematicamente o amadurecimento alcançado pelas relevantes concepções para a comunicação e para os relacionamentos que organizações de hoje necessitam.

O foco dado à complexidade que envolve as organizações nos nossos dias é uma abordagem esclarecedora dos desafios a serem enfrentados que presumem a análise contextual dos contornos da sociedade atual. Compreende-se a necessidade de estabelecer um diálogo entre a forma mais tradicional de comunicação humana - a oralidade, com o pensamento coletivo sobre a era da informação. A "conversa" com a modernidade visa dar forma à defesa da necessidade de resgatar o tradicional, o qual pode conviver harmoniosamente com novos padrões, a partir do mútuo entendimento e da consideração do pensamento humano. Dizendo de outro modo, o resgate foi estruturado na qualidade do pensamento sobre modernidade e seus reflexos na vida cotidiana das pessoas e das organizações.

O século XXI traz consigo tamanho desenvolvimento social que foi preciso adotar uma nomenclatura que representasse o seu acelerado nível de evolução. Esta época foi, então, designada a "era da informação" que se exprime pela ocorrência de uma densa revolução cultural, pois aí existe um novo componente que é o relacionamento entre indivíduos que se comunicam com o mundo, por meio da tecnologia e das redes de informação. O volume de informações disponíveis na modernidade tem representação nos discursos organizacionais. Torres (2009, p. 54) ,no entanto, metaforiza que o conhecimento na época atual é uma "biblioteca de Babel". A crítica do autor menciona a fragmentação como um fator prejudicial ao conhecimento sobre o todo, pois o contato com tantas visões sobre as coisas produz o surgimento de tensões sobre os contraditórios.

Halliday (2009, p. 32) afirma que o termo discurso está absorvido no próprio entendimento que se tem sobre modernidade e globalização. Esses termos parecem promover a "biblioteca de Babel" mencionada por Torres (2009), embora 
não como termos multifacetados e com sentidos diferentes, mas sim como paradigmas contemporâneos, portanto vigentes na sociedade atual. Desconsiderar tais aspectos e seus domínios na contextualização do contorno do desenvolvimento socioeconômico mundial poderia ser uma excentricidade e, mais ainda, se também desconsiderasse a essência de tais mudanças dentro de uma conjunção mais ampla que é o processo da globalização e sua interferência nos espectros do mundo.

As mudanças aparentes nos modos de ser e fazer da sociedade global permanecem recobertas de incertezas e gradativamente apontam mais e mais desafios para as organizações sociais. Essas mudanças assinalam, como menciona lanni (1999, p. 11), "[...] a emergência da sociedade global, como uma totalidade abrangente, complexa e contraditória". Essa nova e ainda pouco conhecida realidade, conforme lanni, "[...] desafia práticas e ideias, situações consolidadas e interpretações sedimentadas, formas de pensamento e voos da imaginação" (IANNI, 1999, p. 11). O prenúncio do século moderno foi coberto de expectativas e previsões direcionadas a um novo tempo como se, a partir de seu início, o mundo estivesse recomeçando e tudo que foi usual até então, deixasse de ter proveito para a nova realidade. Houve uma mistificação demasiada, embora os relacionamentos nas organizações globais sejam uma representação autêntica de interferência dos paradigmas vigentes. "Um paradigma estabelece as regras (escritas ou não), define os limites e diz como alguém se deve comportar dentro desses limites para ter sucesso" (TARAPANOFF, 2001, p. 33).

O impacto provocado pelas previsões sobre "o novo tempo" levou os organismos sociais a se despirem de sua altivez e a reformularem a orientação de seus princípios. Conforme analisa lanni (1999, p. 16), se considerada como um todo em movimento, a sociedade global constitui determinadas condições e possibilidades "[...] que podem nortear as condições e as possibilidades de nações e nacionalidades, assim como de indivíduos, grupos, classes, coletividades, povos, movimentos sociais, partidos políticos, correntes de opinião pública”. Destaca Castells (1999, p. 119), que "[...] é nessa escala global que ocorrem atividades estratégicas produtivas e comerciais, bem como acumulação de capital, geração de conhecimentos e gerenciamento da informação". lanni (1999, p. 16) refere-se às empresas, corporações e conglomerados transnacionais afirmando que, “[...] em suas alianças estratégicas, e por meio de suas redes de comunicação, podem estar presentes em muitos lugares ou mesmo em todo o mundo". A globalização motiva 
um conjunto de ações que possibilita exercer facilidade sobre o acesso à informação, desenvolver maior consciência coletiva, melhorar os conteúdos da comunicação e conjugar relações sociais e econômicas. Essas ações determinam as ideologias e fomentam um desenvolvimento mais seguro e avançado, portanto asseguram maior competitividade no cenário internacional.

Adotar as tecnologias de comunicação não representa, necessariamente, a exclusão da essência do campo de conhecimentos profissionais específicos para uma organização funcionar. Como lembra lasbeck (2009, p. 8) "[...] a identidade das organizações emerge das relações que se estabelecem entre discurso e imagem" e a adequação de paradigmas se faz necessária devido à existência de uma sociedade heterogênea, em evolução constante e que deve absorver a diversidade como uma característica presente. Trata-se aqui de não se negar a atribuição de responsabilidades, mas de as assumir de modo a contribuir com a formação de uma sociedade mais justa e voltada para as reais necessidades coletivas.

Com a globalização, segundo lanni (1999, p. 14), ocorre a reestruturação de empresas de qualquer porte, "[...] em conformidade com as exigências da produtividade, agilidade e capacidade de inovação abertas pela ampliação dos mercados, em âmbito nacional, regional e mundial". Por ocasião do advento das novas tecnologias, a cautela e a tradição corporativas incitaram questionamentos sobre as reais vantagens do uso das mesmas em seus processos. Concomitantemente, estabeleceu-se a percepção de que o quadro funcional não estava apto para visualizar o potencial de benefícios que teriam implicação direta na redução de esforços e na otimização do empenho dos sujeitos. Decorrida mais de uma década do início do novo século, percebe-se que a essência das relações humanas não pode ser a(du)lterada e que a necessidade de preservar formas basilares de relacionamentos é inconteste. Não se trata de sugerir o resgate de costumes perdidos no decorrer de uma evolução cultural porque estes não se perderam.

O novo perfil para organizações pode ser delineado a partir de julgamentos de público, os quais decorrem tanto do processo de globalização, como do avanço tecnológico. Tecnologias avançadas dão suporte para os contatos das organizações em todo mundo, para o acesso a variadas fontes de informação, para a opinião pública manifestar-se "em rede", entre outras possibilidades. 
A organização que não se comunica bem deslegitima-se. Esse poderia ser o aforismo-chefe das pessoas jurídicas do século XXI. Não porque o século seja novo, mas porque a necessidade de legitimação é tão antiga quanto os agrupamentos humanos. Aqueles que adotam a abordagem retórica para os estudos da comunicação organizacional sabem que sempre foi assim: a legitimidade de uma ideia, uma causa, um comportamento ou uma instituição é construída, em grande parte, por uma comunicação de boa qualidade, o que equivale dizer "uma boa argumentação" (HALLIDAY, 2009, p. 46).

Ainda que o avanço tecnológico ofereça soluções inteligentes para o cotidiano das organizações, prevalece na percepção das pessoas que uma organização seja merecedora de reputação favorável quando esta se relaciona com a intimidade que somente o diálogo direto com uma pessoa que fale a voz e em nome da organização é capaz de transmitir. A comunicação, na modernidade, confere o sentido das ações organizacionais e, conforme reflete Torres (2009, p. 55), "[...] embora a tecnologia nos propicie as maravilhas dos computadores, da telemática, da internet, tais ferramentas tecnológicas prescindem de entender o fenômeno humano". A mudança de uma era para outra não implica o fim da anterior, pois é possível ambas coexistirem e, independentemente da tecnologia disponível, fazer prevalecer o uso de variadas formas culturais. Deste modo, orientações estratégicas para o fortalecimento de relações com públicos prescindem de incluir a comunicação oral e o uso da oralidade como transmissores de habilidades comunicacionais em gestores e em funcionários.

A comunicação face a face é uma forma original de comunicação que está enraizada na própria natureza humana e independe de reconfigurações de tempo e espaço. Trata-se de um traço natural que coexiste com os paradigmas contidos na evolução do homem e da sociedade. A palavra, componente essencial da linguagem, é uma prerrogativa do homem que faz uso da linguagem verbal para se comunicar com seus semelhantes. Compõem a linguagem outras características, contudo não somente humanas, como é o caso dos gestos, dos sinais e dos símbolos. Desde quando a retórica inspira estudiosos, a comunicação oral e os requintes da oralidade se fazem presentes. Pelo advento da oralidade, o homem diferenciou-se de outros animais ao usar processos mais complexos de comunicação, transmitir conhecimentos por meio da fala e, assim, transformar modos e formas de se relacionar e de se comunicar. 
Para além das características da linguagem, Citelli, (2008, p. 14) acrescenta que "[...] a Comunicação, afora os aspectos empresariais ou técnicoindustriais, é, fundamentalmente, linguagem sob diferentes configurações de códigos e signos". No nível das relações organizacionais, a complexidade dos estudos sobre linguagem cumpre um papel essencial para caracterizar as variáveis envolvidas na comunicação estabelecida pelas organizações com seus públicos estratégicos.

Até este ponto, na sequência de capítulos desta tese, foram discutidos, de forma abrangente, os conceitos de linguagem e suas interfaces com as organizações, porém com o cuidado de estabelecer, com clareza, dois direcionamentos: linguagem como campo da comunicação e linguagem em seu vínculo com o discurso nas organizações. Nessa discussão, os temas foram examinados de modo recorrente com apoio em fundamentações que melhor ilustrassem a maneira como se estabelecem condições para ver a organização como território para o diálogo e atribuir-Ihe enfoques como tradição e pós-moderno, tecnologia, globalização, mudanças culturais. Com isso se buscava um adensamento teórico que conseguisse fazer desembocar a comunicação como mediadora das relações da organização com os públicos. Em seguida, entraram em destaque, já no capítulo que aqui se conclui, as diferentes posições que assume a comunicação interna quando se examina sua aptidão para promover o diálogo. A finalidade foi acentuar as definições sobre comunicação interna e, ao mesmo tempo, vê-la associada à tecnologia, à performance de líderes e liderados, à configuração que assume como elemento da área mais ampla da comunicação organizacional e ainda adicionar, a essa leitura, as atenções da área de relações públicas. Chega, agora, o momento de desdobrar todo esse encaixe de temas para particularizá-lo nos princípios e conceitos envolvendo o fenômeno da oralidade e o da comunicação face a face, para dar nitidez à ligação existente entre ambas, aspecto chave na proposta deste estudo. Isso passará a ser efetivado nos próximos dois capítulos. 


\section{ORALIDADE: PRINCÍPIOS E CONCEITOS}

A oralidade aflora nos indivíduos que buscam o diálogo como sustentação para criar ou para projetar relacionamentos interpessoais, desde que seja entendida como a transmissão oral dos conhecimentos armazenados na memória humana. O contato direto entre atores sociais permite que ideias sejam discutidas até o ponto em que, surgindo barreiras ou ruídos à comunicação, estes sejam prontamente sanados através de uma atitude elementar como é o uso da palavra. Analisando a palavra como forma basilar de comunicação, pode-se então considerar seu uso como um princípio das relações humanas. Um principio é a essência, a substância ou a regra primeira que fundamenta a formação do conjunto de outros princípios que cada pessoa carrega em seu interior. A oralidade, como princípio de relações interpessoais, constitui-se em uma forma de participação e de influência sobre os interlocutores, no que diz respeito às decisões que devam tomar como sujeitos de uma sociedade democrática.

Oralidade não se reduz à exposição física entre sujeitos, pois um de seus princípios foca-se na oportunidade de conduzir um ator social a se expressar com a mediação da palavra. Palavras são estímulos e representações traduzidas pelos significados, pelos objetos e pelos conceitos aos quais se referem naquele processo interacional. As palavras fazem referência tanto ao palpável, quanto à abstração, conforme o contexto situacional dentro do qual sejam utilizadas. Esta é uma dinâmica que ocorre através de exemplos e de outras formas de ilustração que acrescentem clareza e significado ao que a mensagem encerra. É, então, esperado que a oralidade seja um dos suportes para atingir os fins da comunicação interna na organização. $O$ uso da palavra, exercido por executivos e equipe de funcionários de organizações empresarias, tem potencial para acessar bom relacionamento interno e acrescentar qualidade naquilo que a organização propõe fazer para a sociedade. Como derivação da palavra oral, o sentido da palavra oralidade tende a ser traduzido como um procedimento verbal que afasta a consideração de seu potencial para desencadear ações. A ênfase da oralidade está na comunicação pela fala, mas uma das ações que ela pode desencadear é o ato da escrita como meio cuja finalidade é registrar e perpetuar valores, ideias e conhecimentos que originalmente foram lançados pela palavra falada. A força que a oralidade exerce sobre os 
públicos organizacionais pode caracterizar uma orientação estratégica para as relacionamentos entre stakeholders e organização. Sabe-se que a comunicação é primordial para obter a adesão do receptor, contudo é a palavra que, ao ser dita e repetida, modifica conceitos, provoca adesões e forma percepções. Através da oralidade, triunfa o diálogo e ganha força a comunicação interpessoal.

Inseridos numa perspectiva conservadora da comunicação administrativa, a manifestação de conceitos, de adesões e de percepções constituem a mais genuína forma de poder nas organizações empresariais ou podem também funcionar em sentido inverso. Uma leitura avançada de poder e traduzida para nossos dias desvenda um direito de deliberar menos instintivo, muito mais estudado e que se realiza pelo estilo de gestão das lideranças. Maximiano (2004) declara o caráter essencial da oralidade para as organizações quando afirma que a comunicação oral é o primeiro e o mais importante canal de comunicação das empresas. Gaudêncio Torquato (2011) menciona que a comunicação oral não é tratada da mesma forma que a escrita e os profissionais, com raras exceções, não estão lidando com a oralidade como pertencente a uma importante forma de comunicação, que é a oral.

No ambiente onde se alteram os processos administrativos e as formas de relacionamento com os públicos de interesse, novas atitudes e mudanças podem ser verificadas pela crescente preocupação com a comunicação interna, resgatando o valor da oralidade como estratégia para bons relacionamentos públicos. No espaço interno de uma organização, o quadro funcional conserva a importância de valores como autoridade e sabedoria, porém sua manifestação é quase subliminar. Os valores contidos na nova cultura levam a entender que a contínua aparição de um líder diante de sua equipe determina o conceito formado pelos liderados a seu respeito. Uma atitude assim adotada por um líder desvenda sua autoridade e demonstra uma sabedoria unanimemente percebida pelas equipes.

O uso adequado da oralidade impulsiona bons resultados de comunicação entre atores internos até as técnicas aplicáveis serem naturalmente compreendidas. A construção ou a reconstrução de um modelo para uso da oralidade como estratégia para a comunicação interna somente poderá surgir de quem detém poder. Evidentemente que o modelo estará de acordo com interesses individuais, cuja legitimidade se sustentará no poder e na autoridade do líder que assim atuar. A palavra falada promove a transmissão imediata da mensagem, e sua 
clareza tem interface com a entonação, o entusiasmo, o ritmo, os gestos, dentre outras linguagens que se manifestam durante uma interlocução. Estes atributos da oralidade e da linguagem são utilizados pelo ator social que atua como emissor, lembrando que tanto emissor quanto receptor são atores, portanto conhecem o contexto e a situação do seu entorno, logo a comunicação torna-se mais breve e imediata.

Acredita-se que as relações dialógicas estabelecidas em uma organização sejam preciosas para construir interação entre pessoas, ainda que ocorram por meio de conversas informais. O diálogo é entendido como alicerce para qualquer atividade profissional, pois este é um processo contínuo e diário que ocorre pela via da linguagem verbal. A comunicação oral é a plataforma para interações que se incorporam à rotina das empresas. Seu uso está evidente nas reuniões, nos telefonemas, nas entrevistas com variados fins, bem como através de avançadas tecnologias de áudio. A comunicação interna é o espaço onde interações se manifestam e é um elemento essencial à existência e ao funcionamento de uma organização. A oralidade, portanto, merece distinção e análise apuradas para que a comunicação cumpra sua função dentro de uma empresa.

Gerenciar e fortalecer uma organização envolve ampliar oportunidades de negócios por meio de estratégias de comunicação interna, desde que esta comunicação respalde os objetivos organizacionais de curto, médio e longo prazo. Caso o plano estratégico estimule o diálogo no ambiente interno, esta será uma iniciativa que aproximará dirigentes e funcionários de modo a conciliar esforços, equilibrar interesses e atingir resultados almejados institucionalmente.

\subsection{Interfaces da Comunicação, Cultura do Diálogo e da Oralidade}

O Século XX tirou a cultura de massa de uma fase embrionária a partir da ocorrência de processos produtivos sistematizados para grande escala. Neste momento, a comunicação tem um caráter cosmopolita; "vende" sonhos e ilusões dando surgimento a uma sociedade que idealiza mitos e que transforma o consumo em um consolo para a vida que os indivíduos criam em suas imaginações. Bastante complexa, a cultura de massa é contraditória, uma vez que essa sociedade é marcada pela fusão de diferentes elementos culturais. Dessa forma, a comunicação busca atingir os pontos em comum e os veículos mais abrangentes. 
Do paradigma tecnológico emergiram mudanças nas relações culturais da sociedade, pois os meios de comunicação de massa misturaram-se aos avanços das tecnologias e geraram uma nova realidade de comunicação. Sem definições fragmentadas, o novo paradigma carrega como característica o novo posicionamento dos indivíduos perante os processos comunicativos. As transformações sociais e tecnológicas resultam na desmassificação, isto é, na pluralização das visões de mundo e novos posicionamentos e anseios da sociedade em relação ao todo. Ao mesmo passo em que a cultura comunicacional da sociedade foi se modificando e aprimorando assim também se deu na totalidade dos fenômenos sociais.

Baccega (1995) analisa a influência do social na formação do homem e o papel da linguagem, em especial da fala, na conceituação dos discursos sociais. Afirma que as palavras ganham sentidos através de longos processos históricos e culturais, constantemente transformados pela interação social própria do homem.

Ao nascer, o homem encontra, portanto, uma história em processo. É como se tomasse um trem numa determinada estação. Este trem, que carrega cultura, está vindo de muitas e muitas estações, já transportou milhões e milhões de pessoas entre as várias estações. São (e/ou foram) pessoas que realizaram, juntas, um número incontável de ações, as quais se manifestaram numa pluralidade de significações que as palavras registraram em discursos. [...] Logo, a mediação entre o homem e a realidade objetiva é exercida pelas linguagens, sobretudo pela linguagem verbal, pela palavra. Essas palavras assumem seus significados em discursos (BACCEGA, 1995, p. 31).

O significado de cada discurso insurge de limites culturais e da diversidade que neles reside. $O$ que une os homens é a linguagem verbal, a qual é o ponto de convergência dos discursos. O processo de formação dos discursos comporta individualidades sociais e culturais que devem ser projetadas para 0 estudo da oralidade. A fala é um elemento básico no processo de socialização, uma vez que é de sua natureza efetivar a comunicação. Reafirmar a importância original da fala e sua presença na história da humanidade atende à compreensão acerca de como hoje são construídos os discursos. Emergiram tempestivamente à evolução do próprio homem os processos comunicativos e as relações interpessoais e/ou organizacionais. 
Vivemos uma sociedade organizacional, pois as organizações se proliferaram para satisfazer aos anseios humanos. As organizações de hoje não somente interferem na vida coletiva, como também afetam a vida particular das pessoas que nelas ou a serviço delas vivem grande parte de seu dia.

As pessoas chegarão e se reunirão, vindas de diferentes culturas ou subculturas, com diferentes pressuposições e opiniões. Podem não ter consciência disso, mas têm uma certa tendência a defender suas ideias préformadas e opiniões contra evidências de que elas podem não estar corretas. Ou simplesmente têm uma tendência a defendê-las contra alguém que apresenta outras opiniões (BOHM, 2005, p. 42).

Compreender o surgimento e a reconfiguração de processos comunicativos orais se torna essencial no momento em que se retoma a necessidade de proximidade e de interações comunicativas diretas entre interlocutores. A cultura do diálogo pode ser efetivada como um processo de comunicação organizacional, mediante a criação de uma cultura que se sustente, seja transmitida e mudada pela interação social, cujas atividades se baseiem na troca de mensagens e na definição de significados. Vale lembrar que a interação entre membros de uma organização é um dos pilares de sustentação de sua própria cultura. Segundo Bohm (2005, p. 67) "[...] a sociedade se baseia em significados compartilhados, os quais constituem a cultura".

Em entrevista com o consultor norte-americano de comunicação interna, Thomas J. Larkin (2005), questionou-se a respeito da cultura organizacional que desenvolve campanha de comunicação interna inserindo logomarca, slogans e outros apelos publicitários. A pergunta surgiu porque esses são apelos mais adequados ao público externo. Larkin (2005) foi direto ao afirmar que a propaganda busca estimular a venda de um produto, e que o funcionário cumpre funções nos processos da empresa. Afirma o norte-americano que os funcionários não estão interessados em comprar, mas sim em cumprir aquilo que a empresa determina que eles façam, conforme transparece a cultura organizacional no que concerne ao relacionamento interno. Durante a entrevista Larkin (2005, p. 5) analisou que "[...] os trabalhadores não estão comprando nada, eles não têm uma escolha. Eles são forçados a fazer algo que é imposto pela organização". Ainda que a comunicação interna exponha um momento crítico da empresa ou uma crise interna, a controvérsia tem que ser comunicada, independentemente da aceitação imediata do funcionário ao que foi comunicado. Se a organização é um ambiente de tensões, a 
oralidade pode funcionar como um suporte para que necessidades de informação imediata e precisa sejam comunicadas internamente de modo satisfatório.

A empresa enfrenta dificuldade com o conteúdo da mensagem originária da comunicação interna, conforme analisa Larkin (2005). Embora a oralidade muitas vezes receba um tratamento informal e seja abordada sem sua devida importância, é inegável o potencial presente na comunicação oral para sua (re)adequação durante o processamento. O caráter estratégico que a oralidade pode assumir, por vezes em grau de superioridade perante outras frentes e formas comunicacionais, deve-se ao fato de a comunicação oral possuir maior riqueza de detalhes, possibilitar resposta imediata e facilitar o contato direto. Por este motivo, enfatiza-se a autoridade de um supervisor para comunicar face a face. A cultura organizacional ensina que o líder deve conquistar e manter a confiança do funcionário para, ao se manifestar diretamente, oferecer a tranquilidade que a equipe espera ter na organização onde trabalha.

Embora persistam organizações que ainda não reconhecem a necessidade de se dedicar e estruturar a comunicação dialógica que perpassa os processos comunicacionais, internos e externos com públicos institucionais, as organizações já atentaram para o fato de a comunicação ter-se tornado diferencial competitivo. Estas correntes de pensamento se consolidaram mediante estudos desenvolvidos com evidência sistemática ao reconhecimento do valor que as pessoas devem ter nas organizações e corporações para que bons resultados sejam atingidos. É preciso saber ouvir a polifonia das vozes sociais que o indivíduo reproduz e reelabora, pois, afirma Baccega (1995) que a palavra, enquanto signo, sobrevive em âmbito social dentro de um discurso que produz seu significado e sentido. Pode-se ainda acreditar no avanço que o campo da comunicação interna possa atingir dentro da comunicação corporativa, a ponto de obter a visibilidade possível somente aos componentes da cultura de organizações pós-modernas.

A problemática apresentada considera que a cultura oral possibilitou avanços nos modos de comunicar, haja vista que a oralidade permanece, apesar da evolução tecnológica e dos meios comunicativos. Mesmo com a transformação nos modos de comunicação humanos surgidos juntamente com as tecnologias, ressaltase a necessidade de sistematizar o uso da oralidade, de analisar sua origem e de estudar modos para edificar seu valor para a construção ou reconstrução da cultura organizacional e humana. Constata-se a influência da oralidade como forma de 
comunicação interativa, apesar de parecer renegada pela comunicação interna e pelos gestores. Conforme afirma Nassar ([2005], p. 18), "[...] parece incrível, mas, em plena era da informação e da comunicação, muito se esqueceu sobre a boca, que reúne a matéria e a alma, o alimento e a palavra". Presencia-se um movimento que converge para resgatar formas diretas de relacionamento. A busca pela participação é crescente, a transmissão de informação conforme a concepção mecanicista não satisfaz ao homem de hoje. A tese em construção localiza a interação como palavra de ordem nos dias atuais.

\subsection{Oralidade no Processo de Gestão Criativa}

A negligência com a oralidade nas organizações contemporâneas deriva de sua dinâmica transitória, das interferências do contexto e da interpretação dada ao discurso oral. Segundo analisam Fernandes, Leite e Oliva (2012, p. 7), fatores intervenientes ao enfraquecimento da oralidade são as oscilações que ocorrem por quem interpreta as palavras e pela influência que o modelo de armazenamento pode carregar. A oralidade é comparada a um "território movediço", que registra a história das mudanças sofridas pelo ator social, paralelamente à sua existência. Ao receptor da comunicação oral, aufere-se a ideia de um performer, pois ele atua sobre o texto oral dando-lhe uma ressignificação que resulta do modo como se deu a atuação do emissor sobre as palavras pronunciadas no fenômeno de interlocução. A performance na oralidade envolve uma multiplicidade de linguagens que repercute em alto grau, especialmente quando o emissor da mensagem oral é um líder que está interagindo com sua equipe de liderados. A mediação da palavra em um contexto organizacional é uma linguagem de conciliação e de exclusão e competirá aos objetivos estabelecidos pelo nível ascendente definir os contornos do território sobre o qual os atores atuarão.

Sabe-se que a realidade de uma pessoa se forma a partir da sua relação com o outro e das múltiplas plataformas e linguagens que esta dinâmica interativa comporta. Afirmam Fernandes, Leite e Oliva (2012, p. 19) que "[...] a palavra e sua efetivação no contexto da oralidade é um fenômeno de importância porque atribui eficácia ao mundo, configura a natureza e interliga o homem com 'as coisas' ". A oralidade abriga significados como o de troca, de interação e diálogo contados pelas histórias de cada ator ou grupo social, as quais se processam pela 
inserção das mudanças que os sistemas organizados atravessam e incorporam. As histórias são entrelaçamentos constituintes de redes interativas nas organizações sociais. O sujeito que conta uma história, apoia-se na fala para despertar sobre si valores como confiança, conhecimento, cooperação, entre tantos outros.

Um aspecto interativo da narrativa oral, conforme analisou Walty (2012), é a existência do presente coexistindo com o passado em uma rede relacional fascinante e harmoniosa de convivência do novo com a tradição. A aderência entre os polos processa o desenvolvimento a despeito da negligência com o oral. Berger e Luckmann (2002) disseram que a realidade de uma pessoa é independente de todas as demais realidades com as quais convive. A ênfase dos autores dá-se sobre a realidade organizar-se em torno do aqui, do meu corpo e do "agora", limites dentro dos quais debitam a natureza e o foco da atenção dos indivíduos humanos. A sociedade pós-moderna é uma galeria de contrastes, contudo "[...] pode-se refletir sobre a presença ainda significativa da oralidade na chamada América Latina, seja em forma de oralidade primária, seja na sua absorção pela literatura escrita, seja nas leituras críticas cientes de sua transitividade" (WALTY, 2012, p. 35). Berger e Luckmann (2002) advertem para as múltiplas realidades contidas no mundo e enfatizam que a mais predominante é a realidade da vida cotidiana, portanto esta é a que mais importa para os atores sociais.

Um paradigma que hoje se mostra significativo e provoca impacto em outros padrões que se renovaram ou que surgiram na sociedade atual é a velocidade. Este é um desafio que permanece imbricado na rotina diária da pessoas e que estimula criatividade para tomar decisões nem sempre possíveis de serem avaliadas sob diferentes enfoques, porque o tempo não permite tanta elaboração. Repetidas vezes, a discussão dialogal do fenômeno ou novo fato para construir coletivamente soluções acertadas é a forma de abordagem adequada e, em seu interior, equilibra tradição e experiência. As narrativas dos indivíduos reproduzem sua história para outras gêneses, e essas naturalmente selecionam elementos absorvidos pela tradição de uma cultura passada para nortear o seu presente. $O$ relato de uma experiência vivida pode ser um apelo motivador para encaminhar soluções no presente e pode produzir reflexos no futuro.

A linguagem adiciona os significados do entorno social para o indivíduo. A interação face a face envolve o corpo, os sinais verbais, a subjetividade e permite a uma pessoa participar da realidade por meio de suas relações com o 
mundo. A socialização emana de formas interacionais simplistas como são as relações de trabalho, e nestes ambientes relacionais as pessoas serão (re)conhecidas pela figura que representam. Azevedo (2012) analisou os efeitos que o improviso e a oralidade causaram no samba brasileiro e esta é uma análise que comporta uma analogia com organizações, pois quanto mais afinado for o compasso entre os empregados de uma empresa, maiores serão suas chances de projetar uma imagem favorável, de participar positivamente com a sociedade e de constituir meios para alcançar seus resultados.

O improviso está em oposição a qualquer tipo de fixação, contudo este é um paradigma que pode ser analisado sobre outros enfoques, incluindo-se o da criatividade para decidir rapidamente sobre as demandas organizacionais e que pode estar alinhada ao plano estratégico. Um episódio de improviso dentro de um sistema organizado será referência para outras ocasiões e, assim analisado, ganha significado de decisão para uma demanda imediata.

"[...] a música improvisada ganha muito numa performance ao vivo, face a face, nos moldes daquelas descritas pelos estudos sob oralidade. Dependendo da participação da plateia, do clima geral ou mesmo da situação pessoal do intérprete, o improviso será mais longo ou mais curto, mais inventivo ou menos, e assim por diante" (AZEVEDO, 2012, p. 90).

A performance dos sujeitos dos processos comunicacionais internos de uma empresa aceita indicações documentadas em seus planos administrativos e institucionais. É um improviso necessário para adequar o que a cultura organizacional tem bem definido. O líder de equipe em uma empresa é alguém que precisa ser avaliado pela sua grandeza e inventividade como improvisador, prosseguindo-se na analogia com Azevedo (2012). Um líder conduz a performance de sua equipe nas situações face a face por meio de uma experiência compartilhada de criação, improvisação e de recriação de processos e sistemas vigentes na empresa. Afirma o autor que um resultado oral costuma variar conforme quem o executa, o tempo para execução e a memória de quem o executa, entre outros fatores, mas o resultado oral sempre será alcançado de maneira diferente. A performance tem caráter dialógico, de participação e de improvisação, portanto pode ser traduzida usualmente como esforço coletivo, identificação e compartilhamento.

Afirma Azevedo (2012, p. 112) que a performance é um evento interativo e que o improviso aceita acréscimo de novos e inesperados significados incorporados durante a performance "[...] o improviso é um recurso natural e 
recorrente de toda e qualquer cultura marcada pela oralidade". Essa é uma manifestação essencialmente dialógica e relacional. A comunicação face a face é a mais importante experiência do homem e dela deriva tudo que orbita em seu universo. Defendem os autores que, na situação face a face, os sujeitos são mutuamente apreendidos por uma convivência partilhada que favorece o intercâmbio sucessivo de experiência, bem como afirmam a força que a interação direta e face a face tem sobre como um indivíduo compreende o mundo.

\begin{abstract}
Na situação face a face o outro é plenamente real. [...] Sem dúvida, o outro pode ser real para mim sem que eu o tenha encontrado face a face, por exemplo por nome ou por me corresponder com ele. Entretanto, só se torna real para mim no pleno sentido da palavra quando o encontro pessoalmente. De fato, pode-se afirmar que o outro na situação face a face á mais real para mim que eu próprio" (BERGER; LUCKMANN, 2002, p. 47).
\end{abstract}

A conversa é uma forma de interação que sofre variações de acordo com a frequência e com a intensidade com que ocorre. A conversa entre um líder e seu liderado pode acontecer sem muita frequência, mas a intensidade colocada quando a experiência face a face ocorrer poderá suprir o período durante o qual não houve um diálogo. A gestão demanda a habilidade para comunicar oralmente com equipes e as conduzir para alcançar resultados considerados por todos satisfatórios. Azevedo (2012, p. 116) recomenda que o improviso seja uma experiência focada na performance, na criação imediata, no uso do talento e da intuição inesperada. Vale refletir criticamente sobre o modelo de impessoalidade que desvaloriza o potencial humano e coisifica toda uma obra com vistas ao produto final.

\title{
6.3 A Obscuridade dos Discursos nos Negócios
}

Embora seja recomendado que organizações valorizem a plurivocalidade e os discursos dialógicos na busca pela aproximação dos sujeitos, existe outra tendência observada atualmente nas organizações, especialmente quando se trata da oralidade, que é o palavrório. Trata-se da artificialidade em discursar, especialmente dos executivos, como forma de justificar a falta de clareza e concisão de ideias, ou até mesmo para omitir verdades que não soariam tão bem aos receptores em conversas reais. Segundo Fugere, Hardaway e Warshawsky (2007, p.10): 
Há uma grande distância entre essas conversas reais e autênticas e a voz artificial dos executivos e gerentes de empresas em todos os níveis. Num mundo que implora por mais humanidade, é isso justamente o que falta às mensagens deles. Entre reuniões, memorandos e gerentes, perdemos de vista a arte de conversar. A embromação se tornou a linguagem dos negócios.

A necessidade mundial de seduzir pelos discursos é confundida com o uso de jargão empolado que faz com que o dialeto empresarial incompreensível e superficial pareça ter conteúdo. Estes discursos contrariam a tendência contemporânea de valorização da comunicação oral como forma de humanizar as relações e atender interesses mercadológicos. Palavras bonitas, jargões, discursos decorados e impessoalidade estabelecem barreiras para a comunicação oral das organizações, pois os relacionamentos são vulneráveis e os públicos sentem-se vítimas quando a prolixidade os desestimula. De acordo com Fugere, Hardaway e Warshawsky (2007, p. 31), o "[...] emprego de linguagem rebuscada gera efeito contrário nos ouvintes. Assim, quando ele pára de entender e já não precisa se concentrar no que você está dizendo, tem tempo de ver de quem é a culpa por não estar entendendo nada".

Até mesmo as tecnologias têm contribuído sobremaneira nessa tendência moderna ao distanciamento, ainda que elas facilitem e agilizem processos, têm proporcionado uma "terceirização da voz". O uso de e-mail, voice mails, roteiros sistemáticos e textos escritos que manipulam até mesmo a entonação desconsideram o poder da voz como mecanismo para criar relacionamento. Muitos são os profissionais que deixam de usar o telefone pela comodidade de responder instantaneamente uma mensagem de correio eletrônico. Fugere, Hardaway e Warshawsky (2007, p. 92) sugerem que "[...] se você tem uma relação tênue, se troca cinco e-mails sem nenhum telefonema, se está lidando com uma questão importante ou se está tentando persuadir alguém de alguma coisa, trate de investir alguns minutos num telefonema".

Argumentam os autores que existem duas "armadilhas" reais na comunicação das empresas hoje: a obscuridade e o anonimato. Assim, a obscuridade remete às evasivas, aos discursos empolados e à falta de objetividade. Por sua vez, o anonimato é caracterizado pela automatização da voz, roteiros monótonos, palestras que se dirigem a espectadores genéricos e que deixam claro a não participação do palestrante na autoria do discurso, entre outros. Essas situações de desvalorização da fala nas quais são utilizados a impessoalidade e jargões 
gratuitos são muito mais que simples problemas de gramática ou modismos. Falar de modo objetivo exige:

"[...] honestidade, humanidade e confiança da parte de quem faz negócios. Qualquer um pode montar uma apresentação que descreva 'as sinergias extensíveis derivadas do reposicionamento das metas dos ativos intelectuais'. Dá mais trabalho expressar a ideia [...] em linguagem comum" (FUGERE; HARDAWAY; WARSHAWSKY, 2007, p. 15).

Pode-se dizer, então, que essas formas de comunicação pouco atraentes estão vazias de linguagem que desafie a imaginação, instigue a curiosidade ou entusiasme o receptor. Nesse sentido, dentro da organização ou partindo delas para o ambiente externo, o discurso passa a ser um problema se não for dotado de criatividade e humanidade. É preciso praticar a oralidade, sim, mas ela deve ser um elemento transformador que vise a aproximar pessoas, diferentemente de ser mecanizada e monótona e, assim, levar as pessoas a não fazerem questão de ouvir o que se tem a dizer. A força da oralidade pode caracterizar uma estratégia relacional da organização, pois assim concebida a comunicação organizacional incorpora a oralidade como uma força a mais para o convencimento. Pode-se antever o triunfo da palavra falada como um mecanismo modificador de conceitos, que provoca adesões e forma percepções nos públicos empresariais.

No universo da comunicação administrativa, esses elementos traduzem-se pela manifestação do poder, nos dias de hoje menos instintivo e muito mais estudado, e se realiza na ação do gestor. No espaço interno de uma organização, o quadro funcional passa a dar importância a valores tais como autoridade e sabedoria, posto que a cultura vigente leva-os a entender que a contínua aparição de um líder em seu meio determina um conceito que é subliminar, mas que é relacional, antes de ser administrativo. Técnicas podem ser apreendidas para o adequado uso da oralidade, de modo a projetar bons resultados de comunicação entre agentes internos. A palavra falada promove a transmissão imediata da mensagem e sua clarificação tem interface com a entonação, o entusiasmo, o ritmo, os gestos, dentre outras linguagens que se manifestam durante uma interlocução. Estes atributos da oralidade e da linguagem são utilizados pelo agente social que atua como emissor. Tanto emissor quanto receptor são atores, portanto, conhecem o contexto situacional que os rodeia e a comunicação oral soma um imediatismo na sua que a escrita não est apta a alcançar. 
$\mathrm{Na}$ organização, relações dialógicas estabelecidas por meio de conversas informais são preciosas, pois constroem interação entre pessoas. 0 diálogo é entendido como alicerce de qualquer atividade profissional, pois este é um processo contínuo e diário e ocorre pela via da linguagem verbal empregada em sua forma oral em reuniões, entrevistas, avaliações individuais ou coletivas, em telefonemas ou em plataformas avançadas de tecnologia de áudio. A comunicação interna é o universo onde interações se manifestam, essas que são elementos essenciais à existência e ao funcionamento de uma organização.

Gerenciar uma organização implica fortalecê-la e ampliar oportunidades de negócios por meio de estratégias de comunicação que dêem respaldo aos objetivos organizacionais de curto, médio e longo prazo. O plano estratégico de comunicação que estimular o diálogo no ambiente interno, será sempre uma iniciativa de aproximação entre dirigentes e funcionários com impactos muito significativos na natureza e abrangência desses relacionamentos. 


\section{COMUNICAÇÃO FACE A FACE: PRINCÍPIOS E CONCEITOS}

A comunicação face a face é uma forma modernizada de comunicar. O ambiente hoje é de conversa e de uso da oralidade. A criatividade do líder será o meio para despertar a cooperação de sua equipe para com suas metas e para com os macro-objetivos organizacionais, visto que o público interno é quem gera fatos, notícias, conhecimentos, todos esses de interesse público. A proposta de Bohm (2005) para a prática de diálogo incorpora conceitos diversificados daquilo que a etimologia do termo sugere. Argumenta que o diálogo é um processo multifacetado passível de análise ampla que perpassa os valores, as emoções, os processos de pensamento, a memória, a cultura, o tempo e o espaço. Compreendido desse modo, o diálogo é mais do que a prática de interlocução, como também supera o termo discussão que tem como significado quebrar, fragmentar. Para o autor, o diálogo é um método cujo uso se dá pela técnica de reuniões nas quais os participantes são colocados em círculo, o papel de líder é dispensável e o objetivo é conceder liberdade de expressão para todos os engajados no método.

A exemplo da cultura indígena que conserva a tradição de conversar para fortalecer laços entre os componentes da tribo, o modelo de reunião para o diálogo proposto por Bohm, é aplicado face a face, é isento de formalidades e não segue pauta. A proposta assim formatada busca realizar diálogo como um pensamento que emerge e se mantém do coletivo. Comenta Alvarenga (2011) sobre o que observa no hábito de pessoas conversarem: "[...] o que mais admiro e observo [...] é a capacidade de conversar, o que inclui o ouvir e o falar com um ou mais interlocutores com o mesmo respeito que têm pelos demais elementos da natureza". Ao participar de uma conversa, o interlocutor deve ouvir e falar imbuído de respeito pelo seu interlocutor, vigiar sua vaidade e reprimir qualquer manifestação explícita de poder.

A resposta dada nas interlocuções ocorridas por meio da comunicação face a face é um indicador relevante sobre a compreensão do que foi dito. Isto justifica a proeminência conferida ao retorno da comunicação oral na atualidade e ao tratamento necessário para inserir a oralidade nas estratégias de comunicação interna. Palavras não transportam precisamente o mesmo significado para todos os indivíduos do público interno. A habilidade almejada em um líder para 
comunicar oralmente confere a ele a capacidade para instruir sua equipe por meio de uma comunicação apoiada em experiências específicas. O sucesso da comunicação interna sustenta-se na clareza e na compreensão sobre os objetivos organizacionais, do mesmo modo como deve esclarecer sobre as reações pretendidas do público interno para alcançar estes objetivos. Internamente, a comunicação oral abrange amplas finalidades que podem ir desde a informação, passar pela persuasão e alcançar o entretenimento das equipes, mediante a comunicação desenvolvida face a face.

O estudo desenvolvido pelas norte-americanas Stafford, Vanc e White (2010) examinou a visão de funcionários sobre os fluxos de informação com gestores de elevado nível de influência pessoal; suas preferências de comunicação quanto ao volume, aos canais e aos tipos de informação; o seu senso de comunidade dentro da organização e a relação entre essas percepções e a vontade do empregado de defender a organização. A importância dada à comunicação interna como objeto de estudos se deve ao fato de que, neste ambiente de comunicação os funcionários são um público estratégico. O estudo considera a influência pessoal igualmente importante para a comunicação interna, pois lembram as pesquisadoras que investigações anteriores exploraram o modelo da influência pessoal, considerado a partir de uma perspectiva de ampliação de limites, na qual o foco esteve nas relações de um individuo com outros indivíduos estratégicos, porém do ambiente externo.

A pesquisa indicou que a influência pessoal do Chief Executive Office (CEO) e dos gestores tem efeito sobre a satisfação com a informação e, consequentemente, sobre o que falam os funcionários de sua organização para os stakeholders externos. Independentemente de nível hierárquico, os empregados que têm uma relação com o CEO mostraram-se mais satisfeitos com as informações que recebem e sentem uma maior responsabilidade de defender a organização, conforme constatou a pesquisa. Um dado relevante para essa tese, e que foi apurado pelas norte-americanas, diz respeito ao uso de canais eletrônicos pela comunicação interna. Segundo os resultados da pesquisa, os funcionários reconhecem que o e-mail é eficaz para a troca de informações, mas todos os grupos de trabalhadores declararam que a forma de comunicação preferida por eles, ainda é a interação face a face. "Comunicação interpessoal, comunicação dialógica 
continua a ser importante para os empregados, em todos os níveis da organização" (STAFFORD; VANC; WHITE, 2010, p. 2, tradução nossa).

Uma dimensão assim proposta, admite refletir sobre as redes de comunicação tecidas a partir de tecnologias avançadas de comunicação pois, segundo Bohm (2005, p. 27), "[...] em que pese esse sistema mundial de ligações, há, neste exato momento, um sentimento generalizado de que a comunicação está se deteriorando em toda parte, numa escala sem precedentes". A sociedade em rede transporta tamanha diversidade que instiga o surgimento de conflitos étnicos, cronológicos e culturais inerentes ao sistema atual. Sobre estes capítulos, Bohm (2005) analisa a ansiedade mundial pelo "problema de comunicação" e a complexidade como reflexo da incapacidade dos grupos de ouvir uns aos outros. A falta desta que deveria ser uma forma de empatia entre atores sociais, conduz as pessoas à frustração, discordância e, consequentemente, desencadeia mais violência do que o entendimento e confiança almejados por todos os povos. Os canais eletrônicos têm sua utilidade admitida pelos informantes da pesquisa de Stafford, Vanc e White (2010), desde que usados com moderação. Os funcionários reconheceram que canais eletrônicos podiam achatar a estrutura hierárquica tradicional e despertar a sensação de que todos os funcionários recebiam coisas em primeira mão, enviadas por seus superiores na organização.

Apesar de reconhecidas como demoradas, as reuniões foram valorizadas como canal para fornecimento de feedback mediante o contato direto com gestores organizacionais. Stafford, Vanc e White (2010) salientaram que os termos da comunicação interna precisavam ser redefinidos como parte da construção de relações favoráveis entre a administração e os empregados. O desgaste das relações humanas, nos nossos dias, motiva estudos científicos sobre culturas primitivas e seu costume de praticar o diálogo. A vantagem estratégica do face a face na comunicação interna vem não só dos benefícios óbvios de satisfação e produtividade do funcionário, mas também das contribuições positivas que funcionários bem informados podem fornecer a uma empresa.

Os empregados podem ser os melhores embaixadores de uma organização, bem como seus mais altos críticos, e isto procederá de obterem ou não informações úteis em seu cotidiano na organização. É um paradigma global que os funcionários sejam particularmente vistos pelos agentes externos como fontes de comunicação confiáveis, portanto podem melhorar a reputação corporativa e sua 
credibilidade. Stafford, Vanc e White (2010, tradução nossa) afirmaram que "[...] os empregados são o rosto de uma organização e têm uma poderosa influência sobre o sucesso organizacional". A influência pessoal é um componente importante da comunicação relacional. Executivos superiores, em uma organização, exercem forte influência pessoal em suas relações com outros empregados para afetar atitudes, satisfação no trabalho e, consequentemente, em como os funcionários falam sobre a organização aos agentes externos.

Segundo informações da pesquisa norte-americana, a comunicação interpessoal é o cerne do modelo de influência pessoal, e nela residem o status, confiabilidade e credibilidade do indivíduo. A influência pessoal pode ser estrategicamente importante para a comunicação interna, posto que os funcionários são o público-alvo e os agentes internos que dão movimento às engrenagem do fazer organizacional. Uma organização que consegue comunicar valores desejáveis e objetivos traçados obterá êxito na identificação natural entre empregados e organização. Esse é um tipo de reconhecimento que predispõe os funcionários a falarem positivamente sobre a organização e, assim, influenciar outras chaves de stakeholders. Empregados com informações suficientes sobre sua organização são menos propensos a espalhar rumores e mais propensos a defendê-la.

Os resultados que uma conversa podem atingir o surgimento de perspectivas distintas do foco que the deu origem. O que emerge dessas conversas, muitas vezes, afasta-se do objeto que as originou, porque a liberdade de expressão e de elaboração do pensamento encaminha para novas opiniões e experiências possivelmente porque "[...] o 'novo' assunto é bem mais importante que todos os outros, caso contrário não teria surgido", como analisa Alvarenga (2011). A convivência com a diversidade seria possível pelas vias da comunicação, apesar da dinâmica que difunde variados meios comunicacionais. Conforme levantaram Stafford, Vanc e White (2010) os funcionários que estavam mais satisfeitos com a comunicação interna foram os que receberam informações de várias fontes, incluindo os canais interpessoais.

Traduz Bohm (2005, p. 29) que a comunicação é uma forma diferenciada de diálogo que transcende a concepção de comunicar como "fazer alguma coisa juntos”. Salienta, ainda, que no processo de mudança da concepção sobre diálogo e comunicação "[...] os interlocutores estão fazendo algo em comum, isto é, criando juntos alguma coisa nova". Este processo transforma os interlocutores 
em sujeitos criativos, pois não há dogmas nem verdades totalitárias, “[...] ninguém adere em definitivo às suas ideias nem as defende de maneira radical. Por que é tão difícil na prática, comunicar-se dessa maneira?", questiona Bohm (2005, p. 31). A resposta pode ter vindo de Alvarenga (2011) ao afirmar que, "[...] afinal, somos seres que desaprendemos a conversar".

Reconhecida a conveniência dos e-mails, um alto valor foi conferido à comunicação face a face na pesquisa de Stafford, Vanc e White (2010), embora muitos trabalhadores tenham referido que as reuniões eram demoradas. Canais face a face incluem reuniões e oportunidade de encontros com os colegas e administradores. Confirmaram os funcionários pesquisados a inexistência de um canal exclusivo de informação, pois consideraram a variedade importante. Afirmaram que quando estavam frente a frente com um interlocutor, existia um potencial para 0 surgimento de laços que davam o start para formar equipes.

O método do diálogo de Bohm (2005) pressupõe participação de um game em que não há vencedor, pois as jogadas ocorrem com e não contra as pessoas. Pressupostos e opiniões todo indivíduo tem os seus, contudo aqui o diálogo penetrará no processo do pensamento e não somente no que está por detrás dos pressupostos. As opiniões remetem ao que se pensou no passado e que ficou registrado na memória sobre o que se experimentou, o que foi ouvido. $O$ pensamento como processo ultrapassa os limites do conteúdo para atingir a mudança no modo como coletivamente o pensamento acontece. Recomenda Bohm (2005) que o processo do pensamento seja um modo de pensar distante das divisões para ser edificado no interior do coletivo. Assim como o pensamento, a linguagem é coletiva.

Mantemos nossas conviç̧ões e respostas, enquanto aguardamos a vez de apresentá-las. Com esse pensamento, perde-se duas oportunidades importantes das rodas de conversa: a possibilidade de olhar uma mesma situação sob novos ângulos, o que propicia maior criatividade na resolução de conflitos e problemas; e a chance de melhorar a capacidade de relacionar-se, o que repercute na vida como um todo (ALVARENGA, 2011).

As pesquisadoras norte-americanas Stafford, Vanc e White (2010, tradução nossa), reproduziram o depoimento de um respondente que afirmou ser "[...] um crente firme na política de reuniões de equipe de departamentos como uma ferramenta de comunicação - a roda funciona mais suavemente quando os raios estão em uníssono". Outro depoimento destacado pelas autoras veio de um funcionário que declarou trabalhar há anos na empresa e que durante sua 
permanência tinha avistado efeitos negativos causados pela falta de ocorrência de reuniões internas, bem como identificava os efeitos positivos na equipe quando essas reuniões eram realizadas. Considerando o adiantado desenvolvimento científico e social norte-americano, esta constatação dá suporte para a defesa do uso de instrumentos conservadores para que a comunicação interna atue estrategicamente.

\subsection{Por Que Comunicação Face a Face}

A comunicação interna como espaço para contatos interpessoais compreende a inclusão de funcionários, como também dos gestores e dirigentes localizados nos níveis hierárquicos mais elevados da organização. Nos dias atuais, a comunicação compete com outros interesses e com outras informações, de modo que o desafio lançado é equilibrar os interesses e dosar a comunicação face a face perante o outro universo comunicacional que é calcado na tecnologia. Em curso realizado na Associa Brasileira de Comunicação Empresarial (Aberje), ministrado por Carlos Parente e Fábio Betti (2010, informação verbal) ${ }^{6}$ foi afirmado que transmitir mensagem hoje é fácil, porém foi lançado o questionamento sobre onde ficam a assimilação e a compreensão sobre esta mensagem. Segundo afirmaram, dados quantitativos sobre quantos receberam a mensagem nada revelam sobre comunicar. Comunicar é, conforme defendeu Betti (2010), "[...] um convite a uma nova forma de conversa, de diálogo e de escutar. Escutar inicia com o convite ao outro para assim também fazer". Onde houver barreira ao aprendizado da habilidade de comunicação, é provável que o obstáculo encontre-se no íntimo da pessoa que não acredita em seu próprio potencial. A timidez, ansiedade, vícios de linguagem, nervosismo, prolixidade e medo de falar em público são dificuldades que deverão ser superadas por quem pretende ser oralmente hábil para se comunicar.

O diálogo fluente é a estratégia adequada para quando se pretende percorrer uma trajetória fértil, tanto para os negócios, como para os relacionamentos públicos. Sem olhar para dentro, ouvir a si mesmo, fica mais difícil analisar cenários, encontrar e propor soluções. Há muita coisa sendo feita, porém os resultados são moderados. Por tudo isso, é preciso resgatar questões que se perderam na história,

\footnotetext{
6 Informação obtida no curso "A comunicação face a face no processo de transformação organizacional', promovido pela Aberje, São Paulo, 19 ago. 2010.
} 
segundo informou Betti (2010), durante o curso "A comunicação face a face no processo de transformação organizacional". O contato direto é dos mais relevantes pontos a serem absorvidos para que a comunicação ocorra de modo eficaz, particularmente através do contato face a face. Como pode ser observado pela crítica dos entusiastas da comunicação direta como, brasileiros e estrangeiros como Goffman (2011), Betti (2010), Bohm (2005), Larkin (2005), Parente (2005), Zanetti (2005), entre outros, o emprego de meios tecnológicos avançados para se comunicar com funcionários está contra indicado. O caminho da conciliação e do diálogo é o mais seguro nos dias de hoje, pois desvia do percurso que seria o do embate. Betti (informação verbal) alertou que, no mundo virtual, um funcionário pode "estilhaçar" com a imagem de uma empresa, mesmo que este não seja ouvido no ambiente interno da organização e recomendou atenção e cuidado redobrados com a comunicação interna, na atualidade. Ao analisar estrategicamente o ambiente externo das empresas no mundo, apresentou quatro pontos críticos para analisar o cenário da comunicação interna:

1. Revolução no local de trabalho: de uma sociedade industrial para uma sociedade da informação...

2. Isso quer dizer que os colaboradores se transformaram na "essência" do negócio...

3. Mas os colaboradores estão a cada dia mais céticos, se não cínicos...

4. O que demanda estratégicas mais inteligentes de comunicação para estimular as pessoas a cooperarem (BETTI; PARENTE, 2010).

A comunicação introduz o engajamento no ambiente corporativo, e as pesquisas de clima organizacional geralmente são os instrumentos que avaliam sua intensidade no interior da empresa. Afirma Betti (2010) que, nas organizações, existe uma quantidade relevante de pessoas que torcem contra seus resultados em virtude da sua insatisfação com as empresas. O poder de contágio dessas pessoas sobre a impressão e a imagem da empresa é importante e precisa ser considerado. Afirma Larkin (2005) que o uso de veículo impresso ou eletrônico pode ocorrer na comunicação interna, "[...] mas os empregados não querem assistir a alguma coisa, eles não querem ler. Querem uma relação direta, fazer perguntas, ouvir respostas. Os funcionários não querem ouvir o que temos para informar. "[...] As pessoas querem saber os planos da organização e o que afeta diretamente no trabalho delas". O norte-americano é assertivo ao afirmar que muitas das mensagens que uma empresa divulga aos funcionários nada mais são do que autopromoção voltada 
para o segmento errado. Segundo afirma Larkin (2005), a comunicação interna dissemina mensagens alegando que a empresa é ambientalmente responsável, adequada aos padrões internacionais de qualidade, praticante de salários e jornada justos, contudo estas não são as mensagens que as pessoas do quadro funcional querem ouvir.

A própria linguagem organizacional é masculina, como orienta Betti (2010), pois fala-se em missão, estratégia, termos originários do clima de guerra. Cria-se um descompasso sério, pois atualmente o melhor funcionário é aquele que reclama, não há mais lealdade, um insatisfeito joga seu problema no blog, portanto comprometimento é a palavra de ordem para empresas que pretendem sucesso. Recomenda Larkin (2005, p. 6) que "[...] quando os funcionários entendem o que você quer dizer, mas eles não querem, não aceitam ou são contra, aí tem que ser comunicação face a face". Esta é uma teoria reafirmada por Bohm (2005, p. 58) ao defender que "[...] todas as discussões sérias, seja na família ou nos grupos de diálogo, se dão sobre pontos de vista diferentes a respeito do que é absolutamente necessário".

Instiga-se a pensar a comunicação face a face nos casos em que os funcionários tenham reservas pessoais com seus superiores, os quais serão os praticantes de interlocuções com a equipe. Resultados de pesquisas mostram que os empregados estão sensíveis aos superiores que utilizam a comunicação face a face nos ambientes organizacionais. Larkin (2005) informou que $70 \%$ dos empregados admitiam o face a face como um modelo ideal de comunicação de resultados internos. Embora signifique uma barreira entre empregado e superior, admite também o risco que isso representa. Larkin $(2005$, p.6) orientou que "[...] esses $30 \%$ que não gostam podem procurar as informações por meio de um supervisor de outra área, com quem tenham mais afinidade". A importância da comunicação está nas relações interpessoais e envolve o universo que permite criar relacionamento. Desenvolver habilidade para comunicação significa transmitir ideias, conceitos e competências, visando comunicar métodos e técnicas de trabalho para atingir objetivos preestabelecidos. Ruídos podem ocorrer no interior deste processo e as razões para isso podem ser a falta de clareza e objetividade, o excesso de informações e a falta de controle sobre os resultados da comunicação. Possivelmente, o emprego de métodos e técnicas inadequados provoquem confusão quanto ao sentido de certas expressões e pensamentos expostos na comunicação 
face a face. Outros fatores de estrangulamento à comunicação face a face são o despreparo para receber determinada comunicação, as mensagens longas e sem conteúdo.

Há casos em que o gestor é desinformado sobre a sua unidade e sobre as expectativas da equipe por ele comandada. Nem toda informação exige o face a face, e este é um tipo de comunicação indispensável nas situações em que ocorre resistência do público interno e para desvendar o que o empregado quer. Para evitar esses ruídos, é preciso planejar as interlocuções, levantar questionamentos construídos a partir das expectativas da equipe, ter em mente a clareza das ideias antes de comunicar, os propósitos, aspectos físicos e humanos, ter conteúdo e controle a fim de facilitar a comunicação. O líder com habilidade para o face a face é igualmente hábil para exposições orais. Atenta-se para técnicas de comunicação e postura, sabe escolher e utilizar o melhor recurso audiovisual e, principalmente, aprende a organizar o contexto a ser exposto de forma clara e objetiva, além de colaborar para uma boa apresentação. A comunicação está na essência do ser humano e se relaciona à sabedoria para se comunicar, pois muito pouco acontece sem comunicação.

\subsection{Comunicação Face a Face para Empresas Brasileiras}

Ao analisar a oralidade como a essência da comunicação interna, Damante (2005) questionou o modo como as pessoas expressavam em palavras até mesmo sua criatividade para solucionar problemas ou para comunicar sobre rotinas da empresa. A rigidez na cultura organizacional produz uma hierarquia exagerada, causa obscuridade ao surgimento das ideias que deveriam ser incentivadas, abriga gestores sem consciência da importância da comunicação, todos estes, fatores que representam risco para a organização. A grande questão é a comunicação permear a totalidade da organização, ser elaborada de modo simples, coerente e sequencialmente planejado. Lamentável é que as decisões sobre comunicação recaiam mais sobre ferramentas do que sobre seu potencial estratégico para estabelecer relacionamentos, pois esse amadorismo reduz o alcance da comunicação organizacional. A comunicação face a face fortalece laços nos funcionários, mas as estruturas das empresas inibem a fluência eficaz da 
comunicação oral porque dão maior atenção às formas de evitar ruídos, antes mesmo de acionar seu mecanismos comunicacionais.

Depoimentos de profissionais sobre a comunicação oral e os benefícios possíveis de serem alcançados pelos gestores empresariais, através de seu uso, insere Amauri Marchese (2005, p. 23) que apresenta recomendações valiosas sobre o assunto ao revelar que:

Na complexa tarefa de fazer a comunicação oral fluir na empresa de maneira eficiente, transparência e agilidade da informação oficial são fundamentais. Também a qualificação do gestor para o discurso comunicativo merece cuidado. Saber ajustar os discursos, com os tons emocionais e racionais necessários, é uma tarefa a ser desenvolvida por todos os gestores da organização, mas que podem ter a ajuda do profissional de comunicação.

As habilidades desejáveis para um gestor utilizar a comunicação oral podem ser desenvolvidas através de treinamento. Os quesitos fundamentais deste exercício foram relacionados por Marchese (2005, p. 23) ao afirmar que o gestor empresarial atingirá eficácia na comunicação focada na oralidade por meio de contato face a face, conhecendo bem o tema, tendo "[...] postura e atitude, criatividade, poder de síntese, memória, voz bem colocada, bom vocabulário, bom jogo de palco, boa expressão corporal e entusiasmo". A humanização nas formas de comunicar é hoje tão destacada que as empresas que, se movidas pela velocidade como mote para tomar decisões e para seus negócios, veem a comunicação interna como um pilar para bons resultados até mesmo de rentabilidade.

A qualificação do líder inclui capacidade para se comunicar, como também para ser um bom contador de histórias, portanto há a expectativa de que o gestor empresarial seja acessível para o contato direto. Aquele que não tem boa vontade para estabelecer comunicação face a face com sua equipe, entrega-se como refém ao "[...] virtuosismo tecnológico, preferindo apresentar seus Power points, escrever e-mails e elaborar 'blogs do presidente' a ter contato com os funcionários diretamente" (Zanetti, 2005, p. 24). O referido autor mostra entusiasmo na defesa da comunicação direta, face a face, fisicamente presencial e distanciada das muralhas erguidas pelas mesas executivas dentro da empresa. Ele ainda defende que "[...] nada substitui a oralidade", pensamento este corroborado por Parente (2005, p. 24) ao acrescentar que "[...] o tema da comunicação oral vem avançando com a capacitação dos gestores para a correta dimensão e entonação do face a face". Tal como os brasileiros, o norte-americano Thomas Larkin (2005, p. 
4) assim se posiciona: a "[...] melhor forma de comunicação interna é o face a face. Os funcionários não querem ler ou assistir o que a empresa fala, querem saber o que Ihes interessa. As tecnologias não comunicam, apenas divertem".

Afirma Bohm (2005) que o conflito emerge do diálogo estabelecido com base em fundamentos impostos por pessoas que pensam diferente sobre um mesmo problema. O tema discutido pode conter uma verdade transparente para um interlocutor, contudo a base do diálogo deve ser o respeito aos fundamentos do conhecimento do outro, do modo como recomenda Bohm. Lembra Betti (2010) que o embate existente entre a "minha verdade versus a sua verdade", é uma situação na qual não há soma. "Quem fala muito, discute e não ouve, logo, não acrescenta, nem absorve". Recomenda-se que se vá além da superfície dos meios de comunicação, fenômeno possível com as experiências comunicacionais face a face, e que antes de planejar uma campanha de comunicação interna, chamem-se as pessoas para ouvir o que e o modo como elas desejam receber sua comunicação.

Sobre o paradoxo do capital humano, Betti e Parente (2010) registram que muitas organizações ainda enxergam "[...] os empregados como meras unidades de custo intercambiáveis". Analisam o dilema para engajar, motivar pessoas, desbloquear o livre-arbítrio, questões que sintetizam perguntando "[...] como experimentar neste mundo em que você não pode errar?" A resposta apresentada é somente "não experimenta", pois a resposta correta está no acionamento dos líderes. Os gestores organizacionais relacionam ao seu estilo de gestão o clima de trabalho que será positivo ou negativo segundo a confiança e o respeito que conseguirem conquistar de sua equipe de liderados. Métodos para treinar gestores podem seguir formas tradicionais, como também são susceptíveis à naturalidade como o acolhimento de sugestões para incrementar a comunicação. Estes são métodos compartilhados que refletem prática adequada de gestão empresarial.

Observa-se, em reuniões de trabalho, que prevalece um repertório de sugestões, críticas ou encaminhamentos porque comumente são os mesmos agentes que se manifestam neste tipo de evento empresarial. Pessoas devem ser movidas a se manifestar pelo estímulo dos funcionários a participarem do exercício de comunicação no dia a dia da empresa. Recentemente, Parente (2010) afirmou verbalmente que "[...] a comunicação é uma competência exercida diariamente". Os fundamentos sugeridos para o estilo vanguardista de comunicação interna, segundo 
Betti e Parente (2010) são a "[...] nova forma de pensar, nova forma de fazer, nova forma de sentir", entendendo que apesar de o termo diálogo remeter à fala, é preciso saber ouvir para que o diálogo traga resultados produtivos de comunicação. Betti destaca a existência de três tipos de organizações na atualidade: "[...] aquelas onde existe o movimento do face a face, as ainda fechadas para o face a face e as que adotam como visão 'somos seres que dialogam' ".

Betti e Parente (2010) elaboraram um roteiro para construir a estratégia de comunicação face a face, composto por dez passos a saber:

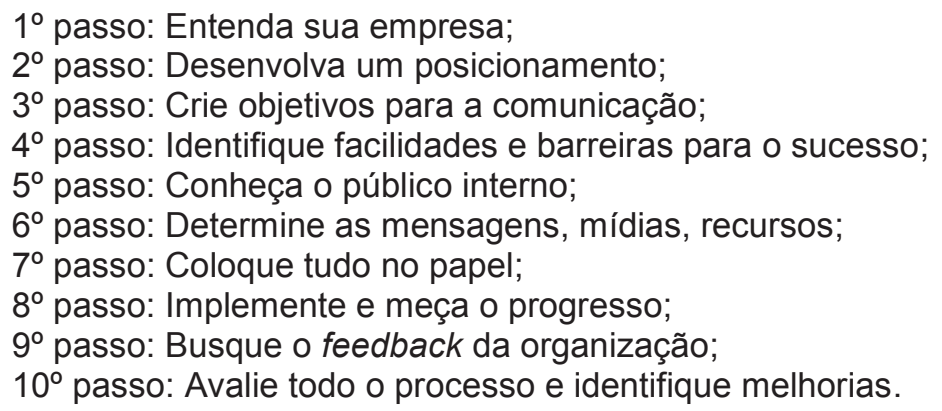

A realidade plural e multifacetada das empresas brasileiras redirecionam as ações comunicacionais para atender ao paradigma da velocidade incorporado à própria cultura das organizações. O clima da sociedade, hoje, é de insegurança e é exigente, portanto limita a liberdade que deveria estar inserida no cotidiano das pessoas. No interior desta sociedade habitam atores sociais que se empregam nas organizações pelo mundo todo. Empresas que hoje são expostas ao ciclo de negócios e, neste clima de tensões, discussões e competição, somente a prática humanística de comunicação face a face resgata a figura do homem como ser essencialmente social.

\subsection{Deslocamento para a Comunicação Face a Face}

Comunicar bem não é isoladamente saber transmitir ou receber bem as informações. Comunicação é troca e entendimento, e não é possível entender e se fazer entender sem considerar, além das palavras, as emoções e a situação em que ocorre o compartilhamento de conhecimentos, ideias, instruções ou qualquer outra mensagem, seja ela oral, escrita ou corporal. Por este motivo, deve-se analisar a comunicação em diferentes dimensões. O público é capaz de perceber, pelo discurso, o comportamento e as opiniões que constituem os reais valores de um interlocutor e de seu papel naquela ocasião. "Um papel sustenta o outro. Esses 
'papéis', que na realidade se baseiam em pressupostos e opiniões, também interferem no diálogo" (BOHM, 2005, p. 70). Essa comunicação não é imediatamente percebida, pois, para comunicar, são necessárias intuição e sensibilidade para transmitir, ao público, mais do que conteúdo e expressar uma identidade, as crenças, os valores, as atitudes, as habilidades, os pensamentos e os sentimentos do emissor da comunicação. Os níveis intrapessoal e interpessoal de comunicação necessitam ser flexíveis e facilitar tanto o processamento quanto a percepção sobre a informação. Um emissor provido de autoestima, coragem, autocontrole, entusiasmo, empatia e flexibilidade conduz a comunicação de uma mensagem alicerçada em seu desempenho particular. A pessoa que não acredita em si terá dificuldade para fazer com que outras pessoas confiem e aceitem o que está dizendo pela comunicação oral.

É no nível intrapessoal de comunicação que se cultiva o entusiasmo para despertar a atenção de quem está ouvindo e legitimar o discurso. Cultivar o entusiasmo é uma das regras para a boa comunicação interpessoal. Falar com entusiasmo contagia e cativa as pessoas e potencializa os argumentos de modo a aproximar mais da aceitação do interlocutor sobre o que esteja sendo dito. $O$ entusiasmo, associado ao desempenho oral do falante, desperta a atenção de quem está ouvindo. Valendo-se do conhecimento sobre o ouvinte e sobre o que ele espera do discurso, procura estimular a inteligência e a sua curiosidade, desafia a refletir sobre o assunto e a desenvolver suas convicções. A forma como o falante se porta interfere na sua credibilidade e confiança. Segundo relata Passadori (2003), gestos, postura, olhar, expressões faciais, impõem a ampliação dos cuidados com o comportamento corporal diante do público.

Para Polito (2005, p. 91), cuidar da expressão corporal é fundamental na comunicação face a face, "[...] seja numa pequena reunião na empresa, seja numa importante conferência, a maneira de se expressar com o corpo será sempre fundamental para que se obtenha sucesso". A linguagem corporal se soma à comunicação oral, mas a postura adotada deve condizer com o discurso do momento. Atitudes como manter gestos moderados e olhar para o interlocutor permitem prender a atenção do ouvinte. O equilíbrio e o bom senso devem reger as atitudes do emissor para cumprir adequadamente a tarefa de comunicar sua mensagem. Afirma Bohm (2005, p. 85) que a linguagem corporal mostra o que acontece com as pessoas. "Faz parte da comunicação, que é tanto não-verbal 
quanto verbal. Você não tenta de modo algum comunicar-se corporalmente; pode nem mesmo perceber que também se comunica dessa maneira".

Três elementos compõem a oralidade: a voz, a fala e as manifestações do corpo que marcam presença no processo de comunicação. Para obter atenção e interesse do público, transmitir credibilidade e informar de maneira precisa é importante conhecer os fatores que interferem negativamente na produção da voz, como má alimentação, uso de cigarros e bebidas alcoólicas, de forma a evitá-Ios (KYRILLOS, 2003). As características mais fundamentais à oralidade de um líder são o "conhecimento do tema a ser discorrido, postura e atitude, criatividade, poder de síntese, memória, voz bem colocada, bom vocabulário, bom jogo de palco, boa expressão corporal e entusiasmo" (DAMANTE, 2005, p. 24). A imposição corporal é condicionante à eficácia e eficiência da comunicação. $O$ volume variado da voz, a tonalidade, a velocidade, o uso da pausa e a boa dicção são os princípios da fala analisados e treinados. Estes princípios da fala equilibramse totalmente no âmbito vocal, conforme Polito (2005).

As habilidades pertinentes ao que se exprime pela voz abrangem planejamento mediante a preparação para se apresentar. Antecede ao planejamento a decisão sobre se a apresentação será persuasiva, motivacional ou informativa. $O$ planejamento implica preparar a apresentação em consonância com o perfil do público, o qual demanda conhecimento sobre si, o correto uso das normas gramaticais da língua falada e a memorização do emissor sobre a mensagem oral. Decisões posteriores decorrem da organização das ideias, da análise sobre o ambiente e da adequação dos recursos audiovisuais aos propósitos do comunicador e daquela comunicação. Melantonio (apud PASSADORI, 2003, p. 15) questiona sobre "[...] quantas empresas também não se percebem incapazes de produzir mais em menos tempo, melhor e mais barato por falta de eficiência na comunicação oral, principalmente nos escalões superiores?" Comunicar oralmente com competência pode exigir mudanças do emissor na sua forma de atuar. Acima do esforço pessoal do emissor, estão os objetivos da comunicação e aquele que não detém aptidão para mudar a si mesmo, não estará apto a mudar qualquer outra coisa dentro da esfera organizacional.

A oralidade é uma forma de contato entre indivíduos em que a comunicação verbal relaciona-se diretamente com a não verbal. Gera significados promulgados em gestos, expressões e atitudes que são compreendidos e 
interpretados pelas pessoas. Conhecer os elementos da comunicação oral que influenciam a transmissão das informações organizacionais e, principalmente, saber controlá-los durante o processo de interação com funcionários, é fundamental para executivos e empregados de organizações que prezam por uma comunicação de resultados. Analisa Kyrillos (2003) que cada agente tem sua voz que é diferente da voz de outrem, o que não significa que as pessoas não possam aprimorar as características individuais da voz, tornando-a um elemento favorável e estratégico no processo de comunicação. A pessoa verbaliza suas ideias e transmite informações oralmente, por isso a voz pode chamar a atenção do ouvinte de forma positiva, ou não. Pessoa com voz aguda pode irritar seus ouvintes, provocar a perda da disposição para ouvi-la e reduzir a assimilação do que é dito. A prática de hábitos saudáveis à saúde contribuem para o sucesso da voz na comunicação oral, conforme a autora.

A fala, outro componente da oralidade, é determinada pela frequência, intensidade, ritmo e velocidade, ressonância e articulação. Esses elementos da fala determinam positiva ou negativamente a interpretação do ouvinte sobre o falante e sobre a mensagem. Redução na intensidade da fala sugere ao ouvinte medo, insegurança ou timidez. A intensidade adequada na fala favorece uma articulação concisa e transmite ao ouvinte a ideia de domínio da voz, clareza de ideias e de pensamentos. Paralelamente a essas interpretações, caminha a conquista de credibilidade diante dos interlocutores expostos àquele episodio de comunicação face a face, como esclarece Kyrillos (2005a). A autora recomenda exercícios propostos por fonoaudiólogos para melhorar a qualidade da voz e da fala, para o uso adequado dos recursos vocais, como a ênfase, a pausa e a inflexão tão necessários para o desempenho face a face favorável de um líder com sua equipe.

A voz e a fala são carregadas de significados que ajudam ou atrapalham as interações dos atores daquele situação comunicacional. Pessoas podem, por força da circunstância, serem obrigadas a dizer algo que não gostariam de dizer. Nesta ocasião, expressões e gestos podem contradizer a fala, justamente pela falta de domínio do não verbal. As expressões faciais e os gestos nos eventos orais de comunicação devem acompanhar e confirmar o que se está falando, nunca contradizer a fala. A postura adequada soma-se aos demais fundamentos que, juntos, equivalem à linha do falante (Goffman, 2011), transmitem domínio sobre a situação, firmeza e equilíbrio. 
Voz, fala e manifestações do corpo compõem a expressividade das pessoas que pode ser traduzida à linha mencionada por Goffman (2011). O maior ou menor domínio dessa expressividade é o que determina se o objetivo da comunicação será ou não alcançado. Tão importante quanto saber o que dizer nos momentos de manifestação oral, é saber a forma mais adequada de dizê-lo e estar preparado para isso. A capacidade para ouvir é uma dimensão indispensável, pois apesar da inexistência de regras para que um diálogo ocorra "[...] podemos aprender certos princípios que nos ajudarão à medida que prosseguimos. A necessidade de proporcionar oportunidades suficientes para que todos falem é um deles" (BOHM, 2005, p. 71). A comunicação oral será estratégica quando executivos e funcionários souberem estabelecer interação, comunicarem-se de forma clara e precisa, serem entendidos e receberem o feedback para estender o diálogo entre os atores internos da organização.

Muito do que até aqui se expôs em defesa ao emprego na oralidade como estratégia de comunicação interna foi reunido por Goffman (2011) anlisando o "ritual de interação". Na concepção do autor, a interação face a face envolve um breve período de tempo, um limite espacial e seus eventos têm início, meio e fim quando inseridos nesses limites. O assunto elementar para o surgimento da interação social desenvolve-se a partir e como consequência da copresença, pois afirma Goffman (2011, p. 9) que os materiais comportamentais definitivos na copresença "[...] são as olhadelas, gestos, posicionamentos e enunciados verbais que as pessoas continuamente inserem na situação, intencionalmente ou não". Pessoas compartilhando um mesmo espaço físico e temporal estabelecem uma presença que imediatamente gera comportamentos distintos, tanto em termos de padrões quanto em termos de atividade interacional. O autor refere-se à "sociologia de ocasiões" a qual aborda a análise das interações temporárias e dos atos das pessoas que delas participam por curtos períodos de tempo e que se colocam mutuamente presentes umas às outras em variadas formas de eventos. Trata-se das inter-relações entre situações vivenciadas e pessoas que delas participam dentro de um contexto organizado por objetivos particulares, porém não necessariamente análogos, nas díspares possibilidades de surgimento de evento interacional.

Encontros sociais podem ocorrer por contato face a face ou mediado, todavia as pessoas participam das interações através de atos verbais e não verbais, pois assim expressam suas opiniões, avaliam a si mesmas e aos 
outros. A esses padrões Goffman (2011, p. 13) dá o nome de linha e afirma que seu desempenho independe da vontade do sujeito, posto que a pessoa invariavelmente desempenhará uma linha em seus atos interacionais. A linha dos participantes das ocasiões sociologicamente analisadas pode ser impetrada das declarações escritas ou mesmo dos registros profissionais. Afirma que a fachada, termo original do inglês, face, trata-se de um valor social que pode ser traduzido pelo grupo como o respeito ao outro. A fachada é, então, o modo como a pessoa aspira ser acolhida pelos demais participantes da interação a partir da linha que assumiu durante o espaço geográfico-temporal em que os rituais de interação social ocorreram. Particularmente nos contatos pessoais diretos, a fachada tende a se revelar com total clareza e resplandescência.

A fachada é uma imagem do eu delineada em termos de atributos sociais aprovados -mesmo que essa imagem possa ser compartilhada, como ocorre quando uma pessoa faz uma boa demonstração de sua profissão ou religião ao fazer uma boa demonstração de si mesma (GOFFMAN, 2011, p. 14).

A fachada encaminha o emissor para experimentar sentimentos que podem ser de frustração, de surpresa, de ofensa ou de insucesso. A leitura que o outro faz da fachada de um sujeito é o sustentáculo para a impressão atingida durante o contato estabelecido. Para construí-la, os participantes da interação tomam por base um conjunto de constructos originários de regras comportamentais em grupo. A impressão traduzida pelos outros participantes da interação causará impactos na resposta emocional do sujeito que estabeleceu contato ao participar de um ato interacional.

[...] uma pessoa tem, está com ou mantém a fachada quando a linha que ela efetivamente assume apresenta uma imagem dela que é internamente consistente, que é apoiada por juízos e evidências comunicadas por outros participantes, e que é confirmada por evidências comunicadas por agências impessoais na situação. [...] a fachada da pessoa claramente é algo que não está alojado dentro ou sobre seu corpo, mas sim algo localizado difusamente no fluxo de eventos no encontro, e que se torna manifesto apenas quando esses eventos são lidos e interpretados para alcançarmos as avaliações expressas nele (GOFFMAN, 2011, p. 14-15, grifo do autor).

A pessoa cuja fachada atingiu valor social positivo experimentará o sentimento de confiança e se mostrará convicta sobre a correção da linha por ela assumida. Segundo Goffman (2011, p. 16) a pessoa sentirá "[...] que pode manter a cabeça erguida e se apresentar a outros abertamente". Quando a pessoa percebe que sua fachada está errada, haverá uma forte possibilidade de se sentir inferior e envergonhada, pois "[...] esperava que o encontro apoiasse uma imagem do eu à 
qual ela se sente emocionalmente ligada e que agora encontra ameaçada". Associa o autor a dignidade que pode ser conquistada e transmitida via fachada e da aceitação à fachada dos outros participantes da interação face a face. Não basta o respeito próprio, pois o respeito ao outro é condição para que este desempenhe seu papel, conforme sua própria escolha para aquela ocasião. Trata-se de aceitar a linha que cada participante assume, pois a aceitação mútua é a estrutura elementar para interação e conversa face a face, embora a manutenção da fachada não seja o objetivo pretendido nos rituais de interação social. O repertório praticado para formar um juízo de valor positivo acerca da fachada é variável de acordo com cada pessoa, subcultura e sociedade.

Por mais triviais que sejam ou pareçam ser as ocasiões de fala, o uso da oralidade exige que cada participante manifeste uma preocupação genuína consigo e com o outro. A ocasião de início da fala, compreendida como um fenômeno de interação social, surge do cumprimento de protocolos como a decisão sobre as abordagens colocadas na conversação e sobre quem as fará. O conjunto de gestos que dá o start para a comunicação é também o meio para que cada pessoa reconheça-se como um participante legítimo daquilo que Goffman (2011, p. 40) nomeia como o estado da fala (grifo do autor). Independentemente do contexto hodierno da sociedade global, há ocorrência de oportunidade física da interação falada quando então "[...] um sistema de práticas, convenções e regras de procedimentos entra em jogo, funcionando como um meio de orientar e organizar o fluxo de mensagens" (GOFFMAN, 2011, p. 39). Há, contudo, uma tendência característica da natureza humana que leva o participante da interação falada a focar sua atenção visual e cognitiva em um único fluxo de fala. As "dicas de autorização formais ou informais", dão os sinais sobre o momento em que um orador está se aproximando do término de sua fala e a tênue percepção sobre este indicador motiva outro orador a sinalizar sua vontade de falar.

O conjunto de gestos do orador e do receptor legitima comportamentos adotados para o estado da fala (GOFFMAN, 2011, grifo do autor). Os receptores comunicam, através de gestos apropriados, que estão dando atenção ao orador. Os participantes da conversa distanciam-se de questões externas ao encontro falado para terem domínio sobre o fio condutor do diálogo. Permitem pausa, desde que não provoque nenhum impacto no fluxo das mensagens. De acordo com Goffman (2011, p. 41) "[...] seguimos regras para facilitar a transição, se 
houver, de um tópico de conversa para outro" e, deste modo, a conversa consente o foco único de atenção que o conjunto de participantes mantém em movimento.

Fica perceptível que são imputadas convenções para que as conversas sejam tomadas como uma solução eficaz e suficiente para organizar fluxos de mensagens projetadas por meio da comunicação oral. O ator social, convidado a participar de uma conversa, precisa dar "dicas de autorização" certificando sua disponibilidade para salvar a fachada dos demais participantes, no breve período de tempo que sustenta a ocasião da fala. É também esperado que a quantidade de atenção dada ao orador, durante a conversação, seja proporcional ao seu valor social relativo atribuído pelo conjunto de participantes. Havendo quebra de convenções, a exemplo de pausa prolongada ou desatenção do receptor, estes sinais comunicam desrespeito com o orador ou com o grupo de participantes e pode ser ocasionado porque um dos atores não se sinta integrante legítimo da conversa.

O comportamento do participante da conversação traduz como o orador está sendo percebido pelo seu grupo de interlocutores, cujos atos coincidem com a imagem que o orador está projetando através de seu ato de fala.

Muitas vezes, também, o medo da perda possível de fachada impede a pessoa de iniciar contatos em que informações importantes podem ser transmitidas e relações importantes estabelecidas; ela pode ser levada a buscar segurança da solidão em vez do perigo dos encontros sociais (GOFFMAN, 2011, p. 44).

Uma pessoa transita por distintos grupos e adota proporcionalmente códigos de conduta apropriados a cada situação vivenciada, contudo o protocolo dos diálogos é reaplicável, ainda que ajustados aos objetivos de cada grupo. Ao se tratar das relações formais, o dispêndio de energia, com a finalidade de impedir que expressões inadequadas emerjam, é muito mais intenso, visto que a quebra de protocolo nas relações informais está prevista devido à total ausência de cerimônia entre os atores do diálogo. O compromisso pessoal de zelar pela fachada constitui a estrutura da fala e as relações travadas entre os atores da conversa são atreladas ao zelo com a fachada dos outros participantes. O líder, assim analisado, é a pessoa que vincula sua posição de líder em sintonia com a posição dos liderados para que esta seja uma relação social possível no ambiente corporativo. O relacionamento social força pessoas a confiarem sua imagem aos atos dos outros participantes legítimos de um grupo. Ao proceder a uma análise relacional das ocasiões de fala, preconiza-se que este movimento que é acionado por meio do diálogo e das 
interações face a face, retroalimenta a função e o reconhecimento formal da liderança.

O ser social é um construto de natureza humana que cria regras morais para serem absorvidas pelo homem de fora para dentro, as quais auxiliam na tecelagem da linha de conduta, bem como na criação e na preservação de sua fachada. Linha e fachada são acionadas em cada um dos momentos de interação e de relacionamento social e, assim como as regras morais, são todas construídas em encontros que podem ser de fala. Então, os encontros sociais modulam o ser humano através de um conjunto particular de regras que surge no interior desses eventos sociais de fala.

A natureza humana de um conjunto particular de pessoas pode ser especialmente projetada para o tipo especial de empreendimentos em que elas participam, mas ainda assim todas essas pessoas precisam ter dentro delas algo do equilíbrio de características necessárias para um participante utilizável em qualquer sistema organizado ritualmente de atividade social (GOFFMAN, 2011, p. 50).

Como participante de uma equipe de empregados de uma organização, novas regras morais e profissionais são apresentadas para que a pessoa as incorpore à fachada que será transmitida para seus pares. Esta é uma condição unidirecional que independe de o ator social exercer liderança ou de ser um integrante de um grupo de liderados na empresa. As regras de conduta orientam os atos pessoais nos relacionamentos humanos de forma a que estes sejam justos e adequados às ocasiões interacionais, incluindo-se a vida social corporativa de um empregado de empresa. O ambiente corporativo estabelece um padrão de comportamento imbricado no interior de sua cultura, tal como seria a disposição de telhas que, justapostas, cobririam um telhado.

Goffman (2011) afirma que o indivíduo absorve regras de conduta que representam um guia para a ação. As regras submergem no íntimo da pessoa de forma direta ou indireta. Em sua forma direta, as regras são absorvidas como obrigações (grifo do autor) que se referem ao modo como a pessoa deve se conduzir. Na forma indireta, uma regra de conduta é absorvida por meio das expectativas (grifo do autor) que se referem ao modo como os outros são orientados a agir em relação ao outro, então "[...] demonstra o caráter interpessoal, atorreceptor de muitas regras: a obrigação de um homem muitas vezes será a expectativa de outro" (GOFFMAN, 2011, p. 53). Fala-se assim do cumprimento de ações que podem parecer um dever agradável, desejável ou desagradável. O 
sentimento embutido no ato do receptor terá consonância com o contexto geral onde o ato ocorrer, pois as expectativas e obrigações do receptor serão permitidas e apoiadas pelo ator.

Nos relacionamentos internos, a equipe de empregados convive com sinais não verbais representativos da hierarquia formal da empresa. Residem aí traços subjetivos que norteiam um "comportamento cerimonial" que sinaliza uma relação de deferência entre os atores da organização. Goffman (2011, p. 78) define deferência como "[...] a apreciação que um indivíduo mostra sobre outro para esse outro" porque o receptor considera aquele emissor de mensagem como um símbolo da organização, sua extensão ou como seu agente. Assim pode ser analisado o modo como as relações internas são celebradas entre um ator e um receptor de comunicação oral em uma organização. A deferência é um atributo desejado, conquistado ou merecido que necessariamente será identificado pelos atos do receptor, pois um indivíduo não pode atribuir deferência a si mesmo e pretender a autenticação dos outros participantes do grupo.

O chefe precisa se fazer respeitar e merecer respeito sob pena de ser chefe de si mesmo. A deferência como regra de conduta é absorvida diretamente pela rotina cotidiana de relacionamento interno e coexiste com a relação subordinado e superior, em simetria com pessoas socialmente iguais dentro de um dado contexto e seguindo um fluxo descendente. Há obrigações de deferência que os líderes formais devem a sua linha de subordinados e que participam dos rituais interpessoais que representam confiança ou "respeito pela capacidade, como quando o indivíduo aceita o conselho técnico de outro" (GOFFMAN, 2011, p. 62). A deferência é um ato subjetivo que revela a atividade real entre ator e receptor.

A presença de tensão no relacionamento entre superior e subordinado, que também é objeto ne argumentação de Baldissera (2008), modifica a manifestação da deferência, pois estimula os indivíduos a assumirem uma distância física e emocional que será recíproca.

Entre pessoas de estatuto igual, podemos encontrar uma interação guiada pela familiaridade simétrica. Entre superior e subordinado, podemos esperar encontrar relações assimétricas, tendo o superior o direito de exercer certas familiaridades que o subordinado não tem permissão de retribuir" (GOFFMAN, 2011, p. 66). 
O estilo de deferência é orientado pela cultura organizacional, portanto as pessoas das organizações estruturalmente semelhantes podem destoar nas atitudes de deferência adotadas. Alerta o autor para o cuidado verbal necessário ao superior para não expor temas que possam causar constrangimento, humilhação ou desconforto para o subordinado receptor nas suas interações orais, sejam elas face a face ou não.

O "comportamento cerimonial" defendido implica em outro elemento que o autor denomina de porte, referindo-se ao que é comunicado por uma pessoa em decorrência da postura adotada, do vestuário e do aspecto do orador. Esta linguagem não verbal subjetivamente comunica se aquela pessoa possui qualidades desejáveis ou indesejáveis para os receptores que estão compartilhando de uma interação face a face em um evento de fala. Os sentimentos do orador são puncionados de seu porte e expostos à luz da interpretação do receptor para identificar características pessoais e de personalidade do ator da fala, as quais vão desde a sua sinceridade, seu controle da fala, controle de seus movimentos, até seu espírito esportivo. O porte solicita uma aprovação positiva sobre o ator da fala, pois desnuda traços desejáveis em um líder empresarial que seja hábil para se comunicar com sua equipe, particularmente pela prática de comunicação oral.

[...] o bom porte é aquilo que é requisitado de um ator se ele quiser ser
transformado em alguém em que se pode confiar para se manter como um
participante da interação, aprumado para a comunicação, e para agir de
forma que os outros não se coloquem em perigo ao se apresentarem como
participantes da interação com ele" (GOFFMAN, 2011, p. 78).

Trata-se de atributos que não se sustentam pela declaração verbal de "este é seu líder", pois passa pela interpretação que os liderados fazem sobre o cuidado que o indivíduo líder tem consigo e com outro. Esta é uma percepção extraída durante o intercurso social. A imagem de um líder é uma construção particular da equipe ou grupo de liderados que sofre impacto muito fortemente da comunicação oral inserida no repertório da comunicação interna. Os atos cerimoniais realizados por uma pessoa numa interação falada com outras pessoas conduz para a formação de sua imagem, aos olhos de cada participante do grupo, naquele evento de uso da oralidade. Ocasiões assim sucedem frequentemente e permitem variação nos propósitos, funções, no tipo de evento, número de participantes, no local e em outros elementos descritivos. A comunicação face a face permite que a conversação seja espontânea, apesar de fazer exigências em nome da manutenção 
do diálogo. A conversação é "[...] um pequeno sistema social com suas próprias tendências de manutenção de fronteiras; ela é um pedacinho de compromisso com seus próprios heróis e vilões" (GOFFMAN, 2011, p. 111). Na presença imediata entre pessoas, um repertório de palavras, de gestos, regras de conduta, atos e outros eventos - conversas paralelas, por exemplo - apresentam-se e são componentes edificáveis da imagem que o ator da comunicação falada projeta para os receptores.

Ainda que a hierarquia empresarial promova relações de deferência e de porte espontaneamente, quando se trata de interação face a face o papel social do indivíduo não dará o suporte necessário para o encontro. Compete mais densamente o papel de participante da interação e da conciliação de propósitos com o grupo do que o de ator da fala que transmite comunicação para um receptor. Como processo, a comunicação implica compartilhamento, negociação e deslocamento de posição entre falante e ouvinte.

Neste capítulo e no precedente foram discutidos princípios e conceitos de oralidade e princípios e conceitos de comunicação face a face. Está na correlação entre esses conceitos a principal opção analítica selecionada para o estudo desta tese, e eles terão sua presença apontada nas análises desenvolvidas após o capítulo a seguir, que dá início à apresentação do locus onde foi constituído o corpus da pesquisa e o modo como foi organizada a coleta dos dados. 


\section{ESTUDO DA ORALIDADE EM ORGANIZAÇÃO ESTATAL}

Para integrar a base teórica e a realidade, realizou-se uma pesquisa empírica que teve como universo a Empresa Brasileira de Pesquisa Agropecuária Embrapa e focou-se a unidade Embrapa Soja, na cidade de Londrina, PR. A definição do universo de pesquisa deu-se pelo porte da estatal Embrapa, pela sua atuação internacional, como também pelo ramo de atividades de pesquisa e produção de tecnologias que contribuem com o desenvolvimento econômico, social e científico da sociedade brasileira. $O$ interesse por este perfil organizacional em particular justifica-se pelo fato de que a pesquisadora reside no Sul do país, local onde prevalecem bases econômicas na produção agrícola e por existir, nesta mesma região, a Embrapa Soja, uma das unidades da estatal. A justificativa para a delimitação do universo de investigação parte do que recomenda Triviños (1990), sobre o foco de uma pesquisa de pós-graduação,

[...] estar vinculado a dois aspectos fundamentais: o tópico da pesquisa deve pertencer ao âmbito cultural do autor e o assunto deve surgir da prática quotidiana que o pesquisador realiza como profissional. Ainda, uma base teórico-metodológica necessita ser evidenciada, na qual o contexto do problema, demonstrando sua utilidade, viabilidade, originalidade e importância, é condição básica para que direcionamentos possam ser estabelecidos (TRIVIÑOS, 1990, p. 93).

Os dados apurados descrevem e analisam as relações conceituais da oralidade e da prática do diálogo como estratégias de comunicação interna. A natureza quali-quantitativa desta pesquisa compreendeu um estudo exploratório, com base descritiva.

\subsection{Empresa Brasileira de Pesquisa Agropecuária - Embrapa}

Em 7 de dezembro de 1972, a Lei 5.851, sancionada por Emílio Garrastazu Médici, Presidente da República naquela época, autorizou o Poder Executivo a instituir a estatal Empresa Brasileira de Pesquisa Agropecuária Embrapa, vinculada ao Ministério da Agricultura, Pecuária e Abastecimento, com sede provisória no Edifício Palácio do Desenvolvimento, em Brasília/DF ${ }^{7}$. A primeira diretoria desta empresa pública foi empossada em 26 de abril de 1973, tendo como

\footnotetext{
${ }^{7}$ Informações disponíveis em <http://www.embrapa.br>. Acesso em: 27 jul. 2012.
} 
diretor-presidente José Irineu Cabral, e esta então foi a data oficial da criação da empresa. A Embrapa é um sistema que abriga unidades administrativas e unidades de pesquisa e de serviços.

As unidades administrativas ou centrais estão fixadas no edifíciosede da Embrapa, na cidade de Brasília/DF e são órgãos integrantes da administração superior da empresa. As unidades centrais são responsáveis por "[...] planejar, supervisionar, coordenar e controlar as atividades relacionadas à execução de pesquisa agropecuária e à formulação de políticas agrícolas", conforme informação do portal eletrônico da empresa. Em suas unidades administrativas a Embrapa reúne os seguintes organismos:

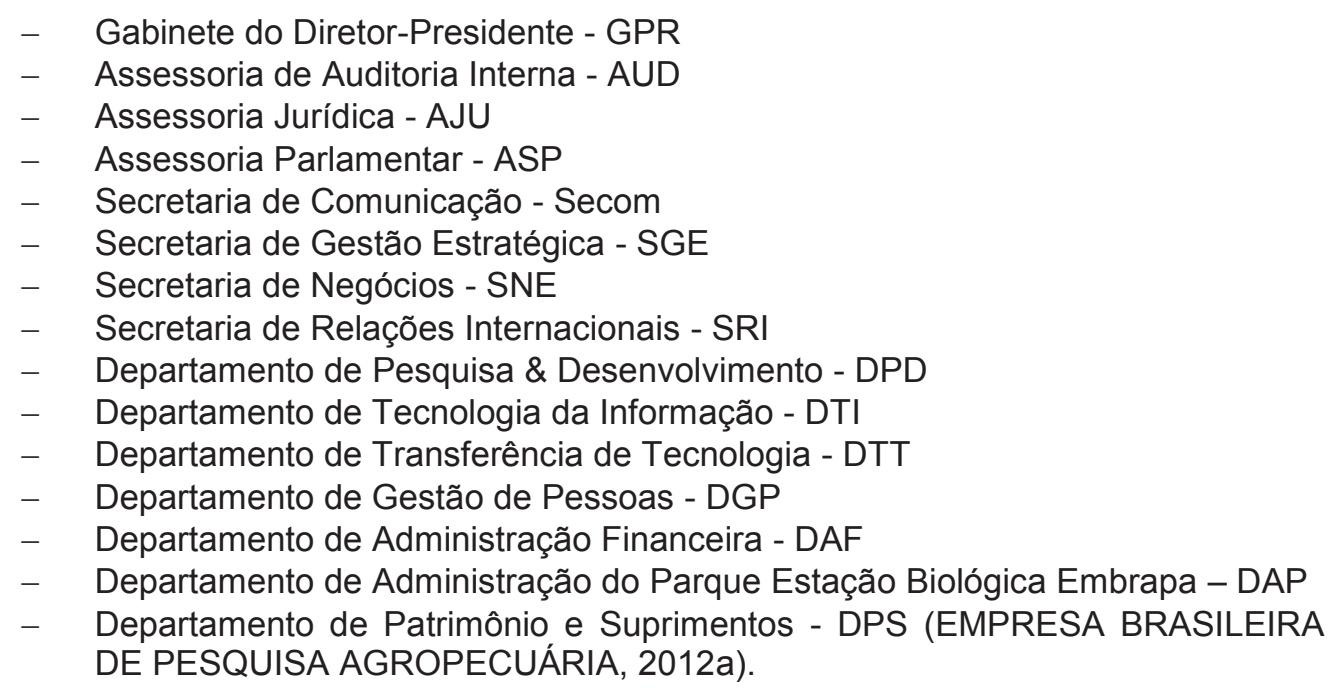

A estrutura empresarial da estatal Embrapa é ainda composta por unidades de pesquisa e de serviços ou unidades descentralizadas, as quais se encontram presentes no território brasileiro, inseridas nas várias regiões. Dentro da estrutura administrativa da Embrapa, as unidades descentralizadas classificam-se em: unidades de serviço, unidades de pesquisa de produtos, unidades de pesquisa de temas básicos e unidades de pesquisa ecorregionais.

\section{Unidades de Serviço}

- Embrapa Café - Brasília/DF

- Embrapa Gestão Territorial - Campinas/SP

- Embrapa Informação Tecnológica - Brasília/DF

- Embrapa Produtos e Mercado - Brasília/DF

- Embrapa Quarentena Vegetal - Brasília/DF

\section{Unidades de Pesquisa de Produtos}

- Embrapa Algodão - Campina Grande/PB

- Embrapa Arroz e Feijão - Santo Antônio de Goiás/GO

- Embrapa Caprinos e Ovinos - Sobral/CE

- Embrapa Florestas - Colombo/PR 
- Embrapa Gado de Corte - Campo Grande/MS

- Embrapa Gado de Leite - Juiz de Fora/MG

- Embrapa Hortaliças - Brasília/DF

- Embrapa Mandioca e Fruticultura - Cruz das Almas/BA

- Embrapa Milho e Sorgo - Sete Lagoas/MG

- Embrapa Pecuária Sudeste - São Carlos/SP

- Embrapa Pecuária Sul - Bagé/RS

- Embrapa Pesca e Aquicultura - Palmas/TO

- Embrapa Soja - Londrina/PR

- Embrapa Suínos e Aves - Concórdia/SC

- Embrapa Trigo - Passo Fundo/RS

- Embrapa Uva e Vinho Bento Gonçalves/RS

\section{Unidades de Pesquisa de Temas Básicos}

- Embrapa Agrobiologia - Itaguaí/RJ

- Embrapa Agroenergia - Brasília/DF

- Embrapa Agroindústria de Alimentos - Guaratiba/RJ

- Embrapa Agroindústria Tropical - Fortaleza/CE

- Embrapa Estudos e Capacitação - Brasília/DF

- Embrapa Informática Agropecuária - Campinas/SP

- Embrapa Instrumentação - São Carlos/SP

- Embrapa Meio Ambiente - Jaguariúna/SP

- Embrapa Monitoramento por Satélite - Campinas/SP

- Embrapa Recursos Genéticos e Biotecnologia - Brasília/DF

- Embrapa Solos - Rio de Janeiro/RJ

\section{Unidades Ecorregionais}

- Embrapa Acre - Rio Branco/AC

- Embrapa Agropecuária Oeste - Dourados/MS

- Embrapa Agrossilvipastoril - Sinop/MT

- Embrapa Amapá - Macapá/AP

- Embrapa Amazônia Ocidental - Manaus/AM

- Embrapa Amazônia Oriental - Belém/PA

- Embrapa Cerrados - Brasília/DF

- Embrapa Clima Temperado - Pelotas/RS

- Embrapa Cocais - São Luis/MA

- Embrapa Meio-Norte - Teresina/PI

- Embrapa Pantanal - Corumbá/MS

- Embrapa Rondônia - Porto Velho/RO

- Embrapa Roraima - Boa Vista/RR

- Embrapa Semiárido - Petrolina/PE

- Embrapa Tabuleiros Costeiros - Aracaju/SE (EMPRESA BRASILEIRA DE PESQUISA AGROPECUÁRIA, 2012a). 


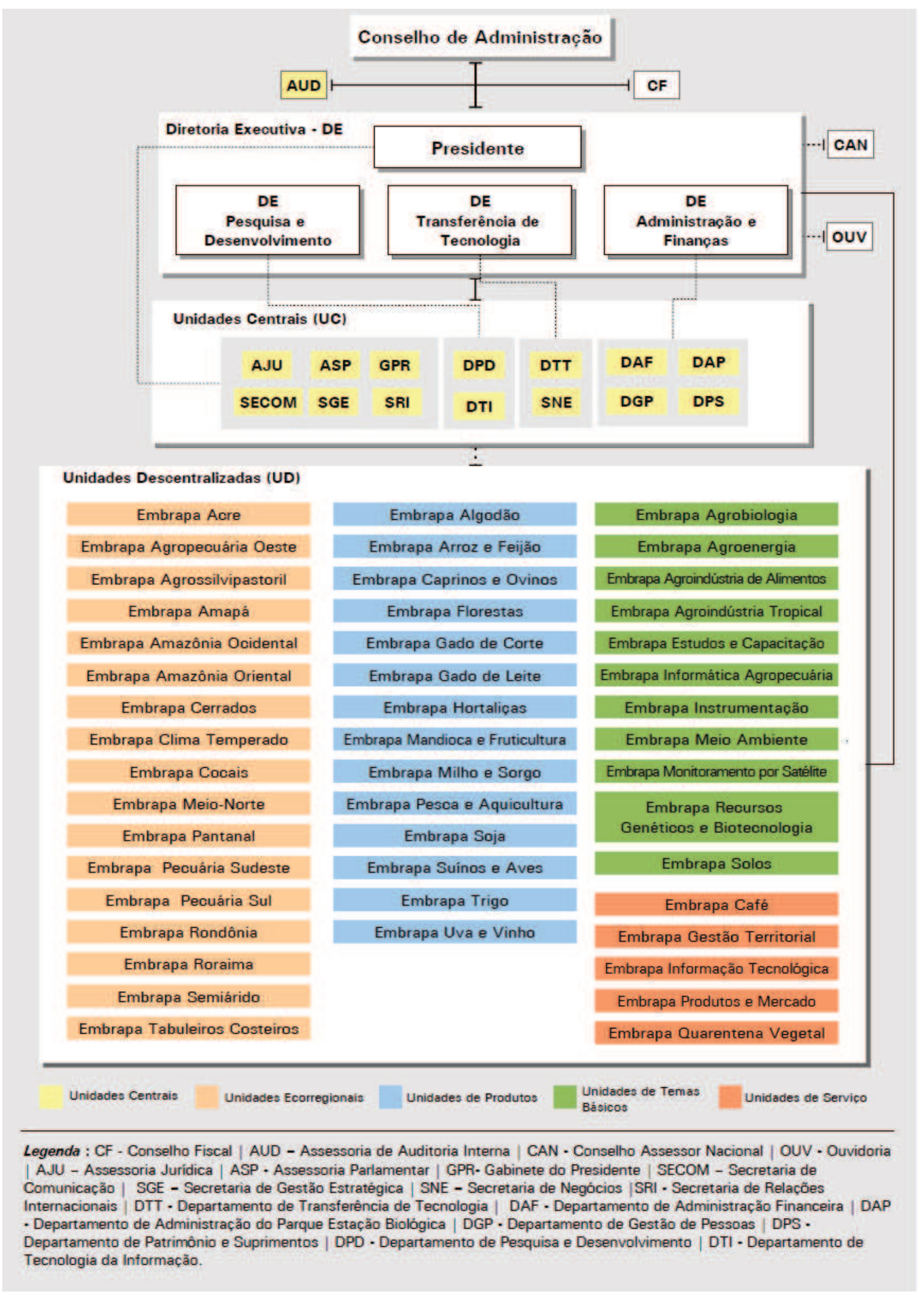

FIGURA 2 - Organograma da Embrapa.

Fonte: Empresa Brasileira de Pesquisa Agropecuária. Organograma. Disponível em: <www.embrapa.br>. Acessso em: 18 jul 2012a. 
Informa o portal eletrônico da Embrapa que a empresa investiu sobretudo no treinamento de recursos humanos, e que o quadro funcional conta com 9.660 empregados, sendo que 2.392 são pesquisadores. Dentre os cientistas empregados na empresa, $18 \%$ possuem título de mestrado, $74 \%$ têm doutorado e 7\% têm pós-doutorado (EMPRESA BRASILEIRA DE PESQUISA AGROPECUÁRIA, 2012a).

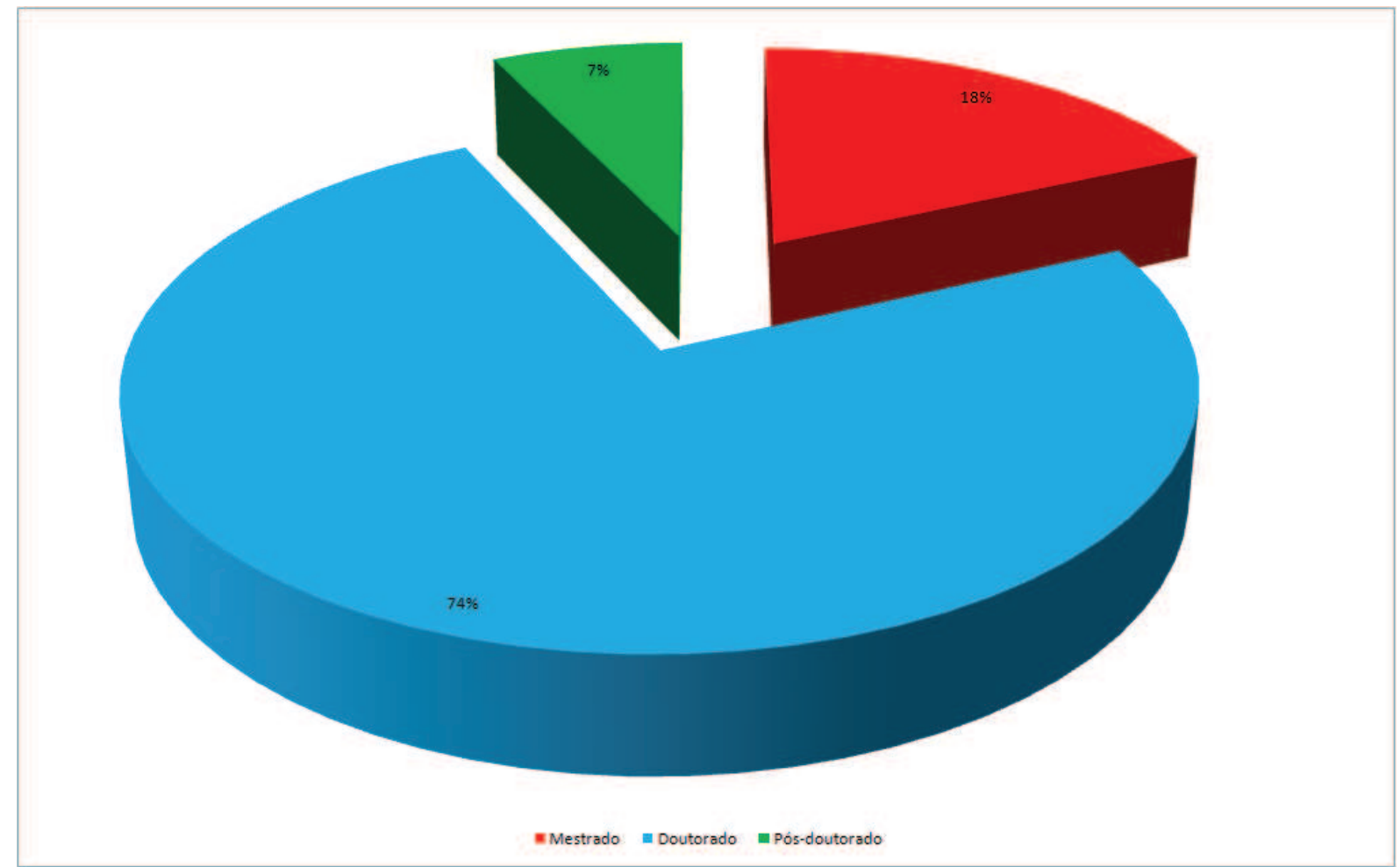

GRÁFICO 1 - Nível de instrução dos cientistas da Embrapa.

\section{Missão da Embrapa}

"Viabilizar soluções de pesquisa, desenvolvimento e inovação para a sustentabilidade da agricultura, em benefício da sociedade brasileira".

\section{Sistema Nacional de Pesquisa Agropecuária - SNPA}

Como é noticiado no portal eletrônico da empresa, as universidades, empresas privadas, instituições públicas federais, estaduais e as fundações, que, de forma cooperada, executam pesquisas em variadas áreas geográficas e campos de conhecimento científico, constituem o Sistema Nacional de Pesquisa Agropecuária SNPA, que é coordenado pela Embrapa. 
Tecnologias geradas pelo SNPA mudaram a agricultura brasileira. Um conjunto de tecnologias para incorporação dos cerrados no sistema produtivo tornou a região responsável por 67,8 milhões de toneladas, ou seja, $48,5 \%$ da produção do Brasil (2008). A soja foi adaptada às condições brasileiras e hoje o País é o segundo produtor mundial (EMPRESA BRASILEIRA DE PESQUISA AGROPECUÁRIA, 2012a).

O SNPA desenvolveu programas de pesquisa específicos para a agricultura familiar e obteve resultados de caráter prático para organizar tecnologias e sistemas de produção que aumentaram a eficiência do pequeno produtor de agronegócio. Hoje, os pequenos produtores atingidos pelos programas de pesquisa alcançaram uma renda mais elevada com reflexos no seu bem-estar, a partir do fazer do SNPA.

\section{Cooperação Internacional}

Inserida em uma sociedade global, a brasileira Embrapa tornou-se parceira de outros povos, compartilhando esforços internacionalmente para beneficiar o desenvolvimento da agricultura e do agronegócio em nível mundial. Projetos para implementar avanço em sistemas produtivos são desenvolvidos pelos pesquisadores e técnicos embrapianos que transferem os conhecimentos vocacionados para causarem impactos na complexidade das demandas sociais e econômicas do mundo. A transferência de tecnologia praticada pela Embrapa capacita recursos humanos e fortalece instituições internacionais localizadas nos países cooperados com a estatal brasileira. Trata-se, aqui, dos acordos de cooperação internacional firmados pela Embrapa. A cooperação internacional cumpre finalidades de longo prazo e pretende impulsionar qualitativamente 0 crescimento e o fortalecimento dos países receptores.

\subsection{Embrapa Soja: Locus Empírico}

A Embrapa Soja ${ }^{8}$ é uma das 47 unidades de pesquisa da estatal Empresa Brasileira de Pesquisa Agropecuária - Embrapa. Conforme a estrutura administrativa da Embrapa, a Embrapa Soja é uma unidade descentralizada com foco na pesquisa de produtos, especificamente cultura de soja, de girassol e trigo. Até a década de 1970, o cultivo de soja era mundialmente praticado em regiões temperadas e subtropicais, condição que excetuava o Brasil de figurar entre os

\footnotetext{
${ }^{8}$ Informações disponíveis em <http://www.cnpso.embrapa.br>. Acesso em: 31 jul. 2012a.
} 
grandes produtores, mesmo com toda a capacidade produtiva, a amplitude geográfica e a riqueza natural dos solos brasileiros. Fundada em 1975, a Embrapa Soja nasceu para atender à demanda por tecnologia para produção interna de soja e para se tornar referência mundial em pesquisa para cultivo de soja em regiões tropicais.

Inicialmente, a unidade funcionou junto à Empresa Paranaense de Classificação de Produtos (CLASPAR), órgão do governo do Estado do Paraná, e logo foi transferida para funcionar no interior do Instituto Agronômico do Paraná (IAPAR), igualmente órgão do mesmo Estado. Os resultados alcançados pelos pesquisadores da Embrapa Soja contribuíram para seu reconhecimento institucional e no dia 4 de novembro de 1988, a unidade de Soja foi inaugurada em Londrina (PR). No ano de 1989, a Embrapa Soja passou a funcionar integralmente em sua própria sede que ocupa uma área de 350 hectares, localizada no Distrito de Warta, no município de Londrina, Estado do Paraná, local onde funciona até os dias de hoje.

O desafio vencido, desde o seu surgimento, pelos pesquisadores da Embrapa Soja causou impactos significativos na agricultura e na geração de divisas para o país. A realização de pesquisas para a cultura da soja em regiões tropicais foi tão largamente desenvolvida que, após aproximadamente 30 anos de existência da Embrapa Soja, o Brasil ascendeu para a segunda posição entre os maiores produtores do grão no mundo. O progresso da Unidade estendeu seu foco de atuação para pesquisas sobre a cultura nacional de girassol e para o cultivo de trigo no Paraná, estas últimas desenvolvidas em parceria com a Embrapa Trigo, localizada em Passo Fundo, Estado do Rio Grande do Sul e com o IAPAR, localizado em Londrina, Estado do Paraná.

A atuação da Embrapa Soja e de seus pesquisadores dá-se também no controle biológico de pragas, nas técnicas de manejo e conservação do solo, entre outras. A unidade de pesquisa ressalta o incremento de tecnologias de produção de soja voltadas para preservação e qualidade ambiental, para avaliar impactos econômicos e sociais, atender nichos de mercado, desenvolver processos agroindustriais e metodologias de administração rural. Produtos, tecnologias e serviços da Embrapa Soja têm como públicos prioritários os produtores rurais, a assistência técnica em agronegócios, as agroindústrias, empresas do setor produtivo, todavia se relaciona com uma multiplicidade de grupos inseridos na 
sociedade em geral. Produtos e serviços da empresa são desenvolvidos por equipe técnica especializada de excelência, para se empenhar plenamente na consecução de valores como qualidade e segurança na produção agrícola.

\begin{tabular}{|c|c|}
\hline $\begin{array}{c}\text { Missão da } \\
\text { Embrapa Soja }\end{array}$ & $\begin{array}{l}\text { "Viabilizar, por meio de pesquisa, desenvolvimento e inovação, soluções para a } \\
\text { sustentabilidade das cadeias produtivas da soja e do girassol, em benefício da } \\
\text { sociedade brasileira". }\end{array}$ \\
\hline $\begin{array}{c}\text { Visão da } \\
\text { Embrapa Soja }\end{array}$ & $\begin{array}{l}\text { "Consolidar-se como centro de referência, internacional para a cultura de soja e } \\
\text { nacional para a cultura de girassol, na geração de conhecimento, tecnologia e } \\
\text { inovação". }\end{array}$ \\
\hline $\begin{array}{c}\text { Valores da } \\
\text { Embrapa Soja }\end{array}$ & $\begin{array}{ll}\text { - } & \text { Excelência em pesquisa e gestão; } \\
- & \text { Responsabilidade sócio-ambiental; } \\
- & \text { Ética; } \\
- & \text { Respeito à diversidade e à pluralidade; } \\
- & \text { Comprometimento; } \\
- & \text { Cooperação. }\end{array}$ \\
\hline $\begin{array}{l}\text { Objetivos } \\
\text { Estratégicos }\end{array}$ & $\begin{array}{l}\text { - } \text { Garantir a competitividade e a sustentabilidade da agricultura brasileira; } \\
\text { - } \quad \text { Atingir um novo patamar tecnológico competitivo em agroenergia e } \\
\text { biodiversidade; } \\
\text { - } \\
\text { Intensificar o desenvolvimento de tecnologias para o uso sustentável dos } \\
\text { biomas e integração produtiva das regiões brasileiras. }\end{array}$ \\
\hline
\end{tabular}

Fonte: Empresa Brasileira de Pesquisa Agropecuária. Disponível em: <www.embrapa.br>. Acesso em: 18 jul 2012a.

\section{Os dirigentes da Embrapa Soja}

A unidade Embrapa Soja é conduzida por uma Chefia-Geral que coordena três chefias adjuntas de Administração, Transferência de Tecnologia e Pesquisa e Desenvolvimento. A estrutura administrativa da empresa é completada por uma equipe gerencial constituída conforme Figura 3. 


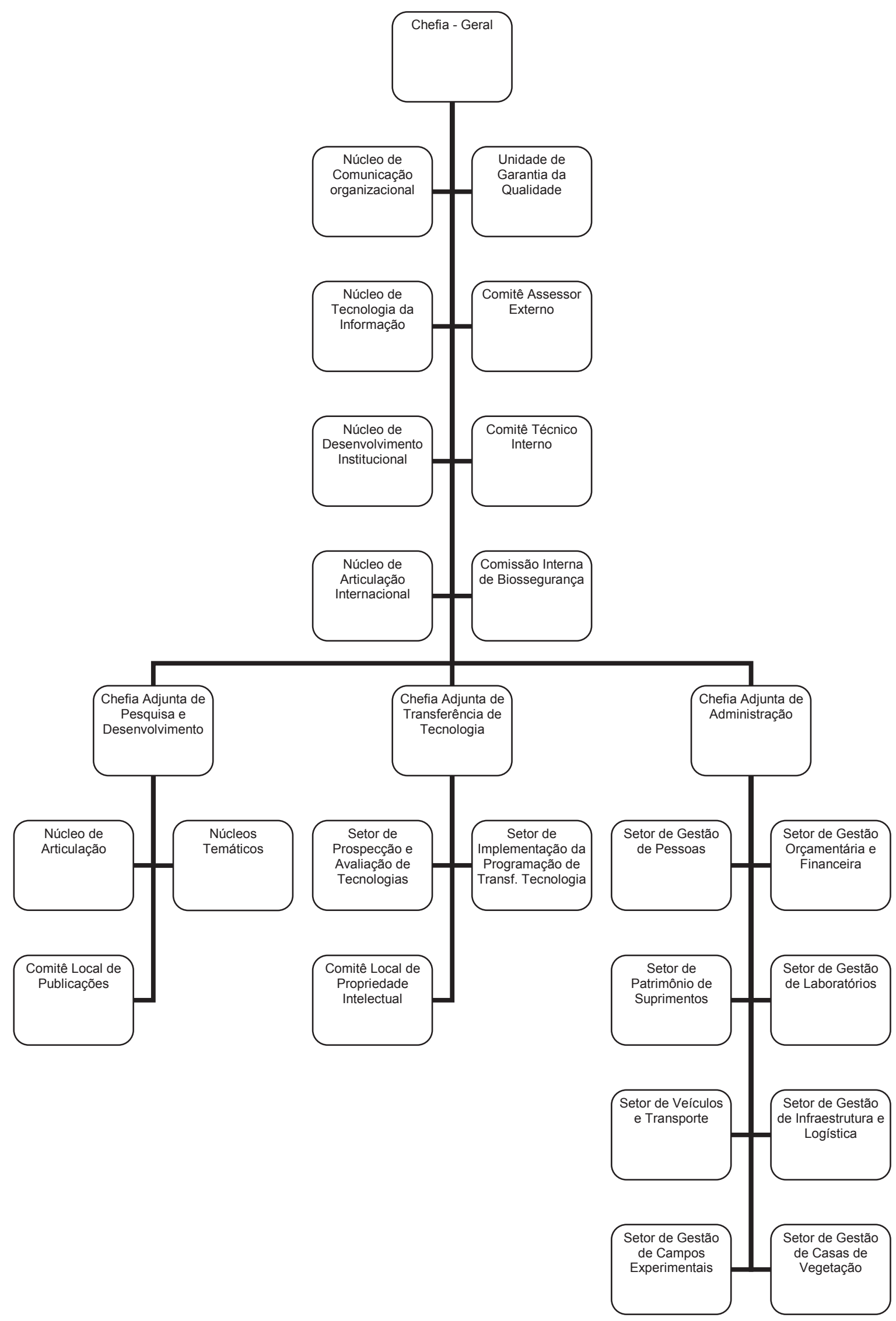

FIGURA 3 - Organograma da Embrapa Soja.

Fonte: Empresa Brasileira de Pesquisa Agropecuária - Embrapa Soja. Organograma Embrapa Soja. Disponível em: <http://www.cnpso.embrapa.br/index.php?op_page=115\&cod_pai=3> 


\section{Estrutura Física}

A Embrapa Soja abriga 29 laboratórios, 34 casas de vegetação, auditório, biblioteca, restaurante, garagem para veículos e máquinas agrícolas, galpões de apoio, cozinha experimental e prédios administrativos que ocupam 22.390 metros quadrados de área construída para sediar a unidade. A base física da empresa é situada em Londrina/PR, contudo mantém pesquisadores em Rondônia, Minas Gerais e Goiás, em conjunto com outras instituições de pesquisa, e desenvolve atividades com parceiros no Brasil e no Exterior.

Nos recursos humanos da empresa, até agosto de 2012, estavam 309 empregados divididos em três grandes grupos funcionais, sendo 66 pesquisadores, 39 analistas e 204 assistentes. O quadro engloba 246 empregados do gênero masculino e 63 do gênero feminino. A maioria dos pesquisadores é titulada com doutorado e pós-doutorado em diversas áreas do conhecimento. $A$ Empresa conta ainda com empregados especializados, que exercem funções de apoio à pesquisa tanto no campo como em laboratórios e na área administrativa. Somam-se aos empregados da Embrapa Soja 169 estagiários, 97 parceiros e colaboradores.

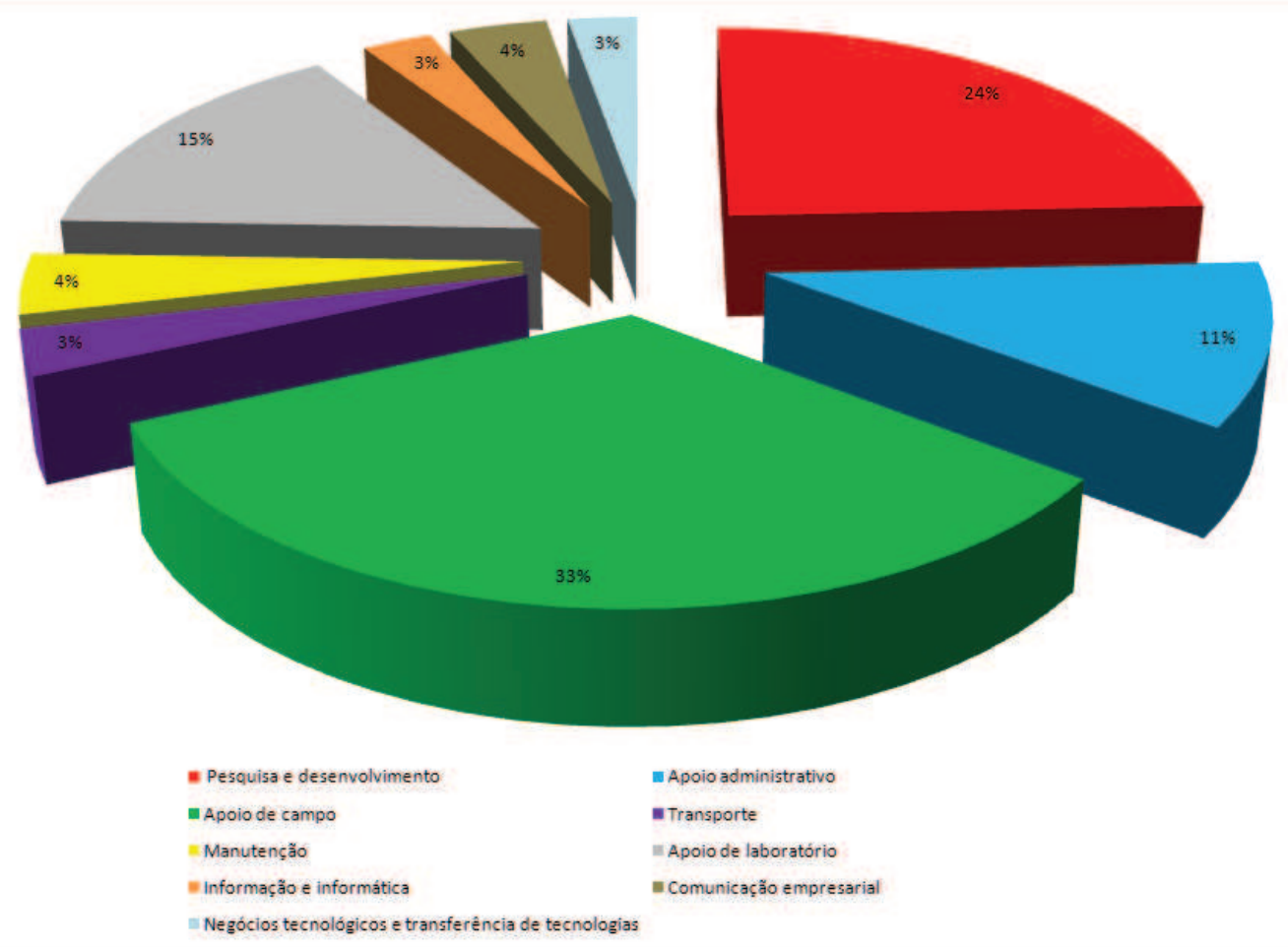

GRÁFICO 2 - Distribuição dos funcionários em setores da Embrapa Soja.

Fonte: Dados da pesquisa 
Os empregados, estagiários, parceiros e colaboradores estão divididos em dez áreas técnicas, oito núcleos temáticos e na área administrativa, composta por outros Núcleos e Setores desenvolvendo suas atividades de modo a cumprir plenamente sua missão. A divisão apresenta-se conforme se mostra no Gráfico 2.

\section{O Núcleo de Comunicação Organizacional da Embrapa Soja}

O Núcleo de Comunicação Organizacional (NCO) é um órgão da Embrapa Soja subordinado à chefia-geral da empresa que atua como seu staff direto. O cargo de supervisão do setor é ocupado por uma Jornalista que coordena uma equipe de cinco profissionais, dentre os quais uma é Jornalista, duas são Relações-Públicas e duas são Designers Gráficas. A equipe do NCO conta também com pessoal de apoio técnico e com estagiários que são estudantes universitários que recebem acompanhamento direto de um dos profissionais na função de supervisor de campo. A comunicação organizacional administra ações de comunicação da Embrapa Soja com os públicos estratégicos. Tem por objetivo construir e fortalecer relacionamentos que conduzam a Empresa para cumprir sua missão junto à sociedade. A atuação do NCO é sintonizada às ações de Pesquisa e Desenvolvimento e Transferência de Tecnologias, uma vez que o grande desafio da comunicação, numa empresa de ciência e tecnologia, é facilitar o conhecimento e a utilização dos resultados da pesquisa científica por todos que possam se beneficiar dela.

O Núcleo de Comunicação Organizacional elabora, coordena e desenvolve sondagens de opinião interna e externa; desenvolve assessoria de imprensa; organiza eventos científicos e institucionais; produz informativos impressos e eletrônicos; promove campanhas educativas, culturais e informativas; produz e edita vídeos técnicos e institucionais; organiza e supervisiona o Programa Embrapa \& Escola na região de Londrina; promove e organiza visitas; cuida do atendimento ao cidadão (sac) e administra o sítio da unidade na Internet. 


\subsection{Gestão e Comunicação Interna na Embrapa Soja: Métodos Utilizados}

A pesquisa teve a comunicação interna como seu objeto dentro do qual a inclusão da oralidade na comunicação entre líderes e equipes de empregados de uma organização foi o recorte definido. Alertam Godoi, Melo e Silva (2010, p. 4) que "[...] por meio da hermenêutica podemos dizer que a tarefa da pesquisa não é descobrir objetos absolutos, mas prosseguir a construção dos sentidos da conversação". Com base nas relações conceituais de linguagem, diálogo, comunicação interna, oralidade e comunicação face a face, analisou-se a comunicação que se estabelece entre organização, gestores e empregados. A investigação desenvolveu-se seguindo um modelo denominado "uma visão qualitativa integrada", tão essencial aos estudos organizacionais.

No lugar em que hoje nos situamos, sabemos que os objetos têm fronteiras
pouco definidas e que a experiência rigorosa tornou-se irrealizável diante da
complexidade, pois exigiria um dispêndio infinito de atividades humanas. O
rigor científico objetualizou, desqualificou, degradou e caricaturizou os
fenômenos: para afirmar a personalidade do cientista destruiu a
personalidade da natureza [...]. O que esperamos hoje é menos conversa
sobre rigor e mais sobre originalidade, para que o conhecimento recupere o
seu encantamento (GODOI; MELO; SILVA, 2010, p. 5).

Segundo os autores citados, o mundo pós-moderno é comunicação e a demanda científica é pela situação comunicativa que produz conhecimento encravado não mais na desmembração disciplinar, mas sim na fragmentação temática. Este conhecimento, conforme mencionam os autores, é produzido à luz de uma pluralidade metodológica que será de interesse para a ciência por "[...] seu caráter comunicativo de mediador e formador das experiências e das necessidades sociais" (GODOI; MELO; SILVA, 2010, p. 8). A visão qualitativa dos estudos organizacionais defende a supressão dos métodos pelas estratégias de pesquisa compreendidas por Godoi, Melo e Silva (2010, p. 9) como "[...] um pacote de concepções, práticas e habilidades que o pesquisador emprega para mover-se do paradigma ao mundo empírico".

Organizações na atualidade convivem com a mudança e esta variável admite que, em seus questionamentos, um pesquisador rediscuta a comunicação, em contraponto com a cultura e com as estratégias de comunicação oral. A contraposição entre paradigmas abriga vertentes positivistas e fenomenológicas, dando ênfase e relevância às pesquisas quali-quantitativas no 
complexo mundo pós-moderno. Exposto está que a oralidade é um capítulo complexo das Ciências Sociais e que sua complexidade incide, igualmente, sobre seu recorte, portanto a pesquisa empírica exigiu o cumprimento de três etapas. A multiplicidade de métodos foi imprescindível para alcançar os objetivos propostos e a problematização desta tese esquematizou uma primeira fase ancorada pela fenomenologia, a preservação da abordagem qualitativa na segunda etapa e uma terceira fase de caráter quantitativo.

\begin{abstract}
A Fenomenologia é o estudo das essências, e todos os problemas, segundo ela, resumem-se em definir essências: a essência da percepção, a essência da consciência, por exemplo[...] É uma filosofia transcendental que coloca em suspenso, para compreendê-las, sempre "ali", antes da reflexão como uma presença inalienável, e cujo esforço todo consiste em reencontrar esse contato ingênuo com o mundo (MOREIRA, 2002, p. 69).
\end{abstract}

Segundo analisa o autor, o fenômeno é o que é e, analogicamente, a comunicação interna pode assim ser considerada dentro do contexto organizacional. A comunicação interna pode ocorrer por diferentes modos e métodos, contudo não significa que esta comunicação esteja alforriada daquilo que lhe é intrínseco e natural. A comunicação interna é o exercício de relações sociais dentro de uma organização, portanto é de se supor que a comunicação face a face e a oralidade sejam suas expressões de maior impacto.

Uma pesquisa de produção bibliográfica conduz o pesquisador a se aprofundar a respeito das questões inseridas no contexto de sua investigação, A pesquisa bibliográfica corresponde à primeira fase de qualquer estudo,

[...] é desenvolvida a partir de material já elaborado, constituído principalmente de livros e artigos científicos. [...] A principal vantagem da pesquisa bibliográfica reside no fato de permitir ao investigador a cobertura de uma gama de fenômenos muito mais ampla do que aquela que poderia pesquisar diretamente (GIL, 2007b, p. 65).

A revisão de literatura subsidiou a definição dos critérios empregados na pesquisa empírica, a qual analisou a comunicação interna praticada por uma organização estatal e pelos seus gestores no que diz respeito à transmissão de informações, motivação, compartilhamento e tomada de decisão, mediante o uso estratégico da oralidade.

A pesquisa de caráter exploratório consistiu de três fases, duas das quais com lideranças formais da empresa. Atendendo ao que caracteriza a pesquisa exploratória, realizou-se uma revisão bibliográfica e entrevistas não padronizadas, 
pois "[...] procedimentos de amostragem e técnicas quantitativas de coleta de dados não são costumeiramente aplicados nestas pesquisas" (GIL, 2007b, p. 43).

Nas duas primeiras fases, realizaram-se entrevistas em profundidade (Apêndices A, B) com os dirigentes e supervisores da empresa, pois, segundo Duarte (2006, p. 63), as entrevistas estão capacitadas para "[...] identificar as diferentes maneiras de perceber e descrever os fenômenos". As entrevistas com as lideranças, na medida do possível, seguiram a tradição do contato face a face entre os atores da pesquisa para explorar, a fundo, a experiência dos entrevistados a respeito do tema investigado. A terceira e última etapa da pesquisa adotou como sujeitos todos os empregados da empresa, pois preencheu a finalidade de confrontar o pensamento das lideranças sobre o uso da oralidade na prática de comunicação interna, com a percepção dos liderados sobre o que de fato ocorria no universo investigado. As entrevistas com os funcionários tiveram como instrumento de coleta questionários semiestruturados (Apêndice $\mathrm{C}$ ).

Resumidamente, desenvolveu-se uma fase com a cúpula da empresa, uma fase com o staff direto dos dirigentes da Embrapa Soja e uma fase que se estendeu para os empregados dos demais níveis hierárquicos que não ocupassem cargo formal de liderança. A análise, fruto do entrelaçamento dos dados obtidos, expõe caminhos para compreender a relação entre líderes e liderados na empresa estatal estudada.

\subsection{Etapa Fenomenológica com Dirigentes da Embrapa Soja}

A primeira etapa do estudo empírico foi dedicada ao levantamento da prática e da percepção dos dirigentes da Embrapa Soja sobre o uso da oralidade no contexto da comunicação interna da empresa. Optou-se pela fenomenologia como estratégia de pesquisa, pois se pretendeu uma imersão dos dirigentes sob o tema proposto com o monitoramento do roteiro norteador da coleta dos dados (Apêndice A). A perspectiva da fenomenologia atende ao requisito da busca pelo conhecimento como uma volta às coisas como elas de fato são ou se apresentam, portanto mostra-se fortemente vocacionada para uma abordagem qualitativa. 0 método de pesquisa fenomenológico procura compreender a realidade social em sua intimidade, visto apresentar que a base de uma pesquisa, seja ela sociológica, natural ou social, é a interpretação da vida cotidiana. Conforme cita Moreira (2002, p. 
66), "[...] aquilo que aparece provê o ímpeto para a experiência e para a geração de um novo conhecimento", portanto fica compreendida a "máxima da Fenomenologia", mencionada pelo autor, que está na "volta às próprias coisas". Interessada na pesquisa organizacional, Sanders (1982) afirma que a fenomenologia pode ser descrita como uma técnica de pesquisa qualitativa que procura tornar explicita a estrutura implícita e dar sentido à experiência humana. Argumenta que a fenomenologia como método de pesquisa organizacional torna-se interessante quando consciência é etimologicamente entendida como o que representa a excelência gerencial ou uma descrição dos mitos organizacionais, culturas e símbolos. De modo simplificado, a fenomenologia é o estudo dos fenômenos conscientes pois, segundo Sanders (1982), o método analisa a maneira como as coisas ou experiências se mostram. A norte-americana afirmou que a palavra fenômeno deriva do verbo grego que significa mostrar-se para ou aparecer. O fenômeno, como analisa Moreira (2002), é sempre anterior à teoria e ao conceito.

Conforme Sanders (1982), o procedimento fenomenológico tem como base a definição de que se trata de buscar "essências" situadas no modo de ver das pessoas e que sua revelação provém de uma análise intencional da correlação entre objetos no modo como são percebidos (noema) e sua apreensão subjetiva (noesis). As expressões em grego foram associadas por Husserl e tem-se, com elas, que uma experiência é captada fenomenologicamente quando se estabelece a priori uma intencionalidade ou correlação. Isso permite chegar ao fato de que cada fenômeno experimentado se refere ou reflete uma disposição a experimentá-lo. Um exemplo fornecido por Sanders (1982, p. 357, tradução nossa) ilustra, de modo bem exato, a forma de encontrar esses dois elementos numa fala transcrita. A autora cria uma situação hipotética simples de um informante que tenha dito algo como: Meu chefe determina que todos nos tratemos pelo primeiro nome e isso me faz sentir valorizado. A primeira parte da afirmação registra um fato (objeto percebido): tem-se aí a noema. Na segunda parte, ao falar desse fato no que ele representa para quem o percebe (considerar que está sendo valorizado) é uma apreensão subjetiva, portanto, noesis. Tendo em vista que ao apreender essa correlação, abre-se caminho para encontrar a essência de um dado fenômeno, esse raciocínio aqui ilustrado foi transportado para a apreensão da essência do fenômeno oralidade no ambiente estudado. 
Outro importante componente para efetuar essa correlação foi não perder de vista, no momento de conhecer o grau de consciência que o informante tinha do fenômeno que vivenciava, realizar a chamada epoché. Trata-se de buscar a forma sempre mais isenta de se pôr em contato com a descrição encontrada. Isso será conseguido se o pesquisador lograr encontrar um modo de isolar seus vieses, preconceitos, concepções excludentes ou conservadoras e quaisquer outros fatores seus que possam ser contaminadores da resposta que obtém.

A fenomenologia eleita como estratégia de pesquisa ocorreu em respeito à pluralidade de enfoques dada pelos dirigentes da Embrapa e que estava prevista para ocorrer nesta primeira etapa da pesquisa devido à protuberância científica e profissional dos sujeitos selecionados. O roteiro (Apêndice A) foi inspirado nos argumentos dos autores contidos na revisão de literatura e em outros instrumentos que mostraram proximidade com esta investigação e adotou o desenho de uma entrevista não estruturada. A construção do instrumento (Apêndice A) resultou, ainda, de uma pré-testagem realizada com um sujeito de uma Unidade Administrativa da Embrapa e com mais dois sujeitos alocados em distintas Unidades Ecorregionais da empresa, aos quais a pesquisadora tinha acesso para desenvolver esta fase que deveria preceder a coleta de dados. Absorvidas as sugestões dos sujeitos participantes do pré-teste, realizou-se uma reunião da pesquisadora com a gerente de comunicação organizacional da Embrapa Soja e com a profissional responsável pela comunicação interna da unidade. Novos ajustes foram sugeridos pelas duas profissionais de comunicação e procedidos para refinar o roteiro o mais possível, alcançar os objetivos da pesquisa e resguardar a compreensão dos entrevistados sobre o assunto investigado.

As entrevistas foram concedidas por quatro sujeitos que ocupavam cargos de direção na Embrapa Soja e que conduziam outras lideranças responsáveis por equipes de empregados de nível científico, administrativo e de nível operacional dentro da unidade. A gerente de comunicação organizacional foi a mediadora entre os dirigentes e a pesquisadora, tomou parte informando sobre a pesquisa, solicitando a participação dos sujeitos e agendando as entrevistas. plano de entrevistas previu períodos específicos para execução de cada um dos encontros, porém não foi possível distribuí-los nos períodos matutino e vespertino de um mesmo dia. Nas datas das entrevistas, o acesso da pesquisadora às instalações da empresa foi concedido pela gerente de comunicação que a acompanhou aos 
gabinetes dos entrevistados, procedeu às devidas apresentações e se colocou à disposição de ambas as partes. Os horários de atendimento pelos dirigentes foram rigorosamente cumpridos, e as entrevistas iniciaram conforme o agendamento preliminar, sem nenhum episódio de transferência, suspensão ou remarcação de horário. Observou-se que nenhuma interrupção ao processo de entrevista ocorreu por interferências externas. Os interlocutores puderam manter o foco singularmente nas questões contidas na entrevista

Ao iniciar cada uma das entrevistas, os entrevistados receberam mais informações sobre as atividades acadêmicas e profissionais da pesquisadora, sobre os objetivos da pesquisa e foram brevemente esclarecidos sobre as características gerais de uma estratégia fenomenológica de pesquisa. Cumpridos os protocolos de abertura, era solicitada autorização para gravar a entrevista em áudio e dava-se início à gravação com a fala da pesquisadora acentuando o registro da autorização obtida do entrevistado para gravar aquela conversação. O andamento da entrevista seguiu a ordem sequencial aos assuntos introdutórios, conforme o que estava organizado no roteiro. Realizar gravação em áudio, para posterior transcrição na íntegra, foi uma das garantias de distanciamento e de adoção da époche que é recomendada ao seguidor da fenomenologia como método de investigação.

$O$ instrumento (Apêndice $A$ ) foi configurado com a flexibilidade necessária para se adaptar ao comportamento e ao discurso de cada entrevistado. Os sujeitos responderam livremente com maior ou menor detalhamento, conforme sua motivação para abordar os assuntos elencados. Houve situações em que o roteiro foi ampliado ou modificado, afinando-se ao ritmo do entrevistado. A análise das entrevistas seguiu o modelo sugerido por Sanders (1982, p. 357, tradução nossa) e que, resumidamente, contém quatro perguntas que o pesquisador deve responder:

1. Como pode o fenômeno ou experiência sob investigação ser descrito?

2. Quais são as invariantes ou temas emergentes nessas descrições?

3. Quais são as reflexões subjetivas desses temas?

4. Quais são as essências presentes nesses temas e reflexões subjetivas? 


\subsection{Etapa Qualitativa com os Supervisores da Embrapa Soja}

A segunda etapa da pesquisa na Embrapa Soja seguiu procedimentos qualitativos que regeram a coleta de dados e a interpretação de fenômenos cotidianos vivenciados pelos sujeitos pesquisados. $\mathrm{Na}$ pesquisa organizacional, pessoas pertencentes aos quadros diretivo e funcional da empresa representam sua voz e reproduzem um discurso que é o da organização. A oralidade compreendida como uma forma natural para a prática das relações humanas admite uma abordagem qualitativa, pois conforme esclarece Luz (2001, p. 104),

[...] a pesquisa qualitativa significa diferentes coisas em diferentes momentos; envolve uma abordagem interpretativa, naturalista de seu objeto, o que significa que estuda os fenômenos em seu ambiente natural, tentando dar-lhes sentido ou interpretá-los em termos dos significados que as pessoas atribuem a eles.

O método qualitativo é uma estratégia indutiva de pesquisa com referências variadas, sendo adequado listar as características que Godoi, Melo e Silva (2010, p. 96) registram como: a questão do ambiente natural ser fonte de dados, da compreensão do fenômeno ocorrer a partir da perspectiva dos entrevistados e da suposição de um contato direto entre os atores participantes da investigação.

É fundamental o pesquisador mapear a população para, à luz de uma apreciação crítica sobre as pessoas que dela fazem parte, identificar os atores que melhor expressem questões relativas ao tema da investigação, conectando-as a sua experiência vivida em dado espaço físico e temporal. A seleção dos respondentes considerou pessoas de elevado envolvimento com a empresa, com conhecimento e experiência abrangentes sobre o uso da oralidade na comunicação interna da Embrapa Soja e que ocupassem formalmente cargos de liderança na empresa. Nesta etapa da pesquisa, os supervisores da Embrapa Soja, cargo administrativo que usualmente equivale ao de gerente, eram os que poderiam aferir relevância aos dados coletados, trazer energia e rigor científico para a pesquisa e, pelas razões descritas, foram eleitos como alvo da segunda etapa da pesquisa. Identificou-se no organograma da empresa (Figura 3), 17 sujeitos interligados na hierarquia e na comunicação que correspondiam aos critérios adotados e assim compuseram o quadro de respondentes para a pesquisa qualitativa. As informações colhidas com os dirigentes, através da fenomenologia, permearam a composição da entrevista desta segunda etapa de pesquisa para ratificar, ampliar e confrontar o 
discurso dos dirigentes com a prática de comunicação interna da Embrapa Soja, agora, segundo a percepção dos supervisores. Um conjunto de técnicas interpretativas compreendidas no método qualitativo ocorreu no contorno de entrevistas com formato semiestruturado (Apêndice B) que abriram possibilidades para os pesquisados adequarem sua disponibilidade ao processo de resposta às questões propostas.

Os participantes selecionados receberam uma pré-notificação sobre - desenvolvimento da pesquisa enviada pela profissional responsável pela comunicação interna do Núcleo de Comunicação Organizacional na Embrapa Soja. O protocolo posterior ocorreu após sete dias quando foram notificados, com maiores detalhes, por mensagem eletrônica. O e-mail continha apresentação pessoal da pesquisadora, breve esclarecimento sobre o tema e sobre o objetivo da pesquisa e enfatizava as razões de escolha da Embrapa Soja. O argumento principal da justificativa foi o fato de ser uma empresa marcante na pesquisa agropecuária e agronegócio, que opera em nível de excelência pelo fazer dos cientistas que nela atuam e porque sua missão empresarial de produzir conhecimento a distingue como ambiente conexo para acolher uma pesquisa científica de doutorado. A mensagem convidava o destinatário a participar da pesquisa e determinava a data para devolução do instrumento que seguiu anexo. Ficou estabelecido um intervalo de 20 dias entre a data de remessa do e-mail e o prazo final para a devolução do instrumento (Apêndice B) porque os sujeitos cumpriam uma dinâmica agenda de compromissos e necessitavam de prazo compatível para atender ao apelo da coleta de dados. Houve respondentes que manifestaram sua preferência pela entrevista direta, face a face com a autora da pesquisa e que foram atendidos em suas escolhas. As entrevistas foram gravadas em áudio e transcritas para os campos do instrumento de coleta de dados (Apêndice B).

Decorrido o prazo estabelecido, observou-se um retorno baixo de respostas. As informações fornecidas mostravam-se valiosas para analisar o comportamento da Embrapa Soja no que diz respeito à comunicação oral, uso do diálogo e comunicação face a face entre líderes e empregados. Um reforço foi enviado para quem não havia retornado a pesquisa, ratificando que a resposta era condição indispensável para a sua qualidade e rigor científico. O primeiro follow-up ${ }^{9}$

\footnotetext{
${ }^{9}$ Follow-up foi um esforço para buscar retorno dos sujeitos que não tivessem respondido até a data estabelecida no cronograma da coleta de dados.
} 
trouxe resultados discretos, por isso novo reforço foi enviado para os atores inadimplentes com a pesquisa. Alguns sujeitos então responderam de modo negativo sobre a disponibilidade para participar, justificando como motivo o acúmulo de trabalho naquele momento. A segunda etapa da pesquisa foi encerrada com a obtenção de 13 respostas entre os 17 sujeitos identificados como respondentes. Acompanhando os agradecimentos aos respondentes da etapa qualitativa solicitouse que os líderes disseminassem a realização da pesquisa para suas equipes e informassem sobre a posterior abordagem dos funcionários no levantamento de dados, bem como estimulassem a participação dos empregados. Nesta ocasião, final de ano, período de colheitas, de recessos e de férias, situações que interferiam na presença dos empregados na unidade e infligiram aguardar seu transcurso para proceder à coleta de dados da terceira fase da pesquisa. As informações prestadas pelos entrevistados foram analisadas qualitativamente, a partir da fundamentação teórica e em total coerência com os objetivos propostos como expõe o capítulo de análise dos dados.

\subsection{Etapa Quantitativa com os Empregados da Embrapa Soja}

A terceira fase adotou procedimentos metodológicos recomendados em pesquisa de natureza quantitativa e descritiva e foi desenvolvida com os funcionários da empresa. A empresa detinha, na unidade sob estudo, um quadro de 309 empregados na época da coleta de dados, como informou seu setor de recursos humanos. Era critério, para identificar a amostra, que o empregado não ocupasse cargo formal de liderança na hierarquia da empresa e, por esse motivo, foram excluídos do cálculo os respondentes das duas primeiras fases da pesquisa, eliminando-se 17 sujeitos da população-alvo. Outro critério definido para a população-alvo foi quanto ao sujeito sofrer impacto direto da comunicação interna da Embrapa Soja, pois o respondente se manifestaria sobre a presença da oralidade na prática de comunicação oral, uso do diálogo e das interações face a face na rotina de relacionamento entre superior e subordinado. A unidade dispunha, naquela data, de 25 empregados atuando em instituições parceiras e em outras unidades da estatal Embrapa, os quais foram desconsiderados do cálculo, exatamente por não serem impactados pela comunicação interna da empresa. A facilidade de acesso ao empregado foi mais um critério seguido para identificar sujeitos, então excluíram-se 
outros 32 empregados porque 25 encontravam-se em férias, viajando e em licença para pós-graduação; sete empregados estavam trabalhando na safra de trigo, portanto externamente à empresa e igualmente inacessíveis. A população-alvo considerada resultou em 235 empregados.

A natureza quali-quantitativa desta pesquisa de doutorado consentiu validar resultados, independente de tratamento estatístico. O cálculo amostral da etapa quantitativa foi simulado para nortear o esforço de confirmar, cientificamente, a pesquisa. O cálculo amostral foi processado on-line ${ }^{10}$ e a amostra foi calculada sobre uma população de 235 empregados, com 95\% de nível de confiança, 5\% de margem de erro e a quantidade adequada de elementos calculada foi de 147 respondentes. Características da amostra foram apreciadas em conjunto com o NCO da Embrapa Soja e esta parceria analisou a conveniência de produzir o instrumento de coleta de dados (Apêndice $C$ ) em duas versões, sendo uma impressa e outra eletrônica, que seriam distribuídas conforme as especificidades e facilidades de acesso aos meios eletrônicos do setor onde o empregado atuasse.

O questionário (Apêndice $\mathrm{C}$ ) replicou informações coletadas nas fases um e dois, nas quais os líderes se expressaram sobre a oralidade e seu uso na gestão de pessoas e na comunicação interna. As questões foram elaboradas de modo a permitir que o empregado avaliasse esta comunicação e manifestasse sua percepção sobre benefícios, limitações, aplicações e implicações do uso da comunicação oral, do diálogo e da comunicação face a face e dos seus impactos, segundo o relacionamento cotidiano desenvolvido com seu superior imediato. Buscou-se confrontar os pontos dirigente/supervisor/empregado para descrever a presença da oralidade na comunicação interna da Embrapa Soja através do relacionamento analisado tanto pelos líderes, quanto pelas equipes de empregados.

O questionário (Apêndice $\mathrm{C}$ ) foi organizado em cinco blocos de questões elaboradas em conformidade com os eixos teóricos do relatório de tese comunicação interna, comunicação oral, uso do diálogo, comunicação face a face e, no último bloco, questões sobre o conjunto de eixos. Perguntas abertas, fechadas e de múltipla escolha compuseram o instrumento de coleta de dados quantitativos. As perguntas de múltipla escolha eram classificadas como de estimação ou avaliação, pois: "[...] consistem em emitir um julgamento por meio de uma escala com vários

\footnotetext{
${ }^{10}$ Site estatístico disponível em: <http://www.calculoamostral.vai.la/>. Acesso em 12 mar. 2012.
} 
graus de intensidade para um mesmo item. As respostas sugeridas são quantitativas e indicam um grau de intensidade crescente ou decrescente". (LAKATOS; MARCONI, 2011, p. 91).

Informam as autoras citadas que as perguntas de múltipla escolha não se colocam como um vácuo diante das questões abertas, pois permitem um aprofundamento similar, embora a técnica ofereça facilidade para tabular os dados coletados. O procedimento de pré-notificação igualou-se ao adotado na segunda fase da pesquisa ficando ao encargo da responsável pela comunicação interna do NCO da Embrapa Soja. Os instrumentos impressos foram distribuídos pela comunicação interna da empresa que reforçou oralmente as instruções gerais, a data de retorno e disponibilizou o espaço físico do setor como local para a entrega pelos respondentes do questionário preenchido.

O questionário on-line foi produzido na plataforma Google pela facilidade e agilidade que confere ao processo de coleta de dados para usuários de formulários de pesquisa. As mensagens circularam diretamente no sistema de informação da empresa, portanto havia restrição factual para a intervenção direta da pesquisadora. $\mathrm{O}$ Google Docs ${ }^{11}$ gerou um link de acesso à pesquisa que demandou o envolvimento do NCO da empresa para distribuí-lo aos sujeitos da amostra que acessavam meios eletrônicos. Inseridas no corpo da notificação seguiram as instruções sobre o preenchimento e sobre a data final para preenchimento on-line.

A meta de retorno impetrou duas ocorrências de follow-ups que resultaram pouco produtivas. O impacto para alcançar retorno significativo foi dado com a adoção de uma nova estratégia para a coleta dos dados e partiu da autorização da empresa para proceder entrevista direta, no interior de suas dependências, durante o horário de funcionamento da unidade, com os empregados pertencentes à amostra identificada. A estratégia de pesquisa caracterizou a definição de uma amostra não probabilística por conveniência, pois a pesquisa elegeu como sujeitos os membros da população mais acessíveis. Defende Mattar (2005) que este tipo de amostra é apropriada para pesquisa exploratória e selecionada para alcançar uma conveniência do pesquisador. O autor afirma que a

\footnotetext{
${ }^{11}$ O Google Docs, é um pacote de aplicativos do Google. Funciona totalmente on-line diretamente no browser. Os aplicativos são compatíveis com o OpenOffice.org/BrOffice.org,KOffice e Microsoft Office, e atualmente compõe-se de um processador de texto, um editor de apresentações, um editor de planilhas e um editor de formulários. Ele permite aos usuários criar e editar documentos online ao mesmo tempo colaborando em tempo real com outros usuários. Disponível em: http://pt.wikipedia.org/wiki/Google_Docs. Acesso em: 20 out. 2012.
} 
amostra por conveniência é uma estratégia para os casos em que sujeitos mostramse indispostos a responder a pesquisa, tal como ocorreu nesta terceira fase da investigação e serviu como critério para decidir pela amostra não probabilística.

Os empregados foram notificados sobre as datas de presença dos entrevistadores para aplicar a pesquisa através do boletim eletrônico diário "Em Dia", veículo de comunicação interna da empresa com elevada penetração junto ao público alvo. No primeiro, do período de quatro dias previstos para as entrevistas diretas, na empresa, o "Em Dia" noticiou sobre o início da visitação dos três entrevistadores externos às divisões da empresa e publicou foto da equipe. A profissional responsável pela comunicação interna da Embrapa Soja acompanhou os entrevistadores pelos setores, apresentou a equipe, levantou informações sobre os sujeitos que já haviam respondido o formulário impresso ou on-line e solicitou a cooperação dos demais empregados com a pesquisa. Os empregados recebiam os formulários impressos e os devolviam após o preenchimento. O êxito da estratégia foi atestado pelos 171 questionários respondidos a partir do contato direto face a face com os entrevistados. Todos os questionários impressos recebidos foram lançados no formulário Google Docs (Apêndice C), a planilha eletrônica (Apêndice D) gerada por um aplicativo foi transferida para o Microsoft Excel e os dados processados através do programa para fins de estatística descritiva, com medidas de frequências e porcentagens apresentados por meio de gráficos.

Uma primeira conclusão emergiu do processo de coleta de dados, pois o retorno alcançado estabeleceu nitidamente conexão com o tema da pesquisa. Pode-se afirmar que a população alvo manifestou com clareza sua preferência por interações face a face em todas as três etapas da pesquisa empírica. 


\section{APRESENTAÇÃO E ANÁLISE DOS DADOS}

Tratando-se de pesquisa quali-quantitativa, a demanda para a análise foi de procedimentos que se ajustaram para que se entrelaçassem em uma rede e se equilibrassem como faria um fiel de balança imaginário. As metáforas aplicam-se para ilustrar como se conduziu a discussão que integrou as decisões metodológicas sob o amparo de três estratégias de pesquisa para os achados atingirem a envergadura científica necessária. A análise fenomenológica das entrevistas em profundidade (Apêndice A) trouxe, nas vozes dos dirigentes da Embrapa Soja, a identificação de fenômenos tratados com a imparcialidade metodológica que a corrente filosófica recomenda. Este foi um procedimento que exigiu repetidas revisões de texto, pois nele é fundamental o distanciamento do pesquisador de qualquer juízo de valor particular.

A interpretação das entrevistas semiestruturadas (Apêndice B), desenvolvidas com supervisores da Embrapa Soja, amparada na estratégia de pesquisa qualitativa, efetuou-se sobre o que disseram os atores pesquisados no âmbito dos eixos teóricos aqui abordados e empiricamente investigados. Houve momentos em que um montante de abordagem funcionalista foi necessário para agrupar informações sobre a gestão da empresa a fim de tornarem-se claramente visíveis ao leitor do relatório. Algumas respostas envolviam uma linguagem técnica própria, portanto subjetiva na forma como é expressada "por e para" alguém externo a este ambiente organizacional e distante dos traços de sua cultura interna.

A estratégia quantitativa desenvolveu-se pelo uso de um instrumento amplo que foi construído com perguntas elaboradas com base no que disseram dirigentes e supervisores da Embrapa Soja, nas primeiras fases da pesquisa. $O$ questionário (Apêndice $\mathrm{C}$ ) foi construído de modo a apreciar a percepção dos empregados sobre o discurso apresentado por seus líderes. Estilos variados de perguntas foram adotados quando se mostravam necessários para maior eficácia do instrumento. Adotou-se, predominantemente, o uso de escala com intervalo de cinco pontos no questionário que estabeleceu um ponto de quebra bem definido entre concordância e discordância. Concordância e discordância foram posicionadas em dois pontos extremos para tornar nítida a oposição e o distanciamento entre os estados de concordância e de discordância totais. A escala também continha dois 
pontos intermediários - um situado entre o ponto de quebra e o polo da concordância e outro intercalado pelo extremo da discordância. Os cinco pontos da escala intervalar ofereceram opções para que os entrevistados graduassem com maior conforto suas percepções a respeito dos temas internos da empresa perguntados na pesquisa. As análises estão apresentadas a seguir, em três seções específicas que serão integradas no capítulo subsequente.

\subsection{Análise da Fenomenologia com Dirigentes da Embrapa Soja}

Realizou-se a transcrição das entrevistas e a leitura criteriosa dos conteúdos guiou a busca pelos eixos temáticos alojados no trajeto do quadro teórico que estrutura os argumentos da tese, com a finalidade de iluminar o corpus aos olhos da pesquisadora. Na essência do discurso dos entrevistados localizou-se a conexão de suas palavras com os eixos teóricos, recordando: comunicação interna, comunicação oral, uso do diálogo e comunicação face a face. Note-se que o eixo intitulado comunicação oral absorveu as questões referentes à linguagem e oralidade, pois entendeu-se que esta relação impetraria o alcance maior de objetivos da tese, sem que interpretações distintas dos entrevistados acerca dos vocábulos impactassem os resultados e originassem vieses na interpretação dos fenômenos analisados.

$\mathrm{Na}$ análise que aqui é empreendida, tratou-se de compreender que essência possuía a oralidade experimentada no contexto examinado e como essa essência aparecia para aqueles que a vivenciavam. Tratou-se, portanto, respectivamente, de objeto conforme percebido (noema) e apreensão subjetiva desse objeto (noesis). Vale lembrar que se teve o cuidado de realizar a epoché para correlacionar noema e noesis ao grau de consciência que o informante tinha do fenômeno que vivenciava. Agregou-se, também, a esse resgate da proposição fenomenológica, menção sobre o modo como foram encaminhadas as perguntas indicadas por Sanders (1982) para proceder às inferências que levaram a encontrar as "essências" buscadas. A primeira delas se referia a como podia ser descrito o fenômeno ou experiência investigada. Para essa finalidade, as respostas foram reestruturadas a partir dos próprios elementos nelas contidos. 
Para encontrar as invariantes ou temas emergentes nas descrições, os quatro eixos estabelecidos destinaram-se a cumprir esse propósito. As informações foram agrupadas em cada um e também havia a abertura para incorporar quaisquer elementos que se mostrassem divergentes. As duas outras perguntas completaram o tratamento das respostas e permitiram conclusões aptas a serem transportadas para os resultados do estudo: Quais são as reflexões subjetivas desses temas? e Quais são as essências presentes nesses temas e reflexões subjetivas? A sequência das análises aparece agrupada em itens subordinados aos eixos temáticos (compondo as invariantes ou os temas emergentes) e cada uma das classificações respondeu à questão acercas das invariantes e temas presentes nas descrições. O método fenomenológico orienta que se busque a "relação noemática" que significa encontrar, da perspectiva dos informantes, a parte que se refere ao noema (objeto percebido) e aquela que indica a noesis (apreensão subjetiva). No momento em que esses dois polos foram identificados, pode-se fazer inferências acerca do fenômeno examinado. Esse foi o raciocínio adotado para comentar as transcrições obtidas nesta parte da apresentação e análise dos dados. As expressões foram utilizadas livremente, podendo ora fazer referência direta aos termos noema-noesis, ora ao seu significado. Tentou-se, com essa alternância, produzir uma leitura dos dados em que se fixasse a correlação que a abordagem fenomenológica permitiu encontrar.

A fim de preservar o anonimato dos entrevistados, suprimiram-se palavras que remetessem diretamente à sua identificação, assim, informações com essa característica foram substituídas por reticências. O procedimento repetiu-se ao ser utilizado para eliminar as redundâncias de um mesmo entrevistado. Nos casos em que a fala do entrevistado não revelou relevância para os fenômenos investigados, sua resposta foi desconsiderada para a transcrição nessa pesquisa. Alguns traços comuns do perfil dos entrevistados puderam ser identificados, dentre eles a orientação de gênero, pois eram todos do sexo masculino; a escolaridade que ficou no nível superior, sendo que o nível de titulação equilibrou-se entre metade de doutores e metade de pós-doutores. 


\subsubsection{EIXO 1 - Comunicação interna}

A comunicação entre os dirigentes da organização assumiu um papel de verdadeira mediadora das relações profissionais, como será visto mais adiante. Não obstante, havia uma hierarquia predeterminada, onde grupos de trabalho se formavam e atuavam. Nesses grupos, percebeu-se haver uma forte noção dos dirigentes com relação à sua função e às posições flutuantes e temporárias que os cargos diretivos simulavam. Pode-se notar que os entrevistados, de modo geral, entenderam-se como pesquisadores que compartilhavam formas distintas de autoridade e de influência alinhadas às suas atribuições como dirigente e às suas atribuições como lideres de equipe. Note-se o depoimento do Sujeito A:

Tenho um cargo e uma função. Sou pesquisador. Tenho uma equipe de trabalho de suporte ao de pesquisa. Na gestão alguns momentos a gente está gerente, está ocupando cargo de chefia. Tenho de 180 a 200 empregados diretamente subordinados a mim.

O entrevistado deixou claro que era um pesquisador, seu cargo e função na instituição. Contudo, tinha a percepção de que, em alguns momentos, seu papel era de gestor. Seus subordinados, entre 180 e 200 empregados, respondiam ao seu comando (objeto percebido - noema). Chama a atenção que ele foi o entrevistado que relatou possuir mais subordinados, embora não fosse o dirigente maior da empresa. Essa noção pode surgir devido à ideia de comando imediato, ou seja, que o entrevistado (apreensão subjetiva - noesis) considerou aqueles sobre os quais tinha influência direta e não incluiu os comandados de seus subordinados como submetidos à sua autoridade na empresa.

O entrevistado B se expressou de maneira bem sintética: "São três áreas. Você tem os nomes das áreas? 17 pessoas”. Pode-se notar que ele possuía uma visão das diferentes áreas de atuação na empresa e que ele não fez menção explícita à sua função e à linha de comando.

O Sujeito C respondeu: "Agrônomo, pesquisador. Atualmente sou o chefe [...] eu devo ter em torno de dez pessoas diretamente". Aqui, o objeto percebido (noema) é que ele se colocou como agrônomo e pesquisador, antes de ser dirigente. Em apreensão subjetiva (noesis), transmitiu a noção de que ele estava exercendo a função de dirigente, mas que tinha a ideia precisa de sua função original. Ao dizer que possuía dez pessoas sob seu comando direto, o entrevistado considerou sua autoridade na linha da estrutura hierárquica da empresa, como pode 
ser constatado no organograma da Embrapa Soja (Figura 3). Por sua vez, o Sujeito D disse: "É a chefia mais voltada para o ambiente interno. Sou contratado como pesquisador. No grupo de supervisores são oito. Tenho uma secretária que me auxilia no dia a dia". É possível notar que o entrevistado se reconheceu como pesquisador e que expressou os limites decisórios do conjunto de setores conduzidos sob sua direção, registrando uma abrangência de caráter interno. $\mathrm{O}$ dirigente apontou a presença de oito supervisores diretos e de uma secretária que o auxiliava. Os dados desta fala associam esse objeto percebido à apreensão subjetiva de reafirmar com clareza a distribuição interna de seu comando ao percorrer mentalmente a linha hierárquica formal na estrutura organizacional da Embrapa Soja, pois a secretária atuava diretamente ligada ao dirigente, contudo não liderava outras equipes de empregados que compunham o conjunto de setores dirigidos pelo entrevistado em análise.

\subsubsection{Como a missão da área se relacionava à empresa}

A respeito da missão da área e sua relação com a empresa, obtevese o seguinte comentário do Sujeito A:

A missão dela é gerar soluções tecnológicas através de pesquisa.
Procuramos estimular uma interação, um bom relacionamento com as áreas
e todas as equipes. Cada um com seu objetivo, por isso sou contra
premiação pra indivíduos. Deveria ser para unidades. Porque ninguém é
mais produtivo que outro. Todas as equipes são estratégicas, o somatório
de esforços é que trará bons resultados.

Seu entendimento com relação à missão foi claro. O objeto percebido (noema), era de que se deviam gerar novas tecnologias baseadas na pesquisa. A apreensão subjetiva (noesis) era de que o alcance dessa meta subordinava-se à cooperação e ao bom relacionamento entre as áreas e equipes. Essas duas posições se tornam ainda mais nítidas no momento em que o entrevistado certifica que cada área possuía seu objetivo particular devido à sua função estratégica dentro da empresa e frisou que os bons resultados eram alcançados pela integração das diversas áreas (noema). Acentuou, também, sua contrariedade (noesis) às premiações individuais. Analisou que quando premiações ocorressem deveriam ser dadas às unidades. Isso expôs sua coerência na percepção da atividade de pesquisa, como algo que era efetuado em equipe, e as condutas de valoração de produtividade. 
A resposta do Sujeito B seguiu um outro percurso, como pode ser observado no discurso destacado abaixo:

Não. Não se sabe direito ainda o que a Embrapa quer [...], qual é o nosso papel realmente. [...] Então nós ainda estamos atuando numa área que não é apenas de intermediários [...] Nós deveríamos fazer o papel de intermediários, treinando agrônomos, veterinários, zootecnistas, que trabalham com o produtor. [...] ainda estamos buscando exatamente saber qual é o nosso espaço. [...] então o pesquisador tem que estar envolvido. Apenas ele deve aprender a falar uma linguagem mais compreensível.

A resposta mostrou (objeto percebido) que a imprecisão a respeito da missão da área dirigida pelo Sujeito B descendia da Embrapa Sede e não da unidade de Soja. Declarou (apreensão subjetiva) que o papel da sua direção ainda era vago e que, consequentemente, ainda não atuava voltando-se para a intermediação de treinamentos. As declarações do Sujeito B apontaram para além da indefinição quanto à missão da área e expuseram sua relação com a empresa como um todo (noema). Ao dizer que sua função ainda não era de intermediário de conhecimento (treinamento), o dirigente apontou para algo que entendeu como o que deveria ser a missão da área sob sua direção na Embrapa Soja e mostrou nitidamente a presença da noesis em sua fala. A resposta, nesse contexto, remeteu à importância do pesquisador que, conforme definiu o entrevistado $B$, era fundamental para que conceitos fossem discutidos e depurados. O excesso de tecnicidade, implícita na resposta do Sujeito B, mostrou seu juízo de valor sobre um fator que pareceu relevante para o processo de comunicação interna, no seu ponto de vista. Tem-se como objetos percebidos no discurso do entrevistado B a importância do pesquisador, a linguagem que define rumos da empresa e o excesso de tecnicidade empregado em sua fala (noema). A apreensão subjetiva (noesis) está nas falas sobre a natureza da linguagem e o juízo de valor manifestado pelo Sujeito $B$, de que esse era fator relevante para a comunicação interna.

Esses setores têm que ser bastante eficientes porque são todas áreas de suporte à pesquisa, então a missão geral da empresa está vinculada a desenvolvimento e inovação na área de ciência agropecuária, agronômica, mais especificamente, e essas áreas que a gente coordena eles têm essa missão de operacionalizar e de não criar empecilhos para que a pesquisa possa ser executada. Então do ponto de vista da organização, [...] o que a gente procura na área [...] coordenando e promovendo esse trabalho cotidiano para impactar o mínimo possível no processo de pesquisa (Sujeito D).

A missão da empresa, relatada pelo Sujeito $D$, era a de desenvolver e inovar na área científica, especificamente na agropecuária e agronomia. Declarou que os diferentes setores da empresa deviam ser eficientes, uma vez que davam 
suporte à pesquisa. Do ponto de vista organizacional cotidiano, os dirigentes participavam na condução do fazer da Embrapa Soja eliminando ou contornando fatores internos que repercutissem em interferências com impactos negativos à sua produtividade. $\mathrm{O}$ dirigente $\mathrm{D}$ retomou a ideia de missão relacionada à pesquisa $\mathrm{e}$ que as demais áreas atuavam como suportes para essa atividade. Ao afirmar que os segmentos que davam o suporte à pesquisa não deveriam criar dificuldades, o Sujeito D sugeriu, ainda que implicitamente, a integração entre as demais áreas diretivas com a área de Pesquisa e Desenvolvimento (noesis) como conduta de gestão assumida e incorporada pelos dirigentes da Embrapa Soja (noema).

\subsubsection{Sobre a "Política de Comunicação"da Embrapa}

A escolha dos dirigentes das unidades da Embrapa é institucionalizada em um processo seletivo interno. Os candidatos são sabatinados sobre as normas, diretrizes e políticas da empresa. Os dirigentes da Embrapa Soja aqui entrevistados foram conduzidos aos respectivos cargos porque alcançaram os critérios de seleção, à época em que se inscreveram para concorrer aos cargos. Um dos conteúdos exigidos era o conhecimento sobre o que diz a "Política de Comunicação" ${ }^{12}$ da empresa, portanto a abordagem a respeito desta política fez-se presente no roteiro de entrevistas (Apêndice A). O assunto foi enfocado pelo Sujeito A do seguinte modo: "Sim, conheço a política de comunicação da Embrapa. Se identifico o que é tratado sobre a comunicação interna da Embrapa? Do que é tratado? Mais ou Menos. A política de comunicação ou o que é feito de comunicação interna? Tranquilo".

O objeto percebido na resposta foi que o dirigente $A$ conhecia a política (noema), mas mostrou-se inseguro para afirmar que conhecia o que era tratado sobre comunicação interna no documento formal da Embrapa. Sugeriu, com isso, que a política não era um diretiva rotineiramente consultada para o exercício de seu cargo de gestão na empresa (noesis).

\footnotetext{
${ }^{12} \mathrm{O}$ arquivo eletrônico formato Portable Document Format - PDF encontra-se disponível em <http://www.embrapa.br/publicacoes/institucionais/polcomembrapa.pdf/view> e passa por um novo processo de revisão e atualização, porém não concluído até o momento de criação deste relatório de tese.
} 
A seguinte resposta foi dada pelo Sujeito B: "Sim. Eu acho que sim, não posso ter tanta certeza. O que é comunicação interna dentro dos documentos de comunicação da Embrapa? Eu acho que sim". Ele demonstrou incerteza tanto a respeito da "Política de Comunicação" quanto ao que era comunicado (noema). Foi uma resposta que sugeriu haver dúvidas a respeito da natureza e conteúdo da comunicação interna da empresa (noesis).

A resposta "Sim, consigo", dada pelo Sujeito C, foi extremamente direta. A expressão do entrevistado permitiu apreender subjetivamente a segurança em sua resposta. O conhecimento sobre a "Política de Comunicação" da Embrapa declarado pelo Sujeito C é aqui o noema manifestado.

Os comentários do Sujeito D a respeito da política foram esclarecedores:

Sim. Em termos de orientações operacionais? Eu acho que não.
Simplesmente existe um organograma de estrutura hierárquica, mas não é
feito, que eu me lembre, não tem nenhuma norma de comunicação
especifica. Somente a questão de organização, é feita uma publicação
desta estrutura hierárquica através de portarias e grupos temporários de
trabalhos são feitos via ordem de serviço, essa é a politica. Mas o
relacionamento diário, até onde eu sei, não tem uma política orientativa, não
de como deve ser feito. Minto. O relacionamento diário, não sei se é uma
política de comunicação. O que existe é uma estrutura de registro de
tramitação de documentos na unidade. Mais focado na questão
administrativa do que na questão relacional para fazer a rastreabilidade de
documentação, de processos. Não é um documento orientador de
mecanismos de comunicação.

O Sujeito D expôs que conhecia a "Política de Comunicação", embora não estivesse certo sobre uma clara orientação organizacional. Referiu-se ao sistema de comunicação administrativa em sobreposição ao reconhecimento sobre a legitimidade que o documento formal da "Política de Comunicação" deveria ocupar. A estrutura publicada por meio de portaria explicitava o modo de ação dos grupos de trabalho. A atuação diária possuía uma orientação para o registro da tramitação de documentos na unidade, que era focado na questão administrativa e rastreamento de processos. O noema aqui presente são as questões relacionais que possuíam regulamentação na "Política de Comunicação" da Embrapa. Embora existisse uma estrutura oficial que deveria ser seguida no processo de comunicação interna, ela não estava presente formalmente na comunicação relacional. Ocorreu, no depoimento do Sujeito D, a apreensão subjetiva de uma supervalorização para assuntos de natureza funcional e burocrática. 


\title{
9.1.1.3 Adotava a política na comunicação com os liderados
}

O Sujeito A respondeu à questão do uso da "Política de Comunicação" com seus liderados da seguinte forma:

Mais ou Menos. Sobre políticas de comunicação interna entendo mais como sendo os sistema de comunicação usados [...] pela nossa área de comunicação que cria formas de divulgação de novos procedimentos. Já a política de comunicação que tenho que usar com meus subordinados, depende do público que tenho que trabalhar, [...] tenho que fazer entender e passar aquilo que eu preciso para o meu grupo de subordinado, [...] mas são formas de comunicação totalmente diferentes.

A resposta mostrou que o dirigente A seguia uma política ajustada às necessidades do público específico com quem ia se relacionar, tal como dita o documento formal da "Política de Comunicação" da empresa, pois a necessidade de entendimento era recomendação formalizada na política. Reforçou-se a adaptabilidade necessária aos diferentes cenários de comunicação, sendo a flexibilidade um fenômeno que autorizou a coexistência com uma política comunicacional mais regional, conforme reforçou o Sujeito $A$ na sequencia da entrevista:

\begin{abstract}
A gente passa uma coisa no papel escrito e muitas vezes a forma de assimilação é diferente de um e de outro. Na conversa não, no olho a gente começa a ver qual é a reação de um e de outro. [...] por menor que seja o grau de instrução dele, sempre ele tem o que colaborar. É importante ouvir esse cara e dar oportunidade para ele falar. Eu gosto muito do oral. Acho que a gente perde menos tempo.
\end{abstract}

A resposta pontuou a diferença de entendimento daquilo que era escrito (noema)e ressaltou a importância da oralidade no processo comunicacional (noesis). Reforçou a prática de uma política de comunicação interna baseada na oralidade:

Na outra forma de política interna que a gente tem, uma política institucional que a gente passa a informação, mas às vezes a gente não tem muita preocupação para ver se ela atingiu mesmo o público que precisava ou não. Eu vejo que são formas diferentes de comunicar: uma como gerente que eu tenho que passar e ver se o cara pegou mesmo que ali adiante eu vou cobrar isso dele, e aquela outra forma de comunicação que a gente passa a título de informação, passa e se o cara aceitou ou não, depende mais do interesse dele pelo que a gente está passando.

A resposta dada pelo Sujeito $B$ foi uma apreciação crítica a respeito dos sistemas comunicacionais e de seus âmbitos filosóficos e pragmáticos nas rotinas gerenciais: 
Não é um documento que vou olhar de vez em quando pra ver. Como muitos documentos da empresa são totalmente desconhecidos. Quanto importante são estes documentos para as pessoas envolvidas? São muito genéricos, muito amplos, então não são consultados. Eu pelo menos não consulto. Vai tocando.

O entrevistado B analisou que a documentação relacionada à "Política de Comunicação" não era algo para consulta frequente. Afirmou que, do mesmo modo como outros documentos, o da política comunicacional não costumava ser acessado periodicamente. Com relação à sua importância, esclareceu que vários documentos eram muito gerais e por isso não eram consultados, ao menos por ele. A fala dos sujeitos entrevistados remeteu a entender que a consulta às diretrizes e as políticas comunicacionais não fazia parte da rotina. Sua natureza geral, talvez abstrata, não ajudava diretamente na resolução dos problemas diários, conforme corrobora o dirigente $\mathrm{B}$ em mais uma fala destacada abaixo:

[...]até penso que deva perguntar para mais gente. Esse documento te ajudou no trabalho em comunicação? Esse documento te ajudou a redirecionar sua linha de atuação? Não sei, eu tenho a percepção de que a maioria dirá - Não mudou nada, eu não entendi bem. O que eles querem com isso aí, afinal?

O Sujeito C declarou utilizar a política comunicacional ao responder :

"Sim, adoto". No entanto, relatou mais adiante:

Naquela avaliação [...] os avaliadores, no entender que eles por meio das entrevistas, eles entenderam que o pessoal de campo não estava bem atendido na comunicação interna. [...] Nós mudamos a nossa estratégia de comunicação, inclusive com os murais, fizemos um rearranjo dos boletins, procuramos alterar um pouco a questão da linguagem. Então quando a gente consegue perceber que está havendo um ruído de comunicação a gente tenta melhorar. Eu acredito que em alguns casos a gente não consiga perceber isso.

Assim foi mostrado que houve uma avaliação do processo comunicacional interno e que ela apontou certo nível de carência nesse aspecto. Ele disse que houve mudanças na linguagem e mais acuidade com as necessidades comunicacionais, incluindo-se a de controle de ruídos no processo de comunicação interna. Reconheceu casos em que não se poderia perceber os problemas de comunicação. Sugeriu o entrevistado $C$ que as políticas de comunicação estavam presentes, formal ou informalmente e que os mecanismos envolvidos no controle do processo de comunicação deveriam ser aprimorados.

Os objetos percebidos (noema) nas falas dos entrevistados foram que os dirigentes seguiam a "Política de Comunicação" da empresa, procediam ajustes às necessidades dos públicos, reconheciam a importância das diretrizes comunicacionais e que a consulta às diretrizes e as políticas comunicacionais não 
fazia parte da rotina, mas que essas estavam presentes nas suas deliberações diárias. Do ponto de vista da subjetividade presente nessas falas apreendeu-se as seguintes noesis: a flexibilidade coexistia com o que era normatizado na Politica, pois a política de comunicação interna, praticada pelos dirigentes, baseava-se na oralidade, os dirigentes avaliaram subjetivamente o processo comunicacional interno e identificaram uma natureza geral que abrigava abstratações e impactava muito discretamente a resolução de problemas diários, portanto os mecanismos envolvidos no controle do processo de comunicação deveriam ser aprimorados.

O depoimento dos dirigentes interferiram diretamente na decisão por remeter o documento da "Política de Comunicação" da Embrapa ao instrumento que seria utilizado na etapa de pesquisa com supervisores. A decisão ocorreu para esclarecer questões conflitantes das entrevistas dos dirigentes sobre a política e que estavam imersas neste fenômeno comunicacional.

\subsubsection{Encontrava recomendações sobre a comunicação oral entre chefes e empregados na comunicação interna da unidade}

$\mathrm{Na}$ apreciação do Sujeito A sobre se existiam recomendações a respeito da comunicação oral, a seguinte resposta foi apresentada:

Não. Um norteador da instituição para este tipo de ação, não. Eu acho que
isto vai muito da cabeça do supervisor. [...] a gente tem muitos problemas
de relacionamento dentro das equipes [...] porque o supervisor daquela
equipe não consegue se comunicar com o grupo ou porque muitas vezes
dentro destas equipes, a gente tem "euquipes" com grupos isolados e não
há comunicação.

A resposta em forma de desabafo mostrou que a instituição não proporcionava diretrizes para a comunicação oral, a qual interdependia das noções e da postura de cada supervisor. O Sujeito A expressou que o contato com os empregados, em geral na unidade, era atribuição dos supervisores, não dos dirigentes. O modelo de gestão declarado explicitou que os dirigentes delegam autoridade para seus supervisores sobre as equipes de empregados. O Sujeito A apontou problemas de relacionamento interno nas equipes e atribuiu o fenômeno à inabilidade do supervisor para se comunicar ou ao excesso de individualismo destes gestores. Os fenômenos apontados como decorrências de questões comunicacionais fragilizadas eram a formação de grupos isolados e uma comunicação insuficiente para cumprir missão relacional, informativa e institucional: 
Fizemos um processo para a gente se conhecer, pois houve a introdução de pessoas novas por conta de aposentadorias e demissões. A equipe de comunicação então apresentou a empresa e cada um de seus setores para motivar o funcionário e para que ele conheça bem a empresa e os demais colegas. Isso resulta em boa imagem institucional [...] Foi um processo de decisão do funcionário. Ele participou se quis [...] Muitas das queixas entre setores são porque os setores não se conhecem, não conversam entre si (Sujeito A).

A afirmação mostrou o entendimento do entrevistado $A$ de que os eventos de acolhimento e de interação para novos empregados foram acolhidos com simpatia pelo público interno, embora a estratégia não fosse considerada capaz de sanar o problema.

Por ser uma empresa pública, os procedimentos de comunicação interna acontecem conforme a condução do chefe de cada área, pois os cargos permanecem, mas as pessoas que os ocupam mudam. Seria interessante a empresa, a cada três ou quatro anos, rediscutir seus processos e se deu certo, aí sim coloca no papel, chama os empregados para participar, porque se vem goela abaixo, fica mais difícil de ter aceitação porque você se sente pouco participativo e naturalmente reage contra (Sujeito $A$ ).

O relato indicou a visão particular do dirigente $A$ de que era interessante discutir os procedimentos com os empregados e verificar o que pudesse ser feito para melhorar. Analisou o Sujeito A que somente após convocar a participação dos empregados era que as diretrizes deveriam ser formalizadas, pois assim a aceitação e provável adesão seriam facilitadas.

Um ponto de vista diferente foi apresentado pelo Sujeito B:

Existem estas orientações e nós entendemos que estão fluindo perfeitamente. A comunicação interna aqui na Embrapa Soja eu não sei se posso dizer que ela é perfeita, mas eu acho que não temos realmente problemas de comunicação interna, principalmente porque temos mecanismos até de estar constantemente informando sobre tudo que acontece, a principal delas é o "Em Dia".

Percebeu-se uma sutil contraposição do Sujeito B em relação ao Sujeito A. O entrevistado B relatou que o sistema de comunicação interna funcionava bem, embora pudesse apresentar algumas falhas. A presença de mecanismos de informação, tal como o "Em Dia" (boletim eletrônico diário da empresa), seriam os principais responsáveis pelo bom funcionamento da comunicação interna na apreciação do Sujeito B.

O Sujeito C respondeu de modo semelhante, dizendo que "Se são apresentadas recomendações da comunicação oral? Ah, alguma coisa, sim. Acho que não é completo, mas sim, tem”. Ou seja, houve a percepção de algumas diretrizes para a comunicação oral. No entanto, reconheceu que elas são incompletas. O Sujeito $\mathrm{C}$ disse também: 
Sim, recomendo, sim. Nós temos algumas instâncias que são de comunicação oral né. Por exemplo, com os meus assessores diretos nós temos reuniões periódicas [..] ou conforme a necessidade. [...] Nós temos reuniões gerais, que aí são com todos os empregados. Então nós temos algumas instâncias de comunicação oral que são institucionalizadas, fora o informal também, né.

A mensagem discursiva chamou a atenção para a afirmação acerca da comunicação oral institucionalizada em algumas instâncias da empresa. Por sua vez, o Sujeito $D$ acentuou o caráter cotidiano e ágil da comunicação oral, ao dizer: "Sim, o dia a dia é comunicação oral. Eu acho que por tornar mais ágil o processo assim eu acho que ele é feito já há bastante tempo dessa forma".

Persistiu a identificação dos objetos paralelos nas respostas dos dirigentes da empresa, a respeito da existência de recomendações para o uso da comunicação oral. Os noemas aqui identificados foram que a instituição não proporcionava diretrizes para a comunicação oral, que o contato com os empregados era delegado aos supervisores, havia supervisor individualista porque era inábil para se comunicar, os eventos para novos empregados eram positivos e que o processo comunicacional dependia da direção geral.

As noesis expostas foram que a comunicação oral dependia das noções e da postura do supervisor, que a presença de grupos isolados decorria de comunicação insuficiente para cumprir missão relacional, informativa e institucional, pois havia a percepção de diretrizes para a comunicação oral, no entanto, essas eram incompletas.

\subsubsection{Falava ou escrevia a relação entre os objetivos da empresa e o trabalho dos liderados}

O Sujeito A revelou usar linguagem verbal escrita e oral (noema) nos seus relatos sobre a relação entre os objetivos da empresa e a atuação dos liderados. O depoimento levou a se atentar para a deferência conferida ao uso da oralidade quando os assuntos são internos (noesis):

Geralmente as duas. Às vezes quando vem pronto de fora aí a gente tem que impor porque vem da sede. Se o assunto é interno é importante discutir. Se é uma avaliação da nossa equipe, a gente discute muito com o grupo. $O$ grupo define o que vai fazer a avaliação do grupo" (Sujeito A).

O entrevistado expressou com clareza a subordinação da unidade à sede, contudo trouxe indicativos que descreveram a cultura de comunicação interna da Embrapa Soja que era de compartilhar decisões que afetassem mais diretamente 
os participantes da empresa. Para as questões internas que oferecessem reflexos nas equipes de empregados, a oralidade foi relatada como estratégia de negociação.

O Sujeito B manifestou diretamente sua preferência pela oralidade para apresentar relatos e associar objetivos da empresa à atuação de sua equipe. Segundo informou, utilizava a escrita apenas em casos especiais. Despertou a atenção para o que declarou o Sujeito B quando afirmou que, ainda que a comunicação fosse feita por escrito, convidava seus subordinados a irem conversar pessoalmente com ele sobre o assunto em pauta:

Normalmente, esse trabalho com empregados é uma atividade do supervisor. [...] A gente fala na hora, não deixamos que coisas que preocupem passem de um dia para outro, conversamos no mesmo dia, mas não tenho feito reuniões com os supervisores, porque cada um tem atribuição e demandas diferentes. A não ser que seja pra dar uma palestra sobre o que a empresa quer, então você tem que operar dessa maneira. Uso falar e dependendo da situação, mando por e-mail, mas chamo "vem aqui, vamos conversar sobre isso" (Sujeito B).

Um fenômeno reafirmado foi a delegação de autoridade do dirigente para seus supervisores, pois o Sujeito B afirmou que os supervisores eram comprometidos com suas atribuições e com as respectivas demandas. Tema que reforçou a distribuição de tarefas e responsabilidades entre o dirigente e seus supervisores foi sua declaração de que cabia ao supervisor a missão de se comunicar diretamente com os empregados, contudo esclareceu que os assuntos mais impactantes eram tratados imediatamente ao seu surgimento, preferencialmente pelas conversas face a face.

A resposta do Sujeito C ocorreu pontualmente de forma que confirmou o uso da linguagem verbal escrita e oral para que o dirigente relacionasse objetivos organizacionais com performance das equipes. Ao ser abordado sobre o tema, o dirigente $\mathrm{C}$ redundou sobre um advérbio e respondeu: "Sim, sim".

O desenho de raciocínio do Sujeito D deu evidência ao seu consentimento para dialogar porque acreditava que os processos administrativos eram executados por pessoas, portanto por atores dialógicos:

A escrita seria uma forma regimental que possibilita garantir a execução, pelo menos a forma de trabalho de determinado setor, independente das pessoas. Então se houver substituição de pessoal pelo menos tem uma orientação. Agora, o dia a dia, a operacionalização, até o refinamento, a melhoria dos processos é feito realmente por comunicação oral. E solução de problemas que são normalmente bastante simples, seja numa conversa como é uma comunicação pessoal ou por telefone, mas é o que a gente procura fazer para dar mais dinamismo para o trabalho. 
Percebeu-se a distinção conferida pelos entrevistados às decisões acerca da comunicação escrita e da comunicação oral nas suas demandas e rotinas Mostraram compreender que comunicados escritos eram regimentares e cumpriam a missão de garantir que a tarefa fosse executada, independentemente de quem a executaria (noema). O atributo da oralidade no contexto de exercício e prática de gestão era sua aptidão para resolver os problemas e injetar dinamismo ao cotidiano das suas equipes de liderados (noesis).

\subsubsection{Clareza sobre o que é esperado de cada empregado da equipe}

A declaração do Sujeito $A$ em relação à clareza do que era esperado de cada membro da equipe, focou em processos (noema), pois assim se manifestou o entrevistado: "É registrado. Há uma cobrança posterior. São métodos muito rígidos. Pesquisa é um processo dinâmico e não poderia ser tão rígido assim, porque as coisas mudam". O dirigente A referiu-se aos critérios que norteavam relatórios e que constavam da política de cargos e salários dos empregados da Embrapa. A afirmativa anunciou uma crítica do dirigente $A$, quando contrapôs a rigidez de um processo formal de avaliação de produtividade, frente ao dinamismo característico da pesquisa (noesis).

Os Sujeitos B e C posicionaram-se antagonicamente e manifestaram extremos opostos, quando questionados se esclareciam os empregados das equipes sobre o que esperavam deles. O dirigente B mostrou sua exprobração ao tema quando afirmou pontualmente "Não. Não vejo necessidade disso". O entrevistado C manifestou-se de modo mais receptivo ao tema e replicou com a seguinte afirmação: "Eu acredito que sim, que eu faço isso, né". A contraposição manifestada pelas leituras que os entrevistados B e C mostraram fazer sobre modelos de gestão sinalizou para abstrair que essa era uma questão tratada de modo muito particular pelos líderes em cada grupo e mais orientada pelo perfil pessoal (noesis) do que por diretrizes internas (noema). Já o Sujeito D diz:

Então um agrupamento antigo de pessoas que já vem desempenhando, não são pessoas que foram colocadas por esta gestão ali. Eles já vem desempenhando essa função de líder dos seus setores e naturalmente eles têm sido mantidos, têm permanecido ali na supervisão. A gente não vê nem a necessidade de ficar levando porque a gente reconhece o grau de comprometimento. 
Pela voz do Sujeito D ocorreu uma descrição de cenário interno, pois foi relatado que o quadro de líderes da empresa era formado por pessoas que trabalhavam na empresa há tempos. A experiência que a trajetória profissional de um líder da Embrapa Soja adquiriu durante muitos anos como empregado da empresa foi um valor apreciado pelo Sujeito D, que manifestou o potencial do sentimento de confiança para orientar suas relações de líder com suas equipes. Ficou posto que, de modo geral, a clareza sobre o que era esperado do membro da equipe, não era uma preocupação uniforme entre os dirigentes da empresa. Havia uma tendência dos dirigentes em divergir sobre o tema, pois alguns o analisaram como uma forma de comunicar as expectativas sobre o trabalho a ser realizado, outros consideraram que se tratava de algo desnecessário.

Outras formas de abordar o mesmo tema foram introduzidas na entrevista para clarear se haviam ou não contradições quanto às orientações dos dirigentes para os empregados de suas equipes. Perguntado se solicitava conselhos de seus liderados para aumentar a eficácia da equipe, o Sujeito A confirmou este tipo de atitude afirmando que "Sim, com conversa. Questionar cada um, sugerir soluções, estimular formas diferentes a partir do grupo". O dirigente A atribuiu relevância ao aconselhamento com os integrantes de sua equipe de supervisores como estratégia para fluírem soluções internas acerca de assuntos importantes. Afirmou o Sujeito A que os modos como se reportava a sua equipe encontravam-se no universo da comunicação oral.

Postura similar foi afirmada pelo Sujeito B quando respondeu que "Pra eu decidir eu me oriento com ele 'como é que isso é aqui, funciona isso aqui, porque você conhece melhor do que eu' Me sirvo da opinião dele pra decidir". Foi reafirmado o valor do conhecimento acumulado por um empregado estável na empresa, para agregar confiança no seu desempenho funcional de líder. O Sujeito C mostrou que o pedido de sugestões era diretamente vinculado às reuniões setoriais e que estas eram demandas grupais para momentos em que houvesse problema específico a ser resolvido. Informou o Sujeito $C$ que questões mais graves ou emergenciais eram discutidas particularmente nos contatos pessoais e de interação entre dirigente e subordinado, como pode ser observado na transcrição de sua fala que se segue: 
Sim, porque nessas reuniões semanais que a gente faz nós discutimos aquilo que está ocorrendo, o que vai ocorrer, o que cada um tem que fazer mais ou menos a gente distribui as tarefas e se houver necessidade de alguma correção de rumo, normalmente eu faço nesse momento. A não ser se for alguma coisa assim um pouco mais grave, aí eu falo [...] particularmente (Sujeito $\mathrm{C}$ ).

Pela narrativa do Sujeito $D$, na transcrição destacada abaixo, alegou o entrevistado que na divisão por ele dirigida o pedido de auxílio dava-se por ocasião do surgimento de problemas bem específicos e relacionados a processos:

Essas discussões são feitas mais frequentes quando o supervisor começa a reclamar 'estou com problema em tal processo' até numa forma de solicitar algum auxilio como nós tentarmos promover algum auxilio na solução, na redefinição daquele processo, mas de maneira geral eu estou entendendo que estão fazendo a supervisão e identificando os seus gargalos e já promovendo a suas melhorias necessárias. Muitas vezes o que eu recebo depois é um retorno sobre o que foi feito, mediante um relato oral, face a face (Sujeito D).

$\mathrm{Na}$ maioria dos casos, acreditava o Sujeito $\mathrm{D}$ que os problemas estivessem sendo resolvidos, pois muitas vezes recebia o feedback sobre as atividades. Essa realimentação da informação ocorria por via de comunicação oral, fenômeno que se mostrou comum a todos os entrevistados quando abordaram o mesmo tema. Os objetos percebidos (noemas) pelos dirigentes, conforme suas manifestações, foram que os comunicados escritos eram regimentares e cumpriam a missão de garantir que a tarefa fosse executada, que questionar, sugerir soluções, estimular formas diferentes a partir do grupo era uma estratégia que dava margem ao surgimento de soluções internas acerca de assuntos relevantes. Subjetivamente (noesis) mostraram perceber que a experiência acumulada ao longo de anos de trabalho na empresa semeava a confiança na competência que um agente tinha para desempenhar função de comando.

\subsubsection{Modo como estimula a equipe a contribuir com o melhor}

Sobre estímulo à excelência como desafio apresentado à equipe, respondeu o Sujeito A que: "Não temos muitos meios de estimular. É no gogó. No convencimento". A resposta revelou a perspectiva do dirigente de que o estímulo era muito mais um processo de convencimento verbal do que associado aos procedimentos diretivos oficiais da empresa. Apresentou o estímulo como um resultado atingível por via de interação dialógica com sua equipe. 
As respostas do Sujeito B ao longo da entrevista foram desenhando seu perfil como de um gestor pragmático que focava suas decisões em critérios sistemáticos, imersos no modelo estrutural e na administração de recursos humanos da empresa Embrapa. O dirigente B sugeriu que uma forma usada para estimular 0 empregado para dar o seu melhor na empresa era remetê-lo à lembrança de seus vencimentos pagos pela empresa e comparar com os salários praticados pelo mercado. Deu destaque para o argumento de que a satisfação do empregado com seus benefícios era inter-relacionado com a satisfação dos objetivos e metas organizacionais, sobre os quais o empregado tinha atribuição de responsabilidade:

Lembrá-lo constantemente que ele ganha um salário muito acima do salário que é praticado na iniciativa privada. Que ele deve pensar que isso aí se mantém se a empresa sobreviver, mas que ele só se preocupar em saber quais são os benefícios e quais são as vantagens, isso aí mata a empresa" (Sujeito B).

A resposta do Sujeito $C$ analisou um cenário abrangente sobre os ambientes de atuação da empresa. O dirigente C pontuou aspectos internos e externos da empresa e argumentou que não seria admissível entender a estabilidade como uma zona de conforto sobre a qual o empregado embrapiano estaria protegido:

Olha, eu acho que de diversas formas. A nossa unidade, por exemplo, tem a característica [...] de trabalhar muito com o setor produtivo, com o setor privado, ou seja, muito em parceria. Então os próprios parceiros eles nos cobram muito, então não só a cobrança interna de desempenho, mas nós temos a cobrança externa também muito grande de desempenho, nós temos avaliações objetivas, por exemplo "como está nossa participação no mercado de sementes" [...] Então são avaliações que nos colocam de forma competitiva no mercado e várias outras. Aí então eu vejo que nós temos muito isso de diferentes formas, então essa é uma forma, por exemplo "a nossa participação no mercado caiu. Oh gente, peraí, o que a gente pode fazer para melhorar nossa participação?" é uma forma também de estimular, de apresentar desafios. Procurar mostrar sempre o que tá ocorrendo no mundo em termos de inovações, como nós podemos nos inserir nisso aí. Buscar também criar um clima, vamos dizer assim, que seja estimulante intelectualmente, Isso é feito de diversas formas, por exemplo, trazendo algum palestrante, alguém aqui, de nível bom, alguém que possa puxar pelo raciocínio ou coisa desse tipo, trazendo manifestações culturais também. Por exemplo, nós tivemos aqui recentemente a orquestra de viola caipira, em um domingo, coisas desse tipo que a gente procura estimular de forma geral, mais holística e coisa assim as pessoas, falar também na questão da imagem que a Embrapa tem uma imagem muito boa, mas que a gente tem que preservar essa imagem, trabalhar para isso então são coisas que a gente faz de forma até assistemática eu diria (Sujeito C).

Foram notórias as referências do Sujeito $C$ às exigências internas em justaposição com as exigências do ambiente externo. Mencionou que a empresa estatal funcionava também com parceiros externos e que era submetida a 
avaliações objetivas sobre sua participação que colocavam a Unidade de Soja de forma competitiva no mercado. Lembrou da necessidade de se manter informado sobre o que ocorria mundialmente no âmbito negocial da empresa como forma de estabelecer o clima intelectualmente estimulante para os empregados de uma empresa cuja missão era a pesquisa e distribuição de conhecimento. Exemplificou que palestras e atividades culturais eram meios de promover integração e estimular desempenho relevante. Finalizou argumentando a imagem de líder do setor conferido à Embrapa como inspiração para manter o alto nível de atuação. Analisou que estes ambientes de pressão por resultados, nos quais atua a Embrapa Soja, seriam estimulantes para o empregado dedicar seu melhor desempenho funcional.

As vozes dos dirigentes manifestaram noemas como: o estímulo era um resultado possível de alcançar, o desenho dos ambientes de atuação da empresa tinha amplitude e a empresa era submetida a avaliações objetivas. Em suas apreensões subjetivas esses dirigentes afirmaram que a interação dialógica direcionava bons resultados, que alguns entendiam a estabilidade como uma zona de conforto que era inexistente, em sua prática e se referiram à intelectualidade com uma competência para empregados da Embrapa Soja.

\title{
9.1.2 EIXO 2 - Comunicação oral
}

\subsubsection{Linguagem e oralidade}

Ao explorar o tema "Comunicação Oral", mais especificamente a relação linguagem e oralidade, obteve-se a seguinte resposta do Sujeito A:

\begin{abstract}
Se você passa um negócio tudo por e-mail, tudo por jornalzinho, qual a receptividade? Quem tá gerenciando não consegue, eu pelo menos não consigo, ter o retorno [...] Agora no olho a olho a gente vai conversando. Porque aqui a gente tem que gerenciar, a gente trabalha com indivíduos dos mais diferentes níveis [...] então é diferente a comunicação o processo que a gente tem que ter com um e com outro, mas todos eles sabem falar, todos eles sabem ouvir, eles podem ter reações diferentes, formas de interpretação diferente, um linguajar diferente. A gente tem que identificar isso e conversar com cada um deles de acordo com isso, por isso que eu acho que é muito importante.
\end{abstract}

A relação noemática se explicita aqui, fazendo emergir um aspecto noesis quando o entrevistado esclareceu que sua preferência pela comunicação oral era por causa da possibilidade que este conjunto de meios oferecia para apreciar as reações do receptor imediatamente após sua recepção do estímulo comunicacional. 
O Sujeito A mostrou valorizar a comunicação do "olho a olho" porque era possível perceber as características individuais dos interlocutores e que, assim procedendo, era possível adequar o discurso a cada realidade individual.

O mesmo aspecto continua a aparecer na sequência de falas.

Sujeito B mostrou que compartilhava o pensamento do Sujeito A e acrescentou a dificuldade que era estabelecer diálogo com pessoas sem treinamento técnico e que não conhecessem especificidades do vocabulário científico e tecnológico no campo da agropecuária:

[...] às vezes nós vamos atender associações de produtores, enfim associações, sindicatos, aonde você tem que falar com o público que o pesquisador não está habilitado. Quer dizer, o pesquisador vai lá, começa a falar de transgênicos e o máximo que o produtor entende é que transgênico é esse negócio...ele vai falar de transpossons, pcr, não sabe usar a linguagem do produtor. Como faz a TV. [...] O jornalista é treinado para botar a tua linguagem de pesquisador no nível do produtor. O pesquisador se for falar, usará uma linguagem pouco compreensível, então por isso nós não deveríamos estar atuando diretamente junto ao público externo, o público usuário da tecnologia que é o produtor (Sujeito B).

O Sujeito B ressaltou que programas de televisão (noema), a exemplo do "Globo Rural"13, eram facilitadores para o processo de ajustamento da linguagem técnico-científica (noesis) que, por vezes, o pesquisador embrapiano não tinha habilidade para fazer no mesmo nível de simplificação que o jornalista fazia. O entrevistado B afirmou que o jornalista assumia um importante papel, porque sua intervenção resultava numa comunicação mais apropriada ao nível de compreensão de um público estratégico para a Embrapa Soja, que era o produtor rural.

Eu entendo que existem os momentos. Por exemplo, nós temos duas reuniões anuais, às vezes três [...] Fora isso existem várias reuniões mais temáticas. O que eu percebo é que eles não levam em consideração o que a gente fala. Uma coisa é falar, outra coisa é quem tá escutando realmente escutar aquilo. A impressão que nos dá é que eles ouvem, mas que fica por isso mesmo e só vale a opinião deles. Essa é a percepção que nós temos (Sujeito C).

Para o Sujeito C havia um problema adicional, que não estava relacionado apenas à linguagem que era utilizada. Os argumentos do Sujeito C vincularam o real interesse em escutar o que estivesse sendo dito e em aceitar o ponto de vista do outro. Segundo afirmou esse dirigente, sua percepção era de que o receptor precisava ser motivado para a comunicação, fenômeno que antecederia a adequação da linguagem (noesis).

13 Globo Rural é um telejornal rural brasileiro, produzido e exibido pela Rede Globo. Retrata o universo do campo e interessa o agricultor. Disponível em: <http://pt.wikipedia.org/wiki/Globo_Rural>. Acesso em: 18 out. 2012. 


\title{
9.1.2.2 A linguagem era compreendida por todos os empregados
}

\begin{abstract}
O Sujeito A foi remetido a analisar os trabalhadores de nível operacional que eram do quadro de funcionários da Embrapa Soja e que não tinham escolaridade avançada, como se supunha nos demais níveis de interferência no funcionamento da unidade de Soja. Com isso ofereceu uma apreensão subjetiva noesis:

O trabalhador de campo é estratégico para a unidade. Quebrar a barreira de comunicação, a barreira de posição, aí a pessoa começa a falar livremente. Ele fica mais franco com a gente. Mais importante que a linguagem é quebrar o distanciamento. Deixa mais calcado no contato face a face. A estratégia que eu uso não é a comunicação, sim a forma de relacionamento, criar intimidade, diálogo mais franco, comunicação melhor. Melhora o processo de comunicação (Sujeito $\mathrm{A}$ ).
\end{abstract}

Percebeu-se que o Sujeito A entendia a interferência das barreiras (noema) que refletiam negativamente na comunicação com trabalhadores do campo (noesis). O entrevistado afirmou que a linguagem equivalente ao perfil do interlocutor era um estímulo favorável para aproximar os atores dialógicos. No que foi mencionado pelo Sujeito $A$, houve o sentido da oralidade aceitar um tratamento estratégico que não só trouxesse impactos na melhoria da comunicação interna, mas que, conforme a experiência vivida pelo entrevistado, seria um fenômeno que impactava no estreitamento da relação profissional (noesis).

O depoimento do Sujeito D pautou-se no mesmo princípio analisado pelo Sujeito A, contudo ampliou para o emprego da comunicação oral e escrita nos sistemas internos da Embrapa Soja:

Na interlocução com supervisores eu não vejo problemas. Até a vantagem
de fazer a comunicação oral é a gente realmente dirimir qualquer duvida.
Quando a gente faz uma comunicação escrita com todos os funcionários da
empresa, a gente percebe que existe um grau de compreensão bastante
diferenciado, o nível de escolarização aqui é bastante distinto, então mesmo
quando estamos em uma reunião aberta para todo o público da empresa,
percebe-se que nem todos realmente têm garantia de compreensão daquilo
que é apresentado muitas vezes. A gente percebe isso pelas perguntas que
surgem. Nós fazemos uma reunião geral com os empregados a cada três
meses aqui na unidade. Às vezes o tema é interessante, mas as perguntas
são recorrentes, às vezes. Muitas vezes dá para perceber pela forma como
é feita a pergunta que houve até de nossa parte uma dificuldade de
exposição de forma que houvesse uma compreensão geral (Sujeito D). O entrevistado em seu relato distinguiu plataformas de comunicação oral e de comunicação escrita na empresa (noemas). Houve, na resposta do Sujeito D, uma tendência a acreditar que a escrita estava aberta a diferentes interpretações, de acordo com o nível de formação do trabalhador. Segundo sua percepção 
(noesis), ao se comunicar oralmente podia-se resolver as dúvidas com mais eficácia, pois algumas vezes o entrevistado D percebia dificuldades de entendimento recorrentes nos interlocutores. Seu depoimento expôs uma autocrítica (também noesis) que o conduziu a apreender a necessidade de se tornar mais hábil para se comunicar com o quadro geral de empregados, tanto pelos meios escritos, quanto pelos orais. Prevalecia a linguagem verbal nos eventos comunicacionais descritos então, analisou o Sujeito D que era indispensável esta linguagem ser compreensível pelo receptor.

O Sujeito C apelou para instrumentos impessoais de feddback: "Eu procuro me certificar na medida do possível. Por exemplo, nas nossas reuniões gerais se aplica um questionário depois da reunião e se avalia este questionário, que é a área de comunicação que faz isso". O entrevistado C trouxe um instrumento formal como a abordagem para avaliar se a comunicação estava sendo efetiva. Isso implicou em uma estratégia pontual institucionalizada pelos sistemas de comunicação da empresa e, que afirmou o Sujeito $C$, era o parâmetro para os casos de problema comunicacional entre os integrantes do grupo de empregados da Embrapa Soja.

O dirigente B desenhou os limites de sua influência sobre grupos de empregados com nível cultural mais elevado:

Acho que sim. [...] A gente não tem instancias em que temos dificuldade de usar linguagem ou que temos que usar linguagem mais simples. Como esses temas administrativos, temas técnicos tratados com equipe técnica, então nossa linguagem é perfeitamente entendida por todo mundo. São coisas comuns (Sujeito B).

O entrevistado afirmou que a linguagem utilizada na comunicação era adequada e supria as necessidades do grupo, pois descreveu a equipe como um grupo técnica e culturalmente homogêneo.

Por ser um tema que tinha como elemento chave o termo "compreensão", predominou, neste tópico, a posição noesis. Era uma coerência esperada, tendo em vista que se falava de aferições de grau, maior ou menor, em que essa compreensão ocorria. 


\subsubsection{Usava a comunicação oral com seus liderados, de outras equipes e empregados}

O discurso do Sujeito A sobre seu uso da comunicação oral na gestão de equipes, apresentou sua afinidade com teorias críticas de organizações pautadas na humanização da comunicação:

Eu acho que é mais fácil. Dá valor a essas interações humanas. Eu acho que é um processo mais eficiente e consigo ter um retorno quase que na hora ali que estamos conversando, somente ao ouvir. Eu acho que comunicação não é só a gente falar, expor, é também ouvir. [...] O retorno que tem é o que a gente chama de rádio corredor. A informação é aquela que foi interpretada de forma diferente e acaba circulando de forma distorcida, então é o seguinte: é mais fácil clarear e deixar bem claro o que é, o que não é (Sujeito A).

Foi possível perceber que o entrevistado não apenas utilizava essa modalidade de comunicação, como acreditava que ela era responsável por evitar ruídos na comunicação. Argumentou o Sujeito A sobre fenômenos informais de comunicação interna quando citou (noema) a rádio corredor, os quais podiam receber alguma interferência da gestão por meio do uso da oralidade com os receptores. $O$ entrevistado $A$ ressaltou que a oralidade permitia obter um feedback preciso e rápido do processo comunicacional (noesis). A ênfase maior dada pelo dirigente $A$ foi sobre um valor simbólico ou noesis do ambiente interno, fruto de uma comunicação humanizada, cujo foco ficou no julgamento favorável às interações humanas. O Sujeito $C$ remeteu-se às reuniões gerais para exemplificar o uso da comunicação oral com empregados da Embrapa Soja. Descreveu a periodicidade em que as reuniões gerais eram realizadas, sua finalidade e esclareceu que, nessas ocasiões, ele procurava deixar espaço para que questões, independente de estarem pautadas, fossem levantadas pelo grupo, antes ou durante as reuniões:

[...] com os empregados é uma vez a cada três meses que a gente se reúne com todos os empregados [...].A finalidade destes encontros trimestrais é fazer um balanço da gestão, nós apresentamos normalmente a questão orçamentaria [...] algum fato importante que ocorreu ou que vai ocorrer que está programado, falamos de melhoria de processos. Então, na verdade são vários assuntos e nós abrimos para questões tanto antes da reunião, a gente abre se alguém tem alguma questão já pode apresentar que nós vamos abordar, ou no próprio momento ali da discussão a gente abre também essa possibilidade. Na nossa unidade isso está institucionalizado (Sujeito C). 
O dirigente $\mathrm{A}$ assumiu que esta era uma variável institucionalizada na unidade de Soja (noema). O significado do seu discurso repousou sobre a oralidade flutuar sobre as condutas gerenciais, por conta disso era assimilada por todos e fazia parte da rotina dos empregados:

Sim, eu encorajo, eu encorajo, inclusive isso está no meu plano de trabalho
e foi uma das primeiras orientações que eu passei para os adjuntos porque
nós tínhamos um sistema de avaliação, que agora está mudando, e que se
chamava SAU - Sistema de Avaliação de Unidades. [...] Uma das primeiras
coisas que eu disse para eles quando eu entrei foi o seguinte "a nossa
diretriz, o que nos move não é o SAU. [...JNós não vamos fazer alguma
coisa para nós simplesmente pontuarmos. Nós vamos fazer aquilo que nós
entendemos que é importante, que é fundamental, nós vamos cooperar com
as demais unidades, com os demais parceiros. Se isso resultar em
pontuação no SAU, ótimo, [...] Hoje a unidade é avaliada e comparada
contra ela mesma, ou seja, a evolução dela no tempo. Isso melhorou,
facilitou muito o relacionamento com as outras unidades (Sujeito C).

O dirigente $\mathrm{C}$ afirmou que encorajava os empregados a usarem a comunicação oral e declarou (noesis) o caráter estratégico da oralidade para sua gestão, pois revelou que esta era uma orientação formal em seu plano de trabalho. Notou-se no dirigente C uma crítica ao instrumento oficial de avaliação Sistema de Avaliação de Unidades (SAU) que, a seu ver, não podia ser o principal norteador da unidade. Segundo revelou o Sujeito C, a Embrapa Soja não era conduzida para pontuar positivamente no SAU e sim, para realizar aquilo que os dirigentes identificavam como suas prioridades, fundamentando-se na cooperação e no empreendedorismo. O Sujeito D respondeu que encorajava a comunicação oral. Afirmou que no desempenho de sua função ele dialogava principalmente com os supervisores: "A delegação é feita junto aos supervisores que se encarregam de repassar aos seus subordinados". A conduta do dirigente D mostrou-se seletiva ao afirmar que dialogava frequentemente com seus supervisores, contudo não era de sua rotina reportar-se aos demais empregados sobre sua subordinação porque os supervisores eram os responsáveis por repassar as informações aos seus grupos de liderados. Sugeriu o Sujeito D (noesis) a presença de um nível de autonomia dos grupos que Ihes proporcionasse a possibilidade de adequar sua comunicação interna. 


\subsubsection{EIXO 3 - Uso do diálogo}

\subsubsection{Importância atribuída pelo líder ao uso da fala, diálogo e da comunicação face a face entre chefes e equipes na empresa}

O relato do Sujeito A apontou a importância da oralidade na comunicação interna da Embrapa Soja, especialmente porque supria os problemas do sistema de comunicação da empresa e acelerava o amadurecimento profissional (noema) que era, a seu ver (noesis), um momento muito oportuno para o supervisor absorver o diálogo e as interações face a face como práticas de gestão. No entanto, sugeriu que mesmo tendo estimulado a comunicação oral, a postura profissional do supervisor para dialogar com os funcionários, nem sempre era correta. Ele afirmou que incentivava a comunicação oral, pois quando o supervisor adotava o diálogo, acelerava a eficácia da comunicação internamente:

Eu acho que isso é extremamente importante e que muitos dos problemas que a gente tem, principalmente de relacionamento, é porque não existe um bom sistema de comunicação. Então são duas coisas: uma, não existe bom sistema de comunicação, e outra é que muitas vezes a gente não tem maturidade profissional para chegar e assumir, ter uma conversa franca, um diálogo franco com o subordinado.

Então muitas vezes a gente estimula, tenta fazer com que eles conversem, com que eles se reúnam e a gente acha que a forma mais eficiente de comunicação em vários momentos é a comunicação oral porque ela permite uma troca de informação, a informação não vai só em um sentido, não é só no sentido informativo (Sujeito A).

O Sujeito B declarou-se muito favorável à comunicação oral, pois para ele (noesis) o olhar face a face era um fator determinante para que a atribuição de tarefas fosse bem sucedida, independente do sentido que tivesse de despertar sensações agradáveis ou não. Para o Sujeito B o gestor tinha que aderir ao diálogo, ser compreensivo, contudo foi enfático ao afirmar que tudo isso "[...] sem deixar de ser enérgico". A capacidade para o diálogo era fundamental, desde que não perdesse o controle sobre seus subordinados. A energia seria o meio pelo qual o supervisor alcançaria do subordinado aquilo que ele pretendesse:

Eu considero isso fundamental. Para mim essa comunicação, essa necessidade que há do chefe sentar com o funcionário. Olhar na cara, dar um recado pessoalmente, mesmo que seja um recado desagradável. [...] Eu acho que é o segredo de um gestor ter êxito ou fracasso em uma determinada atribuição. É a sua capacidade de dialogar com compreensão, mas enérgica (Sujeito B). 
De acordo com o Sujeito C (objeto percebido - noema) "[...] existe essa questão da sede em Brasilia determinar como as coisas são sem ouvir muito as bases. Isso é uma reclamação que, desde que estou nisso, a gente ouve". Embora houvesse diretrizes advindas da sede, determinando o modo pelo qual a comunicação devia ser executada, o Sujeito C acreditava (apreensão subjetiva noesis) que a comunicação oral tinha relevância para a comunicação interna da Unidade de Soja. O dirigente $\mathrm{C}$ estendeu sua fala para opinar sobre as regras que eram impostas não levarem em consideração as bases, suas necessidades e possibilidades locais. A oralidade, por outro lado, permitia uma relação mais propícia para o diálogo. O estar à frente do outro permitia que opiniões fossem dadas e dúvidas sanadas:

Eu vejo que é muito importante, porque uma coisa é a gente passar um boletim, passar um memorando e outra é a gente falar olho no olho e ter oportunidade para eles também se expressarem, darem sua opinião ou questionarem, coisa desse tipo, então eu vejo que estes momentos são muito importantes (Sujeito C).

A relação noemática trazida pelo Sujeito $\mathrm{D}$ aponta noema (objeto percebido) quando disse que o ambiente gerado pela comunicação oral permitia ao supervisor fazer-se mais presente.

É uma forma de se fazer mais presente na solução de problemas onde não é simplesmente uma delegação de funções a até para tornar mais claro as expectativas do setor da administração com relação à necessidade dos nossos objetivos. Então é feito quase que diariamente (Sujeito D).

Neste caso, a relação noemática se complementa com a noesis (apreensão subjetiva), ao mencionar que ele podia tomar parte da solução de problemas e deixaria claro a relação entre as expectativas administrativas e as necessidades operacionais para que se alcançassem os objetivos do grupo.

\subsubsection{Situações que o líder dialogava com subordinados}

A resposta do Sujeito A foi que a comunicação oral era utilizada em várias oportunidades (noema). Informou a rotina de reuniões periódicas que ocorriam semanalmente. Relatou que quando surgiam necessidades específicas, outras reuniões eram marcadas, em grupo ou como uma conversa individual. $O$ Sujeito A reafirmou que o diálogo face a face era o mais importante, inclusive que ele não tinha o hábito de usar o telefone. Afirmou (noesis) que o ambiente de diálogo era uma barreira para a comunicação, por esse motivo ele se deslocava ao local de 
trabalho do subordinado quando queria desenvolver alguma interlocução e assim evitava o "território" constrangedor da sala do superior:

A gente faz isso semanal. Na medida em que se observa a necessidade de outras, vai definindo outros grupos e vai fazendo reuniões especificas. [...] mas tenha tempo suficiente para se discutir, ser mais objetivo e focar no que a gente quer. E geralmente essas comunicações orais são feitas em reuniões. Eu uso pouco telefone. Sempre que tenho que pedir, passar alguma coisa para alguém ou solicitar alguma coisa para alguém pego um papel e uma pasta e vou na sala do indivíduo. [...] Então eu gosto mais de ir até o meu interlocutor. Então comunicação oral não por telefone, sempre interpessoal e face a face, e sempre evitando chamar à minha sala. $O$ ambiente é uma barreira (Sujeito A).

O Sujeito D informou (noema) que seu diálogo com os subordinados

diretos era realizado diariamente e que tinha a finalidade de decidir sobre questões correntes:

Com o setor [...]existe um relacionamento diário por obrigações [...], por compromissos [...], tem uma interlocução diária. Com os demais setores mediante demanda, então havendo alguma necessidade a gente ou convoca aqui para uma reunião aqui na sala ou a gente visita o setor. Gosto de ir visitar os setores, até para não ficar muito preso à sala, mas a gente sabe que pela dinâmica do nosso trabalho, muitas vezes para ganhar tempo a gente precisa que o supervisor venha até nós. Daí nos outros casos eu não tenho uma periodicidade estabelecida, mas em função de demandas mesmo (Sujeito D).

Em noesis, o Sujeito D argumentou sobre a agenda repleta que cumpria e que impactava na realização de suas visitas aos setores, as quais ele apreciava fazer. A exemplo do que disse o Sujeito $A$, o entrevistado $D$ também fez menção ao ambiente como fator interveniente nas interlocuções. Revelou o Sujeito $D$ que outras demandas eram motivos para convocar reuniões com os demais subordinadas ou para motivar visitas aos setores.

\subsubsection{Abertura para equipe dialogar com líder}

Observe-se a relação noemática encontrada nesse aspecto quando o Sujeito A foi instigado a falar sobre a abertura da equipe para o diálogo: ele retomou (noesis) sua apreciação sobre seus cuidados para que a comunicação oral fluísse livremente. O entrevistado reafirmou que a vinda do funcionário ao escritório dele tornava o diálogo diferente daquele que se efetuaria, caso ele fosse ao encontro do subordinado (noema). Analisou que quando o superior convidava um subordinado para sua sala, havia uma tensão maior, pois o funcionário vinha principalmente para ouvir. Quanto a se deslocar até o ambiente de trabalho dos subordinados, o Sujeito A declarou que esta era uma maneira de se aproximar das 
equipes, pois o ambiente ficava (apreensão subjetiva noesis) mais relaxado e aflorava o sentimento de pertença e as reações positivas às interlocuções eram assim despertadas. O dirigente $A$ pontuou a existência de assuntos que eram conversados apenas na área de trabalho e sugeriu que algumas informações eram conhecidas na zona de conforto do funcionário:

[...] costumam chamar as pessoas aqui, o cara entra lá nervoso. É um tipo de diálogo, quando a gente vai lá é um outro tipo de diálogo. Lá ele sente liberdade para falar, expressar-se. Aqui ele vem mais para ouvir, sentindose tenso. Eu acho que é melhor ir lá. Fico mais perto dos caras, eles se sentem mais à vontade, eu fico mais participativo. Se a gente fica muito parado aqui, a gente deixa de conhecer o que tá acontecendo lá. Tem muito assunto que é conversado só na área de trabalho dos caras. Gosto de fazer uma comunicação oral, ao vivo, no local deles: diferente (Sujeito A).

$\mathrm{O}$ relato do Sujeito B deixou claro que a abertura existia (noema) e que era uma forma de tornar o trabalho mais eficaz (noesis). Manifestou nitidamente seu modelo de gestão que era dialógico e valorizou o conhecimento do subordinado a respeito de suas funções. Mostrou-se disposto a dialogar com o empregado para, em conjunto, encontrar formas para melhorar a eficácia, pois era o empregado que realizava e conhecia de perto a tarefa realizada:

Só dou. [...] Eu não estou ali para dizer o que ele tem que fazer e sim para discutir com ele pra ver que forma melhor ele poderia fazer, mas quem sabe é ele. [...] Eles acham que assumiram a chefia em uma determinada comunidade ou departamento, eles acham que tem a obrigação de saber tudo melhor do que o cara que coordena. Não, não. [...] Então a minha atitude quanto a isso é total abertura para que ele diga o que que ele acha que deve ser feito e eu tenho apenas que assinar e eu assino concordando com isso (Sujeito B).

A resposta dada pelo Sujeito C acrescentou a ideia (apreensão subjetiva - noesis) de que o supervisor devia estar aberto a sugestões, mas que isso não era o bastante, pois ele defendeu que as sugestões deviam refletir na tomada de alguma decisão. Esta seria uma das maneiras de dar um feedback ao funcionário (objeto percebido - noema), conforme analisou o Sujeito C, porém não dispensava o dever do líder (apreensão subjetiva - noesis) de informar ao empregado os motivos para não acatar o que foi sugerido, fosse por não ter sido aceito ou pela impossibilidade para implementar:

Eu acredito que sim, que eu demonstre esse interesse real e, na medida do possível, a gente sempre tenta tomar ações concretas em relação às coisas que são trazidas, principalmente quando são problemas ou mesmo sugestões. E se é alguma coisa que a gente, por um motivo ou outro, não consegue implementar ou acha que não se justifica também damos um retorno (Sujeito C). 
Note-se que o Sujeito D reafirmou, então com isso revelou apreensão subjetiva (natureza do noesis) o modelo de gestão dialógica quando manifestou seu respeito ao conhecimento sobre as funções que cada empregado designado tinha. O entrevistado destacou que o conhecimento do empregado dava suporte às suas decisões como dirigente, pois os subordinados forneciam algumas das mais importantes informações para a análise e tomada de decisões com respeito à gestão do grupo:

Sim, porque a gente está fazendo um trabalho de coordenação central e as especialidades de cada ambiente de supervisão eles têm o conhecimento do dia a dia ali de atuação, então acho que a opinião deles é importante para nos ajudar numa análise, numa tomada de decisão. De maneira geral eles nos subsidiam para uma tomada de decisão (Sujeito D).

\subsubsection{Ouve e acata relatos e sugestões dos subordinados}

A aceitação de sugestões e relatos dos subordinados foi respondida afirmativamente pelo Sujeito A. "Tranquilo. Tem que acatar né, é porque muitas vezes eles sabem muito mais do que a gente e se ele verbalizou é justamente pra gente acatar", relação noemática com os dois elementos embutidos na fala. Mais uma vez percebeu-se que esse dirigente valorizava e respeitava (noesis) a opinião de seus subordinados. Ele apontou que se algo era verbalizado pelo funcionário (noema), isso devia ter alguma relevância e merecia a atenção do superior (noesis). Na sequência dos próximos informantes a relação noemática se acha distribuída da mesma maneira.

O Sujeito B disse que ouvia, acatava e discutia com seus subordinados sugestões e outros relatos trazidos por eles: "Se eu tenho opinião diferente, discuto. Se eu só tenho a opinião dele e me parece boa, perfeito, ótimo. De minha parte vale aqui. É um traço diário em meu modelo de gestão permanente, é o meu 'modus operandi' ". Destacou que se posicionava quando necessário, mas que não desmerecia as mensagens de seus subordinados pelo respeito ao que era dito pelos mesmos. Acrescentou que quando havia divergências de opinião, a discussão era parte do processo decisório.

Do mesmo modo, o Sujeito C confirmou que acatava as ideias dos funcionários, quando eram procedentes. O entrevistado $C$ ressaltou que muitas sugestões eram espontâneas, pois os subordinados o procuravam para expressar o que podia ser melhorado. 
A aceitação por relato e sugestões de empregados foi constante entre os dirigentes e reafirmada pelo Sujeito $D$ que disse que acatava sugestão quando era pertinente. As suas tomadas de decisão eram baseadas na posição assumida por um colegiado, embora algumas vezes houvesse divergências de posição. Nessas ocasiões as justificativas apresentadas tinham peso e caso fossem acatadas, era solicitada sua implementação:

Sim, sendo pertinente eu acato. Nas tomadas de decisões a gente sempre acaba procurando levar para um colegiado ali do grupo de chefia isso sempre vem na forma de subsídios, essas sugestões. Obviamente, em algumas situações a gente acaba tendo uma postura diferenciada do supervisor. O que a gente tenta é realmente convencê-los quais são as justificativas para a gente adotar um procedimento diferente do que tinha sido inicialmente proposto e solicita que seja implementado (Sujeito D).

\subsubsection{Encorajamento para a cooperação com outros grupos, unidades ou operações}

A reflexão do Sujeito $D$ a respeito da cooperação da unidade foi de conformismo, embora tenha registrado que considerava que a unidade podia ser mais colaborativa (noesis):

A gente acha necessário que isso aconteça, mas a gente verifica que nós somos ainda muito setorizados, as caixinhas são muito bem definidas, mas seria importante ter maior colaboração. Alguns processos perpassam vários setores, já são integrados, mas eles poderiam ser melhor organizados se existisse uma cooperação, pelo menos uma nova discussão de como executar. Na medida do possível a gente sempre pede a colaboração intersetores, sim (Sujeito D).

O Sujeito D analisou que a empresa ainda era muito setorizada, talvez por reflexo da própria estrutura formal (noema). O dirigente entrevistado reconheceu a importância da colaboração intersetores e sugeriu que ela deveria ser mais estimulada do que as tentativas existentes neste sentido. Devido ao fato de alguns processos passarem por diferentes setores, a organização do processo produtivo era comunicacional, contudo o Sujeito D avaliou que este modelo deveria ser reorganizado.

\subsubsection{EIXO 4 - Comunicação face a face}

Este eixo faz emergirem quatro temas nos quais se pode identificar, por meio da relação noemática, a natureza do fenômeno e a apreensão subjetiva que ele produz. A declaração do Sujeito A se referiu à importância do face a face ao 
dizer: "Na hora que a pessoa tá passando, que a informação tá sendo comunicada ele tá recebendo também o retorno daquele cara que é subordinado ali, então a gente acha que isso é muito importante, mas nem sempre a gente consegue fazer que seja exercitado dentro das equipes". Nesse tipo de situação, o feedback daquilo que é informado é facilitado, embora nem sempre se tenha condições de colocá-la em prática constantemente:

Com uma conversa olho no olho a gente pode ver qual a reação do indivíduo, a gente pode utilizar a conversa de repente para motivar, para trocar o foco, de repente conforme o cara tá olhando você percebe que não tá agradando, eu acho que é importantíssimo comunicação boca a boca, olho a olho, pequenos grupos, é muito bom, porque a gente age conforme $o$ cara vai reagindo (Sujeito $A$ ).

O Sujeito B disse (noesis) que a comunicação presencial funcionava muito bem, especialmente com a área técnica. Segundo ele: "Esses são recados que a gente vive dando, mais com a área técnica. [...] Via contatos face a face, é o que mais funciona". O Sujeito C complementou dizendo: "Eu acho que tem que ter momentos para esta comunicação face a face". Para ele, embora houvesse abertura para o diálogo face a face, nem sempre era possível. A agenda de trabalho podia ser um fator limitador:

Sim, ham ham. Outros dirigentes, os gerentes, mesmo empregados porque nós somos abertos na medida do possível. Têm muitos empregados que vêm diretamente aqui para conversar comigo. Na medida do possível que eu digo é na medida em que a agenda permita porque eu tenho muitas reuniões, muitas viagens, mas sempre que a agenda permita e que alguém quer conversar a gente abre este espaço, então tem muitos que vêm diretamente fazer alguma sugestão 'ah, eu acho que deveria melhorar tal coisa'. Então quando a gente acha que aquilo justifica, que é procedente, nós aplicamos (Sujeito C).

No relato destacado abaixo, o Sujeito C retomou o que havia dito anteriormente sobre o diálogo e a justificativa dada à sugestão que, se adequada, era colocada em prática:

Olha, eu vejo assim que a questão da confiança e da sinceridade, da franqueza eu vejo isso como fundamental. [...] quando a gente conversa, quando a gente ouve, não significa que a gente tenha que concordar. Então isso eu sempre falo de uma forma bem franca e transparente. [...] então eu sempre procuro ser muito transparente nesse relacionamento. [...] E essa construção acontece melhor quando a relação não é mediada pela tecnologia, ou seja quando a relação é feita face a face (Sujeito C).

$\mathrm{O}$ entrevistado $\mathrm{C}$ expressou valores que para ele eram relacionados à comunicação face a face como a confiança, a sinceridade e a franqueza, os quais são fundamentais para o diálogo. A relação entre líder e equipe (apreensão subjetiva - noesis) devia ser transparente, analisou o Sujeito C. Afirmou que aplicava estes 
valores nas suas interações face a face porque não aprovava nenhuma mediação para alcançar o mesmo nível de interação relacional com seus subordinados.

\subsubsection{Encorajamento de opiniões face a face sobre o estilo de liderar}

O Sujeito A, ao ser perguntado sobre o encorajamento de opiniões face a face sobre o estilo de liderança (noema), disse que sim e que tentava motivar os supervisores a adotarem a mesma tática de gestão:
Tranquilo. Criticar e conversar. Procuro estimular isso aí e também procuro fazer com que eles façam o mesmo na equipe deles. Cria essa cumplicidade que eu acho que é um negócio muito bom. Procuro sempre esclarecer que não somos chefes, ou supervisores, mas sim que estamos chefe e supervisores, porque na verdade somos empregados de uma instituição que tem que fazer em função do momento dela, fazer aquilo que ela espera da gente (Sujeito A).

O entrevistado colocou-se (noesis) a favor de opiniões a respeito do seu estilo de liderança e dos seu comandados, porque lembrava a todos que os cargos de liderança na empresa eram transitórios, pois todos eram empregados da mesma empresa e tinham que alcançar as metas que Ihes fossem lançadas. $O$ Sujeito A apresentou, assim, seu pensamento sobre o modo como ele acreditava que devia ser a liderança. O Sujeito B mostrou-se contrário ao diálogo para receber avaliação sobre seu estilo e liderar: "Não chamo eles para perguntar isso e nem pretendo fazer. Porque se vou fazer isso, parece que to pedindo elogios." A resposta do Sujeito B sugeriu que a discussão/avaliação do superior hierárquico podia ser prejudicada no face a face, pois esse tipo de avaliação podia ser muito constrangedora.

A manifestação do Sujeito $C$ foi menos repulsiva à ideia de solicitar avaliação de seu estilo de liderança, embora ele tenha destacado o constrangimento que poderia surgir: "Eles podem colocar oralmente também. O que acontece é o seguinte, eles têm um certo receio de colocar isso oralmente. Então existe a oportunidade, mas poucos colocam oralmente. Normalmente eles fazem isso por escrito". Para o entrevistado C havia momentos que possibilitavam essa avaliação, mas que o modo mais utilizado era a avaliação institucional. Ao afirmar esse aspecto, dá acesso ao objeto percebido (noema): 
Existem, nessas reuniões, é um momento, tem as reuniões com os gerentes, com os líderes de equipe que também é uma possibilidade que aí não diretamente com todos os empregados, mas que eles podem fazer isso chegar por seus representantes, por seus supervisores. Existe uma avaliação institucional que é feita no meio do mandato, no meu caso já foi feita, então há uma comissão externa que vem aqui (Sujeito C).

O sujeito $D$ forneceu a apreensão subjetiva (noesis) quando disse que não encarava as críticas como problemas porque as julgava construtivas. No entanto, um diálogo a respeito desse tema nunca fora prioridade:

Acho que eu nunca conversei sobre isso com eles. De fato nunca passou isso por mim. Nunca estimulei. Não tenho problema nenhum de ouvir críticas, acho que é mais um modelo na verdade procurando ser uma coisa construtiva, um direcionamento para tornar mais eficiente o relacionamento. (Sujeito D).

\subsubsection{Encoraja opiniões sobre o trabalho de sua equipe}

Com relação ao encorajamento às opiniões sobre o trabalho da equipe, o Sujeito A revelou:

Tranquilo. Isso a gente faz sempre por meio de programas, melhor dizendo, de eventos de avaliação, de apresentação de resultados, de discussão do que cada um está fazendo. Para motivar mais a participação de todos os empregados, faremos a cada 15 dias a apresentação de duas equipes que apresentarão o que estão fazendo [...] às vezes pra conhecer e principalmente pra identificar oportunidades de trabalho em conjunto, de parceria, de utilização de recursos porque embora o grupo seja pequeno, existe um clima de competição muito grande, isso é uma política da empresa e eu não gosto disso, [...] nesta competição leva muito ao individualismo e muitas vezes o indivíduo não sabe o que o colega de sala dele está fazendo, o que o restante da equipe está fazendo, e isto é ruim porque não há interação, há multiplicidade de trabalho e a gente não aproveita os recursos todos que estão sendo utilizados na instituição a gente faz isso aí justamente pros caras obrigá-los a conversar dentro da equipe a expor pro grupo, pro grupo questionar o que tá fazendo (Sujeito A).

Nessa fala, tem-se, portanto, em noema, que havia eventos para a avaliação das atividades realizadas no grupo. O modo como ele direcionava esses eventos visava criar um ambiente que permitia aos diferentes grupos da equipe conhecerem-se e tentarem encontrar oportunidades de trabalho conjunto (noesis). Isso otimizava a utilização de recursos e evitava a multiplicidade de tarefas, além de que combatia o individualismo e amenizava a disputa interna por melhores resultados. Tal tipo de competição, que era estimulada pela própria empresa, era um dos fatores cruciais a serem combatidos para que se pudesse trabalhar bem em equipe. 
O ambiente de liberdade e de diálogo foi apontado como fator a ser incentivado pelo Sujeito B: "Total, para falar o que eles quiserem, dar opinião de como eles gostariam que fosse, o que é que não está bem, como é que poderia ser feito para melhorar. Dou liberdade mesmo". A informação do Sujeito complementou a relação noemática com o aspecto noesis quando afirma, em seu relato, que ele procurava incentivar os supervisores a serem abertos às críticas e procurar o melhor ambiente de trabalho:

Sim, sim. Sempre reforço a função deles enquanto supervisores, gestores daquela equipe que tem que procurar motivação e logicamente estarem abertos a receber comentários até para mudar, se for o caso, para mudar a postura, a forma de atuação de modo a sempre colaborar com o ambiente. Ficar melhor (Sujeito D).

O Sujeito D trouxe a discussão para o âmbito de habilidades exigidas de um líder, sendo uma das mencionadas a de motivar o melhor desempenho da equipe por meio de interações dialógicas entre supervisores e empregados.

\subsubsection{Discute face a face melhorias para o desempenho dos subordinados}

O Sujeito B relatou (objeto percebido - noema) que as melhorias de desempenho dos subordinados eram trabalhadas diariamente. Se houvesse algo que necessitasse melhorar, o entrevistado B tratava nas reuniões ou ia até o funcionário para discutir o assunto. No segundo caso, como foi apresentado em seções anteriores, esta apareceu como uma solução apreciada pelo Sujeito B. A noção de ambiente familiar (noesis) apontava para a supressão ou minimização do constrangimento formal da sala do chefe. Ao ir ao encontro do subordinado, o chefe dava ao empregado um valor que não teria visibilidade, caso o espaço da interlocução fosse o escritório do dirigente:

Bom isso é o que eu disse, se eu discuto? Não, eu acho que isso é um trabalho diário. Se eu tenho alguma coisa que acho que pode melhorar a performance dele naquela atividade isso eu já digo na reunião que eu reúno as vezes o grupo todo ou então eu vou lá, eu nem peço pra ele vir aqui, eu vou lá na sala do cara, falo lá com ele porque me parece que se você está na sua casa as coisas são diferentes do que você vem na sala do chefe pra resolver um assunto (Sujeito B).

Para o Sujeito D, e aqui se encontra o aspecto apreensão subjetiva (noesis), a discussão face a face sobre o desempenho devia ser incentivada e ocorrer com frequência. Apesar de defender o diálogo para melhorar o desempenho, 
o Sujeito $D$ deu ênfase à rotina de trabalho e aos compromissos diários, como fatores de estrangulamento para praticá-lo. Embora se conhecia relativamente bem os principais problemas, ele tentava incentivar a ação conjunta para encontrar a sua solução.

A gente deveria incentivar que isso aí fosse feito com mais frequência, mas a gente sabe que a gente é pego muitas vezes pela rotina que se estabelece. Mas, em cada nível de supervisão a gente tem uma ideia de quais sãos os principais gargalos que a gente deveria procurar melhorar. $O$ que peço a eles é 'vamos procurar pensar juntos para a gente ver como que a gente pode melhorar cada um desses processos', mas dando liberdade, é lógico, para quem esta executando, coordenando aquele setor nos ajudar, nos subsidiar com propostas de mudanças (Sujeito D).

O Sujeito A confirmou a percepção do Sujeito D sobre a carência de evolução interna da Unidade, no que dizia respeito à melhoria de desempenho dos empregados. A resposta do Sujeito A traduziu a reflexão que ele foi conduzido a fazer sobre o tema em foco. Ele disse que utilizava a comunicação face a face para melhorar o desempenho dos subordinados. Apontou que havia grande espaço para melhorias e sua resposta assumiu um tom mais político, nesse momento. O Sujeito A citou as limitações institucionais e a estrutura organizacional da empresa como entraves para os fluxos comunicacionais circularem mais livremente:

A gente adota, mas tem muito espaço pra isso ser melhorado não só comigo, mas em todos os sentidos dentro da unidade. [...] Entendo como característica de empresa pública porque as ferramentas que temos de gestão de pessoal são poucas. O que a gente tem pra motivar são palavras, você não tem a motivação financeira, no aspecto de punição também são palavras, dificilmente você consegue mandar embora ou trocar as atividades do indivíduo, então eu acho que isso tem que ser muito no diálogo, que não é fácil porque o indivíduo coloca muitas vezes mais aspectos pessoais do que os funcionais ou, pior, não reagem na hora, guardam isso e vai azedando o relacionamento. Não é fácil resolver, não é problema de comunicação. Competição é institucional, por conta dos sistemas de promoção e de premiação, com base no sistema de avaliação que considero injusto porque ranqueia os sujeitos, não avalia verdadeiramente. Há também uma certa reserva de mercado, pois como o desempenho individual é que é cobrado pela empresa, então um líder de equipe prefere subutilizar seu empregado do que estimular sua integração em outra equipe que tenha maior demanda no momento. A Embrapa estimula a competição e não a cooperação, conforme deveria ser, pois avalia o desempenho individual ao invés de avaliar o resultado global da unidade. Se a Embrapa foi produtiva todos vão ganhar, se não for produtiva, ninguém ganhará. Esta seria uma filosofia de trabalho em equipe e otimizar o uso de recursos. Se o sucesso de cada um dependesse do sucesso da ação de todos. Isso é parte da cultura da empresa e da natureza das pessoas (Sujeito A).

$\mathrm{O}$ dirigente $\mathrm{A}$ chamou a atenção para o fato de algumas limitações estarem relacionadas à natureza estatal da empresa (objeto percebido - noema). Segundo analisou o Sujeito A, essa característica institucional da Embrapa trazia 
limitações tanto para a motivação quanto para repreensão do funcionário, pois a gestão de pessoas era acanhada pelos limites formais. Dadas as características empregatícias nesse tipo de empresa, o que se tinha como recurso motivacional e punitivo era a palavra. A palavra, segundo o Sujeito A (apreensão subjetiva noesis), assumia um papel importante, mas era um apelo frágil devido ao caráter estatal da empresa. Outro ponto analisado pelo Sujeito A foi a maneira como a avaliação era feita, na qual os funcionários eram ranqueados de acordo com o desempenho, gerando uma competição interna. Isso era um problema de cultura da empresa e da natureza das pessoas, relatou o dirigente A. Embora a resposta tenha sido mais política, o entrevistado mostrou que a comunicação interna estava diretamente vinculada às políticas assumidas pela empresa.

\subsubsection{Facilidade para dialogar e para comunicar face a face: habilidade inata do indivíduo ou competência gerencial que podia ser desenvolvida}

Ao discutir esse ponto, o respondente $\mathrm{C}$ fez referência à sua crença no treinamento e na capacitação, associando com a noção de que deficiências podiam ser conhecidas e sanadas nessa área: "Eu vejo que são as duas coisas, que tem pessoas que tem muito mais facilidade para a comunicação do que outras, mas que com certeza dá para ser melhorado, tanto é que de tempos em tempos a gente faz um treinamento, uma capacitação e que esse é um dos lados que a gente procura desenvolver". O mesmo informante demonstrou lucidez na visão de que um treinamento não era panaceia e que se tratava de uma situação individual, cujo tratamento ultrapassava condições formais e institucionais:

Agora têm alguns que sinceramente, eles não evoluem muito neste lado. Só que aí a gente não tem muitas opções para trocar e acaba ficando gestor, mas ele não é bom neste aspecto (comunicação), mas é bom em outro aspecto e não teria ninguém para substituí-lo. Mas a gente tenta melhorar essa habilidade dele (Sujeito C).

O entrevistado $\mathrm{C}$ mencionou (noema) a necessidade de atendimento especializado em algumas situações e a intervenção do próprio dirigente, se a ocasião exigisse. A habilidade para comunicar oralmente foi referida pelo Sujeito $\mathrm{C}$ como fundamental para um gestor (noesis): "Dependendo do momento a área de comunicação, a psicóloga ou a própria chefia, dependendo do caso pode dar um suporte, sim". A estrutura da empresa foi revelada pelo dirigente C como muito 
especializada, pois foram mencionadas qualificações profissionais variadas durante sua entrevista:

Lembrei de um ponto importante, Temos uma psicóloga do trabalho. Ela se reúne periodicamente com as equipes e setores, sem a presença de chefia, ela e a equipe. Ela trabalha muito em função das pesquisas [...] Então quando ela vai conversar com uma equipe, ela mais ou menos já sabe alguns problemas que foram levantados, naquela equipe nestas pesquisas. [...] momento que eles podem se expressar e aí sim eles se expressam de forma bastante espontânea, porque ali não tem nenhum controle [...] Depois a psicóloga nos traz os problemas que precisam de alguma intervenção ou coisa assim ou muitas coisas já se resolvem ali (Sujeito C).

O Sujeito $D$ respondeu diretamente à questão e afirmou que acreditava na competência gerencial para assegurar o diálogo e a comunicação face a face como processo evolutivo que se construía no ambiente de trabalho: "Acho interessante que isso aconteça, sim. O que a gente sempre procura aqui na Embrapa Soja é trazer o grupo para um nível de comprometimento maior, mostrar a importância do trabalho da pessoa e que isso tenha reflexo para o desempenho global, do grupo". O relato do Sujeito D mostrou alguma contradição com o ambiente formado pela avaliação institucional referido por outros dirigentes entrevistados no que dizia respeito à cooperação: "Natural que o supervisor não seja realmente um ordenador de funções e que dialogue e procure corrigir na medida do possível os desvios de funcionários, mas sempre estimulando a que eles possam ser cada vez mais colaborativos". O respondente ofereceu uma associação que enfatizou a comunicação oral através do reconhecimento de um valor intrínseco:

Reforçar realmente que a principal ferramenta que a gente usa no dia a dia e que acreditamos que torna o processo de comunicação mais ágil, as soluções mais rápidas é a comunicação oral. A dificuldade de você se basear fortemente na comunicação oral é você perder eventualmente a informação, por isso há uma necessidade de um complemento com algum registro, mas sem dúvida ela torna os processos mais ágeis, principalmente porque nós temos necessidades de soluções muito pontuais que muitas vezes não interferem no regimento, na norma de funcionamento então, é uma tomada de decisão que pode realmente ser feita por um contato oral (Sujeito D).

O entrevistado expressou sua convicção no fato de que a comunicação oral podia ser associada com agilidade. Ao encaminhar suas observações para um ponto conclusivo, o Sujeito $D$ acrescentou elementos às rotinas de trabalho que inseriram a tecnologia no contexto exposto pelo entrevistado: 
A tecnologia é um facilitador para a comunicação que acaba aumentando os momentos de relacionamento porque ultrapassa o período do presente porque você consegue passar informações, deixar recados, mas é complementar. Tem situações que realmente é necessário, na verdade eu julgo que aqui a maioria dos casos é necessário você fazer a comunicação oral. Quando é passar algum recado de alguma coisa que está bem estabelecida, tem que ser frio, não tem que se preparar, então é feito com auxílio de uma ferramenta de gestão de informação que ela facilita e não deve deixar de ser utilizada (Sujeito D).

O entrevistado $D$ lembrou atributos da tecnologia muito necessários ao bom funcionamento da comunicação interna de uma organização, mas reconheceu que este era um ambiente relacional de gestão necessitado de interações diretas e dialógicas que somente a comunicação face a face tinha alcance para assumir em uma empresa com a performance como a da Embrapa Soja.

Os quatro eixos temáticos foram aqui discutidos com a finalidade de centrar-se no que o método fenomenológico aponta como uma de suas bases, a identificação da relação noemática, passo preliminar para que se conheça a essência de um fenômeno. O cruzamento entre noema e noesis foi aplicado ao fenômeno em exame, a oralidade. Funcionaram como organizadores do olhar para compreendê-la no modo como essa oralidade é praticada, vendo-a, por uma extremidade, como objeto percebido e, por outra, na apreensão subjetiva a que se vinculava na mente dos que trabalhavam na organização. A maneira como os dados foram dispostos mostrou o grau em que essa relação emergiu e era reiterada, além da capacidade que esse processo tinha de produzir contato com o conhecimento de essência buscado, esse sim, inclusive meta de pesquisa. Os elementos ensejados comporão a enunciação de propriedades do fenômeno apresentada nas conclusões.

\subsection{Análise da Etapa Qualitativa com Supervisores Embrapa Soja}

A estratégia qualitativa de pesquisa foi um desdobramento da fase fenomenológica que se estendeu para os subordinados diretos dos dirigentes, que eram os supervisores de equipe, e preservou uma tipologia que avançasse no cenário da inexistência de consenso científico. Esta foi uma questão muito presente, pois a comunicação interna em sua característica de uso da oralidade foi o objeto estudado. $O$ foco foi a palavra falada e as interações face a face entre líderes e equipes. Abordou-se a oralidade comunicacional interna do nível intermediário da gestão na Embrapa Soja que foi traduzida para uma linguagem familiar aos atores e 
referida nos termos comunicação oral, diálogo e comunicação face a face. A apresentação do perfil dos pesquisados foi um modelo seguido para contextualizar os sentidos do corpus como um dos passos da sistematização dos dados obtidos na pesquisa.

Dos 17 supervisores da empresa selecionados como sujeitos da segunda etapa da investigação, obteve-se 13 respondentes à pesquisa qualitativa na Embrapa Soja. Constatou-se que dois dos 13 atores pesquisados eram do sexo feminino e que os cargos de supervisão eram ocupados por indivíduos do sexo masculino, na totalidade da área administrativa, bem como quase totalmente nos setores geral, no de pesquisa e desenvolvimento e no de transferência de tecnologia. Os atores declararam escolaridade predominantemente de nível superior, além de elevado índice de pós-graduados. Foram identificados quatro doutores, um mestre e cinco especialistas, informação que confirmou o que diz o senso comum a respeito da política de recursos humanos da estatal Embrapa de atrair e manter um quadro funcional de excelência, já tendo como base a capacitação de pesquisador que essa titulação, em princípio, proporciona. O alto nível intelectual desses empregados era um fator contributivo no sentido de cumprir a missão de encontrar permanentemente as soluções científicas para a agropecuária, uma poderosa força do Brasil em sua inserção e importância no mundo, hoje. Embora o elevado nível de titulação acadêmica pudesse indicar, em princípio, constituir-se o quadro de pessoal de uma equipe exclusivamente na faixa etária de maturidade, foram identificados alguns supervisores com pouco mais de 30 anos de idade. Os demais se encontravam na faixa dos 40 e 50 anos, e a idade máxima declarada por um supervisor foi de 67 anos.

Um bloco de questões concentrou-se na comunicação interna da empresa, quando se buscou inicialmente a descrição das linhas gerais da área de atuação do entrevistado e das principais funções de sua equipe na Embrapa Soja. As informações coletadas foram dispostas na Quadro 2 e expressam o funcionamento científico, administrativo e operacional do respectivo setor, como também ilustram a influência recebida das áreas de direção da empresa e o modo como se distribuem as responsabilidades científicas, institucionais e administrativas que integravam as tarefas da gestão. 


\begin{tabular}{|c|c|c|}
\hline Setor & Área & Funções \\
\hline Geral & $\begin{array}{l}\text { Tecnologia da Informação/ } \\
\text { Informática. }\end{array}$ & $\begin{array}{l}\text { Planejamento, realização e avaliação das } \\
\text { ações de comunicação da Embrapa Soja } \\
\text { com diferentes públicos; zelo pelos fluxos de } \\
\text { informação e influência entre Embrapa e } \\
\text { públicos, pela identidade e reputação. } \\
\text { Atendimento do cliente e manutenção de } \\
\text { equipamentos de informática, administração } \\
\text { de rede de computadores e de sua } \\
\text { segurança, desenvolvimento de sistemas }\end{array}$ \\
\hline $\begin{array}{l}\text { Pesquisa e } \\
\text { Desenvolvimento }\end{array}$ & $\begin{array}{l}\text { Equipe técnica do girassol } \\
\text { Gerência, liderança de equipes } \\
\text { e de um Núcleo Temático }\end{array}$ & $\begin{array}{l}\text { Pesquisa } \\
\text { Pesquisa }\end{array}$ \\
\hline $\begin{array}{l}\text { Transferência de } \\
\text { Tecnologia }\end{array}$ & $\begin{array}{l}\text { Transferência da produção de } \\
\text { pesquisa da Embrapa Soja }\end{array}$ & $\begin{array}{l}\text { Disponibilizar aos profissionais de assistência } \\
\text { técnica e de extensão rural e ao setor } \\
\text { produtivo os conhecimentos e tecnologias } \\
\text { geradas pelas equipes de pesquisa da } \\
\text { Embrapa Soja }\end{array}$ \\
\hline Administração & $\begin{array}{l}\text { Fiscal e tributária } \\
\text { Apoio direto às equipes de } \\
\text { pesquisa }\end{array}$ & $\begin{array}{l}\text { Orçamento, contabilidade e finanças. } \\
\text { Irrigação, operações mecanizadas } \\
\text { (aplicações de defensivos, preparos de solo e } \\
\text { equipamentos agrícolas e de pesquisa), } \\
\text { manutenção de duas fazendas da Embrapa, } \\
\text { estradas, galpões e equipamentos, tratores, } \\
\text { colhedeiras, implementos e equipamentos. } \\
\text { Políticas de gestão de pessoas, benefícios, } \\
\text { desenvolvimento de RH, qualidade de vida, } \\
\text { clima organizacional, administração de RH, } \\
\text { reconhecimento e recompensa } \\
\text { Técnicos subordinados ao pesquisador da } \\
\text { área. }\end{array}$ \\
\hline
\end{tabular}

QUADRO 2 - Áreas de atuação e funções da equipe.

Fonte: Dados da pesquisa.

Figurava no setor administrativo a maior concentração de subordinados que um supervisor declarou, tendo 19 empregados sob sua supervisão direta. Houve supervisores que afirmaram não ter nenhum empregado diretamente sob sua subordinação, pois sua tarefa não se enquadrava naqueles casos em que cabia ao pesquisador a função de supervisionar uma equipe formada para o propósito específico de execução de um projeto. Ou seja, essa informação sinalizou que a empresa entendia que a articulação das equipes devia ser direcionada mais em função da ciência do que na pura hierarquia administrativa. A distinção conquistada pela estatal Embrapa no cenário global resulta de uma 
conduta sempre exigente com o profissionalismo e, por isso, pautada pela sofisticação de processos e práticas interna e externamente.

A comunicação da empresa foi formalizada em 1995 e está disponível em documento intitulado "Política de Comunicação". Por compreender que política e história são temas indissociáveis, a empresa procedeu a uma reformulação deste documento em 2002. O conceito de comunicação empresarial contido no documento da política de comunicação da Embrapa prega como responsabilidade da área "[...] criar e manter fluxos de informação e influência recíproca entre a empresa, seus públicos de interesse e a sociedade em geral". (EMPRESA BRASILEIRA..., 2012b, p. 28). Consta do documento o status estratégico concedido à comunicação empresarial como parte efetiva do planejamento global e que orienta as esferas institucional e mercadológica da empresa. Os objetivos específicos de âmbito interno na "Política de Comunicação" da Embrapa são os seguintes:

Criar e consolidar fluxos de comunicação que promovam a interação entre a direção da Empresa, o staff técnico e gerencial e demais empregados, estimulando a participação de todos e potencializando a realização pessoal e profissional. Conscientizar o público interno, em todos os níveis, para o fato de que a imagem da Empresa se forma também a partir das posturas e dos comportamentos individuais, tendo cada empregado a responsabilidade de contribuir para a boa imagem da Embrapa perante a sociedade. Internalizar a ideia de que a interação com os públicos de interesse, interno e externo, é vital para o processo de sustentabilidade institucional e que essa interação deve ser balizada pela ética e pelo profissionalismo. Querer e saber comunicar-se constitui-se em item importante do processo de avaliação do desempenho profissional" (EMPRESA BRASILEIRA DE PESQUISA AGROPECUÁRIA, 2012b, p. 33-34).

Buscou-se então apreciar a penetração desta política junto aos supervisores da Embrapa Soja perguntando-Ihes sobre seu conhecimento a respeito da "Política de Comunicação" da Embrapa. Os 13 entrevistados afirmaram conhecer a política de comunicação e três destes alegaram conhecê-la em parte, apenas. Como era proposta desta pesquisa, investigou-se se os entrevistados identificavam o que era tratado sobre comunicação interna na "Política de Comunicação" da Embrapa. A resposta veio afirmativa de 11 entrevistados. Indagou-se se o superior imediato adotava o que a política de comunicação da Embrapa indicava nas relações com os supervisores e obteve-se resposta afirmativa de oito entrevistados, contudo ocorreram manifestações negando o conhecimento sobre como a política de comunicação tratava a questão, uma resposta negativa e três não respostas. Ao confrontar com as três respostas de conhecimento parcial sobre a "Política de 
Comunicação", pode-se concluir que sua penetração junto aos supervisores da Embrapa Soja era significativa sim, pois de fato a quase totalidade dos entrevistados a conhecia.

Ao serem indagados sobre o modo como o superior imediato adotava o que a política de comunicação da Embrapa estabelece quando se comunicava com os supervisores, relatos estimulantes para o tema em análise surgiram. Manifestaram que o superior imediato dava orientações sobre a expectativa em torno dos subordinados diretos e que este relacionamento era pautado no diálogo, na apreciação crítica e, em alguns casos, no redirecionamento de ações. Revelaram que a "Política de Comunicação" é normativa e de orientação, por isso praticada pelo superior imediato nas relações com os supervisores. Outros reafirmaram que o superior conversava com os subordinados. Em uma abordagem, o entrevistado justificou que seu superior adotava o que diz a política por ser "[...] o maior conhecedor de tudo sobre a empresa. Ele é muito bom!" Ocorreram menções a instrumentos utilizados como memorandos, e-mails, contatos telefônicos e boletim gerencial da Embrapa, mas as relações interpessoais prevaleceram entre as manifestações dos respondentes das questões.

Para confirmar como se dava o processo de comunicação interna na empresa, questionou-se os respondentes se havia acompanhamento ou cobrança da utilização do que era comunicado. Estes supervisores afirmaram que seu dirigente imediato monitorava as mensagens transmitidas a eles que, por sua vez, faziam o monitoramento de suas equipes de subordinados.

Como parte do levantamento sobre a comunicação interna da Embrapa Soja, buscou-se avaliar como os supervisores projetavam a interface da missão das equipes em relação à organização. Identificou-se na "Política de Comunicação" o que segue:

Na prática, a comunicação com os públicos internos parte do pressuposto de que, como parceiros, eles devem estar suficientemente esclarecidos a respeito da visão, da missão e dos compromissos da empresa e do papel que cada um desempenha para que eles sejam plenamente atendidos (EMPRESA BRASILEIRA DE PESQUISA AGROPECUÁRIA, 2012b, p. 42). 


\begin{tabular}{|c|c|}
\hline Setor & Missão descrita \\
\hline Geral & $\begin{array}{l}\text { Manter a empresa em comunicação com diversos públicos, monitorar } \\
\text { expectativas e realimentar o processo de gestão técnica e institucional com } \\
\text { informações relevantes. } \\
\text { Trabalho integrado dos dirigentes e supervisores com múltiplas interfaces. } \\
\text { Contribuir para o conhecimento e apropriação dos públicos das tecnologias, } \\
\text { serviços e produtos. Conhecer as expectativas dos públicos para a } \\
\text { organização atendê-los, em termos de comunicação, e das demandas } \\
\text { técnicas. } \\
\text { É fundamental o conhecimento da arte e técnicas de comunicação com os } \\
\text { diferentes públicos para o sucesso da missão da organização, Esse } \\
\text { relacionamento é estruturado na política de Comunicação da Empresa e } \\
\text { assumido como compromisso fundamental de todos seus membros } \\
\text { permitindo revisões constantes para permitir o acompanhamento da evolução } \\
\text { do conhecimento. }\end{array}$ \\
\hline $\begin{array}{l}\text { Pesquisa e } \\
\text { Desenvolvimento }\end{array}$ & $\begin{array}{l}\text { Desenvolver tecnologias para a cultura do girassol no Brasil. } \\
\text { Produção de conhecimento. Atender às demandas }\end{array}$ \\
\hline $\begin{array}{l}\text { Transferência de } \\
\text { Tecnologia }\end{array}$ & $\begin{array}{l}\text { A nossa equipe atua na interface entre a Embrapa e o setor produtivo, ou } \\
\text { seja, ao mesmo tempo em que divulga os resultados de pesquisas gerados } \\
\text { no âmbito da instituição, também capta demandas dos problemas que } \\
\text { afetam o setor produtivo e que podem vir a se transformar em novas linhas de } \\
\text { pesquisa da instituição. }\end{array}$ \\
\hline Administração & $\begin{array}{l}\text { Como atividade meio os processos administrativos objetivam viabilizar as } \\
\text { condições de apoio aos demais processos da área de pesquisa. Trabalho com } \\
\text { harmonia na consecução de objetivos comuns. } \\
\text { Prestar o melhor serviço e de maneira mais eficiente, para que a Embrapa } \\
\text { cumpra com seus objetivos e missão. } \\
\text { Na Embrapa Soja, minha equipe está ligada ao apoio para desenvolvimento } \\
\text { de novas variedades de soja visando a produtividade e sanidade da mesma. } \\
\text { Especialmente na captação, retenção e no desenvolvimento dos talentos } \\
\text { necessários aos objetivos estratégicos da Empresa. } \\
\text { Produção de tecnologias }\end{array}$ \\
\hline
\end{tabular}

QUADRO 3 - Missão da equipe em relação à Embrapa Soja. Fonte: Dados da pesquisa.

Foi constatado que este capítulo era muito bem absorvido por parte significativa dos entrevistados, pois suas descrições mostraram-se conexas com a política, como pode ser visto na Quadro 3. Os casos de não respostas podem significar, entre outros motivos, falta de clareza do entrevistado sobre o modo como a missão de sua equipe se relaciona com a organização.

Um aspecto particular destacado na fase fenomenológica foi a vocação da Embrapa Soja para a pesquisa e produção de tecnologias. Observou-se 
que a cultura da empresa e seu funcionamento administrativo eram marcadamente focados no trabalho e na produção dos pesquisadores. Perguntou-se como o superior imediato via a relação entre processos administrativos e área de pesquisa, o que ele enfatizava e como o supervisor abordava a questão com sua equipe.

As respostas dos supervisores reforçaram a conclusão alcançada na pesquisa fenomenológica, pois foram obtidas informações de que os processos administrativos eram atividades com objetivos de apoio aos processos de pesquisa. "Trabalho com harmonia na consecução de objetivos comuns", afirmou um supervisor. O apoio à pesquisa foi também manifestado como sistema que liberava o pesquisador para se manter focado na pesquisa, uma vez que a parte administrativa e operacional caberiam aos setores e equipes de apoio. A pesquisa foi reafirmada como a atividade fim da empresa e que os processos administrativos eram posicionados na empresa como atividade meio e de apoio. "Isso faz parte da cultura. Os empregados conhecem bem essa realidade e conduzem o trabalho de forma a evitar conflitos dessa natureza", informou um entrevistado.

Uma habilidade exigida dos chefes e supervisores da Embrapa era a capacidade de mobilizar, conscientizar e esclarecer os subordinados. Questionou-se como o superior imediato estimulava cada empregado a contribuir com o seu melhor dentro da empresa. Foi afirmado o monitoramento de resultados para a empresa, o diálogo para contornar falhas e a viabilização financeira de projetos pelo orçamento geral da empresa. Um valor expressado foi o relacionamento respeitoso e a valorização profissional como estímulos essenciais, pois se afirmou que os recursos financeiros dependiam exclusivamente da competência de cada ator. A avaliação de desempenho era um processo que interessava aos empregados que ocupavam cargos de gestão e liderança, portanto receber atribuições que eram avaliadas nos processo de avaliação de desempenho foi mais um valor manifestado que, embora pragmático, não desprezava enfoques de nível relacional interferindo na delegação das atribuições, na confiança na capacidade e na valorização profissional subjetivadas neste comportamento administrado.

O corpus até aqui analisado expôs argumentos que forneceram evidências para conclusões acerca da extensão em que se pode afirmar, no ambiente pesquisado, que a oralidade constrói comunicação face a face, pois é uma habilidade que projeta a competência do líder para conduzir equipes e alcançar objetivos de comunicação interna. A tese proposta manifestou-se formalmente no 
documento da política de comunicação da Embrapa quando a empresa chama para si o compromisso de garantir informações de interesse dos empregados e rapidez no seu acesso. O discurso da empresa expressava sua responsabilidade em "[...] conscientizar as chefias e gerentes sobre a importância da comunicação como fator de desenvolvimento organizacional" (EMPRESA BRASILEIRA DE PESQUISA AGROPECUÁRIA, 2012b, p. 37).

A pesquisa qualitativa trouxe subsídios para identificar características da oralidade que foram descritas nesse universo e que podem ser absorvidas pela comunicação interna, pois a Embrapa defendia a livre circulação de ideias, a participação dos empregados e atribuiu valor a este fazer destinado à sua comunicação interna. Outras características pontuais da oralidade inferidas pelos supervisores eram o foco nas pessoas e não em processos administrativos ou operacionais; a oralidade impactava a melhoria dos processos pela intervenção de pessoas; era também dinâmica e previa comportamento compatível com uma estratégia de gestão. A análise do corpus até aqui construída expôs o modo como este fenômeno imerso na organização foi naturalmente apontado e manifestado pelos sujeitos pesquisados.

O eixo temático que defende o caráter estratégico do diálogo entre líder e equipe foi abordado em dois blocos de questões apresentadas aos supervisores de equipes da Embrapa Soja. Um bloco focou o uso da comunicação oral e confirmou junto aos pesquisados a existência de recomendações que estimulavam seu uso entre chefes, supervisores e empregados da equipe. A negativa da comunicação oral no processo de comunicação interna da unidade da Embrapa veio de um grupo relevante, o que justificou afirmar que se recomendações existem, estas podem ser mais agressivas para atingir o nível de orientação interna de comunicação, conforme reza a "Política de Comunicação" da Embrapa:

A relação transparente e democrática com os empregados é vital para a empresa e se instaura pela adoção de um processo de gestão que estimula o diálogo e a participação e que advoga a implementação de um autêntica cultura de comunicação. Isso significa conscientizar todos os empregados para a necessidade de manter fluxos horizontais e verticais de comunicação e de participar ativamente do processo de tomada de decisões. Ela compreende também o fluxo de comunicação oficial e controlada que se estabelece entre a direção da Embrapa e os empregados, consubstanciada em atos de gestão da Empresa e demais documentos oficiais emitidos pelas instâncias de decisão (presidência, diretoria executiva, chefias de unidades etc.) (EMPRESA BRASILEIRA DE PESQUISA AGROPECUÁRIA, 2012b, p. 42). 
O discurso da empresa focou no caráter formal que a comunicação interna devia adotar, contudo não sobrepunha a comunicação administrativa sobre a informalidade permitida nas interlocuções e interações presenciais entre atores dialógicos inseridos no processo comunicacional interno. Isso porque o estímulo ao diálogo está normatizado pela política, como pode ser observado no destaque acima. Informações prestadas por dirigentes na pesquisa fenomenológica conduziu o questionamento dos supervisores respectivos sobre a existência de barreiras à comunicação oral entre líderes e equipes, pois a intenção era proceder ao cruzamento das percepções de ambos os níveis hierárquicos. A negação de barreiras à comunicação oral foi integralmente manifestada pelos atores pesquisados. Fez-se, então, necessário interrogar os supervisores se eles usavam a comunicação oral com os dirigentes a que estivessem imediatamente ligados. Vale registrar que a quase totalidade de sujeitos respondeu afirmativamente e, então, voltou-se a abordagem para o uso pelo supervisor da comunicação oral com os empregados da sua equipe. As respostas positivas de todos os supervisores entrevistados confirmaram definitivamente que eles usavam a comunicação oral com seus liderados.

Dentre as situações relatadas pelos líderes para usar a comunicação oral internamente foram mencionadas as rotinas objetivas, o planejamento, acompanhamento e avaliação de resultados, a contiguidade física que permitia avaliar reações e estreitar relacionamento entre as pessoas e as situações emergenciais que demandavam agilidade nas decisões ou divisão de tarefas. Notese que a oralidade nas comunicações entre líderes e equipes era uma prática que se expandia das simples rotinas cotidianas, passava pela complexidade de um processo de planejamento e alcançava os limites das questões emergenciais com suas demandas por decisões compartilhadas e ágeis. A interpretação decorrente da análise destas informações determinou noticiar que a comunicação oral estava presente nas rotinas internas da empresa e se encontrava incorporada à cultura de comunicação da Embrapa Soja. A análise comporta avanços na resposta sobre a comunicação face a face acelerar a transferência de mensagens internas na Embrapa Soja.

Foi registrado que a empresa possuía veículos de comunicação interna que permitiam aos empregados divulgar, para seus pares, informações de interesse coletivo. Reafirmou-se as reuniões gerais que ocorriam trimestralmente e 
que eram conduzidas pela chefia geral da unidade para se reportar a todos os empregados, conforme foi relatado na etapa em que os dirigentes foram investigados. Segundo informaram os supervisores, essas eram maneiras de abordagem ampla de empregados que equilibravam o uso da comunicação oral com outras formas, sempre que os empregados em geral fossem o alvo da comunicação. Quanto à eficiência e retorno da comunicação oral, apurou-se ser uma forma de comunicação útil para perceber as reações dos interlocutores, pois foi afirmado que a atribuição de um gestor de equipe pressupõe capacidade para articular.

Segundo a experiência de vida de um entrevistado, influente no meio pesquisado, os resultados de articulação pareciam mais eficientes quando se dedicava tempo a conversar, a ouvir e a orientar as equipes. Mencionou-se a necessidade de registros formais de comunicação, em alguns casos, para os quais veículos escritos eram utilizados, contudo foi declarado pelo supervisor que "[...] quando o assunto é relevante, converso com a pessoa antes de escrever". A apreciação crítica das informações expôs que a oralidade produz reflexos na relação do líder com as equipes internas. À luz destes discursos, compreendeu-se que a comunicação oral na gestão de pessoas caracterizava a oralidade como uma forma de aprendizagem dialógica. O diálogo entre líder e equipe pressupõe um ator aprender com o outro, pois é a oportunidade para cada um para falar o que pensa, para apresentar propostas e soluções que trazem nitidez sobre o que fazer e como deva ser feito.

A "Política de Comunicação" normatiza práticas de gestão orientadas pelo uso do diálogo e da comunicação oral, pois nela consta o estímulo, a comunicação interpessoal "[...] por meio de debates e reuniões, particularmente quando estiverem em pauta assuntos que mereçam esclarecimento e para os quais seja necessário um contato direto com os empregados" (EMPRESA BRASILEIRA..., 2012b, p. 53). O bloco de questões associadas ao eixo temático sobre o uso da comunicação oral deram o tom para as abordagens sobre a prática do diálogo no locus da pesquisa. Guiados para expressarem se as expectativas dos superiores eram claramente faladas para as equipes, supervisores afirmaram que sim. Houve destaque para a autonomia concedida para administrar a rotina de atividades e conflitos. A informação indica que os dirigentes convocavam subordinados para discutir, informar mudanças normativas administrativas, para apoiar e executar atividade não rotineira, pois a relação de confiança com os subordinados diretos 
recebia aval da delegação que era conferida aos supervisores para exercerem, livremente, a gestão de assuntos funcionais.

Uma divisão diretiva da Embrapa Soja enfrentava, na época da coleta de dados, uma limitada compreensão sobre as atribuições que lhe eram conferidas e que foi apresentada por um dirigente. A mesma falta de clareza foi mencionada por supervisores respectivos ao justificarem que o superior não falava com clareza suas expectativas porque não existia clareza sobre as atribuições daquele campo diretivo. Via de regra, os dirigentes da empresa reportavam-se aos subordinados pela comunicação interpessoal, exceção somente para o campo que se encontrava pouco definido naquela ocasião.

A linguagem usada pelos líderes era uma questão relevante para a comunicação interna, particularmente em uma empresa como a Embrapa que incorpora um quadro funcional elitizado intelectualmente. Era de se supor que a linguagem técnica seria dominada pelos atores, porém poderia ser um ponto de dificuldade no momento de transferir o conhecimento e as tecnologias produzidas internamente para os públicos estratégicos da empresa. Dados coletados certificaram que a linguagem era uma questão diretamente relacionada pelos supervisores ao elevado nível de escolaridade dos empregados e compreendida como isenta da necessidade de adequações aos atores daquele universo. Ocorre que o nível operacional integrava a estrutura administrativa da empresa e, não necessariamente, seria desempenhado por indivíduos com a mesma sofisticação intelectual. Vale destacar que a estatal cumpria uma missão focada em assistência técnica e na sociedade em geral, logo a linguagem era carente de adequações para ser compreendida e incorporada à vida destas pessoas alocadas externamente aos limites da empresa.

Cabe recomendar o que traz a "Política de Comunicação" (EMPRESA BRASILEIRA..., 2012b, p. 36) ao definir que qualificar a informação é "[...] traduzir a informação relativa à ciência e à tecnologia, visando à eficácia de sua recepção, obedecidos os níveis de complexidade e de discurso compatíveis com cada público em particular". Houve destaque dos supervisores para a didática empregada nas explanações dentro de uma empresa que cultivava relações mais de respeito do que de escolaridade. Do ponto de vista interno, revelaram os sujeitos que a oralidade estava sendo capaz de produzir reflexos na adequação de linguagem e na relação do líder com as equipes, como se questionou no conjunto de 
questões que nortearam o desenvolvimento do presente estudo. Já a conclusão alcançada foi que não se pode afirmar uma proporção totalitária entre a elevada formação do líder e sua preocupação com relacionamentos com públicos variados. O peso da responsabilidade que sobre esta elite recaía, podia ser impeditivo para alguns exercerem um comportamento focado para além da produção de conhecimento, visto que este era um insumo produzido para pessoas.

O diálogo como prática de gestão estava plenamente absorvido pelos líderes da Embrapa Soja, contudo as contradições encontradas certificaram compreender que seu valor como estratégia de gestão permanecia inestimado no plano comunicacional da unidade. Afirmaram os supervisores a presença do diálogo no dia a dia das relações líderes/liderados, o qual ocorria por telefone, conversa pessoal e reunião. Os meios relatados eram plataformas para dialogar sobre fenômenos que, como tal, dialogavam entre si e interferiam no desempenho, na análise de cenários e de riscos, na imagem e nos relacionamentos da organização, entre outros. Barreiras à comunicação oral foram refutadas pelos pesquisados, contudo a interferência do local ou ambiente onde ocorria o diálogo para a qualidade da comunicação foi afirmada pela metade dos supervisores que abordaram o assunto.

"Costuma despachar por escrito apenas o que é mais trivial, que não demanda negociação", afirmou um entrevistado mostrando que a comunicação oral era preponderante nas relações entre dirigente/supervisor. Novamente o nível de escolaridade dos empregados foi destacado para justificar que o diálogo com o superior era aberto e que, acreditava o entrevistado, "dever-se ao nível técnico do pessoal que compõe a equipe". Por se tratar de empresa de pesquisa, os pesquisadores da Embrapa Soja eram muito respeitados na unidade e pousavam sobre esta relevância ao afirmarem que são profissionais com nível superior e com formação educacional adequada para conhecerem seus limites e travar um relacionamento profissional bilateralmente respeitoso.

Declararam ser convidados a dialogar com seus superiores quando o prazo era estreito e quando havia necessidade de obter informações para alcançar um posicionamento bem fundamentado para tomada de decisão. Provado foi que assuntos emergenciais eram concentradamente discutidos através do diálogo entre os atores da Embrapa Soja, portanto era uma prática efetiva no direcionamento e condução da empresa. Pode-se afirmar que o diálogo como fenômeno bilateral 
estava institucionalizado na cultura de comunicação da empresa. Os depoimentos dos supervisores mostraram que a tendência natural para quem exercia cargo de liderança na empresa era acompanhar o estilo de gestão de seu dirigente direto e, assim, assumiram que o exercício de um cargo de gestão trazia implícita a habilidade para gerir relacionamentos interpessoais nos quais as partes dialogavam entre si e com outros. Considerou-se a capacidade para ouvir liderados como complementar da habilidade de comunicação do gestor, pois dialogar pressupõe ouvir o que foi falado. Diz a "Política de Comunicação" EMPRESA BRASILEIRA...,2012b, p. 52) que "[...] os chefes e gerentes respondem pela qualidade e intensidade dos fluxos de comunicação em sua área de atuação, devendo empenhar-se para que seja estimulada a participação dos empregados no dia a dia da Empresa".

As interações face a face abordadas como um eixo temático foram, como se mencionou, consideradas na "Política de Comunicação" da Embrapa no parágrafo que recomenda estimular a comunicação interpessoal. Este tópico da Política constitui os nós que tecem os entrelaçamentos entre os eixos que traduziram o termo oralidade, adequando-o para uma linguagem que traduzisse a palavra falada como o foco estabelecido. Os supervisores puderam se expressar a respeito da receptividade que seus superiores imediatos mostravam para as opiniões sobre o estilo deles dirigirem a unidade. Ficou registrada a motivação para ouvir e a disposição para incentivar interações no ambiente interno da empresa. Veículos orais foram citados como meios para que as opiniões, as sugestões, avaliações de metas, avaliações de impactos causados por decisões descendentes fossem comunicadas. A conversa face a face liderou as menções dos entrevistados sobre o tipo de instrumento mais utilizado pelos superiores para analisar rotinas, emergências e para orientar a tomada de decisão, seguida pela menção às reuniões pautadas com estes fins. Quanto à importância da oralidade nas relações entre líderes e equipes, foi afirmado que o diálogo sempre foi uma oportunidade para a aprendizagem dos interlocutores. Uma manifestação mereceu destaque, pois afirmou o supervisor que a palavra falada dava "emoção àquilo que é pedido por escrito". Os supervisores, em seus depoimentos, validaram a oralidade para proceder comunicação clara e objetiva, para transmitir política de trabalho dos chefes, diretrizes da empresa, para promover o desenvolvimento da organização, 
para integrar as partes e para agilizar o delineamento da direção que a empresa deve seguir.

A etapa de coleta de dados com o nível hierárquico intermediário da Embrapa Soja contornou o que era consensual sobre a oralidade na comunicação interna. Os supervisores visualizaram a palavra falada como um meio híbrido que combina um conjunto de possibilidades para a delegação compartilhada de responsabilidades. A comunicação oral pode significar destacada vantagem na gestão organizacional, pois as pessoas têm necessidade de contato, de proximidade com seus pares e este episódio pode ser viabilizado pelas interações orais e face a face. Certamente que erros de transmissão e de interpretação podem ocorrer com o uso de meios orais de comunicação, entretanto registraram os supervisores que uma característica da oralidade era a oportunidade dada para observar o interlocutor e identificar o contorno que a decodificação da mensagem estava produzindo e se este representava um desvio ao que originalmente precisava ser comunicado. A empresa estudada mostrou-se predisposta para a comunicação oral que pareceu movimentar os sistemas de comunicação interna. Outras mídias internas cumpriam a função de disseminar informações de interesse coletivo, contudo percebeu-se que a empresa era um ambiente no qual as pessoas mostraram-se maduras para apreciar e assumir posição frente a temas delicados ou sensíveis e que a comunicação oral, o diálogo e as interações face a face eram rotineiramente acessados pelos líderes na gestão de suas equipes.

\subsection{Análise da Etapa Quantitativa com Empregados Embrapa Soja}

A estratégia quantitativa da pesquisa foi realizada com todos os empregados da Embrapa Soja que sofressem impacto da comunicação interna da empresa, estivessem acessíveis à época da coleta de dados e que não tivessem sido abordados pelas duas etapas anteriores. Responderam ao questionário (Apêndice C) um total de 171 empregados. Para a análise quantitativa, foram descartados 12 respondentes pelo fato de não terem completado totalmente o questionário. Assim, para que o corpo de respostas fosse consistente ao longo de todas as questões, optou-se por considerar o conjunto de 159 respondentes que completaram integralmente o instrumento quantitativo dando forma a esta porção do corpus levantado. O estilo escolhido para apresentar analiticamente os resultados da 
etapa quantitativa foi a segmentação em blocos de análise, paralelos aos modelos de formulação das perguntas abertas, de múltipla escolha e questões em escala de concordância e discordância. Os dados inicialmente apresentados são os das perguntas com formas de abordagem distintas do parâmetro de concordo e discordo. Estas foram questões que preservaram alguma característica qualitativa, portanto adaptaram-se à lógica desenvolvida até este ponto de apresentação da pesquisa empírica.

A análise cita a localização dos itens no questionário aplicado, portanto segue uma ordenação atribuída a cada um deles, e não uma simples sequência numérica. O primeiro bloco mostra uma classe de análise segmentada para refletir o que apontaram os respondentes em questões dicotômicas, de múltipla escolha e questões abertas.

\subsubsection{Comunicação interna}

A questão de número dois (Q2) era dicotômica e perguntava se a divulgação das políticas, dos objetivos, das metas e resultados alcançados pela empresa era direcionada para todos os empregados. A maioria respondeu que sim. Os $53 \%$ que responderam afirmativamente à questão dois (Q2) preencheram a questão três (Q3) para registrar quais meios eram utilizados para esse fim. A questão três (Q3) era uma pergunta aberta, portanto os respondentes tiveram espaço para mencionar quantos meios julgassem necessários e se expressar livremente. Para efeito de análise, as inferências dos sujeitos pesquisados foram agrupadas em classes de veículos distribuídos nas categorias de meios eletrônicos, internos, orais e administrativos. Os dados agrupados são os que se apresentam no Quadro 4.

\begin{tabular}{|l|c|}
\hline CATEGORIA & RESULTADOS \\
\hline Eletrônicos & 37 \\
\hline Internos & 46 \\
\hline Orais & $\mathbf{5 3}$ \\
\hline Administrativos & $\mathbf{0 6}$ \\
\hline
\end{tabular}

QUADRO 4 - Resumo dos modos de divulgação.

Fonte: Dados da pesquisa. 
Os respondentes fizeram 46 menções à categoria de veículos internos e o "Mural" foi o meio mais citado, recebendo 22 menções. Na categoria de meios eletrônicos mencionados, a maior incidência recaiu sobre o e-mail, que foi indicado 18 vezes, seguido por um boletim diário, o "Em Dia", que pautava os principais fatos na rotina cotidiana da empresa e foi mencionado 16 vezes. Houve respondentes que escreveram 53 meios como reuniões e eventos, veículos que são classificados como orais. Considerando-se que o "Mural" liderou as indicações na categoria de veículos internos e que esta se aproximou da categoria de veículos orais, os dados do Quadro 4 mostraram a tendência de aceitação dos pesquisados para os meios de comunicação com características informais.

O Gráfico 3 representa a pergunta quatro sobre se o superior imediato mantinha sua equipe informada a respeito dos assuntos do setor (Q4).

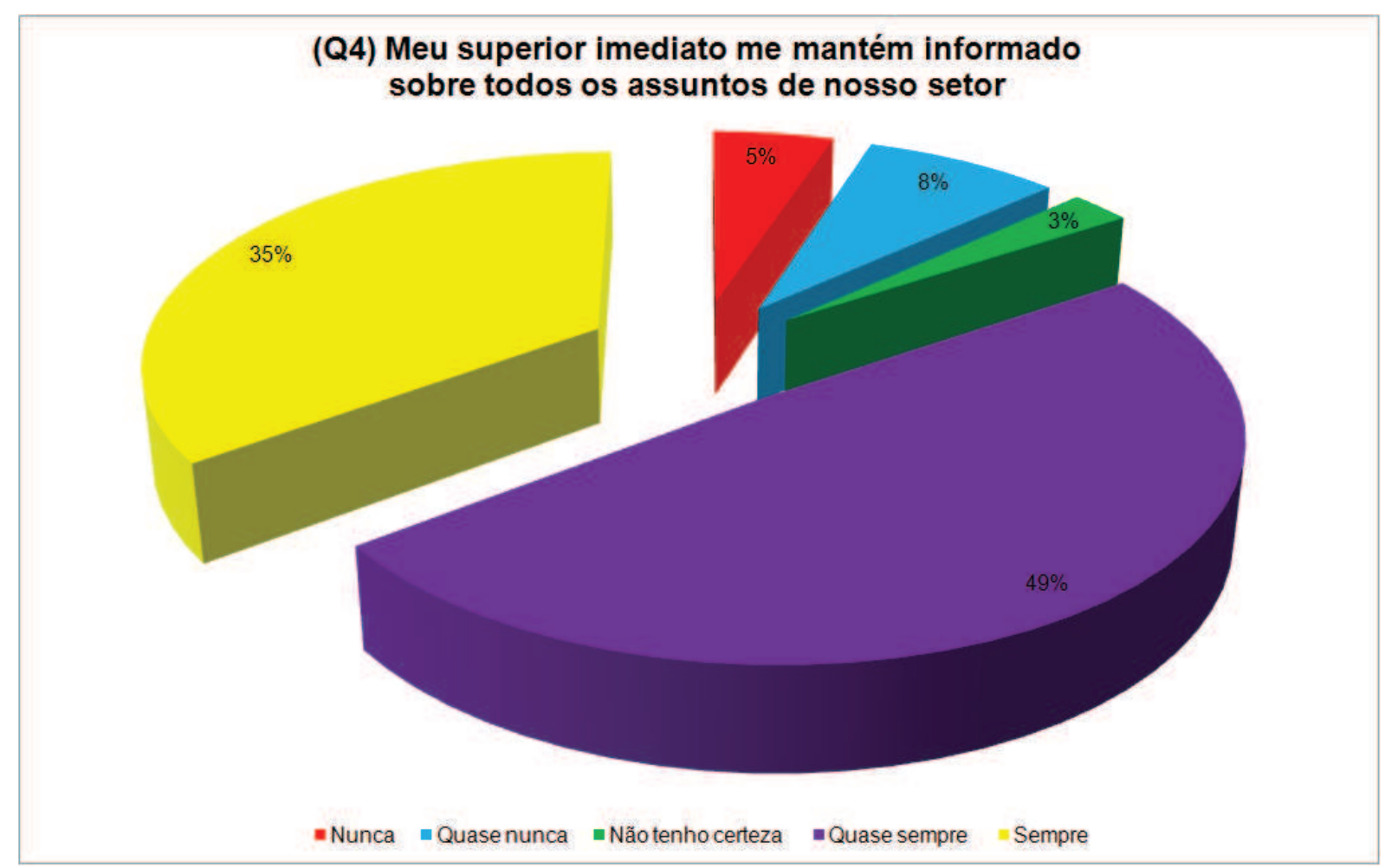

GRÁFICO 3 - Informação sobre o setor para os empregados. Fonte: Dados da pesquisa.

A alternativa "sempre" foi assinalada por 56 empregados e representou $35 \%$ das respostas válidas. Foram 78 os empregados que elegeram a alternativa "quase sempre", representando $49 \%$ do total de respostas. O nível de informação interna que os empregados da Embrapa Soja declararam ter, permitiu 
apreciar o desempenho do líder para disseminar informações para sua equipe e o reconhecimento coletivo de seu esforço. Os dados obtidos por meio das respostas às questões sobre comunicação interna do questionário aplicado, refutaram a hipótese um (H1) que sugeriu que a Embrapa Soja não considerava a oralidade como um componente a ser destacado na sua comunicação interna. Os empregados focaram meios orais de comunicação com relevância, portanto negaram o que a hipótese um apresentava. Na hipótese dois $(\mathrm{H} 2)$ foi suposto que o diálogo não seria reconhecido como resultado de processo comunicacional. Os empregados manifestaram que este era um reconhecimento presente no sistema de comunicação interna da empresa, como mostraram o Quadro 4 e o Gráfico 3 e, assim, negaram o que a hipótese dois enunciou.

A questão de número sete (Q7) perguntou aos empregados como era o relacionamento entre o superior imediato e os subordinados, dentro do setor onde atuavam. As respostas apuradas mostraram que os sujeitos aprovavam a capacidade relacional da liderança imediata, pois 66\% afirmaram estar satisfeitos e $19 \%$ disseram estar totalmente satisfeitos com estas relações. Embora existissem as insatisfações, essas apareceram pouco relevantes diante dos $5 \%$ de totalmente insatisfeitos, $6 \%$ de insatisfeitos e $4 \%$ que não tinham certeza. A hipótese três $(\mathrm{H} 3)$ previa que a maioria dos líderes era reconhecida pela sua oralidade. Esta foi confirmada pelo valor que os empregados deram ao relacionamento que afirmaram estabelecer com seu líder, por causa de sua habilidade para construir esse tipo de laço. O bloco de questões sobre comunicação interna validou a proposição da hipótese quatro $(\mathrm{H} 4)$ de que a oralidade era um método relevante desenvolvido pela comunicação interna da organização.

\subsubsection{Comunicação oral entre os empregados}

Foram 127 os empregados que confirmaram usar comunicação oral no processo de tomada de decisão com seus chefes diretos (Q11) e representaram $79 \%$ das respostas obtidas. Um grupo de $15 \%$ de respondentes respondeu que usava, mas em algumas ocasiões e, 6\% dos empregados negaram o uso desta classe de comunicação. Esses são dados que confirmaram a hipótese três $(\mathrm{H} 3)$ e a hipótese quatro $(\mathrm{H} 4)$, ou seja, os líderes eram reconhecidos pela sua oralidade e este era um método relevante desenvolvido pela comunicação interna da 
organização. Os motivos apresentados pelos que responderam "não" à questão 11 (Q11) pareceram interessantes porque traduziram rotinas profissionais, nas quais outras categorias de veículos seriam recomendadas. Pareceu que as operações da empresa não tinham foco significativo nestes tipos de atividades, pois assim responderam os empregados às perguntas seguintes (Q12 e Q13)) sobre os motivos para não usar comunicação oral, conforme se apresenta no Quadro 5.

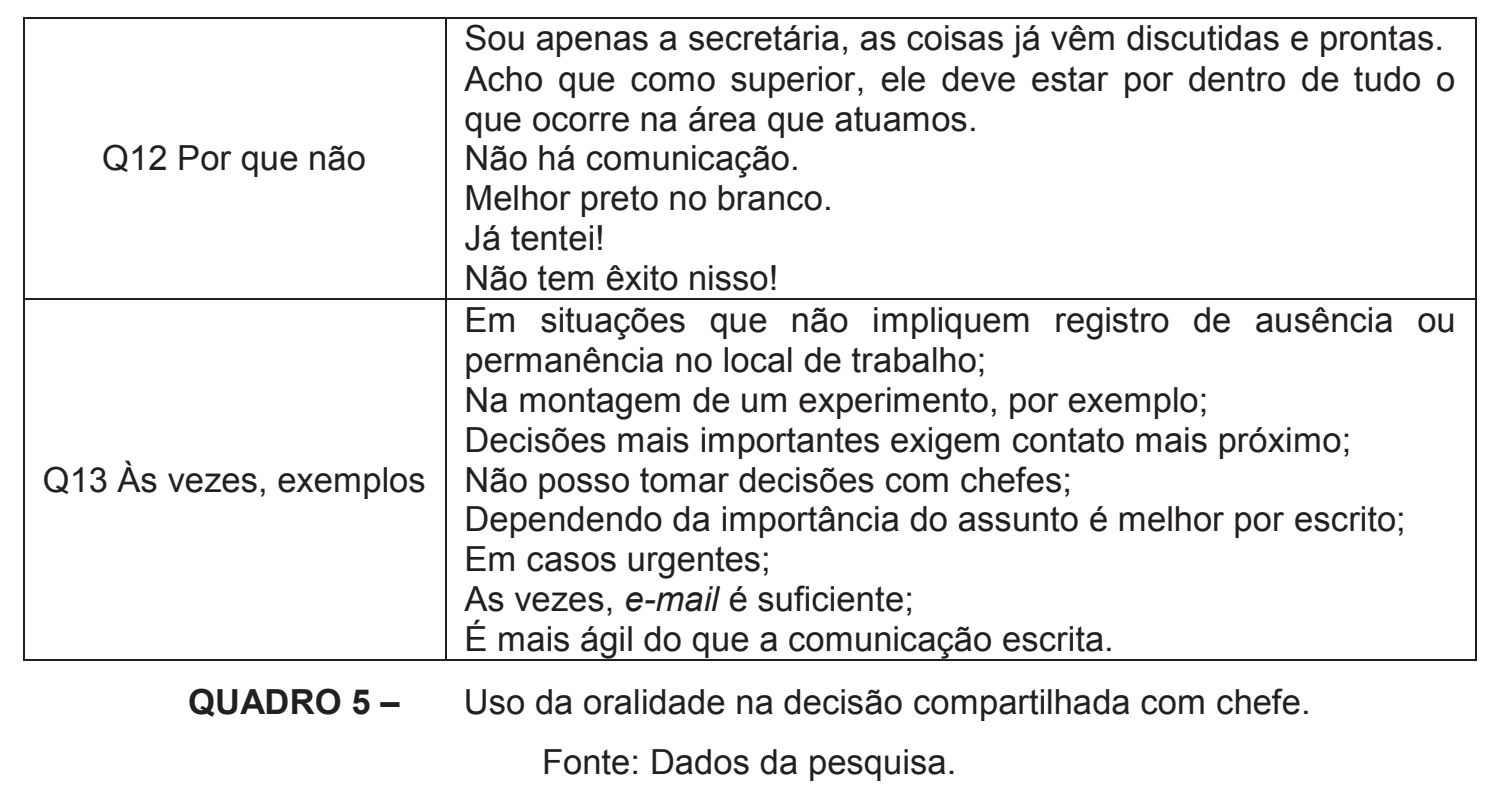

\subsubsection{Uso do diálogo}

Os empregados da Embrapa Soja analisaram situações internas nas quais eles consideravam indispensável o diálogo ocorrer entre todos os níveis na empresa. As respostas referiram-se às questões 17 e 18 (Q17 e Q18) que solicitavam exemplos de situações em que a oralidade era indispensável entre chefes de todos os níveis e empregados. Os respondentes citaram conjunturas cuja ênfase era no diálogo como estratégia de relacionamento e de gestão. Os dados analisados são os apresentados a seguir:

1) O diálogo criava expectativas, comprometimento e responsabilidade das partes envolvidas;

2) Era indispensável em situações que necessitavam de argumentação direta, discussão de ideias e negociação;

3) O diálogo em situações de conflito atua para não haver empregados insatisfeitos e chefes insatisfeitos; 
4) Quando havia mudanças de normas ou regras internas, o diálogo era a estratégia mais acertada, mesmo que haja outras formas de divulgação;

5) Indispensável quando algum outro tipo de comunicação não surtiu efeito;

6) Situações que exigiam decisões em curto prazo;

7) Dialogar sempre que a comunicação não pudesse ser mal interpretada.

A análise acima reafirmou que a hipótese um $(\mathrm{H} 1)$ foi refutada, pois a empresa destacava a oralidade na sua comunicação interna. Segundo o que revelaram os pesquisados sobre o uso do diálogo em todos os níveis da empresa, pode-se aferir que os gestores reconheciam o valor estratégico da oralidade para a comunicação interna e, assim, as questões 17 e 18 confirmaram a hipótese seis $(\mathrm{H} 6)$.

A questão 19 (Q19), de formato dicotômico, perguntava se o local ou ambiente onde ocorria o diálogo tinha influência na qualidade da comunicação realizada e obteve $51 \%$ de respostas positivas. A esses 82 respondentes que equivaleram a $51 \%$ de respostas positivas sobre o local interferir na qualidade da comunicação, foi perguntado na questão 20 (Q20) por que haviam respondido afirmativamente ao enunciado da questão 19. Por meio das respostas dadas à questão 20 (Q20), os empregados justificaram que locais ou ambientes formais escolhidos para a comunicação pressupunham temas severos para serem conversados e predispunham o interlocutor imediatamente. O diálogo foi mencionado como facilitador para que dúvidas não prevalecessem na comunicação e para preservar a privacidade dos interlocutores quando a situação fosse sigilosa ou com potencial para ocorrerem melindres.

A questão relacional também foi mencionada pelos que registraram que o diálogo amenizava a frieza das comunicações sobre trabalho. Condições ambientais como a presença de ruídos sonoros, más condições de higiene, presença de pessoas sem intimidade com o assunto pautado, foram outras barreiras citadas nas respostas à questão 20 (Q20). Um respondente da mesma questão 20 observou que "se falamos ao telefone, por exemplo, não há presença física, então não há o 'olho no olho' dos interlocutores". De acordo com os dados obtidos com as questões 19 e 20, pode ser dito que, ao contrário do que supunha a hipótese cinco (H5), a necessidade de resgatar a oralidade para os relacionamentos da empresa com os públicos não foi confirmada, exatamente porque este era um modelo de 
comunicação que jamais deixou de ter relevância nas práticas relacionais internas da Embrapa Soja.

Uma interrogação apresentada no instrumento de coleta (Apêndice C) foi a respeito do tipo de comunicação que o empregado usava para solicitar ao supervisor conselhos sobre como o trabalho poderia ser feito de maneira mais eficaz. As respostas estão graficamente representadas abaixo:

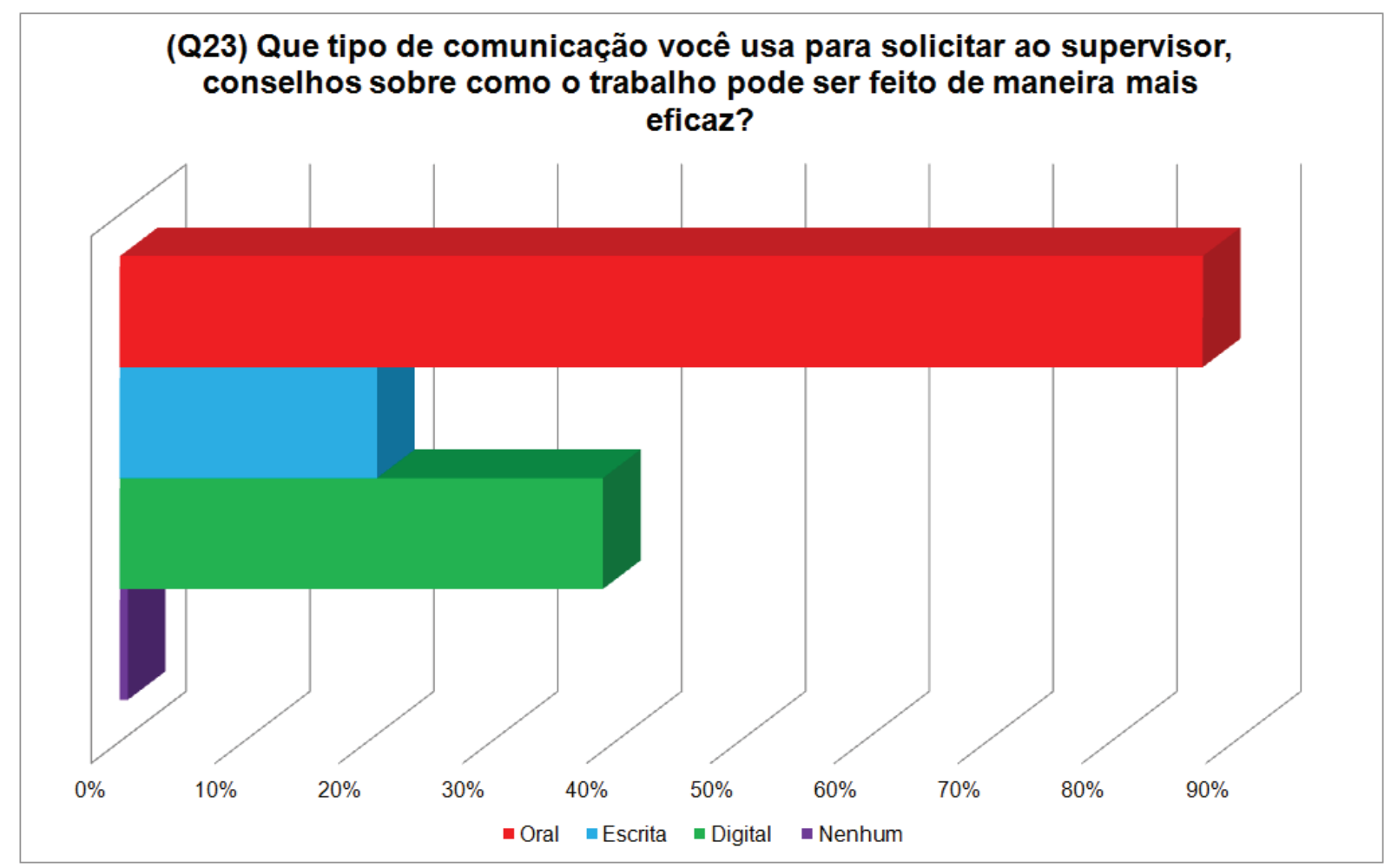

GRÁFICO 4 - Informação sobre tipo de comunicação para melhorar o trabalho.

Fonte: Dados da pesquisa.

A quase totalidade de respondentes elegeu a comunicação oral, pois a opção recebeu 144 marcações, entre os 159 questionários válidos para a análise, como pode ser observado no Gráfico 4. Os dados do Gráfico 4 expuseram alguma contradição com as informações contidas no Quadro 4 onde se observa que os meios eletrônicos de comunicação foram enfatizados no sistema interno da Embrapa Soja. A comunicação interna vinha sendo efetuada sobre plataformas distintas da comunicação oral, a qual os empregados afirmaram apreciar (Gráfico 4). As estratégias de comunicação interna (Quadro 4) mostraram-se contrapostas às inferências dos empregados. Ainda que os objetivos dos atores comunicacionais sejam distintos, note-se que a preferência por meios orais revelava um procedimento 
muito preciso adotado pelos empregados, conforme revelaram os dados do Gráfico 4. As informações confrontadas demonstraram que o sistema de comunicação interna da unidade de Soja não privilegiava meios apontados como de maior aceitação pelo público alvo.

Avançou-se para levantar do empregado quais instrumentos de comunicação o superior usava para abordar questões internas sobre o trabalho da equipe. As respostas estão demonstradas no Gráfico 5.

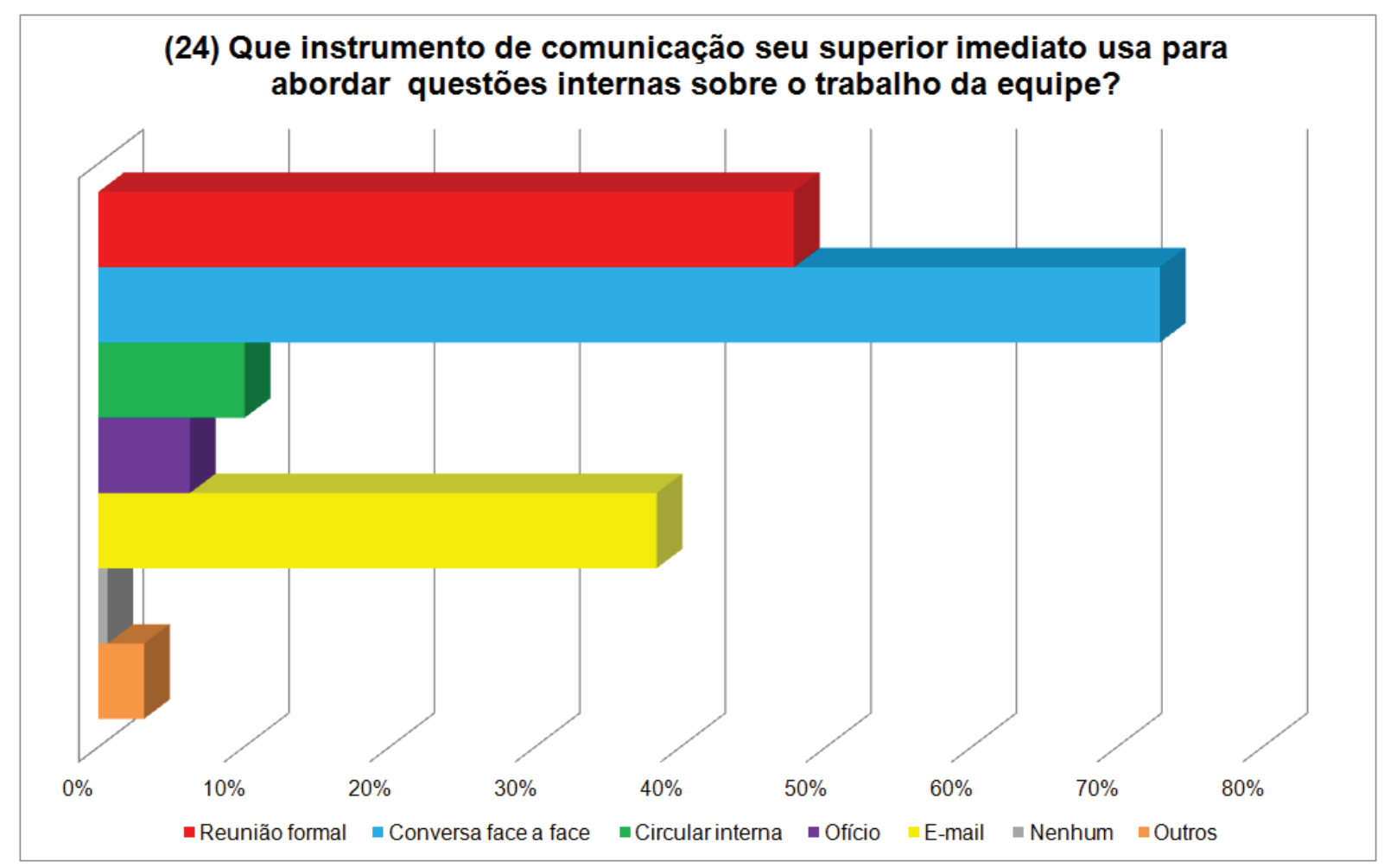

GRÁFICO 5 - Informação sobre meio de comunicação para melhorar o trabalho.

Fonte: Dados da pesquisa.

Apurou-se que $49 \%$ dos respondentes assinalaram a reunião formal e $74 \%$ marcaram a conversa face a face como os meios usados pelos supervisores para se reportar às suas equipes, conforme o que se vê no Gráfico 5. Observe-se que o bloco analisado revelou que os assuntos mais relevantes circulavam internamente na empresa por meio da comunicação oral, tomando-se por base a validade que o retorno alcançado conferiu aos dados. A partir desse ponto passa-se a apresentar e a analisar as perguntas do questionário (Apêndice $C$ ), cujas respostas estavam distribuídas em escala de concordância e discordância e que receberam tratamento de análise distinto, conforme explicado abaixo. 
A concepção dos gráficos a seguir, que embasaram essa análise, aconteceu a partir da atribuição de um valor numérico correspondente a cada resposta do questionário: discordo totalmente 1; discordo 2; não tenho certeza 3 ; concordo 4; concordo totalmente 5. Dessa maneira, obteve-se a moda e a média para os blocos de questões.

A moda representava a resposta cuja frequência era a maior. Tratouse de um dado estatístico importante para avaliar qual era a resposta mais representativa de todo o conjunto. A média, diferentemente da moda, leva em consideração a variação ao longo de todo o corpo de respostas. Isso significa que a média é influenciada pela dispersão das respostas. Significa dizer que é possível que duas questões tenham a mesma moda (resposta com maior frequência), mas médias diferentes (a média sendo maior devido à presença relativamente de mais respostas positivas e a média sendo menor devido ao acúmulo de mais respostas negativas).

A partir desses dados, foram construídos dois tipos de gráficos. $O$ primeiro, de argolas, indica a relação entre a moda e a média, considerando apenas o conjunto de questões em cada bloco. O segundo, estilo radar, revela a tendência de discordância, concordância ou neutralidade a respeito de cada questão. A opção por este tipo de gráfico se deu por representar visualmente de maneira objetiva a disposição das respostas, sendo que a tendência ao lado esquerdo indica concordância, ao lado direito revela discordância e, a posição acima mostra a neutralidade do respondente.

\begin{tabular}{|c|l|}
\hline Categoria & \multicolumn{1}{c|}{ Resultados } \\
\hline Masculino & Nenhuma diferença relevante. \\
\hline Feminino & Nenhuma diferença relevante. \\
\hline 21 a 30 anos & Nenhuma diferença relevante. \\
\hline 31 a 40 anos & Nenhuma diferença relevante. \\
\hline 41 a 50 anos & Nenhuma diferença relevante. \\
\hline 51 a 60 anos & Nenhuma diferença relevante. \\
\hline Mais de 60 anos & Poucos dados (8 respondentes). \\
\hline Ensino fundamental & Poucos dados (10 respondentes). \\
\hline Ensino médio & Nenhuma diferença relevante. \\
\hline Ensino superior & Nenhuma diferença relevante. \\
\hline
\end{tabular}

QUADRO 6 - Resumo dos achados dos gráficos segmentados por perfil. Fonte: Dados da pesquisa. 
Ou seja, ao mesmo tempo em que permite identificar a moda, este gráfico também revela a dispersão, característica influenciadora da média.Cabe ressaltar que foram feitas análises segmentadas segundo o perfil dos respondentes para que houvesse a possibilidade de discutir eventuais divergências. Assim, fez-se todo o conjunto de gráficos radar com a seguinte segmentação: gêneros masculino e feminino; faixa etária de 21 a 30 anos, de 31 a 40 anos, de 41 a 50 anos, de 51 a 60 anos e mais de 60 anos; escolaridade com ensino fundamental completo, ensino médio completo e ensino superior completo. A síntese dos gráficos está presente no quadro acima, Quadro 6.

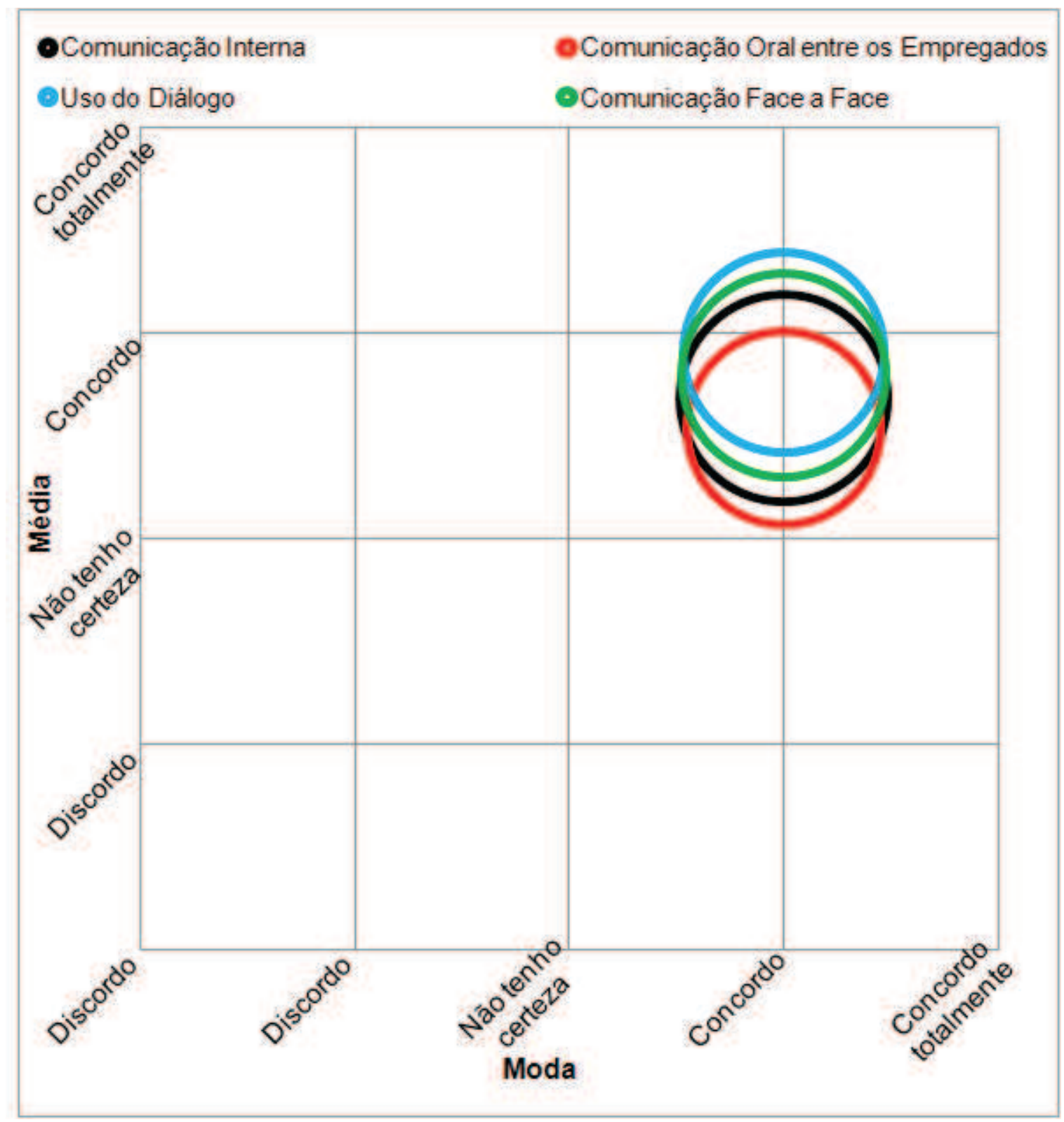

GRÁFICO 6 - Relação entre a moda e a média encontradas para cada bloco de questões. Fonte: Dados da pesquisa. 
O Gráfico 6 apresenta a relação obtida entre a moda e a média em cada bloco de questões. O tamanho de cada argola representa a frequência de respostas que a moda recebeu em cada bloco. Ou seja, quanto maior a argola, significa dizer que o bloco obteve relativamente mais respostas na moda. Mostra, por meio da ilustração em argolas, que a concentração de respostas se deu num quadrante em que se reúnem as posturas de concordância. Há quase que uma disposição concêntrica, o que ainda realça mais o fato de que os assuntos a elas ligados são vistos de modo convergente. A intersecção no centro é larga e aberta, o que representa uma significativa parcela da distribuição. Pode-se dizer que essa área, no centro da ilustração, refere-se a um grande número de respondentes. $\mathrm{A}$ relação obtida entre a moda e a média em cada bloco de questões, conforme o que é apresentado no Gráfico 6, reforçou a confirmação das hipóteses três, quatro e seis (H3, H4 e H6), pois expõe a aprovação dos entrevistados pelo uso da oralidade, do diálogo e das interações face a face no sistema de comunicação interna da Embrapa Soja. O critério de análise ainda convergiu para se recusar as hipóteses um e dois (H1 e H2), cuja proposição era de que a oralidade não seria uma forma comunicacional valorizada na empresa. Mais um reforço ocorreu, pois a hipótese cinco (H5), que supunha a necessidade de resgatar a oralidade, também foi negada porque essa última não havia perdido sua relevância nos processos internos da organização estudada.

Embora o gráfico apresente, de maneira geral, o reforço positivo de concordância em todos os blocos estudados, fez-se necessário aprofundar a análise em cada categoria, a fim de se observar o comportamento dos respondentes ao longo do preenchimento das questões.

\subsubsection{Comunicação interna}

Levando-se em conta dados levantados na categoria comunicação interna, construiu-se o Gráfico 7, que revela o comportamento predominantemente em concordância com as proposições do questionário. Os números dispostos nos eixos referem-se à quantidade média de respostas dentro do bloco. 


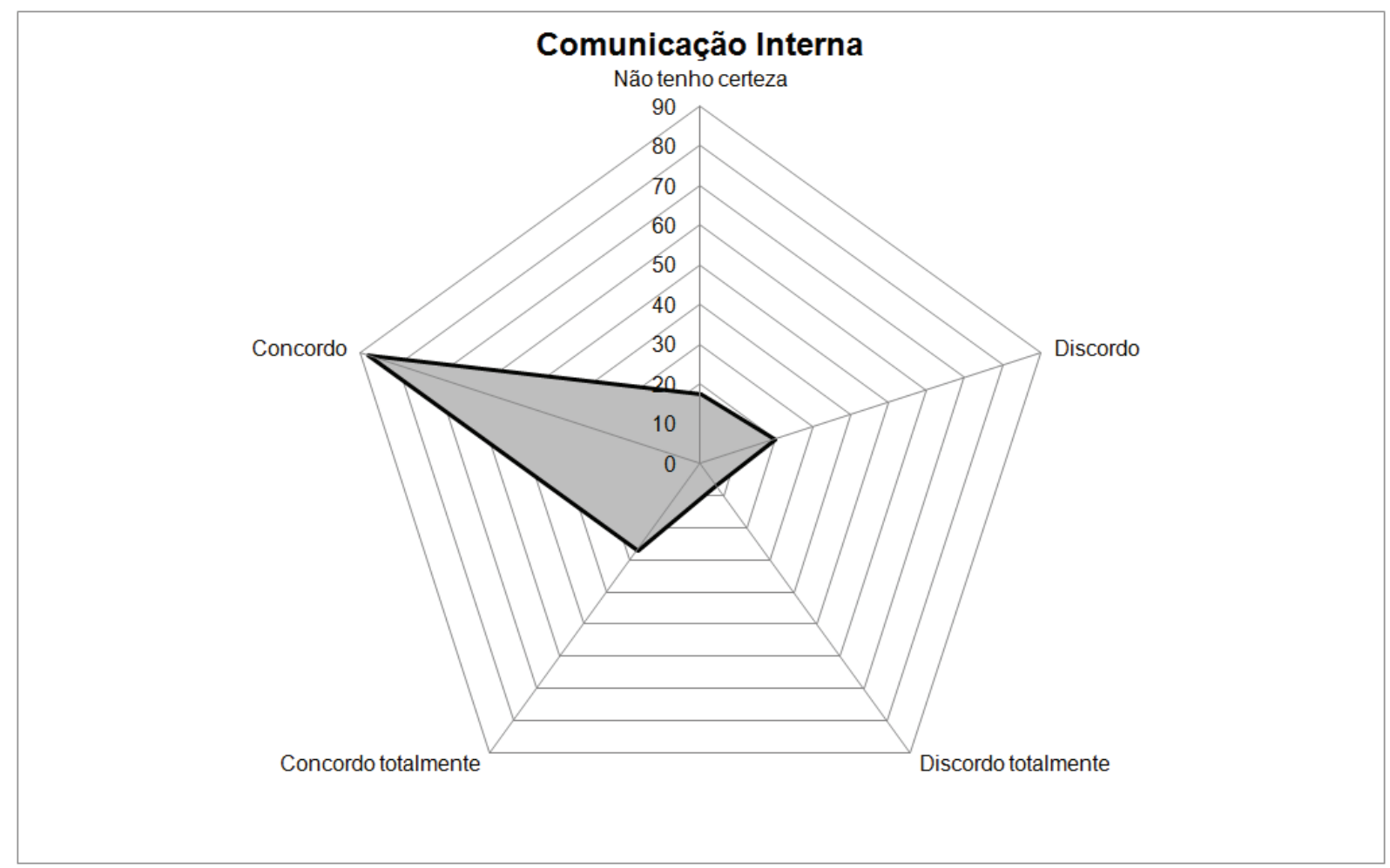

GRÁFICO 7 - Composição com o agrupamento das respostas para comunicação interna. Fonte: Dados da pesquisa.

O Gráfico 7 refere-se à somatória das respostas em todo o bloco de questões voltadas ao eixo comunicação interna consideradas na sua elaboração. $\mathrm{Na}$ região sombreada concentra-se a soma das respostas e pode-se perceber uma forte inclinação para a esquerda - lado da postura de concordância. Há uma discreta penetração da figura para a direita, lado da discordância. O que se depreende da figura formada é a dominância da posição concordo e também uma acentuada inclinação para baixo, em direção à postura concordo totalmente. O desenho é revelador e permite inferência nas hipóteses levantadas neste estudo. A expressão da imagem constitui uma metáfora ao conceito de radar, e a escolha do formato para representar os dados dessa modalidade na pesquisa é um modo de associação com a ideia de que se buscou captar o fenômeno na forma como faz um radar, como um "rastreamento". 


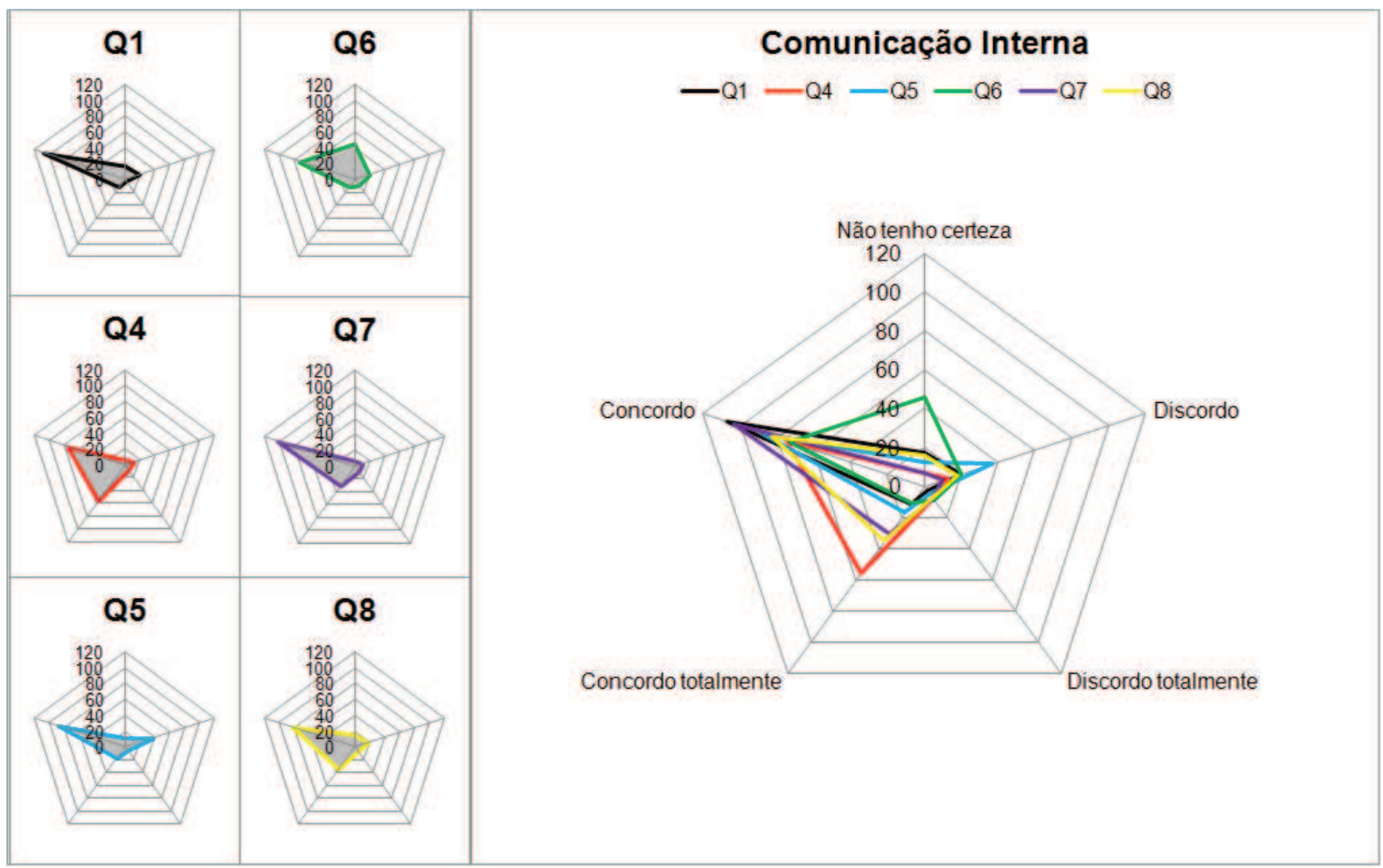

GRÁFICO 8 - Acoplamento das distribuições de respostas em comunicação interna.

Fonte: Dados da pesquisa.

O Gráfico 8 dá um outro ângulo de observação à distribuição dos dados, porque não representa unicamente somatória. Ele desdobra e detalha, em sua parte esquerda, o desenho formado em cada apuração individual de respostas dentro do bloco. Na parte direita, é mostrada, em um único desenho, a sobreposição de todos os desenhos que, na porção esquerda, aparecem particularizados questão por questão. Forma-se, agora, um conjunto único e acoplado de respostas pertencentes ao bloco "Comunicação interna". Obtém-se, portanto, uma visão de detalhe e uma visão de conjunto. O mesmo processo será repetido nas demonstrações dos demais blocos.

É notável a semelhança, retomando o bloco até agora discutido, do desenho formado e no qual se encontra a inclinação para a posição de concordo. $O$ esquema apresentado no desenho maior demonstra gráfica e visualmente as tendências de respostas válidas para as questões um, quatro, cinco, seis, sete e oito, conforme o Quadro 7. 


\begin{tabular}{|l|l|}
\hline Q1 & $\begin{array}{l}\text { A comunicação que encontro no ambiente de trabalho me empolga e me motiva a dar o meu } \\
\text { melhor desempenho na empresa. }\end{array}$ \\
\hline Q4 & Meu superior imediato me mantém informado sobre todos os assuntos de nosso setor. \\
\hline Q5 & $\begin{array}{l}\text { A comunicação e a divulgação interna dos eventos e das atividades dos diversos setores são } \\
\text { conhecidas por todos os empregados na empresa. }\end{array}$ \\
\hline Q6 & $\begin{array}{l}\text { Meu superior imediato segue o estilo da comunicação interna definida em manual pela } \\
\text { empresa para se comunicar com os subordinados. }\end{array}$ \\
\hline Q7 & $\begin{array}{l}\text { O relacionamento entre o superior imediato e os subordinados dentro do meu setor é } \\
\text { considerado. }\end{array}$ \\
\hline Q8 & $\begin{array}{l}\text { Meu superior imediato estimula cada membro da equipe/setor a dar contribuição e a realizar } \\
\text { o seu melhor dentro da empresa. }\end{array}$ \\
\hline
\end{tabular}

QUADRO 7 - Relação de questões referentes ao bloco comunicação interna.

Fonte: Elaborado pela autora.

A forma de apresentação das respostas na porção à direita no Gráfico 8 dimensiona a tendência e comportamento orgânico das afirmações feitas pelos entrevistados e, de maneira geral, reforça a tendência de respostas positivas para todas as questões, em detrimento das repostas negativas, que tiveram baixos indicativos de incidência de resposta.

De maneira específica, a primeira questão (Q1) é a que apresenta o vértice mais agudo em torno do eixo "concordo", absorvendo 107 respostas válidas. É importante observar também que, reflexo desse predomínio de respostas, houve pouca dispersão para os demais eixos do gráfico.

Em continuidade, a quarta pergunta (Q4) apresenta o maior alargamento e distribuição de respostas por mais de um eixo principal. Contudo, essa polarização aconteceu apenas entre os eixos de concordância. Em outras palavras, esta é a questão em que houve maior certeza acerca da concordância plena dos termos presentes (56 respostas em "concordo totalmente").

$\mathrm{O}$ quinto questionamento (Q5), assim como o primeiro, centralizou a maioria das repostas no eixo "concordo". Entretanto, cabe aqui destacar uma observação relevante: trata-se da questão que apresentou o maior espalhamento para a direita, revelando a maior discordância dentro deste bloco (37 respostas em "discordo"). Ressalte-se, no entanto, que embora registrada essa tendência, ela é discreta, se comparada ao formato da figura como um todo.

A análise da questão seis (Q6) apresenta outra peculiaridade, na medida em que há grande dispersão para o eixo neutro (46 respostas em "não tenho 
certeza"). Ainda assim, a moda, identificada pelo eixo de maior frequência, ficou assentada sobre "concordo".

Por fim, tanto a questão sete (Q7), quanto a questão oito (Q8), apresentam comportamento semelhante a Q1, com os vértices se deslocando para a esquerda, revelando o predomínio de concordância.

\subsubsection{Comunicação oral entre os empregados}

Levando-se em conta todos os dados apresentados e os esquemas gráficos individuais na primeira tabela desse bloco de questões, demonstra-se, a seguir, o Gráfico $9 \mathrm{com}$ as respostas agrupadas que repetem quase a mesma tendência no Gráfico 7, exceto por um acréscimo, embora um pouco mais dilatado, porém ainda mantendo-se discreto para o quadrante da posição discordo.

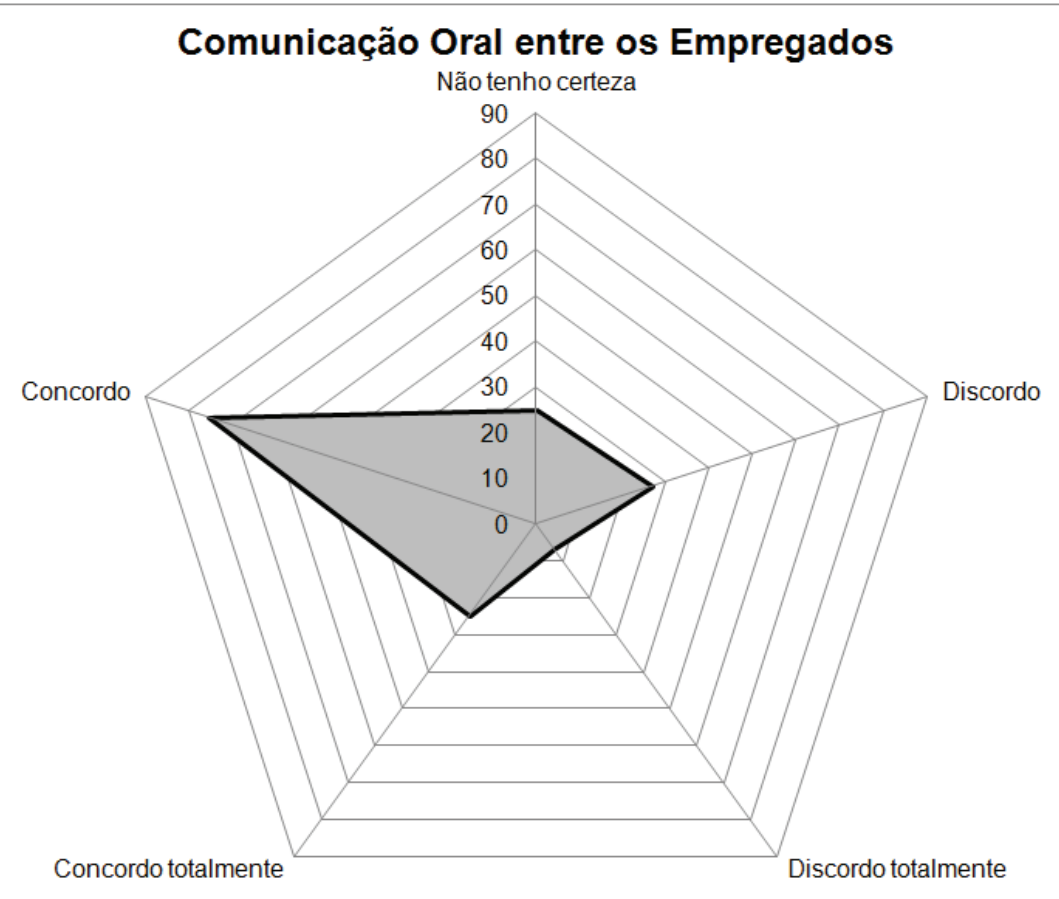

GRÁFICO 9 - Composição com o agrupamento das respostas para comunicação oral entre os empregados.

Fonte: Dados da pesquisa. 


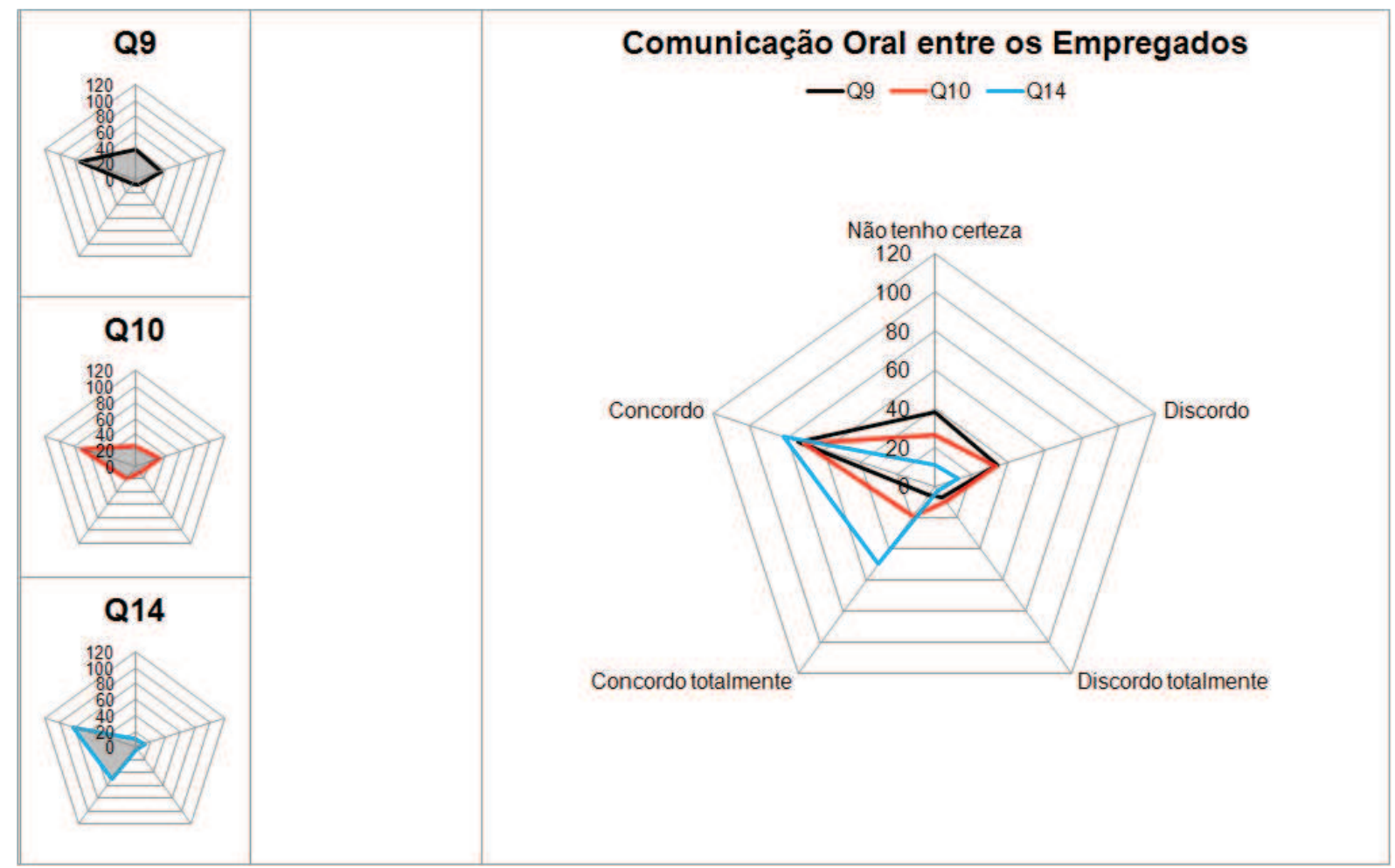

GRÁFICO 10 - Acoplamento das distribuições de respostas em comunicação oral entre os empregados.

Fonte: Dados da pesquisa.

O esquema estatístico representado pelo gráfico 10 expressa visualmente as respostas válidas dadas pelos sujeitos que responderam às questões nove, 10 e 14, conforme quadro descritivo abaixo. A parte à esquerda do Gráfico 10 revela o comportamento individual das respostas ao longo do bloco Comunicação Oral entre os Empregados. A composição desses desenhos menores é mostrada na porção direita do Gráfico 10, sendo possível a comparação do conjunto de respostas dentro de uma mesma escala visual.

\begin{tabular}{|c|l|}
\hline Q9 & $\begin{array}{l}\text { No processo de comunicação interna da Unidade, eu consigo identificar, de modo claro, as } \\
\text { recomendações para que seja utilizada a comunicação oral entre chefes, supervisores e } \\
\text { empregados da equipe. }\end{array}$ \\
\hline Q10 & $\begin{array}{l}\text { Existem e estão claras para mim, no meu local de trabalho, barreiras para o uso da } \\
\text { comunicação oral entre chefes, supervisores e empregados. }\end{array}$ \\
\hline Q14 & $\begin{array}{l}\text { A linguagem que meu superior imediato usa é compreendida por todos os empregados do } \\
\text { setor. }\end{array}$ \\
\hline
\end{tabular}

QUADRO 8 - Relação de questões referentes ao bloco comunicação oral entre os empregados. Fonte: Elaborado pela autora 
A forma como as respostas estão apresentadas no gráfico expressa a dimensão da tendência e o comportamento orgânico das afirmações feitas pelos entrevistados. Observe-se pelo que mostra o gráfico 10 que, de maneira geral, a tendência é para respostas positivas em todas as questões, expressando a desvantagem das repostas negativas, que receberam menores indicativos de incidência de resposta.

De maneira específica, a nona questão (Q9), primeira pergunta deste segundo bloco de questionamentos, apresenta duas informações relevantes para a análise dos resultados. A primeira delas é o maior apontamento de assertivas no eixo 4, que recebeu 74 marcações na alternativa "concordo". A segunda informação é uma polarização entre os eixos dois, "discordo" com 34 respostas assinaladas, e eixo três, "neutro" assinalado por 38 empregados, portanto, a segunda resposta mais indicada.

Já a questão 10 (Q10), demonstrada no esquema gráfico, apresenta quase a mesma organização visual de sua pergunta precedente, com uma leve diferença: um maior índice de respostas no eixo cinco, "concordo totalmente". De maneira geral, centralização no eixo quatro que recebeu 71 indicações na alternativa "concordo".

Como última questão do segundo bloco, a pergunta 14 (Q14) demonstra visualmente que suas respostas tiveram, aproximadamente, indicações equivalentes, o que, visualmente, demonstra-nos uma polarização entre os eixos quatro e cinco, "concordo" e "concordo totalmente", respectivamente.

\subsubsection{Uso do diálogo}

Considerando-se a junção dos dados em análise e os esquemas gráficos individuais na primeira tabela apresentada neste bloco de questões, repetese a demonstração visual por meio de um gráfico (G8) que abrange, em um único esquema, todas as respostas obtidas.

$\mathrm{Na}$ região sombreada do Gráfico 11 percebe-se a expressiva inclinação para a esquerda, reforçando a tendência para o lado da postura de concordância. Uma discreta penetração da figura para a direita, que é o lado da discordância, pode ser observado na representação gráfica. O que se depreende da 
figura formada é a dominância da posição concordo e também uma acentuada inclinação para baixo, em direção à postura concordo totalmente.

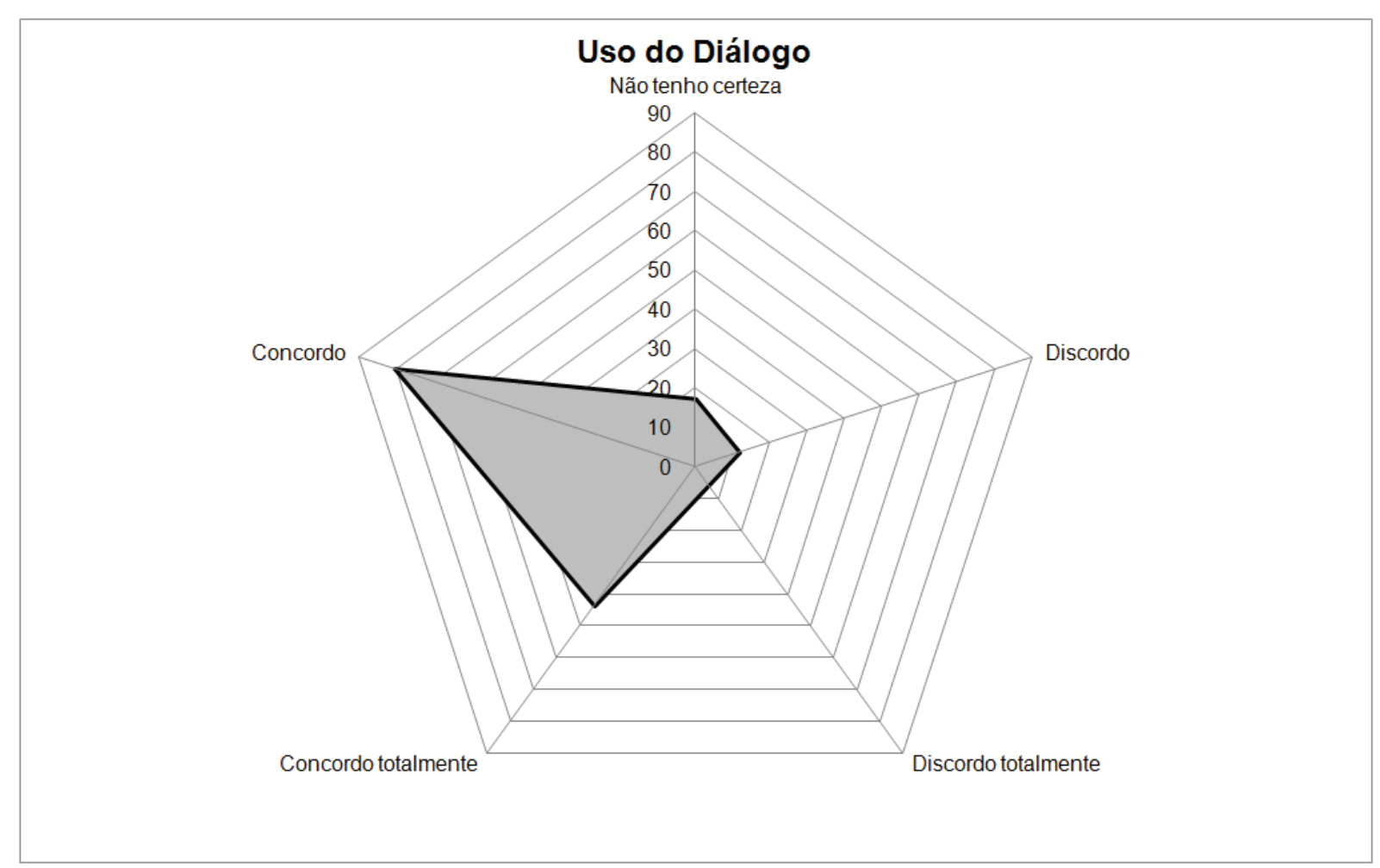

GRÁFICO 11 - Composição com o agrupamento das respostas para uso do diálogo.

Fonte: Dados da pesquisa.

O esquema estatístico apresentado no Gráfico 12 refere-se às questões 15,16, 21e 22 que estão demonstradas gráfica e visualmente a partir das tendências de resposta dos questionários válidos. O Quadro 9 expõe os enunciados dos questionamentos procedidos aos empregados da Embrapa Soja.

\begin{tabular}{|l|l|}
\hline Q15 & Meu superior imediato dá abertura para o diálogo com os empregados da equipe. \\
\hline Q16 & $\begin{array}{l}\text { Há situações em que o diálogo é a forma de comunicação indispensável entre chefes de } \\
\text { todos os níveis de autoridade e empregados. }\end{array}$ \\
\hline Q21 & $\begin{array}{l}\text { Meu superior imediato ouve e acata o que seus subordinados relatam e sugerem para a sua } \\
\text { área na empresa. }\end{array}$ \\
\hline Q22 & $\begin{array}{l}\text { Eu tenho autonomia para propor ao meu superior imediato melhorias na execução de meu } \\
\text { trabalho. }\end{array}$ \\
\hline
\end{tabular}

QUADRO 9 - Relação de questões referentes ao bloco uso do diálogo.

Fonte: Elaborado pela autora. 


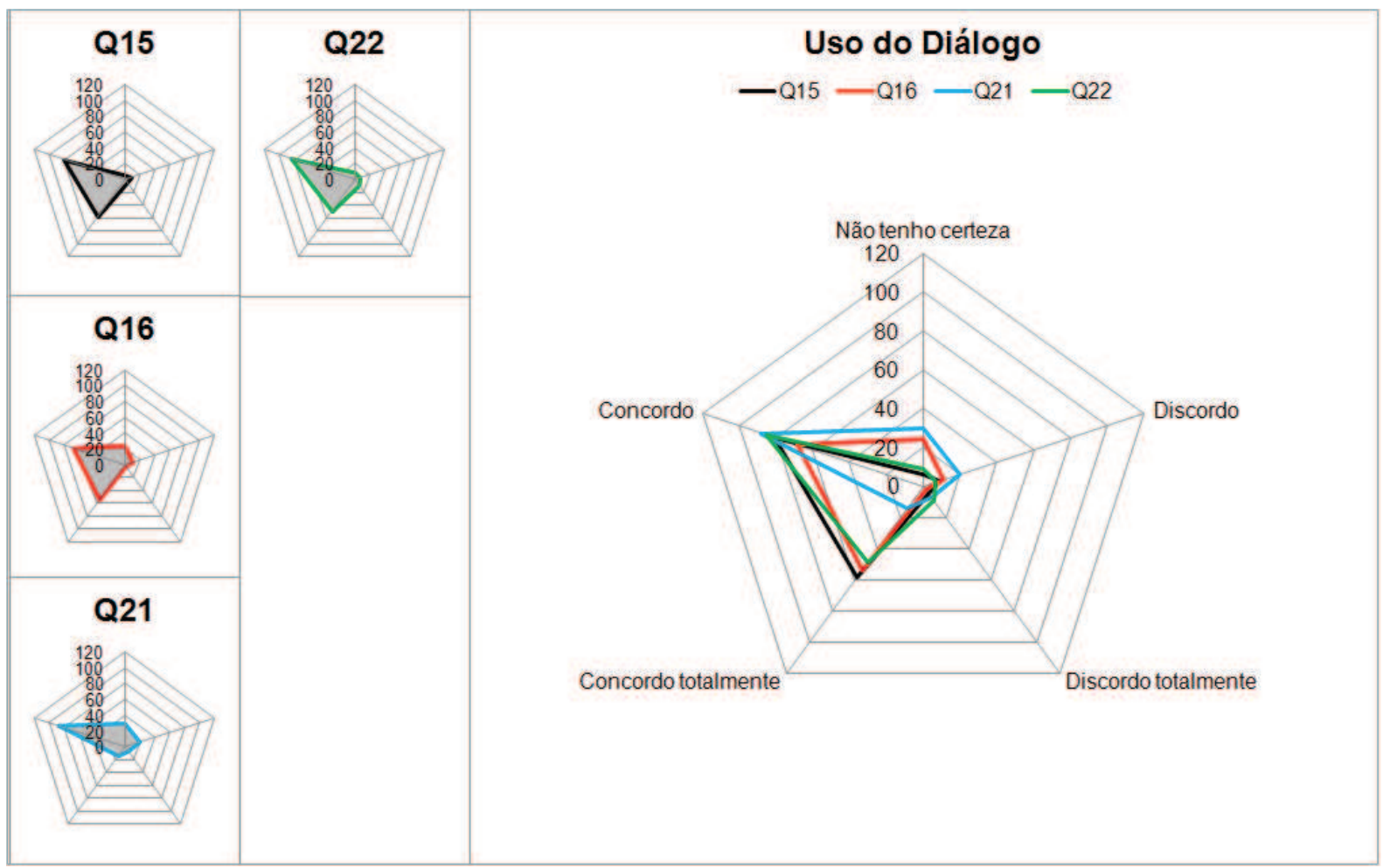

GRÁFICO 12 - Acoplamento das distribuições de respostas em uso do diálogo.

Fonte: Dados da pesquisa.

O Gráfico 12 demonstra, em sua porção esquerda, o resultado obtido pelo tratamento dos dados de forma individualizada para cada questão. $\mathrm{Na}$ parte direita, no desenho maior, é possível verificar a justaposição, numa mesma escala, de todos os efeitos obtidos na parte à esquerda do gráfico.

Apresentam-se os dados no Gráfico 12, no qual se visualiza a proporção de respostas positivas para todas as questões. Mais uma vez a incidência de respostas negativas apresentou indicativos baixos, comparadas às respostas positivas. De maneira especial, a primeira questão demonstrada (Q15) apresenta uma polarização significativa entre as respostas que indicam os eixos 4, "concordo", e 5, "concordo totalmente". Inclusive, importa ressaltar nesse quadro esquemático, que a questão 15 é a com maior indicativos de resposta no quinto eixo, de concordância completa, pois foi assinalada por 58 empregados respondentes.

Em continuidade, a segunda questão aqui descrita (Q16) apresenta a mesma polarização mostrada em Q15 (significativa entre as respostas que indicam os eixos quatro, "concordo", e eixo cinco, "concordo totalmente", mas com menor incidência nas respostas, incidência tal que foi contraposta por um desvio significativo em direção ao eixo três, "neutro". 
O terceiro questionamento deste bloco de questões (Q21) apresenta uma nítida prevalência de respostas na direção do eixo quatro, "concordo", e uma significativa percepção de equivalência, como segunda escolha entre os entrevistados, entre os eixos dois, três e cinco, que se referem respectivamente às opções "discordo" , "neutro" e "concordo totalmente".

Encerra o bloco de questões do Quadro 9, a questão 22 (Q22) convergindo a maioria de suas respostas no eixo quatro, "concordo", seguida de uma relevante indicação para o eixo cinco, "concordo totalmente", e um leve desvio para o eixo um "discordo totalmente".

\subsubsection{Comunicação face a face}

Levando-se em conta todos os dados apresentados e os esquemas gráficos individuais na primeira representação visual apresentada neste bloco de questões, apresenta-se, abaixo, o Gráfico 13 com as respostas agrupadas em um mesmo esquema visual.

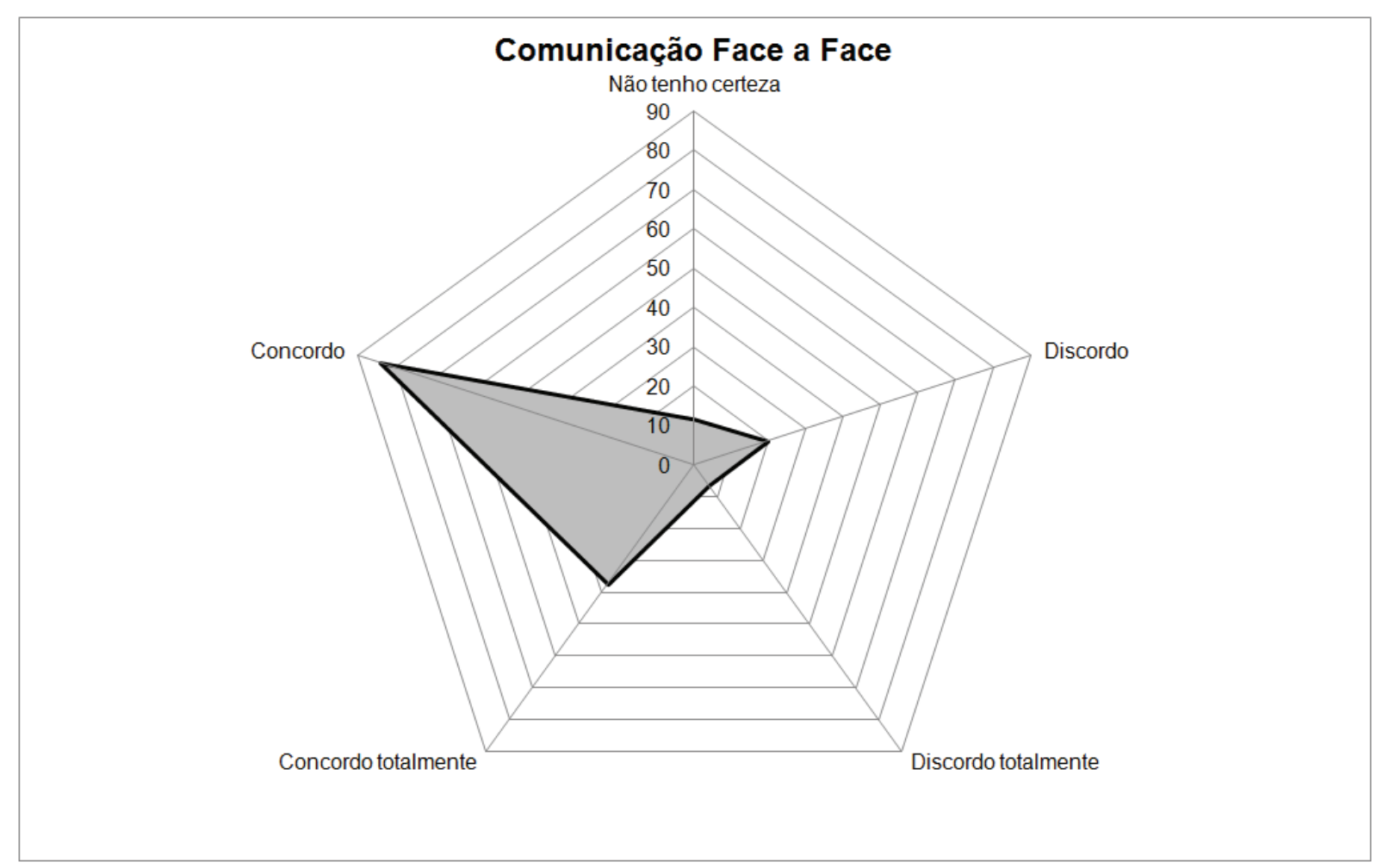

GRÁFICO 13 - Composição com o agrupamento das respostas para comunicação face a face. Fonte: Dados da pesquisa. 
Observa-se, no Gráfico 14, em sua porção esquerda, o efeito obtido pelas respostas para cada uma das questões integrantes do bloco "comunicação face a face". Ao realizar a sobreposição dos desenhos menores, é possível comparar e analisar o efeito conjunto das respostas, efeito mostrado num desenho maior presente na porção direita do gráfico.

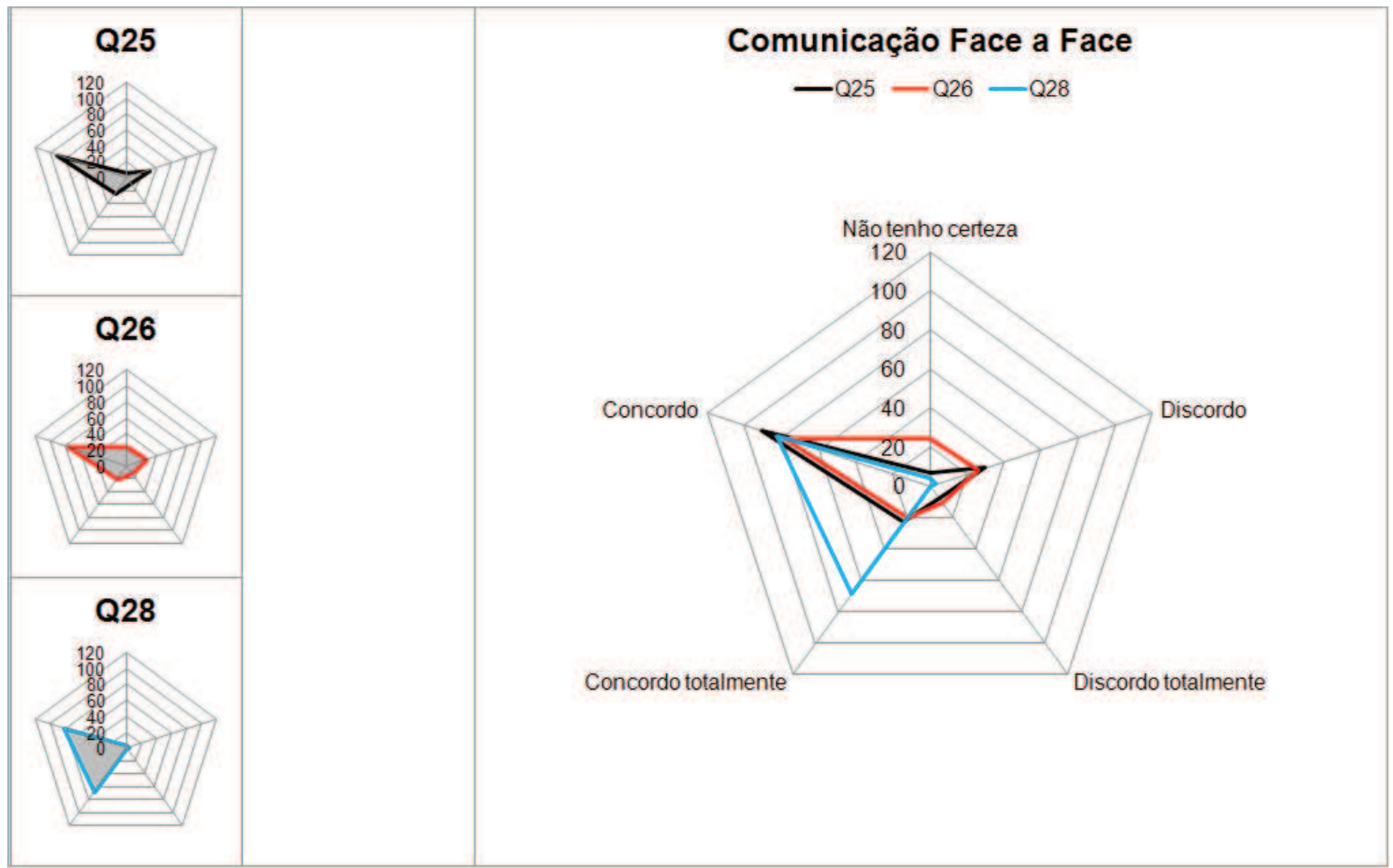

GRÁFICO 14 - Acoplamento das distribuições de respostas em comunicação face a face.

Fonte: Dados da pesquisa.

O esquema estatístico (Gráfico 14) demonstra gráfica e visualmente as tendências de resposta dos questionários válidos para as questões 25, 26 e 28, conforme Quadro 10.

\begin{tabular}{|l|l|}
\hline Q25 & Meu superior imediato discute face a face comigo ações para melhorar o meu desempenho. \\
\hline Q26 & $\begin{array}{l}\text { Meu superior imediato encoraja os empregados a se expressarem face a face e fornece, } \\
\text { com franqueza, suas opiniões sobre o estilo dele de liderar. }\end{array}$ \\
\hline Q28 & $\begin{array}{l}\text { Que importância você atribui ao uso da comunicação oral (fala), do diálogo e da } \\
\text { comunicação face a face entre chefes e equipes na empresa? }\end{array}$ \\
\hline
\end{tabular}

QUADRO 10 - Relação de questões referentes ao bloco comunicação face a face.

Fonte: Elaborado pela autora. 
Ao observar as representações isoladas das questões do bloco "comunicação face a face", percebe-se mais uma vez a tendência e comportamento orgânico das afirmações feitas pelos entrevistados. O reforço às respostas positivas foi preservado e prevaleceu sobre as baixas indicações ocorridas de repostas negativas.

De maneira especial, a primeira questão demonstrada (Q25) apresenta uma intensa incidência de respostas no eixo 4, "concordo", com um leve desvio para o eixo número cinco, "concordo totalmente", e, inclusive, uma significativa quantidade de resposta no eixo dois, "discordo", o que deforma o esquema visual em direção ao lado direito do gráfico.

A segunda questão aqui demonstrada (Q26) apresenta a mesma incidência prioritária de respostas no eixo quatro, "concordo", com uma diferença da questão antecessora. Ela apresenta, se a leitura visual tiver como referência o centro do gráfico, um abaulamento significativo, demonstrando que todos os outros eixos receberam, aproximadamente, a mesma quantidade de respostas nos questionários válidos.

O terceiro e último questionamento deste quarto bloco de questões (Q28), apresenta uma nítida polarização, com prevalência de respostas na direção do eixo quatro, "concordo", e significativa percepção de equivalência, como segunda escolha entre os entrevistados, para o eixo cinco, "concordo totalmente". Interessante ainda notar a mínima deformação gráfica sofrida em outros eixos, o que revela a quase unanimidade positiva dessa questão.

\subsection{Análise Triangular da Pesquisa}

A comunicação interna em sua característica de uso da oralidade definida como objeto deste estudo, mostrou-se abrangente e complexa em sua essência. Somou-se a isso a decisão por um locus empírico não menos abrangente, pois a Embrapa Soja representa um universo elitizado, movido por uma performance de produção de ciência e tecnologias agropecuárias. A comunicação interna, como ambiente comunicacional, pressupõe a vivência de pessoas em organizações. As inter-relações entre pessoas são movidas por objetivos particulares que carregam em seu interior possibilidades para que agentes interajam diretamente entre si, ainda que este seja um evento involuntário e que esteja interiorizado na cultura da 
empresa, conforme analisa Goffman (2011) e que ficou provado por esta tese. Salienta Mumby (2010) que grande parcela da existência de uma pessoa acontece atrelada fortemente ao seu ambiente de trabalho, então, este deveria ser um espaço associado às sensações de prazer e ao crescimento profissional e particular. O diálogo entre os autores estudados e as estratégias de pesquisa se harmonizaram em um conceito plural de métodos e foram recursos essenciais para fundamentar a discussão do corpus obtido. A combinação de métodos adotada na pesquisa será, aqui, metodologicamente integrada e analisada mediante a triangulação de métodos e de dados.

O escopo do estudo foi averiguar como a oralidade produzia impactos para resgatar e fortalecer o diálogo entre dirigentes, gestores e equipes de empregados e se este seria o modo para sua precipitação ao campo das estratégias da comunicação interna. Os dados apresentados foram capazes de apontar que a oralidade estava fortemente articulada ao estilo como a gestão era praticada na Embrapa Soja. A unidade podia ser conceitualmente definida como empresa humanizada, pois acomodava a comunicação como o lugar "[...] da fala, da interação e do conhecimento, levando as pessoas ao desenvolvimento humano e de suas competências profissionais", conforme Marchiori, (2010, p. 139) e se revelou na análise de dados apresentada. Os dirigentes e supervisores da empresa assumiram que conduziam suas equipes interagindo diretamente com seus liderados e que a fala era o componente para exprimir seus pensamentos para planejar e tomar decisões internamente. O respeito que norteava a conduta de relacionamento interno foi analisado nos conceitos de linha e fachada definidos por Goffman (2011), coexistindo com uma hierarquia administrativamente predominante.

A fim de que não se produza uma concepção errônea dessa ligação, pois o termo fachada, no emprego que recebe no ambiente brasileiro pode vir a ensejar uma conotação diversa, inclusive pejorativa (algo de fachada, noção de falso), cabe lembrar que o termo de Goffman, no texto original em inglês, é face. $\mathrm{Na}$ realidade, é um elemento da expressão face-to-face. Uma vez que a comunicação face a face é fulcral na discussão desta análise e a contribuição de Goffman é essencial, será adotada a tradução livre para face, ao invés de fachada. Assim, se buscará compreender os processos de simbolização que ocorrem no momento em que as pessoas estão em presença umas das outras (noção de copresença). Essa copresença, o autor entendia como aquela que se dá, seja em estruturas 
organizadas como trabalho, escola, igreja, ou em situações circunstanciais (interações temporárias) como casamentos, incidentes, encontros de grupo. Utilizase, portanto, face sem o compromisso de manter fidelidade à tradução brasileira pelas razões acima explicadas.

A noção de face indica o sentido de "o lado que se via", ou lado que se mostrava. Reações involuntárias dos atores sociais em momentos de interações, equivalem ao conceito de linha, defendido por Goffman (2011), como os atos verbais e não verbais manifestados durante esses eventos. Esse é, portanto, o sentido que se dá às menções à linha inseridas nessa análise. A face mostrou-se no momento em que as falas dos informantes tornaram evidente qual imagem aprovada pelos empregados, os dirigentes e supervisores ocupavam. Ou seja, compreendendo a dinâmica produzida pela projeção dessa imagem aprovada (funcionando como linha para compor a face desses líderes), é possível afirmar o marcante papel da oralidade na comunicação face a face em seu efeito de transmitir subjetivamente a competência e a eficácia na gestão de pessoas.

Ocorriam, no locus empírico, relações entre pessoas socialmente iguais dentro do contexto organizacional, mas que eram alvo de um fluxo comunicacional descendente. Essa configuração compunha a linha, da qual os participantes extrairiam as condutas para compor a fachada. Em sua fala, os líderes tornaram evidente que essas demandas eram sustentadas pelo diálogo direto e, eventualmente tinham seu conteúdo mediado por alguma tecnologia de suporte. Os informantes também ilustraram, na prática, a linha defendida como atos verbais e não verbais aplicados na ocorrência de interações entre agentes organizacionais. A linha desempenhada pelos dirigentes e supervisores independia da sua vontade particular, pois eram seus atos comunicacionais que falavam por eles. Essa característica é um registro marcante quando observado no grupo dos líderes por meio do valor social positivo da imagem que exibiam e que lhes permitia estar confiantes e convictos da conformidade de sua posição de líder em sintonia com a posição dos liderados. O depoimento dos líderes confirmou que a estrutura da fala e as relações travadas entre os atores da comunicação face a face, atreladas ao zelo com a face dos outros participantes, só puderam exercer influência sobre os resultados operacionais do respectivo setor na empresa. Isso porque a oralidade, aplicada rotineiramente no ambiente interno, atingira uma densidade alta o suficiente para tornar-se um meio que materializava o relacionamento. 
Ainda, a postura dos líderes da Embrapa Soja confirmou o discurso de Mumby (2010, p. 27) de que “[...] nosso sentido de identidade está 'sujeito a' (isto é, vulnerável a) uma atração de possibilidades discursivas que desafiam quem nós somos". A maneira como os sujeitos investigados mostraram desempenhar seus cargos de liderança expôs sua habilidade para compreender o funcionamento da oralidade junto às suas equipes de empregados. Este é um desafio que, conforme acentuou Mumby (2010, p. 27), transcende a noção de desenvoltura para alcançar a competência, pois a comunicação concebida como "[...] intersecção dialética de possibilidades e horizontes experimentais" articulava os dirigentes, supervisores e empregados da Embrapa Soja no cumprimento de suas funções. Defendeu-se a expectativa acerca da especialidade do líder para influenciar e conseguir bons resultados organizacionais, pois sugeriu Passadori (2003) que o líder seria um ator social capaz de polarizar valores e aprendizagem e os conectar à capacidade, aos dons e talento de suas equipes. Constatou-se, pelo que se inferiu do corpus, que a oralidade na comunicação interna caracterizava uma forma de aprendizagem, pois foi confirmado que o diálogo entre os atores de uma organização atingia proporções e adquiria contornos que sugeriam uma aprendizagem contínua entre as partes, particularmente pelo desenho que a comunicação oral traçava para as relações internas.

A oralidade sempre precedeu todas as formas de transmitir conhecimento humano, ao longo de épocas remotas. Se, por um lado, consideram alguns que subjugar a tecnologia na comunicação organizacional seja um desleixo, parece também um desleixo que o uso da comunicação oral entre atores sociais brasileiros seja desvinculado desta que é uma cultura de acentuada oralidade. Omissão de grande impacto seria, pois, desprender a oralidade dos estudos organizacionais que, na visão da pesquisadora, está imersa na responsabilidade científica das relações públicas. A presença da tecnologia nos processos internos e externos está posta e bem acolhida, porém as questões humanas é que precisam urgentemente figurar nos níveis mais elevados de discussão gerencial -, e isto poderá ser possível a partir de uma abordagem dialógica da academia com o mercado de trabalho. "Mais do que de máquinas, precisamos de humanidade. Mais do que de inteligência, precisamos de afeição e doçura. Sem essas virtudes, a vida 
será de violência e tudo será perdido"14. Apurou-se que a realidade organizacional brasileira não difere do que se encontra em organizações norte-americanas e britânicas, onde os empregados "[...] valorizam a comunicação face a face acima de qualquer outro canal, principalmente quando ela parte de seu próprio superior" (PRADO, 2009, p. 80). A oralidade tende a estar vinculada a essa prática tanto lá como aqui, mas no ambiente deste país, pela característica informal de seu povo, o cientista da administração necessita ficar atento ao fato de que oralidade é tema central e as formas que assume são de difícil sistematização: daí o permanente objetivo de mantê-la sob a mira dos projetos de pesquisa institucionalizados.

Desde a coleta de dados deste estudo, podia ser afirmado que a população alvo manifestou nitidamente a preferência pelas interações face a face em todas as etapas. Nesse caso, conforme terminologia de Goffman (2011), a face conduz o emissor a identificar reações de seus interlocutores que desencadeiam nele sentimentos de frustração, surpresa ou insucesso. Isso ela faz porque é em seu interior que se localiza a definição de que a imagem de uma pessoa é algo que não se aloja dentro ou sobre seu corpo, mas de natureza difusa proveniente do fluxo de eventos. Ela se torna manifesta somente quando os eventos são interpretados no que neles está expresso - e a face expressa o que é proveniente da linha: reconhecimentos, reverências, regras que são absorvidas como obrigações e expectativas quanto ao modo de agir. Tratava-se aqui de compreender como apareciam em face os elementos de linha que davam procedência à agilidade para obter feedback por meio de interações face a face e que mostraram os informantes da pesquisa sobre o modo como viam a absorção de regras em seu caráter interpessoal.

Kunsch (2010, p. 43) afirmou que a análise da comunicação nas organizações tem como foco os significados que os atores compartilham nos "[...] relacionamentos interpessoais e grupais, valorizando as práticas comunicativas cotidianas e as interações nas suas mais diversas formas de manifestação e construção social". A presença da oralidade na Embrapa Soja foi registrada pelo uso da fala para conduzir diálogos, estimular a comunicação face a face e as interações. A oralidade foi narrada como meio para conduzir e para dar agilidade aos processos internos. O conjunto de conhecimento que ratifica a competência de um líder inclui

\footnotetext{
${ }^{14}$ CHAPLIN, O Último discurso, do filme O Grande Ditador. Disponível em <http://pensador.uol.com.br/charles_chaplin_poemas_sobre_a_vida/>. Acesso em: 07 set. 2012.
} 
sua habilidade para conduzir sua equipe a alcançar objetivos e metas organizacionais.

Na Embrapa Soja, foi constatado que desde sua concepção o plano da unidade era disseminado e negociado verbalmente com as equipes. $O$ processo culminava com reuniões coletivas para expor resultados da empresa e para avaliar sua performance, tanto no nível científico e tecnológico, quanto no de apoio para a produção técnico-científica no campo do agronegócio. De Goffman (2011) tem-se que, nas ocasiões de fala, é típico cada participante manifestar uma preocupação genuína consigo e com o outro. A aplicabilidade desta recomendação para os dirigentes e supervisores da empresa refletia no seu merecimento do respeito das equipes e na aprovação de suas faces ou imagens. O sistema de avaliação da empresa foi mencionado como uma "incubadora" de conflitos, e que nesse caso, havia o mérito de os dirigentes e supervisores mostrarem-se muito hábeis para estimular as relações interpessoais com seus subordinados diretos. Estes últimos propagavam os efeitos dessa iniciativa em um comportamento grupal. Novamente aqui foi possível colher evidências do que disse o texto de Goffman (2011) sobre a prática cotidiana, pois os informantes confirmaram que mais do que respeito próprio, o respeito ao outro era condição para que cada empregado da empresa desempenhasse seu papel. Tendo esse aspecto como elemento de linha, tornou-se possível avistar, pela expressão que assumia na face, que o uso da oralidade na comunicação era amplamente disseminado entre todos os empregados da empresa, e comprovava que o diálogo, a interação face a face e a comunicação oral eram estratégias relacionais impactantes no clima interno. Aqui, também, pode-se inferir que as relações humanas se mostraram vigorosas e não se encontraram vulnerabilizadas diante da presença ou ausência das mais avançadas tecnologias.

O nível intermediário de liderança no locus pesquisado refletiu o mesmo estilo de gestão dos dirigentes da empresa. A relação linha-face (imagem dos supervisores e seus atos verbais e não verbais) confirma que cargos diretivos têm sido delegados aos que tenham habilidade para gerir relacionamentos interpessoais, para dialogar e para estimular o diálogo com os outros. O gestor inábil para interatuar com questões desta natureza não terá perfil para cumprir a atribuição de desenvolver sua habilidade de comunicação. É evidente, pois, que a organização se encarregava de assegurar esta como uma variável incondicional para associar resultados positivos à condução das equipes de empregados. Aqui se torna 
oportuno convocar mais uma vez o pensamento de Musa (1990), quando assevera que a comunicação oral é um procedimento estratégico que se associa diretamente ao desempenho de um dirigente de equipes e de organizações no presente. Recomenda-se a transposição da dinâmica da comunicação face a face para o nível mais estratégico de gestão. Política de comunicação nas empresas conjetura uma orientação para os relacionamentos internos, e esta foi mais uma constatação que a pesquisa empírica possibilitou.

A "Política de Comunicação" da Embrapa retratava tão nitidamente o objeto de estudo desta tese que sua versatilidade para manifestar-se pela comunicação oral e face a face esteve presente na quase totalidade das associações ensejadas pelo corpus analisado. O procedimento analítico concebeu apreender que a "Política de Comunicação" da Embrapa, criada em 1995, estava absorvida naturalmente no dia a dia da empresa. Esse foi um fenômeno, mencionado pelos empregados, que mostrou a política de tal modo introjetada na cultura da empresa, a ponto de dispensar o procedimento de consulta ao documento formal. Embora mostrassem dúvidas quando foram questionados sobre a "Política de Comunicação" (EMPRESA BRASILEIRA..., 2012b), os sujeitos inferiram por si mesmos que a cultura da empresa era oral. A maturidade do documento formal escrito que regulava a comunicação na empresa cumpria muito bem o papel de nutrir a linha e projetar-se pela via da oralidade, ganhando corpo na experiência adquirida por um grupo significativo de empregados. Tomou-se por base o perfil levantado que indicou a presença de sujeitos com alguns anos de exercício funcional na Embrapa Soja. Declarou um dirigente entrevistado a existência de um agrupamento antigo de pessoas que já vinha desempenhando suas funções, as quais tinham sido alocadas anteriormente à atual gestão. Os valores e as orientações sobre comunicação interna foram pragmatizados com as rotinas a ponto de a "Política de Comunicação" parecer camuflada para os dirigentes da empresa. Contrariamente, os empregados expressaram sua concordância sobre o uso da "Política de Comunicação" por seus superiores imediatos.

Confirmou-se, por outro lado, também a fala de Baldissera (2008, p. 155), de que "[...] a apreensão que se faz dos fenômenos é mediada pela linguagem e, portanto, não mais se trata do fenômeno em si, mas do fenômeno mediado/falado". O conjunto de inferências validou definitivamente a percepção sobre a cultura de comunicação da empresa existir e ter suas bases fortemente 
associadas na oralidade, conforme celebra a política, a prática e o discurso dos empregados embrapianos. Vale resgatar ainda Bazerman (2006, p. 26), ao afirmar que "[...] é claro que para nossas palavras realizarem seus atos, elas devem ser ditas pela pessoa certa, na situação certa, com o conjunto certo de compreensões". Confirmou-se, no corpus, a figura do líder como um agente comunicacional que valoriza o contato direto, a comunicação face a face e as interações com sua equipe de liderados. A "Política de Comunicação" da empresa foi um instrumento valioso para constatar que a oralidade é uma habilidade que projeta a competência do líder para conduzir equipes e alcançar escopos de comunicação interna, conforme um dos objetivos da pesquisa.

O valor do diálogo e das interações foi marcante nas inferências dos empregados que declararam apreciar exposição oral de seu líder imediato, pois confirmaram que a comunicação face a face era uma forma de interação que permitia adequações imediatas às necessidades, à linguagem e às condições do interlocutor. O líder que expõe oralmente suas ideias e projetos inspira o receptor a interpretar um discurso que é da organização para com seus stakeholders. Para o líder, a interação face a face expõe uma linguagem não verbal que traduz o feedback de sua comunicação e dá forma aos procedimentos a serem adotados na interlocução. No locus investigado, foi provado que o uso da comunicação oral era diretamente relacionado à relevância dos assuntos e que, quanto maior a proeminência dos assuntos, mais se recorria à argumentação direta, à discussão de ideias e à negociação. A oralidade para a comunicação interna é um fenômeno complexo impactado pelo conteúdo que o interlocutor compartilhará com seus pares. O teor de conhecimento de um líder racionaliza sua escolha por métodos e técnicas de comunicação que incitarão, bilateralmente, um salto de qualidade no exercício de seu cargo no sistema empresarial. 


\section{CONCLUSÕES}

Esta tese dimensionou a oralidade dentro do campo de conhecimento das Ciências da Comunicação como forma de firmar relações organizacionais internas, por meio do recorte fortemente concentrado em relatos descritivos das características do fenômeno estudado. A pesquisa quali-quantitativa assumiu uma natureza polissêmica, pois se amparou no estudo exploratório para que um novo olhar (re)interpretasse a palavra falada como fundamental às ações das pessoas nos territórios organizacionais. Os atores sociais têm, nas interações face a face, o nível mais básico e fundamental de relações mútuas, posto que a vida e as ações humanas são eminentemente sociais. Obteve-se segurança para afirmar que essas interações alcançam elevados patamares de relacionamento de gestores com suas equipes e provocam impactos na produtividade e na performance das organizações.

A comunicação é hoje multidirecional, seu caráter é dialógico e fundamentalmente interativo, pois reconhece e intensifica a participação das pessoas para cumprir uma de suas metas que é a transformação. No ambiente interno das organizações os empregados querem visualizar os valores da empresa sendo praticados rotineira e espontaneamente, como também requerem estar autorizados a dialogar com a organização e com seus atores internos e externos. Por valorizar as interações face a face, o indivíduo pós-moderno acolhe a oralidade como fonte valiosa para que a comunicação cumpra um papel efetivo nas suas experiências vividas em ambientes de trabalho. Compõe a rotina das equipes funcionais nas organizações produzir, compartilhar, reproduzir conhecimento e, portanto, situou-se o interesse nas manifestações e usos da fala, em particular na linguagem oral, porque esta é a maneira como se percebe a ênfase nas interações humanas. A problematização emergiu porque se observava a oralidade e os atos comunicacionais originados por meio da fala como componentes naturais de comunicação que, como tal, não podiam ficar ausentes dos estudos de comunicação organizacional. Considera-se, portanto, que este é um conhecimento tão necessário que não se tolerava que ficasse relegado a um plano secundário nas pesquisas desenvolvidas modernamente. 


\subsection{Abordagem às Hipóteses da Pesquisa}

A pluralidade de métodos e a amplitude dos dados fornecidos pelos sujeitos investigados na pesquisa empírica junto à empresa estatal selecionada, comprovaram que essa organização tinha suas rotinas fortemente assentadas na oralidade em múltiplos sentidos e com ela norteava a execução de suas práticas. Atentou-se para a possibilidade isso ter-se dado por causa da natureza da empresa, bem como de sua finalidade, características e pelo elevado nível de escolaridade predominante em seus empregados. Esses fatores tornaram inegável a relevância de adotar a oralidade como objeto de estudo científico para conhecer mais sobre ela, seu funcionamento e formas pelas quais se propaga e está presente nas esferas individual e coletiva. Foi também com reconhecimento da intensa presença de oralidade que os informantes se referiram à tomada de decisões e às razões que, em seu modo de ver, determinavam o posicionamento de destaque da empresa, na comunidade global. O contato da pesquisadora com esse aspecto tornou-a, portanto, convicta de negar-se a hipótese um (H1) que não considerava a oralidade como um componente a ser destacado na comunicação interna. Os empregados convidados a manifestar-se sustentaram com firmeza o fato de usarem a comunicação direta e as interações face a face sempre que se defrontavam com limites de conhecimento, de segurança ou quando se surpreendiam diante de fatos novos que lhes movessem a se reportarem aos seus superiores - sobretudo para buscar respostas e soluções, muitas vezes de modo coletivo.

O mesmo comportamento foi relatado pelos dirigentes e supervisores quando se referiam ao modo como conduziam e lidavam com rotinas, encaminhavam situações, davam curso a processos decisórios ou sobre como agiam nos momentos em que tinham de difundir, de modo inequívoco, para as diferentes equipes, as informações sobre o que devia ser implementado e todas as deliberações que afetavam a unidade como um todo. Essa coincidência de posições só pode ser reveladora - ou pelo menos, constitui evidência muito forte - de que na realidade noticiada pelos que faziam parte da empresa havia reconhecimento do diálogo como resultado de processo comunicacional. Isso refutou a hipótese dois $(\mathrm{H} 2)$ originalmente formulada antevendo relações dialógicas distantes de uma qualificação estratégica para a comunicação interna da empresa. Pode-se depreender, portanto, que negociações e comunicações de variados níveis que 
aconteçam por meio das interações dialógicas tornam possível afirmar sua capacidade de delinear os traços presentes na cultura de empresas que alcançam resultados compatíveis e coerentes com a performance avançada esperada por um cenário global de sociedade.

A estratégia qualitativa de pesquisa expôs que os líderes formais da empresa entendiam que quanto mais fluidos estivessem os fluxos comunicacionais, menos conflituosas seriam as relações internas e maior seria a produtividade de suas equipes. Essas relações foram produtos do volume acentuado de inferências de que a oralidade dá conta e do reconhecimento do esforço do supervisor para manter os empregados informados sobre tudo que dissesse respeito ao setor. Isso possibilitou afirmar que o uso da oralidade por aqueles líderes era uma inspiração para exercer uma influência que tivesse absorção pelas equipes e, assim, confirmouse a hipótese três $(\mathrm{H} 3)$ de que os líderes entrevistados no estudo empírico eram reconhecidos pela sua oralidade.

A análise do documento da "Política de Comunicação" da empresa e os achados desta pesquisa promoveram contato com a tradição de que a comunicação oral e as interações face a face eram praticadas amplamente na empresa. Pode ser percebido que as macro-orientações da empresa-sede foram tão absorvidas que, hoje, nota-se uma assimilação/apreensão perpetrada por esse fato desde o nível interpessoal de comunicação, até os fluxos descendentes de decisão e autoridade. Constatou-se, assim, a hipótese quatro $(\mathrm{H} 4)$ de que a oralidade era um método relevante desenvolvido pela comunicação interna da organização. O que isso revelou a respeito da comunicação face a face é que sua participação planejada na comunicação interna de uma empresa é uma forma de gestão que funciona sintonizada com a cultura brasileira. A empresa, assim orientada, respeita as tradições do povo latino-americano, pois está adaptada ao comportamento social de escutar e falar, tal como a ênfase maior desta sociedade atribui à forma de comunicação oral e diretamente colocada. Nossa cultura é de oralidade, e esta constrói a comunicação face a face na gestão interna, com muito maior presença e intensidade do que a forma escrita.

As lideranças entrevistadas utilizavam notadamente a oralidade como suporte para os relacionamentos intersetoriais da organização, embora admitissem a criatividade e a eficácia da comunicação interna da empresa com os empregados. Deste modo, a hipótese cinco $(\mathrm{H} 5)$ de que as lideranças teriam o 
anseio de resgatar a oralidade ficou anulada, pois esta era uma empresa na qual o diálogo e a comunicação face a face nunca perderam sua posição de destaque. $O$ que se verificou, portanto, nesse aspecto, foi que não faria sentido falar em resgates: o que se afirma com a refutação dessa hipótese é que o profissionalismo exigido para produzir frutos em comunicação não deriva de um plano formal que expressa, por si só, todo o discurso de uma empresa. Estudos organizacionais, hoje, abstraem um modelo de comunicações orientado para resultados, particularmente de sua origem em relacionamentos. Um modelo de comunicação assim reconhecido prescinde de estratégias para que a comunicação face a face ofereça indicativos para os atores fazerem aflorar, no discurso institucional, aquilo que devem falar, quais são os parceiros e demais públicos para quem debitem o desenvolvimento de suas interlocuções.

A oralidade que constrói comunicação face a face tem ainda a característica estratégica de sociabilizar o discurso comunicacional interno de uma organização. Deste modo, ainda se pode anunciar, com a convicção que somente um estudo científico permite, que gestores reconheceram, sim, o caráter estratégico da oralidade para a comunicação interna, conforme se levantou nesta tese a respeito da hipótese seis $(\mathrm{H} 6)$. Apenas reconhecer, no entanto, não é suficiente: é necessário saber como funciona essa oralidade, de que modo se integra e influencia resultados no panorama da cultura em que opera e no cenário global que persiste e avança nos dias de hoje. Antever o que os sujeitos pós-modernos precisam, certamente não pode focalizar o uso de tecnologias com total exclusividade.

A transição para uma nova ordem social representa, sem dúvida, uma redefinição de desígnios; contudo, jamais será tão arrasadora a ponto de arruinar ou modificar drasticamente toda uma cultura humana, sobretudo seu dia-adia e sua comunicação face a face. O que se almeja fazer entender é que nenhum avanço é capaz de interferir nesta natureza que mantém as interações face a face como as mais significativas experiências de socialização. Uma empresa de alto sucesso e prestígio, como a aqui estudada, certamente alcançou esse êxito porque não modificou esse quadro. Resta pensar no grau de consciência que possui dessa acertada decisão em seu ambiente de comunicação interna. Trata-se, na realidade, de mais trabalho para pesquisa, o que para essa organização não constitui dificuldade nenhuma por ser de sua própria natureza - e missão - realizá-la e apoiála. 


\subsection{Direcionamentos Alcançados à Luz dos Objetivos Propostos}

A reputação conferida ao universo pesquisado e a límpida identificação da presença da oralidade na sua cultura interna são elementos associados que se voltam para confirmar o alcance do objetivo colocado para a pesquisa de investigar o modo como a oralidade produz impactos para resgatar e fortalecer o diálogo entre líderes e empregados e para projetá-la ao campo das estratégias de comunicação interna. Reafirma-se a necessidade imperativa de orientar estrategicamente o relacionamento do gestor com suas equipes por meio das interações face a face. Distribuída pelo nível estratégico, esta orientação é um guia para abonar os argumentos discutidos no percurso teórico, metodológico e empírico desta tese. Provou-se que a oralidade é um instrumento de comunicação interna, cujo suporte tem caráter coletivo, pois não é uma atribuição associada, nem tem origem na hierarquia administrativa. Muito para além disso, a oralidade construtora da comunicação face a face é um contorno para criar comprometimento e para que cada ator organizacional adote individualmente responsabilidade com representações no desempenho global da equipe.

O objetivo de apurar como a oralidade era considerada na gestão da comunicação interna da organização estudada despertou, para um supervisor de equipe, o necessário estimulo ao aperfeiçoamento ou a ampliação de sua habilidade para comunicar com um grupo de liderados. O ambiente organizacional ressente-se na sua produtividade para o caso de grupos isolados que não compartilhem sua produção com a totalidade de empregados de uma empresa. A existência de um setor de comunicação é requisito para sua boa imagem, e este núcleo terá, dentre suas atribuições, a de erigir programas internos para inserir novos empregados, para estimular o funcionário a adquirir intimidade com a empresa e com seus pares ou, mais especificamente, para neutralizar possíveis desacoimas ocorridos porque os setores não dialogam entre si. O que se depreendeu do objetivo que foi alcançado é que o uso da oralidade é uma habilidade gerencial indispensável para conduzir equipes em empresas de elevada performance. A oralidade é, portanto, um elemento indissociável da estratégia de comunicação interna que impacta uma organização em seus ambientes interno e externo e, por isso merece, maior atenção dos gestores nas suas práticas cotidianas. 
Como o objetivo de analisar os impactos produzidos pela comunicação estabelecida através do diálogo entre líderes e liderados, pode-se depreender que a trajetória profissional de um líder é um percurso temporal, pois demanda tempo para que seu discurso seja acolhido como um reflexo de sua experiência e seja estabelecido como um valor apreciado pelas equipes. $\mathrm{O}$ diálogo de um gestor com sua equipe é embrionário da confiança que emerge destas interações e estas fortalecem relações de trabalho e de comunicação entre empregados de uma empresa. Investigaram-se características da oralidade que contribuíam para esclarecer sobre os objetivos da comunicação interna, e o escopo alcançado trouxe à dedução de que a oralidade caracteriza-se pela defesa à livre circulação de ideias, à participação dos empregados e à atribuição de valor a este modelo de comunicação. A inserção de tais características na prática organizacional deve ser destinada a enriquecer o fazer da comunicação interna e adotada como uma estratégia para humanizar o ambiente de trabalho. Identificou-se a fluidez das interações face a face como fator fundamental para a identificação de características relacionais internamente à organização.

A comunicação face a face, como constructo da oralidade, por si só congrega caráter estratégico de gestão no contexto da comunicação interna, como era objetivado verificar na pesquisa. $\mathrm{O}$ que revelaram os dados permitiu inferir que o gestor pós-moderno não é um autocrata que toma decisões solitárias. Hoje, o gestor expressa o respeito pela sua equipe por meio das interações face a face. O estudo aqui realizado permite afirmar que, atualmente, um dos mais importantes instrumentos de gestão, e que não deve ser subestimado, é a oralidade. Um fenômeno administrativo, assim planejado, direciona os atos de uma equipe para além do imaginário coletivo, porque é facultado a todos o direito de opinar sobre as questões organizacionais com base no domínio que o repertório de cada integrante da equipe agrupa no conhecimento construído acerca da função que executa no sistema empresarial.

Uma parcela significativa de empregados da organização pesquisada afirmou que seu superior imediato era sensível às interações face a face em situações variadas. Provou-se que este era um estilo de comunicação que tranquilizava o subordinado para acessar seu chefe, sempre que sentisse necessidade ou que fosse solicitado a fazê-lo. Do lado dos dirigentes e gestores, foi afirmado que a comunicação oral era, em muitos casos, recomendada para afinar o 
mais possível seu nível de comunicação com o das equipes e para afastar qualquer barreira ou distorção à mensagem. A coincidência entre o que disseram líderes e empregados em geral apontou a vocação para o uso da oralidade do líder para apurar sua visibilidade junto aos liderados. O objetivo traçado subsidiou a afirmação de que a oralidade expande-se sobremaneira sobre a gestão, cujo foco é o ativo mais elementar de uma empresa que são as pessoas que a impulsionam. Posto está que a visibilidade de um líder e a comunicação oral, como abordagem de gestão, são hoje exercícios atrelados.

O modo como a linguagem interferia na compreensão dos liderados sobre a competência de seu líder foi um ponto direcionado nesta tese. A pesquisa revelou que os interlocutores reagiam imediatamente ao estímulo comunicacional e que, nas interações face a face, essas reações eram avaliadas e (re)conduzidas com o mesmo imediatismo. A visão proporcionada pelo alcance deste objetivo é a precedência da comunicação oral para possibilitar perceber características particulares dos interlocutores, pois este conjunto de meios valoriza a comunicação e orienta o (re)ajuste do discurso a cada fato individual. Afirma-se, assim, que dialogar com pessoas implica analisar todas as formas de linguagem que possam facilitar o processo comunicacional, sem deixar de reconhecer que é forçoso admitir que quanto mais performático for o episódio de comunicação, mais amplo será o repertório de linguagens para transmitir o que se quer ou se precisa comunicar. A oralidade abarca um conjunto de linguagens que podem se valer do não verbal para (re)afirmar normativas, inclusive técnicas, para o elenco de empregados de uma empresa.

Mais um objetivo buscado foi o das características da oralidade que eram aplicadas na comunicação interna da empresa estudada. Identificou-se que o uso da oralidade viabilizava delimitar uma pauta de discussão que, em certos casos, era elaborada em caráter emergencial para atender às demandas da empresa. Esclareceu-se a defesa à livre circulação de ideias, à participação dos empregados e à atribuição de valor a este modelo de comunicação como características da oralidade que contribuíam com o compartilhamento de objetivos. Tratando-se de um objetivo pontual sobre o estudo empírico, pode-se afirmar que, na empresa estudada, a oralidade tinha como características a delimitação de um foco comunicacional, o imediatismo tanto temporal quando corretivo para o fenômeno da comunicação interna, a discussão coletiva das demandas internas que injetava 
dinâmica aos episódios interativos e a realimentação da informação que ocorria por via de comunicação oral, fenômeno que se mostrou comum no ambiente pesquisado.

\subsection{Equacionamentos Provocados}

Muitos foram os questionamentos preliminares levantados no projeto e no desenvolvimento do estudo. Surgiram assim, as respostas às perguntas que o estudo colocou como encadeadoras do esforço de pesquisa neste trabalho de tese:

Em que extensão se pode afirmar, no ambiente pesquisado, que a oralidade, entendida como construtora de comunicação face a face, é uma habilidade que projeta a competência do líder para conduzir equipes e alcançar objetivos de comunicação interna?

A oralidade inerente aos discursos diários dos sujeitos da pesquisa provou que gestores e empregados vivenciavam experimentos e conviviam com fenômenos comunicacionais impactantes nas rotinas internas, nos relacionamentos e no processo de gestão dos líderes com suas equipes de empregados. A disseminação dos objetivos, metas e resultados da empresa era direcionada à totalidade dos empregados e a comunicação oral prevalecia em rotinas e em momentos críticos da empresa. O que estava nos documentos escritos, estava também disseminado com grande eficácia na prática da oralidade do líder e sua equipe. Os resultados organizacionais são obtidos sem prejuízo de metas de uniformização e identidade porque não são os documentos os únicos responsáveis pelo sentido coletivo do que se produz. Está na dinâmica conferida pela oralidade desse relacionamento, uma significativa parcela de êxito. Daí seu valor de estudo como componente da comunicação interna.

O que se pode também afirmar é que uma comunicação interna, dimensionada no nível que se encontrou na empresa estudada revelou que a competência de líderes faculta o desempenho de um conjunto de habilidades, e que a inserção da pesquisadora acentuou ainda mais a percepção sobre o alcance dado ao uso da oralidade. Uma ênfase necessária é que a habilidade oral para construir comunicação face a face não é compreendida como pura eloquência retórica, mas 
sim, como competência relacional para a gestão interna. A comunicação interna deve ser uma plataforma de sociabilização que estimule o diálogo entre setores internos e promova o entendimento coletivo, a partir do conhecimento empreendido junto aos interlocutores.

Que características da oralidade identificada e descrita nesse ambiente podem ser absorvidas pela comunicação interna?

Os achados da pesquisa desenharam as linhas gerais para se indicar que a comunicação interna de uma empresa endosse as seguintes recomendações a todos os que administram:

- Impele a livre circulação de idéias;

- Estimula a participação de empregados;

- Atribui valor ao fazer dos empregados;

- Mantém foco nas pessoas e não em processos administrativos ou operacionais;

- Promove impactos na melhoria de processos, porém pela intervenção de pessoas;

- Seja dinâmico;

- Preenche um procedimento compatível com a estratégia de gestão;

- Avista a comunicação oral, não como meio, mas como um comportamento estratégico que deve ser adotado por dirigentes empresariais.

Em que medida essa mesma oralidade é capaz de restabelecer diálogo entre líder e sua equipe?

O que se encontrou foi que a oralidade, embora não se saiba com que grau de consciência existia entre seus participantes, era tradicional, administrativa e naturalmente empreendida no cotidiano da empresa. Sua capacidade e abrangência foram, portanto, dimensionadas para uma nova ordem, porém respeitando a natureza das relações que se estabelecem em ambientes de alta performance. A oralidade, hoje, preocupa-se em impulsionar o que já é 
estabelecido em termos de seu uso como fator de preservação da cultura, de humanização e de analogia com a reputação da empresa.

A comunicação face a face acelera a transferência de mensagens internas nessa organização?

A resposta é "sim", pois os fenômenos descritos pelos atores como favoráveis ao uso da comunicação face a face autorizaram afirmar positivamente nessa direção. Na empresa estudada, a comunicação face a face acelerava a tomada de decisão conforme as demandas rotineiras e era basilar para encaminhar e decidir sobre questões emergenciais. A linguagem verbal escrita era usada com maior realce internamente no registro formal de processos administrativos e operacionais.

A oralidade encontrada está sendo capaz de produzir reflexos na adequação de linguagem que, por sua vez, se projetam sobre a relação do líder com as equipes internas?

Tratava-se de um ambiente de sofisticadas tecnologias e de elevado conhecimento acadêmico/científico detido tanto por empregados como por suas chefias. Por estes motivos, identificou-se o reconhecimento dos gestores e dos empregados para o real interesse em escutar o que estivesse sendo dito e em aceitar o ponto de vista do outro como reflexos essenciais para amoldar linguagens. Foi constatada a necessidade imediata de motivar o receptor para a comunicação e apreender este fenômeno como precedente da adequação de linguagem.

Com esse conjunto de respostas obtidas e o vínculo destas com os objetivos de pesquisa, pretende-se que uma contribuição seja oferecida no sentido de enunciar propriedades da oralidade como construtora de comunicação face a face, um fenômeno organizacional que encoraja gestores e funcionários a investirem em mais investigação nesse campo das relações humanas e internas. Um estudo das relações organizacionais com o público interno, com base na capacidade inata de pessoas para dialogar com outros atores, está potencialmente vocacionado para se expandir rumo ao campo das estratégias de gestão e de comunicação interna e, 
ainda, para ser uma produção que se incorpore ao diálogo construído entre a academia e o ambiente de mercado. Tais propriedades seriam:

- A oralidade pode ser projetada em uma análise do tipo $\operatorname{swot}^{15}$ e figurar com destaque no campo das estratégias de comunicação interna em organizações. O uso da comunicação oral está diretamente associado à natureza das interlocuções e das interações entre atores sociais. Quanto mais fluidos os fluxos comunicacionais, menos conflituosas as relações internas;

- Os atores sociais têm nas interações face a face o nível mais fundamental de relações mútuas. Melhor desempenho nesse aspecto pode significar maior produtividade entre as equipes;

- A comunicação face a face é um modelo inerente ao processo de delegação de autoridade;

- Um supervisor de equipe necessita de estímulo permanente para aperfeiçoar e ampliar sua habilidade de comunicar com equipes de trabalho;

- A oralidade que constrói comunicação face a face tem como característica estratégica sociabilizar o discurso comunicacional interno de uma organização;

- A transição para uma nova ordem social representa uma redefinição de desígnios, contudo jamais tão arrasadora a ponto de arruinar toda uma cultura humana;

- O ambiente organizacional sofre impactos negativos em sua produtividade quando grupos se mantêm isolados por falta de integração com a forma de comunicação que difunde o que está sendo conseguido pela totalidade da empresa;

- A oralidade é uma habilidade de comunicação que impetra visibilidade ao líder junto aos liderados;

- A grandeza e a manutenção do prestígio de uma empresa podem ter relação direta com o nível de interações face a face ocorridas entre seus atores.

A comunicação interna é uma dentre outras áreas de estudo, e é evidente que não cabe apostar exclusivamente nela a solução de todos os problemas organizacionais. Está localizado dentro dela, no entanto, um vasto campo de estudo ensejado pela relação entre oralidade e comunicação face a face, com

\footnotetext{
${ }^{15}$ Termo em inglês para expressar a parte referente a pontos fortes e pontos fracos, ameaças e
} oportunidades de uma análise estratégica. Nesse estudo, importaram os fatores internos de análise. 
potencial de gerar descobertas surpreendentes, e o que é ainda melhor, produzir novos conhecimentos a respeito da inserção do homem no trabalho. Desafios de uma pesquisa são muitos, porém a convicção sobre a viabilidade de um estudo se mostra no momento de coletar dados. Essa etapa costuma produzir um choque "de contato" que entrava o pesquisador quando tenta, por todos os meios que define, cumprir seu plano de pesquisa. Esta não foi uma variável distinta no caso em foco, mas antes de ser descrita como dificuldade, vale mencionar que o processo de coleta foi mais confirmação do que obstáculo para a tese que se construía. Enquanto a abordagem aos sujeitos era realizada por plataformas tecnológicas, o retorno foi incipiente e, por vezes, incompleto. A partir da circulação direta da pesquisadora pelo espaço delimitado para a pesquisa, tudo se modificou: os retornos atingiram a quase totalidade, e os sujeitos se envolveram de modo interessado e pleno. Eis uma prova de que a comunicação face a face é um potente recurso até para falar de si mesma. A peculiaridade desse estudo empírico, marcada pela tipologia, natureza da empresa, pelas suas características e nível educacional dos funcionários, não permite generalizar que a questão da oralidade aconteça dessa forma em todas as empresas. Pode-se inferir que, um fenômeno complexo e polifônico não se traduz em generalização, mas está autorizado afirmar que esse é um fenômeno que precisa ser levado em conta pelas organizações, em geral.

A conclusão dessa tese está ilustrada na Figura 4 que apresenta as recomendações da pesquisadora a respeito das características da oralidade e das propriedades que o relacionamento entre líder e liderado pode adotar, no contexto da comunicação interna, em organizações pós-modernas. Fornece um mapa em que fica patenteado o raciocínio de pesquisa que encaminhou a proposição do estudo. Essa apresentação diagramática tem a finalidade, além de dar uma visão de conjunto, deixar implicado que todo conhecimento é evolutivo e as conclusões são sempre provisórias, cabendo os aspectos relacionais serem enriquecidos na replicação do método para estudos subsequentes.

Registra-se a compreensão de que, em ciência, nenhuma teoria encerra-se em si mesma, mas o estudo realizado, quer teórico, quer empírico, deixou constatada a necessidade de maior valorização da oralidade na comunicação interna das organizações. 


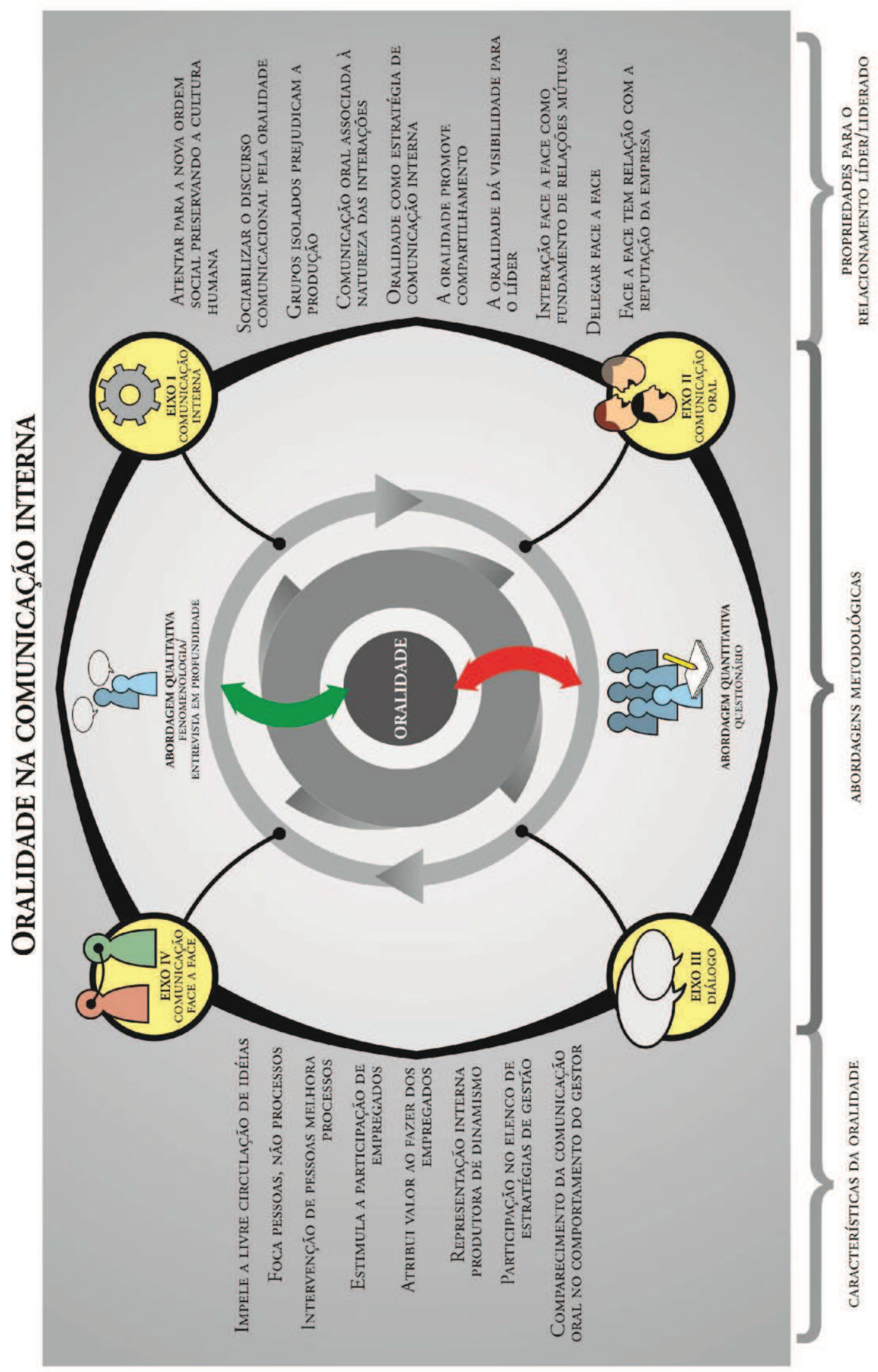

FIGURA 4 - Oralidade na comunicação interna - resultados da pesquisa.

Fonte: Elaborado pela autora. 


\section{REFERÊNCIAS BIBLIOGRÁFICAS}

ALVARENGA, Mônica. Sabemos conversar?: aprendendo com as rodas de conversa. Disponível em: <http://www.aberje.com.br/acervo_colunas_ver.asp?ID_C OLUNA=221\&ID_COLUNISTA=57>. Acesso em: 7 abr. $201 \overline{1}$.

ARAÚJO, Rodrigo. O que não pode faltar a um alto executivo: recrutadores priorizam capacidade de decisão e habilidade para se comunicar de forma convincente, explica sócio-diretor da Korn/Ferry. Portal EXAME. Disponível em: <http://portalexam e.abril.com.br/negocios/nao-pode-faltar-alto-executivo-477505.html>. Acesso em: 25 jun. 2009.

ARGENTI, Paul A. Comunicação Empresarial: a construção da identidade, imagem e reputação. Rio de Janeiro: Elsevier, 2006.

ARRUDA, Luciana. Linguagem: até que ponto existimos a partir do momento que falamos? Disponível em: <http://www.kplus.com.br/materia.asp?co=199\&rv=Literatur a>. Acesso em: 22 set. 2010.

AZEVEDO, Ricardo. Samba, improviso e oralidade. In: FERNANDES, Federico; LEITE, Eudes Fernando (Org.). Trânsitos da voz: estudos da oralidade e literatura. Londrina: EDUEL, 2012. p. 89-119.

BACCEGA, Maria Aparecida. Palavra e discurso: história e literatura. São Paulo, Ática, 1995.

BAITELLO JUNIOR, Norval. A mídia antes da máquina. Disponível em: <http://www. cisc.org.br/portal/pt/biblioteca/viewdownload/7-baitello-junior-norval/4-a-midia-antesda-maquina.html>. Acesso em: 6 jun. 2011a.

O tempo lento e o espaço nulo: mídia primária, secundária e terciária. Disponível em: <http://www.cisc.org.br/portal/pt/biblioteca/viewdownload/7-baitello-ju nior-norval/10-o-tempo-lento-e-o-espaco-nulo-midia-primaria-secundaria-e-terciaria.h tml>. Acesso em: 6 jun. 2011b.

BAKHTIN, Mikhail Mikhailovich. A interação verbal. In: Marxismo e filosofia da linguagem: problemas do método sociológico na ciência da linguagem. 3. ed. São Paulo: Hucitec, 1986. cap. 6, p. 110-127. . Problemas da poética de Dostoievski. Rio de Janeiro: Forense, 1981. 
BALDISSERA, Rudimar. Organizações como complexus de diálogos, subjetividades e significação. In: $\mathrm{KUNSCH}$, Margarida M. Krohling (Org.). A comunicação como fator de humanização das organizações. São Paulo: Difusão, 2010. p. 61-76.

Comunicação organizacional: uma reflexão possível a partir do paradigma da complexidade. In: OLIVEIRA, Ivone de Lourdes; SOARES, Ana Thereza Nogueira (Org.). Interfaces e tendências da comunicação no contexto das organizações. São Caetano do Sul: Difusão, 2008. p. 149-177.

BAUMAN, Zygmunt. Fronteiras do pensamento. Entrevista publicada em vídeo. Disponivel em: <http://www.youtube.com/watch?v=POZcBNo-D4A\&feature=share>. Acesso em: 8 maio 2012.

BAZERMAN, Charles. Gêneros textuais, tipificação e interação. 2. ed. São Paulo: Cortez, 2006.

BERGER, Peter L; LUCKMANN, Thomas. A construção social da realidade: tratado de sociologia do conhecimento. 21. ed. Petrópolis: Vozes, 2002.

BERWIG, Carla Anéte; GODOI, Elena; RIBEIRO, Anely. Mal-entendidos lingüísticos: a interface entre o poder e a polidez na comunicação organizacional. In: CONGRESSO BRASILEIRO CIENTÍFICO DE COMUNICAÇÃO ORGANIZACIONAL E RELAÇÕES PÚBLICAS, 2.,2008, Belo Horizonte. Anais eletrônicos. Belo Horizonte: Associação Brasileira de Pesquisadores de Comunicação organizacional e Relações públicas, 2008. Disponível em: <http://www.abrapcorp.org.br/anais2009/ pdf/GT4_Ribeiro_Guimaraes.pdf>. Acesso em: 8 out. 2010.

BETTI, Fábio; PARENTE, Carlos. Cursos Aberje. São Paulo: ABERJE, 2010. Material de apoio didático ao curso: A comunicação face a face no processo de transformação organizacional, ministrado em 19 ago. 2010.

BOHM, David. Diálogo: comunicação e redes de convivência. São Paulo: Palas Athena, 2005.

BURGO, Vanessa Hagemeyer; FERREIRA, Eduardo Francisco; STORTO, Letícia Jovelina (Org.). Análise de textos falados e escritos: aplicando teorias. Curitiba: CRV, 2011. 
CASALI, Adriana Machado; TAYLOR, James R. Comunicação: o olhar da "Escola de Montreal" sobre o fenômeno organizacional. In: MARCHIORI, Marlene Regina (Org.). Comunicação e organização: reflexões, processos e práticas. São Paulo: Difusão, 2010. p. 69-82.

CASALI, Adriana Machado. Comunicação organizacional: uma introdução à perspectiva da "Escola de Montreal". Estudos de Jornalismo e Relações Públicas, São Bernardo do Campo, ano 3, n. 6, p. 28-40, 2005.

CASTELLS, Manuel. A sociedade em rede - a era da informação: economia, sociedade e cultura. São Paulo: Paz e Terra, 1999. v.1.

CHANLAT, Alain; BÉDARD, Renée. Palavras: a ferramenta do executivo. In: CHANLAT, Jean-François. O indivíduo na organização: dimensões esquecidas. São Paulo: Atlas, 1996. v.1, p. 125-148.

CHAPMAN, Pamela; PHILIPS, Nelson; PUTNAM, Linda. Metáforas da comunicação e da organização. In: CLEGG, Stewart R. et al. (Org.). Handbook de estudos organizacionais. São Paulo: Atlas, 2004. p. 77-129.

CITELLI, Adilson. Comunicação e linguagem: diálogos, trânsitos e interditos. MATRIZes: Revista do programa de pós-graduação em Ciências da Comunicação da Universidade de São Paulo, São Paulo, ano 2, n. 1, p.13-30, 2.sem. 2008.

COLTRO, Alex. A fenomenologia: um enfoque metodológico para além da modernidade. Caderno de Pesquisas em Administração, São Paulo, v. 1, n. 11, p. 37-45, 1. trim. 2000.

DAMANTE, Nara. Oralidade é a essência da comunicação interna eficiente. Comunicação Empresarial: a insubstituível oralidade, São Paulo, n. 57, p. 22-25, out./dez. 2005.

DUARTE, Jorge. Entrevista em profundidade. In: BARROS, Antonio; DUARTE, Jorge (Org.). Métodos e técnicas de pesquisa em comunicação. 2. ed. São Paulo: Atlas, 2006. p. 62-82.

EMPRESA BRASILEIRA DE PESQUISA AGROPECUÁRIA. Disponível em: <http://www.embrapa.br>. Acesso em: 18 jul. 2012a. 
EMPRESA BRASILEIRA DE PESQUISA AGROPECUÁRIA. Política de comunicação. Brasília: 2002. Disponível em: <http://www.embrapa.br/publicacoes/ins titucionais/polcomembrapa.pdf>. Acesso em: 18 jul. 2012b.

FAIRHURST, Gail T.; PUTNAM, Linda. As organizações como construções discursivas. In: MARCHIORI, Marlene Regina (Org.). Comunicação e organização: reflexões, processos e práticas. São Paulo: Difusão, 2010. p. 103-148.

FÁVERO, Leonor Lopes; ANDRADE, Maria Lúcia C. V. O; AQUINO, Gilda G. O. Oralidade e escrita: perspectivas para o ensino de língua materna. São Paulo: Cortez, 2005.

FERNANDES, Federico; LEITE, Eudes Fernando; OLIVA, Alfredo dos Santos. Os trânsitos da voz: de experiências poéticas, religiosas e orais. In: FERNANDES, Federico; LEITE, Eudes Fernando (Org.). Trânsitos da voz: estudos da oralidade e literatura. Londrina: EDUEL, 2012. p. 7-20.

FEYEREISEN, Pierre; LANNOY, Jacques-Dominique de. Linguagem do corpo, gestualidade e comunicação. In: CHANLAT, Jean-François (Coord.). O indivíduo na organização: dimensões esquecidas. São Paulo: Atlas, 1994. v.2, p. 17-38.

FORTES, Waldyr Gutierrez; SILVA, Mariângela Benine Ramos. Eventos: estratégias de planejamento e execução. São Paulo: Summus, 2011.

FORTES, Waldyr Gutierrez. Relações públicas: processo, funções, tecnologia e estratégias. 2.ed. São Paulo: Summus, 2003.

FREITAS, Sidinéia Gomes. Comunicação interna e diálogo nas organizações. In: KUNSCH, Margarida M. Krohling (Org.). Gestão estratégica em comunicação organizacional e relações públicas. 2. ed. São Caetano do Sul: Difusão, 2009. p. 138-153.

FREITAS, Sidinéia Gomes; GARCIA, Maria José Guerra de Figueiredo. Comunicação e paixões nas organizações. Organicom: Revista Brasileira de Comunicação Organizacional e Relações Públicas, São Paulo, Ano 5, n. 9, p. 118$129,2 . s e m .2008$. 
FREITAS, Sidinéia Gomes; GUERRA, Maria José. Poder, Cultura e Comunicação organizacional: contribuições da teoria semiótica. In: CONGRESSO BRASILEIRO CIENTÍFICO DE COMUNICAÇÃO ORGANIZACIONAL E DE RELAÇÕES PÚBLICAS, 1., 2007, São Paulo. Anais eletrônicos. São Paulo: Associação Brasileira de Pesquisadores de Comunicação Organizacional e Relações públicas, 2007. 1-13 p. Disponível em: <http://www.abrapcorp.org.br/anais2007/trabalhos/relacao_gt4.htm >. Acesso em: 18 mar. 2011.

FUGERE, Brian; HARDAWAY, Chelsea; WARSHAWSKY, Jon. Por que as pessoas de negócios falam como idiotas: um guia de combate à embromação. Rio de Janeiro: Best Seller, 2007.

GIL, Antonio Carlos. Como elaborar projetos de pesquisa. 4. ed. São Paulo: Atlas, 2007a. . Métodos e técnicas de pesquisa social. 5. ed. São Paulo: Atlas, 2007b.

GODOI, Christiane Kleinübing; MELLO, Rodrigo Bandeira de; SILVA, Anielson Barbosa. Pesquisa qualitativa em estudos organizacionais: paradigmas, estratégias e métodos. 2.ed. São Paulo: Saraiva, 2010.

GODÓI, Elena; RIBEIRO, Anely. A contribuição das ciências da linguagem para o estudo da comunicação organizacional. In: KUNSCH, Margarida M. Krohling (Org.). Comunicação organizacional: linguagem, gestão e perspectivas. São Paulo: Saraiva, 2009. v.2, p. 159-188.

GOFFMAN, Erving. Ritual de interação: ensaios sobre o comportamento face a face. Petrópolis: Vozes, 2011.

GUIMARÃES, Marcelo Hagebock; RIBEIRO, Anely. A linguagem verbal e não verbal: influência da corporalidade no processo de comunicação organizacional. In: CONGRESSO BRASILEIRO CIENTÍFICO DE COMUNICAÇÃO ORGANIZACIONAL E RELAÇÕES PÚBLICAS, 3., 2009, São Paulo. Anais eletrônicos... São Paulo: Associação Brasileira de Pesquisadores de Comunicação Organizacional e Relações Públicas, 2009. Disponível em: <http://www.abrapcorp.org.br/anais2009/pd f/GT4_Ribeiro_Guimaraes.pdf>. Acesso em: 29 set. 2010.

HABERMAS, Jürgen. Teoria de la acción comunicativa: racionalidad de la acción y racionalización social. Madri: Taurus, 1987a. v. 1. 
- Teoria de la acción comunicativa: crítica de la razón funcionalista. Madri:

Taurus, 1987b. v. 2.

HALLIDAY, Tereza Lúcia. Discurso organizacional: uma abordagem retórica. In: KUNSCH, Margarida Maria Krohling (Org.). Comunicação organizacional: linguagem, gestão e perspectivas. São Paulo: Saraiva, 2009. v.2, p. 31-52.

IANNI, Octavio. A era do globalismo. 4. ed. Rio de Janeiro: Civilização Brasileira, 1999.

IASBECK, Luiz Carlos Assis. Identidade organizacional e a construção dos discursos institucionais. In: KUNSCH, Margarida Maria Krohling (Org.). Comunicação organizacional: linguagem, gestão e perspectivas. São Paulo: Saraiva, 2009. v.2, p. 7-29.

KUNSCH, Margarida Maria Krohling (Org.). A comunicação como fator de humanização das organizações. São Paulo: Difusão, 2010.

- Relações públicas na gestão estratégica da comunicação integrada nas organizações. In: KUNSCH, Margarida Maria Krohling (Org.). Relações públicas: história, teorias e estratégias nas organizações contemporâneas. São Paulo: Saraiva, 2009. cap. 7, p. 185-208.

. Comunicação organizacional: surgimento, evolução das práticas, conceitos e dimensões. In: BARBOSA, Ivan Santo; PEREZ, Clotilde (Org.). Hiperpublicidade: fundamentos e interfaces. São Paulo: Thomson Learning, 2007. v.1, p. 369-390.

. Planejamento de Relações públicas na comunicação integrada. São Paulo: Summus, 2003.

KYRILLOS, Leny. A voz. In: COTES, Cláudia; FEIJÓ, Deborah; KYRILLOS, Leny. Voz e corpo na TV: a fonoaudiologia a serviço da comunicação. São Paulo: Globo, 2003. cap. 1, p. 19-44.

KYRILLOS, Leny (Org.). Expressividade: da teoria à prática. Rio de Janeiro: Revinter, 2005a.

Falar bem sem olhar a quem. Comunicação Empresarial, São Paulo, n.55, p. 16-18, abr./jun. 2005b. 
LAKATOS, Eva Maria; MARCONI, Marina de Andrade. Técnicas de pesquisa: planejamento e execução de pesquisas, amostragens e técnicas de pesquisa; elaboração, análise e interpretação de dados. 7. ed. São Paulo: Atlas, 2011.

LARKIN, Thomaz J. Face a face, a melhor forma de comunicar. Comunicação Empresarial: a insubstituível oralidade, São Paulo, n. 57, p. 4-7, out./dez. 2005. Entrevista concedida a Nara Damante.

LUZ, Talita Ribeiro da. TELEMAR-MINAS: competências que marcam a diferença. 2001. 322 f. Tese (Doutorado em Administração) - Faculdade de Ciências Econômicas, Universidade Federal de Minas Gerais, Belo Horizonte, 2001.

LIPPI, Roberta. Contatos pessoais reforçam mensagem: atuação direta dos gestores da área amplia o foco e melhora o entendimento das informações transmitidas por diferentes canais. Revista Valor Setorial: Comunicação Corporativa, São Paulo, p 54-58, nov. 2009.

MARCHESE, Amauri. Oralidade é a essência da comunicação interna eficiente. Comunicação Empresarial: a insubstituível oralidade, São Paulo, n. 57, p. 23, out./dez. 2005. Entrevista concedida a Nara Damante.

MARCHIORI, Marlene Regina (Org.). Comunicação e organização: reflexões, processos e práticas. São Paulo: Difusão, 2010.

. Comunicação organizacional e perspectivas metateóricas: interfaces e possibilidades de diálogo no contexto das organizações. In: OLIVEIRA, Ivone de Lourdes; SOARES, Ana Thereza Nogueira (Org.). Interfaces e tendências da comunicação no contexto das organizações. São Caetano do Sul: Difusão, 2008. p.170-200.

. Cultura e comunicação organizacional. São Paulo: Difusão, 2006.

MARTINS, Marta T. M. Campos; GRECA, Aislan Ribeiro. Qualidade de vida no trabalho: o papel da liderança na construção de seu sentido. In: CHAMON, Edna Maria Querido de Oliveira (Org.). Qualidade de vida no trabalho. Rio de Janeiro: Brasport, 2011. cap. 3, p. 49-72. 
MARTINS, Marta T. M. Campos. A oralidade absorvida pela comunicação interna: elemento de integração com funcionários e clientes externos. In: CONGRESSO BRASILEIRO CIENTÍFICO DE COMUNICAÇÃO ORGANIZACIONAL E DE RELAÇÕES PÚBLICAS, 4., 2010, Porto Alegre. Anais eletrônicos... Porto Alegre: Associação Brasileira de Pesquisadores de Comunicação organizacional e Relações públicas, 2010. Disponível em: <http://www.abrapcorp.org.br/anais2010/trabalhosGT 4.html>. Acesso em: 10 jan. 2011.

. Gestão estratégica como perspectiva holística de pensar a comunicação. Organicom: Revista Brasileira de Comunicação organizacional e Relações públicas, São Paulo, ano 6, n. 10/11, p. 258-261, 2009a. Edição especial. Recensão de: KUNSCH, Margarida Maria Krohling (Org.). Gestão estratégica em comunicação organizacional e relações públicas. São Caetano do Sul: Difusão, 2008. 308 p.

MARTINS, Marta T. M. Campos; GRECA, Aislan Ribeiro. Oralidade para líderes: abordagem estratégica da comunicação organizacional. In: CONGRESSO BRASILEIRO DE CIÊNCIAS DA COMUNICAÇÃO, 32., 2009, Curitiba. Anais... Curitiba: INTERCOM, 2009b. p. 1-15.

MARTINS, Marta T. M. Campos; FORTES, Waldyr Gutierrez. A expressividade da comunicação oral e sua influência no meio corporativo. Communicare, São Paulo, v. 8 , p. 139-148, 2008a.

O resgate da oralidade dentro das práticas de relacionamentos com os públicos organizacionais. In: CONGRESSO BRASILEIRO CIENTÍFICO DE COMUNICAÇÃO ORGANIZACIONAL E DE RELA ÇÕES PÚBLICAS, 2., 2008, Belo Horizonte. Anais... Belo Horizonte: Associação Brasileira de Pesquisadores de Comunicação Organizacional e Relações Públicas, 2008b. v.2, p.1-10.

. A expressividade da comunicação oral e sua influência no meio corporativo. In: CONGRESSO BRASILEIRO DE CIÊNCIAS DA COMUNICAÇÃO, 31., 2008, Natal. Anais... São Paulo: INTERCOM, 2008c. p. 01-14.

. Desenvolvimento da comunicação organizacional agencia a constância da oralidade. Communicare, São Paulo, v. 7, p. 45-56, 2007a.

MARTINS, Marta T. M. Campos; FORTES, Waldyr Gutierrez. Desenvolvimento da comunicação humana e organizacional e em suas formas de comunicar. Comunicação \& Informação, Goiânia, v. 10, p. 126-133, 2007b. 
. Desenvolvimento da comunicação organizacional agencia a constância da oralidade. In: CONGRESSO BRASILEIRO DE CIÊNCIAS DA COMUNICAÇÃO, 30., 2007, Santos. Anais... São Paulo: INTERCOM, 2007c. p. 1-15.

. A oralidade como vetor estratégico para construção de imagem corporativa. In: CONGRESSO BRASILEIRO CIENTÍFICO DE COMUNICAÇÃO ORGANIZACIONAL E DE RELAÇÕES PÚBLICAS, 1., 2007, São Paulo: Associação Brasileira de Pesquisadores de Comunicação Organizacional e Relações Públicas. Anais... São Paulo:, 2007d. p. 11.

MATTAR, Fauze Najib. Pesquisa de marketing: metodologia e planejamento. 6. ed. São Paulo: Atlas, 2005.

MAXIMIANO, Antonio Cesar Amaru. Introdução à administração. 6. ed. São Paulo: Atlas, 2004.

MOREIRA, Daniel Augusto. O método fenomenológico na pesquisa. São Paulo: Pioneira Thomsom, 2002.

MOTTER, Maria Lourdes. Campo da Comunicação: cotidiano e linguagem. In: BACCEGA, Maria Aparecida (Org.). Gestão de processos comunicacionais. São Paulo: Atlas, 2002. cap. 2, p. 28-47.

MUMBY, Dennis K. Reflexões críticas sobre comunicação e humanização nas organizações. In: KUNSCH, Margarida Maria Krohling (Org.). A comunicação como fator de humanização das organizações. São Paulo: Difusão, 2010, p. 19-39.

NASSAR, Paulo. Tudo é comunicação. São Paulo: Lazuli, [2005].

NORI, Walter; VALENTE, Célia. Portas abertas - A experiência da Rhodia: novos caminhos da comunicação social na empresa moderna. São Paulo: Best Seller, 1990.

OLIVEIRA, Ivone de Lourdes. Espaços dialógicos e relacionais nas organizações e sua natureza ético-política. In: KUNSCH, Margarida Maria Krohling (Org.). Comunicação organizacional: linguagem, gestão e perspectivas. São Paulo: Saraiva, 2009. v.2, p. 321-332.

OLIVEIRA, Ivone de Lourdes; PAULA, Carine F. Caetano de. Comunicação no contexto das organizações produtora ou ordenadora de sentidos? In: OLIVEIRA, 
Ivone de Lourdes; SOARES, Ana Thereza Nogueira (Org.). Interfaces e tendências da comunicação no contexto das organizações. São Caetano do Sul: Difusão, 2008. p. 91-108.

OLIVEIRA, Maria José da Costa. Relações públicas e as questões sociais nos três setores da sociedade. In: KUNSCH, Margarida Maria Krohling; KUNSCH, Waldemar Luiz (Org.). Relações públicas comunitárias: a comunicação em uma perspectiva dialógica e transformadora. São Paulo: Summus, 2007. p. 181-193.

ONG, Walter. Oralidade e cultura escrita: a tecnologização da palavra. Campinas: Papirus, 1998.

PARENTE, Carlos. Oralidade é a essência da comunicação interna eficiente. Comunicação Empresarial: a insubstituível oralidade. São Paulo, n. 57, p. 22-25, out./dez. 2005. Entrevista concedida a Nara Damante.

PASSADORI, Reinaldo. Comunicação essencial: estratégias eficazes para encantar seus ouvintes. São Paulo: Gente, 2003.

PICCOLOTTO, Leslie; SOARES, Regina Maria Freire. Técnicas de impostação e comunicação oral. São Paulo: Summus, 1977.

POLITO, Reinaldo. Superdicas para falar bem: em conversas e apresentações. São Paulo: Saraiva, 2005.

PRADO, Elisa. Uma experiência diferente em comunicação interna. Disponível em: $<$ http://www.aberje.com.br/acervo_colunas_ver.asp?ID_COLUNA=80\&ID_COLUNIS TA=8>. Acesso em: 8 ago. 2011.

PRETI, Dino (Org.). Diálogos na fala e na escrita. São Paulo: Associação Editorial Humanitas, 2005.

PROSS, Harry. Medienforschung. Darmstadt: Carl Habel, 1971.

PUTNAM, Linda L. Metáforas da comunicação organizacional e o papel das relações públicas. In: KUNSCH, Margarida Maria Krohling (Org.). Relações públicas e comunicação organizacional: campos acadêmicos e aplicados de múltiplas perspectivas. São Caetano do Sul: Difusão, 2009. p. 43-67. 
RICHARDSON, Roberto Jerry. Pesquisa social: métodos e técnicas. São Paulo: Atlas, 1989.

ROMAN, Artur Roberto. Organizações um universo de discursos bem-ditos, malditos e não-ditos. In: KUNSCH, Margarida Maria Krohling (Org.). Comunicação organizacional: linguagem, gestão e perspectivas. São Paulo: Saraiva, 2009. v.2, p. 125-157.

SANDERS, Patricia. Phenomenology: a new way of viewing organizational research. Academy of Managements Review, v. 7, n.1, p. 353-360, 1982.

SANTAELLA, Lúcia. Comunicação e pesquisa: projetos para mestrado e doutorado. São Paulo: Hacker Editores, 2001.

SCROFERNEKER, Cleusa Maria Andrade. Trajetórias teórico-conceituais da comunicação organizacional. Revista Famecos, n. 31, dez. 2006. Disponível em: <www.pucrs.br/famecos/pos>. Acesso em: 14 out. 2010.

- Comunicação organizacional: certezas e incertezas. In: scroferneker, Cleusa Maria Andrade (Org). O diálogo possível: comunicação organizacional e paradigma da complexidade. Porto Alegre: EDIPUCRS, 2008. p. 15-30.

A comunicação organizacional estratégica desvendada. Organicom: Revista Brasileira de Comunicação Organizacional e Relações Públicas, São Paulo, ano 4, n.6, p. 216-219, 1. sem. 2007. Recensão de: CORELLA, M. A. R. Comunicación estratégica em las organizaciones.

STAFFORD, Gena; VANC; Antoaneta; WHITE, Candace. Internal communication, information satisfaction and sense of community: the effect of personal influence. Journal of Public Relations Research, v.22, n.1, p.65-84, jan. 2010.

STUMPF, Ida Regina C. Pesquisa bibliográfica. In: BARROS, Antonio; DUARTE, Jorge (Org.). Métodos e técnicas de pesquisa em comunicação. 2. ed. São Paulo: Atlas, 2006. p. 51-61.

TARAPANOFF, Kira. Inteligência organizacional e competitiva. Brasília: Universidade de Brasília, 2001. 
TAYLOR, James. Comunicação organizacional: uma ciência híbrida. Estudos de Jornalismo e Relações Públicas, São Bernardo do Campo, ano 3, n. 6, p. 9-15, 2005. Entrevista concedida a Adriana Casali.

TORRES, Alvair Silveira Junior. Comunicação organizacional: retórica e dramaturgia na implantação de um novo modelo de produção. In: KUNSCH, Margarida M. Krohling (Org.). Comunicação organizacional: linguagem, gestão e perspectivas. São Paulo: Saraiva, 2009. v.2, p. 53-83.

TORQUATO, Francisco Gaudêncio. Comunicação interna: os desafios da integração. Disponível em: <http://www.portal-p.com.br/bibliotecavirtual/relacoespubli cas/funcoesetecnicas/0128.htm> Acesso em: 14 mar. 2011.

TRIVIÑOS, Augusto N. S. Introdução à pesquisa em ciências sociais: a pesquisa qualitativa em educação. São Paulo: Atlas, 1990.

VILAÇA, Wilma Pereira Tinoco. Comunicação organizacional: um olhar brasileiro sobre o pensamento da "Escola de Montreal". In: CONGRESSO LATINOAMERICANO DE INVESTIGACIÓN DE LA COMUNICACIÓN, 9., 2008, México. Anais... México: ALAIC, 2008. Disponível em: <http://alaic.net/alaic30/ponen cias/cartas/com_org_yRP/ponencias/GT2_17wilma.pdf>. Acesso em: 14 out. 2010.

WALTY, Ivete Lara Camargos. Textualidade e territorialidade no discurso oral. In: FERNANDES, Federico; LEITE, Eudes Fernando (Org.). Trânsitos da voz: estudos da oralidade e literatura. Londrina: EDUEL, 2012. p. 21-43.

ZANETTI, Eloi. Oralidade é a essência da comunicação interna eficiente. Comunicaçao Empresarial: a insubstituível oralidade, São Paulo, n. 57, p. 22-25, out./dez. 2005. Entrevista concedida a Nara Damante. 
APÊNDICES 


\section{APÊNDICE A - PAUTA DE ENTREVISTA COM DIRIGENTES DA EMBRAPA SOJA}

Fazer uma breve apresentação pessoal, do tema, objetivos e métodos da pesquisa. Iniciar a gravação com pedido de autorização para procedê-la. A partir da autorização para gravar, dar o "start" da entrevista.

\section{PERFIL DO ENTREVISTADO}

Sexo/ldade

Grau de instrução/Nível de pós-graduação, se tiver/Tempo na empresa.

\section{ROTEIRO DA ENTREVISTA}

- $\quad$ LINHAS GERAIS DA ÁREA DE ATUAÇÃo NA EMPRESA E AS PRINCIPAIS FUNÇÕES DE SUA EQUIPE.

- $\quad$ QuANTIDADE DE EMPREgados DIRETAMENTE SUBORDINADOS

- $\quad$ CONHECIMENTO SOBRE A POLÍTICA DE COMUNICAÇÃO DA EMBRAPA.

1. IDENTIFICAÇÃO DO QUE É TRATADO SOBRE A COMUNICAÇÃO INTERNA DA EMBRAPA.

2. ADOTA A POLITICA PARA SE COMUNICAR COM OS SUPERVISORES.

3. RECOMENDAÇÕES SOBRE A COMUNICAÇÃO ORAL ENTRE CHEFES E EMPREGADOS DA EQUIPE NA COMUNICAÇÃO INTERNA DESTA UNIDADE.

4. IMPORTÂNCIA QUE ATRIBUI A COMUNICAÇÃO ORAL (FALA), DO DIÁLOGO E DA COMUNICAÇÃO FACE A FACE ENTRE DIRIGENTES E EQUIPES NA EMPRESA?

5. USO DA COMUNICAÇÃO ORAL COM SUPERVISORES DIRETOS, INDIRETOS E EMPREGADOS.

6. SITUAÇÕES PARA DIALOGAR COM SUPERVISORES

7. ENCORAJA SUPERVISORES E EMPREGADOS A EXPRESSAREM FACE A FACE OPINIÕES SOBRE ESTILO DE LIDERAR

8. ENCORAJA OPINIÕES SOBRE O TRABALHO DOS SUPERVISORES.

9. OUVE E ACATA O QUE SUPERVISORES RELATAM E SUGEREM PARA A ÁREA.

10. DISCUTE FACE A FACE COM SUPERVISORES AÇÕES PARA MELHORAR O DESEMPENHO DELES.

11. ESTIMULA SUPERVISORES A DISCUTIREM FACE A FACE AÇÕES PARA MELHORAR O DESEMPENHO DOS EMPREGADOS.

12. FREQUÊNCIA COM QUE OS SUPERVISORES DISCUTEM AÇÕES PARA MELHORAR O DESEMPENHO DOS EMPREGADOS.

13. COMO A MISSÃO DA EQUIPE SE RELACIONA COM A ORGANIZAÇÃO.

14. MODO (FALA, ESCRITA, AMBOS) COMO SE EXPRESSA PARA INFORMAR A RELAÇÃO DOS OBJETIVOS DA EMPRESA COM O TRABALHO DOS EMPREGADOS.

15. MODO (FALA, ESCRITA, AMBOS) COMO SE EXPRESSA PARA DAR FEEDBACK SOBRE O DESEMPENHO POSITIVO DE UMA TAREFA.

16. FALA CLARAMENTE O QUE É ESPERADO DE CADA EMPREGADO DA EQUIPE.

17. DEMONSTRAÇÃO DE INTERESSE REAL EM OUVIR AS NECESSIDADES DA EQUIPE E ENCONTRAR SOLUÇÕES.

18. MODO COMO ESTIMULA CADA MEMBRO DE SUA EQUIPE A CONTRIBUIR COM O SEU MELHOR DENTRO DA EMPRESA.

19. ENCORAJAMENTO À COOPERAÇÃO DA EQUIPE COM OUTROS GRUPOS DE TRABALHO, UNIDADES OU OPERAÇÕES.

20. A LINGUAGEM QUE USAM É COMPREENDIDA POR TODOS OS FUNCIONÁRIOS DA EMPRESA.

21. SOLICITA CONSELHOS SOBRE COMO O TRABALHO PODE SER FEITO DE MANEIRA MAIS EFICAZ.

22. MEIO (ORAL, ESCRITO, VIRTUAL) DE COMUNICAÇÃO USADO PARA ESTE FIM.

23. INSTRUMENTO DE COMUNICAÇÃO QUE É COMUMENTE USADO.

24. ALGO A ACRESCENTAR. 


\section{APÊNDICE B - INSTRUMENTO PARA ENTREVISTA COM SUPERVISORES}

\section{COMUNICAÇÃO ORAL, DIÁLOGO E COMUNICAÇÃO FACE A FACE}

Entrevista para pesquisa de Doutorado na ECA-USP, orientação da Profa. Dra. Margarida M. Krohling Kunsch, doutoranda Marta T. Motta Campos Martins, docente do Departamento de Comunicação da Universidade Estadual de Londrina-UEL. O objeto deste estudo é a comunicação interna. Agradeço sua colaboração.

\section{IDENTIFICACÃO:}

Sexo / Idade

Grau de instrução/Nível de pós-graduação, se tiver/Tempo de empresa.

\section{Bloco 1 - Sobre Comunicação Interna}

- Apresente linhas gerais de sua área de atuação na empresa e as principais funções de sua equipe.

- Quantos empregados estão diretamente subordinados a você?

- Conhece a política de comunicação da Embrapa?

- Identifica o que é tratado sobre a comunicação interna da EMBRAPA?

- Seu superior imediato adota o que a política de comunicação da Embrapa indica ao se comunicar com os supervisores?

- Há acompanhamento ou cobrança da utilização do que foi comunicado?

- Descreva como a missão de sua equipe se relaciona com a organização.

- Como seu superior imediato estimula cada membro da equipe a contribuir com o seu melhor dentro da empresa? (Levantar, entre outros aspectos, em termos de recursos, processo de avaliação e benefícios).

\section{Bloco 2 - Sobre Uso da Comunicação Oral entre os Empregados}

- No processo de comunicação interna da Embrapa Soja, identifica recomendações que estimulem o uso da comunicação oral entre dirigentes, supervisores e empregados da equipe?

- Há barreiras para o uso da comunicação oral entre dirigentes, supervisores e empregados da equipe?

- Usa a comunicação oral com o seu dirigente imediato? Exemplos. 
- Usa a comunicação oral com os empregados de sua equipe? Exemplos de situações, por que.

- Analise, entre outros aspectos, a eficiência e o retorno da comunicação efetuada oralmente.

- Seu superior imediato fala claramente o que é esperado de cada empregado de sua equipe na empresa? (Considerar, entre outros aspectos, o tempo dentro da empresa e comprometimento).

- A linguagem que seu superior imediato e você usam é compreendida por todos os empregados da empresa? (Avaliar, entre outros aspectos, em termos de escolaridade e relacionamento).

\section{Bloco 3 - Sobre uso do Diálogo}

- Em quais situações dialoga com seu superior imediato?

- Seu superior imediato dá abertura para o diálogo com a equipe de supervisores? (Avaliar, entre outros aspectos, em termos de conhecimento técnico).

- Há situação em que o diálogo é a forma de comunicação necessária entre superior e supervisores de equipes? Quais?

- O local ou ambiente onde ocorre o diálogo interfere na qualidade da comunicação realizada? Por que?

- Seu superior imediato demonstra interesse real em ouvir as necessidades da equipe e encontrar soluções?

- Seu superior imediato ouve e acata os relatos e sugestões dos supervisores sobre sua área na empresa?

- Que tipo de comunicação seu superior imediato usa para solicitar aos supervisores conselhos sobre como o trabalho pode ser feito de maneira mais eficaz? (Oral, escrita, eletrônica, etc.)

- Qual instrumento de comunicação seu superior imediato usa para solicitar aos supervisores conselhos sobre como o trabalho pode ser feito de maneira mais eficaz?

- Seu superior imediato encoraja a cooperação de sua equipe com outros grupos de trabalho, unidades ou operações? Exemplos.

\section{Bloco 4 - Sobre Comunicação Face a Face}

- Seu superior imediato encoraja você a expressar face a face e com franqueza suas opiniões sobre o estilo dele liderar?

- Seu superior imediato discute face a face com você ações para melhorar o seu desempenho? (Explique, entre outros aspectos, em termos de ambiente competitivo, ambiente político, valor do trabalho em equipe). 
- Seu superior imediato estimula os gerentes a discutirem face a face com os demais supervisores ações para melhorar o desempenho de cada um deles? E com os empregados?

\section{Bloco 5 - Sobre Comunicação Interna, Comunicação Oral, Diálogo e Comunicação Face a Face, em Conjunto}

- Seu superior imediato encoraja opiniões sobre o trabalho de sua equipe?

- De que modo (fala, escrita, ambos) seu superior imediato expressa-se para dar informações sobre a relação entre objetivos da empresa e o trabalho dos supervisores e dos empregados? (Comente, entre outros aspectos sobre a frequência de utilização de cada modo, solução de problemas).

- Que importância você atribui ao uso da comunicação oral (fala), do diálogo e da comunicação face a face entre supervisores e equipes na empresa? (Explique, entre outros aspectos, a utilização desta comunicação em termos de linguagem empregada).

- Deseja acrescentar outras informações, comentários e/ou sugestões sobre o tema enfocado nesta entrevista?

\section{Muito obrigada pela atenção e colaboração!}




\section{APÊNDICE C - QUESTIONÁRIO PARA EMPREGADOS}

\section{PESQUISA SOBRE USO DE COMUNICAÇÃO ORAL}

Esta pesquisa sobre comunicação interna está sendo realizada por uma doutoranda do programa de Ciências da Comunicação da Universidade de São Paulo. Ela solicita sua cooperação no sentido de responder às perguntas abaixo, de modo a refletir a sua experiência em cada tópico indicado. Uma vez que serão extraídas conclusões científicas dos dados que você fornecer, será fundamental que você examine as alternativas e assinale aquela que melhor representa a posição que você adota sobre o assunto. Obrigada.

* Obrigatório

\section{Bloco 1 - Sobre Comunicação Interna}

1. A comunicação que encontro no ambiente de trabalho me empolga e me motiva a dar o meu melhor desempenho na empresa. *

Discordo totalmente

Discordo

Concordo totalmente

(C) Concordo

(- Não tenho certeza

2. A divulgação das políticas, dos objetivos, das metas e resultados alcançados pela empresa é direcionada para todos os empregados. *

(C) $\operatorname{Sim}$

C. Não

(C) Não tenho certeza

3. Se você assinalou a alternativa "Sim" na pergunta 2, responda como a divulgação das políticas, dos objetivos, das metas e resultados alcançados pela empresa é direcionada para todos os empregados.

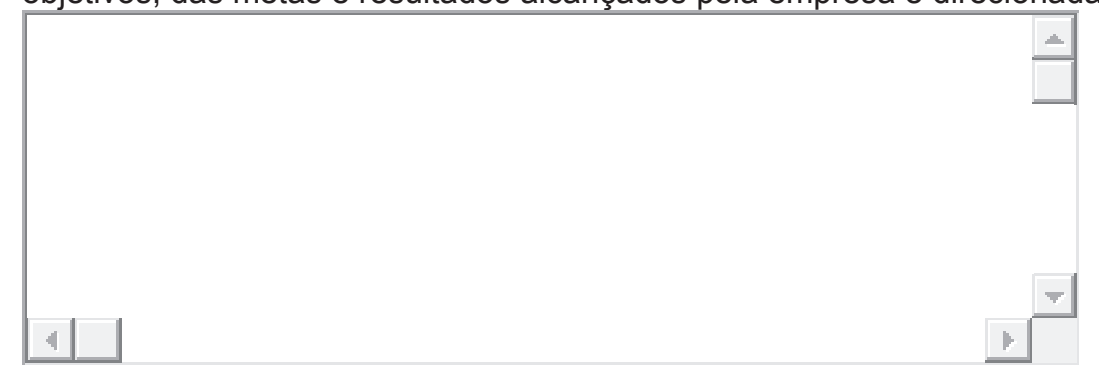

4. Meu superior imediato me mantém informado sobre todos os assuntos de nosso setor. *
(C) Nunca
Quase nunca
Sempre
Q Quase sempre
Não tenho certeza 
5. A comunicação e a divulgação interna dos eventos e das atividades dos diversos setores são conhecidas por todos os empregados na empresa. *

r.

Discordo totalmente

Discordo

Concordo totalmente

Concordo

Não tenho certeza

6. Meu superior imediato segue o estilo da comunicação interna definida em manual pela empresa para se comunicar com os subordinados.*

(C) Discordo totalmente

(C) Discordo

Concordo totalmente

Concordo

Não tenho certeza

7. O relacionamento entre o superior imediato e os subordinados dentro do meu setor é considerado:*

Totalmente satisfatório

(C) Satisfatório

Totalmente insatisfatório

Insatisfatório

Não tenho certeza

8. Meu superior imediato estimula cada membro da equipe/setor a dar contribuição e a realizar o seu melhor dentro da empresa. *

C

Discordo totalmente

(C) Discordo

Concordo totalmente

Concordo

Não tenho certeza

\section{Bloco 2 - Sobre uso da Comunicação Oral entre os Empregados}

9. No processo de comunicação interna da Unidade, eu consigo identificar, de modo claro, as recomendações para que seja utilizada a comunicação oral entre chefes, supervisores e empregados da equipe. *

(C)

Discordo totalmente

Discordo

Concordo totalmente

(C) Concordo

C Não tenho certeza 
10. Existem e estão claras para mim, no meu local de trabalho, barreiras para o uso da comunicação oral entre chefes, supervisores e empregados.*

r.

Discordo totalmente

Discordo

Concordo totalmente

Concordo

Não tenho certeza

11. Utilizo a comunicação oral no processo de tomada de decisão com os chefes ligados diretamente a mim:*

(C) $\mathrm{Sim}$

(C) Não

À̀s vezes

12. Se você assinalou a alternativa "Não" na pergunta 11, responda por que não usa a comunicação oral no processo de tomada de decisão com os chefes ligados diretamente a você.

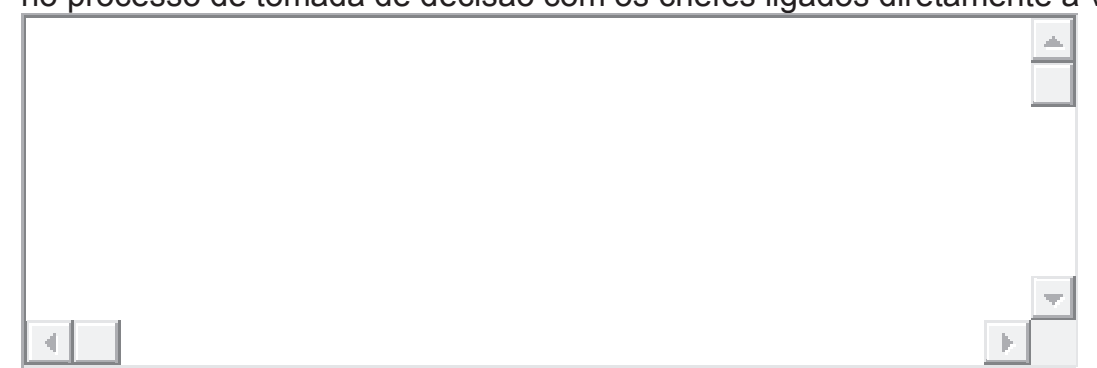

13. Se você assinalou a alternativa "Às vezes" na pergunta 11, dê exemplos de uso da comunicação oral no processo de tomada de decisão com os chefes ligados diretamente a você.

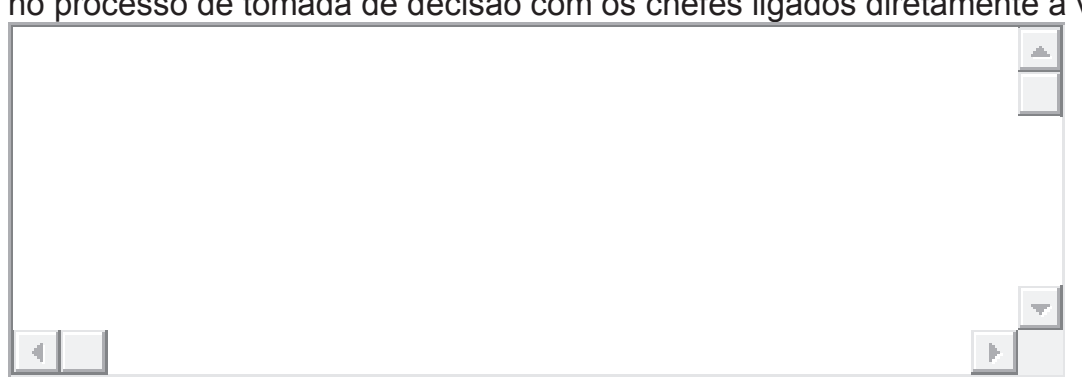

14. A linguagem que meu superior imediato usa é compreendida por todos os empregados do setor. *

Discordo totalmente

Discordo

C Concordo totalmente

(C) Concordo

(C) Não tenho certeza 


\section{Bloco 3 - Sobre uso do Diálogo}

15. Meu superior imediato dá abertura para o diálogo com os empregados da equipe.*

$\mathrm{C}$

Discordo totalmente

C.

Discordo

C

Concordo totalmente

Concordo

Não tenho certeza

16. Há situações em que o diálogo é a forma de comunicação indispensável entre chefes de todos os níveis de autoridade e empregados. *

Discordo totalmente

Discordo

Concordo totalmente

Concordo

Não tenho certeza

17. Se você assinalou a alternativa "Concordo totalmente" na pergunta 16, exemplifique situações em que o diálogo é a forma de comunicação indispensável entre chefes de todos os níveis de autoridade e empregados.

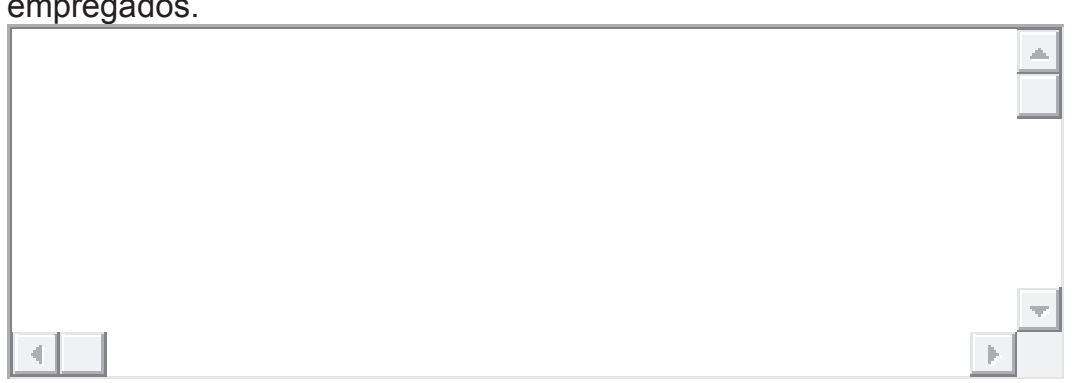

18. Se você assinalou a alternativa "Concordo" na pergunta 16, exemplifique situações em que o diálogo é a forma de comunicação indispensável entre chefes de todos os níveis de autoridade e empregados.

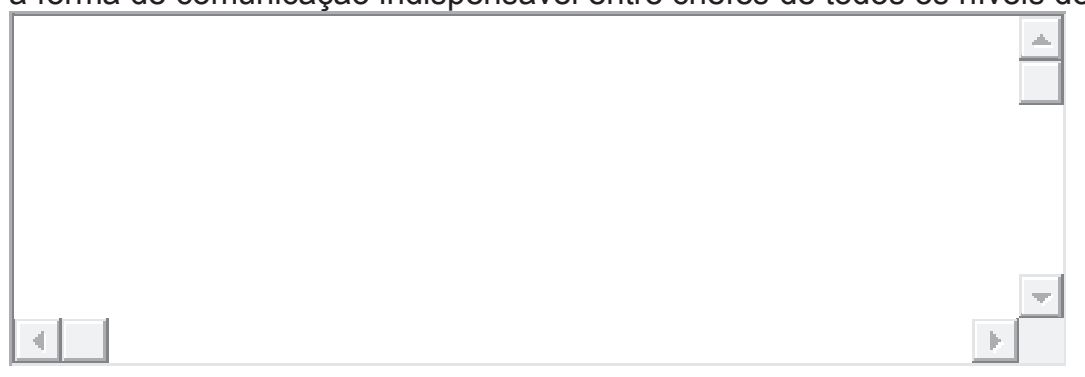

19. O local ou ambiente onde ocorre o diálogo tem influência na qualidade da comunicação realizada. *

(C) $\mathrm{Sim}$

C Não 
20. Se você assinalou a alternativa "Sim" na pergunta 19, responda por que o local ou ambiente onde ocorre o diálogo tem influência na qualidade da comunicação realizada?

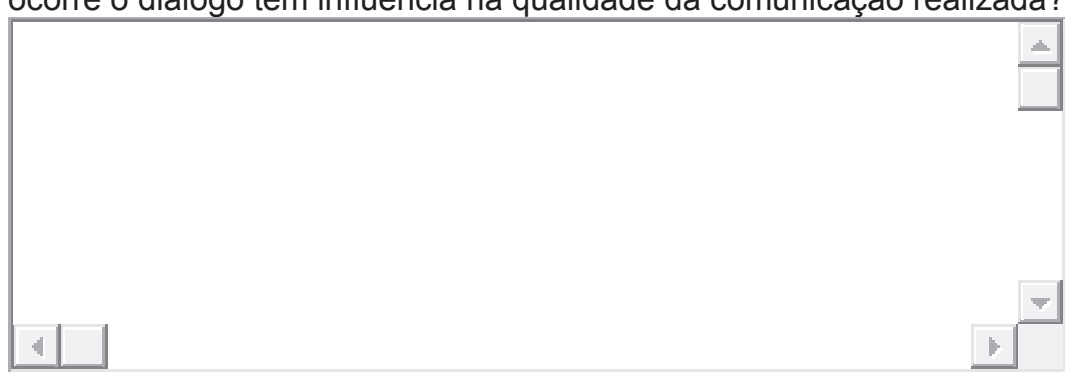

21. Meu superior imediato ouve e acata o que seus subordinados relatam e sugerem para a sua área na empresa.*

(.)

Discordo totalmente

(C) Discordo

Concordo totalmente

(C) Concordo

(C) Não tenho certeza

(C) Não respondeu

22. Eu tenho autonomia para propor ao meu superior imediato melhorias na execução de meu trabalho. *

(C) Discordo totalmente

Discordo

Concordo totalmente

(C) Concordo

Não tenho certeza

23. Que tipo de comunicação você usa para solicitar ao supervisor, conselhos sobre como o trabalho pode ser feito de maneira mais eficaz? *ASSINALE MAIS DE UMA ALTERNATIVA SE FOR NECESSÁRIO PARA A SUA RESPOSTA.

Г

Oral

ए Escrita

$\Gamma$ Digital

$\ulcorner$ Nenhum

Г Outro:

24. Que instrumento de comunicação seu superior imediato usa para abordar questões internas sobre o trabalho da equipe. *ASSINALE MAIS DE UMA ALTERNATIVA SE FOR NECESSÁRIO PARA A SUA RESPOSTA.

ए Reunião formal

Г Conversa face a face

ᄃ Circular interna

ए Ofício

ए E-mail 


\section{Bloco 4 - Sobre Comunicação Face a Face}

25. Meu superior imediato discute face a face comigo ações para melhorar o meu desempenho.*

C

Discordo totalmente

Discordo

Concordo totalmente

Concordo

Não tenho certeza

26. Meu superior imediato encoraja os empregados a se expressarem face a face e fornece, com franqueza suas opiniões sobre o estilo dele de liderar.*

$\mathrm{C}$

Discordo

Concordo totalmente

Concordo

Não tenho certeza

Não respondeu

\section{Bloco 5 - Sobre Comunicação Interna, Comunicação Oral, Diálogo e Comunicação Face a Face, em Conjunto}

27. De que modo seu superior imediato se expressa com você para dar informações sobre a relação entre os objetivos da empresa e o trabalho dos empregados? *

C

$$
\text { Fala }
$$

Escrita

Fala e escrita

(C) Nenhum

Outro:

28. Que importância você atribui ao uso da comunicação oral (fala), do diálogo e da comunicação face a face entre chefes e equipes na empresa? *

Totalmente irrelevante

Irrelevante

C Totalmente relevante

Relevante

Não tenho certeza 


\section{IDENTIFICAÇÃO}

29. Sexo*

Feminino

Masculino

Não respondeu

30. Idade*

31. Escolaridade*

Ensino fundamental

Ensino Médio

Superior

C Não respondeu

32. Há quanto tempo você trabalha nesta Unidade da Embrapa? *

Um a dois anos

Três a cinco anos

S Seis a 10 anos

C. Mais de 10 anos

Não respondeu

Muito obrigada pela atenção e colaboração! 


\section{APÊNDICE D - TABULAÇÃO DAS RESPOSTAS OBTIDAS}

\begin{tabular}{|c|c|c|c|c|}
\hline \# & $\begin{array}{c}\text { Indicação de data } \\
\text { e hora }\end{array}$ & $\begin{array}{c}\text { 1. A } \\
\text { comunicação } \\
\text { que encontro } \\
\text { no ambiente } \\
\text { de trabalho } \\
\text { me empolga } \\
\text { e me motiva } \\
\text { a dar o meu } \\
\text { melhor } \\
\text { desempenho } \\
\text { na empresa. }\end{array}$ & $\begin{array}{c}\text { 2. A } \\
\text { divulgação } \\
\text { das } \\
\text { políticas, } \\
\text { dos } \\
\text { objetivos, } \\
\text { das metas e } \\
\text { resultados } \\
\text { alcançados } \\
\text { pela } \\
\text { empresa é } \\
\text { direcionada } \\
\text { para todos } \\
\text { os } \\
\text { empregados. }\end{array}$ & $\begin{array}{l}\text { 3. Se você assinalou a alternativa "Sim" na pergunta 2, } \\
\text { responda como a divulgação das políticas, dos objetivos, } \\
\text { das metas e resultados alcançados pela empresa é } \\
\text { direcionada para todos os empregados. }\end{array}$ \\
\hline 1 & 4/17/2012 11:48:33 & $\begin{array}{l}\text { Discordo } \\
\text { totalmente }\end{array}$ & Sim & Através de Reunioes Gereais e Informativos Diários \\
\hline 2 & 4/17/2012 11:52:21 & Concordo & Sim & \\
\hline 3 & 4/17/2012 12:08:34 & Concordo & $\begin{array}{l}\text { Não tenho } \\
\text { certeza }\end{array}$ & \\
\hline 4 & 4/17/2012 12:11:34 & Concordo & Sim & Por meio de reuniões e veículos de comunicação interna. \\
\hline 5 & 4/17/2012 12:19:15 & Concordo & $\begin{array}{l}\text { Não tenho } \\
\text { certeza }\end{array}$ & \\
\hline 6 & $4 / 17 / 201212: 55: 10$ & Concordo & Não & \\
\hline 7 & 4/17/2012 13:35:24 & Concordo & Não & \\
\hline 8 & 4/17/2012 13:37:19 & Concordo & Sim & e-mail, jornal eletrônico diário \\
\hline 9 & 4/17/2012 13:43:37 & Discordo & $\begin{array}{l}\text { Não tenho } \\
\text { certeza }\end{array}$ & \\
\hline 10 & 4/17/2012 14:01:55 & Concordo & Não & \\
\hline 11 & 4/17/2012 15:12:18 & Concordo & $\begin{array}{l}\text { Não tenho } \\
\text { certeza }\end{array}$ & \\
\hline 12 & 4/17/2012 15:14:44 & $\begin{array}{l}\text { Não tenho } \\
\text { certeza }\end{array}$ & $\begin{array}{l}\text { Não tenho } \\
\text { certeza }\end{array}$ & \\
\hline 13 & 4/17/2012 15:36:31 & Concordo & Sim & $\begin{array}{l}\text { Reuniões periódicas com a Chefia. } \\
\text { Divulgação meios internos de comunicação: intranet, emdia. }\end{array}$ \\
\hline 14 & 4/17/2012 16:45:55 & Concordo & $\begin{array}{l}\text { Não tenho } \\
\text { certeza }\end{array}$ & \\
\hline 15 & 4/17/2012 17:20:05 & $\begin{array}{l}\text { Concordo } \\
\text { totalmente }\end{array}$ & Sim & $\begin{array}{l}\text { a) Pelo envolvimento de todos os empregados na elaboração do } \\
\text { Plano Diretor da Unidade - PDU, na divulgação desse PDU e no } \\
\text { seu acompanhemento para certificar-se se as metas estão sendo } \\
\text { atingidas; } \\
\text { b) Pela constante divulgação interna das políticas, objetivos, } \\
\text { metas e resultados através dos mais diversos meios de } \\
\text { comunicação disponíveis na Unidade. } \\
\text { c) Por reuniões gerais (bimestrais) da Chefia com todos os } \\
\text { empregados. } \\
\text { d) Pelo sistema de avaliação }\end{array}$ \\
\hline 16 & $4 / 18 / 20128: 47: 50$ & Concordo & Sim & $\begin{array}{l}\text { São variados os canais de comunicação para essa finalidade, } \\
\text { tais como publicações internas impressas e eletrônicas, como } \\
\text { também reuniões e outros eventos similares }\end{array}$ \\
\hline 17 & 4/18/2012 9:00:16 & $\begin{array}{l}\text { Concordo } \\
\text { totalmente }\end{array}$ & $\begin{array}{l}\text { Não tenho } \\
\text { certeza }\end{array}$ & \\
\hline 18 & 4/18/2012 11:10:45 & Discordo & Não & \\
\hline 19 & 4/18/2012 14:27:11 & Concordo & Sim & $\begin{array}{l}\text { Por intermédio de um evento realizado para internalização do } \\
\text { Plano Diretor da Unidade e também pela divulgação nos murais, } \\
\text { intranet e informativo de comunicação interna. }\end{array}$ \\
\hline 20 & 4/19/2012 11:26:10 & Concordo & Sim & $\begin{array}{l}\text { É DIVULGADO SEMPRE NO JORNAL INTERNO CHAMADO } \\
\text { "EM DIA" TUDO QUE A EMPRESA FAZ, OS SEMINÁRIOS QUE } \\
\text { OS PESQUISADORES PARTICIPAM E A MISSÃO DA } \\
\text { EMPRESA SÃO SEMPRE ENFOCADAS NAS REUNIÕES } \\
\text { (PRINCIPALMENTE INTERNAS). }\end{array}$ \\
\hline 21 & 4/20/2012 11:50:32 & Concordo & Sim & $\begin{array}{l}\text { Por meio de reuniões gerais e murais espalhados por toda a } \\
\text { Empresa. }\end{array}$ \\
\hline 22 & $4 / 20 / 2012$ 14:36:04 & Discordo & Sim & $\begin{array}{l}\text { A divulgação é feita através de panfletos, folderes,ou murais da } \\
\text { unidade, dispostos em locais de fácil acesso a todos os } \\
\text { empregados (em frente ao restaurante). Essa divulgação também } \\
\text { é feita através de e-mails e jornal eletrônico direcionado a todos. }\end{array}$ \\
\hline 23 & 4/24/2012 8:19:07 & $\begin{array}{l}\text { Concordo } \\
\text { totalmente }\end{array}$ & Sim & $\begin{array}{l}\text { Por meio dos informativos como o Em dia, reuniões nos setores, } \\
\text { reuniões entre chefia e todos os empregados e também } \\
\text { divulgação nos murais. }\end{array}$ \\
\hline
\end{tabular}




\begin{tabular}{|c|c|c|c|c|}
\hline 24 & 4/24/2012 11:06:30 & Concordo & Sim & Através das reuniões gerais e nos murais \\
\hline 25 & 5/8/2012 9:10:52 & Concordo & Sim & atraves de divulgação nos murais \\
\hline 26 & 5/8/2012 9:19:52 & Discordo & $\begin{array}{l}\text { Não tenho } \\
\text { certeza }\end{array}$ & \\
\hline 27 & $5 / 10 / 201211: 24: 35$ & Concordo & Sim & $\begin{array}{l}\text { Balanço Social; Plano Diretor; Relatório de Atividades; Política } \\
\text { de Comunicação; Manuais, normas e regras, entre outros. }\end{array}$ \\
\hline 28 & 5/25/2012 10:13:36 & $\begin{array}{l}\text { Não tenho } \\
\text { certeza }\end{array}$ & Sim & \\
\hline 29 & $5 / 25 / 201210: 18: 46$ & Concordo & Sim & Reuniões com chefia geral, mural, e-mail. \\
\hline 30 & $5 / 25 / 201210: 29: 19$ & $\begin{array}{l}\text { Concordo } \\
\text { totalmente }\end{array}$ & Sim & $\begin{array}{l}\text { É colocado no "Em Dia" e Murais, mas nem tudo é divulgado, é } \\
\text { feito o maior esforço, mas ainda não atinge totalmente o público } \\
\text { de nível baixo. }\end{array}$ \\
\hline 31 & $5 / 25 / 201210: 37: 53$ & Concordo & $\begin{array}{l}\text { Não tenho } \\
\text { certeza }\end{array}$ & \\
\hline 32 & $5 / 25 / 201210: 41: 37$ & $\begin{array}{l}\text { Concordo } \\
\text { totalmente }\end{array}$ & Sim & \\
\hline 33 & $5 / 25 / 201210: 46: 53$ & $\begin{array}{l}\text { Não tenho } \\
\text { certeza }\end{array}$ & Sim & Pelas reuniões com chefias da unidade. \\
\hline 34 & $5 / 26 / 201220: 50: 45$ & $\begin{array}{l}\text { Não tenho } \\
\text { certeza }\end{array}$ & Sim & $\begin{array}{l}\text { Pelos meios de comunicação disponíveis: reuniões, murais, e- } \\
\text { mail. }\end{array}$ \\
\hline 35 & $5 / 26 / 2012$ 21:01:00 & Discordo & Sim & Através da reuniões técnicas e com a chefia. \\
\hline 36 & $5 / 26 / 201221: 07: 03$ & Concordo & $\begin{array}{l}\text { Não tenho } \\
\text { certeza }\end{array}$ & \\
\hline 37 & 5/26/2012 21:15:03 & $\begin{array}{l}\text { Não tenho } \\
\text { certeza }\end{array}$ & Sim & Através de informes de forma digital e impressos \\
\hline 38 & $5 / 26 / 201221: 21: 56$ & Concordo & Sim & Em reuniões. \\
\hline 39 & $5 / 26 / 201221: 31: 11$ & Concordo & $\begin{array}{l}\text { Não tenho } \\
\text { certeza }\end{array}$ & \\
\hline 40 & $5 / 26 / 201222: 31: 19$ & Concordo & Sim & E-mail, "Em Dia". \\
\hline 41 & 6/4/2012 15:17:48 & Concordo & Sim & \\
\hline 42 & $6 / 4 / 201215: 52: 42$ & Concordo & $\begin{array}{l}\text { Não tenho } \\
\text { certeza }\end{array}$ & \\
\hline 43 & 6/4/2012 16:04:11 & Discordo & Sim & Reunião, boletim. \\
\hline 44 & 6/4/2012 16:11:01 & Concordo & $\begin{array}{l}\text { Não tenho } \\
\text { certeza }\end{array}$ & \\
\hline 45 & $6 / 4 / 2012$ 16:21:10 & Concordo & Não & \\
\hline 46 & $6 / 4 / 201216: 32: 36$ & Concordo & $\begin{array}{l}\text { Não tenho } \\
\text { certeza }\end{array}$ & \\
\hline 47 & 6/4/2012 16:46:00 & Concordo & Não & \\
\hline 48 & 6/4/2012 16:50:01 & Concordo & $\begin{array}{l}\text { Não tenho } \\
\text { certeza }\end{array}$ & \\
\hline 49 & 6/4/2012 17:34:06 & Concordo & Sim & \\
\hline 50 & 6/4/2012 17:39:12 & Concordo & Sim & Através de reuniões com empregados e outras ferramentas. \\
\hline 51 & 6/4/2012 17:43:06 & Concordo & Sim & \\
\hline 52 & $6 / 4 / 201217: 52: 33$ & Concordo & Sim & \\
\hline 53 & 6/4/2012 17:56:12 & $\begin{array}{l}\text { Concordo } \\
\text { totalmente }\end{array}$ & Sim & \\
\hline 54 & 6/4/2012 18:01:36 & Concordo & Sim & \\
\hline 55 & 6/4/2012 18:07:50 & $\begin{array}{l}\text { Discordo } \\
\text { totalmente }\end{array}$ & Não & \\
\hline 56 & 6/4/2012 18:11:45 & Concordo & $\begin{array}{l}\text { Não tenho } \\
\text { certeza }\end{array}$ & \\
\hline 57 & 6/4/2012 18:20:39 & Concordo & Sim & Através de reuniões, dia de campo. \\
\hline 58 & 6/4/2012 18:25:51 & Concordo & $\begin{array}{l}\text { Não tenho } \\
\text { certeza }\end{array}$ & \\
\hline 59 & 6/4/2012 18:33:14 & Concordo & $\begin{array}{l}\text { Não tenho } \\
\text { certeza }\end{array}$ & \\
\hline 60 & 6/4/2012 18:36:46 & Concordo & Não & \\
\hline 61 & 6/4/2012 18:41:06 & Discordo & Não & \\
\hline 62 & 6/4/2012 18:48:24 & $\begin{array}{l}\text { Não tenho } \\
\text { certeza }\end{array}$ & $\begin{array}{l}\text { Não tenho } \\
\text { certeza }\end{array}$ & \\
\hline 63 & 6/4/2012 18:51:36 & Concordo & Sim & Mural, reunião geral. \\
\hline 64 & 6/4/2012 18:56:35 & Concordo & Sim & Mídia impressa, nos murais e outros. \\
\hline 65 & 6/4/2012 19:02:25 & Concordo & Sim & Cartazes e e-mail. \\
\hline 66 & 6/4/2012 19:20:48 & Concordo & Sim & Reuniões do público interno com a chefia, treinamentos. \\
\hline 67 & 6/4/2012 22:17:19 & Concordo & Sim & Reunião geral. \\
\hline 68 & 6/4/2012 22:26:12 & $\begin{array}{l}\text { Não tenho } \\
\text { certeza }\end{array}$ & $\begin{array}{l}\text { Não tenho } \\
\text { certeza }\end{array}$ & \\
\hline 69 & 6/4/2012 22:29:24 & $\begin{array}{l}\text { Concordo } \\
\text { totalmente }\end{array}$ & $\begin{array}{l}\text { Não tenho } \\
\text { certeza }\end{array}$ & \\
\hline 70 & 6/4/2012 22:38:39 & Concordo & Sim & E-mail, murais, via eletrônica. \\
\hline 71 & 6/4/2012 22:44:02 & Concordo & Sim & Divulgação em reuniões, jornais internos e murais. \\
\hline 72 & $6 / 4 / 201222: 47: 33$ & Concordo & Não & \\
\hline
\end{tabular}




\begin{tabular}{|c|c|c|c|c|}
\hline 73 & 6/4/2012 22:51:35 & | Concordo & Sim & \\
\hline 74 & $6 / 4 / 201222: 55: 30$ & $\begin{array}{l}\text { Concordo } \\
\text { totalmente }\end{array}$ & Não & \\
\hline 75 & 6/4/2012 22:59:27 & Concordo & Não & \\
\hline 76 & 6/4/2012 23:14:14 & Concordo & Sim & E-mail, reunião, mural \\
\hline 77 & 6/4/2012 23:17:51 & Concordo & $\begin{array}{l}\begin{array}{l}\text { Não tenho } \\
\text { certeza }\end{array} \\
\end{array}$ & \\
\hline 78 & 6/4/2012 23:22:17 & Concordo & Sim & Através de reuniões, divulgação em murais, aviso em e-mail \\
\hline 79 & 6/4/2012 23:25:45 & Concordo & $\begin{array}{l}\text { Não tenho } \\
\text { certeza }\end{array}$ & \\
\hline 80 & 6/5/2012 11:45:22 & $\begin{array}{l}\text { Não tenho } \\
\text { certeza }\end{array}$ & Não & \\
\hline 81 & 6/5/2012 11:48:27 & Concordo & $\begin{array}{l}\text { Não tenho } \\
\text { certeza }\end{array}$ & \\
\hline 82 & 6/5/2012 12:20:39 & Concordo & $\begin{array}{l}\text { Não tenho } \\
\text { certeza }\end{array}$ & \\
\hline 83 & 6/5/2012 12:35:29 & Concordo & Não & \\
\hline 84 & 6/5/2012 12:41:18 & Concordo & Sim & \\
\hline 85 & $6 / 5 / 2012$ 12:45:41 & Concordo & Não & \\
\hline 86 & 6/5/2012 12:49:05 & Discordo & Não & \\
\hline 87 & 6/5/2012 12:51:29 & \begin{tabular}{|l} 
Não tenho \\
certeza
\end{tabular} & Não & \\
\hline 88 & $6 / 5 / 201212: 54: 23$ & Concordo & Sim & E-mail \\
\hline 89 & 6/5/2012 12:58:47 & \begin{tabular}{|l|} 
Discordo \\
totalmente
\end{tabular} & Sim & Através de murais e até no auditório \\
\hline 90 & 6/5/2012 15:59:42 & $\begin{array}{l}\text { Não tenho } \\
\text { certeza }\end{array}$ & $\begin{array}{l}\text { Não tenho } \\
\text { certeza }\end{array}$ & \\
\hline 91 & 6/5/2012 16:03:43 & $\begin{array}{l}\text { Concordo } \\
\text { totalmente }\end{array}$ & Sim & Através de e-mail e reuniões \\
\hline 92 & 6/5/2012 16:10:15 & Concordo & Sim & Reuniões gerais, "em dia" e comunicação interna \\
\hline 93 & 6/5/2012 16:15:21 & Concordo & $\begin{array}{l}\text { Não tenho } \\
\text { certeza }\end{array}$ & \\
\hline 94 & 6/5/2012 16:19:02 & Concordo & $\begin{array}{l}\text { Não tenho } \\
\text { certeza }\end{array}$ & \\
\hline 95 & 6/5/2012 16:22:13 & Discordo & Sim & Reunião com empregados \\
\hline 96 & 6/5/2012 16:25:49 & $\begin{array}{l}\text { Concordo } \\
\text { totalmente }\end{array}$ & Sim & E-mail \\
\hline 97 & 6/5/2012 16:29:54 & Discordo & $\begin{array}{l}\text { Não tenho } \\
\text { certeza }\end{array}$ & \\
\hline 98 & 6/5/2012 16:33:49 & Concordo & Sim & Materiais impressos \\
\hline 99 & 6/5/2012 16:37:16 & Discordo & $\begin{array}{l}\text { Não tenho } \\
\text { certeza }\end{array}$ & \\
\hline 100 & 6/5/2012 16:40:36 & Concordo & Sim & Internet, reunião, mídia impressa \\
\hline 101 & 6/5/2012 16:43:37 & Concordo & $\begin{array}{l}\text { Não tenho } \\
\text { certeza }\end{array}$ & \\
\hline 102 & 6/5/2012 16:47:01 & Concordo & Sim & Mural, cartazes, internet \\
\hline 103 & 6/5/2012 16:50:49 & Concordo & $\begin{array}{l}\text { Não tenho } \\
\text { certeza }\end{array}$ & \\
\hline 104 & 6/5/2012 19:42:10 & Concordo & Sim & \\
\hline 105 & 6/5/2012 19:46:16 & Discordo & Sim & Reuniões gerais esporádicas \\
\hline 106 & 6/5/2012 19:49:26 & $\begin{array}{l}\text { Não tenho } \\
\text { certeza }\end{array}$ & Sim & Mural, reunião e e-mail \\
\hline 107 & 6/5/2012 19:52:12 & Concordo & Não & \\
\hline 108 & 6/5/2012 19:56:29 & Concordo & Sim & Reuniões, mídia, e-mail \\
\hline 109 & $6 / 5 / 201220: 00: 22$ & Concordo & Sim & E-mail, memorando \\
\hline 110 & 6/5/2012 20:06:31 & Concordo & $\begin{array}{l}\text { Não tenho } \\
\text { certeza }\end{array}$ & \\
\hline 111 & 6/5/2012 20:09:43 & Concordo & Sim & \\
\hline 112 & 6/5/2012 20:13:31 & Concordo & Sim & BCA, boletins técnicos, todos.com, site \\
\hline 113 & 6/5/2012 20:22:09 & Concordo & $\begin{array}{l}\text { Não tenho } \\
\text { certeza }\end{array}$ & \\
\hline 114 & $6 / 5 / 201220: 28: 29$ & $\begin{array}{l}\text { Concordo } \\
\text { totalmente }\end{array}$ & Sim & \\
\hline 115 & $6 / 5 / 201220: 31: 50$ & Concordo & $\begin{array}{l}\text { Não tenho } \\
\text { certeza }\end{array}$ & \\
\hline 116 & 6/5/2012 22:09:52 & Concordo & Sim & Murais, e-mail, prospectos \\
\hline 117 & 6/5/2012 22:12:49 & Concordo & $\begin{array}{l}\text { Não tenho } \\
\text { certeza }\end{array}$ & \\
\hline 118 & 6/5/2012 22:18:18 & Discordo & Não & \\
\hline 119 & $6 / 5 / 2012$ 22:23:26 & $\begin{array}{l}\text { Não tenho } \\
\text { certeza }\end{array}$ & Não & \\
\hline 120 & 6/5/2012 22:26:38 & Discordo & Não & \\
\hline
\end{tabular}




\begin{tabular}{|c|c|c|c|c|}
\hline 121 & 6/5/2012 22:33:55 & \begin{tabular}{|l} 
Não tenho \\
certeza
\end{tabular} & Não & \\
\hline 122 & 6/5/2012 22:39:07 & Concordo & $\begin{array}{l}\text { Não tenho } \\
\text { certeza }\end{array}$ & \\
\hline 123 & 6/5/2012 22:43:18 & Concordo & Não & \\
\hline 124 & 6/5/2012 22:46:29 & Concordo & Sim & Reuniões \\
\hline 125 & 6/5/2012 22:56:20 & $\begin{array}{l}\text { Não tenho } \\
\text { certeza }\end{array}$ & $\begin{array}{l}\text { Não tenho } \\
\text { certeza }\end{array}$ & \\
\hline 126 & 6/6/2012 13:04:30 & Concordo & Sim & Reunião geral \\
\hline 127 & 6/6/2012 19:19:01 & Concordo & Sim & Reunião geral no auditório \\
\hline 128 & 6/6/2012 19:24:46 & Concordo & $\begin{array}{l}\text { Não tenho } \\
\text { certeza }\end{array}$ & \\
\hline 129 & 6/6/2012 19:28:35 & Concordo & Não & \\
\hline 130 & 6/6/2012 19:33:03 & Concordo & Sim & Por e-mail \\
\hline 131 & 6/6/2012 19:39:46 & $\begin{array}{l}\text { Não tenho } \\
\text { certeza }\end{array}$ & $\begin{array}{l}\text { Não tenho } \\
\text { certeza }\end{array}$ & \\
\hline 132 & 6/6/2012 19:48:52 & Concordo & Sim & Através de reuniões gerais com as chefias \\
\hline 133 & 6/6/2012 19:55:33 & Concordo & Sim & Reuniões, comunicados via e-mail e murais \\
\hline 134 & 6/6/2012 20:06:17 & Concordo & Sim & Reuniões, informes eletrônicos e impressos \\
\hline 135 & 6/6/2012 20:14:27 & Concordo & Sim & $\begin{array}{l}\text { Não sei avaliar como, mas funcionários de níveis possuem uma } \\
\text { boa instrução sobre os resultados da empresa, por vezes } \\
\text { atuando como divulgadores destes resultados para a sociedade. }\end{array}$ \\
\hline 136 & 6/6/2012 20:18:09 & Concordo & Não & \\
\hline 137 & 6/6/2012 20:23:49 & Concordo & Não & \\
\hline 138 & 6/6/2012 20:32:06 & $\begin{array}{l}\text { Concordo } \\
\text { totalmente }\end{array}$ & Sim & Reunião, murais, e-mail \\
\hline 139 & 6/6/2012 20:38:33 & Concordo & Sim & PDU, editáis, jornal diário, etc \\
\hline 140 & 6/6/2012 20:43:11 & Concordo & $\begin{array}{l}\text { Não tenho } \\
\text { certeza }\end{array}$ & \\
\hline 141 & 6/6/2012 20:47:09 & Discordo & Sim & Reuniões, impresso, etc \\
\hline 142 & 6/6/2012 20:52:11 & Concordo & Não & \\
\hline 143 & $6 / 6 / 201220: 56: 08$ & Concordo & Sim & Reunião e mural \\
\hline 144 & $6 / 6 / 201220: 59: 32$ & Concordo & Sim & \\
\hline 145 & 6/6/2012 21:03:22 & Discordo & Sim & E-mail \\
\hline 146 & 6/6/2012 21:08:44 & Concordo & Sim & Através do "Em dia" e reuniões \\
\hline 147 & 6/6/2012 21:18:22 & Concordo & Sim & \\
\hline 148 & 6/6/2012 21:21:41 & Concordo & Sim & No "Em dia" e reuniões \\
\hline 149 & 6/6/2012 21:24:40 & Concordo & Sim & \\
\hline 150 & 6/6/2012 21:27:13 & $\begin{array}{l}\text { Não tenho } \\
\text { certeza }\end{array}$ & Não & \\
\hline 151 & 6/6/2012 21:33:33 & $\begin{array}{l}\text { Não tenho } \\
\text { certeza }\end{array}$ & $\begin{array}{l}\text { Não tenho } \\
\text { certeza }\end{array}$ & \\
\hline 152 & 6/6/2012 21:36:19 & Concordo & $\begin{array}{l}\text { Não tenho } \\
\text { certeza }\end{array}$ & \\
\hline 153 & 6/6/2012 21:39:00 & Discordo & Não & \\
\hline 154 & 6/6/2012 21:55:53 & Concordo & Sim & $\begin{array}{l}\text { Através de reuniões gerais com todos os chefes e todos os } \\
\text { funcionários }\end{array}$ \\
\hline 155 & 6/6/2012 21:58:13 & $\begin{array}{l}\text { Concordo } \\
\text { totalmente }\end{array}$ & $\begin{array}{l}\text { Não } \\
\text { respondeu }\end{array}$ & \\
\hline 156 & 6/6/2012 23:00:50 & \begin{tabular}{|l|} 
Não \\
respondeu
\end{tabular} & Sim & Através de palestras e circulares \\
\hline 157 & 6/6/2012 23:03:13 & Concordo & $\begin{array}{l}\text { Não tenho } \\
\text { certeza }\end{array}$ & \\
\hline 158 & 6/6/2012 23:06:03 & Concordo & $\begin{array}{l}\text { Não tenho } \\
\text { certeza }\end{array}$ & \\
\hline 159 & 6/6/2012 23:08:43 & $\begin{array}{l}\text { Não } \\
\text { respondeu }\end{array}$ & $\begin{array}{l}\text { Não tenho } \\
\text { certeza }\end{array}$ & \\
\hline 160 & 6/6/2012 23:11:59 & Concordo & Sim & Através de reuniões com a chefia \\
\hline 161 & 6/6/2012 23:14:46 & Concordo & $\begin{array}{l}\text { Não tenho } \\
\text { certeza }\end{array}$ & \\
\hline 162 & 6/6/2012 23:17:03 & Discordo & Não & \\
\hline 163 & 6/6/2012 23:19:34 & Discordo & Não & \\
\hline 164 & $6 / 6 / 201223: 22: 38$ & \begin{tabular}{|l} 
Discordo \\
\end{tabular} & Não & \\
\hline 165 & 6/6/2012 23:25:54 & Concordo & Sim & E-mail \\
\hline 166 & 6/8/2012 10:36:36 & $\begin{array}{l}\text { Não tenho } \\
\text { certeza }\end{array}$ & Sim & \\
\hline 167 & 6/8/2012 10:40:01 & $\begin{array}{l}\text { Concordo } \\
\text { totalmente }\end{array}$ & Sim & Reuniões periódicas \\
\hline 168 & 6/8/2012 10:43:17 & $\begin{array}{l}\text { Não } \\
\text { respondeu }\end{array}$ & Sim & \\
\hline 169 & 6/8/2012 10:46:36 & Discordo & Sim & \\
\hline 170 & 6/8/2012 10:54:55 & Concordo & Não & \\
\hline 171 & 6/8/2012 10:57:40 & Concordo & Não & \\
\hline
\end{tabular}




\begin{tabular}{|c|c|c|c|c|c|c|c|c|}
\hline \# & $\begin{array}{c}\text { 4. Meu } \\
\text { superior } \\
\text { imediato } \\
\text { me } \\
\text { mantém } \\
\text { informado } \\
\text { sobre } \\
\text { todos os } \\
\text { assuntos } \\
\text { de nosso } \\
\text { setor. }\end{array}$ & $\begin{array}{c}\text { 5. A } \\
\text { comunicaçã } \\
\text { o e a } \\
\text { divulgação } \\
\text { interna dos } \\
\text { eventos e } \\
\text { das } \\
\text { atividades } \\
\text { dos } \\
\text { diversos } \\
\text { setores são } \\
\text { conhecidas } \\
\text { por todos } \\
\text { os } \\
\text { empregados } \\
\text { na empresa. }\end{array}$ & $\begin{array}{c}\text { 6. Meu } \\
\text { superior } \\
\text { imediato } \\
\text { segue o } \\
\text { estilo da } \\
\text { comunicaçã } \\
\text { o interna } \\
\text { definida em } \\
\text { manual pela } \\
\text { empresa } \\
\text { para se } \\
\text { comunicar } \\
\text { com os } \\
\text { subordinad } \\
\text { os. }\end{array}$ & $\begin{array}{c}\text { 7. } 0 \\
\text { relacionam } \\
\text { ento entre o } \\
\text { superior } \\
\text { imediato e } \\
\text { os } \\
\text { subordinad } \\
\text { os dentro } \\
\text { do meu } \\
\text { setor é } \\
\text { considerad } \\
\text { o: }\end{array}$ & $\begin{array}{c}\text { 8. Meu } \\
\text { superior } \\
\text { imediato } \\
\text { estimula } \\
\text { cada } \\
\text { membro da } \\
\text { equipe/setor } \\
\text { a dar } \\
\text { contribuição } \\
\text { e a realizar } \\
\text { o seu } \\
\text { melhor } \\
\text { dentro da } \\
\text { empresa. }\end{array}$ & \begin{tabular}{|} 
9. No processo \\
de \\
comunicação \\
interna da \\
Unidade, eu \\
consigo \\
identificar, de \\
modo claro, as \\
recomendações \\
para que seja \\
utilizada a \\
comunicação \\
oral entre \\
chefes, \\
supervisores e \\
empregados da \\
equipe.
\end{tabular} & $\begin{array}{l}\text { 10. Existem e } \\
\text { estão claras } \\
\text { para mim, no } \\
\text { meu local de } \\
\text { trabalho, } \\
\text { barreiras } \\
\text { para o uso } \\
\text { da } \\
\text { comunicação } \\
\text { oral entre } \\
\text { chefes, } \\
\text { supervisores } \\
\text { e } \\
\text { empregados. }\end{array}$ & $\begin{array}{c}\text { 11. Utilizo } \\
\text { a } \\
\text { comunica } \\
\text { ção oral } \\
\text { no } \\
\text { processo } \\
\text { de } \\
\text { tomada } \\
\text { de } \\
\text { decisão } \\
\text { com os } \\
\text { chefes } \\
\text { ligados } \\
\text { diretamen } \\
\text { te a mim: }\end{array}$ \\
\hline 1 & $\begin{array}{l}\text { Quase } \\
\text { nunca }\end{array}$ & $\begin{array}{l}\text { Discordo } \\
\text { totalmente }\end{array}$ & $\begin{array}{l}\text { Discordo } \\
\text { totalmente }\end{array}$ & $\begin{array}{l}\text { Não tenho } \\
\text { certeza }\end{array}$ & Discordo & \begin{tabular}{|l|} 
Discordo \\
totalmente
\end{tabular} & Concordo & Sim \\
\hline 2 & Sempre & Concordo & Concordo & Satisfatório & Concordo & Concordo & Concordo & Sim \\
\hline 3 & $\begin{array}{l}\text { Quase } \\
\text { sempre }\end{array}$ & Discordo & $\begin{array}{l}\text { Não tenho } \\
\text { certeza }\end{array}$ & Satisfatório & $\begin{array}{l}\text { Concordo } \\
\text { totalmente }\end{array}$ & $\begin{array}{l}\text { Não tenho } \\
\text { certeza }\end{array}$ & $\begin{array}{l}\text { Não tenho } \\
\text { certeza }\end{array}$ & Sim \\
\hline 4 & $\begin{array}{l}\text { Quase } \\
\text { sempre }\end{array}$ & Concordo & $\begin{array}{l}\text { Concordo } \\
\text { totalmente }\end{array}$ & $\begin{array}{l}\text { Totalmente } \\
\text { satisfatório }\end{array}$ & $\begin{array}{l}\text { Concordo } \\
\text { totalmente }\end{array}$ & $\begin{array}{l}\text { Não tenho } \\
\text { certeza }\end{array}$ & $\begin{array}{l}\text { Discordo } \\
\text { totalmente }\end{array}$ & Sim \\
\hline 5 & $\begin{array}{l}\text { Quase } \\
\text { sempre }\end{array}$ & Concordo & Concordo & Satisfatório & $\begin{array}{l}\text { Não tenho } \\
\text { certeza }\end{array}$ & Concordo & Discordo & Sim \\
\hline 6 & $\begin{array}{l}\text { Quase } \\
\text { sempre }\end{array}$ & Discordo & $\begin{array}{l}\text { Não tenho } \\
\text { certeza }\end{array}$ & Satisfatório & Concordo & $\begin{array}{l}\text { Não tenho } \\
\text { certeza }\end{array}$ & Discordo & Sim \\
\hline 7 & $\begin{array}{l}\text { Quase } \\
\text { sempre }\end{array}$ & Concordo & Concordo & Satisfatório & $\begin{array}{l}\text { Não tenho } \\
\text { certeza }\end{array}$ & Discordo & Discordo & Sim \\
\hline 8 & Sempre & Concordo & Concordo & $\begin{array}{l}\text { Totalmente } \\
\text { satisfatório }\end{array}$ & Concordo & Concordo & Concordo & Sim \\
\hline 9 & $\begin{array}{l}\text { Quase } \\
\text { nunca }\end{array}$ & Discordo & $\begin{array}{l}\text { Não tenho } \\
\text { certeza }\end{array}$ & Satisfatório & Concordo & Discordo & Discordo & Sim \\
\hline 10 & $\begin{array}{l}\text { Quase } \\
\text { sempre }\end{array}$ & Discordo & Concordo & Satisfatório & $\begin{array}{l}\text { Concordo } \\
\text { totalmente }\end{array}$ & $\begin{array}{l}\text { Não tenho } \\
\text { certeza }\end{array}$ & Discordo & Sim \\
\hline 11 & $\begin{array}{l}\text { Quase } \\
\text { sempre }\end{array}$ & $\begin{array}{l}\text { Não tenho } \\
\text { certeza }\end{array}$ & $\begin{array}{l}\text { Não tenho } \\
\text { certeza }\end{array}$ & Satisfatório & $\begin{array}{l}\text { Não tenho } \\
\text { certeza }\end{array}$ & $\begin{array}{l}\text { Não tenho } \\
\text { certeza }\end{array}$ & $\begin{array}{l}\text { Não tenho } \\
\text { certeza }\end{array}$ & Às vezes \\
\hline 12 & $\begin{array}{l}\text { Quase } \\
\text { sempre }\end{array}$ & $\begin{array}{l}\text { Não tenho } \\
\text { certeza }\end{array}$ & $\begin{array}{l}\text { Não tenho } \\
\text { certeza }\end{array}$ & Satisfatório & Concordo & $\begin{array}{l}\text { Não tenho } \\
\text { certeza }\end{array}$ & $\begin{array}{l}\text { Não tenho } \\
\text { certeza }\end{array}$ & Sim \\
\hline 13 & $\begin{array}{l}\text { Quase } \\
\text { sempre }\end{array}$ & Concordo & Concordo & Satisfatório & \begin{tabular}{|l}
$\begin{array}{l}\text { Concordo } \\
\text { totalmente }\end{array}$ \\
\end{tabular} & $\begin{array}{l}\text { Não tenho } \\
\text { certeza }\end{array}$ & $\begin{array}{l}\text { Não tenho } \\
\text { certeza }\end{array}$ & Sim \\
\hline 14 & $\begin{array}{l}\text { Quase } \\
\text { sempre }\end{array}$ & Concordo & $\begin{array}{l}\text { Não tenho } \\
\text { certeza }\end{array}$ & Satisfatório & Concordo & \begin{tabular}{|l|}
$\begin{array}{l}\text { Não tenho } \\
\text { certeza }\end{array}$ \\
\end{tabular} & Discordo & Sim \\
\hline 15 & Sempre & Concordo & Concordo & Satisfatório & $\begin{array}{l}\text { Concordo } \\
\text { totalmente }\end{array}$ & Concordo & Discordo & Sim \\
\hline 16 & $\begin{array}{l}\text { Quase } \\
\text { sempre }\end{array}$ & Concordo & Concordo & Satisfatório & Concordo & Concordo & Discordo & Sim \\
\hline 17 & $\begin{array}{l}\text { Quase } \\
\text { sempre }\end{array}$ & $\begin{array}{l}\text { Concordo } \\
\text { totalmente }\end{array}$ & Concordo & Satisfatório & $\begin{array}{l}\text { Concordo } \\
\text { totalmente }\end{array}$ & Concordo & Discordo & Sim \\
\hline 18 & Sempre & Discordo & Discordo & Satisfatório & $\begin{array}{l}\text { Concordo } \\
\text { totalmente }\end{array}$ & Discordo & Discordo & Sim \\
\hline 19 & Sempre & Concordo & Concordo & $\begin{array}{l}\text { Totalmente } \\
\text { insatisfatório }\end{array}$ & $\begin{array}{l}\text { Concordo } \\
\text { totalmente }\end{array}$ & Concordo & Concordo & Sim \\
\hline 20 & $\begin{array}{l}\text { Quase } \\
\text { nunca }\end{array}$ & Discordo & $\begin{array}{l}\text { Concordo } \\
\text { totalmente }\end{array}$ & $\begin{array}{l}\text { Totalmente } \\
\text { satisfatório }\end{array}$ & Concordo & Discordo & Concordo & Sim \\
\hline 21 & $\begin{array}{l}\text { Quase } \\
\text { sempre }\end{array}$ & Discordo & Concordo & Satisfatório & Concordo & Concordo & Concordo & Sim \\
\hline 22 & $\begin{array}{l}\text { Quase } \\
\text { sempre }\end{array}$ & Concordo & $\begin{array}{l}\text { Não tenho } \\
\text { certeza }\end{array}$ & Satisfatório & Discordo & Discordo & Discordo & Sim \\
\hline 23 & Sempre & Concordo & Concordo & $\begin{array}{l}\text { Totalmente } \\
\text { satisfatório }\end{array}$ & $\begin{array}{l}\text { Concordo } \\
\text { totalmente }\end{array}$ & Concordo & $\begin{array}{l}\text { Discordo } \\
\text { totalmente }\end{array}$ & Sim \\
\hline 24 & Sempre & Concordo & $\begin{array}{l}\text { Não tenho } \\
\text { certeza }\end{array}$ & $\begin{array}{l}\text { Totalmente } \\
\text { satisfatório }\end{array}$ & $\begin{array}{l}\text { Concordo } \\
\text { totalmente }\end{array}$ & $\begin{array}{l}\text { Não tenho } \\
\text { certeza }\end{array}$ & Discordo & Sim \\
\hline 25 & Sempre & Concordo & Concordo & $\begin{array}{l}\text { Totalmente } \\
\text { satisfatório }\end{array}$ & Concordo & Concordo & Discordo & Sim \\
\hline 26 & Sempre & $\begin{array}{l}\text { Não tenho } \\
\text { certeza }\end{array}$ & $\begin{array}{l}\text { Não tenho } \\
\text { certeza }\end{array}$ & Satisfatório & Concordo & $\begin{array}{l}\text { Não tenho } \\
\text { certeza }\end{array}$ & $\begin{array}{l}\text { Não tenho } \\
\text { certeza }\end{array}$ & Sim \\
\hline 27 & Sempre & Concordo & Concordo & $\begin{array}{l}\text { Totalmente } \\
\text { satisfatório }\end{array}$ & $\begin{array}{l}\text { Concordo } \\
\text { totalmente }\end{array}$ & Concordo & Discordo & Sim \\
\hline 28 & $\begin{array}{l}\text { Quase } \\
\text { sempre }\end{array}$ & Concordo & Concordo & Satisfatório & Discordo & Concordo & Concordo & Às vezes \\
\hline
\end{tabular}




\begin{tabular}{|c|c|c|c|c|c|c|c|c|}
\hline 29 & $\begin{array}{l}\text { Quase } \\
\text { sempre }\end{array}$ & Concordo & Concordo & Satisfatório & Concordo & Concordo & Concordo & Às vezes \\
\hline 30 & Sempre & Concordo & $\begin{array}{l}\text { Concordo } \\
\text { totalmente }\end{array}$ & Satisfatório & $\begin{array}{l}\text { Concordo } \\
\text { totalmente }\end{array}$ & Concordo & $\begin{array}{l}\text { Discordo } \\
\text { totalmente }\end{array}$ & Sim \\
\hline 31 & \begin{tabular}{|l} 
Quase \\
sempre
\end{tabular} & Discordo & Discordo & Satisfatório & $\begin{array}{l}\text { Não tenho } \\
\text { certeza }\end{array}$ & Concordo & Concordo & Sim \\
\hline 32 & Sempre & $\begin{array}{l}\text { Concordo } \\
\text { totalmente }\end{array}$ & Concordo & $\begin{array}{l}\text { Totalmente } \\
\text { satisfatório }\end{array}$ & $\begin{array}{l}\text { Concordo } \\
\text { totalmente }\end{array}$ & $\begin{array}{l}\text { Concordo } \\
\text { totalmente }\end{array}$ & Discordo & Sim \\
\hline 33 & $\begin{array}{l}\text { Quase } \\
\text { sempre }\end{array}$ & Concordo & Concordo & Satisfatório & Concordo & $\begin{array}{l}\text { Não tenho } \\
\text { certeza }\end{array}$ & Discordo & Sim \\
\hline 34 & \begin{tabular}{|l} 
Quase \\
sempre
\end{tabular} & $\begin{array}{l}\text { Não tenho } \\
\text { certeza }\end{array}$ & $\begin{array}{l}\text { Não tenho } \\
\text { certeza }\end{array}$ & Satisfatório & Concordo & Discordo & Discordo & Às vezes \\
\hline 35 & \begin{tabular}{|l} 
Quase \\
sempre
\end{tabular} & Concordo & $\begin{array}{l}\text { Não tenho } \\
\text { certeza }\end{array}$ & Insatisfatório & Concordo & Discordo & Discordo & Sim \\
\hline 36 & Sempre & $\begin{array}{l}\text { Concordo } \\
\text { totalmente }\end{array}$ & Concordo & Satisfatório & $\begin{array}{l}\begin{array}{l}\text { Concordo } \\
\text { totalmente }\end{array} \\
\end{array}$ & $\begin{array}{l}\text { Concordo } \\
\text { totalmente }\end{array}$ & Concordo & Sim \\
\hline 37 & Sempre & Discordo & $\begin{array}{l}\text { Não tenho } \\
\text { certeza }\end{array}$ & Satisfatório & Concordo & Concordo & $\begin{array}{l}\text { Concordo } \\
\text { totalmente }\end{array}$ & Sim \\
\hline 38 & \begin{tabular}{|l} 
Quase \\
sempre
\end{tabular} & Concordo & Concordo & Satisfatório & Concordo & Discordo & Concordo & Sim \\
\hline 39 & Sempre & $\begin{array}{l}\text { Concordo } \\
\text { totalmente }\end{array}$ & Concordo & Satisfatório & Concordo & Concordo & Discordo & Sim \\
\hline 40 & $\begin{array}{l}\text { Quase } \\
\text { sempre }\end{array}$ & Discordo & $\begin{array}{l}\text { Não tenho } \\
\text { certeza }\end{array}$ & Satisfatório & Concordo & Concordo & Concordo & Não \\
\hline 41 & Sempre & Concordo & Discordo & Satisfatório & Concordo & Discordo & Discordo & Sim \\
\hline 42 & $\begin{array}{l}\text { Quase } \\
\text { sempre }\end{array}$ & Concordo & $\begin{array}{l}\text { Não tenho } \\
\text { certeza }\end{array}$ & Satisfatório & Concordo & $\begin{array}{l}\text { Não tenho } \\
\text { certeza }\end{array}$ & Discordo & Sim \\
\hline 43 & Nunca & Discordo & $\begin{array}{l}\text { Discordo } \\
\text { totalmente }\end{array}$ & $\begin{array}{l}\text { Totalmente } \\
\text { insatisfatório }\end{array}$ & $\begin{array}{l}\text { Discordo } \\
\text { totalmente }\end{array}$ & Discordo & Concordo & Sim \\
\hline 44 & \begin{tabular}{|l} 
Quase \\
sempre
\end{tabular} & $\begin{array}{l}\text { Não tenho } \\
\text { certeza }\end{array}$ & $\begin{array}{l}\text { Não tenho } \\
\text { certeza }\end{array}$ & Satisfatório & Concordo & Concordo & Discordo & Sim \\
\hline 45 & $\begin{array}{l}\text { Quase } \\
\text { sempre }\end{array}$ & $\begin{array}{l}\text { Discordo } \\
\text { totalmente }\end{array}$ & $\begin{array}{l}\text { Discordo } \\
\text { totalmente }\end{array}$ & Satisfatório & Discordo & Discordo & Discordo & Sim \\
\hline 46 & \begin{tabular}{|l|} 
Quase \\
sempre
\end{tabular} & Concordo & Concordo & Satisfatório & Concordo & Concordo & Discordo & Sim \\
\hline 47 & \begin{tabular}{|l|} 
Quase \\
sempre
\end{tabular} & Concordo & Concordo & Satisfatório & Discordo & Discordo & Discordo & Sim \\
\hline 48 & \begin{tabular}{|l|} 
Quase \\
sempre
\end{tabular} & Concordo & Concordo & Satisfatório & Discordo & Concordo & Discordo & Sim \\
\hline 49 & \begin{tabular}{|l} 
Quase \\
sempre
\end{tabular} & Discordo & $\begin{array}{l}\text { Não tenho } \\
\text { certeza }\end{array}$ & $\begin{array}{l}\begin{array}{l}\text { Totalmente } \\
\text { satisfatório }\end{array} \\
\end{array}$ & $\begin{array}{l}\begin{array}{l}\text { Concordo } \\
\text { totalmente }\end{array} \\
\end{array}$ & Concordo & Discordo & Sim \\
\hline 50 & $\begin{array}{l}\text { Quase } \\
\text { sempre }\end{array}$ & Concordo & Concordo & Satisfatório & Concordo & Concordo & Discordo & Sim \\
\hline 51 & Sempre & Concordo & \begin{tabular}{|l} 
Concordo \\
totalmente
\end{tabular} & $\begin{array}{l}\begin{array}{l}\text { Totalmente } \\
\text { satisfatório }\end{array} \\
\end{array}$ & Concordo & Concordo & $\begin{array}{l}\text { Concordo } \\
\text { totalmente }\end{array}$ & Sim \\
\hline 52 & $\begin{array}{l}\text { Quase } \\
\text { sempre }\end{array}$ & Concordo & Concordo & Satisfatório & Concordo & Concordo & Discordo & Às vezes \\
\hline 53 & Nunca & $\begin{array}{l}\text { Concordo } \\
\text { totalmente }\end{array}$ & Discordo & $\begin{array}{l}\text { Totalmente } \\
\text { insatisfatório }\end{array}$ & $\begin{array}{l}\text { Concordo } \\
\text { totalmente }\end{array}$ & $\begin{array}{l}\text { Não tenho } \\
\text { certeza }\end{array}$ & Concordo & Sim \\
\hline 54 & \begin{tabular}{|l} 
Quase \\
sempre
\end{tabular} & Concordo & Concordo & Satisfatório & Concordo & Concordo & Concordo & Sim \\
\hline 55 & $\begin{array}{l}\text { Quase } \\
\text { nunca }\end{array}$ & $\begin{array}{l}\text { Discordo } \\
\text { totalmente }\end{array}$ & $\begin{array}{l}\text { Não tenho } \\
\text { certeza }\end{array}$ & Satisfatório & $\begin{array}{l}\text { Não tenho } \\
\text { certeza }\end{array}$ & $\begin{array}{l}\text { Não tenho } \\
\text { certeza }\end{array}$ & $\begin{array}{l}\text { Não tenho } \\
\text { certeza }\end{array}$ & Às vezes \\
\hline 56 & $\begin{array}{l}\text { Quase } \\
\text { sempre }\end{array}$ & Discordo & $\begin{array}{l}\text { Não tenho } \\
\text { certeza }\end{array}$ & $\begin{array}{l}\begin{array}{l}\text { Totalmente } \\
\text { satisfatório }\end{array} \\
\end{array}$ & Concordo & $\begin{array}{l}\text { Não tenho } \\
\text { certeza }\end{array}$ & $\begin{array}{l}\text { Não tenho } \\
\text { certeza }\end{array}$ & Sim \\
\hline 57 & Sempre & Concordo & Concordo & Satisfatório & Concordo & Concordo & Concordo & Sim \\
\hline 58 & Sempre & Concordo & Concordo & Satisfatório & Concordo & Concordo & Concordo & Sim \\
\hline 59 & \begin{tabular}{|l|} 
Sempre \\
\end{tabular} & Discordo & Concordo & Satisfatório & Concordo & Concordo & Discordo & Sim \\
\hline 60 & Nunca & $\begin{array}{l}\text { Discordo } \\
\text { totalmente }\end{array}$ & Discordo & Insatisfatório & Discordo & Discordo & $\begin{array}{l}\text { Concordo } \\
\text { totalmente }\end{array}$ & Às vezes \\
\hline 61 & Nunca & Discordo & Discordo & Insatisfatório & \begin{tabular}{|l} 
Discordo \\
totalmente
\end{tabular} & $\begin{array}{l}\text { Não tenho } \\
\text { certeza }\end{array}$ & $\begin{array}{l}\text { Concordo } \\
\text { totalmente }\end{array}$ & Às vezes \\
\hline 62 & Sempre & Concordo & Concordo & Satisfatório & $\begin{array}{l}\text { Concordo } \\
\text { totalmente }\end{array}$ & Discordo & Concordo & Sim \\
\hline 63 & $\begin{array}{l}\text { Quase } \\
\text { sempre }\end{array}$ & Concordo & $\begin{array}{l}\text { Não tenho } \\
\text { certeza }\end{array}$ & Satisfatório & Concordo & $\begin{array}{l}\text { Não tenho } \\
\text { certeza }\end{array}$ & Discordo & Sim \\
\hline 64 & Sempre & $\begin{array}{l}\text { Concordo } \\
\text { totalmente }\end{array}$ & Concordo & Satisfatório & $\begin{array}{l}\begin{array}{l}\text { Concordo } \\
\text { totalmente }\end{array} \\
\end{array}$ & $\begin{array}{l}\text { Concordo } \\
\text { totalmente }\end{array}$ & Discordo & Não \\
\hline 65 & \begin{tabular}{|l} 
Quase \\
sempre
\end{tabular} & Concordo & Concordo & Satisfatório & $\begin{array}{l}\text { Não tenho } \\
\text { certeza }\end{array}$ & Concordo & Concordo & Sim \\
\hline 66 & \begin{tabular}{|l} 
Quase \\
sempre
\end{tabular} & $\begin{array}{l}\text { Não tenho } \\
\text { certeza }\end{array}$ & $\begin{array}{l}\text { Não tenho } \\
\text { certeza }\end{array}$ & Satisfatório & $\begin{array}{l}\text { Concordo } \\
\text { totalmente }\end{array}$ & Concordo & Concordo & Às vezes \\
\hline 67 & $\begin{array}{l}\text { Não tenho } \\
\text { certeza }\end{array}$ & Concordo & $\begin{array}{l}\text { Não tenho } \\
\text { certeza }\end{array}$ & Satisfatório & Concordo & $\begin{array}{l}\text { Não tenho } \\
\text { certeza }\end{array}$ & Discordo & Sim \\
\hline
\end{tabular}




\begin{tabular}{|c|c|c|c|c|c|c|c|c|}
\hline 68 & $\begin{array}{l}\text { Quase } \\
\text { sempre }\end{array}$ & Discordo & Discordo & Satisfatório & Concordo & $\begin{array}{l}\text { Não tenho } \\
\text { certeza }\end{array}$ & $\begin{array}{l}\text { Não tenho } \\
\text { certeza }\end{array}$ & Sim \\
\hline 69 & $\begin{array}{l}\text { Quase } \\
\text { nunca }\end{array}$ & Concordo & $\begin{array}{l}\text { Não tenho } \\
\text { certeza }\end{array}$ & $\begin{array}{l}\text { Totalmente } \\
\text { satisfatório }\end{array}$ & Concordo & $\begin{array}{l}\text { Não tenho } \\
\text { certeza }\end{array}$ & $\begin{array}{l}\text { Discordo } \\
\text { totalmente }\end{array}$ & Sim \\
\hline 70 & Sempre & $\begin{array}{l}\text { Concordo } \\
\text { totalmente }\end{array}$ & Concordo & Satisfatório & Concordo & Concordo & Discordo & Sim \\
\hline 71 & \begin{tabular}{|l|} 
Quase \\
sempre
\end{tabular} & Concordo & $\begin{array}{l}\text { Não tenho } \\
\text { certeza }\end{array}$ & Satisfatório & Concordo & Discordo & Discordo & Sim \\
\hline 72 & $\begin{array}{l}\text { Quase } \\
\text { sempre }\end{array}$ & Concordo & $\begin{array}{l}\text { Não tenho } \\
\text { certeza }\end{array}$ & Satisfatório & Concordo & Concordo & Concordo & Sim \\
\hline 73 & \begin{tabular}{|l} 
Quase \\
sempre
\end{tabular} & Concordo & Concordo & Satisfatório & Concordo & Discordo & $\begin{array}{l}\text { Discordo } \\
\text { totalmente }\end{array}$ & Às vezes \\
\hline 74 & Sempre & $\begin{array}{l}\text { Concordo } \\
\text { totalmente }\end{array}$ & $\begin{array}{l}\text { Concordo } \\
\text { totalmente }\end{array}$ & \begin{tabular}{|l|l} 
Totalmente \\
insatisfatório
\end{tabular} & \begin{tabular}{|l|}
$\begin{array}{l}\text { Concordo } \\
\text { totalmente }\end{array}$ \\
\end{tabular} & $\begin{array}{l}\text { Concordo } \\
\text { totalmente }\end{array}$ & Discordo & Sim \\
\hline 75 & \begin{tabular}{|l} 
Quase \\
sempre
\end{tabular} & Concordo & Concordo & Satisfatório & Concordo & Discordo & Discordo & Sim \\
\hline 76 & Sempre & Discordo & Concordo & $\begin{array}{l}\text { Totalmente } \\
\text { satisfatório }\end{array}$ & $\begin{array}{l}\text { Concordo } \\
\text { totalmente }\end{array}$ & Concordo & $\begin{array}{l}\text { Não tenho } \\
\text { certeza }\end{array}$ & Sim \\
\hline 77 & $\begin{array}{l}\text { Não tenho } \\
\text { certeza }\end{array}$ & $\begin{array}{l}\text { Discordo } \\
\text { totalmente }\end{array}$ & Concordo & Satisfatório & Concordo & Concordo & $\begin{array}{l}\text { Concordo } \\
\text { totalmente }\end{array}$ & Sim \\
\hline 78 & Sempre & Concordo & $\begin{array}{l}\text { Concordo } \\
\text { totalmente }\end{array}$ & $\begin{array}{l}\begin{array}{l}\text { Totalmente } \\
\text { satisfatório }\end{array} \\
\end{array}$ & Concordo & Concordo & $\begin{array}{l}\text { Concordo } \\
\text { totalmente }\end{array}$ & Sim \\
\hline 79 & Sempre & Concordo & $\begin{array}{l}\begin{array}{l}\text { Concordo } \\
\text { totalmente }\end{array} \\
\end{array}$ & $\begin{array}{l}\text { Totalmente } \\
\text { insatisfatório }\end{array}$ & Discordo & Discordo & Discordo & Às vezes \\
\hline 80 & $\begin{array}{l}\text { Quase } \\
\text { nunca }\end{array}$ & Discordo & Concordo & Satisfatório & $\begin{array}{l}\text { Não tenho } \\
\text { certeza }\end{array}$ & $\begin{array}{l}\text { Não tenho } \\
\text { certeza }\end{array}$ & Discordo & Sim \\
\hline 81 & \begin{tabular}{|l|} 
Quase \\
sempre
\end{tabular} & Concordo & Concordo & Satisfatório & Concordo & Concordo & Discordo & Sim \\
\hline 82 & Sempre & Discordo & Concordo & Satisfatório & Concordo & $\begin{array}{l}\text { Não tenho } \\
\text { certeza }\end{array}$ & Discordo & Não \\
\hline 83 & \begin{tabular}{|l} 
Quase \\
sempre
\end{tabular} & $\begin{array}{l}\text { Concordo } \\
\text { totalmente }\end{array}$ & Concordo & $\begin{array}{l}\begin{array}{l}\text { Totalmente } \\
\text { satisfatório }\end{array} \\
\end{array}$ & \begin{tabular}{|l|}
$\begin{array}{l}\text { Concordo } \\
\text { totalmente }\end{array}$ \\
\end{tabular} & Concordo & Discordo & Sim \\
\hline 84 & Sempre & Concordo & Concordo & Satisfatório & Concordo & $\begin{array}{l}\text { Não tenho } \\
\text { certeza }\end{array}$ & $\begin{array}{l}\text { Não tenho } \\
\text { certeza }\end{array}$ & Não \\
\hline 85 & Sempre & Concordo & Concordo & Satisfatório & Concordo & Concordo & Discordo & Sim \\
\hline 86 & $\begin{array}{l}\text { Quase } \\
\text { nunca }\end{array}$ & Discordo & \begin{tabular}{|l} 
Discordo \\
totalmente
\end{tabular} & Satisfatório & Discordo & Concordo & Discordo & Sim \\
\hline 87 & \begin{tabular}{|l} 
Quase \\
sempre
\end{tabular} & Concordo & Concordo & Satisfatório & $\begin{array}{l}\text { Não tenho } \\
\text { certeza }\end{array}$ & Concordo & Concordo & Sim \\
\hline 88 & Sempre & Concordo & Concordo & $\begin{array}{l}\text { Totalmente } \\
\text { insatisfatório }\end{array}$ & Concordo & Concordo & Discordo & Sim \\
\hline 89 & $\begin{array}{l}\text { Quase } \\
\text { sempre }\end{array}$ & $\begin{array}{l}\text { Não tenho } \\
\text { certeza }\end{array}$ & Concordo & Satisfatório & Concordo & Concordo & Concordo & Às vezes \\
\hline 90 & \begin{tabular}{|l} 
Quase \\
sempre
\end{tabular} & Concordo & Concordo & Satisfatório & Concordo & Concordo & Discordo & Sim \\
\hline 91 & Sempre & $\begin{array}{l}\text { Concordo } \\
\text { totalmente }\end{array}$ & $\begin{array}{l}\text { Concordo } \\
\text { totalmente }\end{array}$ & Satisfatório & $\begin{array}{l}\text { Concordo } \\
\text { totalmente }\end{array}$ & $\begin{array}{l}\text { Concordo } \\
\text { totalmente }\end{array}$ & Discordo & Sim \\
\hline 92 & Sempre & $\begin{array}{l}\text { Concordo } \\
\text { totalmente }\end{array}$ & Concordo & Satisfatório & $\begin{array}{l}\text { Concordo } \\
\text { totalmente }\end{array}$ & Concordo & $\begin{array}{l}\text { Discordo } \\
\text { totalmente }\end{array}$ & Sim \\
\hline 93 & \begin{tabular}{|l|} 
Quase \\
sempre
\end{tabular} & $\begin{array}{l}\text { Não tenho } \\
\text { certeza }\end{array}$ & $\begin{array}{l}\text { Não tenho } \\
\text { certeza }\end{array}$ & $\begin{array}{l}\text { Totalmente } \\
\text { satisfatório }\end{array}$ & Concordo & Concordo & $\begin{array}{l}\text { Não tenho } \\
\text { certeza }\end{array}$ & Sim \\
\hline 94 & Sempre & $\begin{array}{l}\text { Não tenho } \\
\text { certeza }\end{array}$ & Concordo & $\begin{array}{l}\text { Totalmente } \\
\text { satisfatório }\end{array}$ & $\begin{array}{l}\text { Concordo } \\
\text { totalmente }\end{array}$ & $\begin{array}{l}\text { Não tenho } \\
\text { certeza }\end{array}$ & Discordo & Sim \\
\hline 95 & Sempre & Concordo & Concordo & $\begin{array}{l}\begin{array}{l}\text { Totalmente } \\
\text { satisfatório }\end{array} \\
\end{array}$ & Concordo & Concordo & Discordo & Sim \\
\hline 96 & Sempre & Discordo & Concordo & Satisfatório & Concordo & Discordo & $\begin{array}{l}\text { Não tenho } \\
\text { certeza }\end{array}$ & Sim \\
\hline 97 & Sempre & $\begin{array}{l}\text { Não tenho } \\
\text { certeza }\end{array}$ & Concordo & Satisfatório & $\begin{array}{l}\text { Concordo } \\
\text { totalmente }\end{array}$ & Concordo & Discordo & Sim \\
\hline 98 & Sempre & Discordo & $\begin{array}{l}\text { Discordo } \\
\end{array}$ & Satisfatório & Concordo & Discordo & \begin{tabular}{|l} 
Discordo \\
\end{tabular} & Às vezes \\
\hline 99 & $\begin{array}{l}\text { Quase } \\
\text { nunca }\end{array}$ & Discordo & $\begin{array}{l}\text { Não tenho } \\
\text { certeza }\end{array}$ & $\begin{array}{l}\text { Não tenho } \\
\text { certeza }\end{array}$ & $\begin{array}{l}\text { Não tenho } \\
\text { certeza }\end{array}$ & Discordo & $\begin{array}{l}\text { Não tenho } \\
\text { certeza }\end{array}$ & Sim \\
\hline 100 & \begin{tabular}{|l|} 
Quase \\
sempre
\end{tabular} & Concordo & $\begin{array}{l}\text { Não tenho } \\
\text { certeza }\end{array}$ & Satisfatório & Concordo & Concordo & $\begin{array}{l}\text { Não tenho } \\
\text { certeza }\end{array}$ & Sim \\
\hline 101 & $\begin{array}{l}\text { Quase } \\
\text { sempre }\end{array}$ & Concordo & $\begin{array}{l}\text { Não tenho } \\
\text { certeza }\end{array}$ & Satisfatório & $\begin{array}{l}\text { Não tenho } \\
\text { certeza }\end{array}$ & $\begin{array}{l}\text { Não tenho } \\
\text { certeza }\end{array}$ & $\begin{array}{l}\text { Não tenho } \\
\text { certeza }\end{array}$ & Sim \\
\hline 102 & \begin{tabular}{|l|} 
Quase \\
sempre
\end{tabular} & Concordo & Concordo & Satisfatório & Concordo & Concordo & Discordo & Sim \\
\hline 103 & Sempre & Concordo & Concordo & $\begin{array}{l}\text { Totalmente } \\
\text { satisfatório }\end{array}$ & Concordo & $\begin{array}{l}\text { Não tenho } \\
\text { certeza }\end{array}$ & Discordo & Sim \\
\hline 104 & \begin{tabular}{|l|} 
Quase \\
sempre
\end{tabular} & Concordo & Concordo & Satisfatório & Concordo & $\begin{array}{l}\text { Não tenho } \\
\text { certeza }\end{array}$ & $\begin{array}{l}\text { Não tenho } \\
\text { certeza }\end{array}$ & Sim \\
\hline 105 & $\begin{array}{l}\text { Quase } \\
\text { nunca }\end{array}$ & Concordo & $\begin{array}{l}\text { Não tenho } \\
\text { certeza }\end{array}$ & Satisfatório & $\begin{array}{l}\text { Não tenho } \\
\text { certeza }\end{array}$ & $\begin{array}{l}\text { Não tenho } \\
\text { certeza }\end{array}$ & $\begin{array}{l}\text { Não tenho } \\
\text { certeza }\end{array}$ & Às vezes \\
\hline
\end{tabular}




\begin{tabular}{|c|c|c|c|c|c|c|c|c|}
\hline 106 & $\begin{array}{l}\text { Quase } \\
\text { sempre }\end{array}$ & Concordo & \begin{tabular}{|l} 
Não tenho \\
certeza
\end{tabular} & Insatisfatório & Discordo & Concordo & Discordo & Sim \\
\hline 107 & Sempre & Concordo & $\begin{array}{l}\text { Não tenho } \\
\text { certeza }\end{array}$ & Satisfatório & $\begin{array}{l}\text { Não tenho } \\
\text { certeza }\end{array}$ & Discordo & $\begin{array}{l}\text { Não tenho } \\
\text { certeza }\end{array}$ & Não \\
\hline 108 & \begin{tabular}{|l|}
$\begin{array}{l}\text { Quase } \\
\text { sempre }\end{array}$ \\
\end{tabular} & $\begin{array}{l}\text { Concordo } \\
\text { totalmente }\end{array}$ & $\begin{array}{l}\text { Não tenho } \\
\text { certeza }\end{array}$ & $\begin{array}{l}\begin{array}{l}\text { Totalmente } \\
\text { satisfatório }\end{array} \\
\end{array}$ & Concordo & \begin{tabular}{|l} 
Concordo \\
totalmente
\end{tabular} & \begin{tabular}{|l} 
Discordo \\
totalmente
\end{tabular} & Sim \\
\hline 109 & Sempre & Concordo & Concordo & Satisfatório & Concordo & Concordo & $\begin{array}{l}\text { Discordo } \\
\text { totalmente }\end{array}$ & Sim \\
\hline 110 & Sempre & Discordo & Concordo & Satisfatório & Concordo & Concordo & Discordo & Sim \\
\hline 111 & Sempre & Concordo & Concordo & Satisfatório & Concordo & Concordo & Concordo & Sim \\
\hline 112 & $\begin{array}{l}\text { Quase } \\
\text { sempre }\end{array}$ & $\begin{array}{l}\text { Concordo } \\
\text { totalmente }\end{array}$ & Concordo & Satisfatório & Concordo & Concordo & Discordo & Sim \\
\hline 113 & \begin{tabular}{|l|} 
Quase \\
sempre
\end{tabular} & Discordo & $\begin{array}{l}\text { Não tenho } \\
\text { certeza }\end{array}$ & $\begin{array}{l}\begin{array}{l}\text { Totalmente } \\
\text { satisfatório }\end{array} \\
\end{array}$ & Concordo & Discordo & $\begin{array}{l}\text { Discordo } \\
\text { totalmente }\end{array}$ & Às vezes \\
\hline 114 & $\begin{array}{l}\text { Não tenho } \\
\text { certeza }\end{array}$ & Concordo & Concordo & $\begin{array}{l}\text { Totalmente } \\
\text { satisfatório }\end{array}$ & $\begin{array}{l}\text { Concordo } \\
\text { totalmente }\end{array}$ & Concordo & $\begin{array}{l}\text { Discordo } \\
\text { totalmente }\end{array}$ & Não \\
\hline 115 & $\begin{array}{l}\text { Quase } \\
\text { sempre }\end{array}$ & Concordo & $\begin{array}{l}\text { Não tenho } \\
\text { certeza }\end{array}$ & $\begin{array}{l}\text { Não tenho } \\
\text { certeza }\end{array}$ & Concordo & $\begin{array}{l}\text { Não tenho } \\
\text { certeza }\end{array}$ & Discordo & Às vezes \\
\hline 116 & Sempre & $\begin{array}{l}\text { Concordo } \\
\text { totalmente }\end{array}$ & Concordo & Satisfatório & Concordo & Concordo & Concordo & Sim \\
\hline 117 & \begin{tabular}{|l|} 
Quase \\
sempre
\end{tabular} & Discordo & Discordo & Satisfatório & Concordo & Concordo & Discordo & Sim \\
\hline 118 & Nunca & Discordo & $\begin{array}{l}\text { Discordo } \\
\text { totalmente }\end{array}$ & Insatisfatório & $\begin{array}{l}\text { Discordo } \\
\text { totalmente }\end{array}$ & Concordo & $\begin{array}{l}\text { Concordo } \\
\text { totalmente }\end{array}$ & Não \\
\hline 119 & \begin{tabular}{|l|} 
Quase \\
sempre
\end{tabular} & Discordo & $\begin{array}{l}\text { Não tenho } \\
\text { certeza }\end{array}$ & $\begin{array}{l}\text { Totalmente } \\
\text { satisfatório }\end{array}$ & Concordo & Concordo & $\begin{array}{l}\text { Não tenho } \\
\text { certeza }\end{array}$ & Sim \\
\hline 120 & Sempre & Concordo & Discordo & Insatisfatório & Discordo & $\begin{array}{l}\text { Não tenho } \\
\text { certeza }\end{array}$ & Concordo & Às vezes \\
\hline 121 & $\begin{array}{l}\text { Quase } \\
\text { nunca }\end{array}$ & Concordo & $\begin{array}{l}\text { Discordo } \\
\text { totalmente }\end{array}$ & $\begin{array}{l}\text { Totalmente } \\
\text { insatisfatório }\end{array}$ & $\begin{array}{l}\text { Discordo } \\
\text { totalmente }\end{array}$ & $\begin{array}{l}\text { Discordo } \\
\text { totalmente }\end{array}$ & $\begin{array}{l}\text { Concordo } \\
\text { totalmente }\end{array}$ & Sim \\
\hline 122 & \begin{tabular}{|l|}
$\begin{array}{l}\text { Quase } \\
\text { sempre }\end{array}$ \\
\end{tabular} & Concordo & $\begin{array}{l}\text { Não tenho } \\
\text { certeza }\end{array}$ & $\begin{array}{l}\text { Não tenho } \\
\text { certeza }\end{array}$ & Discordo & $\begin{array}{l}\text { Não tenho } \\
\text { certeza }\end{array}$ & $\begin{array}{l}\text { Não tenho } \\
\text { certeza }\end{array}$ & Sim \\
\hline 123 & \begin{tabular}{|l|} 
Quase \\
sempre
\end{tabular} & Concordo & Concordo & Satisfatório & Concordo & Concordo & Concordo & Sim \\
\hline 124 & Nunca & Concordo & $\begin{array}{l}\text { Discordo } \\
\text { totalmente }\end{array}$ & Insatisfatório & Discordo & $\begin{array}{l}\text { Não tenho } \\
\text { certeza }\end{array}$ & Discordo & Sim \\
\hline 125 & $\begin{array}{l}\text { Quase } \\
\text { nunca }\end{array}$ & Concordo & $\begin{array}{l}\text { Não tenho } \\
\text { certeza }\end{array}$ & Satisfatório & $\begin{array}{l}\text { Não tenho } \\
\text { certeza }\end{array}$ & $\begin{array}{l}\text { Não tenho } \\
\text { certeza }\end{array}$ & $\begin{array}{l}\text { Não tenho } \\
\text { certeza }\end{array}$ & Às vezes \\
\hline 126 & Sempre & Concordo & Concordo & $\begin{array}{l}\text { Totalmente } \\
\text { satisfatório }\end{array}$ & $\begin{array}{l}\text { Concordo } \\
\text { totalmente }\end{array}$ & Concordo & Discordo & Sim \\
\hline 127 & $\begin{array}{l}\text { Quase } \\
\text { sempre }\end{array}$ & Concordo & Discordo & Satisfatório & Concordo & Discordo & $\begin{array}{l}\text { Não tenho } \\
\text { certeza }\end{array}$ & Sim \\
\hline 128 & Sempre & Concordo & Concordo & $\begin{array}{l}\text { Totalmente } \\
\text { satisfatório }\end{array}$ & $\begin{array}{l}\text { Concordo } \\
\text { totalmente }\end{array}$ & Concordo & $\begin{array}{l}\text { Discordo } \\
\text { totalmente }\end{array}$ & Sim \\
\hline 129 & \begin{tabular}{|l|} 
Quase \\
sempre
\end{tabular} & \begin{tabular}{|l|} 
Concordo \\
totalmente
\end{tabular} & Discordo & Satisfatório & Concordo & \begin{tabular}{|l|} 
Discordo \\
totalmente
\end{tabular} & \begin{tabular}{|l} 
Discordo \\
totalmente
\end{tabular} & Às vezes \\
\hline 130 & $\begin{array}{l}\text { Quase } \\
\text { sempre }\end{array}$ & Concordo & $\begin{array}{l}\text { Não tenho } \\
\text { certeza }\end{array}$ & $\begin{array}{l}\begin{array}{l}\text { Totalmente } \\
\text { satisfatório }\end{array} \\
\end{array}$ & Concordo & Concordo & Discordo & Às vezes \\
\hline 131 & $\begin{array}{l}\text { Não tenho } \\
\text { certeza }\end{array}$ & $\begin{array}{l}\text { Não tenho } \\
\text { certeza }\end{array}$ & $\begin{array}{l}\text { Não tenho } \\
\text { certeza }\end{array}$ & Satisfatório & Concordo & Discordo & $\begin{array}{l}\text { Discordo } \\
\text { totalmente }\end{array}$ & Às vezes \\
\hline 132 & \begin{tabular}{|l|} 
Quase \\
sempre
\end{tabular} & $\begin{array}{l}\text { Concordo } \\
\text { totalmente }\end{array}$ & Concordo & $\begin{array}{l}\text { Totalmente } \\
\text { satisfatório }\end{array}$ & $\begin{array}{l}\text { Concordo } \\
\text { totalmente }\end{array}$ & Concordo & Discordo & Sim \\
\hline 133 & \begin{tabular}{|l} 
Quase \\
sempre
\end{tabular} & Discordo & Discordo & Satisfatório & Concordo & Concordo & Discordo & Sim \\
\hline 134 & \begin{tabular}{|l|} 
Quase \\
sempre
\end{tabular} & Discordo & Concordo & Satisfatório & Concordo & Discordo & Concordo & Às vezes \\
\hline 135 & Sempre & Concordo & Concordo & Satisfatório & Concordo & Discordo & $\begin{array}{l}\text { Discordo } \\
\text { totalmente }\end{array}$ & Sim \\
\hline 136 & $\begin{array}{l}\text { Não tenho } \\
\text { certeza }\end{array}$ & Discordo & $\begin{array}{l}\text { Não tenho } \\
\text { certeza }\end{array}$ & $\begin{array}{l}\text { Não tenho } \\
\text { certeza }\end{array}$ & Concordo & $\begin{array}{l}\text { Discordo } \\
\text { totalmente }\end{array}$ & $\begin{array}{l}\text { Discordo } \\
\text { totalmente }\end{array}$ & Às vezes \\
\hline 137 & \begin{tabular}{|l} 
Quase \\
sempre
\end{tabular} & Concordo & $\begin{array}{l}\text { Não tenho } \\
\text { certeza }\end{array}$ & Insatisfatório & Discordo & Concordo & Discordo & Sim \\
\hline 138 & Sempre & Concordo & \begin{tabular}{|l|} 
Concordo \\
totalmente
\end{tabular} & $\begin{array}{l}\text { Totalmente } \\
\text { satisfatório }\end{array}$ & \begin{tabular}{|l}
$\begin{array}{l}\text { Concordo } \\
\text { totalmente }\end{array}$ \\
\end{tabular} & $\begin{array}{l}\text { Não tenho } \\
\text { certeza }\end{array}$ & \begin{tabular}{|l|} 
Discordo \\
totalmente
\end{tabular} & Sim \\
\hline 139 & \begin{tabular}{|l|} 
Quase \\
sempre
\end{tabular} & Concordo & Concordo & Satisfatório & Concordo & Concordo & Concordo & Não \\
\hline 140 & \begin{tabular}{|l|} 
Quase \\
sempre
\end{tabular} & Concordo & Concordo & Satisfatório & Concordo & Discordo & Discordo & Sim \\
\hline 141 & $\begin{array}{l}\text { Quase } \\
\text { sempre }\end{array}$ & Discordo & Discordo & Satisfatório & $\begin{array}{l}\text { Não tenho } \\
\text { certeza }\end{array}$ & $\begin{array}{l}\text { Não tenho } \\
\text { certeza }\end{array}$ & Concordo & Sim \\
\hline 142 & \begin{tabular}{|l|} 
Quase \\
sempre
\end{tabular} & Concordo & Concordo & Satisfatório & Concordo & Discordo & Discordo & Sim \\
\hline 143 & $\begin{array}{l}\text { Quase } \\
\text { nunca }\end{array}$ & Discordo & $\begin{array}{l}\text { Discordo } \\
\text { totalmente }\end{array}$ & $\begin{array}{l}\text { Totalmente } \\
\text { insatisfatório }\end{array}$ & $\begin{array}{l}\text { Discordo } \\
\text { totalmente }\end{array}$ & Discordo & $\begin{array}{l}\text { Concordo } \\
\text { totalmente }\end{array}$ & Não \\
\hline
\end{tabular}




\begin{tabular}{|c|c|c|c|c|c|c|c|c|}
\hline 144 & $\begin{array}{l}\text { Quase } \\
\text { sempre }\end{array}$ & Concordo & $\begin{array}{l}\text { Não tenho } \\
\text { certeza }\end{array}$ & Satisfatório & $\begin{array}{l}\text { Não tenho } \\
\text { certeza }\end{array}$ & Concordo & $\begin{array}{l}\text { Não tenho } \\
\text { certeza }\end{array}$ & Sim \\
\hline 145 & $\begin{array}{l}\text { Quase } \\
\text { sempre }\end{array}$ & Discordo & $\begin{array}{l}\text { Não tenho } \\
\text { certeza }\end{array}$ & Satisfatório & \begin{tabular}{|l|} 
Discordo \\
totalmente
\end{tabular} & $\begin{array}{l}\text { Discordo } \\
\text { totalmente }\end{array}$ & Discordo & Sim \\
\hline 146 & Sempre & Concordo & Discordo & Satisfatório & Concordo & Concordo & $\begin{array}{l}\text { Discordo } \\
\text { totalmente }\end{array}$ & Sim \\
\hline 147 & Sempre & Concordo & Discordo & Satisfatório & Concordo & Concordo & \begin{tabular}{|l|} 
Discordo \\
totalmente
\end{tabular} & Sim \\
\hline 148 & Sempre & Concordo & Discordo & Satisfatório & Concordo & Concordo & $\begin{array}{l}\text { Discordo } \\
\text { totalmente }\end{array}$ & Sim \\
\hline 149 & Sempre & Concordo & Discordo & Satisfatório & Discordo & Discordo & Concordo & Às vezes \\
\hline 150 & $\begin{array}{l}\text { Quase } \\
\text { sempre }\end{array}$ & Concordo & $\begin{array}{l}\text { Não tenho } \\
\text { certeza }\end{array}$ & $\begin{array}{l}\text { Não tenho } \\
\text { certeza }\end{array}$ & Discordo & $\begin{array}{l}\text { Não tenho } \\
\text { certeza }\end{array}$ & Discordo & Sim \\
\hline 151 & $\begin{array}{l}\text { Quase } \\
\text { nunca }\end{array}$ & Discordo & $\begin{array}{l}\text { Discordo } \\
\text { totalmente }\end{array}$ & Insatisfatório & $\begin{array}{l}\text { Discordo } \\
\text { totalmente }\end{array}$ & $\begin{array}{l}\text { Discordo } \\
\text { totalmente }\end{array}$ & $\begin{array}{l}\text { Concordo } \\
\text { totalmente }\end{array}$ & Sim \\
\hline 152 & $\begin{array}{l}\text { Quase } \\
\text { sempre }\end{array}$ & $\begin{array}{l}\text { Não tenho } \\
\text { certeza }\end{array}$ & Concordo & Satisfatório & \begin{tabular}{|l|} 
Concordo \\
totalmente
\end{tabular} & Concordo & Concordo & Sim \\
\hline 153 & Nunca & Discordo & Discordo & Satisfatório & Discordo & Discordo & Discordo & Sim \\
\hline 154 & $\begin{array}{l}\text { Quase } \\
\text { sempre }\end{array}$ & Concordo & Concordo & Satisfatório & Concordo & Concordo & $\begin{array}{l}\text { Não } \\
\text { respondeu }\end{array}$ & Sim \\
\hline 155 & $\begin{array}{l}\text { Não } \\
\text { respondeu }\end{array}$ & $\begin{array}{l}\text { Concordo } \\
\text { totalmente }\end{array}$ & $\begin{array}{l}\text { Não } \\
\text { respondeu }\end{array}$ & $\begin{array}{l}\text { Não } \\
\text { respondeu }\end{array}$ & $\begin{array}{l}\text { Não } \\
\text { respondeu }\end{array}$ & Não respondeu & Discordo & Sim \\
\hline 156 & Sempre & Concordo & Concordo & Satisfatório & Concordo & Discordo & Discordo & Sim \\
\hline 157 & Sempre & Concordo & $\begin{array}{l}\text { Concordo } \\
\text { totalmente }\end{array}$ & $\begin{array}{l}\text { Totalmente } \\
\text { satisfatório }\end{array}$ & $\begin{array}{l}\text { Concordo } \\
\text { totalmente }\end{array}$ & Concordo & Concordo & Sim \\
\hline 158 & $\begin{array}{l}\text { Quase } \\
\text { sempre }\end{array}$ & Discordo & $\begin{array}{l}\text { Não tenho } \\
\text { certeza }\end{array}$ & $\begin{array}{l}\text { Totalmente } \\
\text { satisfatório }\end{array}$ & Concordo & $\begin{array}{l}\text { Não tenho } \\
\text { certeza }\end{array}$ & $\begin{array}{l}\text { Não tenho } \\
\text { certeza }\end{array}$ & Sim \\
\hline 159 & $\begin{array}{l}\text { Quase } \\
\text { sempre }\end{array}$ & $\begin{array}{l}\text { Não tenho } \\
\text { certeza }\end{array}$ & $\begin{array}{l}\text { Não tenho } \\
\text { certeza }\end{array}$ & Satisfatório & Concordo & Concordo & Discordo & Sim \\
\hline 160 & Sempre & $\begin{array}{l}\text { Concordo } \\
\text { totalmente }\end{array}$ & $\begin{array}{l}\text { Concordo } \\
\text { totalmente }\end{array}$ & $\begin{array}{l}\text { Totalmente } \\
\text { satisfatório }\end{array}$ & \begin{tabular}{|l|}
$\begin{array}{l}\text { Concordo } \\
\text { totalmente }\end{array}$ \\
\end{tabular} & \begin{tabular}{|l|} 
Não tenho \\
certeza
\end{tabular} & $\begin{array}{l}\text { Não tenho } \\
\text { certeza }\end{array}$ & Sim \\
\hline 161 & Sempre & Concordo & $\begin{array}{l}\text { Concordo } \\
\text { totalmente }\end{array}$ & $\begin{array}{l}\text { Totalmente } \\
\text { satisfatório }\end{array}$ & $\begin{array}{l}\text { Concordo } \\
\text { totalmente }\end{array}$ & Concordo & Concordo & Sim \\
\hline 162 & Sempre & Concordo & $\begin{array}{l}\text { Não tenho } \\
\text { certeza }\end{array}$ & $\begin{array}{l}\text { Totalmente } \\
\text { satisfatório }\end{array}$ & $\begin{array}{l}\text { Concordo } \\
\text { totalmente }\end{array}$ & Discordo & $\begin{array}{l}\text { Não tenho } \\
\text { certeza }\end{array}$ & Sim \\
\hline 163 & Nunca & Discordo & Discordo & Insatisfatório & Discordo & $\begin{array}{l}\text { Discordo } \\
\text { totalmente }\end{array}$ & Discordo & Sim \\
\hline 164 & Sempre & Concordo & $\begin{array}{l}\text { Não } \\
\text { respondeu }\end{array}$ & $\begin{array}{l}\text { Totalmente } \\
\text { satisfatório }\end{array}$ & $\begin{array}{l}\text { Concordo } \\
\text { totalmente }\end{array}$ & Concordo & Concordo & Sim \\
\hline 165 & $\begin{array}{l}\text { Não tenho } \\
\text { certeza }\end{array}$ & Concordo & Concordo & Satisfatório & Concordo & $\begin{array}{l}\text { Não tenho } \\
\text { certeza }\end{array}$ & $\begin{array}{l}\text { Não tenho } \\
\text { certeza }\end{array}$ & Sim \\
\hline 166 & $\begin{array}{l}\text { Não } \\
\text { respondeu }\end{array}$ & Concordo & $\begin{array}{l}\text { Não } \\
\text { respondeu }\end{array}$ & $\begin{array}{l}\text { Não } \\
\text { respondeu }\end{array}$ & $\begin{array}{l}\text { Não } \\
\text { respondeu }\end{array}$ & Concordo & Discordo & $\begin{array}{l}\text { Não } \\
\text { respondeu }\end{array}$ \\
\hline 167 & $\begin{array}{l}\text { Quase } \\
\text { sempre }\end{array}$ & Concordo & $\begin{array}{l}\text { Não } \\
\text { respondeu }\end{array}$ & $\begin{array}{l}\text { Totalmente } \\
\text { satisfatório }\end{array}$ & Concordo & Concordo & $\begin{array}{l}\text { Discordo } \\
\text { totalmente }\end{array}$ & Sim \\
\hline 168 & Sempre & Concordo & Concordo & $\begin{array}{l}\text { Não } \\
\text { respondeu }\end{array}$ & $\begin{array}{l}\text { Não } \\
\text { respondeu }\end{array}$ & Não respondeu & $\begin{array}{l}\text { Não } \\
\text { respondeu }\end{array}$ & Sim \\
\hline 169 & $\begin{array}{l}\text { Não tenho } \\
\text { certeza }\end{array}$ & Concordo & $\begin{array}{l}\text { Não tenho } \\
\text { certeza }\end{array}$ & $\begin{array}{l}\text { Não tenho } \\
\text { certeza }\end{array}$ & $\begin{array}{l}\text { Não tenho } \\
\text { certeza }\end{array}$ & Discordo & Discordo & Não \\
\hline 170 & $\begin{array}{l}\text { Não tenho } \\
\text { certeza }\end{array}$ & $\begin{array}{l}\text { Não tenho } \\
\text { certeza }\end{array}$ & $\begin{array}{l}\text { Não tenho } \\
\text { certeza }\end{array}$ & $\begin{array}{l}\text { Não } \\
\text { respondeu }\end{array}$ & $\begin{array}{l}\text { Não tenho } \\
\text { certeza }\end{array}$ & Não respondeu & $\begin{array}{l}\text { Não } \\
\text { respondeu }\end{array}$ & $\begin{array}{l}\text { Não } \\
\text { respondeu }\end{array}$ \\
\hline 171 & $\begin{array}{l}\text { Quase } \\
\text { sempre }\end{array}$ & Concordo & Discordo & $\begin{array}{l}\text { Totalmente } \\
\text { satisfatório }\end{array}$ & Concordo & Concordo & $\begin{array}{l}\text { Não } \\
\text { respondeu }\end{array}$ & Sim \\
\hline
\end{tabular}




\begin{tabular}{|c|c|c|c|c|c|}
\hline$\#$ & $\begin{array}{c}\text { 12. Se você } \\
\text { assinalou a } \\
\text { alternativa "Não" na } \\
\text { pergunta 11, } \\
\text { responda por que } \\
\text { não usa a } \\
\text { comunicação oral no } \\
\text { processo de tomada } \\
\text { de decisão com os } \\
\text { chefes ligados } \\
\text { diretamente a você. }\end{array}$ & $\begin{array}{l}\text { 13. Se você assinalou a } \\
\text { alternativa "Às vezes" na } \\
\text { pergunta } 11 \text {, dê exemplos de } \\
\text { uso da comunicação oral no } \\
\text { processo de tomada de } \\
\text { decisão com os chefes } \\
\text { ligados diretamente a você. }\end{array}$ & $\begin{array}{c}\text { 14. A } \\
\text { linguagem } \\
\text { que meu } \\
\text { superior } \\
\text { imediato usa } \\
\text { é } \\
\text { compreendida } \\
\text { por todos os } \\
\text { empregados } \\
\text { do setor. }\end{array}$ & $\begin{array}{c}\text { 15. Meu } \\
\text { superior } \\
\text { imediato dá } \\
\text { abertura } \\
\text { para o } \\
\text { diálogo com } \\
\text { os } \\
\text { empregados } \\
\text { da equipe. }\end{array}$ & \begin{tabular}{|c} 
16. Há \\
situações em \\
que o diálogo \\
é a forma de \\
comunicação \\
indispensável \\
entre chefes \\
de todos os \\
níveis de \\
autoridade e \\
empregados.
\end{tabular} \\
\hline 1 & & & Discordo & $\begin{array}{l}\text { Não tenho } \\
\text { certeza }\end{array}$ & \begin{tabular}{|l|} 
Concordo \\
totalmente
\end{tabular} \\
\hline 2 & & & Concordo & Concordo & $\begin{array}{l}\text { Concordo } \\
\text { totalmente }\end{array}$ \\
\hline 3 & & & \begin{tabular}{|l|}
$\begin{array}{l}\text { Não tenho } \\
\text { certeza }\end{array}$ \\
\end{tabular} & \begin{tabular}{|l}
$\begin{array}{l}\text { Concordo } \\
\text { totalmente }\end{array}$ \\
\end{tabular} & Concordo \\
\hline 4 & & & Concordo & $\begin{array}{l}\text { Concordo } \\
\text { totalmente }\end{array}$ & Concordo \\
\hline 5 & & & Concordo & Concordo & $\begin{array}{l}\text { Não tenho } \\
\text { certeza }\end{array}$ \\
\hline 6 & & & Concordo & Concordo & Concordo \\
\hline 7 & & & Concordo & $\begin{array}{l}\text { Concordo } \\
\text { totalmente }\end{array}$ & $\begin{array}{l}\text { Concordo } \\
\text { totalmente }\end{array}$ \\
\hline 8 & & & $\begin{array}{l}\text { Concordo } \\
\text { totalmente }\end{array}$ & $\begin{array}{l}\text { Concordo } \\
\text { totalmente }\end{array}$ & Concordo \\
\hline 9 & & & Concordo & Concordo & Concordo \\
\hline 10 & & & $\begin{array}{l}\text { Concordo } \\
\text { totalmente }\end{array}$ & $\begin{array}{l}\text { Concordo } \\
\text { totalmente }\end{array}$ & $\begin{array}{l}\text { Concordo } \\
\text { totalmente }\end{array}$ \\
\hline 11 & & $\begin{array}{l}\text { Em situações que não } \\
\text { impliquem registro de ausência } \\
\text { ou permanência no local de } \\
\text { trabalho. }\end{array}$ & Concordo & Concordo & $\begin{array}{l}\text { Concordo } \\
\text { totalmente }\end{array}$ \\
\hline 12 & & & Concordo & $\begin{array}{l}\text { Concordo } \\
\text { totalmente }\end{array}$ & \begin{tabular}{|l|} 
Não tenho \\
certeza
\end{tabular} \\
\hline 13 & & & Concordo & Concordo & Concordo \\
\hline 14 & & & Concordo & Concordo & Concordo \\
\hline 15 & & & $\begin{array}{l}\text { Concordo } \\
\text { totalmente }\end{array}$ & \begin{tabular}{|l|l|} 
Concordo \\
totalmente
\end{tabular} & \begin{tabular}{|l|} 
Concordo \\
totalmente
\end{tabular} \\
\hline 16 & & & Concordo & Concordo & Concordo \\
\hline 17 & & & Concordo & \begin{tabular}{|l|} 
Concordo \\
totalmente
\end{tabular} & Concordo \\
\hline 18 & & & Concordo & Concordo & $\begin{array}{l}\text { Concordo } \\
\text { totalmente }\end{array}$ \\
\hline 19 & & & $\begin{array}{l}\text { Concordo } \\
\text { totalmente }\end{array}$ & $\begin{array}{l}\text { Concordo } \\
\text { totalmente }\end{array}$ & $\begin{array}{l}\text { Concordo } \\
\text { totalmente }\end{array}$ \\
\hline 20 & & & $\begin{array}{l}\text { Concordo } \\
\text { totalmente }\end{array}$ & $\begin{array}{l}\text { Concordo } \\
\text { totalmente }\end{array}$ & $\begin{array}{l}\text { Concordo } \\
\text { totalmente }\end{array}$ \\
\hline 21 & & & Concordo & Concordo & Concordo \\
\hline 22 & & & \begin{tabular}{|l|} 
Não tenho \\
certeza
\end{tabular} & Concordo & Concordo \\
\hline 23 & & & $\begin{array}{l}\text { Concordo } \\
\text { totalmente }\end{array}$ & $\begin{array}{l}\text { Concordo } \\
\text { totalmente }\end{array}$ & $\begin{array}{l}\text { Concordo } \\
\text { totalmente }\end{array}$ \\
\hline 24 & & & \begin{tabular}{|l|l|} 
Concordo \\
totalmente
\end{tabular} & \begin{tabular}{|l|l|} 
Concordo \\
totalmente
\end{tabular} & \begin{tabular}{|l|l|} 
Concordo \\
totalmente
\end{tabular} \\
\hline 25 & & & Concordo & \begin{tabular}{|l|} 
Concordo \\
totalmente
\end{tabular} & Concordo \\
\hline 26 & & & Concordo & Concordo & $\begin{array}{l}\text { Não tenho } \\
\text { certeza }\end{array}$ \\
\hline 27 & & & $\begin{array}{l}\text { Concordo } \\
\text { totalmente }\end{array}$ & \begin{tabular}{|l|} 
Concordo \\
totalmente
\end{tabular} & $\begin{array}{l}\text { Concordo } \\
\text { totalmente }\end{array}$ \\
\hline 28 & & & $\begin{array}{l}\text { Não tenho } \\
\text { certeza }\end{array}$ & Concordo & $\begin{array}{l}\text { Concordo } \\
\text { totalmente }\end{array}$ \\
\hline 29 & & & Discordo & $\begin{array}{l}\text { Concordo } \\
\text { totalmente }\end{array}$ & \begin{tabular}{|l} 
Não tenho \\
certeza
\end{tabular} \\
\hline 30 & & & $\begin{array}{l}\text { Concordo } \\
\text { totalmente }\end{array}$ & $\begin{array}{l}\text { Concordo } \\
\text { totalmente }\end{array}$ & $\begin{array}{l}\text { Concordo } \\
\text { totalmente }\end{array}$ \\
\hline 31 & & & $\begin{array}{l}\text { Não tenho } \\
\text { certeza }\end{array}$ & Concordo & Concordo \\
\hline 32 & & & Concordo & $\begin{array}{l}\begin{array}{l}\text { Concordo } \\
\text { totalmente }\end{array} \\
\end{array}$ & $\begin{array}{l}\begin{array}{l}\text { Concordo } \\
\text { totalmente }\end{array} \\
\end{array}$ \\
\hline
\end{tabular}




\begin{tabular}{|c|c|c|c|c|c|}
\hline 33 & & & $\begin{array}{l}\text { Concordo } \\
\text { totalmente }\end{array}$ & Concordo & $\begin{array}{l}\text { Concordo } \\
\text { totalmente }\end{array}$ \\
\hline 34 & & & Concordo & Concordo & Concordo \\
\hline 35 & & & $\begin{array}{l}\text { Não tenho } \\
\text { certeza }\end{array}$ & Concordo & $\begin{array}{l}\text { Concordo } \\
\text { totalmente }\end{array}$ \\
\hline 36 & & & $\begin{array}{l}\text { Concordo } \\
\text { totalmente }\end{array}$ & $\begin{array}{l}\text { Concordo } \\
\text { totalmente }\end{array}$ & $\begin{array}{l}\text { Concordo } \\
\text { totalmente }\end{array}$ \\
\hline 37 & & & Concordo & Concordo & $\begin{array}{l}\text { Concordo } \\
\text { totalmente }\end{array}$ \\
\hline 38 & & & Concordo & \begin{tabular}{|l} 
Concordo \\
\end{tabular} & \begin{tabular}{|l|} 
Discordo \\
\end{tabular} \\
\hline 39 & & & $\begin{array}{l}\text { Concordo } \\
\text { totalmente }\end{array}$ & $\begin{array}{l}\text { Concordo } \\
\text { totalmente }\end{array}$ & $\begin{array}{l}\text { Não tenho } \\
\text { certeza }\end{array}$ \\
\hline 40 & $\begin{array}{l}\text { Sou apenas a } \\
\text { secretaria, as coisas ja } \\
\text { vem discutidas e } \\
\text { prontas. }\end{array}$ & & $\begin{array}{l}\text { Concordo } \\
\text { totalmente }\end{array}$ & Concordo & Concordo \\
\hline 41 & & & Discordo & Concordo & $\begin{array}{l}\text { Concordo } \\
\text { totalmente }\end{array}$ \\
\hline 42 & & & $\begin{array}{l}\text { Concordo } \\
\text { totalmente }\end{array}$ & Concordo & $\begin{array}{l}\text { Não tenho } \\
\text { certeza }\end{array}$ \\
\hline 43 & & & Discordo & $\begin{array}{l}\text { Discordo } \\
\text { totalmente }\end{array}$ & Concordo \\
\hline 44 & & & Concordo & Concordo & $\begin{array}{l}\text { Concordo } \\
\text { totalmente }\end{array}$ \\
\hline 45 & & & $\begin{array}{l}\text { Concordo } \\
\text { totalmente }\end{array}$ & $\begin{array}{l}\text { Concordo } \\
\text { totalmente }\end{array}$ & Concordo \\
\hline 46 & & & Concordo & Concordo & Discordo \\
\hline 47 & & & Concordo & Concordo & \begin{tabular}{|l|} 
Discordo \\
\end{tabular} \\
\hline 48 & & & Concordo & Concordo & Concordo \\
\hline 49 & & & $\begin{array}{l}\text { Concordo } \\
\text { totalmente }\end{array}$ & Concordo & Concordo \\
\hline 50 & & & Concordo & Concordo & \begin{tabular}{|l|} 
Discordo \\
totalmente
\end{tabular} \\
\hline 51 & & & Concordo & Concordo & Concordo \\
\hline 52 & & & Concordo & $\begin{array}{l}\text { Concordo } \\
\text { totalmente }\end{array}$ & $\begin{array}{l}\text { Concordo } \\
\text { totalmente }\end{array}$ \\
\hline 53 & & & $\begin{array}{l}\text { Não tenho } \\
\text { certeza }\end{array}$ & $\begin{array}{l}\text { Não tenho } \\
\text { certeza }\end{array}$ & $\begin{array}{l}\text { Não tenho } \\
\text { certeza }\end{array}$ \\
\hline 54 & & & Concordo & Concordo & Concordo \\
\hline 55 & & $\begin{array}{l}\text { Na montagem de um } \\
\text { experimento, por exemplo. }\end{array}$ & Concordo & Concordo & $\begin{array}{l}\text { Concordo } \\
\text { totalmente }\end{array}$ \\
\hline 56 & & & Concordo & Concordo & Concordo \\
\hline 57 & & & Concordo & Concordo & Concordo \\
\hline 58 & & & Discordo & Concordo & Concordo \\
\hline 59 & & & Concordo & Concordo & Concordo \\
\hline 60 & & & $\begin{array}{l}\text { Concordo } \\
\text { totalmente }\end{array}$ & $\begin{array}{l}\text { Discordo } \\
\text { totalmente }\end{array}$ & $\begin{array}{l}\text { Concordo } \\
\text { totalmente } \\
\end{array}$ \\
\hline 61 & & & Concordo & $\begin{array}{l}\text { Discordo } \\
\text { totalmente }\end{array}$ & $\begin{array}{l}\text { Concordo } \\
\text { totalmente }\end{array}$ \\
\hline 62 & & & Concordo & \begin{tabular}{|l|} 
Concordo \\
\end{tabular} & Concordo \\
\hline 63 & & & Concordo & Concordo & $\begin{array}{l}\text { Não tenho } \\
\text { certeza }\end{array}$ \\
\hline 64 & $\begin{array}{l}\text { Acho que como } \\
\text { superior ele deve estar } \\
\text { por dentro de tudo o } \\
\text { que ocorre na área } \\
\text { que atuamos. }\end{array}$ & & $\begin{array}{l}\text { Concordo } \\
\text { totalmente }\end{array}$ & Concordo & $\begin{array}{l}\text { Não tenho } \\
\text { certeza }\end{array}$ \\
\hline 65 & & & Concordo & Concordo & $\begin{array}{l}\text { Não tenho } \\
\text { certeza }\end{array}$ \\
\hline 66 & & $\begin{array}{l}\text { Decisões mais importantes } \\
\text { exigem contato mais próximo. }\end{array}$ & $\begin{array}{l}\text { Concordo } \\
\text { totalmente }\end{array}$ & Concordo & $\begin{array}{l}\text { Concordo } \\
\text { totalmente }\end{array}$ \\
\hline 67 & & & Concordo & Concordo & Concordo \\
\hline 68 & & & Concordo & Concordo & $\begin{array}{l}\text { Não tenho } \\
\text { certeza }\end{array}$ \\
\hline 69 & & & Concordo & $\begin{array}{l}\text { Concordo } \\
\text { totalmente }\end{array}$ & Concordo \\
\hline 70 & & & Concordo & Concordo & Concordo \\
\hline 71 & & & $\begin{array}{l}\text { Concordo } \\
\text { totalmente }\end{array}$ & Concordo & $\begin{array}{l}\text { Concordo } \\
\text { totalmente }\end{array}$ \\
\hline 72 & & & $\begin{array}{l}\text { Concordo } \\
\text { totalmente }\end{array}$ & Concordo & Concordo \\
\hline 73 & & & Concordo & $\begin{array}{l}\text { Concordo } \\
\text { totalmente }\end{array}$ & $\begin{array}{l}\text { Concordo } \\
\text { totalmente }\end{array}$ \\
\hline
\end{tabular}




\begin{tabular}{|c|c|c|c|c|}
\hline 74 & t & \begin{tabular}{|l} 
Concordo \\
totalmente
\end{tabular} & $\begin{array}{l}\text { Concordo } \\
\text { totalmente }\end{array}$ & $\begin{array}{l}\text { Não tenho } \\
\text { certeza }\end{array}$ \\
\hline 75 & & Concordo & Concordo & Concordo \\
\hline 76 & & $\begin{array}{l}\text { Concordo } \\
\text { totalmente }\end{array}$ & $\begin{array}{l}\text { Concordo } \\
\text { totalmente }\end{array}$ & Concordo \\
\hline 77 & & $\begin{array}{l}\text { Concordo } \\
\text { totalmente }\end{array}$ & $\begin{array}{l}\text { Concordo } \\
\text { totalmente }\end{array}$ & $\begin{array}{l}\text { Concordo } \\
\text { totalmente }\end{array}$ \\
\hline 78 & & $\begin{array}{l}\text { Concordo } \\
\text { totalmente }\end{array}$ & $\begin{array}{l}\text { Concordo } \\
\text { totalmente }\end{array}$ & $\begin{array}{l}\text { Concordo } \\
\text { totalmente }\end{array}$ \\
\hline 79 & & Concordo & Concordo & Concordo \\
\hline 80 & & $\begin{array}{l}\text { Concordo } \\
\text { totalmente }\end{array}$ & Concordo & Concordo \\
\hline 81 & & Concordo & Concordo & Concordo \\
\hline 82 & & Concordo & Concordo & \begin{tabular}{|l} 
Concordo \\
\end{tabular} \\
\hline 83 & & $\begin{array}{l}\text { Concordo } \\
\text { totalmente }\end{array}$ & Concordo & Concordo \\
\hline 84 & & $\begin{array}{l}\text { Não tenho } \\
\text { certeza }\end{array}$ & Concordo & $\begin{array}{l}\text { Não tenho } \\
\text { certeza }\end{array}$ \\
\hline 85 & & Concordo & Concordo & $\begin{array}{l}\text { Concordo } \\
\text { totalmente }\end{array}$ \\
\hline 86 & & $\begin{array}{l}\text { Concordo } \\
\text { totalmente }\end{array}$ & $\begin{array}{l}\text { Concordo } \\
\text { totalmente }\end{array}$ & $\begin{array}{l}\text { Concordo } \\
\text { totalmente }\end{array}$ \\
\hline 87 & & Concordo & Concordo & \begin{tabular}{|l|} 
Discordo \\
\end{tabular} \\
\hline 88 & & Concordo & Concordo & Concordo \\
\hline 89 & $\begin{array}{l}\text { Não posso tomar decisões com } \\
\text { chefes }\end{array}$ & Concordo & Discordo & $\begin{array}{l}\text { Concordo } \\
\text { totalmente }\end{array}$ \\
\hline 90 & & $\begin{array}{l}\text { Concordo } \\
\text { totalmente }\end{array}$ & $\begin{array}{l}\text { Concordo } \\
\text { totalmente }\end{array}$ & Concordo \\
\hline 91 & & $\begin{array}{l}\text { Concordo } \\
\text { totalmente }\end{array}$ & $\begin{array}{l}\text { Concordo } \\
\text { totalmente }\end{array}$ & Concordo \\
\hline 92 & & $\begin{array}{l}\text { Concordo } \\
\text { totalmente }\end{array}$ & $\begin{array}{l}\text { Concordo } \\
\text { totalmente }\end{array}$ & $\begin{array}{l}\text { Concordo } \\
\text { totalmente }\end{array}$ \\
\hline 93 & & $\begin{array}{l}\text { Concordo } \\
\text { totalmente }\end{array}$ & $\begin{array}{l}\text { Concordo } \\
\text { totalmente }\end{array}$ & $\begin{array}{l}\text { Concordo } \\
\text { totalmente }\end{array}$ \\
\hline 94 & & $\begin{array}{l}\text { Concordo } \\
\text { totalmente }\end{array}$ & $\begin{array}{l}\text { Concordo } \\
\text { totalmente }\end{array}$ & $\begin{array}{l}\text { Não tenho } \\
\text { certeza }\end{array}$ \\
\hline 95 & & Concordo & Concordo & Concordo \\
\hline 96 & & Concordo & $\begin{array}{l}\text { Concordo } \\
\text { totalmente }\end{array}$ & Concordo \\
\hline 97 & & \begin{tabular}{|l} 
Concordo \\
\end{tabular} & Concordo & Concordo \\
\hline 98 & $\begin{array}{l}\text { Dependendo da importância do } \\
\text { assunto é melhor por escrito }\end{array}$ & Concordo & Concordo & Concordo \\
\hline 99 & & Concordo & Concordo & $\begin{array}{l}\text { Não tenho } \\
\text { certeza }\end{array}$ \\
\hline 100 & & Concordo & Concordo & Concordo \\
\hline 101 & & $\begin{array}{l}\text { Concordo } \\
\text { totalmente }\end{array}$ & $\begin{array}{l}\text { Concordo } \\
\text { totalmente }\end{array}$ & $\begin{array}{l}\text { Concordo } \\
\text { totalmente }\end{array}$ \\
\hline 102 & & Concordo & Concordo & Concordo \\
\hline 103 & & $\begin{array}{l}\text { Concordo } \\
\text { totalmente }\end{array}$ & $\begin{array}{l}\text { Concordo } \\
\text { totalmente }\end{array}$ & $\begin{array}{l}\text { Concordo } \\
\text { totalmente }\end{array}$ \\
\hline 104 & & Concordo & Concordo & $\begin{array}{l}\text { Não tenho } \\
\text { certeza }\end{array}$ \\
\hline 105 & & Concordo & Concordo & $\begin{array}{l}\text { Concordo } \\
\text { totalmente }\end{array}$ \\
\hline 106 & & Concordo & Concordo & Concordo \\
\hline 107 & & Concordo & Concordo & $\begin{array}{l}\text { Concordo } \\
\text { totalmente }\end{array}$ \\
\hline 108 & & Concordo & $\begin{array}{l}\text { Concordo } \\
\text { totalmente }\end{array}$ & Concordo \\
\hline 109 & & Concordo & Concordo & Concordo \\
\hline 110 & & Concordo & Concordo & Concordo \\
\hline 111 & & Concordo & Concordo & $\begin{array}{l}\text { Concordo } \\
\text { totalmente }\end{array}$ \\
\hline 112 & & Concordo & $\begin{array}{l}\text { Concordo } \\
\text { totalmente }\end{array}$ & Concordo \\
\hline 113 & & $\begin{array}{l}\text { Concordo } \\
\text { totalmente }\end{array}$ & $\begin{array}{l}\text { Concordo } \\
\text { totalmente }\end{array}$ & Concordo \\
\hline 114 & & Discordo & $\begin{array}{l}\text { Concordo } \\
\text { totalmente }\end{array}$ & Concordo \\
\hline 115 & & \begin{tabular}{|l} 
Não tenho \\
certeza
\end{tabular} & $\begin{array}{l}\text { Não tenho } \\
\text { certeza }\end{array}$ & Concordo \\
\hline 116 & & Concordo & Concordo & Discordo \\
\hline 117 & & Concordo & Concordo & Concordo \\
\hline
\end{tabular}




\begin{tabular}{|c|c|c|c|c|c|}
\hline 118 & Não há comunicação & & \begin{tabular}{|l|} 
Discordo \\
totalmente
\end{tabular} & \begin{tabular}{|l} 
Discordo \\
totalmente
\end{tabular} & $\begin{array}{l}\text { Não tenho } \\
\text { certeza }\end{array}$ \\
\hline 119 & & & $\begin{array}{l}\text { Concordo } \\
\text { totalmente }\end{array}$ & $\begin{array}{l}\text { Concordo } \\
\text { totalmente }\end{array}$ & $\begin{array}{l}\text { Concordo } \\
\text { totalmente }\end{array}$ \\
\hline 120 & & & $\begin{array}{l}\text { Não tenho } \\
\text { certeza }\end{array}$ & Discordo & Discordo \\
\hline 121 & & & Discordo & Discordo & $\begin{array}{l}\text { Concordo } \\
\text { totalmente }\end{array}$ \\
\hline 122 & & & Discordo & Discordo & Concordo \\
\hline 123 & & & Concordo & Concordo & $\begin{array}{l}\text { Concordo } \\
\text { totalmente }\end{array}$ \\
\hline 124 & & & Concordo & Discordo & Concordo \\
\hline 125 & & & Concordo & Concordo & Concordo \\
\hline 126 & & & \begin{tabular}{|l|} 
Concordo \\
totalmente
\end{tabular} & \begin{tabular}{|l} 
Concordo \\
totalmente
\end{tabular} & $\begin{array}{l}\text { Concordo } \\
\text { totalmente }\end{array}$ \\
\hline 127 & & & Concordo & $\begin{array}{l}\text { Concordo } \\
\text { totalmente }\end{array}$ & Concordo \\
\hline 128 & & & \begin{tabular}{|l|} 
Concordo \\
totalmente
\end{tabular} & $\begin{array}{l}\text { Concordo } \\
\text { totalmente }\end{array}$ & $\begin{array}{l}\text { Não tenho } \\
\text { certeza }\end{array}$ \\
\hline 129 & & & \begin{tabular}{|l|} 
Concordo \\
totalmente
\end{tabular} & $\begin{array}{l}\text { Concordo } \\
\text { totalmente }\end{array}$ & $\begin{array}{l}\text { Concordo } \\
\text { totalmente }\end{array}$ \\
\hline 130 & & Em casos urgentes & $\begin{array}{l}\text { Concordo } \\
\text { totalmente }\end{array}$ & $\begin{array}{l}\text { Concordo } \\
\text { totalmente }\end{array}$ & Concordo \\
\hline 131 & & Às vezes, e-mail é suficiente & Concordo & $\begin{array}{l}\text { Concordo } \\
\text { totalmente }\end{array}$ & $\begin{array}{l}\text { Concordo } \\
\text { totalmente }\end{array}$ \\
\hline 132 & & & $\begin{array}{l}\text { Concordo } \\
\text { totalmente }\end{array}$ & $\begin{array}{l}\text { Concordo } \\
\text { totalmente }\end{array}$ & $\begin{array}{l}\text { Concordo } \\
\text { totalmente }\end{array}$ \\
\hline 133 & & & Concordo & Concordo & $\begin{array}{l}\text { Concordo } \\
\text { totalmente }\end{array}$ \\
\hline 134 & & $\begin{array}{l}\text { É mais ágil do que a } \\
\text { comunicação escrita }\end{array}$ & Concordo & Discordo & \begin{tabular}{|l|} 
Concordo \\
totalmente
\end{tabular} \\
\hline 135 & & & \begin{tabular}{|l|} 
Concordo \\
totalmente
\end{tabular} & \begin{tabular}{|l|} 
Concordo \\
totalmente
\end{tabular} & Concordo \\
\hline 136 & & & Concordo & Concordo & $\begin{array}{l}\text { Não tenho } \\
\text { certeza }\end{array}$ \\
\hline 137 & & & Concordo & Concordo & Discordo \\
\hline 138 & & & \begin{tabular}{|l|} 
Concordo \\
totalmente
\end{tabular} & \begin{tabular}{|l|}
$\begin{array}{l}\text { Concordo } \\
\text { totalmente }\end{array}$ \\
\end{tabular} & \begin{tabular}{|l|} 
Concordo \\
totalmente
\end{tabular} \\
\hline 139 & $\begin{array}{l}\text { Melhor preto no } \\
\text { branco }\end{array}$ & & Concordo & Concordo & $\begin{array}{l}\text { Não tenho } \\
\text { certeza }\end{array}$ \\
\hline 140 & & & Discordo & Discordo & $\begin{array}{l}\text { Concordo } \\
\text { totalmente }\end{array}$ \\
\hline 141 & & & Discordo & \begin{tabular}{|l|} 
Não tenho \\
certeza
\end{tabular} & Concordo \\
\hline 142 & & & $\begin{array}{l}\text { Concordo } \\
\text { totalmente }\end{array}$ & $\begin{array}{l}\text { Concordo } \\
\text { totalmente }\end{array}$ & Concordo \\
\hline 143 & $\begin{array}{l}\text { Já tentei! Não tem } \\
\text { êxito nisso! }\end{array}$ & & \begin{tabular}{|l|} 
Discordo \\
totalmente
\end{tabular} & $\begin{array}{l}\text { Discordo } \\
\text { totalmente }\end{array}$ & $\begin{array}{l}\text { Concordo } \\
\text { totalmente }\end{array}$ \\
\hline 144 & & & Concordo & Concordo & $\begin{array}{l}\text { Não tenho } \\
\text { certeza }\end{array}$ \\
\hline 145 & & & Concordo & Concordo & $\begin{array}{l}\text { Não tenho } \\
\text { certeza }\end{array}$ \\
\hline 146 & & & $\begin{array}{l}\text { Concordo } \\
\text { totalmente }\end{array}$ & $\begin{array}{l}\text { Concordo } \\
\text { totalmente }\end{array}$ & Discordo \\
\hline 147 & & & $\begin{array}{l}\text { Concordo } \\
\text { totalmente }\end{array}$ & $\begin{array}{l}\text { Concordo } \\
\text { totalmente }\end{array}$ & Discordo \\
\hline 148 & & & \begin{tabular}{|l|} 
Concordo \\
totalmente
\end{tabular} & \begin{tabular}{|l|}
$\begin{array}{l}\text { Concordo } \\
\text { totalmente }\end{array}$ \\
\end{tabular} & Discordo \\
\hline 149 & & & \begin{tabular}{|l|} 
Discordo \\
totalmente
\end{tabular} & Discordo & Concordo \\
\hline 150 & & & Discordo & Concordo & Concordo \\
\hline 151 & & & $\begin{array}{l}\text { Não tenho } \\
\text { certeza }\end{array}$ & $\begin{array}{l}\text { Não tenho } \\
\text { certeza }\end{array}$ & $\begin{array}{l}\text { Concordo } \\
\text { totalmente }\end{array}$ \\
\hline 152 & & & Concordo & $\begin{array}{l}\text { Concordo } \\
\text { totalmente }\end{array}$ & $\begin{array}{l}\text { Não tenho } \\
\text { certeza }\end{array}$ \\
\hline 153 & & & Discordo & Concordo & \begin{tabular}{|l|} 
Discordo \\
\end{tabular} \\
\hline 154 & & & Concordo & Concordo & Concordo \\
\hline 155 & & & Concordo & Concordo & \begin{tabular}{|l|} 
Não \\
respondeu
\end{tabular} \\
\hline 156 & & & Concordo & Concordo & $\begin{array}{l}\text { Concordo } \\
\text { totalmente }\end{array}$ \\
\hline 157 & & & Concordo & $\begin{array}{l}\text { Concordo } \\
\text { totalmente }\end{array}$ & Concordo \\
\hline
\end{tabular}




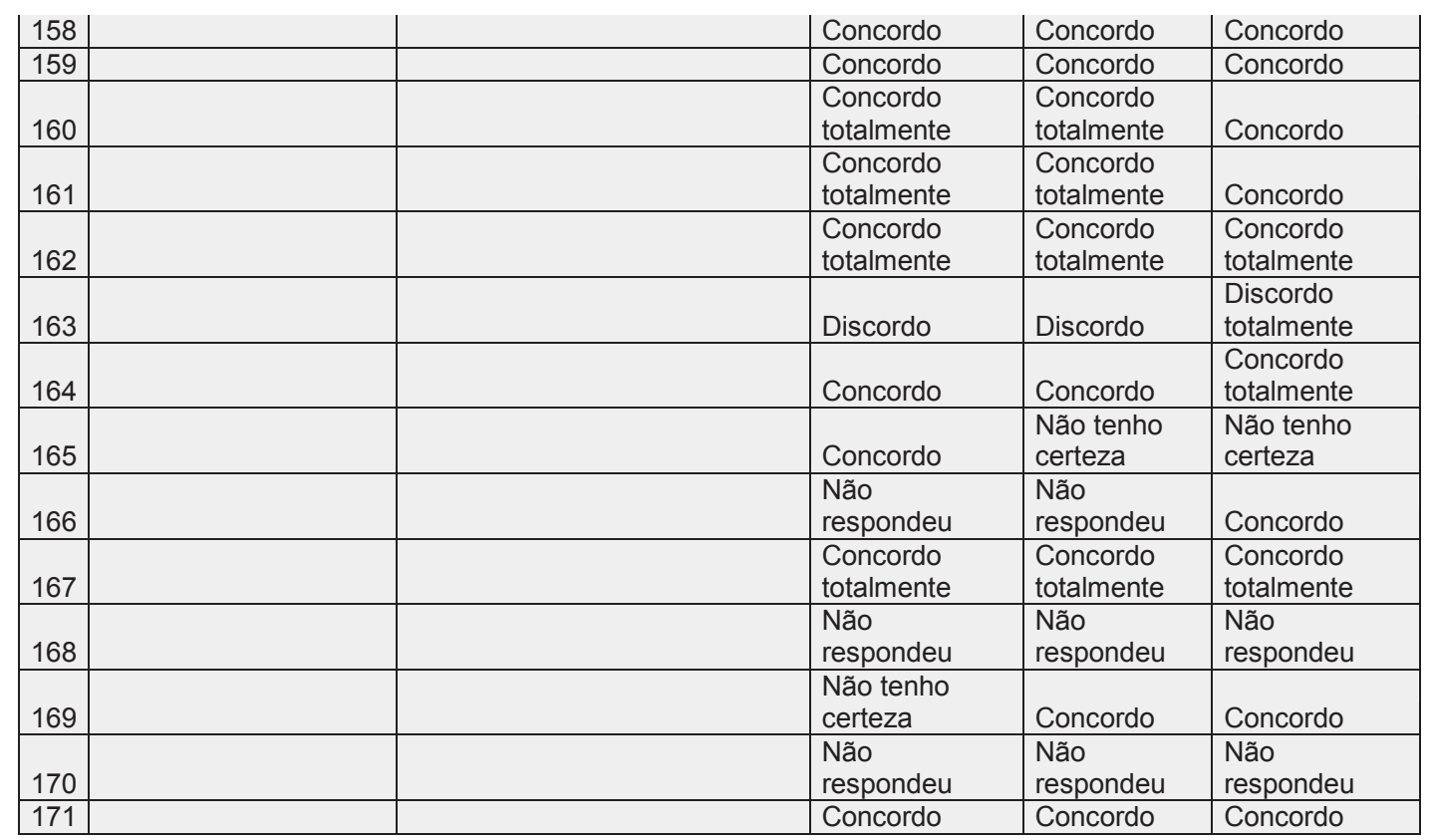


17. Se você assinalou a alternativa "Concordo totalmente" na pergunta 16, exemplifique situações em que o diálogo é a forma de comunicação indispensável entre chefes de todos os níveis de autoridade e

Em uma situação de avaliação do funcionário o diálogo é fundamental.

Por que há situações em existe conflitos e que precisam serem sanados, do contrário temos empregados insatisfeitos ou chefes insastifeitos. Estas arestas precisam e devem serem aparadas de forma que fique adequado a todos ou para a maioria. Não há como alcansar bons resultados sem o comprometimento de todos, dai a

10 importancia do diálogo.

11 Em situações de conflito por razões de divergência quanto a pontos de vista sobre direcionamento nas tarefas.

É indispensável porque é no "olho no olho" que as pessoas devem se relacionar no trabalho. É no diálogo que as pessoas podem questionar ou discutir aquilo que não entendem ou que não concordam. O diálogo franco leva ao entendimento e à resolução de questões discordantes. O foco do diálogo deve ser buscar a solução que melhor

\section{O diálogo proporciona oportunidade de convencimento}

Informações para a equipe sobre transferencia de empregado do setor; informação sobre alteração da estrutura

física do setor dentro da empresa.

PARTO DO PONTO DE VISTA QUE EM TODOS OS COISAS O DIÁLOGO É FUNDAMENTAL, PORTANTO SEJA

Quando há mudanças de normas ou regras internas, como por exemplo, quando foi implantado o novo sistema de ponto. A explicação satisfatória de como funcionaria o processo foi dada oralmente em reunião. Msmo com a 23 divulgação pelas outras formas a oral foi a melhor.

24 Agiliza os encaminhamentos, o entedimento é mais fácil muitas vezes que um papel.

Quando é preciso assegurar que a informação foi compreendida plenamente, sem ruídos ou intrepretações

Quando há necessidade de sugerir ajuste que afeta a todos de maneira negativa no sentido de não aceitação ou positiva também. Em ambas situações isto é muito importante, pois surgem reações inesperadas que são tratadas

prontamente.

Melhoria do ambiente de trabalho.

Após avaliação de desempenho e não cumprimento de meta.

Quando há incompatibilidade de ideias e diferenças de objetivos. 
Decisões importantes para a empresa e resolução de problemas.

m todas as situações.

Reuniões da equipe

Em todos os casos e principalmente fofocas

Demandas de serviços, projetos, avaliações

Dialogando dando abertura

Adequação de conduta e metas

Reuniões, agrupamento entre patrões e empregados

Planejamento de atividades e avaliação de desempenho

Por exemplo, na verticalização do trabalho

Qualquer situação deve contar com essa fase

Quando existem opiniões e interesses a serem harmonizados

Demandas importantes de pesquisa

diálogo é fundamental 


\begin{tabular}{|c|c|}
\hline 126 & Reuniões, apresentações, mesa redonda \\
\hline 127 & \\
\hline 128 & \\
\hline 129 & Reuniões \\
\hline 130 & \\
\hline 131 & Cumprimento, repreensão, pedido de viagem ao exterior \\
\hline 132 & Problemas pessoais, problemas sérios com empregados \\
\hline 133 & Planejamento do trabalho, comunicação de resultados \\
\hline 134 & Para todas as situações, na minha opinião \\
\hline 135 & \\
\hline 136 & \\
\hline 137 & \\
\hline 138 & Questões pessoais \\
\hline 139 & \\
\hline 140 & \\
\hline 141 & \\
\hline 142 & \\
\hline 143 & Toda e qualquer que exija o mesmo \\
\hline 144 & \\
\hline 145 & \\
\hline 146 & \\
\hline 147 & \\
\hline 148 & \\
\hline 149 & \\
\hline 150 & \\
\hline 151 & $\mathrm{~N}$ tomada de decisões \\
\hline 152 & \\
\hline 153 & \\
\hline 154 & \\
\hline 155 & \\
\hline 156 & Certifica que todos tem ciencia do fato \\
\hline 157 & \\
\hline 158 & \\
\hline 159 & \\
\hline 160 & \\
\hline 161 & \\
\hline 162 & \\
\hline 163 & \\
\hline 164 & Principalmente na questão de avaliação e melhorar as condições de trabalho \\
\hline 165 & \\
\hline 166 & \\
\hline 167 & Resolver problemas técnicos e humanos \\
\hline 168 & \\
\hline 169 & \\
\hline 170 & \\
\hline 171 & \\
\hline
\end{tabular}


18. Se você assinalou a alternativa "Concordo" na pergunta 16, exemplifique situações em que o diálogo é a forma de comunicação indispensável entre chefes de todos os níveis de autoridade e empregados.

2

4 Situações que sejam necessárias argumentação direta e/ou discussão de ideias. 5

Qdo algum outro tipo de cominicação não surtiu efeito, ou mesmo, qdo não houve entendimento por 6 parte do empregado.

8 Para comunicar e explicar algumas decisões da empresa.

13 Negociação de metas individuais de desempenho.

Situações cujo prazo para uma tarefa é curto, ou em que não se pode correr o risco de ser mal 14 interpretado/entendido.

Quando ocorre uma situação ou situações que dispensam uma comunicação formal , por exemplo : " vou chegar mais tarde amanhã por motivos particulares ", ou "estou ligando para avisar que chegarei mais tarde porque não me senti bem quando acordei ", ou "vamos organizar o período de férias de 16 cada um", ou "vamos mudar a forma de realizar essa tarefa", etc,...

17 - Nas avaliações pessoais de atividades de pesquisa e de atitudes éticas da Empresa

Situações como desavenças entre funcionários que geram conflitos e desentendimentos, distribuição de tarefas, avaliação do desempenho do funcionário. Em todos este casos, o diálogo é a melhor forma para o entendimento entre as pessoas.

Situações que impliquem na forma de trabalho dificultando e diminuindo o rendimento de determinada

Quando precisa haver um convencimento ou explicação sobre o assunto a ser comunicado. 
Por exemplo, no caso de problemas de convivência.

70 Para solicitar materiais, reparo de aparelhos.

Assuntos mais individuais

Assuntos controversos

Reuniões

Resolver conflitos interpessoais

Reunião geral com empregados

Tomada de decisões que envolvem a equipe

Reuniões

Quando a privacidade é necessária

or exemplo, resultado de avaliação de desempenho do empregado 
Para a tomada de decisões polêmicas e/ou estratégicas para a empresa.

136

137

138

139

140

\begin{tabular}{r|}
141 \\
142 \\
\hline
\end{tabular}

143

144

145

146

147

148

149

150

151

152

153

Quando o subordinado comete algum erro grave é necessário diálogo para que a situação seja 154 explicada

155

156

157

158

159

160

161

162

163

164

165

166

167

168

169

170

171 
20. Se você assinalou a alternativa "Sim" na pergunta 19, responda por que o local ou ambiente onde ocorre o diálogo tem influência na qualidade da comunicação realizada? Recentemente um diálogo durante uma reuniáo deixou claro a necessidade de um processo, porem 1 mesmo assim esse processo nao foi respeitado.

porque se o local escolhida para acomunicação for em um ambiente muito formal, a impressao inicial é de que aconversa vai ser mito séria, e isso de certa foram, faz com que o interlocutor parta de uma 3 interpretação inicial errada.

Onde há diálogo, fica muito mais fácil também a eliminação de possíveis dúvidas, decorrentes do

6 andamento dos trabalhos.

Em uma conversa amistosa em um local reservado e tranquilo fica mais facil a comunicação.

Se o ambiente tiver poluição sonora, sujo, no meio de pessoas estranhas ao que se está discutindo.

Ou se o ambiente pode levar uma das partes a ceder por coerção ou ameaça. Ou seja, o ambiente

deve propiciar uma isenta de coerção, ameaça, barulho e etc.

Em situações de repreensão ou orientação técnica específica o local deve ser reservado, para conferir maior privacidade, tranquilidade e compreensão na transmissão da comunicação para o

11 receptor, minimizando a possibilidade de interferência externa ou inibição para o mesmo.

Acredito que o diálogo deve acontecer em local e hora apropriada. Um diálogo com a finalidade de definir diretrizes, atividades, etc., na empresa tem que ter seu grau de seriedade e até de certa formalidade. Assuntos como esses não podem ser discutidos numa rodada de cerveja, ou na mesa de um bar, ou na saída da missa, portanto, assuntos corporativos têm local e hora para serem

Porque se falamos ao telefone por exemplo não há presença física , então não há o "olho no olho" dos interlocutores. Se o local for menos privado e existe a presença de pessoas alheias ao setor de

16 trabalho pode ocorrer inibição para que as pessoas se exponham livremente.

- Não devem ocorrer constrangimentos a iniciativas ou manifestações, que embora erradas ou

17 discutíveís, devem merecer considerações favoráveis para serem expressas

18 O diálogo necessita de silencio no ambiente.

Informações relativas ao trabalho geralmente são formalizadas em salas de reunião e não nos

19 corredores.

DEPENDENDO DA SITUAÇÃO E O TIPO DE CONVERSA NÃO PODE SER EM QUALQUER

20 LUGAR.

Dependendo do assunto a ser resolvido, muitas vezes é preciso estar em uma sala em que possa reunir os funcionários da equipe para discutir os assuntos. Os assuntos geralmente são de interesse às pessoas envolvidas na equipe e não a todos globalmente.

Porque é diferente receber a informação em uma reunião, que segue todo um planejamento e tem lugar específico para acontecer ou no próprio setor de trabalho e recebê-la ao acaso, no corredor ou

23 outro lugar inapropriado. Ter lugar específico auxilia no entendimento de que a notícia é oficial.

No caso de uma resposta negativa, o diálogo é essencial pois é mais fácil justificar e perceber os 24 motivos da negativa, não é tão frio quanto um papel que simplesmente diz "não".

25 melhor relacionamento entre as pessoas

Por ser uma sala sem paredes, o ambiente favorece a troca de informações entre os profissionais.

Todos respeitam o espaço do outro sem invasão ou intromissão. As discussões costumam ser

27 saudáveis.

Porque pode desviar a atenção e o diálogo pode ficar comprometido. Inibição principalmente ou por

30 barulho excessivo e etc.

31 Porque dependendo do local o diálogo pode sofrer interferência e não fluir a contento.

Concordo

Não tenho

certeza

Não tenho

certeza

Concordo

Concordo

Concordo

Concordo

Concordo

Discordo

Concordo

Concordo

Discordo

Concordo

Concordo

totalmente

Concordo

totalmente

Concordo

Concordo

Concordo

Concordo

Concordo

Concordo

Concordo

Concordo

Não tenho

certeza 


\begin{tabular}{|c|c|c|}
\hline 34 & & Concordo \\
\hline 35 & Alguns pontos do diálogo podem precisar de exemplos no local. & Concordo \\
\hline 36 & & Concordo \\
\hline 37 & & Concordo \\
\hline 38 & Porque assim chegaremos ao resultado esperado ou melhor. & Concordo \\
\hline 39 & & Concordo \\
\hline 40 & Se for dentro da chefia pode haver constrangimento por parte do empregado. & $\begin{array}{l}\text { Não tenho } \\
\text { certeza }\end{array}$ \\
\hline 41 & & Concordo \\
\hline 42 & A espontaneidade depende do local & Concordo \\
\hline 43 & & $\begin{array}{l}\text { Discordo } \\
\text { totalmente }\end{array}$ \\
\hline 44 & & Concordo \\
\hline 45 & & $\begin{array}{l}\text { Não tenho } \\
\text { certeza }\end{array}$ \\
\hline 46 & & Concordo \\
\hline 47 & Para não ficar muito informal. & Concordo \\
\hline 48 & & Concordo \\
\hline 49 & & $\begin{array}{l}\text { Concordo } \\
\text { totalmente }\end{array}$ \\
\hline 50 & Pode influenciar na compreensão e estado emocional dos envolvidos. & Concordo \\
\hline 51 & & Concordo \\
\hline 52 & & $\begin{array}{l}\text { Não tenho } \\
\text { certeza }\end{array}$ \\
\hline 53 & & Discordo \\
\hline 54 & & Concordo \\
\hline 55 & & $\begin{array}{l}\text { Não tenho } \\
\text { certeza }\end{array}$ \\
\hline 56 & & $\begin{array}{l}\text { Não tenho } \\
\text { certeza }\end{array}$ \\
\hline 57 & Há um melhor entendimento. & Discordo \\
\hline 58 & & Concordo \\
\hline 59 & Melhora a qualidade do trabalho. & $\begin{array}{l}\text { Não tenho } \\
\text { certeza }\end{array}$ \\
\hline 60 & & Discordo \\
\hline 61 & & $\begin{array}{l}\text { Discordo } \\
\text { totalmente }\end{array}$ \\
\hline 62 & & Discordo \\
\hline 63 & & Concordo \\
\hline 64 & & Concordo \\
\hline 65 & Diálogo é principal tarefa para bom ambiente de trabalho. & Concordo \\
\hline 66 & Torna as relações mais humanas e menos tecnicistas como é a tendência atual. & $\begin{array}{l}\text { Concordo } \\
\text { totalmente }\end{array}$ \\
\hline 67 & & Concordo \\
\hline 68 & & Concordo \\
\hline 69 & & $\begin{array}{l}\text { Concordo } \\
\text { totalmente }\end{array}$ \\
\hline 70 & Por se tratar do local próprio para isso. & Concordo \\
\hline 71 & É preciso que ambas as partes envolvidas se sintam à vontade e com direito a falar. & Concordo \\
\hline 72 & & Concordo \\
\hline 73 & & Concordo \\
\hline 74 & & Concordo \\
\hline 75 & & Concordo \\
\hline 76 & É a melhor forma para evitar mal esclarecimento & Concordo \\
\hline 77 & Porque fica melhor informado e tira dúvidas & $\begin{array}{l}\text { Não tenho } \\
\text { certeza }\end{array}$ \\
\hline 78 & O diálogo é base para bom andamento da equipe & Concordo \\
\hline 79 & & Discordo \\
\hline 80 & & Concordo \\
\hline 81 & & Concordo \\
\hline 82 & & $\begin{array}{l}\text { Não tenho } \\
\text { certeza }\end{array}$ \\
\hline 83 & & $\begin{array}{l}\text { Não tenho } \\
\text { certeza }\end{array}$ \\
\hline 84 & & Discordo \\
\hline 85 & & Concordo \\
\hline 86 & Alguns assuntos necessitam de cautela e sigilo & Discordo \\
\hline 87 & & Discordo \\
\hline 88 & Aproxima & Concordo \\
\hline 89 & Nosso superior explica bem as coisas & $\begin{array}{l}\text { Não tenho } \\
\text { certeza }\end{array}$ \\
\hline 90 & & Discordo \\
\hline
\end{tabular}


91

Porque ficamos à vontade

Evitar constrangimentos e favorecer a liberdade

93

94

95

96

97

101 Posicionamento dos comunicantes

102

103

104

105 Nenhuma das partes pode se sentir poucou à vontade

106

107

108 Estabelece um consciência mais profunda para o diálogo

109 Dependendo do assunto não se deve discutir em corredor, bwc

110 O ambiente que propicia o meio para que o diálogo alcance seus espectadores

111

Porque é importante

Objetividade, exclusividade

Liberdade

Para um melhor entendimento há necessidade de anotações

Pode necessitar privacidade

131 Silêncio, concentração no diálogo, mostra a importância do funcionário

132 É necessário sempre privacidade.

Dependendo do diálogo é preciso um ambiente reservado. Se o ambiente não for adequado ao

133 diálogo ele não cumprirá com os objetivos

134 Pela inibição natural que causa quando a pessoa não está no seu "habitat" natural de trabalho Locais muito tumultuados atrapalham o entendimento e o desenvolvimento do raciocínio lógico 


\begin{tabular}{|c|c|c|}
\hline 141 & O momento influencia a receptividade & $\begin{array}{l}\text { Não tenho } \\
\text { certeza }\end{array}$ \\
\hline 142 & Fica mais claro todas as tarefas quando se trata de comunicação & $\begin{array}{l}\text { Não tenho } \\
\text { certeza }\end{array}$ \\
\hline 143 & & $\begin{array}{l}\text { Discordo } \\
\text { totalmente }\end{array}$ \\
\hline 144 & & $\begin{array}{l}\text { Não tenho } \\
\text { certeza }\end{array}$ \\
\hline 145 & & Concordo \\
\hline 146 & & Concordo \\
\hline 147 & & Concordo \\
\hline 148 & & Concordo \\
\hline 149 & & $\begin{array}{l}\text { Discordo } \\
\text { totalmente }\end{array}$ \\
\hline 150 & & Concordo \\
\hline 151 & & Discordo \\
\hline 152 & & Concordo \\
\hline 153 & & Concordo \\
\hline 154 & & Concordo \\
\hline 155 & & \begin{tabular}{|l|} 
Não \\
respondeu
\end{tabular} \\
\hline 156 & Para uma boa compreensão & $\begin{array}{l}\text { Concordo } \\
\text { totalmente }\end{array}$ \\
\hline 157 & & Concordo \\
\hline 158 & & $\begin{array}{l}\text { Não tenho } \\
\text { certeza }\end{array}$ \\
\hline 159 & & Concordo \\
\hline 160 & Podem surgir novas idéias ou discussões & $\begin{array}{l}\text { Concordo } \\
\text { totalmente }\end{array}$ \\
\hline 161 & & \begin{tabular}{|l|} 
Não \\
respondeu
\end{tabular} \\
\hline 162 & & $\begin{array}{l}\text { Concordo } \\
\text { totalmente }\end{array}$ \\
\hline 163 & & Discordo \\
\hline 164 & & Concordo \\
\hline 165 & & $\begin{array}{l}\text { Não tenho } \\
\text { certeza }\end{array}$ \\
\hline 166 & & \begin{tabular}{|l|} 
Não \\
respondeu
\end{tabular} \\
\hline 167 & & $\begin{array}{l}\text { Não tenho } \\
\text { certeza }\end{array}$ \\
\hline 168 & & $\begin{array}{l}\text { Não } \\
\text { respondeu }\end{array}$ \\
\hline 169 & & $\begin{array}{l}\text { Não tenho } \\
\text { certeza }\end{array}$ \\
\hline 170 & Por ser reservado & $\begin{array}{l}\begin{array}{l}\text { Não tenho } \\
\text { certeza }\end{array} \\
\end{array}$ \\
\hline 171 & Dependendo do local pode se tornar constrangedor & Concordo \\
\hline
\end{tabular}




\begin{tabular}{|c|c|c|c|c|c|c|}
\hline$\#$ & \begin{tabular}{|} 
22. Eu \\
tenho \\
autonomia \\
para \\
propor ao \\
meu \\
superior \\
imediato \\
melhorias \\
na \\
execução \\
de meu \\
trabalho.
\end{tabular} & $\begin{array}{l}\text { 23. Que tipo } \\
\text { de } \\
\text { comunicação } \\
\text { você usa } \\
\text { para solicitar } \\
\text { ao } \\
\text { supervisor, } \\
\text { conselhos } \\
\text { sobre como } \\
\text { o trabalho } \\
\text { pode ser } \\
\text { feito de } \\
\text { maneira mais } \\
\text { eficaz? }\end{array}$ & $\begin{array}{l}\text { 24. Que instrumento de } \\
\text { comunicação seu superior } \\
\text { imediato usa para abordar } \\
\text { questões internas sobre o } \\
\text { trabalho da equipe. }\end{array}$ & $\begin{array}{c}\text { 25. Meu } \\
\text { superior } \\
\text { imediato } \\
\text { discute face } \\
\text { a face } \\
\text { comigo } \\
\text { ações para } \\
\text { melhorar o } \\
\text { meu } \\
\text { desempenho. }\end{array}$ & $\begin{array}{c}\text { 26. Meu } \\
\text { superior } \\
\text { imediato } \\
\text { encoraja os } \\
\text { empregados } \\
\text { a se } \\
\text { expressarem } \\
\text { face a face e } \\
\text { fornece, } \\
\text { com } \\
\text { franqueza } \\
\text { suas } \\
\text { opiniões } \\
\text { sobre o } \\
\text { estilo dele } \\
\text { de liderar. }\end{array}$ & $\begin{array}{c}\text { 27. De que } \\
\text { modo seu } \\
\text { superior } \\
\text { imediato se } \\
\text { expressa } \\
\text { com você } \\
\text { para dar } \\
\text { informações } \\
\text { sobre a } \\
\text { relação entre } \\
\text { os objetivos } \\
\text { da empresa e } \\
\text { o trabalho } \\
\text { dos } \\
\text { empregados? }\end{array}$ \\
\hline 1 & \begin{tabular}{|l|} 
Discordo \\
totalmente
\end{tabular} & $\begin{array}{l}\text { Oral , Escrita, } \\
\text { Digital } \\
\end{array}$ & Reunião formal & Discordo & $\begin{array}{l}\text { Discordo } \\
\text { totalmente }\end{array}$ & Fala \\
\hline 2 & $\begin{array}{l}\text { Concordo } \\
\text { totalmente }\end{array}$ & Oral & Conversa face a face & $\begin{array}{l}\text { Concordo } \\
\text { totalmente }\end{array}$ & Discordo & Fala \\
\hline 3 & Concordo & Oral, Digital & $\begin{array}{l}\text { Reunião formal, Conversa } \\
\text { face a face, E-mail }\end{array}$ & Concordo & Concordo & Fala \\
\hline 4 & \begin{tabular}{|l|l|} 
Concordo \\
totalmente
\end{tabular} & Oral , Digital & $\begin{array}{l}\text { Reunião formal, Conversa } \\
\text { face a face, E-mail }\end{array}$ & Concordo & Concordo & Fala e escrita \\
\hline 5 & Concordo & Digital & Reunião formal & Discordo & Discordo & Fala e escrita \\
\hline 6 & Concordo & Oral , Digital & $\begin{array}{l}\text { Reunião formal, Conversa } \\
\text { face a face, E-mail }\end{array}$ & Concordo & Concordo & Fala e escrita \\
\hline 7 & Concordo & Digital & Conversa face a face & Discordo & \begin{tabular}{|l|} 
Não tenho \\
certeza
\end{tabular} & Fala e escrita \\
\hline 8 & \begin{tabular}{|l|} 
Concordo \\
totalmente
\end{tabular} & Digital & E-mail & Concordo & Concordo & Fala e escrita \\
\hline 9 & Concordo & Oral , Digital & $\begin{array}{l}\text { Reunião formal, Conversa } \\
\text { face a face, E-mail }\end{array}$ & Concordo & $\begin{array}{l}\text { Não tenho } \\
\text { certeza }\end{array}$ & escrita \\
\hline 10 & Concordo & $\begin{array}{l}\text { Oral, Escrita, } \\
\text { Digital }\end{array}$ & $\begin{array}{l}\text { Reunião formal, Conversa } \\
\text { face a face, E-mail }\end{array}$ & Concordo & $\begin{array}{l}\text { Não tenho } \\
\text { certeza }\end{array}$ & Fala e escrita \\
\hline 11 & $\begin{array}{l}\text { Concordo } \\
\text { totalmente }\end{array}$ & Oral, Digital & $\begin{array}{l}\text { Reunião formal , Conversa } \\
\text { face a face, E-mail , telefone }\end{array}$ & Con & Discc & Nen \\
\hline 12 & Concordo & $\begin{array}{l}\text { Oral , Escrita, } \\
\text { Digital }\end{array}$ & $\begin{array}{l}\text { rmal, Conversa } \\
\text {, E-mail }\end{array}$ & $\begin{array}{l}\text { Con } \\
\text { tota }\end{array}$ & $\begin{array}{l}\text { Conc } \\
\text { totaln }\end{array}$ & scrita \\
\hline 13 & Concordo & Oral, Digital & $\begin{array}{l}\text { Reunião formal, Conversa } \\
\text { face a face, E-mail }\end{array}$ & Concordo & Concordo & Fala e escrita \\
\hline 14 & Concordo & Oral & Conversa face a face & Concordo & $\begin{array}{l}\text { Não tenho } \\
\text { certeza }\end{array}$ & Fala \\
\hline 15 & $\begin{array}{l}\text { Concordo } \\
\text { totalmente }\end{array}$ & Oral , Digital & $\begin{array}{l}\text { Reunião formal , Conversa } \\
\text { face a face, Circular interna } \\
\text {, E-mail }\end{array}$ & Concordo & Concordo & Fala \\
\hline 16 & Concordo & $\begin{array}{l}\text { Oral , Escrita, } \\
\text { Digital }\end{array}$ & $\begin{array}{l}\text { Reunião formal , Conversa } \\
\text { face a face, Circular interna } \\
\text {, Ofício, E-mail }\end{array}$ & 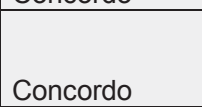 & Con & Fala \\
\hline 17 & Concordo & Digital & Reunião formal & Co & Con & Fala \\
\hline 18 & Concordo & Oral & Reunião formal & Concordo & Concordo & Fala \\
\hline 19 & $\begin{array}{l}\text { Concordo } \\
\text { totalmente }\end{array}$ & Oral, Digital & $\begin{array}{l}\text { Reunião formal , Conversa } \\
\text { face a face, E-mail }\end{array}$ & Concordo & Concordo & Fala e escrita \\
\hline 20 & $\begin{array}{l}\text { Concordo } \\
\text { totalmente }\end{array}$ & Oral & $\begin{array}{l}\text { Reunião formal, Conversa } \\
\text { face a face, E-mail }\end{array}$ & Discordo & Conc & Escrita \\
\hline 21 & Concordo & Oral & Conversa face a face & Concordo & \begin{tabular}{|l|}
$\begin{array}{l}\text { Não tenho } \\
\text { certeza }\end{array}$ \\
\end{tabular} & Fala \\
\hline 22 & Concordo & Oral & Conversa face a face & Concordo & Discordo & Fala \\
\hline 23 & $\begin{array}{l}\text { Concordo } \\
\text { totalmente }\end{array}$ & $\begin{array}{l}\text { Oral , Escrita, } \\
\text { Digital } \\
\end{array}$ & $\begin{array}{l}\text { Reunião formal, Conversa } \\
\text { face a face, E-mail , telefone }\end{array}$ & \begin{tabular}{|l|} 
Concordo \\
totalmente
\end{tabular} & $\begin{array}{l}\text { Concordo } \\
\text { totalmente }\end{array}$ & escrita \\
\hline 24 & $\begin{array}{l}\text { Concordo } \\
\text { totalmente }\end{array}$ & Oral , Digital & Conversa face a face & $\begin{array}{l}\text { Concordo } \\
\text { totalmente }\end{array}$ & $\begin{array}{l}\text { Concordo } \\
\text { totalmente }\end{array}$ & Fala e escrita \\
\hline 25 & Concordo & Oral , Escrita & $\begin{array}{l}\text { Reunião formal , Conversa } \\
\text { face a face, E-mail }\end{array}$ & Concordo & Concordo & rita \\
\hline 26 & Concordo & Oral , Escrita & $\begin{array}{l}\text { Reunião formal , Conversa } \\
\text { face a face, E-mail }\end{array}$ & Concordo & Concordo & Fala e escrita \\
\hline 27 & $\begin{array}{l}\text { Concordo } \\
\text { totalmente }\end{array}$ & Oral, Digital & $\begin{array}{l}\text { Reunião formal, Conversa } \\
\text { face a face, E-mail }\end{array}$ & $\begin{array}{l}\text { Concordo } \\
\text { totalmente }\end{array}$ & $\begin{array}{l}\text { Concordo } \\
\text { totalmente }\end{array}$ & scrita \\
\hline 28 & Discordo & Oral & Conversa face a face & \begin{tabular}{|l} 
Discordo \\
\end{tabular} & Discordo & Fala \\
\hline 29 & $\begin{array}{l}\text { Concordo } \\
\text { totalmente }\end{array}$ & Oral & Conversa face a face & Concordo & Concordo & Fala e escrita \\
\hline
\end{tabular}




\begin{tabular}{|c|c|c|c|c|c|c|}
\hline 30 & $\begin{array}{l}\text { Concordo } \\
\text { totalmente }\end{array}$ & $\begin{array}{l}\text { Oral , Escrita , } \\
\text { Digital }\end{array}$ & $\begin{array}{l}\text { Reunião formal, Conversa } \\
\text { face a face, E-mail, } \\
\text { Apresentação no data-show }\end{array}$ & Concordo & $\begin{array}{l}\text { Não tenho } \\
\text { certeza }\end{array}$ & Fala e escrita \\
\hline 31 & Concordo & Oral, Digital & $\begin{array}{l}\text { Reunião formal , Conversa } \\
\text { face a face }\end{array}$ & Concordo & Concordo & Fala e escrita \\
\hline 32 & Concordo & Oral & Conversa face a face & Concordo & Concordo & $-0-$ \\
\hline 33 & $\begin{array}{l}\text { Concordo } \\
\text { totalmente }\end{array}$ & \begin{tabular}{|l|} 
Oral , Escrita , \\
Digital
\end{tabular} & $\begin{array}{l}\text { Reunião formal, Conversa } \\
\text { face a face, E-mail }\end{array}$ & Concordo & $\begin{array}{l}\text { Não tenho } \\
\text { certeza }\end{array}$ & Fala e escrita \\
\hline 34 & Concordo & \begin{tabular}{|l|} 
Oral , Escrita , \\
Digital \\
\end{tabular} & $\begin{array}{l}\text { Reunião formal, Conversa } \\
\text { face a face, Ofício, E-mail }\end{array}$ & Concordo & $\begin{array}{l}\text { Não tenho } \\
\text { certeza }\end{array}$ & Fala e escrita \\
\hline 35 & Concordo & Oral & $\begin{array}{l}\text { Reunião formal , Conversa } \\
\text { face a face }\end{array}$ & Discordo & Concordo & Fala e escrita \\
\hline 36 & $\begin{array}{l}\text { Não tenho } \\
\text { certeza }\end{array}$ & Oral, Digital & $\begin{array}{l}\text { Conversa face a face, E- } \\
\text { mail }\end{array}$ & \begin{tabular}{|l|} 
Concordo \\
totalmente
\end{tabular} & $\begin{array}{l}\text { Concordo } \\
\text { totalmente }\end{array}$ & Fala \\
\hline 37 & Concordo & \begin{tabular}{|l|} 
Oral , Escrita , \\
Digital
\end{tabular} & $\begin{array}{l}\text { Reunião formal, Conversa } \\
\text { face a face, E-mail }\end{array}$ & Concordo & Concordo & Fala e escrita \\
\hline 38 & $\begin{array}{l}\text { Concordo } \\
\text { totalmente }\end{array}$ & $\begin{array}{l}\text { Oral , Escrita , } \\
\text { Digital }\end{array}$ & Reunião formal & Discordo & Concordo & Nenhum \\
\hline 39 & Concordo & Oral & Reunião formal & Discordo & Concordo & Fala \\
\hline 40 & $\begin{array}{l}\text { Concordo } \\
\text { totalmente }\end{array}$ & Oral & $\begin{array}{l}\text { Reunião formal , Conversa } \\
\text { face a face }\end{array}$ & Discordo & $\begin{array}{l}\text { Não tenho } \\
\text { certeza }\end{array}$ & Fala \\
\hline 41 & Concordo & Oral & Conversa face a face & Concordo & Concordo & Fala \\
\hline 42 & Concordo & Oral & Conversa face a face & Concordo & Concordo & Fala \\
\hline 43 & \begin{tabular}{|l} 
Discordo \\
totalmente
\end{tabular} & Oral & Conversa face a face & \begin{tabular}{|l|} 
Discordo \\
totalmente
\end{tabular} & $\begin{array}{l}\text { Discordo } \\
\text { totalmente }\end{array}$ & Fala \\
\hline 44 & Concordo & Oral & Conversa face a face & Concordo & $\begin{array}{l}\text { Não tenho } \\
\text { certeza }\end{array}$ & Fala e escrita \\
\hline 45 & $\begin{array}{l}\text { Concordo } \\
\text { totalmente }\end{array}$ & Oral & Conversa face a face & Discordo & Concordo & Fala \\
\hline 46 & Concordo & Oral & Conversa face a face & Concordo & Discordo & Fala e escrita \\
\hline 47 & Concordo & Escrita & Reuniões informais & Discordo & Concordo & Fala e escrita \\
\hline 48 & Concordo & Oral & Conversa face a face & Discordo & Concordo & Fala \\
\hline 49 & $\begin{array}{l}\text { Concordo } \\
\text { totalmente }\end{array}$ & Oral & Reunião formal & \begin{tabular}{|l|} 
Concordo \\
totalmente
\end{tabular} & Concordo & Fala e escrita \\
\hline 50 & $\begin{array}{l}\text { Concordo } \\
\text { totalmente }\end{array}$ & \begin{tabular}{|l|} 
Oral , Escrita , \\
Digital \\
\end{tabular} & $\begin{array}{l}\text { Reunião formal, Conversa } \\
\text { face a face, E-mail }\end{array}$ & $\begin{array}{l}\text { Concordo } \\
\text { totalmente }\end{array}$ & Concordo & Fala e escrita \\
\hline 51 & \begin{tabular}{|l|l|}
$\begin{array}{l}\text { Concordo } \\
\text { totalmente }\end{array}$ \\
\end{tabular} & Oral & Reunião formal & \begin{tabular}{|l|l|} 
Concordo \\
totalmente
\end{tabular} & Concordo & Fala \\
\hline 52 & $\begin{array}{l}\text { Concordo } \\
\text { totalmente }\end{array}$ & Oral & Conversa face a face & $\begin{array}{l}\text { Concordo } \\
\text { totalmente }\end{array}$ & Concordo & Fala \\
\hline 53 & Concordo & Oral & Reunião formal & $\begin{array}{l}\text { Não tenho } \\
\text { certeza }\end{array}$ & $\begin{array}{l}\text { Não tenho } \\
\text { certeza }\end{array}$ & Fala \\
\hline 54 & Concordo & Oral & Conversa face a face & Concordo & Concordo & Fala \\
\hline 55 & Concordo & Oral, Digital & $\begin{array}{l}\text { Reunião formal, Conversa } \\
\text { face a face, E-mail }\end{array}$ & $\begin{array}{l}\text { Não tenho } \\
\text { certeza }\end{array}$ & Concordo & Fala \\
\hline 56 & Concordo & Oral & Conversa face a face & Concordo & Concordo & Fala \\
\hline 57 & Concordo & Oral & Conversa face a face & Concordo & Concordo & Fala \\
\hline 58 & Concordo & Oral & Conversa face a face & Concordo & Concordo & Fala \\
\hline 59 & Concordo & Oral & Reunião formal & Concordo & Concordo & Fala \\
\hline 60 & $\begin{array}{l}\text { Não tenho } \\
\text { certeza }\end{array}$ & Oral & Conversa face a face & Discordo & $\begin{array}{l}\text { Concordo } \\
\text { totalmente }\end{array}$ & Fala \\
\hline 61 & Concordo & Oral & Conversa face a face & \begin{tabular}{|l|} 
Discordo \\
totalmente
\end{tabular} & $\begin{array}{l}\text { Discordo } \\
\text { totalmente }\end{array}$ & Fala \\
\hline 62 & Concordo & Digital & Reunião formal & Discordo & Discordo & Fala e escrita \\
\hline 63 & $\begin{array}{l}\text { Não tenho } \\
\text { certeza }\end{array}$ & Oral & Conversa face a face & Concordo & $\begin{array}{l}\text { Não tenho } \\
\text { certeza }\end{array}$ & Fala \\
\hline 64 & Concordo & Oral & Conversa face a face & Concordo & Concordo & Fala \\
\hline 65 & Concordo & Oral , Digital & $\begin{array}{l}\text { Reunião formal, Conversa } \\
\text { face a face, E-mail }\end{array}$ & Concordo & Concordo & Fala \\
\hline 66 & $\begin{array}{l}\text { Concordo } \\
\text { totalmente }\end{array}$ & Oral & $\begin{array}{l}\text { Reunião formal , Conversa } \\
\text { face a face, Circular interna } \\
\text {, Ofício, E-mail }\end{array}$ & Concordo & Concordo & Fala e escrita \\
\hline 67 & Concordo & Oral & E-mail & Discordo & Discordo & Fala \\
\hline 68 & Concordo & Oral, Digital & $\begin{array}{l}\text { Conversa face a face, E- } \\
\text { mail }\end{array}$ & Concordo & $\begin{array}{l}\text { Não tenho } \\
\text { certeza }\end{array}$ & Fala e escrita \\
\hline 69 & \begin{tabular}{|l} 
Concordo \\
totalmente
\end{tabular} & Oral , Digital & E-mail & Concordo & Concordo & Fala e escrita \\
\hline 70 & Concordo & Oral & $\begin{array}{l}\text { Reunião formal , Conversa } \\
\text { face a face }\end{array}$ & Concordo & Concordo & Fala \\
\hline 71 & $\begin{array}{l}\text { Concordo } \\
\text { totalmente }\end{array}$ & $\begin{array}{l}\text { Oral , Escrita, } \\
\text { Digital }\end{array}$ & $\begin{array}{l}\text { Reunião formal , Conversa } \\
\text { face a face, Circular interna } \\
\text {, Ofício, E-mail , telefone }\end{array}$ & $\begin{array}{l}\text { Não tenho } \\
\text { certeza }\end{array}$ & Concordo & Fala e escrita \\
\hline 72 & Concordo & Escrita & Conversa face a face & Concordo & Concordo & Fala e escrita \\
\hline
\end{tabular}




\begin{tabular}{|c|c|c|c|c|c|c|}
\hline 73 & Concordo & Oral , Digital & E-mail & Concordo & Discordo & Fala e escrita \\
\hline 74 & $\begin{array}{l}\text { Concordo } \\
\text { totalmente }\end{array}$ & Digital & Circular interna & $\begin{array}{l}\text { Concordo } \\
\text { totalmente }\end{array}$ & Concordo & Fala e escrita \\
\hline 75 & Concordo & Oral & Conversa face a face & Concordo & Discordo & Fala \\
\hline 76 & $\begin{array}{l}\text { Concordo } \\
\text { totalmente }\end{array}$ & Oral & Conversa face a face & Concordo & $\begin{array}{l}\text { Concordo } \\
\text { totalmente }\end{array}$ & Fala e escrita \\
\hline 77 & Discordo & Oral & $\begin{array}{l}\text { Reunião formal, Conversa } \\
\text { face a face, Circular interna } \\
\text {, Ofício, E-mail }\end{array}$ & Concordo & Concordo & Fala e escrita \\
\hline 78 & $\begin{array}{l}\text { Concordo } \\
\text { totalmente }\end{array}$ & \begin{tabular}{|l|} 
Oral , Escrita , \\
Digital
\end{tabular} & $\begin{array}{l}\text { Reunião formal , Ofício, E- } \\
\text { mail }\end{array}$ & Concordo & $\begin{array}{l}\text { Concordo } \\
\text { totalmente }\end{array}$ & Fala e escrita \\
\hline 79 & $\begin{array}{l}\text { Concordo } \\
\text { totalmente }\end{array}$ & Oral & Conversa face a face & $\begin{array}{l}\text { Concordo } \\
\text { totalmente }\end{array}$ & Discordo & Fala \\
\hline 80 & Concordo & Oral & Conversa face a face & Concordo & Concordo & Fala \\
\hline 81 & Concordo & Oral & Conversa face a face & Concordo & Concordo & Fala \\
\hline 82 & Concordo & Oral & Conversa face a face & Concordo & $\begin{array}{l}\text { Não tenho } \\
\text { certeza }\end{array}$ & Fala \\
\hline 83 & Concordo & Oral & Reunião formal , E-mail & Concordo & $\begin{array}{l}\text { Não tenho } \\
\text { certeza }\end{array}$ & Fala \\
\hline 84 & $\begin{array}{l}\text { Não tenho } \\
\text { certeza }\end{array}$ & Oral & Conversa face a face & Discordo & Concordo & Fala \\
\hline 85 & Concordo & Oral & Reunião formal & Concordo & Concordo & Fala e escrita \\
\hline 86 & Concordo & Oral & $\begin{array}{l}\text { Reunião formal, Conversa } \\
\text { face a face }\end{array}$ & $\begin{array}{l}\text { Concordo } \\
\text { totalmente }\end{array}$ & $\begin{array}{l}\text { Discordo } \\
\text { totalmente }\end{array}$ & Fala \\
\hline 87 & Concordo & Escrita & E-mail & Discordo & Discordo & Fala e escrita \\
\hline 88 & Concordo & Oral & Reunião formal & Concordo & Concordo & Fala e escrita \\
\hline 89 & Concordo & Oral & Conversa face a face & Concordo & Discordo & Fala \\
\hline 90 & Concordo & Oral & $\begin{array}{l}\text { Reunião formal , Conversa } \\
\text { face a face, E-mail }\end{array}$ & Concordo & $\begin{array}{l}\text { Não tenho } \\
\text { certeza }\end{array}$ & Fala \\
\hline 91 & $\begin{array}{l}\text { Concordo } \\
\text { totalmente }\end{array}$ & \begin{tabular}{|l|} 
Oral , Escrita , \\
Digital
\end{tabular} & Conversa face a face & $\begin{array}{l}\text { Concordo } \\
\text { totalmente }\end{array}$ & $\begin{array}{l}\text { Concordo } \\
\text { totalmente }\end{array}$ & Fala \\
\hline 92 & $\begin{array}{l}\text { Concordo } \\
\text { totalmente }\end{array}$ & Oral & $\begin{array}{l}\text { Reunião formal , Conversa } \\
\text { face a face, Circular interna } \\
\text {, E-mail }\end{array}$ & $\begin{array}{l}\text { Concordo } \\
\text { totalmente }\end{array}$ & $\begin{array}{l}\text { Concordo } \\
\text { totalmente }\end{array}$ & Fala e escrita \\
\hline 93 & $\begin{array}{l}\text { Concordo } \\
\text { totalmente }\end{array}$ & Oral & $\begin{array}{l}\text { Reunião formal, Conversa } \\
\text { face a face, Circular interna } \\
\text {, E-mail }\end{array}$ & $\begin{array}{l}\text { Concordo } \\
\text { totalmente }\end{array}$ & $\begin{array}{l}\text { Não tenho } \\
\text { certeza }\end{array}$ & Fala e escrita \\
\hline 94 & \begin{tabular}{|l|} 
Concordo \\
totalmente
\end{tabular} & Oral & $\begin{array}{l}\text { Conversa face a face, E- } \\
\text { mail }\end{array}$ & \begin{tabular}{|l|} 
Concordo \\
totalmente
\end{tabular} & $\begin{array}{l}\text { Concordo } \\
\text { totalmente }\end{array}$ & Fala e escrita \\
\hline 95 & $\begin{array}{l}\text { Concordo } \\
\text { totalmente }\end{array}$ & Oral & Conversa face a face & Concordo & Discordo & Fala \\
\hline 96 & Concordo & Oral & $\begin{array}{l}\text { Reunião formal , Conversa } \\
\text { face a face }\end{array}$ & Concordo & Concordo & Fala \\
\hline 97 & Concordo & Oral & Conversa face a face & Concordo & $\begin{array}{l}\text { Concordo } \\
\text { totalmente }\end{array}$ & Fala e escrita \\
\hline 98 & Concordo & Oral & Conversa face a face & Concordo & $\begin{array}{l}\text { Não tenho } \\
\text { certeza }\end{array}$ & Fala \\
\hline 99 & Concordo & Escrita & Conversa face a face & Concordo & $\begin{array}{l}\text { Não tenho } \\
\text { certeza }\end{array}$ & Fala \\
\hline 100 & Concordo & $\begin{array}{l}\text { Oral , Escrita , } \\
\text { Digital }\end{array}$ & $\begin{array}{l}\text { Reunião formal , Conversa } \\
\text { face a face, Circular interna } \\
\text {, Ofício, E-mail }\end{array}$ & Concordo & Concordo & Fala e escrita \\
\hline 101 & $\begin{array}{l}\text { Concordo } \\
\text { totalmente }\end{array}$ & Oral & $\begin{array}{l}\text { Reunião formal , Conversa } \\
\text { face a face, E-mail }\end{array}$ & Discordo & Concordo & Fala \\
\hline 102 & Concordo & Digital & Reunião formal & Discordo & Discordo & Escrita \\
\hline 103 & $\begin{array}{l}\text { Concordo } \\
\text { totalmente }\end{array}$ & Oral & Conversa face a face & \begin{tabular}{|l} 
Concordo \\
totalmente
\end{tabular} & $\begin{array}{l}\text { Concordo } \\
\text { totalmente }\end{array}$ & Fala e escrita \\
\hline 104 & $\begin{array}{l}\text { Não tenho } \\
\text { certeza }\end{array}$ & Oral & E-mail & Concordo & Concordo & Fala e escrita \\
\hline 105 & Concordo & $\begin{array}{l}\text { Oral , Escrita } \\
\text { Digital }\end{array}$ & Reunião formal , E-mail & Discordo & $\begin{array}{l}\text { Não tenho } \\
\text { certeza }\end{array}$ & Fala e escrita \\
\hline 106 & Concordo & Oral , Digital & $\begin{array}{l}\text { Reunião formal, Conversa } \\
\text { face a face, Circular interna } \\
\text {, Ofício, E-mail }\end{array}$ & $\begin{array}{l}\text { Discordo } \\
\text { totalmente }\end{array}$ & $\begin{array}{l}\text { Discordo } \\
\text { totalmente }\end{array}$ & Fala e escrita \\
\hline 107 & $\begin{array}{l}\text { Concordo } \\
\text { totalmente }\end{array}$ & Escrita & E-mail & Concordo & Concordo & Fala e escrita \\
\hline 108 & Concordo & \begin{tabular}{|l|} 
Oral , Escrita , \\
Digital
\end{tabular} & Reunião formal & Concordo & Concordo & Fala e escrita \\
\hline 109 & Concordo & Oral & E-mail & \begin{tabular}{|l} 
Concordo \\
\end{tabular} & Concordo & Fala e escrita \\
\hline 110 & Concordo & \begin{tabular}{|l|} 
Oral , Escrita , \\
Digital
\end{tabular} & $\begin{array}{l}\text { Reunião formal, Conversa } \\
\text { face a face, Circular interna }\end{array}$ & Concordo & Concordo & Fala e escrita \\
\hline 111 & Concordo & Oral & Conversa face a face & Concordo & Concordo & Fala \\
\hline
\end{tabular}




\begin{tabular}{|c|c|c|c|c|c|c|}
\hline 112 & \begin{tabular}{|l|} 
Concordo \\
totalmente
\end{tabular} & Oral , Digital & $\begin{array}{l}\text { Conversa face a face, E- } \\
\text { mail }\end{array}$ & Concordo & Concordo & Fala \\
\hline 113 & Concordo & Oral & Conversa face a face & Concordo & Discordo & Fala \\
\hline 114 & Discordo & Oral & Conversa face a face & Discordo & $\begin{array}{l}\text { Concordo } \\
\text { totalmente }\end{array}$ & Fala \\
\hline 115 & $\begin{array}{l}\text { Não tenho } \\
\text { certeza }\end{array}$ & Oral & Reunião formal & Concordo & $\begin{array}{l}\text { Concordo } \\
\text { totalmente }\end{array}$ & Fala \\
\hline 116 & $\begin{array}{l}\text { Concordo } \\
\text { totalmente }\end{array}$ & Oral & Reunião formal & $\begin{array}{l}\text { Concordo } \\
\text { totalmente }\end{array}$ & $\begin{array}{l}\text { Concordo } \\
\text { totalmente }\end{array}$ & Fala e escrita \\
\hline 117 & Concordo & Oral & Reunião formal & Concordo & Concordo & Fala \\
\hline 118 & \begin{tabular}{|l} 
Discordo \\
totalmente
\end{tabular} & Nenhum & E-mail & \begin{tabular}{|l} 
Discordo \\
totalmente
\end{tabular} & $\begin{array}{l}\text { Discordo } \\
\text { totalmente }\end{array}$ & Nenhum \\
\hline 119 & \begin{tabular}{|l|l|} 
Concordo \\
totalmente
\end{tabular} & Oral & $\begin{array}{l}\text { Reunião formal , Conversa } \\
\text { face a face }\end{array}$ & \begin{tabular}{|l|} 
Concordo \\
totalmente
\end{tabular} & Concordo & Fala e escrita \\
\hline 120 & Discordo & Oral & Conversa face a face & Discordo & $\begin{array}{l}\text { Discordo } \\
\text { totalmente }\end{array}$ & Fala e escrita \\
\hline 121 & Discordo & Oral & Nenhum & Discordo & Discordo & Nenhum \\
\hline 122 & \begin{tabular}{|l} 
Discordo \\
totalmente
\end{tabular} & Oral & Conversa face a face & Discordo & $\begin{array}{l}\text { Discordo } \\
\text { totalmente }\end{array}$ & Fala \\
\hline 123 & \begin{tabular}{|l} 
Discordo \\
totalmente
\end{tabular} & Oral & Reunião formal & Concordo & Concordo & Fala \\
\hline 124 & Concordo & Oral & Conversa face a face & Concordo & Discordo & Nenhum \\
\hline 125 & Concordo & Digital & Reunião formal & $\begin{array}{l}\text { Não tenho } \\
\text { certeza }\end{array}$ & Concordo & Nenhum \\
\hline 126 & $\begin{array}{l}\text { Concordo } \\
\text { totalmente }\end{array}$ & Oral, Digital & $\begin{array}{l}\text { Reunião formal, Conversa } \\
\text { face a face, E-mail }\end{array}$ & Concordo & $\begin{array}{l}\text { Não tenho } \\
\text { certeza }\end{array}$ & Fala e escrita \\
\hline 127 & Concordo & $\begin{array}{l}\text { Oral , Escrita , } \\
\text { Digital }\end{array}$ & $\begin{array}{l}\text { Reunião formal , Conversa } \\
\text { face a face, Circular interna } \\
\text {, E-mail }\end{array}$ & Discordo & Discordo & Fala e escrita \\
\hline 128 & $\begin{array}{l}\text { Concordo } \\
\text { totalmente }\end{array}$ & Oral & Conversa face a face & $\begin{array}{l}\text { Concordo } \\
\text { totalmente }\end{array}$ & $\begin{array}{l}\text { Concordo } \\
\text { totalmente }\end{array}$ & Fala e escrita \\
\hline 129 & $\begin{array}{l}\text { Concordo } \\
\text { totalmente }\end{array}$ & Digital & E-mail & Concordo & Concordo & Fala e escrita \\
\hline 130 & $\begin{array}{l}\text { Discordo } \\
\text { totalmente }\end{array}$ & $\begin{array}{l}\text { Oral , Escrita , } \\
\text { Digital }\end{array}$ & $\begin{array}{l}\text { Reunião formal, Conversa } \\
\text { face a face, E-mail }\end{array}$ & Discordo & Concordo & Fala e escrita \\
\hline 131 & Concordo & Oral , Digital & $\begin{array}{l}\text { Reunião formal , Conversa } \\
\text { face a face, Circular interna } \\
\text {, Ofício, E-mail }\end{array}$ & Concordo & Discordo & Fala e escrita \\
\hline 132 & \begin{tabular}{|l}
$\begin{array}{l}\text { Concordo } \\
\text { totalmente }\end{array}$ \\
\end{tabular} & \begin{tabular}{|l|} 
Oral , Escrita , \\
Digital
\end{tabular} & $\begin{array}{l}\text { Reunião formal, Conversa } \\
\text { face a face, E-mail }\end{array}$ & Discordo & Concordo & Fala e escrita \\
\hline 133 & $\begin{array}{l}\begin{array}{l}\text { Concordo } \\
\text { totalmente }\end{array} \\
\end{array}$ & Oral & $\begin{array}{l}\text { Reunião formal, Conversa } \\
\text { face a face, E-mail }\end{array}$ & Concordo & Concordo & Fala \\
\hline 134 & Concordo & Oral , Escrita & Conversa face a face & Concordo & Discordo & Fala e escrita \\
\hline 135 & \begin{tabular}{|l} 
Concordo \\
totalmente
\end{tabular} & Oral, Digital & Reunião formal & Concordo & $\begin{array}{l}\text { Concordo } \\
\text { totalmente }\end{array}$ & Fala e escrita \\
\hline 136 & Concordo & Digital & Conversa face a face & \begin{tabular}{|l|} 
Não tenho \\
certeza
\end{tabular} & Discordo & Nenhum \\
\hline 137 & Concordo & Digital & Reunião formal & Discordo & Discordo & Fala e escrita \\
\hline 138 & \begin{tabular}{|l|} 
Concordo \\
totalmente
\end{tabular} & Oral , Digital & E-mail & \begin{tabular}{|l|} 
Concordo \\
totalmente
\end{tabular} & $\begin{array}{l}\text { Concordo } \\
\text { totalmente }\end{array}$ & Fala e escrita \\
\hline 139 & Concordo & Escrita & $\begin{array}{l}\text { Conversa face a face, } \\
\text { Circular interna , E- } \\
\text { mail }\end{array}$ & Concordo & Concordo & Fala e escrita \\
\hline 140 & $\begin{array}{l}\text { Não tenho } \\
\text { certeza }\end{array}$ & Oral & Conversa face a face & Concordo & $\begin{array}{l}\text { Não tenho } \\
\text { certeza }\end{array}$ & Fala \\
\hline 141 & $\begin{array}{l}\text { Não tenho } \\
\text { certeza }\end{array}$ & $\begin{array}{l}\text { Oral , Escrita , } \\
\text { Digital }\end{array}$ & $\begin{array}{l}\text { Reunião formal , Conversa } \\
\text { face a face, Circular interna } \\
\text {, Ofício, E-mail }\end{array}$ & $\begin{array}{l}\text { Não tenho } \\
\text { certeza }\end{array}$ & $\begin{array}{l}\text { Discordo } \\
\text { totalmente }\end{array}$ & Fala e escrita \\
\hline 142 & $\begin{array}{l}\text { Não tenho } \\
\text { certeza }\end{array}$ & Oral & Conversa face a face & Concordo & Concordo & Fala e escrita \\
\hline 143 & $\begin{array}{l}\text { Discordo } \\
\text { totalmente }\end{array}$ & Oral & Conversa face a face & \begin{tabular}{|l|} 
Discordo \\
totalmente
\end{tabular} & $\begin{array}{l}\text { Discordo } \\
\text { totalmente }\end{array}$ & Nenhum \\
\hline 144 & Concordo & Oral & Reunião formal & Concordo & Concordo & Fala \\
\hline 145 & \begin{tabular}{|l} 
Concordo \\
totalmente
\end{tabular} & Oral, Digital & $\begin{array}{l}\text { Conversa face a face, E- } \\
\text { mail }\end{array}$ & \begin{tabular}{|l} 
Discordo \\
totalmente
\end{tabular} & Discordo & Fala e escrita \\
\hline 146 & Concordo & Oral & Conversa face a face & Concordo & Concordo & Fala \\
\hline 147 & \begin{tabular}{|l|} 
Discordo \\
totalmente
\end{tabular} & Escrita & Conversa face a face & Concordo & Concordo & Fala \\
\hline 148 & Concordo & Oral & Conversa face a face & Concordo & Concordo & Fala \\
\hline 149 & \begin{tabular}{|l|} 
Discordo \\
totalmente
\end{tabular} & Digital & Circular interna & Concordo & Concordo & Fala \\
\hline 150 & Concordo & Oral & Conversa face a face & $\begin{array}{l}\text { Discordo } \\
\text { totalmente }\end{array}$ & Discordo & Fala \\
\hline
\end{tabular}




\begin{tabular}{|c|c|c|c|c|c|c|}
\hline 151 & Discordo & Oral & Conversa face a face & Discordo & Discordo & Fala \\
\hline 152 & $\begin{array}{l}\text { Concordo } \\
\text { totalmente }\end{array}$ & Oral & Conversa face a face & Concordo & $\begin{array}{l}\text { Não tenho } \\
\text { certeza }\end{array}$ & Fala \\
\hline 153 & Concordo & Oral & Conversa face a face & $\begin{array}{l}\text { Discordo } \\
\text { totalmente }\end{array}$ & Concordo & Fala \\
\hline 154 & Concordo & Oral , Escrita & $\begin{array}{l}\text { Reunião formal, Conversa } \\
\text { face a face, Circular interna } \\
\text {, Ofício, E-mail }\end{array}$ & Concordo & Concordo & Fala e escrita \\
\hline 155 & Concordo & Oral & Não respondeu & $\begin{array}{l}\text { Não } \\
\text { respondeu }\end{array}$ & $\begin{array}{l}\text { Não } \\
\text { respondeu }\end{array}$ & $\begin{array}{l}\text { Não } \\
\text { respondeu }\end{array}$ \\
\hline 156 & $\begin{array}{l}\text { Concordo } \\
\text { totalmente }\end{array}$ & Oral & Reunião formal & Discordo & Concordo & Fala \\
\hline 157 & Concordo & Oral & Reunião formal & Concordo & Concordo & Fala e escrita \\
\hline 158 & Concordo & Oral & Conversa face a face & Concordo & Concordo & $\begin{array}{l}\text { Não } \\
\text { respondeu }\end{array}$ \\
\hline 159 & Concordo & Oral, Digital & $\begin{array}{l}\text { Reunião formal, Conversa } \\
\text { face a face, E-mail }\end{array}$ & Concordo & Concordo & Fala e escrita \\
\hline 160 & $\begin{array}{l}\text { Concordo } \\
\text { totalmente }\end{array}$ & Oral, Digital & $\begin{array}{l}\text { Reunião formal , Conversa } \\
\text { face a face, E-mail }\end{array}$ & Concordo & Concordo & Fala e escrita \\
\hline 161 & $\begin{array}{l}\text { Não } \\
\text { respondeu }\end{array}$ & $\begin{array}{l}\text { Não } \\
\text { respondeu }\end{array}$ & Não respondeu & $\begin{array}{l}\text { Não } \\
\text { respondeu }\end{array}$ & $\begin{array}{l}\text { Concordo } \\
\text { totalmente }\end{array}$ & Fala e escrita \\
\hline 162 & $\begin{array}{l}\text { Concordo } \\
\text { totalmente }\end{array}$ & Oral & Conversa face a face & $\begin{array}{l}\text { Concordo } \\
\text { totalmente }\end{array}$ & $\begin{array}{l}\text { Concordo } \\
\text { totalmente }\end{array}$ & Fala \\
\hline 163 & Discordo & Oral , Digital & Conversa face a face & Discordo & $\begin{array}{l}\text { Discordo } \\
\text { totalmente }\end{array}$ & Fala \\
\hline 164 & $\begin{array}{l}\text { Concordo } \\
\text { totalmente }\end{array}$ & Oral & Reunião formal & Concordo & Concordo & Fala e escrita \\
\hline 165 & Concordo & Oral, Digital & Conversa face a face & Concordo & Concordo & Fala \\
\hline 166 & $\begin{array}{l}\text { Não } \\
\text { respondeu }\end{array}$ & $\begin{array}{l}\text { Não } \\
\text { respondeu }\end{array}$ & Reunião formal & $\begin{array}{l}\text { Não } \\
\text { respondeu }\end{array}$ & $\begin{array}{l}\text { Não } \\
\text { respondeu }\end{array}$ & $\begin{array}{l}\text { Não } \\
\text { respondeu }\end{array}$ \\
\hline 167 & $\begin{array}{l}\text { Concordo } \\
\text { totalmente }\end{array}$ & Oral & Reunião formal & Concordo & Concordo & Fala e escrita \\
\hline 168 & Concordo & $\begin{array}{l}\text { Não } \\
\text { respondeu }\end{array}$ & Não respondeu & $\begin{array}{l}\text { Não } \\
\text { respondeu }\end{array}$ & $\begin{array}{l}\text { Não } \\
\text { respondeu }\end{array}$ & $\begin{array}{l}\text { Não } \\
\text { respondeu }\end{array}$ \\
\hline 169 & Concordo & $\begin{array}{l}\text { Oral , Escrita, } \\
\text { Digital }\end{array}$ & Reunião formal , E-mail & $\begin{array}{l}\text { Não tenho } \\
\text { certeza }\end{array}$ & $\begin{array}{l}\text { Não tenho } \\
\text { certeza }\end{array}$ & Nenhum \\
\hline 170 & $\begin{array}{l}\text { Não tenho } \\
\text { certeza }\end{array}$ & Oral & Conversa face a face & $\begin{array}{l}\text { Não tenho } \\
\text { certeza }\end{array}$ & $\begin{array}{l}\text { Não tenho } \\
\text { certeza }\end{array}$ & Fala e escrita \\
\hline 171 & $\begin{array}{l}\text { Concordo } \\
\text { totalmente }\end{array}$ & $\begin{array}{l}\text { Oral , Escrita , } \\
\text { Digital }\end{array}$ & $\begin{array}{l}\text { Reunião formal, Conversa } \\
\text { face a face, E-mail }\end{array}$ & $\begin{array}{l}\text { Concordo } \\
\text { totalmente }\end{array}$ & $\begin{array}{l}\text { Concordo } \\
\text { totalmente }\end{array}$ & Fala \\
\hline
\end{tabular}




\begin{tabular}{|c|c|c|c|c|c|}
\hline \# & $\begin{array}{l}\text { 28. Que importância você atribui ao } \\
\text { uso da comunicação oral (fala), do } \\
\text { diálogo e da comunicação face a face } \\
\text { entre chefes e equipes na empresa? }\end{array}$ & 29. Sexo & 30. Idade & $\begin{array}{c}31 . \\
\text { Escolaridade }\end{array}$ & $\begin{array}{l}\text { 32. Há quanto } \\
\text { tempo você } \\
\text { trabalha nesta } \\
\text { Unidade da } \\
\text { Embrapa? }\end{array}$ \\
\hline 1 & Totalmente relevante & Masculino & 34 & Superior & Três a cinco anos \\
\hline 2 & Relevante & Masculino & 42 & Ensino Médio & Mais de 10 anos \\
\hline 3 & Relevante & Feminino & 44 & Superior & Três a cinco anos \\
\hline 4 & Totalmente relevante & Feminino & 29 & Superior & Três a cinco anos \\
\hline 5 & Relevante & Masculino & 50 & Superior & Mais de 10 anos \\
\hline 6 & Relevante & Masculino & 44 & Superior & Mais de 10 anos \\
\hline 7 & Totalmente relevante & Feminino & 30 & Superior & Três a cinco anos \\
\hline 8 & Totalmente relevante & Feminino & 46 & Superior & Mais de 10 anos \\
\hline 9 & Relevante & Masculino & 32 & Superior & Três a cinco anos \\
\hline 10 & Totalmente relevante & Masculino & 48 anos & Superior & Mais de 10 anos \\
\hline 11 & Totalmente relevante & Masculino & 58 & Superior & Seis a 10 anos \\
\hline 12 & Totalmente relevante & Masculino & 39 & Ensino Médio & Seis a 10 anos \\
\hline 13 & Relevante & Masculino & 42 & Superior & Mais de 10 anos \\
\hline 14 & Relevante & Feminino & 37 & Superior & Um a dois anos \\
\hline 15 & Totalmente relevante & Masculino & 63 & Superior & Mais de 10 anos \\
\hline 16 & Relevante & Masculino & 59 & Superior & Mais de 10 anos \\
\hline 17 & Relevante & Masculino & 67 & Superior & Mais de 10 anos \\
\hline 18 & Relevante & Feminino & 46 & Superior & Seis a 10 anos \\
\hline 19 & Totalmente relevante & Feminino & 41 & Superior & Mais de 10 anos \\
\hline 20 & Totalmente relevante & Masculino & 48 ANOS & Ensino Médio & Mais de 10 anos \\
\hline 21 & Relevante & Masculino & 52 & Superior & Mais de 10 anos \\
\hline 22 & Relevante & Feminino & 47 & Superior & Mais de 10 anos \\
\hline 23 & Totalmente relevante & Feminino & 36 & Superior & Seis a 10 anos \\
\hline 24 & Totalmente relevante & Feminino & 38 & Superior & Mais de 10 anos \\
\hline 25 & Relevante & Feminino & 44 & Superior & Seis a 10 anos \\
\hline 26 & Relevante & Masculino & 37 & Superior & Mais de 10 anos \\
\hline 27 & Totalmente relevante & Feminino & 32 & Superior & Um a dois anos \\
\hline 28 & Relevante & Masculino & 57 & $\begin{array}{l}\text { Ensino } \\
\text { fundamental }\end{array}$ & Mais de 10 anos \\
\hline 29 & Totalmente relevante & Masculino & 42 & Ensino Médio & Mais de 10 anos \\
\hline 30 & Relevante & Masculino & 48 & Superior & Mais de 10 anos \\
\hline 31 & Totalmente relevante & Masculino & 42 & Superior & Três a cinco anos \\
\hline 32 & Totalmente relevante & Masculino & 56 & $\begin{array}{l}\text { Ensino } \\
\text { fundamental }\end{array}$ & Mais de 10 anos \\
\hline 33 & Relevante & Masculino & 58 & Superior & Mais de 10 anos \\
\hline 34 & Relevante & Masculino & 40 & Superior & Seis a 10 anos \\
\hline 35 & Relevante & Feminino & 45 & Superior & Mais de 10 anos \\
\hline 36 & Totalmente relevante & Feminino & 43 & Ensino Médio & Mais de 10 anos \\
\hline 37 & Totalmente relevante & Masculino & 39 & Superior & Três a cinco anos \\
\hline 38 & Totalmente relevante & Masculino & 38 & Ensino Médio & Mais de 10 anos \\
\hline 39 & Totalmente relevante & Masculino & 39 & $\begin{array}{l}\text { Ensino } \\
\text { fundamental }\end{array}$ & Mais de 10 anos \\
\hline 40 & Relevante & Feminino & 53 & Superior & Mais de 10 anos \\
\hline 41 & Relevante & Feminino & 50 & Superior & Mais de 10 anos \\
\hline 42 & Relevante & Masculino & 59 & Superior & Mais de 10 anos \\
\hline 43 & Totalmente relevante & Masculino & 28 & Ensino Médio & Três a cinco anos \\
\hline 44 & Relevante & Masculino & 39 & Ensino Médio & Mais de 10 anos \\
\hline 45 & Relevante & Masculino & 40 & Superior & Mais de 10 anos \\
\hline 46 & Totalmente relevante & Masculino & 34 & Ensino Médio & Três a cinco anos \\
\hline 47 & Totalmente relevante & Masculino & 55 & Superior & Seis a 10 anos \\
\hline 48 & Totalmente relevante & Masculino & 42 & Ensino Médio & Um a dois anos \\
\hline 49 & Relevante & Masculino & 43 & Superior & Mais de 10 anos \\
\hline 50 & Totalmente relevante & Masculino & 34 & Superior & Seis a 10 anos \\
\hline 51 & Totalmente relevante & Masculino & 52 & $\begin{array}{l}\text { Ensino } \\
\text { fundamental }\end{array}$ & Mais de 10 anos \\
\hline 52 & Totalmente relevante & Masculino & 60 & Ensino Médio & Mais de 10 anos \\
\hline 53 & Relevante & Masculino & 55 & $\begin{array}{l}\text { Ensino } \\
\text { fundamental }\end{array}$ & Mais de 10 anos \\
\hline 54 & Relevante & Masculino & 0 & Ensino Médio & Mais de 10 anos \\
\hline 55 & Relevante & Masculino & 48 & Superior & Mais de 10 anos \\
\hline 56 & Totalmente relevante & Feminino & 53 & Ensino Médio & Mais de 10 anos \\
\hline 57 & Relevante & Masculino & 56 & Superior & Mais de 10 anos \\
\hline 58 & Totalmente relevante & Masculino & 39 & Superior & Um a dois anos \\
\hline 59 & Relevante & Masculino & 30 & Ensino Médio & Um a dois anos \\
\hline 60 & Relevante & Masculino & 42 & Ensino Médio & Mais de 10 anos \\
\hline
\end{tabular}




\begin{tabular}{|c|c|c|c|c|c|}
\hline 61 & Totalmente relevante & Masculino & 0 & Superior & Um a dois anos \\
\hline 62 & Relevante & Feminino & 29 & Superior & Três a cinco anos \\
\hline 63 & Relevante & Masculino & 29 & Ensino Médio & Três a cinco anos \\
\hline 64 & Relevante & Masculino & 33 & Ensino Médio & Três a cinco anos \\
\hline 65 & Relevante & Feminino & 29 & Ensino Médio & Três a cinco anos \\
\hline 66 & Relevante & Masculino & 41 & Superior & Um a dois anos \\
\hline 67 & Relevante & Masculino & 67 & Superior & Três a cinco anos \\
\hline 68 & Relevante & Masculino & 49 & Superior & Mais de 10 anos \\
\hline 69 & Totalmente relevante & Masculino & 28 & Superior & Um a dois anos \\
\hline 70 & Relevante & Feminino & 53 & $\begin{array}{l}\text { Ensino } \\
\text { fundamental }\end{array}$ & Mais de 10 anos \\
\hline 71 & Relevante & Masculino & 37 & Superior & Três a cinco anos \\
\hline 72 & Relevante & Masculino & 35 & Superior & Um a dois anos \\
\hline 73 & Totalmente relevante & Masculino & 36 & Ensino Médio & Três a cinco anos \\
\hline 74 & Relevante & Masculino & 42 & Ensino Médio & Mais de 10 anos \\
\hline 75 & \begin{tabular}{|l|} 
Relevante \\
\end{tabular} & Masculino & 25 & Ensino Médio & Três a cinco anos \\
\hline 76 & Relevante & Feminino & 29 & Superior & Um a dois anos \\
\hline 77 & Relevante & Masculino & 59 & Superior & Mais de 10 anos \\
\hline 78 & Relevante & Feminino & 38 & Superior & Mais de 10 anos \\
\hline 79 & Relevante & Masculino & 0 & Superior & Seis a 10 anos \\
\hline 80 & Relevante & Masculino & 60 & Superior & Um a dois anos \\
\hline 81 & Totalmente relevante & Masculino & 36 & Ensino Médio & Um a dois anos \\
\hline 82 & Totalmente relevante & Masculino & 43 & Ensino Médio & Três a cinco anos \\
\hline 83 & Relevante & Feminino & 29 & Superior & Três a cinco anos \\
\hline 84 & \begin{tabular}{|l|} 
Irrelevante \\
\end{tabular} & Feminino & 51 & Ensino Médio & Mais de 10 anos \\
\hline 85 & Relevante & Masculino & 40 & Ensino Médio & Mais de 10 anos \\
\hline 86 & Totalmente relevante & Masculino & 42 & Superior & Três a cinco anos \\
\hline 87 & Relevante & Masculino & 45 & Superior & Um a dois anos \\
\hline 88 & Relevante & Masculino & 50 & Superior & Mais de 10 anos \\
\hline 89 & Relevante & Masculino & 50 & Ensino Médio & Mais de 10 anos \\
\hline 90 & Totalmente relevante & Feminino & 30 & Superior & Três a cinco anos \\
\hline 91 & Totalmente relevante & Masculino & 44 & Superior & Um a dois anos \\
\hline 92 & Totalmente relevante & Masculino & 70 & Superior & Mais de 10 anos \\
\hline 93 & Totalmente relevante & Masculino & 41 & Superior & Três a cinco anos \\
\hline 94 & Relevante & Masculino & 38 & Superior & Um a dois anos \\
\hline 95 & Totalmente relevante & Masculino & 55 & Superior & Mais de 10 anos \\
\hline 96 & Relevante & Masculino & 42 & Superior & Mais de 10 anos \\
\hline 97 & Totalmente relevante & Masculino & 30 & \begin{tabular}{|l|} 
Superior \\
\end{tabular} & Seis a 10 anos \\
\hline 98 & Relevante & Feminino & 42 & Superior & Mais de 10 anos \\
\hline 99 & Relevante & Masculino & 0 & Superior & Mais de 10 anos \\
\hline 100 & Relevante & Masculino & 34 & Superior & Um a dois anos \\
\hline 101 & \begin{tabular}{|l|} 
Totalmente relevante \\
\end{tabular} & Masculino & 43 & Superior & Seis a 10 anos \\
\hline 102 & Totalmente relevante & Masculino & 56 & Superior & Mais de 10 anos \\
\hline 103 & Totalmente relevante & Masculino & 43 & \begin{tabular}{|l|} 
Superior \\
\end{tabular} & Seis a 10 anos \\
\hline 104 & Relevante & Masculino & 37 & Superior & Mais de 10 anos \\
\hline 105 & Totalmente relevante & Feminino & 50 & Superior & Mais de 10 anos \\
\hline 106 & Totalmente relevante & Feminino & 45 & Superior & Seis a 10 anos \\
\hline 107 & Totalmente relevante & Masculino & 62 & \begin{tabular}{|l|} 
Superior \\
\end{tabular} & Mais de 10 anos \\
\hline 108 & \begin{tabular}{|l|} 
Relevante \\
\end{tabular} & Masculino & 67 & Superior & Mais de 10 anos \\
\hline 109 & Relevante & Masculino & 62 & Superior & Mais de 10 anos \\
\hline 110 & Totalmente relevante & Masculino & 30 & Superior & Um a dois anos \\
\hline 111 & Relevante & Masculino & 62 & Ensino Médio & Seis a 10 anos \\
\hline 112 & Totalmente relevante & Masculino & 56 & Ensino Médio & Mais de 10 anos \\
\hline 113 & Relevante & Masculino & 46 & Ensino Médio & Mais de 10 anos \\
\hline 114 & Totalmente relevante & Feminino & 32 & Superior & Três a cinco anos \\
\hline 115 & \begin{tabular}{|l|} 
Relevante \\
\end{tabular} & Masculino & 35 & Superior & Mais de 10 anos \\
\hline 116 & Relevante & Masculino & 33 & Superior & Mais de 10 anos \\
\hline 117 & Relevante & Masculino & 55 & Superior & Mais de 10 anos \\
\hline 118 & Totalmente relevante & Masculino & 65 & Superior & Mais de 10 anos \\
\hline 119 & Totalmente relevante & Masculino & 34 & Superior & Três a cinco anos \\
\hline 120 & Relevante & Masculino & 42 & Ensino Médio & Mais de 10 anos \\
\hline 121 & Não tenho certeza & Feminino & 40 & $\begin{array}{l}\text { Ensino } \\
\text { fundamental }\end{array}$ & Mais de 10 anos \\
\hline 122 & Totalmente relevante & Masculino & 0 & Ensino Médio & Seis a 10 anos \\
\hline 123 & Totalmente relevante & Feminino & 54 & $\begin{array}{l}\text { Ensino } \\
\text { fundamental }\end{array}$ & Mais de 10 anos \\
\hline 124 & Totalmente relevante & Masculino & 27 & Superior & Um a dois anos \\
\hline 125 & Relevante & Masculino & 36 & Superior & Mais de 10 anos \\
\hline 126 & Totalmente relevante & Masculino & 46 & Superior & Mais de 10 anos \\
\hline 127 & Totalmente relevante & Masculino & 52 & Superior & Mais de 10 anos \\
\hline 128 & Relevante & Masculino & 29 & Superior & Três a cinco anos \\
\hline 129 & \begin{tabular}{|l|} 
Relevante \\
\end{tabular} & Masculino & 33 & Superior & Mais de 10 anos \\
\hline
\end{tabular}




\begin{tabular}{|c|c|c|c|c|c|}
\hline 130 & Totalmente relevante & Feminino & 62 & Superior & Mais de 10 anos \\
\hline 131 & Totalmente relevante & Masculino & 39 & Superior & Um a dois anos \\
\hline 132 & Relevante & Feminino & 58 & Superior & Mais de 10 anos \\
\hline 133 & Totalmente relevante & Masculino & 35 & Superior & Três a cinco anos \\
\hline 134 & Totalmente relevante & Masculino & 52 & Superior & Mais de 10 anos \\
\hline 135 & Totalmente relevante & Masculino & 29 & Superior & Um a dois anos \\
\hline 136 & Não tenho certeza & Masculino & 34 & Superior & Três a cinco anos \\
\hline 137 & Relevante & Masculino & 52 & Superior & Mais de 10 anos \\
\hline 138 & Totalmente relevante & Masculino & 29 & Superior & Mais de 10 anos \\
\hline 139 & Não tenho certeza & Masculino & 45 & Superior & Mais de 10 anos \\
\hline 140 & Totalmente relevante & Masculino & 28 & Ensino Médio & Um a dois anos \\
\hline 141 & Totalmente relevante & Masculino & 30 & Superior & Mais de 10 anos \\
\hline 142 & Relevante & Feminino & 42 & Ensino Médio & Três a cinco anos \\
\hline 143 & Totalmente relevante & Masculino & 28 & Ensino Médio & Três a cinco anos \\
\hline 144 & Relevante & Masculino & 37 & Ensino Médio & Mais de 10 anos \\
\hline 145 & \begin{tabular}{|l|} 
Relevante \\
\end{tabular} & Masculino & 32 & Ensino Médio & Seis a 10 anos \\
\hline 146 & Relevante & Masculino & 61 & Ensino Médio & Seis a 10 anos \\
\hline 147 & Relevante & Masculino & 55 & $\begin{array}{l}\text { Ensino } \\
\text { fundamental }\end{array}$ & Mais de 10 anos \\
\hline 148 & Relevante & Masculino & 44 & Ensino Médio & Seis a 10 anos \\
\hline 149 & Relevante & Masculino & 46 & $\begin{array}{l}\text { Ensino } \\
\text { fundamental }\end{array}$ & Mais de 10 anos \\
\hline 150 & Irrelevante & Masculino & 35 & Ensino Médio & Três a cinco anos \\
\hline 151 & Relevante & Masculino & 0 & Ensino Médio & Seis a 10 anos \\
\hline 152 & Não tenho certeza & Masculino & 43 & Ensino Médio & Mais de 10 anos \\
\hline 153 & Relevante & Masculino & 44 & Ensino Médio & Mais de 10 anos \\
\hline 154 & Totalmente relevante & Feminino & 49 & Superior & Mais de 10 anos \\
\hline 155 & Não respondeu & Feminino & 54 & \begin{tabular}{|l|} 
Não \\
respondeu
\end{tabular} & Não respondeu \\
\hline 156 & Totalmente relevante & Masculino & 35 & Ensino Médio & Seis a 10 anos \\
\hline 157 & Totalmente relevante & Masculino & 40 & Ensino Médio & Um a dois anos \\
\hline 158 & Não respondeu & $\begin{array}{l}\text { Não } \\
\text { respondeu }\end{array}$ & 59 & $\begin{array}{l}\text { Ensino } \\
\text { fundamental }\end{array}$ & Mais de 10 anos \\
\hline 159 & Relevante & Feminino & 0 & Superior & Não respondeu \\
\hline 160 & Totalmente relevante & Feminino & 31 & Superior & Três a cinco anos \\
\hline 161 & Totalmente relevante & Masculino & 0 & \begin{tabular}{|l} 
Não \\
respondeu
\end{tabular} & Não respondeu \\
\hline 162 & Relevante & $\begin{array}{l}\text { Não } \\
\text { respondeu }\end{array}$ & 0 & \begin{tabular}{|l|} 
Não \\
respondeu
\end{tabular} & Não respondeu \\
\hline 163 & Irrelevante & $\begin{array}{l}\text { Não } \\
\text { respondeu }\end{array}$ & 0 & \begin{tabular}{|l|} 
Não \\
respondeu
\end{tabular} & Mais de 10 anos \\
\hline 164 & Relevante & Feminino & 44 & Superior & Mais de 10 anos \\
\hline 165 & Relevante & $\begin{array}{l}\text { Não } \\
\text { respondeu }\end{array}$ & 0 & Superior & Não respondeu \\
\hline 166 & Totalmente relevante & Masculino & 0 & Superior & Não respondeu \\
\hline 167 & Totalmente relevante & Masculino & 57 & Superior & Mais de 10 anos \\
\hline 168 & Totalmente relevante & Masculino & 38 & Superior & Três a cinco anos \\
\hline 169 & Totalmente relevante & Masculino & 0 & Superior & Não respondeu \\
\hline 170 & \begin{tabular}{|l|} 
Relevante \\
\end{tabular} & Feminino & 32 & Superior & Um a dois anos \\
\hline 171 & Relevante & Masculino & 0 & \begin{tabular}{|l} 
Não \\
respondeu
\end{tabular} & Não respondeu \\
\hline
\end{tabular}

